\title{
National socialist family law : the influence of national socialism on marriage and divorce law in Germany and the Netherlands
}

Citation for published version (APA):

Lenaerts, M. F. (2012). National socialist family law : the influence of national socialism on marriage and divorce law in Germany and the Netherlands. [Doctoral Thesis, Maastricht University]. Maastricht University. https://doi.org/10.26481/dis.20121108ml

Document status and date:

Published: 01/01/2012

DOI:

10.26481/dis.20121108ml

Document Version:

Publisher's PDF, also known as Version of record

Please check the document version of this publication:

- A submitted manuscript is the version of the article upon submission and before peer-review. There can be important differences between the submitted version and the official published version of record.

People interested in the research are advised to contact the author for the final version of the publication, or visit the DOI to the publisher's website.

- The final author version and the galley proof are versions of the publication after peer review.

- The final published version features the final layout of the paper including the volume, issue and page numbers.

Link to publication

\footnotetext{
General rights rights.

- You may freely distribute the URL identifying the publication in the public portal. please follow below link for the End User Agreement:

www.umlib.nl/taverne-license

Take down policy

If you believe that this document breaches copyright please contact us at:

repository@maastrichtuniversity.nl

providing details and we will investigate your claim.
}

Copyright and moral rights for the publications made accessible in the public portal are retained by the authors and/or other copyright owners and it is a condition of accessing publications that users recognise and abide by the legal requirements associated with these

- Users may download and print one copy of any publication from the public portal for the purpose of private study or research.

- You may not further distribute the material or use it for any profit-making activity or commercial gain

If the publication is distributed under the terms of Article $25 \mathrm{fa}$ of the Dutch Copyright Act, indicated by the "Taverne" license above, 

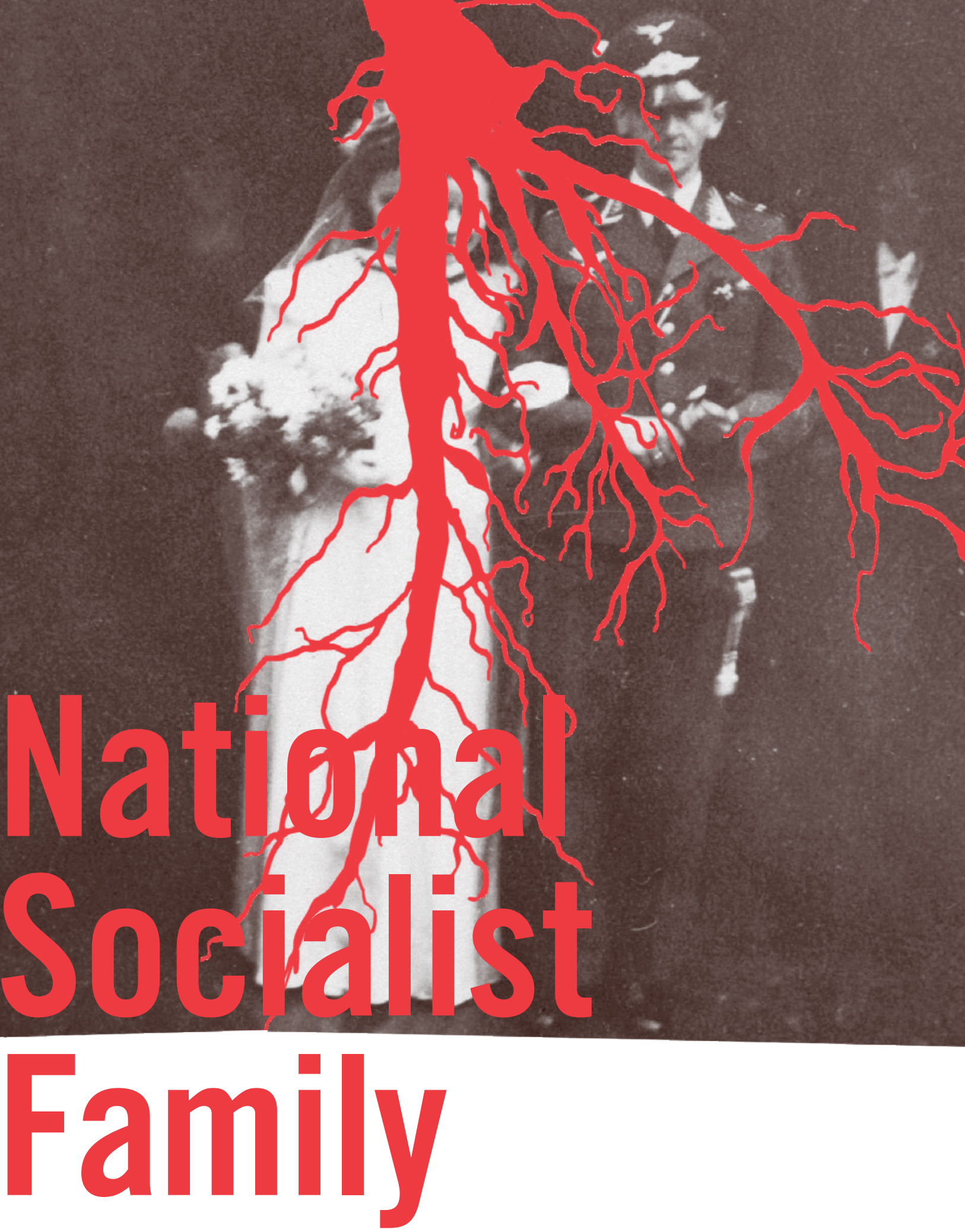

The influence of National Socialism on marriage and divorce law in Germany and the Netherlands Mariken Lenaerts 

National Socialist Family Law

Mariken Lenaerts 



\section{National Socialist Family Law}

\section{The influence of National Socialism on marriage and divorce law in Germany and the Netherlands}

\section{Dissertation}

to obtain the degree of Doctor

at Maastricht University,

on the authority of the Rector Magnificus,

Prof. Dr. L.L.G. Soete

in accordance with the decision of the Board of Deans,

to be defended in public

on Thursday 08 November 2012, at 12.00 hours

by

Maria Francisca Lenaerts 


\section{Supervisors}

Prof. Dr. G.R. de Groot

Prof. Dr. C.H. van Rhee

\section{Assessment Committee}

Prof. Dr. A.M.J.A. Berkvens (chair)

Prof. Dr. C.J.H. Jansen (Radboud Universiteit Nijmegen)

Prof. Dr. G.E. van Maanen

Dr. S.W.E. Rutten

Prof. Dr. R. Schulze (Westfälische Wilhelms-Universität Münster) 
'We can no longer afford to take that which was good in the past and simply call it our heritage, to discard the bad and simply think of it as a dead load which by itself time will bury in oblivion.'

Hannah Arendt, The Origins of Totalitarianism, (Harcourt Brace Jovanovich Publishers, 1973), ix

Voor papa

'Lettertjes worden woorden, woorden worden zinnen, zinnen een verhaal...' 


\section{'A goal is a}

dream with

a deadline.'

'I love deadlines. I love

the whooshing sound they

make as they go by.'

Douglas Adams 


\section{Preface}

Being able to write a $\mathrm{PhD}$ thesis was my dream when I was still a law student, who had just switched from European Law School to the - in the eyes of many - somewhat obscure track of Metajuridica. It became a clearset goal when I was appointed as junior researcher in July 2006. But as with many $\mathrm{PhD}$ theses it has been a constant struggle with deadlines; some dreams are hard to fulfil. At times I used a free interpretation of Douglas Adams' quote: 'I hate deadlines. I hate the nagging sound they make as they come close'. However, when I will place the final full stop at the end of my preface, my dream has been fulfilled, within the set deadline. New dreams can be and will be pursued.

However, before I can start with that, I first have to express my gratitude to many persons who have helped me and at times even proved to be instrumental in achieving this goal. 
First and foremost I would like to express my gratitude to my supervisors, Professor René de Groot and Professor Remco van Rhee, who have truly introduced me in the world of academic research by allowing me to work independently whilst in the mean time reflecting on my research and my tasks as a junior researcher.

Others however, contributed to the realisation of this book as well. Therefore I would like to thank Yuri Michielsen-Tallman for introducing me to the initial topic of this research and helping me to secure a position as junior researcher at Maastricht University, Remme Verkerk, Richard Verkijk and Stefan Weishaar for providing me with interesting and very often helpful literature, Professor Trix van Erp-Jacobs for introducing me to the world of archival research, Professor Hildegard Schneider for her mental support during the past six, sometimes difficult, years, the NIOD Institute on War, Holocaust and Genocide Studies for allowing me to study their archives and in particular Sergio Leatomu who made an endless number of photocopies of all documents I needed, Bibiche Wymenga and Sead Kadic for kindly translating the summary into German, Henry Smaal for designing the cover and the lay-out of this book, Ine Corstjens and Suzanne de Jongste for the vital secretarial support and Emanuel van Dongen for endlessly enduring Genesis on repeat.

Thanks also to all my (ex-)colleagues and friends at the faculty for turning my job from a mere job into a dream job (still!), in particular Emanuel van Dongen, Remme Verkerk, Serban Vacarelu and Tanja van der Meer. Tanja van der Meer deserves to be singled out here. I can not thank her enough for all her help and support in the past six years, which is still ongoing until this very day. Titles like 'unofficial co-supervisor' or 'PhD godmother' are definitely in order.

Furthermore I would like to thank my father, for introducing me into the world of knowledge, my mother and Aafke for their continuous support and interest and my friends for keeping up with me so long and allowing me to neglect them horribly. Finally, when we are talking about 'keeping up'; thank you Jacco. It's done my love, it's done. Let's go! 




\section{Table of Contents}

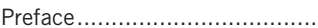

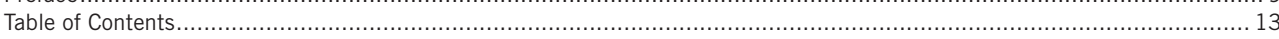

$\begin{array}{lr}\text { I. Introduction } & 16\end{array}$

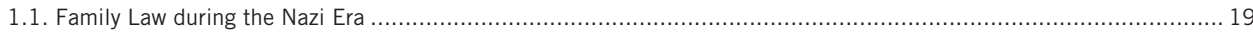

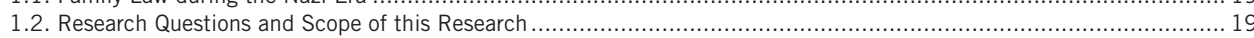

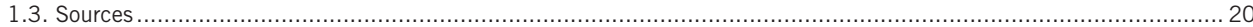

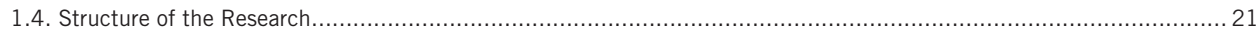

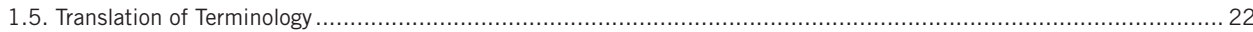

II. Family Policy according to National Socialism 24

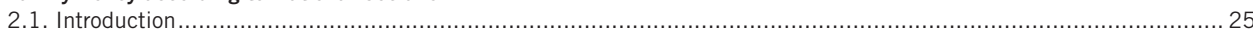

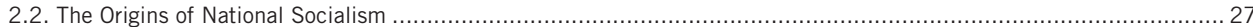

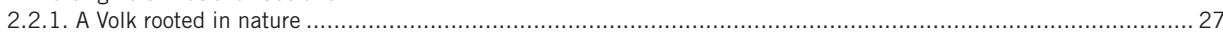

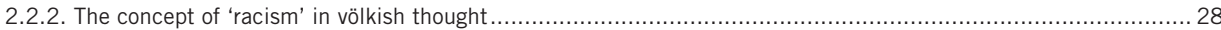

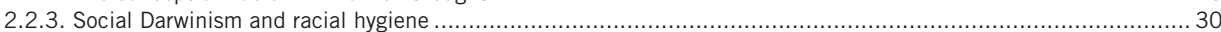

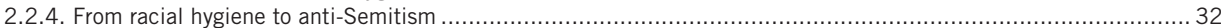

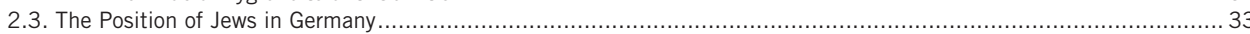

2.4. The Development of Family Policy in the First Half of the Twentieth Century .................................................. 36

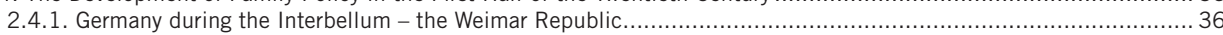

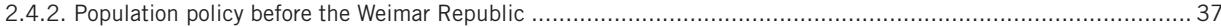

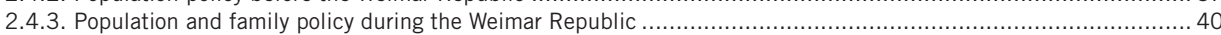

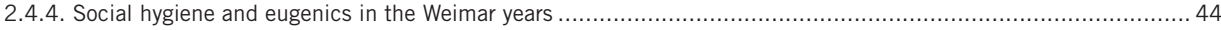

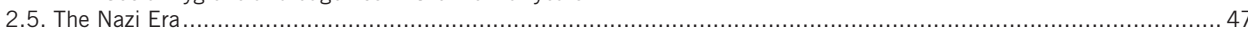

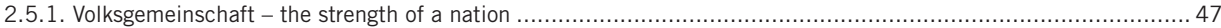

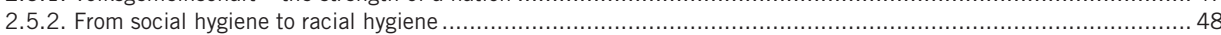

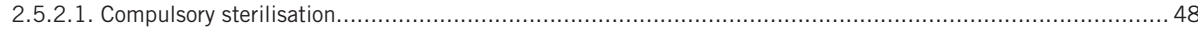

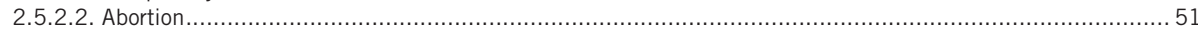

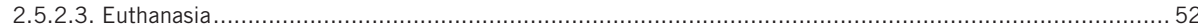

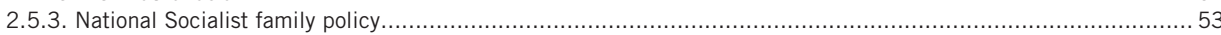

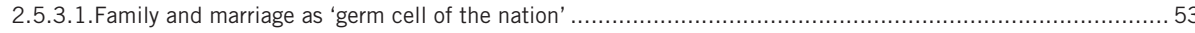

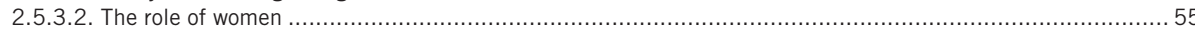

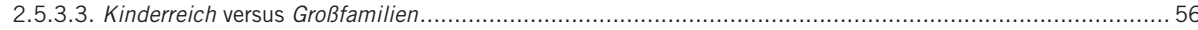

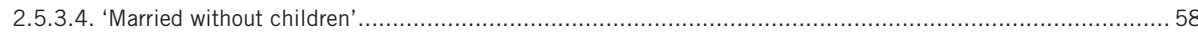

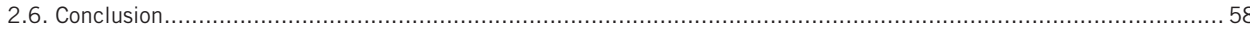

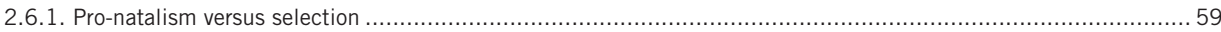

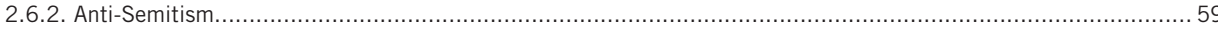

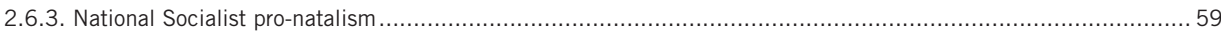

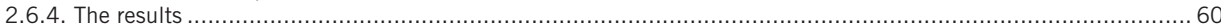

III. National Socialist Racial and Family Law in Germany 62

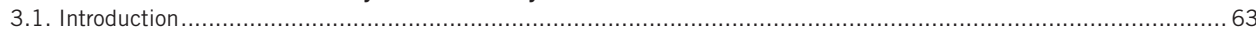

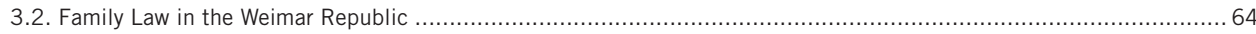

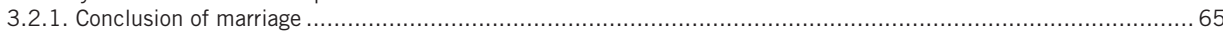

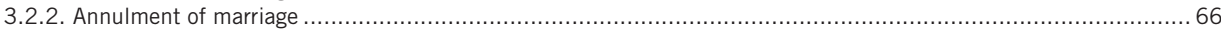

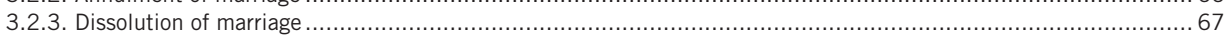

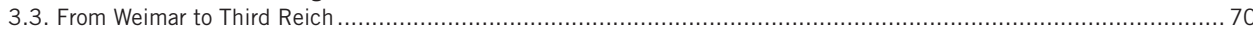

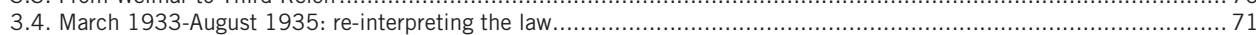

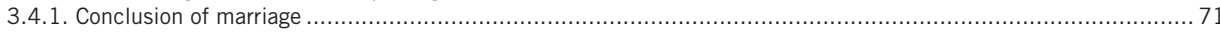

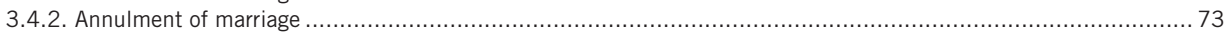

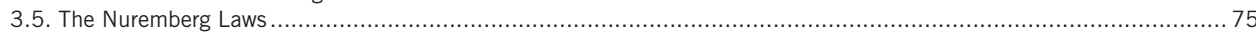

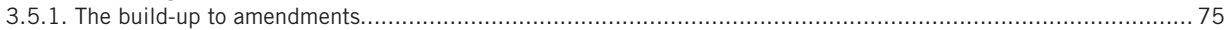

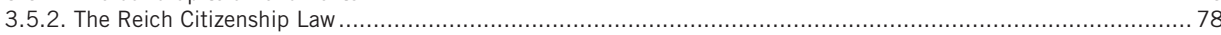

3.5.3. The Law for the Protection of German Blood and German Honour ............................................................. 84

3.6. Keeping the Aryan Race Healthy - the Marriage Health Law ............................................................. 92

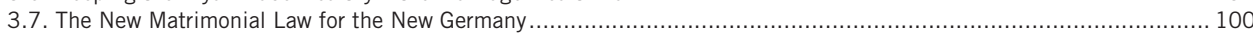

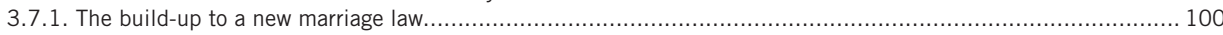

3.7.2. Marriage and divorce law in Austria and the need to adapt the draft revision ................................................ 110

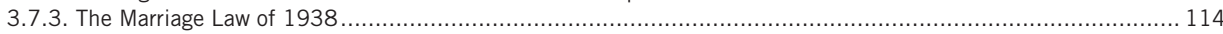

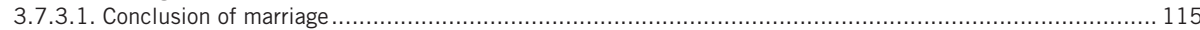

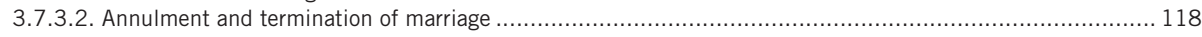

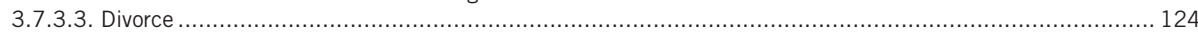

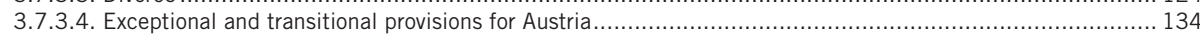

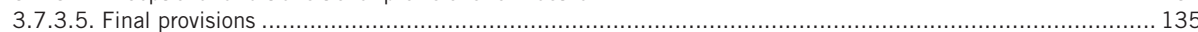

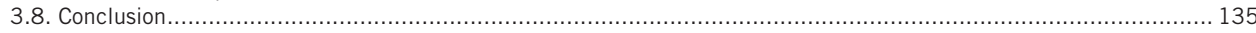

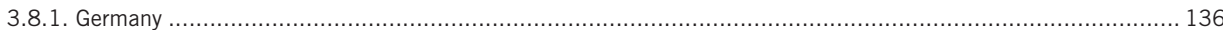

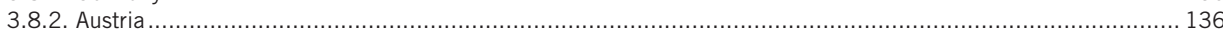

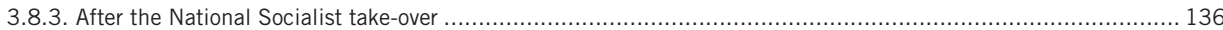




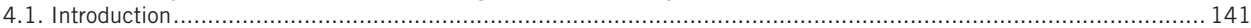

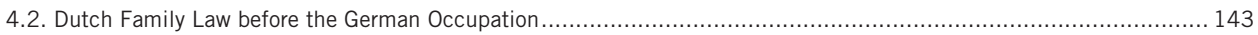

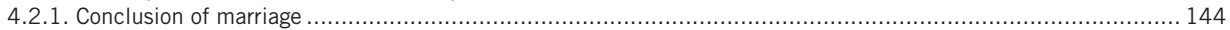

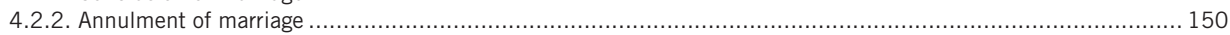

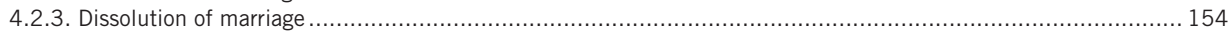

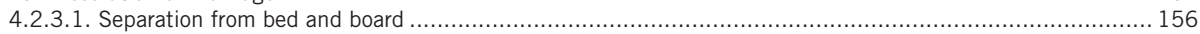

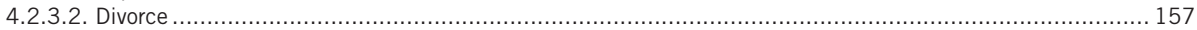

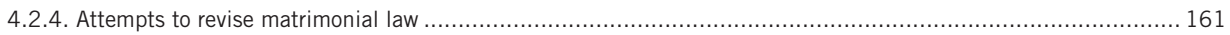

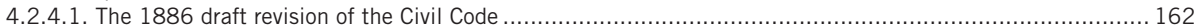

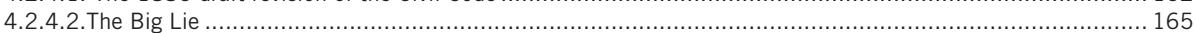

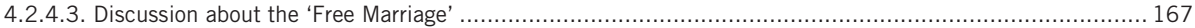

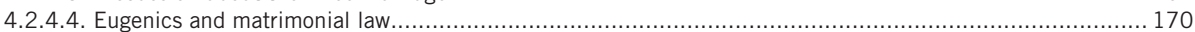

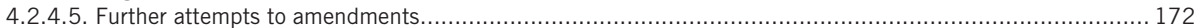

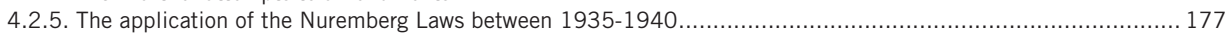

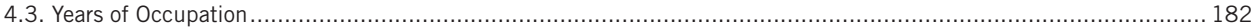

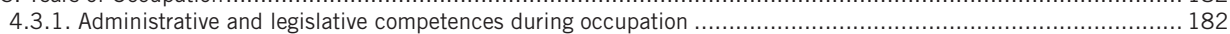

4.3.2. Defining the 'Jewish Question' in the Netherlands ......................................................................... 196

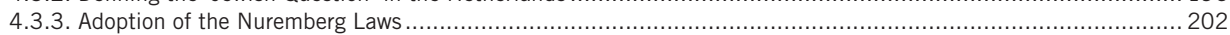

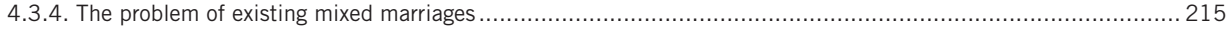

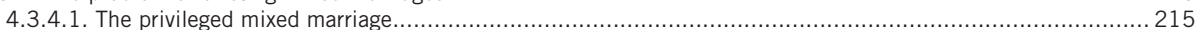

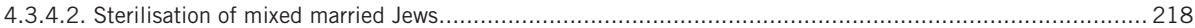

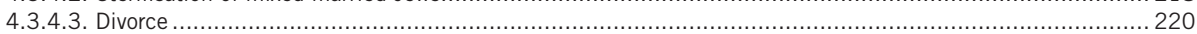

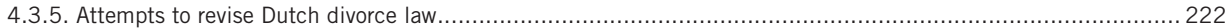

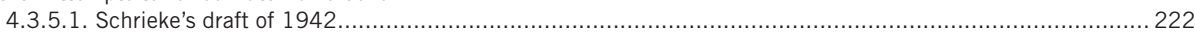

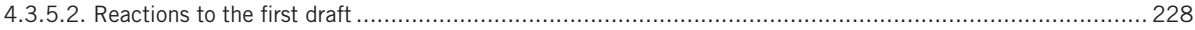

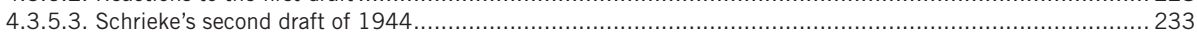

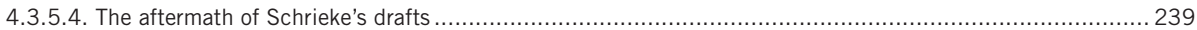

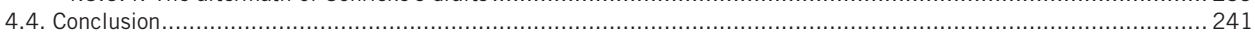

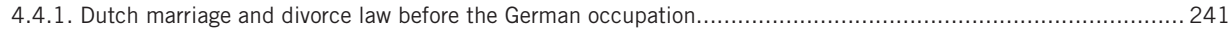

4.4.2. The law of occupation and the German civil administration in the Netherlands.........................................2 242

4.4.3. Marriage and divorce law and the position of Jews in that respect during the German occupation.....................2242

$\begin{array}{lr}\text { V. Conclusion } & 246\end{array}$

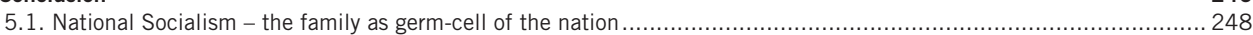

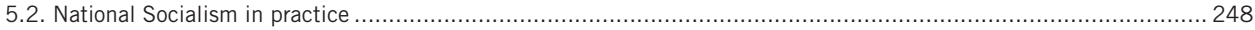

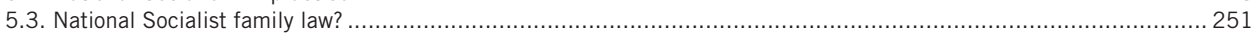

Samenvatting
256

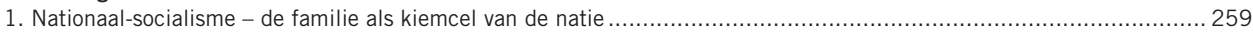

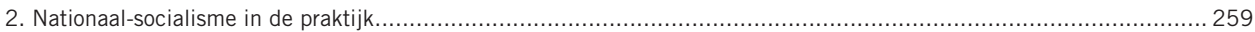

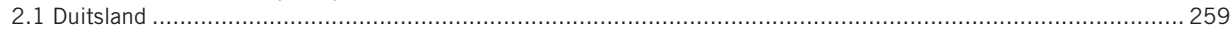

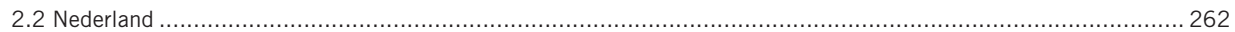

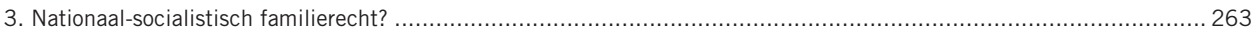

Zusammenfassung $\quad 268$

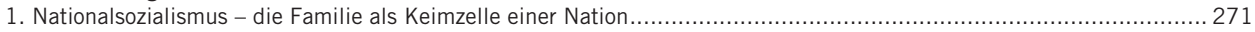

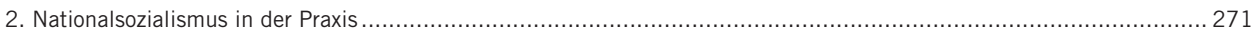

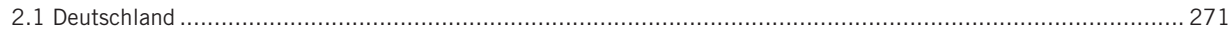

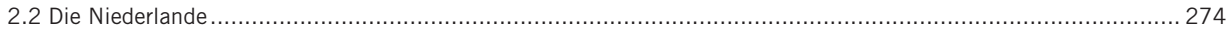

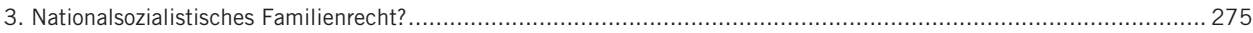

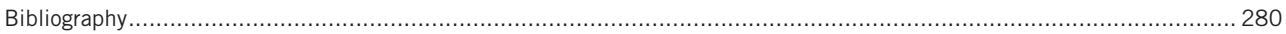

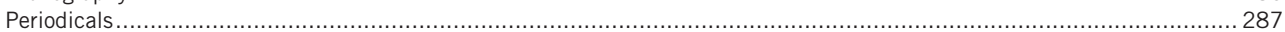

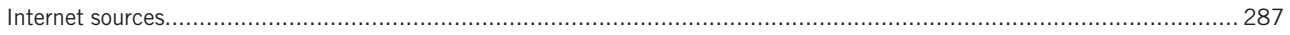

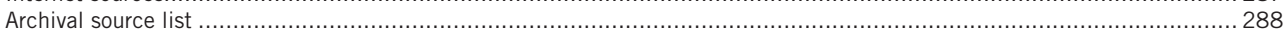

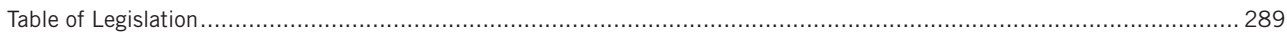

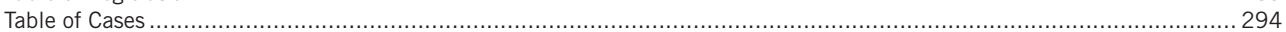

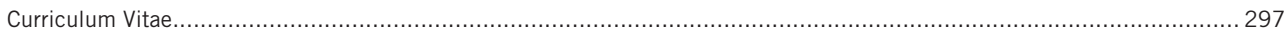



I.

Introduction 
Law in the sense of rules regulating human behaviour fascinates and divides. Yet, although the content of these rules is often debated, we accept everyday that they exist. Although laws clearly limit our freedom, we accept laws as a fact of everyday life. To make sure we do not start fighting amongst each other, to divide resources, to make sure that everyone gets a chance in life, to guarantee everyone's basic rights, basically to make sure life is liveable. Usually, those rules are a reflection of the norms and standards of society. Usually those rules try to steer human behaviour in a direction that is socially acceptable. However, throughout history and up until today it is clear that life is very often not liveable. That every new day constitutes a new threat to life. Sometimes here, sometimes there. Sometimes only to me, sometimes only to you, sometimes to the both of us. Throughout history and up until today, we can pinpoint periods and places where rules regulating human behaviour meant to ensure life is liveable have constituted a threat to the life of human beings. Germany between I 933 and I945 is one of the most striking examples in this respect. In National Socialist Germany laws were a fact of everyday life, just as it is today. However, many of these laws have had far-reaching consequences. With their racial laws the National Socialists have excluded certain groups of people from society. With their laws concerning marriage and divorce they have touched upon one of the most fundamental and private aspects of human social life: the relationship between two human individuals who choose to share their lives with each other. 
It is debatable whether remembrance is indeed adequate to fight evil. Tzvetan Todorov has argued that every day it is proven that memory as a remedy for evil is an ineffective remedy and that the only thing history can teach us is that every day we have to be on our guard against the evils that reside in ourselves. ${ }^{1}$ However, although remembering our past may not prevent evil from happening again, it can help us to develop a better understanding of what has happened. And understanding might help us to prevent evil from happening. To me this knowledge justifies another book on the Nazi period, where so many have been written already. To help us understand, not just what has happened during those dark years, but also what the essence of law is: rules that regulate human behaviour in order to make life liveable. 


\subsection{Family Law during the Nazi Era}

In his book Mein Kampf Hitler describes the greatness and superiority of the 'Aryan' race. According to him the Aryan man was the so-called Prometheus of mankind; all human culture, science, art etcetera found its origin in the Aryan race. The Aryan race was supposedly the only culture-founding race; all other races had always been merely culturebearing. ${ }^{2}$ According to Hitler, this characteristic made the Aryan race superior over other races, which gave it a stronger right of existence. Marriage was regarded as the 'germ-cell' of this race. Therefore, matrimonial law and family policy played a key-role in National Socialist politics. The behaviour of the German population had to be steered in a direction that was desirable to the National Socialists. This was especially true within the field of family policy; the intimate relationship of the individual German with another German had to comply with National Socialist standards, since violation of those standards was thought to have devastating consequences for the survival of the Aryan race. However, when the National Socialists came to power Germany already had official behavioural rules concerning personal relationships between two persons. In order to change human behaviour in this respect, the rules had to be changed. Changes of rules can be brought about in two ways: either literally changing the rules or reinterpreting the existing rules. The National Socialists have applied both ways when steering human behaviour in the direction they favoured.

\subsection{Research Questions and Scope of this Research}

This brings us to the main question of this research: has family law, in particular marriage and divorce law, been influenced by National Socialism and if so, in what way and to what extent? If we want to test changes made in family law against National Socialism, however, we have to determine what National Socialism entails first. What are its origins and what are the main elements? What role did marriage and family play exactly in National Socialism? Secondly, in order to determine what changes have been made, we have to define the then existing rules concerning marriage and divorce. In order to determine whether certain changes can be attributed to National Socialism as such or were perhaps the result of developments that had already been going on before the National Socialists started to steer human behaviour towards National Socialism, we have to take into account the political and academic discussions with regard to marriage and divorce law during the years before the National Socialist take-over, as well as possible draft amendments to matrimonial law that have been discussed in those years.

With regard to family law this research is limited to marriage and divorce law. It will deal in particular with the rules concerning the conclusion of marriage, the annulment of marriage and the dissolution of marriage, i.e. divorce and, in case of the Netherlands and Austria, separation from bed and board. 
In further defining the topic this research is limited to Germany and the Netherlands.

Although National Socialism does not find its origins exclusively in Germany, we can regard Germany as its 'home base', as this was the first country the National Socialists came to power. Germany was therefore the first country in which rules regulating the nation's behaviour could substantially be influenced by National Socialism. As the German Marriage Law of 1938 was promulgated in Austria as well since Austria was incorporated ${ }^{3}$ into Germany as of March I $938,{ }^{4}$ the Austrian rules concerning conclusion of marriage, annulment of marriage and dissolution of marriage before the incorporation will shortly be touched upon as well.

The National Socialists regarded the Netherlands as a brother nation of Germany, with its people sharing the same blood. However, the Netherlands was not incorporated into the German Reich, but occupied by German military forces in May I940. Eight days after the invasion, Hitler replaced the military administration in the Netherlands by a civil administration. ${ }^{5}$ At that time occupations were governed by the Regulations Respecting the Laws and Customs of War on Land of 1907. This determined in Article 43 that the occupant had to take all measures in his power to restore, and ensure, as far as possible, public order and civil life, while respecting, unless absolutely prevented, the laws in force in the occupied country. It is therefore debatable whether the German occupying forces were at all authorised to change family law in the Netherlands.

\subsection{Sources}

For this research I have used primary sources were possible. These sources have been of a diverse nature. I have made use of legislation, codified legislation, but also governmental, ministerial and Führer decrees. With regard to the Netherlands, apart from Dutch legislation, decrees issued by the German authorities have been used, both administrative decrees and police regulations. Case law is used on a regular basis to illustrate the scope of the National Socialist regulations. However, a considerable amount of information has been gathered by studying written correspondence between several officials, both in Germany and the Netherlands. In Germany a selected part of these letters, reports, memoranda and circulars available in archives has been published recently, ${ }^{6}$ in the Netherlands this information is still only available in archives.

3 The incorporation of Austria into Germany is generally referred to as Anschluß, which is somewhat euphemistic, or, in English, annexation. However, it is debatable whether the incorporation of Austria into German can indeed be characterised as an 'annexation', as annexation is a unilateral act by the conquering state, preceded by a military conquest. Through annexation the enemy state ceases to exist, thereby bringing the war to an end. This is called subjugation. In this respect the conquering state acquires enemy territory and de jure sovereignty through conquest followed by subjugation. See Oppenheim-Lauterpacht, International Law. A Treatise, volume 1, 518-519. Although Germany certainly put considerable military pressure on Austria, this pressure does not qualify as 'conquest'. Furthermore, the incorporation was a bilateral act, although, again, Austria was under pressure, although not only from Germany, but also from the inside. See E.B. Bukey, Hitler's Austria, 25-39.

4 Gesetz über die Wiedervereinigung Österreichs mit dem Deutschen Reich vom 13. März 1938, Reichsgesetzblatt (1938), I, 237; Bundesverfassungsgesetz über die Wiedervereinigung Österreichs mit dem Deutschen Reich, Bundesgesetzblatt für den Bundesstaat Österreich (1938), 259.

5 Erlaß des Führers über Ausübung der Regierungsbefugnisse in den Niederlanden vom 18. Mai 1940, Reichsgesetzblatt (1940), I, 778.

6 See i.a. W. Schubert, Die Projekte der Weimarer Republik zur Reform des Nichtehelichen-, des Adoptions- und des Ehescheidungsrechts and W. Schubert, Das Familien- und Erbrecht unter dem Nationalsozialismus. Ausgewählte Quellen zu den wichtigsten Gesetzen und Projekte aus den Ministerialakten. 
The website of the Österreichische Nationalbibliothek has been instrumental with regard to the German Reichsgesetzblatt and the Austrian Bundesgesetzblatt. With regard to German records, I have made use of the collections of Werner Schubert concerning (draft) amendments of divorce law during the Weimar years ${ }^{7}$ and the National Socialist period. ${ }^{8}$ With regard to case law I have made use of case descriptions published in the Deutsches Recht and the Juristische Wochenschrift (from 1939 incorporated in Deutsches Recht) and the Deutsche Justiz, in addition to the Entscheidungen des Reichsgerichts in Zivilsachen. With regard to the Netherlands I did have access to the original records at the NIOD Institute for War, Holocaust and Genocide Studies, ${ }^{9}$ of which I have used the records of the Generalkommissariat für Verwaltung und Justiz, Hauptabteilung Inneres and Hauptabteilung Justiz in particular. The works of amongst others Loe de Jong, ${ }^{10}$ Jacques Presser, ${ }_{11}^{11}$ Coen Stuldreher ${ }^{12}$ and the collection Onderdrukking en Verzet ${ }^{13}$ have been instrumental in reconstructing the chronology of events.

\subsection{Structure of the Research}

The first chapter serves as an historical and 'ideological' background. In the first part of the chapter the origins of National Socialism will be examined. Secondly, an overview of the position of Jews in Germany through the ages and German population and family policy in the decades before the National Socialists came to power will be given. In this part I will also deal with the concept of 'eugenics'. Thirdly, the chapter will deal with the Nazi era, explaining the National Socialist theory of the Volksgemeinschaft and giving some examples of National Socialist population and family policy.

The second chapter aims to give an overview of the changes made by the National Socialists in Germany with regard to marriage and divorce law. The first part of the chapter will give an overview of marriage and divorce law as laid down in the German Civil Code from I9oo, whilst the second part of the chapter analyses the changes made during the Nazi period. As the development of the Marriage Law of I 938 was influenced by the incorporation of Austria, this section will give an overview of Austrian marriage and divorce law before the incorporation as well.

The third chapter discusses the possible influence of National Socialism on marriage and divorce law in the Netherlands. The first part of the chapter will give an overview of the Dutch rules concerning marriage and divorce as stated in the Civil Code of I838. It will furthermore discuss the attempts to revise divorce law in the nineteenth and first four decades of the twentieth century and the different attitudes to divorce law. Additionally it will deal with the application of the Nuremberg Laws in the Netherlands between I 935 and 1940. The second part of the chapter will deal with the German occupation of

7 W. Schubert, Die Projekte der Weimarer Republik zur Reform des Nichtehelichen-, des Adoptions- und des Ehescheidungsrechts

8 W. Schubert, Das Familien- und Erbrecht unter dem Nationalsozialismus. Ausgewählte Quellen zu den wichtigsten Gesetzen und Projekte aus den Ministerialakten.

9 NIOD stands for Nederlands Instituut voor Oorlogsdocumentatie (Netherlands Institute for War Documentation). In 2010, the NIOD fused with the Center for Holocaust and Genocide Studies under the above mentioned name.

10 L. de Jong, Het Koninkrijk der Nederlanden in de Tweede Wereldoorlog.

11 J. Presser, Ondergang. De Vervolging en Verdelging van het Nederlandse Jodendom 1940-1945.

12 C.J.F. Stuldreher, De Legale Rest. Gemengd gehuwde Joden onder de Duitse bezetting.

13 J.J. van Bolhuis, C.D.J. Brandt, H.M. van Randwijk and B.C. Slotemaker (eds.), Onderdrukking en Verzet. Nederland in Oorlogstijd. 
the Netherlands, first explaining the rules regarding occupation and the administrative situation in the Netherlands followed by an overview of the measures implemented by the German authorities with regard to marriage and divorce law. The final part of the chapter will deal extensively with the attempts to revise Dutch divorce law, undertaken by J.J. Schrieke (I884-1976), who had been extraordinary Professor of Constitutional Law of the Dutch East Indies at Leiden University from I934 to I94I. In I94I he was appointed secretary-general of Justice. Although after the war public prosecutor Zaayer remarked that Schrieke had betrayed his country 'in style', Schrieke was sentenced to the death penalty by the Exceptional Court of Justice in The Hague in 1946. The judgment was reversed on appeal by the Exceptional Court of Cassation to twenty years imprisonment. He was released conditionally in October $1955 .{ }^{14}$

The final chapter, the conclusion, will summarise and analyse the main findings and will finally formulate an answer to the question whether family law, in particular marriage and divorce law, has been influenced by National Socialism and if so, in what way and to what extent?

\subsection{Translation of Terminology}

Presenting the outcomes of research on German and Dutch law inevitably leads to translation issues. Being no native speaker of English myself, I have used established translations of legal terminology, names of institutions and quotations were possible. With regard to the translation of the quotations taken from Mein Kampf I have used the translation by Ralph Manheim. With regard to the translation of the different types of courts in Germany I made use of the translations provided by Deborah Lucas Schneider in the book of Ingo Müller, as explained by Detlev Vagts. ${ }^{15}$ Throughout this book I have provided the term, name or quote in the original language as well.

14 See for an extensive biography of J.J. Schrieke: P.J. Knegtmans, P. Schulten and J. Vogel, Collaborateurs van niveau, 30-154.

15 D. Vagts, 'Introduction', in I. Müller, Hitler's Justice. The Courts of the Third Reich, x. Translation by D.L. Schneider. 
II.

Family Policy

according

to National

Socialism 


\subsection{Introduction}

This chapter intends to sketch an historical and 'ideological' framework with regard to the question whether family law has been influenced by National Socialism.

In order to answer this question we first have to establish what National Socialism entails. In the following I will use the term 'National Socialism' to refer to National Socialist ideas instead of 'National Socialist ideology'. Several authors have not questioned whether National Socialism can be called an ideology, ${ }^{1}$ but have simply assumed that it is. ${ }^{2}$ Others have called National Socialism a nihilistic ideology as it was not directed at redetermining norms and values, but solely at acquiring power. ${ }^{3}$ Whether National Socialism can unequivocally be called an ideology remains to be seen, as National Socialism merely consisted of fragments derived from different theories and doctrines - which were nevertheless more or less in line with each other - put together, though without being integrated properly. It lacked an unambiguous theory, which is shown in the differing views within the NSDAP.

However, whether or not National Socialism is an ideology is not relevant in order to answer the question whether family law has been influenced by National Socialist ideas and it would be beyond the scope of this research to determine whether National Socialism is an ideology or not. What is relevant for this thesis though, is to determine what elements National Socialism consisted of. The 'origins' of National Socialism have to be examined.

1 There exists no common indisputable definition of 'ideology'. W.A. Mullins defines ideology as 'a logically coherent system of symbols which, within a more or less sophisticated conception of history, links the cognitive and evaluative perception of one's social condition - especially its prospects for the future - to a program of collective action for the maintenance, alteration or transformation of society.' See W.A. Mullins, 'On the Concept of Ideology in Political Science', 66 The American Political Science Review 2 (1972), 498-510, 510. D.W. Minar however, identifies six types of application of the term ideology: 1) ideology as thought distinguished by content; 2) ideology as thought distinguished by internal structure; 3) ideology as thought distinguished by its personal-social function; 4) ideology as thought distinguished by its organisational function; 5) ideology as thought distinguished by its purpose of transmission of ideas and 6) ideology as thought distinguished by its locus, i.e. 'distinguished as thought that is social in the sense that it is shared among individuals'. See D.W. Minar, 'Ideology and Political Behavior', 5 Midwest Journal of Political Science 4 (1961), 317-331.

2 E.g. L. Pine, Nazi Family Policy, 1933-1945 and H. Krausnick in H. Krausnick and M. Broszat, Anatomy of the SS State.

3 J. Hagen, Nietzsches weerklank in Nazi-Duitsland, 40-41. 
In the first part of this chapter several theories, established well before National Socialism as such came up and from which National Socialism drew inspiration, will be examined, e.g. 'völkish nationalism', racism and anti-Semitism, Social Darwinism, racial hygiene and eugenics. In the second part of this chapter an historical framework will be sketched, by explaining the position of Jews in Germany through the ages and German population and family policy in the decades before the National Socialists came to power. The third part of this chapter will deal with the Nazi era, explaining the National Socialist theory of the Volksgemeinschaft and giving some examples of National Socialist population and family policy. 


\subsection{The Origins of National Socialism \\ - 2.2.1. A Volk rooted in nature}

Völkish ideas were firmly established after I87I when political unity among the Germans was officially proclaimed. Long before $187 \mathrm{I}$ the Germans were already longing for unity, although 'cultural cohesion' was emphasised, rather than political unity. According to many this unity had existed in the past, whilst the modern world denied this. In general, the political unification of $\mathrm{I} 87 \mathrm{I}$ turned out to be a disappointment to the majority of the German population. Political unity had not brought a general feeling of 'social cohesion'. ${ }^{4}$ Furthermore, the unification of Germany, which coincided with the industrialisation, did not turn out to be profitable to everyone. ${ }^{5}$ On the contrary, the dilapidating social and economic circumstances of a large part of the German population - which were the result of the industrialisation process - only added to the feelings of disappointment with regard to the unification. Therefore it was generally believed that modernisation was better declined and that unity among the Germans had to be found in values and strengths from the past. ${ }^{6}$ In their efforts to find a common cultural identity and reject modernisation, rationalism - a remnant of the Age of Enlightenment - was exchanged for emotion. People started looking for their inner self and their individual capacities. At the same time one wanted to belong to a higher force, something greater than man. Individualism was not satisfactory anymore. A solution was found in the völkish ideas. ${ }^{7}$

It is difficult to translate the word 'Volk', as it involves a more comprehensive concept than the word 'people'. 'People' only indicates a certain section of the population, in which the different individuals share some obvious characteristics like language, physical appearance and ancestry. Volk indicates a group of people with a shared 'essence'. According to Mosse this 'essence' was the link between the individual and the Volk as it represented the source of man's creativity, his feelings and his individuality, which he shared with the other members of the Volk. ${ }^{8}$ Furthermore, the Volk was linked to the natural surroundings it lived in. The human soul resembled the 'essence' of nature, in which nature has to be understood as the native landscape. The Germans, for example, lived and used to live in dark, misty forests. Therefore the Germans were considered to be deep and mysterious, whilst the Jews - originating in the dessert - were considered to be 'dry' people, lacking any creativity and spirituality. ${ }^{9}$ With this theory the Volk was made the intermediary between man and the higher force one was looking for, as the Volk received the life force from this higher force and passed it on to the individual. The only way to receive this life force was to be rooted in nature. Only when a person was rooted in nature and in the history of the Volk, he belonged to the Volk which made him a creative being. This excluded the Jews as they did not have their own territory, but were scattered all over the world. ${ }^{10}$

4 G.L. Mosse, The Crisis of German Ideology, 2-4.

5 In 1873 the collapse of the stock market caused an economic crisis, not only in Germany, but in the rest of Europe as well. In Germany tens of thousands of investors lost their capital. See A. Elon, Duitsland en zijn Joden, 218.

G.L. Mosse, The Crisis of German Ideology, 3-4.

Ibid., 13-14.

Ibid., 4.

Ibid., 4-5.

10 Ibid., 16-17. 
As nature was that important to the Volk, man had to live in harmony with it. Living in the city was disapproved of, as one could not 'root' in a city, as one could do on the countryside. A peasant life was therefore preferred above a life in the city. This led to extensive theories about utopian communities of Germans leading an autarkic, rural life. ${ }^{11}$ The Jew was seen as the enemy of the peasant, a conviction which was not entirely based upon imagination. Traditionally, Jews were merchants and often they functioned as moneylenders in times of financial difficulty of the peasants. ${ }^{12}$ Needless to say that as moneylenders Jews were both hated and feared, and this led to novels which told the story about a peasant who becomes indebted to a Jew, who claims and sells the peasant's property to an entrepreneur who builds a factory on it. The story often ended with the peasant committing suicide after he had seen what had become of his land in which he had invested his energy of body and soul. ${ }^{13}$

\section{- 2.2.2. The concept of 'racism' in völkish thought}

Originally the völkish thought was not distinctly racist, as it sought a common identity culminating in unification. Even the classification of human beings into races was originally non-normative. Classification into races was originally based upon external characteristics. Immanuel Kant (I724-I804) wrote in I775: 'Blacks and Whites are not distinct types of people, for they belong to one tribe, and yet to two different races. ${ }^{\text {,14 }}$ Johann Gottfried Herder (I744-I803) openly declared himself against the concept of racism and the submission of one group of people by another. He only recognised differences between groups of people without adding any values to this. According to Herder every nation had its own 'national character' and 'national spirit'. ${ }^{15}$ However, gradually this idea was interpreted in a racist way and connected with the belief that the Germans were a special race which had distinguished itself in the past. Already in Antiquity the Germans had played a leading role. Proof of this was found in the writings of Tacitus. In his book Germania, Tacitus described the heroism of the Germans

11 Ibid., 108-125. One of the advocates of the establishment of true Germanic communities was Willibald Hentschel. He launched the idea of the establishment of Mittgart, a settlement which was dedicated to the promotion of the Germanic race, by careful selection and isolation of the worthy. According to Hentschel selective racial breeding was necessary to guarantee the purity and survival of the race. To reach this goal he suggested polygamy, an idea which was adopted by Himmler, but rejected by the majority of the National Socialists. Influenced by Hentschel the right-oriented sections of the Youth Movement changed into an organisation called Artamanen. The primary goal of the Artamanen was the gathering of Lebensraum in Eastern Europe. Although the Artamanen used to reject the Nazi party - because it was a political party that operated within the existing social structures - many of the Artamanen joined the Nazis after the crisis of 1929, as they thought that only National Socialism could save the country. See also M. Burleigh and W. Wippermann, The Racial State, 35.

12 G.L. Mosse, The Crisis of German Ideology, 27.

13 G.L. Mosse, The Crisis of German Ideology, 19-28.

14 I. Kant, Von den verschiedenen Rassen der Menschen, 12: 'Auf diese Weise sind Neger und Weiße zwar nicht verschiedene Arten von Menschen (denn sie gehören vermutlich zu einem Stamme); aber doch zwei verschiedene Rassen; [...].' English quote taken from M. Burleigh and W. Wippermann, The Racial State, 23.

15 J.G. Herder, Ideen zur Philosophie der Geschichte der Menschheit. See in this respect M. Burleigh and W. Wippermann, The Racial State, 25; G.G. Field, Evangelist of Race, 201. 
extensively, praising their bravery ${ }^{16}$ and purity. ${ }^{17}$ The fact that Tacitus had written this book to show the differences between the Germanic tribes and the Romans and to point out the decadence of the latter, was simply ignored. ${ }^{18}$

At the end of the eighteenth century and the beginning of the nineteenth century the emphasis shifted from external characteristics to internal characteristics and was no longer non-normative. Johann Caspar Lavater (I74I-I8OI) was a supporter of physiognomy, a (pseudo-)science which used facial characteristics to discover and distinguish spiritual and psychological characteristics. The idea was that the character and capabilities of a human being were reflected in his features. ${ }^{19}$ Franz Joseph Gall ( 1758 I 828) invented phrenology, a (pseudo-)science in the line of physiognomy, which used cranial measurements in order to group persons by intelligence, morality and beauty. ${ }^{20}$ Between I 853 and I 855 Count Joseph Arthur de Gobineau (I8I6-I882) published his book Essai sur l'inégalité des races humaines in which he claimed that the rise and fall of civilisations was determined by race. All high civilisations were created by Aryans, a term originally used to indicate the Indo-Iranian cultures to which, according to Gobineau, the white Caucasian race belonged as well. ${ }^{21}$

Originally scientists had believed Hebrew to be the original tongue of man, but in the late eighteenth century this conviction shifted to the belief that European languages were derived from a language close to Sanskrit. Proof for this theory was found in the similarities in grammatical structure between Sanskrit, Greek, Latin, Persian and the Germanic and Celtic languages. This group was called the Indo-Aryan or Indo-European language family, whilst there existed a second one, the Semitic family, which emerged from Hebrew. Following this theory, the conviction grew that man originated in northern India and that people had migrated westwards to Europe, making these Indo-Aryans the ancestors of the modern Europeans. However, after i 850 this conviction gradually shifted to the idea that northern Europe (Germany, Scandinavia and the Baltic States) was the ancestral home of the Aryans instead of northern India. ${ }^{22}$

The Aryan race was the only race in which the inner qualities were thought to be optimally reflected by external characteristics. A civilisation started to decline when the

16 Tacitus, Germania, $\S 14.1$ : 'Cum ventum in aciem, turpe principi virtute vinci, turpe comitatui virtutem principis non adaequare.' 'When they have come into battle, it is shameful for the chieftain to be excelled in valor, shameful for the entourage not to match the valor of the chieftain.' See also $\$ 42.1$ : 'praecipua Marcomanorum gloria viresque, atque ipsa etiam sedes pulsis olim Boiis virtute parta.' 'The prestige and strength of the Marcomani are especially high, and their very home was won by bravery, when they drove out the Boii long ago.' Translation by H.W. Benario.

17 Tacitus, Germania, § 4: 'Ipse eorum opinionibus accedo qui Germaniae populos nullis aliis aliarum nationum conubiis infectos propriam et sinceram et tantum sui similem gentem extitisse arbitrantur.' 'I personally incline to the views of those who think that the peoples of Germany have not been polluted by any marriages with other tribes ant that they have existed as a particular people, pure and only like themselves.' Translation by H.W. Benario.

18 M. Burleigh and W. Wippermann, The Racial State, 25; G.L. Mosse, The Crisis of German Ideology, 67-69.

19 J.C. Lavater, Physiognomische Fragmente zur Beförderung der Menschenkenntnis und Menschenliebe.

20 M. Burleigh and W. Wippermann, The Racial State, 24; G.L. Mosse, The Crisis of German Ideology, 89; A. Elon, Duitsland en zijn Joden, 53.

21 J.A. de Gobineau, Essai sur l'inégalité des races humaines, 214-223, 367 ff. See in this respect also M. Burleigh and W. Wippermann, The Racial State, 27-28.

22 G.G. Field, Evangelist of Race, 202-210. 
Aryan race lost its purity, i.e. when Aryans started to mingle with other, less valuable races. Therefore democracy, which was the embodiment of miscegenation, had to be prevented by all means. ${ }^{23}$ Although Gobineau's book was the starting point for several similar theories that elaborated on his theme, his book was - due to his pessimistic perspective - virtually ignored. According to Gobineau it would be impossible to prevent mingling of the Aryan races with other races. Furthermore, the liberal Germany of that time proved not to be ready yet for his radical and unscientific ideas. Instead, a new theory derived from a pioneering research became leading: Social Darwinism. ${ }^{24}$

\section{- 2.2.3. Social Darwinism and racial hygiene}

In 1859 - a few years after the publication of Gobineau's Essai-Charles Darwin published his book On the Origins of Species by Means of Natural Selection, or the Preservation of Favoured Races in the Struggle for Life. In this book Darwin launched the theory of natural selection, although he explicitly stated that his book only concerned the plant and animal kingdom. ${ }^{25}$ According to Darwin there was a constant struggle for existence taking place in these kingdoms. This struggle was won by those species who where most capable of adaptation, as these species proved to be most successful in procreation. By this way of natural selection all weaker species would become extinct and only the stronger would develop and survive. ${ }^{26}$ With this theory Darwin wanted to demonstrate that life on earth was naturally self-regulating instead of created and looked after by some higher force. ${ }^{27}$

This theory put an end to the controversy over monogenism and polygenism. Monogenists accepted the biblical unity of mankind as the basis for their racial theories, explaining the qualitative differences between races on the basis of effective historical and environmental influences, whilst polygenists believed that all contemporary human races originated from separate acts of divine creation. Darwin accepted the idea of one primordial form as the origin of all life on earth (not only man), thereby repudiating polygenism. However, as Darwin was no outspoken racist, a plausible conclusion could be that as all human races share the same origin, no race would be superior to other races. ${ }^{28}$

Darwin's book became a success and soon there were several theorists stepping forward to interpret his ideas. One of them was Francis Galton (I822-I9I I), who applied Darwins theory on humans and even adopted it in order to launch a theory on improving the biological health of the human species. ${ }^{29}$ Galton introduced the term 'eugenics ${ }^{\text {'30 }}$ and argued in favour of the introduction of a certificate of hereditary health. Eugenics

23 J.A. de Gobineau, Essai sur l'inégalité des races humaines, $367 \mathrm{ff}$.

24 M. Burleigh and W. Wippermann, The Racial State, 27-28; G.L. Mosse, The Crisis of German Ideology, 90-92; H. Krausnick and M. Broszat, Anatomy of the SS State, 20.

25 C. Darwin, On the Origins of Species by Means of Natural Selection, or the Preservation of Favoured Races in the Struggle for Life, 4, 55.

26 C. Darwin, On the Origins of Species by Means of Natural Selection, or the Preservation of Favoured Races in the Struggle for Life, $52 \mathrm{ff}, 396$.

27 C. Darwin, On the Origins of Species by Means of Natural Selection, or the Preservation of Favoured Races in the Struggle for Life, 407-410; M. Burleigh and W. Wippermann, The Racial State, 28-29; H. Krausnick and M. Broszat, Anatomy of the SS State, 27.

28 G.G. Field, Evangelist of Race, 204-205.

29 F. Galton, Hereditary Genius. An inquiry into its laws and consequences.

30 F. Galton, Inquiries into Human Faculty and its Development, 17. 
consisted of a programme to improve the biological health of a nation by using genetics. According to Galton healthy middle class or highly-educated people had to marry young and get lots of children in order to get a generally healthy and intelligent population. People who failed the 'Passed in Genetics' test, were encouraged to emigrate to the fictituous country 'Kantsaywhere'. ${ }^{31}$ Ernst Haeckel (I834-i9i9) even went further. According to Haeckel men and women had to be selected carefully according to race and health, as was done in Sparta in Antiquity, and everyone who was sick or disabled had to be killed. ${ }^{32}$ When he founded the Monist League in I9o6, his ideas were introduced in the more scientific circles. ${ }^{33}$

Soon there was no lack of theorists adopting Darwin's theory in their pursuit of finding a way to ensure the survival and wellbeing of the human race or of a certain group of people. It was generally believed that when sick, weak or otherwise less worthy people were prevented to procreate, these weaknesses could be eliminated which only made the human race stronger. The prevailing view was that imperfections - like alcoholism and criminal behaviour - were caused by bad genes instead of bad education. In I9oo Wilhelm Schallmayer ( 1857 -I9I9) won an essay contest on the topic: "What can we learn from the principles of Darwinism for application to domestic political development and the laws of the state?' In his essay ${ }^{34}$ Schallmayer wrote that the state was obliged to guarantee the biological health of the population. Instead of emphasising human rights and helping the weak in society to survive, the state had to leave them to fend for themselves and help the strong ones. According to Schallmayer strong, healthy people had to be encouraged to marry young and get many children by state subsidies related to children, special financial support for the mothers and even by permitting strong, valuable men to commit polygamy. Couples had to be examined by socio-biologists before receiving permission to marry and state subsidies. Those who did not pass the test should be forbidden to marry and had to be compulsory sterilised. Schallmayer did not connect his theory of social biology to any racial doctrine. Nevertheless the measures he suggested would be quite drastic to the people concerned. ${ }^{35}$ Schallmayer was supported by Alfred Ploetz (I860-I940) who did apply this theory to the racial doctrine. ${ }^{36}$ According to Ploetz the Germanic or Aryan race was superior to other races, especially the Jews. Eugenics had to be used in order to purify the Aryan race. As part of this theory he coined the term 'racial hygiene.' In addition to the measures suggested by Schallmayer, all babies who showed signs of weaknesses or hereditary diseases had to be killed right after birth in order to guarantee the purity and

31 F. Galton, The Eugenic College of Kantsaywhere. See in this respect also M. Burleigh and W. Wippermann, The Racial State, 29.

32 E. Haeckel, Natürliche Schöpfungs-Geschichte, 153; E. Haeckel, Die Lebenswunder: gemeinverständliche Studien über biologische Philosophie.

33 M. Burleigh and W. Wippermann, The Racial State, 30-31.

34 W. Schallmayer, Vererbung und Auslese. Grundriss der Gesellschaftsbiologie und der Lehre vom Rassedienst; W. Schallmayer, Beiträge zu einer Nationalbiologie, nebst einer Kritik der methodologischen Einwände und einem Anhang über wissenschaftliches Kritikerwesen.

35 M. Burleigh and W. Wippermann, The Racial State, 31; H. Krausnick and M. Broszat, Anatomy of the SS State, 28; G.L. Mosse The Crisis of German Ideology, 99.

36 A. Ploetz, Die Tüchtigkeit unserer Rasse und der Schutz der Schwachen. Ein Versuch über Rassenhygiene und ihr Verhältnis zu den humanen Idealen, besonders zum Socialismus. 
health of the Aryan race. In wartime only the weak and inferior had to go to the front to serve as canon fodder. ${ }^{37}$

\section{- 2.2.4. From racial hygiene to anti-Semitism}

Up until now racial hygiene had not been outspoken anti-Semitic. This changed in I9oo after the publication of Die Grundlagen des XIX. Jahrhunderts, written by Houston Stewart Chamberlain (I855-I927) ${ }^{38}$ Chamberlain, born at Southsea on the southern coast of England in 1855 and a naturalised German as of I916, lived most of his life in Austria and Germany and was highly influenced by the Bayreuth Circle and the ideas of Richard Wagner. Chamberlain became a true anti-Semite in his first years in Vienna (1889-I892), ${ }^{39}$ where life was pervaded with anti-Semitism. ${ }^{40}$ In his book Chamberlain expressed his polygenist ${ }^{41}$ conviction that humanity was divided into various races which all had their own physical appearance which subsequently caused differences in moral and mental capacities. According to Chamberlain history was characterised by a series of distinct cultural blooms, all created and ruled by a dominant race. The development of present-day Europe was largely the work of the Teutonic or Aryan race ${ }^{42}$ which fought the destructive power of the Jews. ${ }^{43}$ Jews were the embodiment of the Devil, whilst God was on the side of the Germanic race. ${ }^{44}$ This Germanic race was in need of a Germanic religion as only through a religion could the German soul truly understand the deeper meaning of life. To find this Germanic religion, he fell back on Christianity and disposed it of any Jewish influence by stating that Christ - the embodiment of God in man - could never have been a Jew. ${ }^{45}$ The lessons of Christ could only be linked to the idealistic views of the Aryans, whilst the Jews had a materialistic faith. They wanted to rule the world and this dominion had been promised to them by their God if they obeyed his laws. ${ }^{46}$ The Germanic or Aryan race was therefore superior to the Jewish race. In line with Gobineau's vision Chamberlain argued that the concept of race explained not only the past, but also the future ${ }^{47}$ Although Chamberlain remained somewhat vague about the definition of race ${ }^{48}$ he clearly stated the ingredients for a noble race: I) 'excellent material' had to be

37 M. Burleigh and W. Wippermann, The Racial State, 32; G.L. Mosse, The Crisis of German Ideology, 99.

38 M. Burleigh and W. Wippermann, The Racial State, 36.

39 G.G. Field, Evangelist of Race, 115-117.

40 E.B. Bukey, Hitler's Austria, 22-24. In the past the Catholic Church often had been the instigator of pogroms, but in the late nineteenth century anti-Semitism was strengthened by the Pan-German movement of Georg Ritter von Schönerer, which was aiming for unity between all German-speaking nations of Europe. As Bukey puts it, this movement was 'at once anti-Habsburg, antiliberal, anti-Catholic, anti-capitalist, antisocialist, and, above all, anti-Semitic.' Ibid., 6; see also A. Pelinka, Austria. Out of the Shadow of the Past, 173-183.

41 G.G. Field, Evangelist of Race, 297.

42 Ibid., 191. Chamberlain was never really clear and consistent when using terms like 'race' and 'Teutons'. He frequently used the term 'Aryans', 'Indo-Germanic' and 'Indo-European' instead of 'Teuton', although he never exactly indicated the geographical origin of this race. Nevertheless, his descriptions often matched the convictions of the so-called Blondheitskult, making the Teuton resemble a German, a Celt and a Slav, always implying that the German speaking nations consisted of the largest concentration of pure Teutonic blood. Germanic will therefore be used as an alternative for Teuton.

43 Ibid., 180.

44 M. Burleigh and W. Wippermann, The Racial State, 36; G.L. Mosse, The Crisis of German Ideology, 95.

45 G.L. Mosse, The Crisis of German Ideology, 94; G.G. Field, Evangelist of Race, 183-183.

46 Ibid., 96; ibid.

47 G.G. Field, Evangelist of Race, 215.

48 Ibid. Among scientists like anthropologists and ethnologists the word 'race' was used in different ways on an everyday basis, without clear-cut criteria. Chamberlain never really explained what he meant by the term and used it to all different kinds of groups of people: Aryans, Jews, Teutons, Celts, but also Prussians and the British. 
present; 2) a continuous period of endogamy, e.g. no cross-breeding; 3) natural selection based on the Darwinistic notion of 'survival of the fittest' had to take place; 4) new elements could be added to the race by controlled cross-breeding. This was only natural according to Chamberlain, which he explained by quoting Emerson: 'We are piqued with pure descent, but nature loves inoculation'. ${ }^{49}$ 5) Cross-breeding should occur limitative as too much infusion of other blood would ultimately destroy the race. ${ }^{50}$ Jews were almost the opposite of a noble race, although Chamberlain never clearly labelled them as not pure. The basic material was inferior and cross-breeding had occurred often and uncontrolled although a strict form of endogamy - which had been imposed by the Jewish religion - had prevented the race to degenerate completely. ${ }^{51}$ Although Chamberlain did not present something completely new, only twists and turns to existing theories, his book became a tremendous success, perhaps even because of the familiarity of his ideas. Everything the German intellectual world was preoccupied with - Aryan superiority, Jewish inferiority, völkish thoughts, Social Darwinism, was in it. ${ }^{52}$ Due to this success Jews were no longer considered as Germans with a different religion, but as a distinct race, despite all emancipation efforts that had been put into it as of I87I. Subsequently, the only alternative Jews had to escape discrimination - baptism - no longer helped. ${ }^{53}$

\subsection{The Position of Jews in Germany}

Traditionally the position of Jews in society was not very good. Until the end of the eighteenth century Jews were generally not wanted in Prussian cities. Only because of economic reasons a few of them were allowed to settle in Berlin, although they remained subject to many restrictions. ${ }^{54}$ Jews were considered to be 'stupid', little more than animals, uncultivated and illiterate. Many however could both read and write, though only Hebrew. This situation improved somewhat at the end of the eighteenth century, especially within cultural and intellectual circles. This was mainly due to the efforts of some Jewish intellectuals who argued in favour of integration initiated by Jews themselves. However, many Jews felt the need to convert to Christianity because most old laws concerning Jews remained in force without abatement. ${ }^{55}$ Although Napoleon improved the position of Jews after he had won the French-Prussian war in I806, the situation declined again after his defeat in I8I5. Between I806 and I8I5 Napoleon introduced the French Civil Code in those parts of Prussia which fell under French rule, granting civil rights to Jews and putting them on the same footing as Christian Prussians. This prompted King Frederick William III of Prussia, after much pressure, to sign the Edikt betreffend die bürgerlichen Verhältnisse der Juden in dem Preußischen Staate, ${ }^{56}$ a decree that granted Jews Prussian citizenship whilst abolishing many of the restrictions that existed for Jews. ${ }^{57}$

\footnotetext{
49 H.S. Chamberlain, Die Grundlagen des XIX. Jahrhunderts, 303.

50 Ibid., 301-309.

51 G.G. Field, Evangelist of Race, 221-222.

52 Ibid., 199, 223.

53 M. Burleigh and W. Wippermann, The Racial State, 36.

54 A. Elon, Duitsland en zijn Joden, 21-39.

55 Ibid., 73-97.

56 See for a shortened version of the decree J. Rohlfes, 'Judenemanzipation in Preußen', 333-348, 333-334.

57 J. Rohlfes, 'Judenemanzipation in Preußen', 333-348, 334-336.
} 
However, the decree was short-lived; it was promulgated in $18 \mathrm{I} 2$ and revoked in $18 \mathrm{I} 5$ after Napoleon had been defeated.$^{58}$ The French Civil Code was largely abolished after Napoleons defeat as well, although in the western parts of the former Confederation of the Rhine (the left bank of the Rhine and the grand duchy of Baden $)^{59}$ the Code Civil survived. ${ }^{60}$ However, even there the newly obtained civil rights of Jews turned out to be not inviolable, which was proven by the Austrian-Bavarian LandesAdministrationskommission (that ruled over the provinces of Rheinhessen and Rheinbayern), which prohibited in I8I4 again marriages between Jews and Christians. ${ }^{61}$

In the heyday of the Romantic Movement the uniqueness of people and the alleged insuperable differences between races were emphasised. The so-called Universal Man of the Age of Enlightenment no longer existed. Instead of fearing the unknown, one feared a known enemy: the integrated, assimilated Jew. ${ }^{62}$ It is difficult to explain why especially after the efforts of enlightened thinkers to consider all human beings equal - exactly the Jews were again considered to be the enemy. In Christian Europe Jews always had been outcast, having not accepted Jesus as the Messiah and killed him. ${ }^{63}$ Elon argues that after the defeat by the French feelings of nationalism sprang up. In I 8 I 6 an economic crisis caused by drought had led to famine and unemployment. People simply needed a scapegoat. Furthermore, emancipation of Jews was not extorted bottom-up by the people through a revolution, but enforced top-down by government officials.$^{64}$ This proved to be a fatal combination. In August I 8 I9 riots broke out in many German cities ${ }^{65}$ with demonstrators smashing up Jewish houses and shops, while yelling 'Hep! Hep! Jude verreck. $^{\text {66 }}$

It was not until 1848 - after the revolution in France which toppled king LouisPhilippe - that the population of the major German cities, Christians and Jews side by side, stood on the barricades for liberal reforms. As a result many liberals - including Jews - were appointed to high positions. Furthermore a start was made with the draft of a new, liberal constitution in which Christians and Jews were granted equal rights. Although this constitution was never enforced, the revolts of 1848 meant a turn in the

58 A. Elon, Duitsland en zijn Joden, 97-102.

59 See for an extensive overview of the territories that abolished and the territories that maintained the French legislation W. Schubert, 'Das französiche Recht in Deutschland zu Beginn der Restaurationszeit (1814-1820)', $129-184$.

60 F. Ranieri, '200 Jahre Code civil. Die Rolle des französischen Rechts in der Geschichte des europäischen Zivilrechts oder zum Aufstieg und Niedergang eines europäisches Kodifikationsmodells', 85-125, 90.

61 W. Schubert, 'Das französiche Recht in Deutschland zu Beginn der Restaurationszeit (1814-1820)', 129-184, 169-170

62 A. Elon, Duitsland en zijn Joden, 104-107.

63 Proof for this conviction was found in the Bible. See 1 Thessalonians 2, 15: '[Jews], who killed the Lord Jesus and the prophets and also drove us out. They displease God and are hostile to all men [...].' See also John 8,37 in which Jesus speaks to the Jews: 'Yet you are ready to kill me, because you have no room for my word.' and John 8, 44: 'You belong to your father, the devil, and you want to carry out your father's desire. He was a murderer from the beginning, not holding to the truth, for there is no truth in him. When he lies, he speaks his native language, for he is a liar and the father of lies.'

64 A. Elon, Duitsland en zijn Joden, 101-102. In 1812 liberal Prussian officials had designed a law considering the emancipation of Jews. Although Frederik Wilhelm III was opposed to this law, he finally gave in and signed the law. The Prussian population, however, was clearly not 'ready' for this apparently huge step in the Jewish emancipation process.

65 It started in Würzburg, Bayern and spread to Bamburg, Bayreuth, Darmstadt, Karlsruhe, Mannheim, Frankfurt, Koblenz, Cologne and other cities along the Rhine like Bremen, Hamburg and Lübeck.

66 A. Elon, Duitsland en zijn Joden, 109. Hep stands for Hierosolyma est perdita which means 'Jerusalem is lost'. It is either originating from Roman soldiers who besieged Jerusalem in 70 A.D. or from rioters from the Rhineland during the crusades. The riots of 1819 became known as the Hep-Hep riots. See also H.W. Smith, The Butcher's Tale, 113. 
Jewish emancipation process. This was due to the fact that the revolts had been the first time German Jews had identified themselves with German Christians. After that they considered themselves to be a German people, like the Prussians, the Silesians etc. ${ }^{67}$ After I86o political thinking slowly became more enlightened, a process which was supported by the gradual unification of Germany. ${ }^{68}$ Jews fought in the German army, felt German and proved to be German. In I87I the Gesetz betreffend die Verfassung des Deutschen Reiches finally legalised the emancipation of Jews, putting the Jews on equal footing with other Germans. ${ }^{69}$ Furthermore, mixed civil marriages between Jews and Christians were legalised in $1876 .^{70}$

However, as we have seen, unification proved not to be without difficulties. Political unity had not brought the desired cultural and social cohesion between the different sections of the population. Industrialisation caused social and economic problems and in I873 the collapse of the stock market caused an economic crisis. Again a scapegoat was needed. As most Jews had been economically successful in the last few years, they got the blame, not only for the economic crisis, but also for capitalism as such. Although the crisis was followed by a period of boom, fear for Jews remained an important element in political culture until the end of the Second German Empire in $1918 .^{71}$ The emancipation process nevertheless continued. Jews were encouraged to integrate and assimilate as it was believed that in this way Jews could lose their Jewish, undesirable qualities. ${ }^{72}$ Jews adapted themselves more and more to the German-Christian culture and the Jewish character of Jews was openly criticised by Jews themselves. ${ }^{73}$ Compared to other parts of Europe $^{74}$ the situation German Jews were living in could be called quite bright, although not perfect. ${ }^{75}$ When the First World War started, all Germans - Jews included - were euphoric. ${ }^{76}$ Hoping that the last barrier to full emancipation could be taken when fighting side by side with non-Jewish Germans, many Jews joined the army voluntarily. ${ }^{77}$ This hope was not entirely without foundations. On I August I9I4 the Emperor had spoken to the masses from his balcony: 'Ich kenne keine Parteien und auch keine Konfessionen mehr;

67 A. Elon, Duitsland en zijn Joden, 157-188.

68 Prussia defeated Austria in 1866, ending the German Confederation and establishing the North German Confederation. In 1871 France was defeated by Prussia and the Second German Empire was established, with King Wilhelm I of Prussia being proclaimed German Emperor.

69 Gesetz betreffend die Verfassung des Deutschen Reiches, Reichs-Gesetzblatt (1871), 63, § 2. Prussia adopted an emancipation law in 1869, the Gesetz betreffend die Gleichberechtigung der Konfessionen in bürgerlicher und staatsbürgerlicher Beziehung vom 3. Juli 1869, Bundes-Gesetzblatt des Norddeutschen Bundes (1869), 292, which consisted of one article reading: 'Alle noch bestehenden, aus der Verschiedenheit der religiösen Bekenntnisse hergeleiteten Beschränkungen der bürgerlichen und staatsbürgerlichen Rechte werden hierdurch aufgehoben. Insbesondere soll die Befähigung zur Theilname an der Gemeindeund Landesvertretung und zur Bekleidung öffentlicher Aemter vom religiösen Bekenntnis unabhängig sein.' This law was included in full in the Verfassung des Deutschen Bundes, Bundes-Gesetzblattdes Norddeutschen Bundes (1870), 627, Art. 80, $§ 1$ (20). See also A. Elon, Duitsland en zijn Joden, 212.

70 Reichsgesetz über die Beurkundung des Personenstandes und die Eheschließung vom 6. Februar 1875, Reichs-Gesetzblatt (1875), 23, which came into force on 1 January 1876. See also A. Elon, Duitsland en zijn Joden, 216.

71 Ibid., 218-221.

72 G.L. Mosse, The Crisis of German Ideology, 126-127.

73 A. Elon, Duitsland en zijn Joden, 233-250.

74 France e.g. was generally considered the most anti-Semitic country in Europe, despite the liberal legislation concerning the position of Jews, which had been a result of the French Revolution of 1789 . This anti-Semitism was expressed openly in the Dreyfuss-affair.

75 A. Elon, Duitsland en zijn Joden, 233.

76 Ibid., 310-311.

77 Ibid., 314. 
wir sind heute alle deutsche Brüder und nur noch deutsche Brüder. ${ }^{78}$ These words were repeated in his address from the throne on 4 August I9I4. ${ }^{79}$ Even Houston Stewart Chamberlain praised the Jews for fulfilling their duty. ${ }^{80}$ Nevertheless, when it became clear that Germany was losing the war, Jews were once again turned into scapegoats. The counting of Jews fighting at the front and serving at the rear - which was meant to suppress prejudices against Jews - had a devastating effect on the morality of the (Jewish) soldiers; once again a distinction was made. ${ }^{81}$

\subsection{The Development of Family Policy in the First Half of the Twentieth Century}

\section{- 2.4.1. Germany during the Interbellum - the Weimar Republic}

After a series of popular revolts, strikes and desertion Germany was proclaimed a republic on 9 November i9 $8 .^{82}$ Many Germans had high hopes with regard to this new republic, which was named after the city the democratically elected constitutional assembly resided, and especially Jews turned into true republicans. ${ }^{83}$ The Constitution of the Weimar Republic, which entered into force on I I August i9i9, finally granted Jews complete equal rights. ${ }^{84}$ Apart from that the emancipation of women seemed to boom as well, as they were granted the same civil rights as men, ${ }^{85}$ including the right to vote. ${ }^{86}$ Almost ten percent of the delegates elected in the first National Assembly elections were women. ${ }^{87}$

However, the Weimar Republic was characterised by several economic hardships and political instability. Germany had lost the Great War and was forced to pay reparations. When the Ruhr region was occupied by France and Belgium in January I923 in order to force Germany to pay, the Weimar government decided to passively resist by calling a general strike. In a desperate attempt to finance this passive resistance the Weimar government turned on the printing press, causing a hyper-inflation by the end of I923, when the Reich mark valued at 4.2 trillion to the American dollar (20 November 1923).88

78 Emperor Wilhelm II in his second balconyspeech on 1 August 1914. Quote found on www.dhm.de/lemo/html/dokumente/ wilhelm142/index.html.

79 Quote found on www.dhm.de/lemo/html/dokumente/wilhelm144/index.html.

80 A. Elon, Duitsland en zijn Joden, 317

81 Ibid., 346-347.

82 See for extensive background information on the rise and fall of the Weimar Republic e.g. A. Rosenberg, Entstehung und Geschichte der Weimarer Republik and P. Bookbinder, Weimar Germany. The Republic of the reasonable.

83 A. Rosenberg, Entstehung und Geschichte der Weimarer Republik, 72-73; A. Elon, Duitsland en zijn Joden, 363.

84 Die Verfassung des Deutschen Reichs vom 11. August 1919, Reichs-Gesetzblatt (1919), 1383. See e.g. Article 109: 'Alle Deutschen sind vor dem Gesetze gleich. [...].', Article 135: 'Alle Bewohner des Reichs genießen volle Glaubens und Gewissensfreiheit. [...].' and Article 136: 'Die bürgerlichen und staatsbürgerlichen Rechte und Pflichte werden durch die Ausübung der Religionsfreiheit weder bedingt noch beschränkt. [...].'

85 Verfassung des Deutschen Reichs vom 11. August 1919, Reichs-Gesetzblatt (1919), 1383, Article 109: ‘[...] Männer und Frauen haben grundsätzlich dieselben staatsbürgerlichen Rechte und Pflichten. [...].'

86 The first time women were granted the right to vote was in November 1918, when it was decided that women were allowed to vote for the constitutional assembly as well. See Verordnung über die Wahlen zur verfassungsgebenden deutschen Nationalversammlung vom 30. November 1918, Reichs-Gesetzblatt (1918), 1345, § 2: 'Wahlberechtigt sind alle deutschen Männer und Frauen, die am Wahltag das 20. Lebensjahr vollendet haben.' The Weimar Constitution thereupon recognised women suffrage for the German parliament in Article 22. See Verfassung des Deutschen Reichs vom 11. August 1919, ReichsGesetzblatt (1919), 1383, Article 22: 'Die Abgeordneten werden in allgemeiner, gleicher, unmittelbarer und geheimer Wahl von den über zwanzig Jahre alten Männern und Frauen nach den Grundsätzen der Verhältniswahl gewählt. [...].'

87 R. Bridenthal, A. Grossmann and M. Kaplan, When Biology Became Destiny, 7.

88 H.A. Winkler, Weimar 1918-1933, 188-237; R. Bridenthal, A. Grossmann and M. Kaplan, When Biology Became Destiny, 8; P. Bookbinder, Weimar Germany, 167-168. 
The introduction of the Rentenmark nevertheless stabilised the German currency and the Dawes plan of 1924, which enabled foreign (mainly US) loans to Germany and introduced a long-term repayment schedule, further helped the economy to recover. Between 1924 and 1929 the German economy grew and by 1927 Germany was producing at pre-war rates. The drawback of the Dawes plan (and its 1929 follow-up, the Young plan) was that it made Germany heavily dependent on foreign economies, especially the American economy. When the American stock market prices collapsed in October 1929, Germany was hit hard. ${ }^{89}$ In 1932, when the NSDAP started winning the elections, unemployment figures had risen to 6 million, which was about a fifth of the labour force. ${ }^{90}$

As Germany was politically deeply divided, the German government was unable to stem the tide; between the elections for the National Assembly in I9I9 and January 1933 when Hitler was appointed Reich chancellor, there had been twenty cabinets. ${ }^{91}$ After a flying start, the German population had quickly lost confidence in the Weimar Republic and its politicians. Already in March 1920 the Weimar Republic was threatened to be overthrown when the Marine Brigade Erhardt, a Free Corps which refused to demobilise, marched into Berlin, causing the government's flight from the capital. A general strike among the workers finally ended this Kapp Putsch, named after the intended Reich chancellor Wolfgang Kapp, as General von Seeckt, who had refused to suppress the rebellion, called upon the Free Corps to put down the strike, effectively taking control over the Free Corps again. ${ }^{92}$ Furthermore, it quickly appeared that equal rights on paper did not necessarily mean the end of anti-Semitism. Rosa Luxemburg, a Jewish socialist, was murdered in January 1919, the Jewish Minister for Foreign Affairs Walther Rathenau in June $1922 .{ }^{93}$ Over the years votes increasingly shifted from the pro-Weimar (social) democratic parties to the more nationalistic parties, with the NSDAP getting $18.3 \%$ of the votes in September 1930 and $37.4 \%$ in July I932. ${ }^{94}$ The NSDAP lost some votes in the elections of November 1932, when they got 33.I \%. ${ }^{95}$ On 30 January 1933, Hitler was nevertheless appointed Reich Chancellor of a coalition government with only two NSDAP ministers, in a futile attempt to keep the National Socialists under control. ${ }^{96}$

\section{- 2.4.2. Population policy before the Weimar Republic}

Following the ideas of Thomas Malthus (I766-I834), nineteenth century population policy was characterised by a fear of overpopulation. ${ }^{97}$ In his Essay on the Principle of

89 P. Bookbinder, Weimar Germany, 168-174; R. Bridenthal, A. Grossmann and M. Kaplan, When Biology Became Destiny, 9, 14; H.A. Winkler, Weimar 1918-1933, 357-358.

90 P. Bookbinder, Weimar Germany, 174; R. Bridenthal, A. Grossmann and M. Kaplan, When Biology Became Destiny, 14; R. Grunberger, A Social History of the Third Reich, 24; P. Panayi, 'Continuities and discontinuities in German history, 1919$1945,9$.

91 R. Bridenthal, A. Grossmann and M. Kaplan, When Biology Became Destiny, 6. See also www.bundesarchiv.de/ oeffentlichkeitsarbeit/bilder_dokumente/00755/index-0.html.de.

92 H.A. Winkler, Weimar 1918-1933, 121-126; P. Bookbinder, Weimar Germany, 56-57; R. Bridenthal, A. Grossmann and M. Kaplan, When Biology Became Destiny, 8; A. Elon, Duitsland en zijn Joden, 376.

93 H.A. Winkler, Weimar 1918-1933, 59-60, 174; A. Elon, Duitsland en zijn Joden, 376-377; R. Grunberger, A Social History of the Third Reich, 15.

94 H.A. Winkler, Weimar 1918-1933, 505-506; P. Bookbinder, Weimar Germany, 51.

95 H.A. Winkler, Weimar 1918-1933, 535.

96 H.A. Winkler, Weimar 1918-1933, 535-594; E. Feuchtwanger, 'The transition from Weimar to the Third Reich: the political dimension', in P. Panayi (ed.), Weimar and Nazi Germany, 105-133-110; A. Elon, Duitsland en zijn Joden, 398-399.

97 C. Usborne, The Politics of the Body in Weimar Germany, 1. 
Population, first published anonymously in 1798 and in a much extended edition with acknowledged authorship in I803, Malthus expressed his theory that in times of economic growth the population would grow faster than the production of food, which would have devastating consequences. ${ }^{98}$ Therefore, he pleaded for a limitation of population growth by postponement of marriages and continence. ${ }^{99}$ Despite Malthus' warnings, however, most European countries experienced an explosive population growth in the nineteenth century. In Germany the growth percentage almost tripled from 20 between I750-I80o to 50 between $1800-1850$ and 59 between $1850-1900,{ }^{100}$ leading to a population of over 56 million in I9oo compared to nearly 25 million in I $800 .{ }^{101}$

In the second half of the nineteenth century though, the attitude towards population growth changed. It was no longer considered detrimental to the nation's welfare, but was associated with military power and progress. A nation's power was dependent on its fertility. However, by the turn of the century it became clear that although the population was still growing, the birth rate was rapidly declining. The fact that the population was still growing despite a declining birth rate was largely due to the fact that the mortality rate dropped significantly as well. ${ }^{102}$ The declining mortality rate was caused by better hygienic standards, clean drinking-water, smallpox vaccinations and most of all a change of diet, by replacing wheat by potatoes as popular food. ${ }^{103}$

Although this trend was noticeable in other Western European countries as well, the decline in birth rate went more rapidly in Germany than in other countries. Furthermore, it coincided with an important socio-economic transformation in Germany. ${ }^{104}$ Prussia had won the Franco-Prussian war in I87I and had subsequently formed a unified German empire with the other states of the North German Confederation and the southern German states, excluding, however, Austria. ${ }^{105}$ Germany, the winner, liked to compare itself with France, the loser, which had a much lower fertility rate than Germany, which in 1876 had the highest birth rate in Europe (excepting Russia) with 40.6 per thousand.$^{106}$ France, whose growth percentages were already declining since $1850,{ }^{107}$ was often compared with ancient Rome and the circumstances causing its fall. ${ }^{108}$ After 1876 however, the German birth rate rapidly started to decline, much faster than it did in France, although the population was still growing. These demographic changes coincided with major changes in German politics, the German economy and society. Between the unification in I87I and the start of the First World War in I9I4 Germany became the world's industrial leader, where it had been a mainly agrarian society before. However,

98 T.R. Malthus, An Essay on the Principle of Population, 13-20. See in this respect also E. Kloek, 'Huwelijk en gezinsleven tijdens het Ancien Régime, 1650-1800', 154.

99 T.R. Malthus, An Essay on the Principle of Population, 21-29. See in this respect also E. Kloek, 'Huwelijk en gezinsleven tijdens het Ancien Régime, 1650-1800', 154; D. Damsma, 'De dubbele revolutie en het gezin', 177.

100 D. Damsma, 'De dubbele revolutie en het gezin', 174.

101 C. Usborne, The Politics of the Body in Weimar Germany, 1.

102 D. Damsma, 'De dubbele revolutie en het gezin', 174; C. Usborne, The Politics of the Body in Weimar Germany, 1-2. See furthermore on the first demographic transition in Western Europe T. Zwaan, 'Recente transities in huwelijk, gezin en levenscyclus', 243-247.

103 D. Damsma, 'De dubbele revolutie en het gezin', 174.

104 C. Usborne, The Politics of the Body in Weimar Germany, 3.

105 A. Elon, Duitsland en zijn Joden, 204.

106 C. Usborne, The Politics of the Body in Weimar Germany, 3.

107 D. Damsma, 'De dubbele revolutie en het gezin', 174.

108 C. Usborne, The Politics of the Body in Weimar Germany, 3. 
the economic success was not only attributed to its transformation from ploughs to machines, but also to its enormous population growth. ${ }^{109}$ Despite ideas about eugenics and neo-Malthusianism, the German government pursued a mainly pro-natal population policy. This was largely influenced by medical attitudes as many doctors believed that, as family health was a necessary ingredient for a healthy nation, a decline in birth rates was undesirable. Many of them suggested government interference in order to stop this decline, by recommending e.g. monetary support to encourage people to procreate. ${ }^{110}$ The use of contraceptives was discouraged by a ban on advertising it. ${ }^{111}$ In I9 Io the government even drafted a bill that would prohibit the use of contraceptives. However, due to opposition from the Social Democrat Party, the chemical industry and the press, this bill was rejected. The government increasingly considered stimulating the nation's birth rates its task. However, proposals with regard to economic incentives were not taken up. Instead the government concentrated on repressive legislation. Two other proposals to prohibit the use of contraceptives were drafted in I9I3 and I9I4, but both bills were shelved because of the start of the First World War. ${ }^{112}$

Increasing the nation's birth rate became only more urgent because of the outbreak of the First World War in August I9I4. To win a war soldiers were needed in large quantities. However, many men, much more than expected, perished on the battlefields, whilst the German birth rate, understandably with the majority of the fertile men lying in the trenches, declined even faster. State intervention in family life reached a peak in Germany during the war. ${ }^{113}$ In December I9I4 the Kriegswochenhilfe was introduced, which granted maternity benefits to soldiers' wives. ${ }^{114}$ In I9I5 this was extended to unmarried women who could prove that the father of the child was on active service. ${ }^{115}$ The status of illegitimate children was raised in I9I5, entitling the family to war allowances and the state pension usually paid to the families of soldiers. ${ }^{116}$ However, repressive measures were taken as well. The sale of contraceptives was prohibited in I9I5, although an exception was made for condoms, as soldiers were encouraged to use these to prevent the spreading of venereal diseases. In I9I 8 the rules with regard to abortion and sterilisation were further tightened. ${ }^{117}$

109 Ibid. See also D. Damsma, 'De dubbele revolutie en het gezin', 174. Germany had a growth percentage of 59 between 1850 1900 and even 63 between 1900-1950.

110 C. Usborne, The Politics of the Body in Weimar Germany, 10-11.

111 The so-called Lex Heinze, which was named after a Berlin pimp and came into force on 25 June 1900, altered § 184 of the Penal Code and prohibited in sub 3 the display and advertisement of objects which were intended for 'indecent use'. Breach of the Lex Heinze was punished with up to a year imprisonment or up to a 1000 mark fine. See G. D. Stark, 'Pornography, Society, and the Law In Imperial Germany', 14 Central European History 3 (1981), 200-229, 216-217. The Lex Heine caused indignation amongst artists, laywers and academics, not only in Germany, but also abroad. See e.g. O. Falckenberg (ed.), Das Buch von der Lex Heinze.

112 C. Usborne, The Politics of the Body in Weimar Germany, 11-14.

113 Ibid., 16.

114 Gesetz zur Änderung des Gesetzes, betreffend die Unterstützung von Familien in den Dienst eingetretener Mannschaften, vom 28. Februar 1888 (Reichs-Gesetzbl. S. 59) vom 4 August 1914, Reichs-Gesetzblatt (1914), 332.

115 Bekanntmachung, betreffend Ausdehnung der Wochenhilfe während des Krieges vom 23. April 1915, Reichs-Gesetzblatt (1915), 257.

116 C. Usborne, The Politics of the Body in Weimar Germany, 20

117 Ibid., 21-22. 
Apart from legal measures, an ideological campaign was started to encourage women to have more children. Women were told that they could contribute to the German war effort by bearing children. ${ }^{118}$ Motherhood was glorified and women were encouraged to quit their paid jobs and stay at home to raise the children. That this policy was not very realistic while there was a major war going on, was proven by the figures of women working in the war industries; well over two million, many of them married and having small children. ${ }^{119}$

Despite all measures taken, birth rates continued to decline. Studies undertaken during the war showed that children were regarded as a burden and too expensive instead of a blessing. Banning the sale of contraceptives did little to stop this as the most frequent used method of contraception, coitus interruptus, was free. Furthermore, despite the stern abortion laws, the number of abortions increased during the war as well. ${ }^{120}$

The war did not only take its toll on the German birth rate, traditional family values underwent some changes as well. Before the First World War the family pattern had been very patriarchal. ${ }^{121}$ Due to conscription this patriarchal authority rapidly got lost during the war, creating a social vacuum. ${ }^{122}$ With so many women working in the war industries the traditional role of women gradually changed. ${ }^{123}$ Apart from that many men returned home crippled or traumatised or did not return at all as many had died in battle. ${ }^{124}$ After the war there were only enough potential husbands for about $75 \%$ of the German women aged between 25 and $30 .^{125}$

\section{- 2.4.3. Population and family policy during the Weimar Republic}

With regard to population policy the Weimar years were characterised by a lack of uniform policy. This was already visible in the Constitution. Article i I9 of the Weimar Constitution protected marriage as the foundation of family life and the preservation of the nation. The government was concerned with the welfare of families, in particular kinderreiche families, and motherhood enjoyed special protection by the State. ${ }^{126}$ However, notwithstanding the sanctity of marriage, Article I2I granted illegitimate children the same rights as legitimate children. ${ }^{127}$ Additionally, Article I6 3 granted every German,

118 C. Usborne, The Politics of the Body in Weimar Germany, 18.

119 Ibid., 23. See also R. Bridenthal, A. Grossmann and M. Kaplan, When Biology Became Destiny, 3; A. de Regt, 'Het onststaan van het "moderne" gezin, 1900-1950', 221.

120 C. Usborne, The Politics of the Body in Weimar Germany, 25-28.

121 R. Grunberger, A Social History of the Third Reich, 299; L. Pine, Nazi Family Policy, 1933-1945, 5.

122 L. Pine, Nazi Family Policy, 1933-1945, 5.

123 R. Bridenthal, A. Grossmann and M. Kaplan, When Biology Became Destiny, 3.

124 L. Pine, Nazi Family Policy, 1933-1945, 5.

125 R. Grunberger, A Social History of the Third Reich, 298.

126 Die Verfassung des Deutschen Reichs vom 11. August 1919, Reichs-Gesetzblatt (1919), 1383, Article 119: 'Die Ehe steht als Grundlage des Familienlebens und der Erhaltung und Vermehrung der Nation unter dem besonderen Schutz der Verfassung. Sie beruht auf der Gleichberechtigung der beiden Geschlechter. Die Reinerhaltung, Gesundung und soziale Förderung der Familie ist Aufgabe des Staats und der Gemeinden. Kinderreiche Familien haben Anspruch auf ausgleichende Fürsorge. Die Mutterschaft hat Anspruch auf den Schutz und die Fürsorge des Staats.'

127 Die Verfassung des Deutschen Reichs vom 11. August 1919, Reichs-Gesetzblatt (1919), 1383, Article 121: 'Den unehelichen Kindern sind durch die Gesetzgebung die gleichen Bedingungen für ihre leibliche, seelische und gesellschaftliche Entwicklung zu schaffen wie den ehelichen Kindern.' 
including women, the right to work, ${ }^{128}$ which was at odds with the promise in Article I I9 to promote population growth and to protect motherhood. ${ }^{129}$

In politics the revaluation of motherhood was particularly advocated by the women parliamentarians and women organisations. Apart from increasing the health and welfare of mothers, women should also be offered the choice whether to become a mother or not. ${ }^{130}$ Since after the Great War Germany had to contend with a significant surplus of women, becoming a mother was no longer as self-evident as it used to have been. ${ }^{131}$ Besides that the economic situation during the first Weimar years was far from rosy, prompting many couples to postpone conceiving their first child.

The economic situation during the first Weimar years led to considerable political differences with regard to population policy. With the ever decreasing birth rates hanging as some sort of sword of Damocles over the nation's future, women were on the one hand encouraged to replenish the population lost during the war, ${ }^{132}$ i.e. fallen soldiers, but also children that had never been born because of the war and the Germans lost due to territorial changes after the Treaty of Versailles. ${ }^{133}$ On the other hand it was considered unfair to request young couples to have many children, without knowing whether they would be able to feed them. ${ }^{134}$ Instead of quantity the focus was shifted to quality; not more, but better children. ${ }^{135}$ Although the number of marriages did not decline during the Weimar years - there was even a marriage boom in $1920^{136}$ - birth rates continued to drop. In I 900 the birth rate per thousand had been 36 , which plummeted to 20.3 in the twenties and to 14.7 in $1933 .{ }^{137}$ With this figure, Germany had the lowest birth rate in Europe. $^{138}$

In fulfilment to the promise made in Article i 9 of the Constitution, economic support to families on a more permanent basis was introduced during the Weimar years. The temporary maternity allowances introduced during the war were made permanent in I919. ${ }^{139}$ In 1927 Germany ratified the Washington Maternity Protection Convention, ${ }^{140}$ extending maternity leave from eight to twelve weeks, granting time for breast-feeding

128 Die Verfassung des Deutschen Reichs vom 11. August 1919, Reichs-Gesetzblatt (1919), 1383, Article 163: '[...] Jedem Deutschen soll die Möglichkeit gegeben werden, durch wirtschaftliche Arbeit seinen Unterhalt zu erwerben. [...].'

129 C. Usborne, The Politics of the Body in Weimar Germany, 35.

130 C. Usborne, The Politics of the Body in Weimar Germany, 39, 209.

131 R. Grunberger, A Social History of the Third Reich, 298; C. Usborne, The Politics of the Body in Weimar Germany, 81, 210; R. Bridenthal, A. Grossmann and M. Kaplan, When Biology Became Destiny, 7.

132 L. Pine, 'Women and the family', 200; R. Bridenthal, A. Grossmann and M. Kaplan, When Biology Became Destiny, 7; C. Usborne, The Politics of the Body in Weimar Germany, 32-37.

133 C. Usborne, The Politics of the Body in Weimar Germany, 31; R. Bridenthal, A. Grossmann and M. Kaplan, When Biology Became Destiny, 7.

134 C. Usborne, The Politics of the Body in Weimar Germany, 38, 102-103.

135 C. Usborne, The Politics of the Body in Weimar Germany, 34.

136 W.H. Hubbard, Familiengeschichte, 73. See also C. Usborne, The Politics of the Body in Weimar Germany, 90.

137 W.H. Hubbard, Familiengeschichte, 93; R. Grunberger, A Social History of the Third Reich, 299.

138 C. Usborne, The Politics of the Body in Weimar Germany, 32.

139 Gesetz über Wochenhilfe und Wochenfürsorge vom 26. September 1919, Reichs-Gesetzblatt (1919), 1757.

140 Gesetz über das Washingtoner Übereinkommen, betreffend die Beschäftigung der Frauen vor und nach der Niederkunft vom 16. Juli 1927, Reichsgesetzblatt (1927), II, 497. See also C. Usborne, The Politics of the Body in Weimar Germany, 46-47. 
during working hours and protecting (future) mothers against dismissal. ${ }^{141}$ Child benefits were introduced as of May I924. ${ }^{142}$ To a certain extent these measures did not completely have the intended result. Twelve weeks of maternity leave e.g. proved to be impossible for many women as the maternity benefits were considerably lower than the wages. The child benefits were more symbolic than a real incentive to have children. Furthermore, due to the inflation in 1922 and 1923 maternity benefits no longer covered the actual costs and both in 1924 and during the Depression in the beginning of the nineteenthirties welfare benefits were largely cut. ${ }^{143}$

Despite equality of sexes on paper, the ideology of motherhood was reinforced as well, although during the Weimar years motherhood was largely stimulated by positive incentives. ${ }^{144}$ In Prussia every mother with twelve children was awarded Ioo Reich mark or a Royal Prussian china cup. In Baden 30 Reich mark was awarded for every seventh child, provided that it was a legitimate child. ${ }^{145}$ Despite Article 163 of the Constitution women were encouraged to give up paid labour in order stay at home and raise the children, which was considered the biological duty of women. To a certain extent this point of view was even supported by women organisations that did not so much advocate for a change in the traditional sex stereotyping, but for appreciation of women in their natural role as mothers and maternity benefits. ${ }^{146}$ Women emancipation therefore only slowly began to take shape during these years. After a flying start in I 919 when universal suffrage was established, equality guaranteed by the Constitution and about ten percent of the representatives elected were female, progress waned. Family life remained largely patriarchal. ${ }^{147}$

The shift from quantity to quality is also visible in the changing attitude towards contraceptives and abortion. Abortion was declared punishable in $\mathbb{S} 218-220$ of the Penal Code of I87I. In I926 these three paragraphs were replaced by a new $\mathbb{} 218,{ }^{148}$ which more or less covered the three previous paragraphs. As we have seen before, the advertisement of contraceptives was banned in I9oo. However, by many Germans, especially women, both the use of contraceptives and abortion were regarded as means to prevent the birth of extra mouths to feed in times of economic crisis. And although both the use of contraceptives and abortion were associated with declining morality and indecency, especially by the conservative right-wing parties, under pressure of the several economic and political crises during the Weimar years, the general point of view slowly began to change.

141 Convention concerning the Employment of Women before and after Childbirth (convention C003). This convention was adopted by the International Labour Organisation on 28 November 1919 and entered into force on 13 June 1921. Germany was one of the first countries to ratify this convention. See www.ilo.org/dyn/normlex/en/f?p=NORMLEXPUB:11300:0::NO:11300 :P11300_INSTRUMENT_ID:312148:NO and C. Usborne, The Politics of the Body in Weimar Germany, 48-49.

142 C. Usborne, The Politics of the Body in Weimar Germany, 43.

143 C. Usborne, The Politics of the Body in Weimar Germany, 43-49.

144 C. Usborne, The Politics of the Body in Weimar Germany, 53-63.

145 C. Usborne, The Politics of the Body in Weimar Germany, 44.

146 C. Usborne, The Politics of the Body in Weimar Germany, 210-211; R. Bridenthal and C. Koonz, 'Beyond Kinder, Küche, Kirche: Weimar Women in Politics and Work', 56.

147 L. Pine, Nazi Family Policy, 1933-1945, 6; L. Pine, 'Women and the family', 200.

148 Gesetz zur Abänderung des Strafgesetzbuchs vom 18. Mai 1926, Reichsgesetzblatt (1926), I, 239. 
Especially the use of contraceptives became gradually more accepted. Several factors contributed to this development. First of all, contraceptives could be used in the fight against abortion, which encountered a lot more resistance, but which also posed a potential, serious threat to women's health and lives. But more importantly contraceptives could be used to limit the number of Germans that had to be housed, dressed and fed in times of economic difficulties. The socio-economic hardships of the immediate post-war years fuelled the interest in social hygiene: fewer, but better children. Overcrowding caused many serious health problems such as tuberculosis. Venereal diseases were another threat to public health. Both could be controlled by the use of contraceptives, in the case of venereal diseases by the use of condoms. The strength of the nation was no longer dependent on the amount of children, but on public health. ${ }^{149}$ In 1927 a law was adopted which allowed for 'inoffensive' advertising contraceptives as prophylactics. ${ }^{150}$ When Germany was hit hard by the Depression in 1929, birth control in general became more and more accepted. However, the use of contraceptives should only be allowed on doctor's orders and only in the interest of the nation. Birth control should by no means be regarded as an individual right of women. Obviously, this point of view neglected the fact that coitus interruptus remained the most popular way of contraception as it was easy, free and could be used without consulting a doctor. ${ }^{151}$

Although the opposition to abortion was much stronger, the demand for reforms could be heard here as well. However, these demands did not share a uniform perspective. On the one hand, political parties, especially the left side of the political spectrum, made an economic analysis and considered abortion necessary in times of economic hardship. Their perspective was the nation's welfare. Many women organisations on the other hand demanded legalisation of abortion as a woman's right to control her own body, especially in times when women had the unrewarding task of feeding many mouths when there was nothing available but air. Apart from that, undergoing an abortion was potentially dangerous to a woman's health, sometimes even endangering her life. ${ }^{152}$ In the early nineteen twenties several attempts to legalise abortion in one way or another were undertaken, ${ }^{153}$ until in $1926 \mathbb{\$}$ 21 8 - 220 of the Penal Code were merged into a single $\mathbb{S} 218 .{ }^{154}$ Although it in no way legalised abortion, the merit of this law was the fact that abortion was no longer punishable by penal servitude, but by jail sentence. ${ }^{155}$ When

149 C. Usborne, The Politics of the Body in Weimar Germany, 102-112.

150 Gesetz zur Bekämpfung der Geschlechtskrankheiten vom 18. Februar 1927, Reichsgesetzblatt (1927), I, 61. See in particular $\S 16,11$.

151 C. Usborne, The Politics of the Body in Weimar Germany, 129-133.

152 C. Usborne, The Politics of the Body in Weimar Germany, 159-160, 194-195; A. Grossmann, 'Abortion and Economic Crisis: The 1931 Campaign Against Paragraph 218', 69.

153 In July 1920 the Indepedent Social Democratic Party (Unabhängige Sozialdemokratische Partei Deutschlands, USPD) called for a total abolition of the prohibition of abortion, even the prohibition of abortion without consent. A few weeks later the Social Democratic Party (Sozialdemokratische Partei Deutschlands, SPD) called for abortion on demand within the first three months of the pregnancy, but only when the abortion was either self-induced or procured by a doctor. In 1922, following the USPD's initiative, the Communist Party (Kommunistische Partei Deutschlands, KPD) again called for abolition of the prohibition of abortion, with the exception of the prohibition of abortion without consent. In the same year Gustav Radbruch, then Minister of Justice, attempted to revise the Penal Code, including the articles concerning divorce, although he did not call for a legalisation of divorce as Radbruch correctly assumed that such a proposal would never be accepted by the cabinet. See C. Usborne, The Politics of the Body in Weimar Germany, 166-173; L. Pine, 'Women and the family', 208.

154 Gesetz zur Abänderung des Strafgesetzbuchs vom 18. Mai 1926, Reichsgesetzblatt (1926), I, 239.

155 A. Grossmann, 'Abortion and Economic Crisis: The 1931 Campaign Against Paragraph 218', 80 (note 6); C. Usborne, The Politics of the Body in Weimar Germany, 173; L. Pine, 'Women and the family', 208-209. 
because of the Depression, which started in 1929, the need for birth control became more urgent, the number of illegal abortions rapidly increased ${ }^{156}$ and the call for legalisation of abortion strengthened. Especially the papal encyclical Casti Connubii, issued by Pope Pius XI on 3I December 1930, which denounced women emancipation, confirmed women's subordination to men and condemned the use of contraceptives and abortion since procreation was the natural goal of marriage,${ }^{157}$ and the arrests of Dr. Else Kienle and Dr. Friedrich Wolf on I9 February I93I because of having performed abortions, caused a storm of protest against $\mathbb{\$} 218 .{ }^{158}$ From this time dates Brechts cynical poem Ballade vom Paragraphen 2I8:

\author{
Seien Sie mal 'ne nette kleine Mutter \\ Und schaffen mal 'n Stück Kanonenfutter \\ Dazu ham Sie 'n Bauch, und das müssen Sie auch \\ Und das wissen Sie auch \\ Und jetzt keinen Stuß \\ Und jetzt werden Sie Mutter und Schluß. ${ }^{159}$
}

The protests came to a head on International Women's Day, 8 March I93I, with rallies and protests all over Germany and on I5 April I931, when more than 15,000 people were rallying in Berlin. ${ }^{160}$ However, despite all protests it would take until 1972 for the DDR and 1976 for the BRD before the rules concerning abortion were significantly reformed. ${ }^{161}$ As we will see, the reins were even tightened by the Nazis in $1933 .{ }^{162}$

\title{
- 2.4.4. Social hygiene and eugenics in the Weimar years
}

The shift from quantity to quality reinforced the interest in eugenics. The term 'eugenics' was not new. As we have seen before, it had already been coined by Francis Galton in I883. ${ }^{163}$ The economic and social difficulties of the Weimar Republic and the increased awareness concerning public health and the nation's strength led to a revival of the concept. Gradually the individual, unlike the community, became less important. The individual had to serve the community instead of existing for its own purposes. The German community however, contended with a significant social question that had to

156 Statistics with regard to the estimated annual amount of abortions carried out were notoriously inaccurate and were used by both supporters and opponents of legalisation of abortion for their own propaganda. See A. Grossmann, 'Abortion and Economic Crisis: The 1931 Campaign Against Paragraph 218', 80-81 (note 9); C. Usborne, The Politics of the Body in Weimar Germany, 185-187.

157 Casti Connubii, encyclical of Pope Pius XI on Christian marriage to Venerable Brethren, Patriarchs, Primates, Archbishops, Bishops, and other local ordinaries enjoying peace and communion with the apostolic see (31 December 1930), available at www.vatican.va/holy_father/pius_xi/encyclicals/documents/hf_p-xi_enc_31121930_casti-connubii_en.html.

158 A. Grossmann, 'Abortion and Economic Crisis: The 1931 Campaign Against Paragraph 218', 71-73.

159 Republished under the title Herr Doktor... in B. Brecht, Gesammelte Werke. Band 8, Gedichte 1, 382-383. 'You're going to be a lovely little mother/ You're going to make a bunch of cannonfodder/ That's what your belly's for/ And that's no news to you/ And now do not squall/ You're having a baby, that's all.' Translation by A. Grossmann, 'Abortion and Economic Crisis: The 1931 Campaign Against Paragraph 218', 66-67.

160 A. Grossmann, 'Abortion and Economic Crisis: The 1931 Campaign Against Paragraph 218 ', 74.

161 C. Usborne, The Politics of the Body in Weimar Germany, 164.

162 L. Pine, 'Women and the family', 209.

163 M. Burleigh and W. Wippermann, The Racial State, 29. 
be solved. Eugenics and social hygiene were considered to be the solution. ${ }^{164}$ During the Weimar years eugenics and social hygiene became increasingly supported by government officials ${ }^{165}$ and with the appointment of Fritz Lentz, a student of Alfred Ploetz, as professor of racial hygiene at Munich University ${ }^{166}$ and Carl Correns as professor for human genetics at Berlin University in I923, eugenics became a respected subject in academic circles as well. ${ }^{167}$ Even the Catholic Church seemed to condone eugenic counselling for married couples, although the use of artificial contraceptives, sterilisation and abortion was ruled out. ${ }^{168}$ The interest in eugenics was not solely found on the political right, but with the entire political spectrum. ${ }^{169}$ Not all eugenicists accepted the theories of Nordic supremacy. A distinction has to be made between the Social Darwinists, who used the term 'racial hygiene' and who were focused on keeping a specific group of Germans racially pure and a group of social reformers, mostly from the political left, who were concerned about solving the social problem in a humanitarian way. As this group was not concerned about race, they preferred the term 'eugenics' rather than 'racial hygiene'. Social Darwinists used the term interchangeably. The case of the so-called Rheinlandbastarde (Rhineland Bastards), children born from German mothers and French soldiers who were of African descent, confirmed the significance of racial hygiene for the Social Darwinists. Nevertheless, in the Weimar years, eugenics remained more concerned with class than with race. ${ }^{170}$

When talking about eugenics, we have to distinguish between positive and negative eugenics, positive eugenics encouraging the hereditary 'fit' to procreate through financial benefits, health care and education, whilst negative eugenics entailed the elimination of the 'unfit' by discouraging them to procreate and by sterilisation. Alfred Grotjahn, professor of social hygiene at Berlin University since 1920 and a member of the Social Democratic Party (SPD), advocated a combination of positive and negative eugenic measures. Couples should be classified according to hereditary value, whereby the fit and valuable should be encouraged - by financial incentives - to have more than three children, whereas couples who were clearly genetically inferior, such as people with venereal diseases and alcoholics, should not procreate at all. In-between cases should stick to a maximum of three children. To prevent procreation of the hereditary inferior, Grotjahn was in favour of the use of contraceptives, but also of eugenic sterilisation. ${ }^{171}$

When Germany was hit by the Depression and the costs for social welfare were no longer affordable, the attention for eugenic sterilisation and other forms of negative eugenics increased. The idea of marriage certificates, which had already been proposed in

164 C. Usborne, The Politics of the Body in Weimar Germany, 133-134; M. Burleigh and W. Wippermann, The Racial State, 32-34.

165 C. Usborne, The Politics of the Body in Weimar Germany, 135-136.

166 See for a biography of Fritz Lenz R. Rissom, Fritz Lenz und die Rassenhygiene, 15-25.

167 C. Usborne, The Politics of the Body in Weimar Germany, 137.

168 C. Usborne, The Politics of the Body in Weimar Germany, 137. See also Casti Connubii, encyclical of Pope Pius XI on Christian marriage to Venerable Brethren, Patriarchs, Primates, Archbishops, Bishops, and other local ordinaries enjoying peace and communion with the apostolic see (31 December 1930), point 66, available at www.vatican.va/holy_father/pius_xi/encyclicals/ documents/hf_p-xi_enc_31121930_casti-connubii_en.html.

169 C. Usborne, The Politics of the Body in Weimar Germany, 138; L. Pine, Nazi Family Policy, 11; L. Pine, 'Women and the family', 202.

170 M. Burleigh and W. Wippermann, The Racial State, 128; C. Usborne, The Politics of the Body in Weimar Germany, 133-134; L. Pine, Nazi Family Policy, 11; L. Pine, 'Women and the family', 202-203.

171 C. Usborne, The Politics of the Body in Weimar Germany, 139, 141; M. Burleigh and W. Wippermann, The Racial State, 32. 
the nineteenth century and lobbied for before the First World War by both the Bund für Mutterschutz (League for the Protection of Mothers) and the Monist League, was dug up again. This idea involved a medical examination for future spouses to check whether they were hereditary healthy, after which - in case of approval - a certificate would be issued, which would be a requirement for marriage. Although a compulsory medical examination was not adopted, the National Assembly did accept an amendment of the Gesetz über die Beurkundung des Personenstandes und die Eheschließung in June 1920, ${ }^{172}$ concerning the distribution of a leaflet on the importance of pre-marital medical examination by registrars. ${ }^{173}$ However, prohibiting marriages on eugenic grounds would obviously not prevent the birth of hereditary inferior children. Most likely it would only lead to an increase of extramarital procreation. The establishment of municipal marriage clinics (Eheberatungsstellen) was nevertheless encouraged by the local authorities. ${ }^{174}$

Apart from pre-marital counselling, the call for legalisation of eugenic sterilisation increased as well. Sterilisation was considered an effective and economical method of preventing further decline of the nation's health, as it would guarantee that no children would be born. Strictly speaking, sterilisation was prohibited by $\mathbb{2} 24$ of the Penal Code. However, this article spoke about Körperverletzung, inflicting bodily harm, resulting in infertility. It did not mention sterilisation as such, as this operation was hardly known in I87I, the year the Penal Code was enacted. Therefore, $\mathbb{} 224$ was open to interpretation. In practice voluntary sterilisation happened fairly regularly. ${ }^{175}$

Compulsory eugenic sterilisation was most famously brought to the attention by Gustav Boeters, the Zwickau District Health Officer, who came up with a draft law, entitled Die Verhütung unwerten Lebens durch operative Maßnahmen, allowing for compulsory sterilisation of people born blind, deaf, simpleminded or with epilepsy, people who were mentally ill or having mental deficiencies, people who were 'morally unbalanced' and women having two illegitimate children, whose paternity could not be established. Furthermore, hereditary inferior criminals would be eligible for a reduction of their sentence if they would have themselves sterilised. ${ }^{176}$ However, this draft, popularly called the Lex Zwickau, was rejected by the Reichstag in I925, although it was not entirely without support. ${ }^{177}$ The question was no longer whether eugenic sterilisation should be allowed or not, but whether this should be voluntary or compulsory.

The final attempt to legalise (voluntary) sterilisation was undertaken by the Prussian Health Council in 1932, which drafted a bill that allowed for voluntary sterilisation of certain types of hereditary ill persons. The draft was sent to the Reich government at the end of 1932, but was not passed due to the political problems of that moment. ${ }^{178}$ Officially,

172 Gesetz über den Personenstand vom 11. Juni 1920, Reichs-Gesetzblatt (1920), 1209, Article 1 (4).

173 C. Usborne, The Politics of the Body in Weimar Germany, 142.

174 C. Usborne, The Politics of the Body in Weimar Germany, 143-148.

175 C. Usborne, The Politics of the Body in Weimar Germany, 148-150. See also G. Bock, 'Racism and Sexism in Nazi Germany: Motherhood, Compulsory Sterilizaton and the State', 271-296, 273-275; G. Bock, '"Zum Wohle des Volkskörpers..." Abtreibung und Sterilisation im Nationalsozialismus', 78-84, 79-81.

176 See for the text of the Lex Zwickau W. Brill, Pädagogik im Spannungsfeld von Eugenik und Euthanasie, 192.

177 C. Usborne, The Politics of the Body in Weimar Germany, 151-152; M. Burleigh and W. Wippermann, The Racial State, 34.

178 L. Pine, Nazi Family Policy, 12; L. Pine, 'Women and the family', 203; M. Burleigh and W. Wippermann, The Racial State, 34; C. Usborne, The Politics of the Body in Weimar Germany, 154. 
compulsory sterilisation has never been legalised during the Weimar years. In practice, however, the distinction between voluntary and compulsory sterilisation was often blurred. ${ }^{179}$

\subsection{The Nazi Era}

\section{- 2.5.1. Volksgemeinschaft - the strength of a nation}

When the National Socialists came to power in January 1933, the tone of the population policy debate sharpened. The German 'people', or the Volk, played a key role in National Socialism, which seemed to combine several elements we have discussed earlier, i.e. völkish nationalism, social Darwinism, racial hygiene and anti-Semitism.

The concept of a 'state' was renounced by the National Socialists, especially the way it had manifested itself during the Weimar period. According to the National Socialists, the individual had become too important during this period, which had led to egocentrism and moral decline. ${ }^{180}$ Instead of a state, which was centred upon the idea of a group of individuals sharing a common language and living under a constant governmental supervision, ${ }^{181}$ a Volksgemeinschaft had to be created ${ }^{182}$ in which the public interest would prevail over the rights and interests of the individual. Every person, every member of the Volk, should consider himself as a member of the whole, whose rights were limited by the interests of the community. Man should not be self-sufficient, but serve the community. ${ }^{183}$ If done properly, an invincible nation would arise in which

Der beste Schutz wird dann nicht in seinen Waffen liegen, sondern in seinen Bürgern; nicht Festungswälle werden ihn beschirmen, sondern die lebendige Mauer von Männern und Frauen, erfüllt von höchster Vaterlandsliebe und fanatischer Nationalbegeisterung. ${ }^{184}$

Although the term Volksgemeinschaft somehow embodied the National Socialist legal idea, it can not be defined exactly. It can best be compared with a body that consists of several indispensable parts, which all together form an indivisible, organic whole. ${ }^{185}$ This Volksgemeinschaft is managed by one leader, the Führer, who is not so much a leader but a servant of the Volksgemeinschaft. He makes the laws, but as the Führer is the embodiment of 'community personality', these laws will only reflect the interests of the Volksgemeinschaft. The Führer therefore needs no supervision, as he serves the

179 C. Usborne, The Politics of the Body in Weimar Germany, 154-155.

180 L. Pine, Nazi Family Policy, 9.

181 A. Hitler, Mein Kampf, 426-427.

182 J.H. Carp, Beginselen van Nationaal-Socialisme, 20.

183 A. Hitler, Mein Kampf, 327.

184 A. Hitler, Mein Kampf, 473. "Its best defense will lie not in its weapons, but in its citizens; no fortress walls will protect it, but a loving wall of men and women filled with supreme love of their fatherland and fanatical national enthusiasm.' Translation by R. Manheim, 426.

185 Carp however insists that a National Socialist 'leader-state' can not be compared with a corporative state, as the parts of which it consists of do not represent their own interests, but represent the interests of the community in their own expertise. See J.H. Carp, Beginselen van Nationaal-Socialisme, 47-48. 
community. ${ }^{186}$ Stolleis shows that the concept of Volksgemeinschaft pervaded all spheres of life and therefore also different areas of law, e.g. property law, the law of obligations and criminal law.

The primary goal of this Volksgemeinschaft was the preservation of the Volk, the Aryan race: ${ }^{187}$

\author{
Im allgemeinen soll aber nie vergessen werden, daß nicht die Erhaltung \\ eines Staates oder gar die einer Regierung höchster Zweck des Daseins \\ der Menschen ist, sondern die Bewahrung ihrer Art. ${ }^{188}$
}

With regard to the preservation of the Aryan race, we can identify a dichotomy; on the one hand the expansion of the Aryan race had to be encouraged, on the other hand 'inferior' races and weak elements had to be eliminated from society. 'Mingling' of races therefore had to be prevented at all costs. With regard to racial doctrines, National Socialism was outspokenly anti-Semitic. Jews - a race, not a religion according to Hitler ${ }^{189}-$ were considered to be responsible for the defeat of Germany in the First World War, the Weimar Republic - with all its shortcomings - was considered to be a 'Jewish republic' and Jews were considered to have caused the loss of Germany, not only economically, but morally as well. The devastating consequences of this anti-Semitism need no further explanation.

\title{
- 2.5.2. From social hygiene to racial hygiene
}

\subsubsection{Compulsory sterilisation}

As stated above, one way to 'ensure' the preservation of the Aryan race was eliminating all weak elements. Racial hygiene therefore became a central part of the Nazi state policy. In Mein Kampf Hitler had described the importance of this goal by stating:

186 J.H. Carp, Beginselen van Nationaal-Socialisme, 40; M. Stolleis, The Law under the Swastika, 68; 0. Lepsius, 'The Problem of Perceptions of National Socialist Law or: Was there a Constitutional Theory of National Socialism?', 19-41, 25-26; 0. Lepsius, 'Gab es ein Staatsrecht des Nationalsozialismus?', 102-116, 106-107. Volksgemeinschaft and Führer are held together by the principle of the movement (Bewegung), the 'political bearer of the will of the Volk'. J.H. Carp, Beginselen van NationaalSocialisme, 35-36. See for an elaborate analysis of this principle O. Lepsius, 'The Problem of Perceptions of National Socialist Law or: Was there a Constitutional Theory of National Socialism?', 19-41, 23-27 and O. Lepsius, 'Gab es ein Staatsrecht des Nationalsozialismus?', 102-116, 105-108. This principle of movement was expressed in the National Socialist Party, which in the Netherlands was aptly named Nationaal Socialistische Beweging.

187 According to Carp the Volk in the National Socialist sense assumed a racial community, in which blood was the binding factor. The Volksgemeinschaft presupposed this racial community but was furthermore established on elements like common language, culture, territory and fate. J.H. Carp, Beginselen van Nationaal-Socialisme, 24-25. See furthermore M. Stolleis, The Law under the Swastika, 64-83 about the legal terminology introduced by the Nazis and the legal consequences of the use of the word 'community'. He explains that by the very use of the word Volksgemeinschaft (national community) it did not become clear whether all Aryan people without regard of national boundaries were meant, or just a 'political nation' (page 82).

188 A. Hitler, Mein Kampf, 104. 'In general it should not be forgotten that the highest aim of human existence is not the preservation of a state, let alone a government, but the preservation of the species.' Translation by R. Manheim, 96.

189 A. Hitler, Mein Kampf, 253: 'Die besten Kenner aber dieser Wahrheit über die Möglichkeiten der Anwendung von Unwahrheit und Verleumdung waren zu allen Zeiten die Juden; ist doch ihr ganzes Dasein schon auf einer einzigen großen Lüge aufgebaut, nämlich der, daß es sich bei ihnen um eine Religionsgenossenschaft handle, während es sich um eine Rasse - und zwar was für eine - dreht.' 'The foremost connoisseurs of this truth regarding the possibilities in the use of falsehood and slander have always been the Jews; for after all, their whole existence is based on one single great lie, to wit, that they are a religious community while actually they are a race - and what a race!' Translation by R. Manheim, 232. 
Für was wir zu kämpfen haben, ist die Sicherung des Bestehens und der Vermehrung unserer Rasse und unseres Volkes, die Ernährung seiner Kinder und Reinhaltung des Blutes, die Freiheit und Unabhängigkeit des Vaterlandes, auf daß unser Volk zur Erfüllung der auch ihm vom Schöpfer des Universums zugewiesenen Mission heranzureifen vermag. ${ }^{190}$

Preserving the race was a state obligation, since only then the German people would survive:
Wer von einer Mission des deutschen Volkes auf der Erde redet, muß wissen, daß sie nur in der Bildung eines Staates bestehen kann, der seine höchste Aufgabe in der Erhaltung und Förderung der unverletzt gebliebenen edelsten Bestandteile unseres Volkstums, ja der ganzen Menschheit sieht. ${ }^{191}$

Under the guidance of the Nazis eugenics lost its relative innocence. The theory of Nordic supremacy, highly discussed before i933, now became the leading conviction. The German minds were crammed for the acceptance of the elimination of the 'hereditary inferior' by all kinds of propaganda. Children were taught mathematics with questions like 'The construction of a lunatic asylum costs 6 million RM. How many houses at I5,Ooo RM each could have been built for that amount?'192 Stigmatising documentaries, filmed in asylums, were produced, as were feature films such as the I94I film Ich klage an (I accuse), in which a doctor euthanizes his terminally ill wife at her request and is subsequently charged for murder after which he pleads in court for 'mercy killings'. ${ }^{193}$

In May 1933 the first step towards legalisation of eugenic sterilisation was taken, by including a new article in the Penal Code that stated that voluntary sterilisation (still called Körperverletzung) was only punishable in case it was 'offending against public decency'. ${ }^{194}$ Furthermore, on I4 July I933, the Gesetz zur Verhütung erbkranken Nachwuchses ${ }^{195}$ was passed. Contrary to the I 932 draft this law called for compulsory sterilisation of individuals that were considered as 'hereditary ill'. ${ }^{196}$ According to $\mathbb{S}$ I

190 A. Hitler, Mein Kampf, 234. 'What we must fight for is to safeguard the existence and reproduction of our race and our people, the sustenance of our children and the purity of our blood, the freedom and independence of the fatherland, so that our people may mature for the fulfillment of the mission allotted it by the creator of the universe.' Translation by R. Manheim, 214.

191 A. Hitler, Mein Kampf, 439. 'Anyone who speaks of a mission of the German people on earth must know that it can exist only in the formation of a state which sees it highest task in the preservation and promotion of the most noble elements of our nationality, indeed of all mankind, which still remain intact.' Translation by R. Manheim, 397-398.

192 M. Burleigh and W. Wippermann, The Racial State, 154. Originally published in 1936 in R. Dorner (ed.), Mathematische Aufgaben aus der Volks-Gelände und Wehrkunde, 1. Teil (Mittelstufe), 21.

193 M. Burleigh and W. Wippermann, The Racial State, 154-161; R. Grunberger, A Social History of the Third Reich, 486. For details on the film see L. Maltin (ed.), Speelfilmencyclopedie, 483 and www.imdb.com/title/tt0033750/.

194 Gesetz zur Abänderung strafrechtlicher Vorschriften vom 26. Mai 1933, Reichsgesetzblatt (1933), I, 295, Article 1 (16): ‘Als $\S 226$ a wird folgende Vorschrift eingefügt: $\S 226 a)$ Wer eine Körperverletzung mit Einwilligung des Verletzten vornimmt, handelt nur dann rechtswidrig, wenn die Tat trotz der Einwilligung gegen die guten Sitten verstößt.'

195 Gesetz zur Verhütung erbkranken Nachwuchses vom 14. Juli 1933, Reichsgesetzblatt (1933), I, 529.

196 Gesetz zur Verhütung erbkranken Nachwuchses vom 14. Juli 1933, Reichsgesetzblatt (1933), I, 529, § 1 (1): ‘Wer erbkrank ist, kann durch chirurgischen Eingriff unfruchtbar gemacht (sterilisiert) werden, wenn nach den Erfahrungen der ärztlichen Wissenschaft mit großer Wahrscheinlichket zu erwarten ist, daß seine Nachkommen an schweren körperlichen oder geistigen Erbschäden leiden werden.' 
(2) diseases causing this condition were: 'congenital feeble-mindedness', 'schizophrenia', 'manic depression', 'congenital epilepsy', 'inheritable St. Vitus dance (Huntington's chorea)', 'hereditary blindness and deafness' and 'serious inheritable malformations. ${ }^{197}$ Although not suffering from a hereditary disease, people with severe and chronic alcohol problems could be sterilised as well. ${ }^{198}$ In addition to this law the Gesetz gegen gefährliche Gewohnheitsverbrecher und über Maßregeln der Sicherung und Besserung ${ }^{199}$ was passed on 24 November 1933 allowing for castration as a measure against habitual criminals. ${ }^{200}$ In order to determine whether someone was 'feeble-minded' an intelligence test had to be completed. A standard test form was published in the Reichsgesetzblatt in December I 933 as an enclosure to the Implementing Decree to the Gesetz zur Verhütung erbkranken Nachwuchses, containing questions on personal details, current time and place, sums and language exercises, questions concerning history and geography, but also questions about 'general knowledge of life' ('Why do children have to go to school?', 'What does it mean to boil water?') and 'general moral understandings' ('Why does one learn?', 'What is the opposite of courage?'). ${ }^{201}$

Newly established Hereditary Health Courts (Erbgesundheitsgerichte) had to decide in camera who was supposed to be sterilised. ${ }^{202}$ Doctors had to testify in favour of the health of the German nation, which meant 'without regard to professional confidentiality'. Most eugenicists and doctors were actually happy to obey, as they truly believed to increase the nation's health in this way. ${ }^{203}$ The implementation of National Socialist racial policy involved numerous academics, who - although not all of them were fanatical Nazis generally believed that their work was of scientific value and contributed to the nation's interests. ${ }^{204}$ Hitler considered this close alliance between science and politics inevitable and indispensable in order to preserve the 'Aryan' race:

Die Forderung, daß defekten Menschen die Zeugung anderer ebenso defekter Nachkommen unmöglich gemacht wird, ist eine Forderung

197 Gesetz zur Verhütung erbkranken Nachwuchses vom 14. Juli 1933, Reichsgesetzblatt (1933), I, 529, § 1 (2): ‘Erbkrank im Sinne dieses Gesetzes ist, wer an einer der folgenden Krankheiten leidet: 1. angeborenem Schwachsinn, 2. Schizophrenie, 3. zirkulärem (manisch-depressivem) Irresein, 4. erblicher Fallsucht, 5. erblichem Veitstanz (Huntingtonsche Chorea), 6. erblicher Blindheit, 7. erblicher Taubheit, 8. schwerer erblicher körperlicher Mißbildung.'

198 Gesetz zur Verhütung erbkranken Nachwuchses vom 14. Juli 1933, Reichsgesetzblatt (1933), I, 529, § 1 (3): 'Ferner kann unfruchtbar gemacht werden, wer an schwerem Alkoholismus leidet.'

199 Gesetz gegen gefährliche Gewohnheitsverbrecher und über Maßregeln der Sicherung und Besserung vom 24. November 1933, Reichsgesetzblatt (1933), I, 995.

200 Gesetz gegen gefährliche Gewohnheitsverbrecher und über Maßregeln der Sicherung und Besserung vom 24. November 1933, Reichsgesetzblatt (1933), I, 995, Article 2: 'Im Strafgesetzbuch wird hinter dem ersten Abschnitt des Ersten Teils folgender Abschnitt eingefügt: [...] § 42k. Das Gericht kann neben der Strafe anordnen, daß ein Mann, der zur Zeit der Entscheidung das einundzwanzigste Lebensjahr vollendet hat, zu entmannen ist, [...].' Castration of women was legalised in 1936. See Zweites Gesetz zur Änderung des Gesetzes zur Verhütung erbkranken Nachwuchses vom 4. Februar 1936, Reichsgesetzblatt (1936), I, 119 and Fünfte Verordnung zur Ausführung des Gesetzes zur Verhütung erbkranken Nachwuchses vom 25. Februar 1936, Reichsgesetzblatt (1936), I, 122.

201 Verordnung zur Ausführung des Gesetzes zur Verhütung erbkranken Nachwuchses vom 5. Dezember 1933, Reichsgesetzblatt (1933), I, 1021, Anlage 5a (1032). See also G. Bock, 'Racism and Sexism in Nazi Germany: Motherhood, Compulsory Sterilizaton and the State', 271-296, 281; M. Burleigh and W. Wippermann, The Racial State, 138-140.

202 Gesetz zur Verhütung erbkranken Nachwuchses vom 14. Juli 1933, Reichsgesetzblatt (1933), I, 529, § 5: 'Zuständig für die Entscheidung ist das Erbgesundheitsgericht, in dessen Bezirk der Unfruchtbarzumachende seinen allgemeinen Gerichtsstand hat.'; I Ibid., § 7 (1): 'Das Verfahren vor dem Erbgesundheitsgericht ist nicht öffentlich.' See also M. Burleigh and W. Wippermann, The Racial State, 48.

203 L. Pine, Nazi Family Policy, 1933-1945, 14.

204 M. Burleigh and W. Wippermann, The Racial State, 56. 


\section{klarster Vernunft und bedeutet in ihrer planmäßigen Durchführung die humanste Tat der Menschheit. Sie wird Millionen von Unglücklichen unverdiente Leiden ersparen, in der Folge aber zu einer steigenden Gesundung überhaupt führen. ${ }^{205}$}

Between January I934 and September 1939 nearly 0.5 percent of the German population (approximately 320,000 people) was sterilised, most of them (53\%) because of 'feeble-mindedness', a term which was interpreted very broadly. Most of the sterilised people originated from the poorest sectors of society, many of them being of German ethnicity. ${ }^{206}$ Attempts were made to extend the scope of the sterilisation laws to include e.g. the 'Rhineland Bastards'. However, although this extension was never realised, many 'Rhineland Bastards' were sterilised in 1937 , without a legal basis. ${ }^{207}$

\subsubsection{Abortion}

The fact that National Socialist population policy was built on a double principle encouraging the procreation of the racially and hereditary fit and valuable and preventing the racially and hereditary inferior to procreate - became abundantly clear in the laws and regulations concerning abortion.

Already in May 1933 the abortion laws were tightened up again, by introducing a new $\mathbb{S} 2$ I9 and $\mathbb{S} 220$ in the Penal Code. ${ }^{208}$ Paragraph 2 I9 prohibited the advertisement of means, objects or treatments intended for abortion, whilst $\mathbb{S} 220$ prohibited the offering of one's own or third party's services with regard to carrying out or promoting an abortion. In both cases violation could lead to a fine or imprisonment up to two years. ${ }^{209}$ Furthermore, the abortion laws were more strictly handled than during the Weimar years, leading to an increase of 65 percent in annual convictions between 1932 and $1938 .{ }^{210}$ As of I9 July I935 every abortion and miscarriage before completion of the thirty-second week of the pregnancy had to be reported in writing to the regional public health office within three days. ${ }^{211}$ Miscarriages suspected to be illegal abortions were subsequently investigated by the police. ${ }^{212}$ However, the number of illegal abortions is difficult to

205 A. Hitler, Mein Kampf, 279-280. 'The demand that defective people be prevented from propagating equally defective offspring is a demand of the clearest reason and if systematically executed represents the most humane act of mankind. It will spare millions of unfortunates undeserved sufferings, and consequently will lead to a rising improvement of health as a whole.' Translation by R. Manheim, 255.

206 G. Bock, 'Racism and Sexism in Nazi Germany: Motherhood, Compulsory Sterilizaton and the State', 271-296, 279-282; M. Burleigh and W. Wippermann, The Racial State, 253; L. Pine, Nazi Family Policy, 13; L. Pine, 'Women and the family', 204.

207 M. Burleigh and W. Wippermann, The Racial State, 130; G. Bock, "Zum Wohle des Volkskörpers..." Abtreibung und Sterilisation im Nationalsozialismus', 78-84, 83.

208 Gesetz zur Abänderung strafrechtlicher Vorschriften vom 26. Mai 1933, Reichsgesetzblatt (1933), I, 295.

209 Gesetz zur Abänderung strafrechtlicher Vorschriften vom 26. Mai 1933, Reichsgesetzblatt (1933), I, 295, Article 1 (14): 'Als $\S 219$ und 220 werden folgende Vorschriften eingefügt: $\S 219$ : Wer zu Zwecken der Abtreibung Mittel, Gegenstände oder Verfahren öffentlich ankündigt oder anpreist oder solche Mittel oder Gegenstände an einem allgemein zugänglichen Orte ausstellt, wird mit Gefängnis bis zu zwei Jahren oder mit Geldstrafe bestraft. [...]§ 220: Wer öffentlich seine eigenen oder fremde Dienste zur Vornahme oder Förderung von Abtreibungen anbietet, wird mit Gefängnis bis zu zwei Jahren oder mit Geldstrafe bestraft.'

210 G. Bock, 'Racism and Sexism in Nazi Germany: Motherhood, Compulsory Sterilizaton and the State', 271-296, 276.

211 Vierte Verordnung zur Ausführung des Gesetzes zur Verhütung erbkranken Nachwuchses vom 18. Juli 1935, Reichsgesetzblatt (1935), I, 1035, Article 12 (1): 'Jede Unterbrechung der Schwangerschaft sowie jede vor Vollendung der 32. Schwangerschaftswoche eintretende Fehlgeburt (Fruchtabgang) oder Frühgeburt sind binnen drei Tagen dem zuständigen Amtsarzt schriftlich anzuzeigen.'

212 G. Bock, 'Racism and Sexism in Nazi Germany: Motherhood, Compulsory Sterilizaton and the State', 271-296, 276. 
determine. Estimates vary from I20,00o to one million annually. ${ }^{213}$ In March 1943 the death penalty was even introduced for cases in which the abortion had permanently harmed the 'vitality of the German people'. 214

In cases of hereditary unfit people, however, abortion was encouraged or in some cases even mandatory. E.g. Polish and Russian women who worked as convicts in Germany were encouraged to undergo an abortion in case their babies were expected to be racially inferior. ${ }^{215}$ In 1935 abortion up to the end of the sixth month of the pregnancy was legalised in case the woman was supposed to be sterilised pursuant to the Gesetz zur Verhütung erbkranken Nachwuchses, i.e. when the child was expected to be hereditary unfit. After termination of the pregnancy, the woman would be sterilised. ${ }^{216}$ Abortion in these cases had already secretly been carried out since January I $934 ; ;^{217}$ now it became legal. Officially the abortion could only be carried out with the woman's consent. In practice however, this requirement was often ignored. ${ }^{218}$ From January I934 to September 1939 around 5000 abortions with subsequent sterilisations were carried out. ${ }^{219}$

\subsubsection{Euthanasia}

A third way to diminish the number of inferiors was the use of 'euthanasia', in this sense a euphemistic term for murder. The 'euthanasia' programme initially started with children, after a man named Knauer had asked Hitler in 1938 whether his deformed child could be killed. It led to the killing of at least 5200 children. ${ }^{220}$ In 1939 it was followed by a 'euthanasia' programme for mentally ill adults, in order to create bed space for anticipated military casualties. By means of an off the cuff calculation it was estimated that around 65,000-70,000 persons should be 'euthanized'. ${ }^{221}$ Clinics and asylums had to complete forms for every patient with questions concerning their mental condition, ${ }^{222}$ after which it was decided whether the person should be killed or not. The 'euthanasia' programme was officially approved by Hitler in October 1939 by means of a typed note, backdated to I September I939, ${ }^{223}$ although it was never formally legalised by a law. ${ }^{224}$ It received the codename 'Aktion T-4' after the place the programme was operated from as of April

213 G. Bock, "'Zum Wohle des Volkskörpers..." Abtreibung und Sterilisation im Nationalsozialismus', 78-84, 81.

214 Verordnung zum Schutz von Ehe, Familie und Mutterschaft vom 9. März 1943, Reichgesetzblatt (1943), I, 140, Article II, § 5 (3): '[...] Hat der Tater dadurch (by carrying out an abortion - ML) die Lebenskraft des deutschen Volkes fortgesetzt beeinträchtigt, so ist auf Todesstrafe zu erkennen.' See also G. Bock, 'Racism and Sexism in Nazi Germany: Motherhood, Compulsory Sterilizaton and the State', 271-296, 276; L. Pine, Nazi Family Policy, 20; L. Pine, 'Women and the family', 209.

215 M. Burleigh and W. Wippermann, The Racial State, 263. See also L. Pine, Nazi Family Policy, 20; L. Pine, 'Women and the family', 209.

216 Gesetz zur Änderung des Gesetzes zur Verhütung erbkranken Nachwuchses vom 26. Juni 1935, Reichsgesetzblatt (1935), I, 773, sub 2: 'Nach § 10 wird folgender $\S 10$ a eingeschaltet: "(1) Hat ein Erbgesundheitsgericht rechtskräftig auf Unfruchtbarmachung einer Frau erkannt, die zur Zeit der Durchführung der Unfruchtbarmachung schwanger ist, so kann die Schwangerschaft mit Einwilligung der Schwangeren unterbrochen werden, es sei denn, daß die Frucht schon lebensfähig ist oder die Unterbrechung der Schwangerschaft eine ernste Gefahr für das Leben oder die Gesundheit der Frau mit sich bringen würde. (2) Als nicht lebensfähig ist die Frucht dann anzusehen, wenn die Unterbrechung vor Ablauf des sechsten Schwangerschaftsmonats erfolgt."'

217 G. Bock, 'Racism and Sexism in Nazi Germany: Motherhood, Compulsory Sterilizaton and the State', 271-296, 276.

218 G. Bock, 'Racism and Sexism in Nazi Germany: Motherhood, Compulsory Sterilizaton and the State', 271-296, 276-277.

219 Ibid., 279.

220 M. Burleigh and W. Wippermann, The Racial State, 142-144; M. Burleigh, The Third Reich, 382-384; G. Bock, 'Racism and Sexism in Nazi Germany: Motherhood, Compulsory Sterilizaton and the State', 271-296, 282.

221 M. Burleigh and W. Wippermann, The Racial State, 144; M. Burleigh, The Third Reich, 384-385.

222 An English translation of 'Form 1' of 1941 is published in M. Burleigh and W. Wippermann, The Racial State, 146-147.

223 M. Burleigh and W. Wippermann, The Racial State, 147-148.

224 M. Burleigh, The Third Reich, 383. 
I940, Tiergartenstrasse 4 in Berlin. Selected patients were removed from asylums under the pretext of 'going out', after which they were brought to special asylums where they were killed in gas chambers disguised as shower rooms or through carbon monoxide released in a van. Although all kinds of measures were taken to keep the programme secret, it became known anyhow, causing public indignation and anger. Hitler halted the official programme on 24 August I94I, although it is unclear whether this was done because of the public outcry or because the set target had been reached. ${ }^{225}$ By September I94I, 70,273 persons had been gassed. ${ }^{226}$ Statistics produced by the T-4 programme at the end of I94I stated that out of the 282,696 beds reserved for mental patients, 93,25I beds had been 'released', i.e. that amount of people had been killed. ${ }^{227}$ The fact that the official programme was halted does not mean that mental patients in asylums were no longer killed, although starvation or lethal injections and pills were used rather than gassing. ${ }^{228}$

\section{- 2.5.3. National Socialist family policy}

\subsubsection{Family and marriage as 'germ cell of the nation'}

Concerning the expansion of the Aryan race, the family was regarded the 'germ cell of the nation'. ${ }^{229}$ In order to preserve the Aryan race, the main function of marriage was to produce healthy Aryan children, the so-called 'images of the Lord'. Newlyweds were expected to produce a significant amount of children - Himmler demanded a minimum of four children in each SS marriage ${ }^{230}$ - of whom the boys could join the army and the girls were destined to become the mothers of the next generation. ${ }^{231}$ The existence of the nation was dependent on the nation's fertility and the wish of healthy German families to fulfil their biological obligation.

In order to make the Volksgemeinschaft a success the status of marriage needed to be raised:
Ein völkischer Staat wird damit in erster Linie die Ehe aus dem Niveau einer dauernden Rassenschande herauszuheben haben, um ihr die Weihe jener Institution zu geben, die berufen ist, Ebenbilder des Herrn zu zeugen und nicht Mißgeburten zwischen Mensch und Affe. ${ }^{232}$

225 M. Burleigh and W. Wippermann, The Racial State, 148-153; M. Burleigh, The Third Reich, 384-402; G. Bock, 'Racism and Sexism in Nazi Germany: Motherhood, Compulsory Sterilizaton and the State', 271-296, 282.

226 M. Burleigh and W. Wippermann, The Racial State, 153; M. Burleigh, The Third Reich, 404.

227 M. Burleigh and W. Wippermann, The Racial State, 153; G. Bock, 'Racism and Sexism in Nazi Germany: Motherhood, Compulsory Sterilizaton and the State', 271-296, 282.

228 M. Burleigh and W. Wippermann, The Racial State, 164; M. Burleigh, The Third Reich, 402; G. Bock, 'Racism and Sexism in Nazi Germany: Motherhood, Compulsory Sterilizaton and the State', 271-296, 282.

229 W. Groß, 'Unsere Arbeit gilt der deutschen Familie', 10 Nationalsozialistische Monatshefte 107 (1939), 105. See also L. Pine, Nazi Family Policy, 8-9; R. Grunberger, A Social History of the Third Reich, 298.

230 L. Pine, Nazi Family Policy, 45.

231 A. Hitler, Mein Kampf, 10: "'Deutscher Knabe, vergiß nicht, daß Du ein Deutscher bist!” und “Mädchen, gedenke, daß Du eine deutsche Mutter werden sollst!"' '"German boy, do not forget you are a German", and, "Little girl, remember that you are to become a German mother."' Translation by R. Manheim, 12.

232 Ibid., 444-445. 'A folkish state must therefore begin by raising marriage from the level of a continuous defilement of the race, and give it the consecration of an institution which is called upon to produce images of the Lord and not monstrosities halfway between man and ape.' Translation by R. Manheim, 402. 
Furthermore, marriage could no longer be considered a private issue between two persons; it had to serve the nation:

Auch die Ehe kann nicht Selbstzweck sein, sondern muß dem einen größeren Ziele, der Vermehrung und Erhaltung der Art und Rasse, dienen.

Nur das ist ihr Sinn und ihre Aufgabe. ${ }^{233}$

Germans belonging to the Aryan race should marry at young age since only then a couple could be assured of a 'healthy and resistant offspring'. ${ }^{234}$ Besides that, early marriage could be used as a weapon to combat prostitution and syphilis, which were - according to Hitler - a disgrace to humanity. ${ }^{235}$ Despite this, marriage should not find its origins in pure sexual desire, but in 'sincere mutual love', as these bonds were likely to be much stronger. A stable and enduring marriage was considered the best guarantee for the way children were raised and therefore a guarantee for 'the future of the German people'. ${ }^{236} \mathrm{In}$ order to stimulate marriage - and early marriage in particular - and to protect the Aryan race against undesired racial mixing, a number of measures were taken. ${ }^{237}$

In June 1933 e.g. a marriage loan scheme was introduced, ${ }^{238}$ providing a newlywed German couple, from which the woman had been employed and gave up her job upon marriage, with an interest-free loan of up to I,ooo Reich mark. ${ }^{239}$ This loan was, however, not paid in cash, but provided in vouchers to be used for the purchase of furniture and household equipment. ${ }^{240}$ The loan was to be repaid at I percent per month ${ }^{241}$ ( 3 percent per month if the woman had paid employment, which was again possible and even encouraged from 1936 on ${ }^{242}$ and the birth of each child would cut one quarter of the debt $^{243}$ converting the loan into a gift after four children had been born.

The reason that originally the condition that women should give up their job was set, was to create enough job opportunities for men and to make sure women stayed at home taking care of the children. Besides that, this measure was supposed to lower the male marriage age and therefore diminish the need for prostitution. By converting the loan to a gift - dependent on the number of children - the Nazis hoped to encourage newlyweds to have children as quickly as possible. ${ }^{244}$

As of July 1933, all applicants for a marriage loan were required to undergo a medical

233 Ibid., 275-276. 'And marriage cannot be an end in itself, but must serve the one and higher goal, the increase and preservation of the species and the race. This alone is its meaning and its task.' Translation by R. Manheim, 252.

234 A. Hitler, Mein Kampf, 276.

235 Ibid., 275. See also G. Bock, in D.F. Crew (ed.), Nazism and German Society, 1933-1945, 123.

236 L. Pine, Nazi Family Policy, 15-16.

237 A. Hitler, Mein Kampf, 276: 'Freilich ist zu ihrer ermöglichung eine ganze Reihe von sozialen Voraussetzungen nötig, ohne die an eine frühe Verehelichung gar nicht zu denken ist.' 'To be sure, it can be made possible only by quite a number of social conditions without which early marriage is not even thinkable'. Translation by R. Manheim, 252.

238 Gesetz zur Verminderung der Arbeitslosigkeit vom 1. Juni 1933, Reichsgesetzblatt (1933), I, 323.

239 Ibid., Abschnitt V, § 1.

240 Ibid., Abschnitt V, $\$ 3$.

241 Ibid., Abschnitt V, § 2.

242 G. Bock, in D.F. Crew (ed.), Nazism and German Society, 1933-1945, 123; R. Grunberger, A Social History of the Third Reich, 300.

243 Durchführungsverordnung über die Gewährung von Ehestandsdarlehen vom 20. Juni 1933, Reichsgesetzblatt (1933), I, 377.

244 G. Bock, in D.F. Crew (ed.), Nazism and German Society, 1933-1945, 123; R. Grunberger, A Social History of the Third Reich, 300; L. Pine, Nazi Family Policy, 1933-1945, 17. 
examination in order to prove suitability for marriage. ${ }^{245}$ In case infertility appeared, loans were denied, as they were in case of psychiatric disorders. ${ }^{246}$

\subsubsection{The role of women}

Traditional family life was regarded the best way to provide the safety, love, care and stability necessary to raise the future generation. Young girls should be educated in the values and skills of motherhood, which contained infant care and housekeeping. ${ }^{247}$ Higher education for girls was discouraged and an intellectual woman was considered as 'unhealthy'. After the abolition of the girls' grammar school (Gymnasium) only two options for higher education for girls remained: domestic economy and linguistics. After 1933 only io \% of the matriculants (Abiturienten) were allowed to be women. ${ }^{248}$ Women were discouraged to have outdoor jobs. Their natural job - according to National Socialism - was being housewife and mother. According to Hitler, marriage should even be a requirement for women to obtain citizenship. ${ }^{249}$ A mother working outdoors could have a negative effect on the children and kindergarten was not considered a reasonable alternative. In case women had to work outdoors they should have jobs in line with their role as a mother, such as nursing or social work, which was not a threat to their health and therefore would not endanger their biological capacity to reproduce. ${ }^{250}$

In 1934 the agency Hilfswerk 'Mutter und Kind' was set up with the words 'Mother and child are the pledge for the immortality of the nation'. ${ }^{251}$ The main task of this agency was to help mothers and expectant mothers by e.g. house visits from welfare workers and nurses, providing help and care, material assistance (such as the provision of baby linen) and by the set up of a network of help centres throughout Germany to offer advice to mothers who sought it. ${ }^{252}$

However, although deprived from many laboriously acquired rights, women were not considered as good-for-nothing. Propaganda about family policy was mainly aimed at mothers, who were almost canonised. A real motherhood cult was put in place. It was stated that

there is no more beautiful image of selfless service than that of a mother with her children. She continues to care and to give, to show her child love upon love, never thinking whether she is going to get anything in return... In the very moment she began to calculate returns, she would cease to be a good mother. ${ }^{253}$

245 Zweite Durchführungsverordnung über die Gewährung von Ehestandsdarlehen vom 26. Juli 1933, Reichsgesetzblatt (1933), I, 540.

246 L. Pine, Nazi Family Policy, 1933-1945, 17.

247 L. Pine, Nazi Family Policy, 1933-1945, 72-87.

248 D. Klinksiek, Die Frau im NS-Staat, 40-45.

249 A. Hitler, Mein Kampf, 491.

250 M. Burleigh and W. Wippermann, The Racial State, 242-243.

251 Goebbels in his inaugural speech. See L. Pine, Nazi Family Policy, 1933-1945, 23.

252 G. Bock, in D.F. Crew (ed.), Nazism and German Society, 1933-1945, 125; L. Pine, Nazi Family Policy, 1933-1945, 23-38.

253 Hilgenfeldt reporting to Bormann about a conversation with Himmler, (16 September 1942), BAK, NS 18/2427, quotation taken from G. Bock, in D.F. Crew (ed.), Nazism and German Society, 1933-1945, 125. 
Despite this statement rewards for motherhood were actually introduced. Already in the I920's Mother's Day had been introduced in the Weimar Republic as it had been in other European countries. This day - originally meant to preserve healthy family life, with mothers being promoted as the embodiment of all goodness ${ }^{254}$ - with all its significance came in very opportunely to the Nazis. This annual occasion was taken with both hands to be exploited as propaganda. On Mother's Day, for instance radio programmes consisted almost entirely of programmes about the family. E.g. in 1936 national radio was broadcasting programmes like 'Honour the Mother!' and 'New Poems about Mother and Child'. ${ }^{255}$

Financial benefits were granted. As of July I936 working-class families with a monthly income below 185 Reich mark received ro Reich mark every month for the fifth child and every child after that. As of April 1938 already the third child entitled a family to the monthly io Reich mark fee. Previously, this regulation had already been made applicable for self-employed people, whilst the income limit had been increased to 200 Reich mark. ${ }^{256}$ Mothers with three or more children received Honour Cards, which gave them preferential treatment while shopping ${ }^{257}$ and in December 1938 the 'Honour Cross' of the German Mother was introduced. ${ }^{258}$ This medal - a cross with the inscription 'Das Kind adelt die Mutter'259 (The child ennobles the mother) - was awarded annually on Mother's Day. Bronze was given to mothers with four or more children, silver for six or more and gold for more than eight. ${ }^{260}$ Women wearing this cross in public had to be saluted by the members of the Hitler Jugend. Ironically, the main goal of this cross was not to increase the birth rate, but to create a general sense of the importance and value of the kinderreich family. ${ }^{261}$

\subsubsection{Kinderreich versus Großfamilien}

Only families that could be considered as 'hereditarily healthy' and 'racially valuable' were expected to start large families. Such families, having four or more children, were called kinderreich. According to the National Socialists, in the Weimar Republic, this term had falsely been used to indicate all families having four or more children. However, families that were 'racially inferior' or 'asocial' should not be considered as kinderreich but were labelled as Großfamilien, which were not desirable at all. ${ }^{262}$

The Reichsbund der Kinderreichen $(R d K)$, which already existed before the Nazis

254 Originally Mother's Day had been promoted by the Verband deutscher Blumengeschäftsinhaber (Association of German Florists) to boost the sale of flowers. See K. Hausen, 'Mother's Day in the Weimar Republic', 131-152, 133-135.

255 L. Pine, Nazi Family Policy, 1933-1945, 6-7 and 103; G. Bock, in D.F. Crew (ed.), Nazism and German Society, 1933-1945, 126.

256 M. Schmidt and G. Dietz, Frauen unterm Hakenkreuz, 63-66; L. Pine, Nazi Family Policy, 1933-1945, 109; G. Bock, 'Antinatalism, Maternity and Paternity in National Socialist Racism', in D.F. Crew (ed.), Nazism and German Society, 1933$1945,123$.

257 M. Burleigh and W. Wippermann, The Racial State, 250.

258 Verordnung des Führers und Reichskanzlers über die Stiftung des Ehrenkreuzes der Deutschen Mutter vom 16. Dezember 1938, Reichsgesetzblatt (1938), I, 1923.

259 Satzung des Ehrenkreuzes der Deutschen Mutter vom 16. Dezember 1938, Reichsgesetzblatt (1938), I, 1924, Article 4 (2).

260 Satzung des Ehrenkreuzes der Deutschen Mutter vom 16. Dezember 1938, Reichsgesetzblatt (1938), I, 1924, Article 3 and annex on page 1925.

261 L. Pine, Nazi Family Policy, 1933-1945, 96; M. Burleigh and W. Wippermann, The Racial State, 250; R. Grunberger, A Social History of the Third Reich, 301.

262 L. Pine, Nazi Family Policy, 1933-1945, 88. 
came to power, was entrusted with the task to educate the public mind in the values of kinderreich families. In the Weimar Republic, kinderreich families had often been regarded as a sign of poverty, and regarded as pitiable. This erroneous public opinion had to be corrected and changed into believing that kinderreich families were needed to build a strong Germany. One of the main examples used for this propaganda was very fittingly - the Minister for Popular Enlightenment and Propaganda Josef Goebbels, who was embodying the ideal family man having six children and a pure Aryan blond wife. His numerous extramarital affairs were not mentioned in public. Besides raising the kinderreich family to the correct status, the second aim of the $R d K$ was to advise kinderreich families on practical issues like rent and housing. ${ }^{263}$

Contrary to these long-term measures, financial care was in this respect seen as a short-term measure, which was therefore the responsibility of the Nationalsozialistische Volkswohlfahrt (NSV). We have already discussed the monthly child allowance of Io Reich mark, introduced in I936. In addition to this measure, income tax for the childless (both couples and singles) was raised, whilst the tax exemption amounts to men for his wife and children were increased in 1934 and $1939 .^{264}$

In addition to mere preservation of the Aryan race, kinderreich families could considerably strengthen the nation, since it was generally believed that the probability of having highly gifted children grew with the number of children born in a family. This was explained on the basis of a set of examples taken from German history, like Mozart, who was the youngest of seven and Bach, who was the eighth of twelve. If in history families had limited their offspring to two children, these geniuses would never have been born. ${ }^{265}$

Although marriage was considered extremely valuable, voices, which said that every Aryan child born - whether legitimate or illegitimate - was an asset to the German nation, were heard as well. Hitler had already criticised the traditional opinion that a single mother was to be considered as degenerate. ${ }^{266}$ One of the more extreme voices belonged to Heinrich Himmler who openly declared to be a proponent of bigamy, since only then women would continuously feel the need to seduce their husbands, which would result in more children. ${ }^{267}$

In 1935 the Lebensborn agency was established, setting up maternity homes in which single mothers could give birth to their illegitimate children. After childbirth the mothers were given advice on things like childcare and nutrition. If after a year a mother was still unmarried and not in the position to take care of her child, it was given to foster parents. It should be noted that Lebensborn only served Aryan mothers who would surely give birth to a 'racially superior' child. If both the mother and the father of the child would be 'hereditarily healthy', the child would be 'valuable'. ${ }^{268}$

263 Ibid., 88-93.

264 G. Bock, 'Antinatalism, Maternity and Paternity in National Socials Racism', in D.F. Crew (ed.), Nazism and German Society, 1933-1945, 123.

265 L. Pine, Nazi Family Policy, 1933-1945, 98. See also Hitlers tafelgesprekken (Hitler's Table Talk), 55. Translation (from English) by P. Andriesse.

266 Hitlers tafelgesprekken (Hitler's Table Talk), 267. Translation (from English) by P. Andriesse.

267 L. Pine, Nazi Family Policy, 1933-1945, 39.

268 L. Pine, Nazi Family Policy, 1933-1945, 39-41; R. Grunberger, A Social History of the Third Reich, 314. 
Himmler's opinions and the Lebensborn activities were the subject of considerable controversy, especially in rural, Catholic areas. Opponents were found amongst Nazi leaders as well. Fritz Lenz amongst others believed that children born out of wedlock were attributed with below average intelligence and genetic value. ${ }^{269}$ Illegitimate children were furthermore considered to be a threat to morality. The more illegitimate children a woman had, the more chance there was that this woman did not 'possess the intellectual or moral value that must be called for in the German mother. ${ }^{270}$

\subsubsection{4. 'Married without children'}

Obviously marriage was no guarantee for offspring, let alone healthy, Aryan offspring. In $1938^{271}$ divorce was therefore facilitated in order to dissolve marriages in which this primary purpose could not be fulfilled. Amongst other things, refusal to procreate, a mental illness, a serious contagious disease and premature infertility became grounds for divorce. Divorce was furthermore facilitated in case the marriage was 'permanently disrupted' and partners had been living separate lives for three years already. The main reason for this rule was that in this case both man and woman would be officially enabled to start new families. Marriages, which were of no value to the Volksgemeinschaft, had to be dissolved to make sure the former partners could remarry and still provide the Volk with children. The state concern about fertility always remained present. ${ }^{272}$

Within three years after the promulgation of the Marriage Law the divorce rate had climbed steadily with 383 divorces pronounced on the ground of 'premature infertility' and I,77I for the 'refusal to procreate'. ${ }^{273}$ Chapter two will deal extensively with German National Socialist matrimonial law.

\subsection{Conclusion}

This chapter aimed to give an historical and 'ideological' framework with regard to the question whether family law has been influenced by National Socialism. In that sense the main research question that had to be answered in this chapter was: of what elements did National Socialism consist of? We have started by exploring the 'origins' of National Socialism, examining the theories and ideas of, amongst others, Johann Gottfried Herder, Johann Caspar Lavater, Franz Joseph Gall, Count Joseph Arthur de Gobineau, Francis Galton, Ernst Haeckel, Wilhelm Schallmayer, Alfred Ploetz and Houston Stewart Chamberlain. From these theories and ideas we can deduce four main elements that have influenced or at least inspired National Socialism: völkish nationalism, Social Darwinism, racial hygiene (eugenics) and anti-Semitism. Before the National Socialists came to power in Germany, these theories had primarily been discussed academically, although the Weimar republic, with all its political and economical hardships, saw a growing acceptance of turning some of these theories into practice.

269 R. Rissom, Fritz Lenz und die Rassenhygiene, 63-64.

270 L. Pine, Nazi Family Policy, 1933-1945, 41-43.

271 Gesetz zur Vereinheitlichung des Rechts der Eheschließung und der Ehescheidung im Lande Österreich und im übrigen Reichsgebiet vom 6. Juli 1938, Reichsgesetzblatt (1938), I, 807.

272 L. Pine, Nazi Family Policy, 1933-1945, 18-19; Grunberger, A Social History of the Third Reich, 312-313.

273 L. Pine, Nazi Family Policy, 1933-1945, 18. 


\section{- 2.6.1. Pro-natalism versus selection}

Population policy in Germany has shifted from a distinctively pro-natal policy until the beginning of the Weimar Republic to a more selective population policy during the Weimar years to a combination of both during the Nazi era. During the second half of the nineteenth century and the first two decades of the twentieth century, children were regarded to reflect the nation's future; the more children, the stronger the nation was considered to be. Poverty and uncertainty however, forced people to apply birth control during the First World War and the Weimar years. Eugenics became regarded as a solution for the growing social problems that seem to exist especially amongst the lower class families. Assuming that apart from physical and mental disorders social problems were hereditary as well, birth control and even sterilisation were propagated for men and women living in less favourable conditions, already having illegitimate children, being alcoholic, having a mental deficiency, being simpleminded or suffering from hereditary or contagious diseases or a disability. However, legislation concerning abortion, sterilisation and contraceptives was only marginally liberalised during the Weimar years. The National Socialist take-over caused a dramatic change in that respect. Suddenly theories that had been discussed for decades, first academically, then tentatively on the level of government policy, were turned into practice. We have discussed the dichotomy the National Socialists applied in that respect: a distinctively pro-natal attitude towards the healthy Aryan families, a very selective approach towards the weaker and racially 'inferior' elements in society.

\section{- 2.6.2. Anti-Semitism}

We have discussed the position of Jews in Germany through the ages in order to illustrate the existence and development of anti-Semitism. Jews were not granted full equal rights until the Weimar Constitution was promulgated. Until that moment they had always been slighted, less accepted and even discriminated against, despite their serious attempts to become an integral part of German society. However, hearts and minds of people have only very rarely changed overnight. Being recognised on paper as regular German citizens did not mean that the other, non-Jewish, German citizens accepted Jews as such. Thoughts and concepts reflect this ever-existing anti-Semitism. Although völkish ideas were originally not distinctly racist, gradually the notion that the Nordic race was superior compared to other races, especially the Jews, took root. In I9oo Chamberlain had already presented the theory that Judaism was not merely a religion but a race and an inferior one, which should be prevented from mingling with the superior Aryan race.

Although granted equal rights by the Weimar Constitution, Jews were still scorned upon during the Weimar years. Those who criticised the Weimar Republic, dubbed it the 'Jew Republic', due to the relatively large amount of Jewish intellectuals at high positions. When the Weimar Republic ended in an economic disaster, this nick-name only fuelled the idea that the Jews were to blame.

\section{- 2.6.3. National Socialist pro-natalism}

The fact the National Socialists reacted so strongly against the Weimar views regarding the ideal family can be called remarkable, as the National Socialist view regarding families 
differed not that much from the Weimar notion. Traditional family life and values had been considered of paramount importance both during the Weimar period and the Nazi regime. A certain amount of birth control had only been accepted during the Weimar years out of economic necessity, but motherhood had been idolised during these years as well. Encouragements in the form of financial benefits introduced by the National Socialists were not new either nor were the symbolic gifts to praise mothers. We can therefore conclude that nor National Socialist ideas regarding the nation, its people and families nor the pro-natal family policy executed by the Nazis was original. What was new though is the fact that with regard to eugenics and racial classification theory now became practice. Before the National Socialists came to power, social hygiene had only theoretically been regarded as a solution for the existing social and economic problems, now it became reality. Furthermore, for the first time social hygiene became distinctly racist and especially anti-Semitic. Racism and anti-Semitism had not been new to Germany, but with regard to population policy this was the first time racial ideas were that meticulously applied.

\section{- 2.6.4. The results}

The final question we need to answer is whether the abovementioned pro-natal programmes and projects achieved what they were established for? Is it possible to detect a serious increase of the birth rate? The short answer is 'no'.

It is difficult to give an entirely sound picture, as statistics for the period I943-I946 are largely unavailable, but generally we can detect an upward trend in the number of marriage conclusions and live births during the first years of the Nazi regime, whilst the numbers declined as soon as the war started. In I939 42 percent of the marriages was loan-assisted, but those couples on average had only one child. ${ }^{274}$ The number of marriage conclusions decreased during the war, ${ }^{275}$ due to uncertainties and the men being in the army. ${ }^{276}$ The birth rate increased until I940, but decreased again after that, although it did not again reach the low level of $1933 .{ }^{277}$ Despite the Lebensborn organisation, the number of illegitimate children declined from Io.5 percent in I 932 to 8 percent in $1939 .{ }^{278}$ The proportion of married women having four or more children decreased as well, from 25 percent in 1933 to 2 I percent in $1939 .{ }^{279}$

Those figures show that - despite all their attempts - Nazi family policy did not achieve what it aimed to achieve; early marriage and a considerable number of children

274 L. Pine, Nazi Family Policy, 1933-1945, 18.

275 During the first years of the Nazi regime, the number of marriage conclusions increased to 9.3 between $1931-1935$, where it had been 8.7 between 1926-1930. However, in the years after it declined: 7.9 between 1936-1940 and 7.3 between 1941 1943. No figures are available for 1944 and 1945. See W. H. Hubbard, Familiengeschichte, 73.

276 L. Pine, Nazi Family Policy, 1933-1945, 96.

277 R. Grunberger, A Social History of the Third Reich, 300. See for additional figures W.H. Hubbard, Familiengeschichte, 93. The national birth rate increased between 1936-1940 to 19.6, where it had been 16.5 between 1931-1935, but decreased after 1940 to 16.5 between 1941-1945.

278 R. Grunberger, A Social History of the Third Reich, 313. Hubbard shows that the number of illegitimate children was 101 on a 1000 births between 1931-1935, which decreased to 77 between 1936-1939. No figures are available for the period 19401945. See W.H. Hubbard, Familiengeschichte, 109.

279 L. Pine, Nazi Family Policy, 1933-1945, 116. 
in each healthy Aryan family, in order to preserve the Aryan race and to establish the Volksgemeinschaft Hitler had pleaded for. The failure of this policy is mainly caused by the fact that the incentives given - like the marriage loan - were by and large not enough to cover all the costs of life. Life became extremely expensive during the war and a Cross of Honour apparently would not do for the majority of the German couples. ${ }^{280}$ 
III.

National

Socialist Racial

and Family Law

in Germany 


\subsection{Introduction}

This chapter aims to give an overview of the changes made by the National Socialists in Germany with regard to marriage and divorce law. The main question is whether and in what way German marriage and divorce law has been influenced by National Socialism. In order to answer that question we first need to look at what marriage and divorce law contained before the National Socialist take-over in 1933.

The first part of the chapter will therefore give an overview of marriage and divorce law as laid down in the German Civil Code from I90o. We will deal successively with the rules concerning the conclusion of marriage, annulment of marriage and dissolution of marriage.

The second part of the chapter will deal with the changes made during the Nazi period. The same elements - conclusion of marriage, annulment of marriage and dissolution of marriage - will be examined. This second part will start with the initial period of National Socialism, in which laws were not so much changed, but re-interpreted according to the new 'general national principles'.

As of September 1935 marriage and divorce law were actually altered. We will examine the changes made in marriage and divorce law by the Reich Citizenship Law, the Blood Protection Law, the Marriage Health Law (all of 1935) and the Marriage Law of 1938. As the development of the Marriage Law of 1938 was influenced by the incorporation of Austria, this section will give an overview of Austrian marriage and divorce law before the incorporation as well.

Finally, we will determine whether these changes were the result of National Socialism as such, or can be attributed to other theories and developments. 


\subsection{Family Law in the Weimar Republic}

At the start of the twentieth century, family law was very patriarchal, not only in Germany, but in other European countries as well. ${ }^{1}$ The German Civil Code of I9oo $^{2}$ provided some changes in family law compared to earlier legislation, like the Allgemeines Landrecht für die Preußischen Staaten, which dated from I794. ${ }^{3}$ The basis of family law, however, remained patriarchal. This did not change after I9I8, although the new Weimar Constitution did contain a provision regarding the protection of marriage. According to Article II9 marriage fell under the special protection of the Constitution, as it was the basis for family life and for the preservation and expansion of the nation. ${ }^{4}$ According to Mitteis this was a significant provision as it meant that fundamental changes in family law - like the abolition of monogamy - could only be achieved through constitutional changes. ${ }^{5}$ Furthermore, the provision proclaimed equal rights between the sexes, ${ }^{6}$ a much discussed item at the time. However, the Civil Code was never adapted in line with these provisions, which effectively made them a dead letter. ${ }^{7}$ The husband remained the head of the family although his wife was no longer subordinate but stood beside him. ${ }^{8}$

The Civil Code never gave a definition of marriage and legal scholars only came to technical explanations like 'marriage is a bond between two persons of opposite sex in order to realise a full community life. ${ }^{9}$ Procreation was no longer the purpose of marriage, as it had been according to the Allgemeines Landrecht für die Preußischen Staaten, ${ }^{10}$ although the family remained charged with the responsibility of bringing up children. ${ }^{11}$ This was in accordance with Article 120 of the Weimar Constitution. ${ }^{12}$

1 The man was the head of the family, he decided on family matters. Furthermore, a woman's property was put under her husband's management after her marriage, see $§ 1363$ BGB: 'Das Vermögen der Frau wird durch die Eheschließung der Verwaltung und Nutznießung des Mannes unterworfen (eingebrachtes Gut).'

2 Bürgerliches Gesetzbuch vom 18. August 1896, Reichs-Gesetzblatt (1896), 195. The Civil Code came into force on 1 January 1900 through the Einführungsgesetz zum Bürgerlichen Gesetzbuche vom 18. August 1896, Reichs-Gesetzblatt (1896), 604.

3 The ALR acknowledged eleven main grounds for divorce, of which some were subdivided. The main grounds for divorce were 1) adultery (including sodomy) (Ehebruch), 2) desertion with malicious intent (Bösliche Verlassung), 3) refusal to 'fulfil the conjugal duty' (procreation) (Versagung der ehelichen Pflicht), 4) impotence (including premature infertility and incurable physical ailments) (Unvermögen), 5) insanity (Raserey und Wahnsinn), 6) crimes against life and cruelty (Nachstellungen nach dem Leben), 7) serious offences (Grobe Verbrechen), 8) lawless lifestyle (Unordentliche Lebensart), 9) refusal to maintenance (Versagung des Unterhalts), 10) conversion (Veränderung der Religion) and 11) permanent disruption, but only in case the marriage was childless (Unüberwindliche Abneigung). Allgemeines Landrecht für die Preußischen Staaten, (1794), Zweiter Theil, Erster Titel, Achter Abschnitt, §§ 669-718.

4 Die Verfassung des Deutschen Reichs vom 11. August 1919, Reichs-Gesetzblatt (1919), 1383, Art. 119 (1): 'Die Ehe steht als Grundlage des Familienlebens und der Erhaltung und Vermehrung der Nation unter dem besonderen Schutz der Verfassung. $[\ldots]^{\prime}$

5 H. Mitteis, Bürgerliches Recht. Familienrecht, (1931), 1.

6 Die Verfassung des Deutschen Reichs vom 11. August 1919, Reichs-Gesetzblatt (1919), 1383, Art. 119 (1): '[...] Sie (the marriage - ML) beruht auf der Gleichberechtigung der beiden Geschlechter.'

7 L. Van den hole, Honderd jaar Duits Burgerlijk Wetboek, 28.

8 H. Mitteis, Bürgerliches Recht. Familienrecht, (1931), 2. See also 1354 BGB: 'Dem Manne steht die Entscheidung in allen das gemeinschaftliche ehelich Leben betreffenden Angelegenheiten zu; er bestimmt insbesondere Wohnort und Wohnung.'

9 H. Mitteis, Bürgerliches Recht. Familienrecht, (1923), 4.

10 Allgemeines Landrecht für die Preußischen Staaten vom 5. Februar 1794, II, 1, § 1: 'Der Hauptzweck der Ehe ist die Erzeugung und Erziehung der Kinder.'

11 H. Mitteis, Bürgerliches Recht. Familienrecht, (1931), 2.

12 Die Verfassung des Deutschen Reichs vom 11. August 1919, Reichs-Gesetzblatt (1919), 1383, Art. 120: 'Die Erziehung des Nachwuchses zur leiblichen, seelischen und gesellschaftlichen Tüchtigkeit is oberste Pflicht und natürliches Recht der Eltern, über deren Betätigung die staatliche Gemeinschaft wacht.' 


\section{- 3.2.1. Conclusion of marriage}

According to $\mathbb{I}$ I3I7 BGB a marriage was concluded when both fiancés declared in person and in the presence of a registrar that they wanted to marry each other. ${ }^{13}$ Generally, this had to be preceded by an announcement of marriage (Aufgebot)..$^{14}$ This construction reflected the compromise between the Catholic Church, which considered marriage to be a Sacrament - in which both spouses gave themselves to each other - and the German state, which after the introduction of the Personenstandsgesetz in $1876^{15}$ only recognised civil marriages. According to $\mathbb{S} 4 \mathrm{I}$ of the Personenstandsgesetz only a registrar could conclude the marriage. ${ }^{16}$ However, according to the wording of $\mathbb{I}$ I3I7 BGB the constituent act was performed by the fiancés themselves in declaring each other to marry one another, although a registrar had to be present to make the act legally binding. ${ }^{17}$

The Civil Code contained several impediments to marriage which could be divided into openly separating impediments (öffentlich trennende Ehehindernisse) which led to a possibility of avoidance (Vernichtbarkeit), privately separating impediments (private trennende Ehehindernisse), which led to disputability (Anfechtbarkeit) and clear, unsanctioned impediments (reine, unsanktionierte Eheverbote), which only led to suspension (Verschiebung). This third category was not an impediment in the proper sense of the word, as they did not question the validity of the marriage, but led to 'suspensive' impediments (aufschiebende Ehehindernisse) - binding orders not to conclude a marriage.$^{18}$ Impediments which ultimately could lead to avoidance were consanguinity ${ }^{19}$ and relation by marriage (Schwägerschaft) ( $\$$ I310 and $\$$ I327 BGB), bigamy ( $\$$ I309 and $\mathbb{S}$ I326) and adultery ( $\mathbb{S}$ I312 and $\mathbb{S}$ 1328). Consanguinity as impediment to marriage was more limited in Germany than it was in other European countries as Germany allowed marriages between cousins and between uncles and nieces, despite the medical objections. ${ }^{20}$ Lacking permission of the legal guardian ( $\mathbb{\text { I304}}$ ) led to disputability (Anfechtbarkeit). Clear, unsanctioned impediments were lack of parental permission ( $($ I305) which was required until the suitors reached the age of 2I years, the existence of an avoidable (vernichtbar) marriage in case of a second marriage ( $\$$ I309) and the lack of a marriageable age ( $\mathbb{1}$ I303), which was 2I years for men and I6 years for women. ${ }^{21}$

$13 \S 1317$ BGB: ‘Die Ehe wird dadurch geschlossen, daß die Verlobten vor einem Standesbeamten persönlich und bei gleichzeitiger Anwesenheit erklären, die Ehe miteinander eingeben zu wollen. [...]'

14 See $\$ 1316$ BGB: 'Der Eheschließung soll ein Aufgebot vorhergehen. [...]'

15 Reichsgesetz über die Beurkundung des Personenstandes und die Eheschließung vom 6. Februar 1875, Reichs-Gesetzblatt (1875), 23, which came into force on 1 January 1876.

16 Reichsgesetz über die Beurkundung des Personenstandes und die Eheschließung vom 6. Februar 1875, Reichs-Gesetzblatt (1875), 23, § 41: 'Innerhalb des Gebietes des Deutschen Reiches kann eine Ehe rechtsgültig nur vor dem Standesbeamten geschlossen werden.'

17 H. Mitteis, Bürgerliches Recht. Familienrecht, (1923), 4-5.

18 Ibid., 10-12 and H. Mitteis, Bürgerliches Recht. Familienrecht, (1931), 18-21.

19 The Civil Code used the word 'Verwandtschaft', which can be translated as 'kinship', instead of the word 'Blutverwandschaft' (consanguinity). Verwandtschaft meant related by marriage; § 1589 declared a father and an illegitimate child not to be related. See $\S 1589:$ '[...] Ein uneheliches Kind und dessen Vater gelten nicht als verwandt.' However, with regard to kinship as an impediment to marriage, $\$ 1310$ declared that in the sense of that article Verwandtschaft also meant the blood relation between a father and his illegitimate child. See $\$ 1310$ BGB: '[...] Verwandtschaft im Sinne dieser Vorschriften besteht auch zwischen einem unehelichen Kinde und dessen Abkömmlingen einerseits und dem Vater und dessen Verwandten andererseits.'

20 H. Mitteis, Bürgerliches Recht. Familienrecht, (1923), 11.

21 According to § 2 BGB adulthood was reached at the age of 21. However, according to § 3 BGB a minor who had reached the age of 18 could be declared of age by the court. 
Exceptionally, men could wed at the age of $\mathrm{I} 8$, whilst there was no fixed minimum age for women. Basically, a woman could obtain a release when she was pregnant; the father was left the choice between prison ${ }^{22}$ and marriage. ${ }^{23}$ Furthermore, marriage was prohibited with a person who had had sexual intercourse with an ancestor or a descendant $(\mathbb{I}$ IIIO $(2))$ and between adoptive parents and adopted children ( $\$$ I3II), although this impediment was removed the very moment the offence was committed as $\mathbb{S}$ I77I lifted the legal relation of adoption the moment the marriage between the adoptive parent and the adopted child was concluded. ${ }^{24}$

As of 1876 Jews were no longer prohibited to marry non-Jews. The Personenstandsgesetz of I 875 clearly listed all requirements and impediments to marriage ( $\$ 28-35)$ which did not contain any provisions regarding religious, social or racial differences between the partners. Furthermore, $\mathbb{S} 39$ stated that all provisions which would limit the right to marry outside the scope of the Personenstandsgesetz were abolished..$^{25}$ With the introduction of the Civil Code in I9oo $\$ 28$-40 of the Personenstandsgesetz were abolished ${ }^{26}$ and replaced by $\mathbb{S}$ I3O3-I3I5, $\mathbb{S}$ I322-I335 and $\mathbb{S}$ I348-I350 of the new Civil Code, which did not contain any provisions regarding religious, social or racial differences between the partners either.

\section{- 3.2.2. Annulment of marriage}

A marriage could be annulled when it was declared imperfect (fehlerhaft). The Civil Code recognised three forms of imperfect marriages: the Nichtehe, the nichtige Ehe or vernichtbare Ehe and the anfechtbare Ehe. ${ }^{27}$ The Nichtehe was the only truly invalid marriage. It contained a marriage which was not properly concluded along the lines of \$ I317, which was therefore not concluded at all. This 'non-marriage' was declared void in $\mathbb{S} 324 .^{28}$

The nichtige Ehe was not truly void, but avoidable (vernichtbar). Only when the grounds for avoidance were invoked and the marriage was annulled, the marriage could be called void, a Nichtehe.$^{29}$ Avoidance had retroactive effect and all consequences of marriage were therefore undone. Avoidable were marriages which were not properly concluded but registered in the marriage register $(\mathbb{S}$ I324 (2)). After ten years (or three years in case one of the partners died) of living together it was assumed that the marriage had been valid from the beginning, unless someone had called for avoidance in the mean time.

22 Strafgesetzbuch für das Deutsche Reich vom 15. Mai 1871, Reichs-Gesetzblatt (1871), 127 (which came into force on 01 January 1872), § 182: 'Wer ein unbescholtenes Mädchen, welches das sechzehnte Lebensjahr nicht vollendet hat, zum Beischlafe verführt, wird mit Gefängniß bis zu Einem Jahre bestraft. [...]'

23 H. Mitteis, Bürgerliches Recht. Familienrecht, (1923), 12.

24 See $\$ 1771$ BGB: 'Schließen Personen, die durch Annahme an Kindes Statt verbunden sind, der Vorschrift des $\S 1311$ zuwider eine Ehe, so tritt mit der Eheschließung die Aufhebung des durch die Annahme zwischen ihnen begründeten Rechtsverhältnisses ein. [...]'

25 See Reichsgesetz über die Beurkundung des Personenstandes und die Eheschließung vom 6. Februar 1875, Reichs-Gesetzblatt (1875), 23, § 39: 'Alle Vorschriften, welche das Recht zur Eheschließung weiter beschränken, als es durch dieses Gesetz geschieht, werden aufgehoben.'

26 Art. 46 (1) Einführungsgesetz zum Bürgerlichen Gesetzbuche vom 18. August 1896, Reichs-Gesetzblatt (1896), 604.

27 H. Mitteis, Bürgerliches Recht. Familienrecht, (1923), 8-9.

$28 \S 1324$ BGB: 'Eine Ehe is nichtig, wenn bei der Eheschließung die im $\S 1317$ vorgeschrieben Form nicht beobachtet worden ist.'

29 T. Kipp and M. Wolff, Das Familienrecht, (1920), 80; H. Mitteis, Bürgerliches Recht. Familienrecht, (1931), 15. 
According to $\mathbb{I}$ I325 lack of full legal capacity, unconsciousness or a mental disturbance of one of the partners at the time of the conclusion of the marriage would lead to avoidance as well. Finally openly separating impediments (öffentlich trennende Ehehindernisse) would lead to avoidance, as we have seen above. ${ }^{30}$

Reading $\mathbb{S}$ I343 it would seem that disputability (Anfechtbarkeit) had retroactive effect as well. ${ }^{31}$ However, when a marriage was disputed, it would lead to avoidance and avoidance would lead to annulment of marriage with retroactive effect. ${ }^{32}$ Disputability could only be invoked by one of the spouses ( $\mathbb{1}$ I33I-I335), with the exception of lack of full legal capacity of one the spouses, in which case the legal guardian could call for disputability ( $\$$ I336). Marriages were disputable in case of absence of consent of the legal guardian in case of lack of full legal capacity of one of the spouses at the time the marriage was concluded ( $\mathbb{1}$ I33I), in case of absence of consensus ad idem (Irrtum) and in case of the return of a spouse who was pronounced dead ( $\$$ I350). As absence of consensus ad idem were considered error concerning the conclusion of marriage ( $\$$ I332), error concerning the person or personal qualities of the other spouse ( $\mathbb{1}$ I333), deception $(\mathbb{S}$ I334) and threat ( $\mathbb{1}$ I335). Personal qualities were defined as essential, i.e. physical, psychological or moral characteristics of a person. Other circumstances and relations, i.e. belonging to a certain religion, social group or family, profession or name could not qualify as personal qualities in the sense of $\$ 13333^{33}$

\section{- 3.2.3. Dissolution of marriage}

With regard to dissolution of marriage church doctrine and the more modern notion of man as an individual being with its own needs (that came up during the Enlightenment) did not agree. According to the doctrine of the Catholic Church marriage was a sacrament, not to be separated by men. However, according to the Enlightenment doctrine of man as an individual, every person had his or her own soul, who could share a life together, but who at a certain moment could possibly not live together anymore. German divorce law during the Weimar Republic contained a compromise between these two doctrines. The German state considered marriage as the germ cell of social order and therefore had its own interests in preventing divorce. ${ }^{34}$ The conviction was that the state had to recognise the possibility of divorce in case marriage could no longer fulfil its social tasks, but that divorce could never be an individual affair. Therefore, divorce was largely grounded on the guilt principle (Verschuldensprinzip), which meant that, except in case of a mental disorder, divorce could only be pronounced in case the summoned partner had committed some wrong. However, since the beginning of the I 920 it was already discussed whether the guilt principle should be replaced with more objective grounds for divorce, i.e. the question whether a marriage was permanently disrupted (Zerrüttungsprinzip). ${ }^{35}$

30 Ibid., 82-83; H. Mitteis, Bürgerliches Recht. Familienrecht, (1923), 8-9.

31 See 1343 BGB: 'Wird eine anfechtbare Ehe angefochten, so ist sie als von Anfang an nichtig anzusehen. [...]'

32 See $\$ 1343$ (2) BGB: 'Die Nichtigkeit einer anfechtbare Ehe, die im Wege der Klage angefochten worden ist, kann, solange nicht die Ehe für nichtig erklärt oder aufgelöst ist, nicht anderweit geltend gemacht werden.' See also T. Kipp and M. Wolff, Das Familienrecht, (1920), 85

33 H. Mitteis, Bürgerliches Recht. Familienrecht, (1931), 17, 21-23.

34 H. Mitteis, Bürgerliches Recht. Familienrecht, (1923), 15.

35 H. Mitteis, Bürgerliches Recht. Familienrecht, (1931), 26-27. 
The German Civil Code distinguished two types of grounds for divorce, absolute grounds for divorce and relative grounds for divorce. In case of absolute grounds, a judge was obliged to pronounce the divorce without further judging the marriage. Absolute grounds for divorce were adultery and crimes against morality (Ehebruch und Sittlichkeitsdelikte, $\mathbb{S}$ I565), crimes against life or cruelty (Lebensnachstellung, $\mathbb{S}$ I566) and desertion with malicious intent (bössliche Verlassung, $\mathbb{S} 1567$ ). In order to give a definition of adultery and crimes against morality $\mathbb{S} 565$ refers to the relevant articles in the Penal Code, although $\mathbb{S}$ I72 Penal Code does not give a clear definition of adultery. ${ }^{36}$ Mitteis describes adultery as the normal, completed intercourse between two persons of opposite sex. ${ }^{37}$ This had to be proven; simply stating that adultery had been committed by the other spouse was not enough to have the divorce pronounced. Crimes against morality contained bigamy $(\mathbb{S}$ I7 I StGB) and perverse illicit sexual acts ( $\$$ I75 StGB), like sodomy and bestiality. There was no need for a criminal basis in order to get a divorce on grounds of crimes against life or cruelty, i.e. no charge of attempted murder or assault was needed. Desertion with malicious intent could be a ground for divorce if one of the spouses had had the intent to disturb the domestic community by deserting or repudiating the other spouse against his or her will. Culpable breakdown (schuldhafte Ehezerrüttung, $\mathbb{S}$ I568) and mental disorder (Geisteskrankheit, $\mathbb{S}$ 1569) were considered relative grounds for divorce. Mental disorder as ground for divorce did not fall under the guilt principle, but was acknowledged as a cause of permanent breakdown of marriage. The mental disorder had to be full, not partial and it had to last for a minimum of three continuous years, leading to a permanent disruption of the mental community. Culpable breakdown, however, did fall under the scope of the guilt principle, as the summoned partner had to be found guilty of the disruption. The judge had to decide objectively whether or not the marriage was permanently disrupted and what facts had caused the disruption. Furthermore, the spouse who had caused the disruption could not invoke $\mathbb{1} 1568$ as a ground for divorce. ${ }^{38}$

Under influence of the political left and women's organisations as the Bund Deutscher Frauenvereine the discussion about the replacement of the guilt principle by the breakdown principle came up repeatedly. ${ }^{39}$ The major political parties of the Weimar Republic, however, were divided with regard to reform of divorce law. In November I92I Minister of Justice Gustav Radbruch (Sozialdemokratische Partei Deutschlands - SPD) declared as a result of an interpellation by Marie Elisabeth Lüders that he was in favour of extending the number of grounds for divorce with objective permanent breakdown of marriage, i.e. a revision of $\mathbb{1} 1568$ BGB. In January 1922 he sent a proposed amendment - the unverbindliche Grundlinien eines Gesetzes zur Abänderung der Vorschriften des Bürgerlichen Gesetzbuchs über die Ehescheidung - to the state governments. In Prussia, a

36 See $\S 172$ StGB: 'Der Ehebruch wird, wenn wegen desselben die Ehe geschieden ist, an dem schuldigen Ehegatten, sowie dessen Mitschuldigen mit Gefängniß bis zu sechs Monaten bestraft. Die Verfolgung tritt nur auf Antrag ein.'

37 H. Mitteis, Bürgerliches Recht. Familienrecht, (1931), 28.

38 Ibid., 28-32.

39 C. Usborne, The Politics of the Body in Weimar Germany, 91; see also D. Blasius, Ehescheidung in Deutschland 1794-1945, 165-166. One of the parliamentarians who was a fervent supporter of liberalization of divorce was Marie Elisabeth Lüders, who was a member of the Reichstag on behalf of the Deutsche Demokratische Partei (DDP) from 1919 until September 1930. 
state which opinion carried much weight with the federal government, opinions differed. The Minister of the Interior ${ }^{40}$ as well as the Prussian Prime Minister ${ }^{41}$ were in favour of the proposed amendments whilst the Minister of Justice ${ }^{42}$ and the Minister of Science, Art and Public Education ${ }^{43}$ were against. The Catholic Church joined the discussion through cardinal Bertram who lodged a complaint against the proposed reform. Besides religious arguments the German episcopacy also argued that as the family was the germ cell of the nation, the German nation would meet with disaster when divorce was liberalised. ${ }^{44}$ The bishop's words were very influential, especially among the right-wing politicians, ${ }^{45}$ and the political parties remained divided on the matter. A breakthrough seemed to be forced in I928 with the formation of the 'Große Koalition'. ${ }^{46}$ Erich Koch-Weser as Minister of Justice (DDP) got the discussion going again, which led to a serious debate about the matter in the Reichstag at the end of 1928 and a proposed amendment in I929. During this debate, Koch-Weser declared clearly that he was of the opinion that the grounds for divorce should be extended with the breakdown principle. ${ }^{47}$ In the beginning of 1929 he sent the proposed amendment ${ }^{48}$ to the Reichstag. This proposed amendment was formulated carefully to offend none of the political parties (especially not the Deutsche Zentrumpartei). It contained a new article, $\mathbb{S} 1568 \mathrm{a},{ }^{49}$ to extend the number of grounds for divorce with objective breakdown. This new article would be placed after the existing $\mathbb{S}$ I568, suggesting that the guilt principle remained the most important ground for divorce and that the new article was only another exception just as the existing $\mathbb{S}$ I569 (mental disorder). However, before the proposed amendment could be approved, it was overtaken by political reality. Koch-Weser was replaced as Minister of Justice by his opponent Theodor von Guérard (Zentrum), who was against reform of divorce law, on I3 April I929. The proposed amendment was shelved due to the opposition of the Deutschnationale Volkspartei (DNVP) and the Deutsche Zentrumpartei, and although the proposal was discussed several times, the grounds for divorce were not changed until I $938 .^{50}$

40 Carl Severing, member of the Sozialdemokratische Partei Deutschlands (SPD).

41 Otto Braun, SPD.

42 Hugo am Zehnhoff, member of the Deutsche Zentrumspartei (Zentrum)

43 Otto Boelitz, member of the Deutsche Volkspartei (DVP).

44 'Die Erleichterung der Ehescheidung ist ein neues trauriges Symptom für den fortschreitenden Niedergang der Sittlichkeit unseres Volkes.' Quote taken from D. Blasius, Ehescheidung in Deutschland 1794-1945, 169.

45 However, Wilhelm Kahl, member of the DVP and opposed to any reform of divorce law stated: 'Ich muß aber eine gesetzgebende Körperschaft wie den Reichstag daran erinnern, daß das deutsche Eherecht seit 130 Jahren, seit dem Preußischen Allgemeinen Landrecht von 1794, säkularisiert worden ist, daß hier nicht die Gesichtspunkte des codex iuris canonici, sondern ausschließlich die staatlichen Bedürfnisse maßgebend sind.' Quote taken from D. Blasius, Ehescheidung in Deutschland 1794-1945, 173.

46 SPD, DDP, Zentrum, DVP and Bayerische Volkspartei (BVP).

47 'Ich halte mit den Antragstellern unser heutiges Ehescheidungsrecht für reformbedürftig und bin der Meinung, daß die Abhilfe darin wird bestehen müssen, neben das Schuldprinzip das Zerrüttungsprinzip zu setzen. Zerrüttete Ehen können, auch wenn die Schuld eines der Ehegatten nicht festgestellt werden kann, auf die Dauer nicht wider den Willen der Beteiligten aufrechterhalten bleiben. Die Lösung einer solchen Ehe ist aber heute entweder unmöglich, oder sie erfolgt nur unter Manipulationen, die für die Beteiligten erniedrigend und für die Autorität der Gerichte entwürdigend sind.' Quote taken from D. Blasius, Ehescheidung in Deutschland 1794-1945, 181.

48 Entwurf eines Gesetzes zur Änderung der Vorschriften über die Ehescheidung, published in W. Schubert, Die Projekte der Weimarer Republik zur Reform des Nichtehelichen-, des Adoptions- und des Ehescheidungsrecht, 597-600.

49 Ibid., Artikel 1 (1): 'Hinter $\$ 1568$ wird als $\$ 1568$ a folgende Vorschrift eingefügt: Ein Ehegatte kann ferner auf Scheidung klagen, wenn aus einem anderen Grunde eine so tiefe Zerrüttung des eheliches Verhältnisses eingetreten ist, daß ihm die Fortsetzung der Ehe nicht zugemutet werden kann. Das Klagerecht besteht nicht, wenn er selbst einen Scheidungsgrund gegeben hat oder anderweit die Zerrüttung der Ehe vorwiegend durch sein schuldhaftes Verhalten herbeigeführt worden ist.' See W. Schubert, Die Projekte der Weimarer Republik zur Reform des Nichtehelichen-, des Adoptions- und des Ehescheidungsrecht, 597-598.

50 D. Blasius, Ehescheidung in Deutschland 1794-1945, 165-187. 
To please the Catholic Church, the Civil Code also recognised separation from bed and board (Aufhebung der ehelichen Gemeinschaft, $\mathbb{S}$ 1575). Separation from bed and board could be requested by the spouse who was entitled to request divorce. ${ }^{51}$ Generally, all consequences of divorce were applicable on the separation from bed and board. However, since the marriage was not dissolved, the spouses could not remarry, as this would imply bigamy. The rules concerning avoidance and disputability were still applicable as well. ${ }^{52}$

\subsection{From Weimar to Third Reich}

The Ermächtigungsgesetz of 24 March $1933^{53}$ provided Hitler with the opportunity to enact laws without consulting the Reichstag. ${ }^{54}$ In 1934 the government passed a law uniting the functions of head of state and chancellor, ${ }^{55}$ which enabled him to do pretty much what he wanted. Despite this, German family law was not adapted to National Socialism overnight. Already from the beginning of the National Socialist assumption of power, the importance of the family as germ cell of the nation was emphasised. Nevertheless, it took more than two years before definite measures to protect the Aryan family were taken. Preventing the hereditarily ill to procreate was not enough; preservation of the Aryan race was also done by preventing 'inferior' races, like the Jews to mingle with Aryan blood. ${ }^{56}$ Creating new impediments to marriage or facilitating dissolution of mixed marriages were ways to achieve this. Generally we can distinguish two periods: the first period was a period of reinterpreting existing laws and enacting loose policies, which on the sideline affected family law and put limitations on the right to marry. This period ended with the adoption of the Nuremberg Laws on 15 September 1935. With the adoption of the Reichsbürgergesetz ${ }^{57}$ and the Blutschutzgesetz ${ }^{58}$ the second period, the period of systematic revision of family law, started. The remaining part of this chapter will deal with the re-interpretation of the existing laws and the small regulations directed toward marriage of the first period and the systematic revision of family law of the second period, by discussing the Nuremberg Laws, the Marriage Health Law of $1935^{59}$ and the Marriage Law of $1938 .^{60}$

51 See § 1575: 'Der Ehegatte, der auf Scheidung zu klagen berechtigt ist, kann statt auf Scheidung auf Aufhebung der ehelichen Gemeinschaft klagen. [...]'

52 See § 1586: 'Wird nach § 1575 die eheliche Gemeinschaft aufgehoben, so treten die mit der Scheidung verbundenen Wirkungen ein; die Eingehung einer neuen Ehe ist jedoch ausgeschlossen. Die Vorschriften über die Nichtigkeit und Anfechtbarkeit der Ehe finden Anwendung, wie wenn das Urteil nicht ergangen wäre.'

53 Gesetz zur Behebung der Not von Volk und Reich vom 24. März 1933, Reichsgesetzblatt (1933), I, 141.

54 Ibid., Art. 1: 'Reichsgesetze können außer in dem in der Reichsverfassung vorgesehenen Verfahren auch durch die Reichsregierung beschlossen werden. [...]'

55 Gesetz über das Staatsoberhaupt des Deutschen Reichs vom 1. August 1934, Reichsgesetzblatt (1934), I., 747, § 1: 'Das Amt des Reichspräsidenten wird mit dem des Reichskanzlers vereinigt. Infolgedessen gehen die bisherigen Befugnisse des Reichspräsidenten auf den Führer und Reichskanzler Adolf Hitler über. Er bestimmt seinen Stellvertreter.' § 2: 'Diesen Gesetz tritt mit Wirkung von dem Zeitpunkt des Ablebens des Reichspräsidenten von Hindenburg in Kraft.' Von Hindenburg died the following day.

56 In Mein Kampf Hitler discarded the thesis that Judaism was only a religion and that Jews could be Germans as well: 'Die besten Kenner aber dieser Wahrheit über die Möglichkeiten der Anwendung von Unwahrheit und Verleumdung waren zu allen Zeiten die Juden; ist doch ihr ganzes Dasein schon auf einer einzigen großen Lüge aufgebaut, nähmlich der, daß es sich bei ihnen um eine Religionsgenossenschaft handle, während es sich um eine Rasse - und zwar was für eine - dreht.' A. Hitler, Mein Kampf, 253. 'The foremost connoisseurs of this truth regarding the possibilities in the use of falsehood and slander have always been the Jews; for after all, their whole existence is based on one single great lie, to wit, that they are a religious community while actually they are a race - an what a race!' Translation by R. Manheim, 232.

57 Reichsbürgergesetz vom 15. September 1935, Reichsgesetzblatt (1935), I, 1146.

58 Gesetz zum Schutze des deutschen Blutes und der deutschen Ehre vom 15. September 1935, Reichsgesetzblatt (1935), I, 1146.

59 Gesetz zum Schutze der Erbgesundheit des deutschen Volkes vom 18. Oktober 1935, Reichsgesetzblatt (1935), I, 1246.

60 Gesetz zur Vereinheitlichung des Rechts der Eheschließung und der Ehescheidung im Lande Österreich und im übrigen Reichsgebiet vom 6. Juli 1938, Reichsgesetzblatt (1938), I, 807. 


\title{
3.4. March 1933-August 1935: re-interpreting the law \\ -3.4 .1 . Conclusion of marriage
}

As 'purity of the Aryan race' was considered the ultimate ingredient for the establishment and survival of the Third Reich, 'mingling of races' - i.e. mixed marriages was considered fundamentally wrong. In I930 Alfred Rosenberg had already stated in his major work Der Mythus des 20. Jahrhunderts that:

\begin{abstract}
Ehen zwischen Deutschen und Juden sind zu verbieten, solange überhaupt noch Juden auf deutschen Boden leben dürfen. (Daß die Juden die Staatsbürgerrechte verlieren und unter ein ihnen gebührendes neues Recht gestellt werden, versteht sich von selbst.) Geschlechtlicher Verkehr, Notzucht usw. zwischen Deutschen und Juden ist je nach der Schwere des Falles mit Vermögensbeschlagnahme, Ausweisung, Zuchthaus, und Tod zu bestrafen. ${ }^{61}$
\end{abstract}

With these remarks Rosenberg ran ahead of things, as mixed marriages were not prohibited until September 1935 with the adoption of the Nuremberg Laws. In the meantime the rules set out in the Civil Code were still applicable. In anticipation of legal restrictions with regard to marriage, officials entitled to perform marriages, started refusing to marry Jews and non-Jews on the grounds of 'general national principles'. These 'general national principles' were expressed in the Gesetz zur Wiederherstellung des Berufsbeamtentums from 7 April $1933 .{ }^{62} \mathbb{} 3$ stated that all civil servants, who were not of Aryan descent, were retired, with the exception of those who had already been a civil servant since I August I9I4, had fought in the German army or confederate army during the First World War, or had lost their father or their son(s) in this war. ${ }^{63}$ The first supplementary decree to this law ${ }^{64}$ elaborated the term 'Aryan' in article 2, stating that anyone who descended from non-Aryan parents or grandparents - in particular Jewish parents or grandparents - was considered non-Aryan. Having one non-Aryan parent or grandparent was enough in this respect. ${ }^{65}$ In 1934 Minister of the Interior Frick took action against this practice, stating that the law, although not 'fully conform to National Socialist views', should be respected ${ }^{66}$ The Supreme Court, stating that 'mixed marriages'

61 A. Rosenberg, Der Mythus des 20. Jahrhunderts, 579. 'Marriages between Germans and Jews must be forbidden, at least as long as Jews generally remain upon German soil. That the Jews lose their rights of citizenship and must be subject to a new law appropriate to them, is self-evident. Sexual intercourse, rape, etc., between Germans and Jews must be, according to the gravity of the case, punished by confiscation of property, expulsion, jail and death.' Translation by V. Bird.

62 Gesetz zur Wiederherstellung des Berufsbeamtentums vom 7. April 1933, Reichsgesetzblatt (1933), I, 175.

63 Ibid., § 3: '(1) Beamte, die nicht arischer Abstammung sind, sind in den Ruhestand [...] zu versetzen; [...]. (2) Abs. 1 gilt nicht für Beamte, die bereits seit dem 1. August 1914 Beamte gewesen sind oder die im Weltkrieg and der Front für das Deutsche Reich oder für seine Verbündeten gekämpft haben oder deren Vater oder Söhne im Weltkrieg gefallen sind. [...]'

64 Erste Verordnung zur Durchführung des Gesetzes zur Wiederherstellung des Berufsbeamtums vom 11. April 1933, Reichsgesetzblatt (1933), I, 195.

65 Ibid., Article 2 (1): 'Als nicht arisch gilt, wer von nicht arischen, insbesondere jüdischen Eltern oder Großeltern abstammt. Es genügt, wenn ein Elternteil oder ein Großelternteil nicht arisch ist. Dies ist insbesondere dann anzunehmen, wenn ein Elternteil oder ein Großelternteil der jüdischen Religion angehört hat.'

66 L. Gruchmann, “Das “Blutschutzgesetz” vom 15.9.1935 und die Justiz', 423-424; I. Müller, Hitler's Justice. The Courts of the Third Reich, 92. 
were not illegal, confirmed this. ${ }^{67}$ In practice, however, this rule was not followed and in I935 even more mixed couples were denied the right to marry. The general conviction by those who had to perform marriages was that although 'mixed marriages' were not literally prohibited by the law, they violated 'the most important laws of the nation, which consist in cultivating German blood and maintaining its purity'. ${ }^{68}$ In June I935 the Petty Court in Wetzlar ruled that the refusal to marry a mixed couple was legitimate, even when no formal prohibition on mixed marriages existed. After the National Socialist assumption of power the foundations of the National Socialist Weltanschauung formed the foundations of the new völkish German Reich. ${ }^{69}$ The court concluded with the remark that the National Socialist view of the law implied that every individual had to focus his inner attitude and outward conduct in life on the welfare of the Volk and subordinate oneself to its interests. This rule had to be considered legally binding. ${ }^{70}$ The Petty Court in Bad Sülze confirmed this point of view by stating that a marriage between an Aryan and a non-Aryan contravened with the most important laws of the nation, which were meant to protect and improve the German race. ${ }^{71}$ In August 1935 the County Court of Königsberg added a little extra by stating that the administration of justice was placed in the service of the Volk. ${ }^{72}$ According to the court legal principles were not binding because of their status of laws, "but rather because they are established on the basis of a general sense of justice. ${ }^{73}$ The sense of justice of the German people was invoked by stating that 'no one can be in any doubt that a marriage between a Jew and an Aryan woman is contrary to the German view of the law'. ${ }^{74}$ Before the adoption of the Nuremberg Laws in September 1935, marriages between Aryans and Jews had largely been made impossible already by the Wehrgesetz of 2 I May $1935^{75}$ which stated in $\mathbb{S} 5$ (4) that all members of Germany's active or reserve military forces were prohibited to marry a non-Aryan. ${ }^{76}$ As all Aryan men in the age of 18 to 45 were a member of the military forces, ${ }^{77}$ marriages

67 Reichsgericht, 12 July 1934, 63 Juristische Wochenschrift 42 (1934), 2613-2615: 'Die künftige Eingehung von Mischehen ist nicht verboten. [...] Damit steht in Einklang das Rundschreiben des RinnM. v. 17. Jan. 1934 (PrMBliB. 159), das darauf aufmerksam macht, daß die gesetzlichen Schranken, die sich die Reichsregierung bei der Ariergesetzgebung gesteckt hat, genau zu beachten sind, und daß es nich angängig ist, den Grundsatz des § 3 WBG, auf Gebiete auszudehnen, für die sie nicht bestimmt sind.' See also I. Müller, Hitler's Justice. The Courts of the Third Reich, 92.

68 Amtsgericht Bad Sülze, 8 July 1935, 64 Juristische Wochenschrift 32 (1935), 2309: 'Eine derartige Ehe verstößt gegen die wichtigsten Gesetze des Staates, in der Reinhaltung und Pflege des deutschblütigen Volkes bestehen.'

69 Amtsgericht Wetzlar, 17 June 1935, 64 Juristische Wochenschrift 29 (1935), 2083: 'Mit der Machtübernahme durch den Nationalsozialismus in Deutschland sind die Grundlagen der nationalsozialistischen Weltanschauung zugleich die Grundlagen für den völkisch-staatlichen Neuaufbau des deutschen Reiches geworden.'

70 Ibid.: 'Nationalsozialistische - das ist arteigene - Rechtsanschauung hat demgegenüber wieder das artgemäße Gesetz des Sollens aufgerichtet als Anforderung an jeden einzelnen, seine innere Haltung und äußere Lebensführung allein auf das Wohl seines Volkes auszurichten und dessen Belangen sich unterzuordnen. Dieses Satz is bindendes geltendes Recht des Dritten Reiches [...].'

71 Amtsgericht Bad Sülze, 8 July 1935, 64 Juristische Wochenschrift 32 (1935), 2309: 'Eine derartige Ehe verstößt gegen die wichtigsten Gesetze des Staates, die in der Reinhaltung und Pflege des deutschblutigen Volkes bestehen.'

72 Landgericht Königsberg, 26 August 1935, 97 Deutsche Justiz 38 (1935), 1387: 'Die Rechtsprechung ist nicht weniger als jede andere Staatstätigkeit Dienst am Volke.'

73 Ibid.: 'Nicht daß Rechtsgrundsätze zum Gesetz erhoben warden, ist das Entscheidende, sondern daß sie auf Grund allgemeiner Rechtsüberzeugung aufgestellt sind, rechtfertigt ihre anwendung, selbst bevor sie als Gesetz verkündigt sind.'

74 Ibid.: 'Daß aber gerade die Eheschließung zwischen einem Juden und einer Arierin in Widerspruch zu deutscher Rechtsauffassung steht, kann niemandem zweifelhaft sein [...].' See also I. Müller, Hitler's Justice. The Courts of the Third Reich, 92.

75 Wehrgesetz vom 21. Mai 1935, Reichsgesetzblatt (1935), I, 609.

76 Ibid., § 15 (4): 'Den Angehörigen arischer Abstammung der Wehrmacht und des Beurlaubtenstandes ist das Eingehen der Ehe mit Personen nichtarischer Abstammung verboten. [...]'

77 See ibid., § 1 (2): 'Jeder deutsche Mann is wehrpflichtig.' and § 4: 'Die Wehrpflicht dauert vom vollendeten 18. Lebensjahre bis zu dem auf die Vollendung des 45 . Lebensjahre folgenden 31. März.' 
between Aryan men and Jewish women were largely impossible. ${ }^{78}$ Secretary of Justice Roland Freisler spoke against a analogous application of this article, despite the adoption of the so-called analogy-article of 28 June 1935 in the Penal Code, ${ }^{79}$ as he preferred to regulate this matter in a separate law with general penalty clauses. ${ }^{80}$

\section{- 3.4.2. Annulment of marriage}

Since prohibition of mixed marriages was not entirely possible, other ways to prevent or dissolve mixed marriages - and therewith children of mixed ancestry - had to be found. Divorce on the mere ground that one of the spouses was Jewish was not possible, as the Civil Code required one of the partners to have committed some wrong as ground for a divorce. A solution, ${ }^{81}$ however, was found in $\$$ I333 of the Civil Code, stating:

Eine Ehe kann von dem Ehegatten angefochten werden, der sich bei der Eheschließung in der Person des anderen Ehegatten oder über solche persönliche Eigenschaften des anderen Ehegatten geirrt hat, die ihn bei Kenntnis der Sachlage und bei verständiger Würdigung des Wesens der Ehe von der Eingehung der Ehe abgehalten haben würden. ${ }^{82}$

Originally, being Jewish was not considered to be such a personal quality justifying an annulment of marriage as personal qualities were defined as essential, i.e. physical, psychological or moral characteristics of a person. Other circumstances and relations, i.e. belonging to a certain religion, social group or family, profession or name could not qualify as personal qualities in the sense of $\mathbb{S} 1333 .{ }^{83}$ Furthermore, it was certainly not a quality of which the other spouse remained unaware of during the marriage. Besides that, the claim should be filed within six months of discovering the error ${ }^{84}$ and in case the spouse, who had the grounds for the complaint, had implicitly through his behaviour confirmed that marriage, the grounds for annulment lapsed. ${ }^{85}$

However, voices were raised stating that until recently it was always believed that Judaism was only a religion and that, just as Hitler had pointed out in Mein Kampf, very few

78 See also R.L. Miller, Nazi Justiz. Law of the Holocaust, 145.

79 Gesetz zur Änderung des Strafgesetzbuchs vom 28. Juni 1935, Reichsgesetzblatt (1935), I, 839, § 2: 'Bestraft wird, wer eine Tat begeht, die das Gesetz für strafbar erklärt oder die nach dem Grundgedanken eines Strafgesetzes und nach gesundem Volksempfinden Bestrafung verdient. Findet auf die Tat kein bestimmtes Strafgesetz unmittelbar Anwendung, so wird die Tat nach dem Gesetz bestraft, dessen Grundgedanke auf sie am besten zutrifft.' This article effectively abolished the principle of legality.

80 L. Gruchmann, 'Das "Blutschutzgesetz" vom 15.9.1935 und die Justiz', 428.

81 See I. Müller, Hitler's Justice. The Courts of the Third Reich, 93.

82 Bürgerliches Gesetzbuch vom 18. August 1896, Reichs-Gesetzblatt (1896), 195. 'A marriage can be challenged by a spouse who at the time of its contraction was unaware of personal qualities in the other spouse, qualities that would have prevented a person from entering into the marriage had he had knowledge of the true circumstances and a proper understanding of the nature of marriage.' Translation by D.L. Schneider.

83 H. Mitteis, Bürgerliches Recht. Familienrecht, (1931), 17, 21-23.

84 See $§ 1339$ BGB: 'Die Anfechtung kan nur binnen sechs Monaten erfolgen. Die Frist beginnt [...] in den Fällen der $\S 1332$ bis 1334 mit dem Zeitpunkt, in welchem der Ehegatte den Irrtum oder die Täuschung entdeckt [...].'

85 See $\S 1337$ BGB '[.... In den Fällen der $\S \S 1332$ bis 1335 ist die Anfechtung ausgeschlossen, wenn der anfechtungsberechtigte Ehegatte nach der Entdeckung des Irrtums oder der Täuschung oder nach dem Aufhören der Zwangslage die Ehe bestätigt. [...]' See also I. Müller, Hitler's Justice. The Courts of the Third Reich, 93. 
Germans were aware of the fact that Jews formed a race.$^{86}$ According to several jurists, e.g. Wöhrmann, the German people never had had the chance before to gain knowledge about the 'significance of Jewishness' and 'the inner dimensions of the race questions'. If Germans were to have realised the true identity of their Jewish partners, they would never have entered into the marriage. ${ }^{87}$ This argument should justify the use of $\mathbb{}$ I333 Civil Code to annul mixed marriages, dealing with the problem of the term in which the complaint had to be filed as well, since this term should be considered to start only after 7 April $1933^{88}$ or anyway not before 30 January $1933 .{ }^{89}$ Several courts ${ }^{90}$ adopted this line of reasoning, granting claims for annulment on the mere ground that the complainant had only recently discovered 'what' he or she was married to. Knowledge of the 'essential facts' was considered not to be a matter-of-course, as the innocent spouse was often deceived by the other partner. Proof for this deception was not required. Since the significance of race, blood and national identity only recently had become clear, it could not be assumed out of hand from less educated people to be aware of all the facts. ${ }^{91}$ Although some jurists felt that 'it is not the role of the court to alter the existing laws of the nation, ${ }^{92}$ the Supreme Court ruled in a decision of I2 July 1934 that being a member of the Jewish race was a 'personal quality in the sense of $\$$ I 333 of the Civil Code ${ }^{93}$ and stated that based on $\mathbb{S}$ I333 a mixed marriage could be annulled if one of the spouses had not been aware of the fact that the other spouse was Jewish. ${ }^{94}$ Obviously, complete unawareness was hard to prove and therefore the Supreme Court concurred in the opinion of the County Court Cologne that an error concerning the essence of Judaism and racial differences could be regarded as unawareness of the racial differences itself. ${ }^{95}$ However, the Supreme Court only accepted this line of reasoning in exceptional cases, e.g. when the Aryan spouse under influence of church doctrines - was of the belief that Judaism only comprehended a religion, an obstacle which could be overcome by a conversion to Christianity of the Jewish spouse.$^{96}$ According to the Supreme Court the law did not prohibit mixed marriages ${ }^{97}$ and

86 See A. Hitler, Mein Kampf, 253.

87 Wöhrmann, 'Die Auflösung der Ehe zwischen Juden und Ariern', 62 Juristische Wochenschrift 37 (1933), 2041.

88 On 7 April 1933 the Gesetz zur Wiederherstellung des Berufsbeamtums, Reichsgesetzblatt (1933), I, 175, establishing racial origin as a category with significant legal consequences, came into force. In pursuance of this law legal journals published articles in which the above-mentioned arguments were stated.

89 Hitler was appointed Reichskanzler by President Von Hindenburg on 30 January 1933 after winning the elections with his Nazi Party, the NSDAP.

90 Landgericht Cologne, 1933, 95 Deutsche Justiz 52 (1933), 819 and Oberlandesgericht Karlsruhe, 2 March 1934, Der Deutsche Rechtspfleger (1934), 292. See also Höchstrichterliche Rechtsprechung 7 (1934), no. 489.

91 'Zur Frage der Anfechtbarkeit von Mischehen', 95 Deutsche Justiz 52 (1933), 818, 819.

92 R. Freisler, 'Recht, Richter und Gesetz', 95 Deutsche Justiz 49 (1933), 694, 695. Freisler explicitly stated that only the Führer could formulate laws, whilst the courts had to protect them. Every individual could come up with his own interpretation of 'völkish necessity' (völkischer Notwendigkeit) which would inevitably lead to chaos and anarchy. Therefore courts could not be allowed to decide in violation of the law, even when this law was not in accordance with national socialist principles.

93 Reichsgericht, 12 July 1934, 63 Juristische Wochenschrift 42 (1934), 2613: 'Wegen der besonderen Eigentümlichkeiten der verschiedenen Rassen erscheint die Zugehörigkeit zu einer Rasse, insbes. zur jüdischen Rasse, nach der natürlichen Lebensauffassung als wesentlicher Bestandteil der Persönlichkeit eines Menschen und damit als persönliche Eigenschaft im Sinne der angegebenen Gesetzesvorschrift ( $\$ 1333-\mathrm{ML})$.'

94 Ibid.: 'Hat also ein arischer Ehegatte bei der Eheschließung nicht gewußt, daß der andere der jüdischen Rasse angehört, so hat er sich in einem Irrtum über eine persönliche Eigenschaft des anderen befunden, der ihn beim Vorliegen der sonstigen Voraussetzungen des $§ 1333$ zur Anfechtung der Ehe berechtigt.'

95 Ibid., 2614: 'Völlig auszuschließen ist die Möglichkeit eines Irrtums über eine persönliche Eigenschaft allerdings nicht, auch wenn ein Ehegatte von der bisherigen Zugehörigkeit des andern zum Judentum bereits bei der Eheschließung Kenntnis hatte.'

96 Ibid.: 'Der Fall kann so liegen, daß der arische Teil unter dem Einfluß kirchlicher Lehren vom Rasseunterschied überhaupt nichts wußte, sondern angenommen hat, der andere Teil gehöre lediglich einer anderen Religion an, und der Unterschied werde durch eine Übertritt des anderen zum Christentum beseitigt.'

97 Ibid.: 'Die künftige Eingehung von Mischehen ist nicht verboten.' 
courts were not allowed to extensive interpretation overstepping the limits the National Socialist state had drawn. ${ }^{98}$ With regard to the term the Supreme Court confirmed that the permitted six-month period was not to start before 15 April $1933^{99}$ as the general knowledge of the significance of racial differences could not be presumed to have existed before the change of the Gesetz zur Widerherstellung des Berufsbeamtentums. ${ }^{100}$ This decision showed the compromise the Supreme Court had to find between on the one hand the more radical National Socialists by stating that 'die Gerichte bei der Anwendung des Gesetzes dem durch die Ariergesetzgebung staatlich anerkannten Rasseunterschied Rechnung zu tragen haben'101 and on the other hand people like Frick and Freisler who aimed for a nazification according to the rules, by stating that courts were not allowed to overstep the limits drawn by the National Socialist state. Nevertheless, with this decision the Supreme Court cleared the way for radical revisions of marriage laws. ${ }^{102}$

\subsection{The Nuremberg Laws}

\section{- 3.5.1. The build-up to amendments}

The Reich Party Conference of Freedom, held in Nuremberg on I5 September I935, finally provided the promised legal clarification. However, it took some doing before legal measures towards racial hygiene were drafted since at the Ministry of Justice noone would take the responsibility. In September 1933 the Prussian Minister of Justice Hanns Kerrl and his Secretary of Justice Roland Freisler wrote a memorandum entitled Nationalsozialistisches Strafrecht ${ }^{103}$ in which they listed four acts that had to be made an offence in order to protect the race. Marriages and extramarital intercourse between those of German blood and members of racially alien communities had to be considered 'betrayal of the race' (Rasseverrat), in particular when the act was committed as a result of fraudulent concealment or deception with regard to a person's racial background. Other offences were 'violation of racial honour' (Verletzung der Rassenehre), i.e. public impudent contact with members of coloured races, and 'endangerment of the race' (Rassengefährdung), i.e. breach of the rules concerning the preservation and improvement of the German blood and malicious opposition to educational measures taken by the state. ${ }^{104}$ However, in June 1934 these suggestions were rejected by the criminal law commission of the Ministry of Justice, not because of a deterioration of diplomatic relations with India, Japan, Ceylon and South-America - the discriminatory provisions regarding coloured people had caused quite a stir particularly in Asia - and an economical

98 Ibid.: 'Die Gerichte sind nicht befugt, den nationalsozialistischen Anschauungen über diejenigen Grenzen hinaus Geltung zu verschaffen, die die Gesetzgebung des nationalsozialistischen Staates sich selbst gezogen hat.'

99 Ibid., 2615: 'Als Beginn der Anfechtungsfrist kann der 15. April 1933 angesehen werden, da mit Sicherheit angenommen werden kann, daß an diesem Tage die gedachten gesetzlichen Bestimmungen allgemein bekannt geworden waren.'

100 Ibid.: 'Erst durch das Gesetz zur Wiederherstellung des Berufsbeamtentums v. 7. April 1933 [...] (insbes. § 3) sind aus der Rasseverschiedenheit staatliche Folgerungen gezogen worden. Vor dieser staatlichen Anerkennung der Bedeutung der Rasseverschiedenheit war eine Anerkennung dieser Bedeutung durch die Gerichte im Eheanfechtungsstreit nicht zu erwarten. Bis dahin erscheint daher die Anfechtungsfrist gehemmt.'

101 'the Courts, when applying the law, have to take into account the racial distinctions as acknowledged by the State through the legislation concerning Aryans.'

102 Reichsgericht, 12 July 1934, 63 Juristische Wochenschrift 42 (1934), 2613-2615. See also I. Müller, Hitler's Justice. The Courts of the Third Reich, 95-96.

103 H. Kerrl and R. Freisler (ed.), Nationalsozialistisches Strafrecht.

104 Ibid., 47-49. See also L. Gruchmann, "'Blutschutzgesetz" und Justiz', 418-419. 
boycott of German products, but due to technical reasons. Reich Minister of Justice Franz Gürtner was of the opinion that protection of the race should not be enforced by regulations carrying a penalty. Instead Germans should become aware of the importance of racial hygiene by education and information campaigns. Furthermore, if one wanted to protect the race by means of criminal law, i.e. declaring marriages and extramarital intercourse by members of different races an offence, it had to be declared an impediment to marriage first, i.e. a prohibition to marry according to civil law, which infringement would lead to an offence carrying a penalty according to criminal law. ${ }^{105}$ However, one was of the opinion that such a far-reaching decision had to be taken by the political leadership instead of the criminal law commission. The commission therefore could not include these proposals in its draft. Consequently, when mixed marriages could not be prohibited, extramarital intercourse between members of different racial communities could not be prohibited either, as it was not possible to objectively determine whether the resulting child was a half-breed or not. Gürtner gained support from Landgerichtsdirektor ${ }^{106} \mathrm{Grau}$, although Grau was of the opinion that fulfilment of the Nazi Party Programme had to be established by legislation, i.e. a legal impediment to marriage, besides education and information campaigns. However, as the memorandum had caused significant political unrest abroad, he advised not to include any provisions considering race protection in the Penal Code. The commission did include the provision considering fraudulent concealment or deception with regard to a person's racial background. This introduced a new problem as a definition of 'alien race' (fremde Rasse) lacked. The question was which races had to be defined as 'alien'. This proved to be a controversial question about which opinions differed even within the Ministry of the Interior. According to then existing ideas the German people already consisted of five main races. ${ }^{107}$ Therefore Gürtner insisted that the draft only mentioned the distinction of races, without passing a value judgement. Freisler suggested including the following definition: 'Fremdrassig im Sinne dieser Bestimmungen ist jeder dessen Vater oder Mutter farbig oder jüdischen Blutes ist'. ${ }^{108}$ Gürtner, however, decided that the competent authorities had to come up with a definition. At the end of the day the commission's draft never came into force. ${ }^{109}$

In January 1934 Reich Minister of the Interior Wilhelm Frick had already distributed his memorandum stating that the law, 'although not fully conform National Socialist views', had to be respected. This memorandum was followed by the decision of the Supreme Court of I2 July 1934, which confirmed this statement. ${ }^{110}$ However, as already explained before, in 1935 more and more mixed couples were denied the right to marry, a practice

105 L. Gruchmann, '"Blutschutzgesetz" und Justiz', 419-420; I. Müller, Hitler's Justice. The Courts of the Third Reich, 91.

106 President of County Court (Landgericht). Nowadays this function is no longer called Landgerichtdirektor but Vorsitzender Richter am Landgericht.

107 Leading scholar in this field was Hans F.K. Günther. He distinguished five main European races: the Nordic race, the Western or Mediterranean race, the Eastern or Alpine race, the Dinaric race and the Eastbaltic race. He furthermore added the Phalian race to this list, whilst other authors regarded the Phalian race as a mere subcategory of the Nordic race. See H.F.K. Günther, Rassenkunde des deutschen Volkes, (1930), 22-25, 144.

108 'Of an alien race within the meaning of these provisions is everyone whose father or mother is either coloured or of Jewish blood.'

109 L. Gruchmann, "'Blutschutzgesetz" und Justiz', 420-423.

110 Reichsgericht, 12 July 1934, 63 Juristische Wochenschrift 42 (1934), 2613-2615. 
which was approved of and confirmed by several courts. ${ }^{111}$ In the meantime both the Ministries of Justice and the Interior were put under pressure by several organs. In December 1934 the participants in a physician's conference requested Frick to adopt regulations prohibiting extramarital intercourse between those of German blood and Jews. ${ }^{112}$ As Frick did not want to take the responsibility, the request was forwarded to the Minister of Justice who returned it to Frick. ${ }^{113}$ The Wehrgesetz of 21 May I935 ${ }^{114}$ already made marriages between Aryans and Jews largely impossible. However, the prohibition stated in $\mathbb{S} I_{5}(4)^{115}$ did not contain a general impediment to marriage according to civil law. This can be derived from the second sentence of $\mathbb{S} I_{5}(4)$ which stated that violation of the rule given in the first sentence would result in the loss of all military ranks. ${ }^{116}$ Such a consequence would not be necessary in case of a civil impediment to marriage, for the marriage concerned could never be concluded, as an impediment like this would likely lead to avoidance. ${ }^{117}$ In July I 935 Frick circularised all registrars that the Government was in the process of drafting a law to prohibit marriages between Aryans and non-Aryans. In the meantime all intended marriages between a full-Aryan and a full-Jew had to be suspended. However, this new law was some time coming, due to discussions about the classification and treatment of half-breeds. In addition, the Geheime Staatspolizeiamt requested a legal prohibition of extramarital intercourse between Aryans and nonAryans. This claim was defended in an article written by Hauptsamtsleiter Fischer in August 1935, in which he demanded a legal ban on mixed marriages and extramarital intercourse, to protect the race. According to Fischer the Party principles - which were considered to be legally binding - did not allow mixed marriages. In order to protect the Volksgemeinschaft the state had to incorporate betrayal of the race (Rasseverrat) and race violation (Rasseschändung) in the Penal Code. ${ }^{118}$ The Party Leadership furthermore required more extreme measures than the Ministries of Justice and the Interior had drafted, i.e. forced dissolution of existing mixed marriages, application of provisions applicable to half-breeds on so-called Achteljuden ${ }^{119}$ and forced sterilisation or even the death penalty in case of dishonouring the race. This divergence of views led to even more delay. $^{120}$

111 We have seen examples of the Amtsgericht of Wetzlar (17 June 1935), the Amtsgericht of Bad Sülze (8 July 1935) and the Landgericht of Königsberg (26 August 1935).

112 The measures suggested by the physicians were as plain as day. In case of attempted extramarital intercourse the German woman had to be punished with deprivation of her German nationality, a stay in a workcamp and, in case of completed extramarital intercourse, with sterilization. The Jewish man had to be punished with deprivation of his German nationality, seizure of property, at least five years detention centre, followed by immediate deportation from Germany as undesirable alien. See L. Gruchmann, "'Blutschutzgesetz" und Justiz', 425.

113 L. Gruchmann, '"Blutschutzgesetz" und Justiz', 425.

114 Wehrgesetz vom 21. Mai 1935, Reichsgesetzblatt (1935), I, 609.

115 Ibid., § 15(4): 'Den Angehörigen arischer Abstammung der Wehrmacht und des Beurlaubtenstandes ist das Eingehen der Ehe mit Personen nichtarischer Abstammnung verboten. [...]'

116 Ibid.: '[...] Zuwiderhandlungen haben den Verlust jedes gehobenen militärischen Dienstgrades zur Folge.'

117 L. Gruchmann, "'Blutschutzgesetz" und Justiz', 428.

118 L. Fischer, 'Rasseschande als strafbare Handlung', 536-537.

119 People with only one Jewish great-grandmother or great-grandfather.

120 L. Gruchmann, "'Blutschutzgesetz" und Justiz', 429-430. See also I. Müller, Hitler's Justice. The Courts of the Third Reich, 96-98. 
After two years of tug-of-war Hitler eventually decided to conclude the Reichsparteitag der Freiheit, speeding up the lawmaking process significantly. According to Gruchmann it is to assume that Hitler was persuaded of the necessity of legislation concerning the status of Jews and mixed marriages, although originally he intended only to pass the Reichsflaggengesetz ${ }^{121}$ All experts of the Ministry of Justice were called to Nuremberg the day before the session of the Reichstag, where they were assigned to draft a proposal. ${ }^{122}$ Besides a prohibition of mixed marriages and extramarital intercourse between Aryans and Jews, the draft proposal also had to contain a ban on the employment of Aryan maid servants in Jewish households to protect them from 'racially pernicious sexual threats'. The first proposal drafted by the Ministry of the Interior was subsequently rejected by Hitler, who ordered the draft of both a Reich Citizenship Law - in which Jews should be assigned a different status than Aryans - and a Law to protect the German Blood. Hitler chose the most 'mild' draft, assigning among other things imprisonment as punishment for extramarital intercourse instead of detention centres as suggested by the Ministry of the Interior in the first draft. Nevertheless, he crossed off the provision that this law was only applicable on Volljuden (full-Jews). ${ }^{123}$ At the end of the Conference, the Reichstag unanimously ${ }^{124}$ passed three laws, ${ }^{125}$ which were called after the place the conference was hold. In his speech Hitler made clear that the only way to deal with the 'Jewish problem' remained was legislative action. In case the problem was not solved, it should 'be handed over by law to the National Socialist Party for a final solution. ${ }^{126}$

\section{- 3.5.2. The Reich Citizenship Law}

Traditionally, German nationality (Staatsangehörigkeit) was related to being subject of a federal state (Landesangehörigkeit). During the Northern German Confederation this was regulated by $\mathbb{S}$ I of the Gesetz über den Erwerb und den Verlust der Bundesund Staatsangehörigkeit of $1870,{ }^{127}$ which was replaced in 1913 by the Reichs- und Staatsangehörigkeitsgesetz. This law stated in $\mathbb{S}$ I that 'German is he, who is subject of a

121 The Reichsflaggengesetz (Reichsflaggengesetz vom 15. September 1935, Reichsgesetzblatt (1935), I, 1145) declared the Nazi flag with the swastika to be the national flag of the new German Reich. Jews were prohibited from displaying it by $\S 4$ of the Blutschutzgesetz (Gesetz zum Schutze des deutsche Blutes und der deutschen Ehre vom 15. September 1935, Reichsgesetzblatt (1935), I, 1146). Although in practice this was already prohibited by administrative action, it was now made punishable by one year of imprisonment and a fine. Nitpicking as it may seem, this measure helped to identify Jews. See L. Gruchmann, "'Blutschutzgesetz" und Justiz', 431. See also B. Lösener, 'Als Rassereferent im Reichsministerium des Innern', 9 Vierteljahrshefte für Zeitgeschichte 3 (1961), 264-313, 273.

122 See for a detailed account on the proceedings B. Lösener, 'Als Rassereferent im Reichsministerium des Innern', 9 Vierteljahrshefte für Zeitgeschichte 3 (1961), 264-313, 272-277.

123 However, this provision was included in the report on the Nuremberg Laws of the German Press Agency, causing significant difficulties until the First Supplementary Decree of 14 November 1935 clarified the definition of 'Jew' (Erste Verordnung zum Reichsbürgergesetz vom 14. November 1935, Reichsgesetzblatt (1935), I, 1333, § 2 (2) and § 5). See also L. Gruchmann, "'Blutschutzgesetz" und Justiz', 431-432.

124 I.e. with 651 votes out of 669. 18 members of the Reichstag were excused. See B. Lösener and F.U. Knost, Die Nürnberger Gesetze über das Reichsbürgerrecht und den Schutz des deutschen Blutes und der deutschen Ehre, 36, 63.

125 Reichsflaggengesetz vom 15. September 1935, Reichsgesetzblatt (1935), I, 1145; Reichsbürgergesetz vom 15. September 1935, Reichsgesetzblatt (1935), I, 1146; Gesetz zum Schutze des deutschen Blutes und der deutschen Ehre vom 15. September 1935, Reichsgesetzblatt (1935), I, 1146.

126 Adolf Hitler in his speech in the Reichstag on the Nuremberg Laws, in N.H. Baynes (ed.), The Speeches of Adolf Hitler, 731-732.

127 Gesetz über den Erwerb und den Verlust der Bundes- und Staatsangehörigkeit vom 1. Juni 1870, Bundes-Gesetzblatt des Norddeutschen Bundes (1870), 355, § 1 (1): 'Die Bundesangehörigkeit wird durch die Staatsangehörigkeit in einem Bundesstaate erworben und erlischt mit deren Verlust.' NB: this law used the term 'Bundesangehörigkeit' instead of 'Staatsangehörigkeit', whilst it used the term 'Staatsangehörigkeit' to describe a subject of a federal state. As Germany as nation state did not exist at the time the term 'Landesangehörigkeit' was not used. 
federal state or who has direct nationality. ${ }^{128}$ The Weimar Constitution of I9I9 reasoned along the same lines by stating in Article i Io that every subject of a federal state automatically was a German national. ${ }^{129}$ This dichotomy was abolished in 1934 when the Landesangehörigkeit was abolished and only the Staatsangehörigkeit remained. ${ }^{130}$ The Reichsbürgergesetz, ${ }^{131}$ however, introduced a new distinction: state nationals (Staatsangehörige) and state citizens (Reichsbürger).

According to some authors ${ }^{132}$ this distinction was not new. It was also found in the Staatsgrundgesetz of the former duchies Coburg and Gotha of 3 May 1852, which stated:

\section{$\mathbb{S} 23$ : Als Staatsangehörige der vereinigten Herzogthümer sind vdiejenigen anzusehen, welche in einem derselben ihren bleibenden Wohnsitz haben. [...] $\mathbb{\$} 24$ : Staatsbürger der vereinigten Herzogthümer sind diejenigen, welche in einem derselben Heimathsrecht haben. ${ }^{133}$}

Recent developments such as the Treaty of Versailles of I9I9 had caused an unintended shift in nationalities, which was a thorn in the flesh of the National Socialists. Because of the Treaty of Versailles many members of the German Volk (the so-called Volksgenossen) had lost their German political rights, as they had become e.g. French or Polish nationals instead of Germans, whilst others, who where not of German or kindred blood, did have German political rights as they were German nationals. However, according to the National Socialists, only people of pure German or kindred blood should be allowed to decide upon the future of the Volksgemeinschaft, which was why a distinction between state nationals and state citizens was needed. This line of reasoning can already be seen in point 4 to 6 of the Party Principles of 1920. ${ }^{134}$

However, the interpretation of the term Staatsangehörige was debated. According to some authors, the nature of state nationality remained untouched by the Reichsbürgergesetz. Being a state national contained, adjectively, the legal relationship of belonging to a certain state and substantively, the public domain of rights and duties

128 Reichs- und Staatsangehörigkeitsgesetz vom 22. Juli 1913, Reichs-Gesetzblatt (1913), 583, § 1: ‘Deutscher ist, wer die Staatsangehörigkeit in einem Bundesstaat [...] oder die unmittelbare Reichsangehörigkeit [...] besitzt.' NB: the term 'Staatsangehörige' is still used to describe a subject of a federal state, whilst a German national is called either 'Deutsche' or 'Reichsangehörige'.

129 Die Verfassung des Deutschen Reichs vom 11. August 1919, Reichs-Gesetzblatt (1919), 1383, Art. 110: ‘[...] Jeder Angehörige eines Lande sist zugleich Reichsangehöriger.' NB: the term 'Reichsangehörige' is used instead of 'Staatsangehörige'.

130 Verordnung über die deutsche Staatsangehörigkeit vom 5. Februar 1934, Reichsgesetzblatt (1934), I, 85, § 1: ‘(1) Die Staatsangehörigkeit in den deutschen Ländern fällt fort. (2) Es gibt nur noch eine deutsche Staatsangehörigkeit (Reichsangehörigkeit).'

131 Reichsbürgergesetz vom 15. September 1935, Reichsgesetzblatt (1935), I, 1146.

132 See M. Lichter and F.U. Knost, Deutsches und ausländisches Staatsangehörigkeitsrecht, 56 and B. Lösener and F.U. Knost, Die Nürnberger Gesetze über das Reichsbürgerrecht und den Schutz des deutschen Blutes und der deutschen Ehre, 10.

133 Italics by me - ML. See Staatsgrundgesetz für die Herzogthümer Coburg und Gotha vom 3. Mai 1852, Gemeinschaftliche Gesetzsamm/ung für die Herzogthümer Coburg und Gotha (1852), no. 2, 3.

134 See Das 25-Punkte-Programm der Nationalsozialistischen Deutschen Arbeiterpartei vom 24. Februar 1920, '4: Staatsbürger kann nur sein, wer Volksgenosse ist. Volksgenosse kann nur sein, were deutschen Blutes ist, ohne Rücksichtnahme auf Konfession. Kein Jude kan daher Volksgenosse sein. 5: Wer nicht Staatsbürger ist, soll nur als Gast in Deutschland leben können und muß unter Fremden-Gesetzgebung stehen. 6: Das Recht, über Führung und Gesetze des Staates zu bestimmen, darf nur dem Staatsbürger zustehen. Daher fordern wir, daß jedes öffentliche Amt, gleichgültig welcher Art, gleich ob im Reich, Land oder Gemeinde nur durch Staatsbürger bekleidet werden darf. Wir bekämpfen die korrumpierende Parlamentswirtschaft einer Stellenbesetzung nur nach Parteigesichtspunkten ohne Rücksichtnahme auf Charakter und Fähigkeiten.' 
within this mutual relationship between a state and its nationals. ${ }^{135}$ This view was challenged by both Reinhard Höhn in his article 'Staatsangehöriger und Reichsbürger' and Wilhelm Stuckart and Hans Globke in their book 'Kommentare zur deutschen Rassengesetzgebung. ${ }^{137}$ According to these authors the nature of the state had changed. In the $I 9^{\text {th }}$ century a state had been regarded as an independent entity with legal personality. This independent, sovereign body was capable of entering into legal relationships with individuals. ${ }^{138}$ The arrival of National Socialism and in particular the Reichsbürgergesetz had changed this. According to Stuckart and Globke, the Romanesque view on the nature of a state, in which a state was an independent entity, superior to and - from time to time - an opponent of all individuals, had given way to the Germanic view on the nature of a state, in which a state consisted of its citizens. A state had to be regarded as the political manifestation of the people, the Volk. Strictly speaking, the Volk had legal personality, not the state. ${ }^{139}$ Therefore, the adjective meaning of the term Staatsangehörige given by Lösener and Knost did not tally completely with this new belief. According to Stuckart and Globke, the rights and duties of a state national followed from his incorporation in the so-called 'protective sphere' (Schutzverband). ${ }^{140}$

With the introduction of the Reichsbürgergesetz political rights, such as the right to vote and the right to hold public office, became only available for state citizens, as $\mathbb{2} 2$ (3) stated:

Der Reichsbürger ist der alleinige Träger der vollem politischen Rechte nach Maßgabe der Gesetzes. ${ }^{141}$

However, the overtone of the term 'political rights' had changed as well. The liberal conception of a domain in which the state could not intervene and where the individual could freely and fully enjoy his natural rights was abandoned. Did political rights use to constitute a safeguard against state intervention, within the National Socialist conception they had to be regarded as tools to shape the Volksgemeinschaft, to fulfil ones social responsibility. As state citizens were no longer regarded as individuals, they all shared the responsibility of shaping this new Reich, for which political rights were granted. ${ }^{142}$ The fact that whether one was carrier of political rights was now related to the concept of descent was enabled by this new interpretation of the term 'political rights', as the liberal conception, considering political rights a safeguard for freedom and full enjoyment of natural rights, emphasised equality among men. ${ }^{143}$

135 M. Lichter and F.U. Knost, Deutsches und ausländisches Staatsangehörigkeitsrecht, 10 and B. Lösener and F.U. Knost, Die Nürnberger Gesetze über das Reichsbürgerrecht und den Schutz des deutschen Blutes und der deutschen Ehre, 11, 37.

136 R. Höhn, 'Staatsangehöriger und Reichsburger', 6 Deutsches Recht (1936), 20-23.

137 W. Stuckart and H. Globke, Kommentare zur deutschen Rassengesetzgebung, Band 1, Reichsbürgergesetz, Blutschutzgesetz, Ehegesundheitsgesetz.

138 R. Höhn, 'Staatsangehöriger und Reichsburger', 20.

139 W. Stuckart and H. Globke, Kommentare zur deutschen Rassengesetzgebung, Band 1, Reichsbürgergesetz, Blutschutzgesetz, Ehegesundheitsgesetz, 19-23.

140 Ibid., 51.

141 Reichsbürgergesetz vom 15. September 1935, Reichsgesetzblatt (1935), I, 1146.

142 See W. Stuckart and H. Globke, Kommentare zur deutschen Rassengesetzgebung, Band 1, Reichsbürgergesetz, Blutschutzgesetz, Ehegesundheitsgesetz, 20: '[...] die Genossen der Gemeinschaft bilden in ihrer Gesamtheit den Staat.'; R. Höhn, 'Staatsangehöriger und Reichsburger', 23: 'Die Reichsbürger sind es, die das Reich darstellen.'

143 W. Stuckart and H. Globke, Kommentare zur deutschen Rassengesetzgebung, Band 1, Reichsbürgergesetz, Blutschutzgesetz, Ehegesundheitsgesetz, 23-25. 
From that moment on state nationals were mere inhabitants of Germany, carrying a German passport. Political rights were taken away, duties, such as conscription, remained. Furthermore, a state national could claim state protection of his person, his property and the practice of his profession. ${ }^{144}$ The Reichsbürgergesetz laid the emphasis on duties by stating in $\mathbb{S}$ I (I):

Staatsangehöriger is, wer dem Schutzverband des Deutschen Reichs angehört und ihm dafür besonders verpflichtet ist. ${ }^{145}$

That state nationality was nothing more than a politically empty shell was confirmed by Stuckart and Globke by stating:

Durch die Trennung des Besitzes der Staatsangehörigkeit und des Erwerbs der Staatsbürgerrecht durch die Verleihung des Reichsbürgerrechts hat die Staatsangehörigkeit ihren politischen Inhalt verloren. ${ }^{146}$

To become a state citizen, one already had to be a state national. Further requirements were, objectively, being of German or kindred blood and subjectively, given proof of the intention and ability to loyally serve the German Volk and Reich. ${ }^{147}$ These requirements were clearly stated in $\$ 2(\mathrm{I})$ :

Reichsbürger ist nur der Staatsangehörige deutschen oder artverwandten Blutes, der durch sein Verhalten beweist, daß er gewillt und geeignet ist, in Treue dem Deutschen Volk und Reich zu dienen. ${ }^{148}$

Although not of German of kindred blood, state nationals without citizenship were considered German according to international law. ${ }^{149}$ From the text of the Reichsbürgergesetz could be derived that state citizenship was attributed on individual basis as $\mathbb{2} 2(2)$ stated:

Das Reichsbürgerrecht wird durch Verleihung des Reichsbürgerbriefes erworben. ${ }^{150}$

Obviously, this proved to be a devil of a job. The First Supplementary Decree to the Reichsbürgergesetz of I 4 November 1935 came with a temporary solution by stating in

144 B. Lösener and F.U. Knost, Die Nürnberger Gesetze über das Reichsbürgerrecht und den Schutz des deutschen Blutes und der deutschen Ehre, 39.

145 Reichsbürgergesetz vom 15. September 1935, Reichsgesetzblatt (1935), I, 1146. Emphasis by me - ML.

146 W. Stuckart and H. Globke, Kommentare zur deutschen Rassengesetzgebung, band 1, Reichsbürgergesetz, Blutschutzgesetz, Ehegesundheitsgesetz, 29-30.

147 B. Lösener and F.U. Knost, Die Nürnberger Gesetze über das Reichsbürgerrecht und den Schutz des deutschen Blutes und der deutschen Ehre, 39.

148 Reichsbürgergesetz vom 15. September 1935, Reichsgesetzblatt (1935), I, 1146.

149 M. Lichter and F.U. Knost, Deutsches und ausländisches Staatsangehörigkeitsrecht, 57.

150 Reichsbürgergesetz vom 15. September 1935, Reichsgesetzblatt (1935), I, 1146. 
$\mathbb{S}$ I (I) that until further notice all state nationals of German or kindred blood who had the right to vote for the Reichstag at the time the Reichsbürgergesetz came into force were to be considered state citizens. Those ones who were attributed provisional state citizenship by the Minister of the Interior in accordance with the Führers deputy were considered state citizens as well. ${ }^{151}$ Jews could never be state citizens, only state nationals, as they were not of German or kindred blood. Since they could not be state citizens, they lost the right to vote and the right to hold public office. This was already implied by $\mathbb{2}$ of the Reichsbürgergesetz, but was further emphasised by $\mathbb{S}_{4}$ (I) of the First Supplementary Decree which clearly stated these facts. ${ }^{152}$ Furthermore, Jewish civil servants were forced to retire by 31 December I935, as they could no longer hold public office. ${ }^{153}$ An exception was made for teachers. ${ }^{154}$

Furthermore, the First Supplementary Decree provided clarification on who was to be considered Jewish. In order to determine who was to be considered Jewish, the status of the grandparents was decisive. Generally speaking, a person was considered to be Jewish when he or she had three or four full-Jewish grandparents. ${ }^{155}$ In case of four Jewish grandparents, both parents would count as full-Jewish, which would automatically lead to full-Jewish offspring. Persons with three Jewish grandparents were strictly speaking not full-Jewish, but were considered as such as he or she had been exposed to predominantly Jewish influences. ${ }^{156}$ Persons with only one or two full-Jewish grandparents were considered jüdische Mischlinge (Jewish half-breeds). ${ }^{157}$ The National Socialists were at a loss what to do with this group. Technically, they were not Jewish nor Aryan, but a bit of both, and treating them as Jewish would imply a loss of German blood. Therefore, $\mathbb{S} 2$ (I) of the First Supplementary Decree stated they had to be treated as state citizens. ${ }^{158}$ The exception was found in $\mathbb{S}_{5}(2)$ which stated that first degree half-breeds ${ }^{159}$ were to

151 Erste Verordnung zum Reichsbürgergesetz vom 14. November 1935, Reichsgesetzblatt (1935), I, 1333, § 1 (1): 'Bis zum Erlaß weiterer Vorschriften über den Reichsbürgerbrief gelten vorläufig als Reichsbürger die Staatsangehörigen deutschen oder artverwandten Blutes, die beim Inkrafttreten des Reichsbürgergesetzes das Reichstagswahlrecht besessen haben, oder denen der Reichsminister des Innern im Einvernehmen mit dem Stellvertreter des Führers das vorläufige Reichsbürgerrecht verleiht.'

152 Erste Verordnung zum Reichsbürgergesetz vom 14. November 1935, Reichsgesetzblatt (1935), I, 1333, § 4 (1): 'Ein Jude kann nicht Reichsbürger sein. Ihm steht ein Stimmrecht in politischen Angelegenheiten nicht zu; er kann ein öffentliches Amt nicht bekleiden.'

153 Erste Verordnung zum Reichsbürgergesetz vom 14. November 1935, Reichsgesetzblatt (1935), I, 1333, § 4 (2): ‘Jüdische Beamte treten mit Ablauf des 31. Dezember 1935 in den Ruhestand. [...]'

154 Erste Verordnung zum Reichsbürgergesetz vom 14. November 1935, Reichsgesetzblatt (1935), I, 1333, § 4 (4): 'Das Dienstverhältnis der Lehrer an öffentlichen jüdischen Schulen bleibt bis zur Neuregelung des jüdischen Schulwesens unberührt.' See also B. Lösener and F.U. Knost, Die Nürnberger Gesetze über das Reichsbürgerrecht und den Schutz des deutschen Blutes und der deutschen Ehre, 46-48.

155 Erste Verordnung zum Reichsbürgergesetz vom 14. November 1935, Reichsgesetzblatt (1935), I, 1333, § 5 (1): 'Jude ist, wer von mindestens drei der Rasse nach volljüdischen Großeltern abstammt. [...]'

156 B. Lösener and F.U. Knost, Die Nürnberger Gesetze über das Reichsbürgerrecht und den Schutz des deutschen Blutes und der deutschen Ehre, 21.

157 Erste Verordnung zum Reichsbürgergesetz vom 14. November 1935, Reichsgesetzblatt (1935), I, 1333, § 2 (2): ‘Jüdischer Mischling ist, wer von einem oder zwei der Rasse nach volljüdischen Großelternteilen abstammt, sofern er nicht nach $\$ 5$ Abs. 2 als Jude gilt. [...]'

158 Ibid., § 2 (1): 'Die Vorschriften des § 1 gelten auch für die staatsangehörigen jüdischen Mischlinge.'

159 Half-breeds with two full-Jewish grandparents were called first degree half-breeds, whilst persons with only one full-Jewish grandparent were called second degree half-breeds. See B. Lösener and F.U. Knost, Die Nürnberger Gesetze über das Reichsbürgerrecht und den Schutz des deutschen Blutes und der deutschen Ehre, 44. 
be considered Jewish in case ${ }^{160}$ a) he was a member of the Jewish religious community when the Reichsbürgergesetz was issued or if he had joined the community later; $b$ ) he was married to a Jew when the Reichsbürgergesetz was issued, or subsequently married a Jew; c) he was the issue from a marriage between a non-Jew and a Jew in the sense of $\mathbb{5}$ (I), when the marriage was concluded after the Gesetz zum Schutze des deutschen Blutes und der deutschen Ehre had come into effect; d) he was the issue from an extramarital relationship between a non-Jew and a Jew in the sense of $\mathbb{5}_{5}$ (I), and was born out of wedlock after 31 July I936. ${ }^{161}$ Children born in a mixed marriage which was concluded after the Blutschutzgesetz had come into effect just like illegitimate children born in a mixed relationship after 3I July I936 were considered to be Jewish instead of half-breeds as their parents should have known what they were doing was not only against the law, but also contrary to decency. According to Lösener and Knost labeling these children as Jewish should be a warning for potential non-Jewish parents not to start a racially pernicious relationship. ${ }^{162}$ Note that strictly speaking the option described in $\mathbb{S}_{5}(2)$ (c) could not occur as $\mathbb{S}$ I (I) of the Blutschutzgesetz prohibited marriages between Jews and persons of German or kindred blood, whilst marriages concluded in defiance of the rule were declared void, even when concluded abroad. ${ }^{163}$ Children born from a marriage between a first degree half-breed with a person of German or kindred blood or a second degree half-breed which was concluded before the Blutschutzgesetz came into force were strictly speaking second degree half-breeds, but had to be considered of German or kindred blood. ${ }^{164}$

This approach was not without difficulties. Grandparents were considered to be fullJewish when they (had) adhered to the Jewish religious community, ${ }^{165}$ which - all in all - was an unusual factor to take into consideration as it specifically concerned a racial matter and not a religious one. Having said that, obviously religion was the most assignable factor. According to Lösener and Knost a grandparent also had to be considered as Jewish when he or she was racially so without having adhered to the Jewish religious community,

160 Erste Verordnung zum Reichsbürgergesetz vom 14. November 1935, Reichsgesetzblatt (1935), I, 1333, § 5 (2): 'Als Jude gilt auch der von zwei volljüdischen Großeltern abstammende staatsangehörige jüdische Mischling, a) der beim Erlaß des Gesetzes der jüdischen Religionsgemeinschaft angehört hat oder danach in sie aufgenommen wird, b) der beim Erlaß des Gesetzes mit einem Juden verheiratet war oder sich danach mit einem solchen verheiratet, c) der aus einer Ehe mit einem Juden im Sinne des Absatzes 1 stammt, die nach dem Inkrafttreten des Gesetzes zum Schutze des deutschen Blutes und der deutschen Ehre vom 15. September 1935 (Reichsgesetzbl. I S. 1146) geschlossen ist, d) der aus dem außerehelichen Verkehr mit einem Juden im Sinne des Absatzes 1 stammt und nach dem 31. Juli 1936 außerehelich geboren wird.'

161 The Gesetz zum Schutze des deutschen Blutes und der deutschen Ehre came into force on 17 September 1935. Its purpose was to prevent the birth of Jewish half-breeds. After this ten month term it would become clear whether the German population would have understood the meaning of the legislator. See B. Lösener and F.U. Knost, Die Nürnberger Gesetze über das Reichsbürgerrecht und den Schutz des deutschen Blutes und der deutschen Ehre, 49-50.

162 B. Lösener and F.U. Knost, Die Nürnberger Gesetze über das Reichsbürgerrecht und den Schutz des deutschen Blutes und der deutschen Ehre, 24: 'Diese beiden Bestimmungen sollen vor allem eine Warnung für den nichtjüdischen Elternteil sein, daß er nicht leichtfertig eine rassisch verderbliche Verbindung eingeht und sich damit über den ihm bekannten Willen des Gesetzes hinwegsetzt.

163 Gesetz zum Schutze des deutschen Blutes und der deutschen Ehre vom 15. September 1935, Reichsgesetzblatt (1935), I, 1146, § 1 (1): 'Eheschließungen zwischen Juden und Staatsangehörigen deutschen oder artverwandten Blutes sind verboten. Trotzdem geschlossene Ehen sind nichtig, auch wenn sie zur Umgehung dieses Gesetzes im Ausland geschlossen sind.'

164 B. Lösener and F.U. Knost, Die Nürnberger Gesetze über das Reichsbürgerrecht und den Schutz des deutschen Blutes und der deutschen Ehre, 24.

165 Erste Verordnung zum Reichsbürgergesetz vom 14. November 1935, Reichsgesetzblatt (1935), I, 1333, § 2 (2): '[...] Als volljüdisch gilt ein Großelternteil ohne weiteres, wenn er der jüdischen Religionsgemeinschaft angehört hat.' 
i.e. having two full-Jewish parents. ${ }^{166}$ However, Lösener and Knost contradict themselves in this explanation as they also state that in order to determine whether a person was Jewish, great-grandparents would never be taken into consideration. ${ }^{167}$ Furthermore, this approach lead to inconsistencies which could have far-reaching consequences, especially with the so-called Achteljuden, in particular Dreiachteljuden (persons with three Jewish great-grandparents) and Fünfachteljuden (persons with five Jewish great-grandparents). A person with three Jewish great-grandparents could be considered of German or kindred blood, a Vierteljude or second degree half-breed (one Jewish grandparent), Halbjude or first degree half-breed (two Jewish grandparents) or Dreivierteljude (three Jewish grandparents), which counted as Jewish, depending on the division of Jewish great-grandparents and whether they had raised their child as Jew (see figure 3.I). A Fünfachteljude could be anything between Vierteljude and full-Jewish (see figure 3.2).

With the Reichsbürgergesetz and its First Supplementary Decree one of the fundamental principles of National Socialism as expressed by point 4 to 6 of the Party Principles of I920 was established by law, though in somewhat mitigated form. ${ }^{168}$

However, it should be noted that fanatical Nazi officials have tried several times to extent the definition of Jew, by including half-Jews and sometimes even quarter-Jews. Hitler, who was advised on this matter by Rassereferent Bernhard Lösener, has never agreed to this, as this would affront the Aryan part of the family of the half-Jew or quarter-Jew. Apart from that a considerable number of quarter-Jews fought in the German army. ${ }^{169}$ Lösener had drafted a list with twelve arguments that pleaded against the equation of half-Jews with full-Jews. ${ }^{170}$ Whether Hitler has also been relatively generous to this group of people because of uncertainties with regard to his own lineage ${ }^{171}$ is impossible to prove.

\section{- 3.5.3. The Law for the Protection of German Blood and German Honour}

A definition of the term 'Jew' was necessary in order to enforce the third law, the Gesetz zum Schutze des deutschen Blutes und der deutschen Ehre ${ }^{172}$ or in short Blutschutzgesetz. The preamble of this law indicated its importance:

166 B. Lösener and F.U. Knost, Die Nürnberger Gesetze über das Reichsbürgerrecht und den Schutz des deutschen Blutes und der deutschen Ehre, 23.

167 Ibid., 22.

168 See Das 25-Punkte-Programm der Nationalsozialistischen Deutschen Arbeiterpartei vom 24. Februar 1920, '4: Staatsbürger kann nur sein, wer Volksgenosse ist. Volksgenosse kann nur sein, were deutschen Blutes ist, ohne Rücksichtnahme auf Konfession. Kein Jude kan daher Volksgenosse sein. 5: Wer nicht Staatsbürger ist, soll nur als Gast in Deutschland leben können und muß unter Fremden-Gesetzgebung stehen. 6: Das Recht, über Führung und Gesetze des Staates zu bestimmen, darf nur dem Staatsbürger zustehen. Daher fordern wir, daß jedes öffentliche Amt, gleichgültig welcher Art, gleich ob im Reich, Land oder Gemeinde nur durch Staatsbürger bekleidet werden darf. Wir bekämpfen die korrumpierende Parlamentswirtschaft einer Stellenbesetzung nur nach Parteigesichtspunkten ohne Rücksichtnahme auf Charakter und Fähigkeiten.'

169 B. Lösener, 'Als Rassereferent im Reichsministerium des Innern', 9 Vierteljahrshefte für Zeitgeschichte 3 (1961), 264-313, 274-282. See also C. Stuldreher, De Legale Rest, 26, 112-114.

170 B. Lösener, 'Als Rassereferent im Reichsministerium des Innern', 9 Vierteljahrshefte für Zeitgeschichte 3 (1961), 264-313, 280-281.

171 K. Heiden, Adolf Hitler. Das Zeitalter der Verantwortungslosigkeit, 15-16; H.B. Gisevius, Adolf Hitler, 12-18.

172 Gesetz zum Schutze des deutschen Blutes und der deutschen Ehre vom 15. September 1935, Reichsgesetzblatt (1935), I, 1146-1147. 


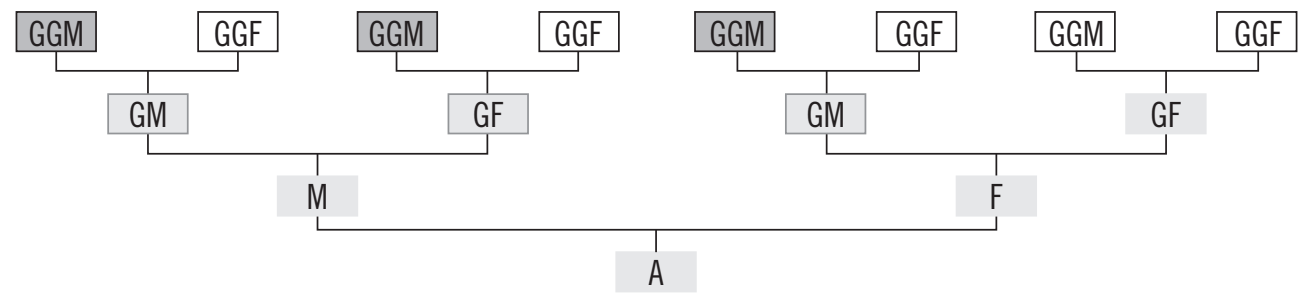

Figure 3.1

Dreivierteljude. Given this division of Jewish greatgrandparents, A could be considered anything between of German or kindred blood and Dreivierteljude, depending on whether his grandparents were raised as Jews or not. In case all grandparents with one Jewish parent were raised as Jews, A was considered a Dreivierteljude. In case non of his grandparents was raised as a Jew, he was considered of German or kindred blood. Subsquently, one grandparent raised as Jew would make A a Vierteljude, whilst two grandparents raised as Jew would make A a Halbjude.

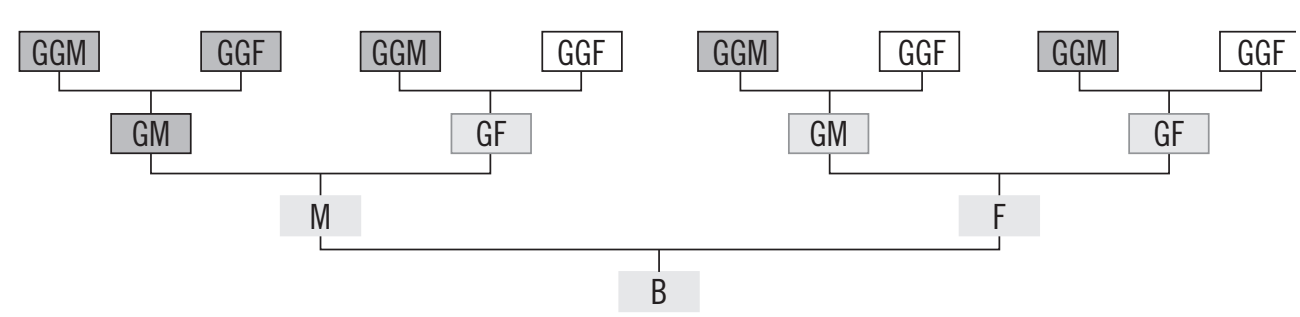

Figure 3.2

Fünfachteljude. Given this division of Jewish greatgrandparents, B could be considered anything between Vierteljude and full Jewish, depending on whether his grandparents were raised as Jews or not. Given that in case of a Fünfachteljude at least one couple of greatgrandparents consisted of Jews, it is likely that B at least had one Jewish grandparent, which would make him a Vierteljude. In case his other grandparents, who all had one Jewish parent, were raised as Jews, B would be considered a full Jew. Subsequently, two grandparents raised as Jew would make B a Halbjude, whilst three grandparents raised as Jew would make B a Dreivierteljude.

\begin{tabular}{|c|lll|}
\hline GGM & Full-Jew & A/B & Person concerned \\
\cline { 1 - 1 } & Aryan & M/F & Mother/Father \\
\hline GM & Possible member of the Jewish religious community & GM/GF & Grandmother/Grandfather \\
\hline M & Undefined & GGM/GGF & Great-grandmother/Great-grandfather \\
\hline
\end{tabular}


Durchdrungen von der Erkenntnis, daß die Reinheit des deutschen

Blutes die Voraussetzung für den Fortbestand des Deutschen Volkes ist, und beseelt von dem unbeugsamen Willen, die Deutsche Nation für alle Zukunft zu sichern, hat der Reichstag einstimmig das folgende Gesetz beschlossen, das hiermit verkündigt wird [...]:

The core of the Blutschutzgesetz was the prohibition of marriages between Jews and state nationals of German or kindred blood, as stated in $\mathbb{S}$ I (I). Furthermore, this article declared all marriages concluded in defiance of this prohibition void, even when concluded abroad. ${ }^{173}$ Existing marriages, however, i.e. marriages concluded before I7 September 1935, on which day the Blutschutzgesetz came into force, remained untouched as the Blutschutzgesetz had no retroactive effect. ${ }^{174}$ The First Supplementary Decree to the Blutschutzgesetz of 14 November 1935 elaborated upon this prohibition by stating that marriages between Jews and second degree half-breeds were prohibited as well, ${ }^{175}$ just like marriages between second degree half-breeds. ${ }^{176}$ The rationale behind this rule was that with this measure second degree half-breeds, who for the most part already consisted of German or kindred blood, could merge with the German people, which prevented the loss of valuable blood. ${ }^{177}$ Marriages between first degree half-breeds and state nationals of German or kindred blood or second degree half-breeds were only allowed after consent of the Minister of the Interior and the Führers deputy. ${ }^{178}$ Furthermore, a general prohibition was included in $\mathbb{S}$, which stated that all marriages were prohibited, in which case offspring which was in any way harmful to the purity of the German blood was to be expected. ${ }^{179}$ According to Stuckart and Globke $\mathbb{S} 6$ in no way implied a value judgement, but it was - according to them - common knowledge that mingling of blood carried negative consequences for the viability of either race with it. The German blood had to be prevented not only from mingling with Jewish blood, but from mingling with other foreign blood as well. ${ }^{180}$ According to Lösener and Knost, this article was designed to deal with all negative influences other than Jews, in particular

173 Ibid., § 1 (1): 'Eheschließungen zwischen Juden und Staatsangehörigen deutschen oder artverwandten Blutes sind verboten. Trotzdem geschlossene Ehen sind nichtig, auch wenn sie zur Umgehung dieses Gesetzes im Ausland geschlossen sind.'

174 W. Stuckart and H. Globke, Kommentare zur deutschen Rassengesetzgebung, band 1, Reichsbürgergesetz, Blutschutzgesetz, Ehegesundheitsgesetz, 77, 108-109; B. Lösener and F.U. Knost, Die Nürnberger Gesetze über das Reichsbürgerrecht und den Schutz des deutschen Blutes und der deutschen Ehre, 66-67.

175 Erste Verordnung zur Ausführung des Gesetzes zum Schutze des deutschen Blutes und der deutschen Ehre vom 14. November 1935, Reichsgesetzblatt (1935), I, 1334, § 2: 'Zu den nach § 1 des Gesetzes verbotenen Eheschließungen gehören auch die Eheschließungen zwischen Juden und staatsangehörigen jüdischen Mischlingen, die nur einen volljüdischen Großelternteil haben.'

176 Ibid., § 4: 'Eine Ehe soll nicht geschlossen werden zwischen staatsangehörigen jüdischen Mischlingen, die nur einen volljüdischen Großelternteil haben.'

177 W. Stuckart and H. Globke, Kommentare zur deutschen Rassengesetzgebung, band 1, Reichsbürgergesetz, Blutschutzgesetz, Ehegesundheitsgesetz, 126-130.

178 Erste Verordnung zur Ausführung des Gesetzes zum Schutze des deutschen Blutes und der deutschen Ehre vom 14. November 1935, Reichsgesetzblatt (1935), I, 1334, § 3 (1): 'Staatsangehörige jüdische Mischlinge mit zwei volljüdischen Großeltern bedürfen zur Eheschließung mit Staatsangehörigen deutschen oder artverwandten Blutes oder mit staatsangehörigen jüdischen Mischlingen, die nu einen volljüdischen Großelternteil haben, der Genehmigung des Reichsministers des Innern und des Stellvertreters des Führers oder der von ihnen bestimmten Stelle.'

179 Ibid., § 6: 'Eine Ehe soll ferner nicht geschlossen werden, wenn aus ihr eine die Reinerhaltung des deutschen Blutes gefährende Nachkommenschaft zu erwarten ist.'

180 W. Stuckart and H. Globke, Kommentare zur deutschen Rassengesetzgebung, band 1, Reichsbürgergesetz, Blutschutzgesetz, Ehegesundheitsgesetz, 132. 
Negroes and gypsies. ${ }^{181}$ Furthermore, $\mathbb{S} 6$ was only applicable when at least the man was a German national as only then would offspring be regarded as of German nationality as well. As long as children of mixed ancestry were no German nationals, they constituted no threat to the purity of the German blood. As throughout the Blutschutzgesetz and the First Supplementary Decree second degree half-breeds were put on the same footing as state nationals of German or kindred blood, $\mathbb{S} 6$ was also applicable in case one of the fiancés was a second degree half-breed. ${ }^{182}$ Stuckart and Globke published an elaborate list explaining which marriages were allowed and which were not. ${ }^{183}$ The most striking aspect in this list was that a second degree half-breed holding German nationality was not allowed to marry another German second degree half-breed, not even with consent of the Minister of the Interior and the Führers deputy, whilst he was allowed to marry a foreign second degree half-breed.

Obviously, purity of the blood could not only be guaranteed by prohibiting mixed marriages. Extramarital intercourse between Jews and state nationals of German or kindred blood was prohibited as well. ${ }^{184}$ However, the terminology used in this article caused quite some judicial arbitrariness and the interpretation of the term Verkehr (intercourse) was laid on the table. The First Supplementary Decree to the Blutschutzgesetz explained in $\mathbb{S}$ I I that by the term Außerehelicher Verkehr (extramarital intercourse) only Geschlechtsverkehr (sexual intercourse) was meant. ${ }^{185}$ This explanation, however, did not clarify the matter as earlier the law had only used the terms Beiwohnung (cohabitation), Beischlaf (coition) and Unzucht (fornication). ${ }^{186}$ Stuckart and Globke came up with a more extensive interpretation. Citing the prevention of offspring of mixed ancestry as the main goal of the Blutschutzgesetz, they extended the interpretation of 'intercourse' to include not only 'coition', but 'all acts similar to coition, such as mutual masturbation'. Other erotic acts, however, such as kissing, hugging and lewd touching did not fall within the scope of the article, as those acts did not pose the threat of offspring of mixed ancestry. ${ }^{187}$ Lösener and Knost followed this line of reasoning in $1937,{ }^{188}$ although in 1936 they had still interpreted intercourse merely as coition. ${ }^{189}$ In March I 936 the County Court of Nürnberg-Fürth followed this interpretation, ruling that the

181 B. Lösener and F.U. Knost, Die Nürnberger Gesetze über das Reichsbürgerrecht und den Schutz des deutschen Blutes und der deutschen Ehre, 65, 80.

182 W. Stuckart and H. Globke, Kommentare zur deutschen Rassengesetzgebung, band 1, Reichsbürgergesetz, Blutschutzgesetz, Ehegesundheitsgesetz, 133-134.

183 W. Stuckart and H. Globke, Kommentare zur deutschen Rassengesetzgebung, band 1, Reichsbürgergesetz, Blutschutzgesetz, Ehegesundheitsgesetz, 99-100.

184 Gesetz zum Schutze des deutschen Blutes und der deutschen Ehre vom 15. September 1935, Reichsgesetzblatt (1935), I, 1146, § 2: 'Außerehelicher Verkehr zwischen Juden und Staatsangehörigen deutschen oder artverwandten Blutes ist verboten.'

185 Erste Verordnung zur Ausführung des Gesetzes zum Schutze des deutschen Blutes und der deutschen Ehre vom 14. November 1935, Reichsgesetzblatt (1935), I, 1334, § 11: 'Außerehelicher Verkehr im Sinne des § 2 des Gesetzes is nur der Geschlechtsverkehr. [...].'

186 I. Müller, Hitler's Justice. The Courts of the Third Reich, 99-100. See e.g. §§ 825 and 1300 BGB (Beiwohnung), §§ 173, 177, 179 and 182 StGB (Beischlaf) and $\S \S 175,180$ and 183 StGB (Unzucht).

187 W. Stuckart and H. Globke, Kommentare zur deutschen Rassengesetzgebung, band 1, Reichsbürgergesetz, Blutschutzgesetz, Ehegesundheitsgesetz, 112

188 B. Lösener and F.U. Knost, Die Nürnberger Gesetze über das Reichsbürgerrecht und den Schutz des deutschen Blutes und der deutschen Ehre, (1937), 69-70.

189 B. Lösener and F.U. Knost, Die Nürnberger Gesetze über das Reichsbürgerrecht und den Schutz des deutschen Blutes und der deutschen Ehre, (1936), 64. 
term intercourse had to be interpreted as only a sexual act uniting the mutual genitals. ${ }^{190}$ Other courts, however, adopted the broader interpretation as, according to them, the Blutschutzgesetz was not only meant for preserving the purity of the German blood, but also to protect the German honour. Therefore, sexual intercourse had to contain all sexual activities even when no actual coition was performed. If only coition was meant, the term Beischlaf would have been used instead of Geschlechtsverkehr. ${ }^{191}$ The Supreme Court was charged with the task of clarifying the ambiguous terms. On 9 December I 936 they ruled that:

Der Begriff Geschlechtsverkehr im Sinne des Blutschutzgesetzes umfaßt nicht jede unzüchtige Handlung, ist aber auch nicht auf den Beischlaf beschränkt. Er umfaßt den gesamten natürlichen und naturwidrigen Geschlechtsverkehr, also außer dem Beischlaf auch alle geschlechtlichen Betätigungen mit einem Angehörigen des anderen Geschlechtes, die nach der Art ihrer Vornahme bestimmt sind, an Stelle des Beischlafs der Befriedigung des Geschlechtstriebes mindestens des einen Teiles zu dienen. ${ }^{192}$

With this decision the Supreme Court agreed with the adherents of the broader interpretation who used the argument that the law was also meant to protect the German honour. Besides that, the narrower interpretation was rejected as

[...] sie die Gerichte vor mitunter kaum überwindliche Beweisschwierigkeiten stellen und zu Erörterungen über die heikelsten zwingen würde. ${ }^{193}$

On 9 February 1937 the Supreme Court went one step further by declaring that all unilateral lewd acts qualified as sexual intercourse as well. ${ }^{194}$

Whilst mixed marriages concluded abroad were declared void in $\$$ I ( I), the Blutschutzgesetz nor the First Supplementary Decree to the Blutschutzgesetz mentioned a word about sexual intercourse committed abroad. According to $\mathbb{S}_{4}$ (3) of the Penal Code a German having committed a crime abroad could only face prosecution in Germany when the act concerned was punishable by the law of the country where the offence was committed. ${ }^{195}$ According to Freisler, however, pursuant to the new $\mathbb{} 2$ of See also Gruchmann, "'Blutschutzgesetz" und Justiz', 436.

195 See § 4 StGB: 'Wegen im Auslande begangenen Verbrechen und Vergehen findet in der Regel keine Verfolgung statt. Jedoch kann nach den Strafgesetzen des Deutschen Reichs verfolgt werden: [...] 3) ein Deutscher, welcher im Auslande eine Handlung begangen hat, die nach den Gesetzen des Deutschen Reichs als Verbrechen oder Vergehen anzusehen und durch die Gesetze des Orts, an welchem sie begangen wurde, mit Strafe bedroht ist. [...]' 
the Penal Code, the so-called analogy-article, ${ }^{196}$ prosecution should be possible in case a couple had specifically left the country to commit this act. According to Freisler this behaviour was clearly a case of trying to find a loophole in the law which deserved to be punished according to 'sound community senses'. ${ }^{197}$ This view was endorsed by the Supreme Court in a decision of 23 February I938. In this case a Jewish man, being a German national, had, prior to his immigration to South America, invited his girlfriend, who was of German or kindred blood, to come to Prague to say goodbye properly and to have sexual intercourse. The Supreme Court subscribed to the view that behaviour like this was punishable according to 'sound community senses'. It furthermore stated that since the Blutschutzgesetz served as a basic law for the Third Reich, the goal of this law - protecting the purity of the German blood in order to guarantee preservation of the German race - was jeopardised in case unwanted behaviour could not be punished because it was committed abroad. ${ }^{198}$ In a decision of I4 October 1938 the Supreme Court added a little extra by declaring that sexual intercourse between a Jew and a person of German or kindred blood constituted a crime against the German people, which had to be regarded as a living organism, protected as a whole by the Blutschutzgesetz. Therefore, sexual intercourse between a Jew and a person of German or kindred blood committed abroad had to be regarded as if it had been committed within the borders of the German Reich. ${ }^{199}$

In practice 'dishonour to the race' (Rassenschande) was already committed in case a Jew and an Aryan played a game of cards together. ${ }^{200}$ And although the Supreme Court ruled in 1937 that kissing was not considered sexual intercourse, ${ }^{201}$ in 1938 the County Court in Hamburg sentenced a man to two years imprisonment for kissing an Aryan girl. In this case the court regarded kissing 'dishonour to the race' as the accused was no longer capable of sexual intercourse and therefore kissing 'took the place of normal sexual intercourse', thus completing dishonour to the race. ${ }^{202}$ A young Hungarian, baptised as a Christian, even received the death penalty for having several short-term affairs with women of 'German blood', while - only by coincidence - it was discovered in the parish register that his parents were probably Jewish. ${ }^{203}$ This punishment was made possible by a law passed on 4 September I94 $\mathrm{I}^{204}$ which was an amplification of the 1933 Gesetz gegen

196 Gesetz zur Änderung des Strafgesetzbuchs vom 28. Juni 1935, Reichsgesetzblatt (1935), I, 839, § 2: 'Bestraft wird, wer eine Tat begeht, die das Gesetz für strafbar erklärt oder die nach dem Grundgedanken eines Strafgesetzes und nach gesundem Volksempfinden Bestrafung verdient. Findet auf die Tat kein bestimmtes Strafgesetz unmittelbar Anwendung, so wird die Tat nach dem Gesetz bestraft, dessen Grundgedanke auf sie am besten zutrifft.' This article effectively abolished the principle of legality.

197 L. Gruchmann, "'Blutschutzgesetz" und Justiz', 436.

198 Großer Senat für Strafsachen, 23 February 1938, 100 Deutsche Justiz 11 (1938), 422-424.

199 4. Strafsenat des Reichsgerichts, 14 October 1938, 101 Deutsche Justiz 2 (1939), 102-103.

200 R.L. Miller, Nazi Justiz. Law of the Holocaust, 146. See also W. Deuel, People under Hitler, 139

201 Decision of 15 January 1937, cited in R. Leppin, 'Der Schutz des deutschen Blutes und der deutschen Ehre. Ein Überblick über Rechtsprechung und Schriftum', 66 Juristische Wochenschrift 49 (1937), 3076-3082, 3079.

202 Landgericht Hamburg, 29 June 1938, 2049/37. See H. Robinsohn, Justiz als politische Verfolgung, 35.

203 Oberlandesgericht Kassel, 20 April 1943, cited in full in E. Noam and W.A. Kropat, Juden vor Gericht 1933-1945, 168-173. According to Noam and Kropat the fact that the accused also had had an affair with the married daughter of a county court president might have played a part in this decision.

204 Gesetz zur Änderung des Reichsstrafgesetzbuchs vom 4. September 1941, Reichsgesetzblatt (1941), I, 549. 
gefährliche Gewohnheitsverbrecher und über Maßregeln der Sicherung und Besserung. ${ }^{205}$ This supplement provided in $\mathbb{S}$ t that

\begin{abstract}
Der gefährliche Gewohnheitsverbrecher ( $\mathbb{} 20 a$ des Strafgesetzbuchs) und der Sittlichkeitsverbrecher ( $\$ \$ 176$ bis 178 des Strafgesetzbuchs) verfallen der Todesstrafe, wenn der Schutz der Volksgemeinschaft oder das Bedürfnis nach gerechter Sühne es erfordern. ${ }^{206}$
\end{abstract}

According to $\mathbb{S}$ of the Blutschutzgesetz, infringement of the marriage prohibition stated in $\mathbb{S}$ I was punished with detention in a house of correction. ${ }^{207}$ Infringement of $\mathbb{2} 2$ prohibition of extramarital intercourse - was punished likewise or with imprisonment. However, according to sub 2 of $\mathbb{5}$ only a man could be punished for violating $\mathbb{S} 2{ }^{208}$ Hitler was of the opinion that within married and sex life the woman was only a passive part as opposed to a man who acted actively. ${ }^{209}$ However, this provision was included purely for efficiency reasons, as one had to prevent men forcing women into an intimate relationship by threating her with reporting the crime. Some courts nevertheless convicted women as an accomplice when they had tried to thwart prosecution by a false report. The fact that they had had an intimate relationship which qualified as dishonour to the race only increased the penalty. ${ }^{210}$ However, as a result of a judgement of the County Court Karlsruhe from 9 March 1937, Hitler personally interfered for the benefit of a Jewish woman, who, as an accomplice, was sentenced to three months imprisonment. According to Hitler the judgement had to be reconsidered as prosecution because of dishonour to the race could only be directed at the man. ${ }^{211}$ This lead to a wide debate about the punishability of women because of complicity. Some argued in favour of punishability of women as dishonour to the race was hard to prove without a confession of the woman in question. This confession could only be obtained when women were liable to prosecution. Furthermore, it was believed that a truthful confession could only be expected when giving a false testimony was punishable. ${ }^{212}$ Not everyone agreed on this point of view. Others believed that prosecution because of dishonour to the race would put a lot of pressure on women, generally believed to be emotionally weaker than men. This pressure and the fear for disgrace and prosecution because of adultery would lead to false testimony. ${ }^{213}$ Another reason to plead in favour of punishability of women was

205 Gesetz gegen gefährliche Gewohnheitsverbrecher und über Maßregeln der Sicherung und Besserung vom 24. November 1933, Reichsgesetzblatt (1933), I, 995.

206 See for a general overview on courts' decisions in this respect I. Müller, Hitler's Justice. The Courts of the Third Reich, 101115.

207 Gesetz zum Schutze des deutschen Blutes und der deutschen Ehre vom 15. September 1935, Reichsgesetzblatt (1935), I, 1146, § 5 (1): 'Wer dem Verbot des $\$ 1$ zuwiderhandelt, wird mit Zuchthaus bestraft.'

208 Ibid., § 5 (2): 'Der Mann, der dem Verbot des § 2 zuwiderhandelt, wird mit Gefängnis oder mit Zuchthaus bestraft.'

209 A. Hitler, Mein Kampf, 275: '[...] die Schaffung der Möglichkeit einer der menschlichen Natur entsprechenden frühzeitigen Heirat vor allem des Mannes, denn die Frau ist ja hier ohnehin nur der passive Teil.' '[...] the creation of an opportunity for early marriage as compatible with human nature - particularly for the man, as the woman in any case is only the passive part.' Translation by R. Manheim, 251. See also L. Gruchmann, "Blutschutzgesetz" und Justiz', 437.

210 L. Gruchmann, "'Blutschutzgesetz" und Justiz', 437.

$211 \mathrm{Ibid}$. See also A. Przyrembel, Rassenschande, 173.

212 E.g. the Attornies-General of Breslau, Frankfurt am Main and Karlsruhe. See A. Przyrembel, Rassenschande, 177-178.

213 E.g. the Attornies-General of the Kammergericht in Berlin and of the Hanseatischen Oberlandesgericht in Hamburg. See ibid., 177. 
to prevent women to help their lovers to hide or to escape. ${ }^{214}$ The matter was resolved in February I940 with the Verordnung zur Ergänzung der Ersten Ausführungsverordnung zum Blutschutzgesetz. ${ }^{215}$ This decree, which consisted of only one article, extended $\mathbb{S}$ I I of the First Supplementary Decree to the Blutschutzgesetz by adding the statement that only men could be held responsible for any dishonour to the race and that women could not be punished because of complicity. ${ }^{216}$ However, this rule did not completely exempt women from prosecution. Prosecution because of perjury remained possible. Hitler was not opposed to prosecution of women in general as his reaction on the case of Leo Katzenberger in 1942 proved. Leo Katzenberger, a Jewish merchant, was sentenced to death on I3 March 1942 because of an alleged affair with his former tenant Irene Seiler, a woman of German or kindred blood. Both defendants had denied the charges, with no avail. Irene Seiler was sentenced to two years detention in a house of correction because of perjury. ${ }^{217}$ In a letter to the Minister of Justice Hitler confirmed his view that a woman could not be punished because of complicity of dishonour to the race. However, a woman could be punished because of behaviour which constituted a criminal offence irrespective of the offence committed by the man, which in this case was perjury. ${ }^{218}$

Apart from the distinction based on gender, a discrepancy in the treatment of male suspects arose. In theory both Aryan men having a love affair with Jewish women and Jewish men having a sexual relationship with 'German-blooded' women were guilty of dishonour to the race. The Blutschutzgesetz made no distinction based on descent. In practice, however, Aryan men often received better treatment. They were more often granted the right to plead mitigating circumstances and received considerable lower sentences. In most cases responsibility was for a large part shifted to the Jewish woman, whilst the German-blooded man was regarded as having a weak character, being easily impressionable or intellectually challenged. ${ }^{219}$

The division between Jews and Germans was furthermore expressed in $\mathbb{S}$, which dealt with the prohibition for Jews to employ German-blooded maid servants younger than 45 years. $^{220}$ The First Supplementary Decree elaborated upon $\mathbb{S} 3$ in $\mathbb{S}$ I2 which defined a household as Jewish when a Jewish man was head or part of the household. ${ }^{221}$

214 E.g. Public Prosecutor at the Reichsgericht Emil Brettle and President of the Oberlandesgericht of Hamburg Curt Rothenberger. See ibid., 174, 179

215 Verordnung zur Ergänzung der Ersten Ausführungsverordnung zum Blutschutzgesetz vom 16. Februar 1940, Reichsgesetzblatt (1940), I, 394.

216 Ibid.: '[...] In § 11 der Ersten Verordnung zur Ausführung des Gesetzes zum Schutze des deutschen Blutes und der deutschen Ehre vom 14. November 1935 [...] wird als zweiter Absatz eingefügt: "(2) Für das Verbrechen der Rassenschande ist der Mann verantwortlich. Daher kann die beteiligte Frau auch nicht wegen Teilnahme oder Begünstigung [...] bestraft werden."'

217 Sondergericht Nuremberg, 13 March 1942. The judgement is published in full in A. Przyrembel, Rassenschande, 522-538.

218 BA Berlin, R43 II/1544, 165. See A. Przyrembel, Rassenschande, 180.

219 E.g. Landgericht Hamburg, 12 November 1937, 971/37 and Landgericht Hamburg, 9 February 1938, 1762/37. See H. Robinsohn, Justiz als politische Verfolgung, 67-68.

220 Gesetz zum Schutze des deutschen Blutes und der deutschen Ehre vom 15. September 1935, Reichsgesetzblatt (1935), I, 1146 , § 3: 'Juden dürfen weibliche Staatsangehörige deutschen oder artverwandten Blutes unter 45 Jahren in ihrem Haushalt nicht beschäftigen.'

221 Erste Verordnung zur Ausführung des Gesetzes zum Schutze des deutschen Blutes und der deutschen Ehre vom 14. November 1935, Reichsgesetzblatt (1935), I, 1334, § 12 (1): 'Ein Haushalt ist jüdisch (§ 3 des Gesetzes), wenn ein jüdischer Mann Haushaltungsvorstand ist oder der Hausgemeinschaft angehört.' 
Finally, $\mathbb{S} 4$ prohibited Jews to display the national flag and to wear the national colours. ${ }^{222}$ To keep up the appearance of equality, sub 2 allowed Jews to display and wear Jewish colours. This privilege was even protected by the state. ${ }^{223}$

With the Nuremberg Laws the painfully obtained equality of all Germans was annulled. The emancipation of Jewish Germans, which was only more or less completed in I9I9, was back to square one. Only in Upper Silesia was this legal discrimination impossible, as the Deutsch-Polnischen Oberschlesien-Abkommen from I922 stated in Article 67 that all German state nationals were equal in the eyes of the law irrespective of their race, language or religion. ${ }^{224}$ These rights were further elaborated upon in Part 3 (Articles 64 to 158 ) of which the rights described in the Articles 66 to 68 were considered civil rights. Article 65 stated that it was not allowed to deviate from this rule and that no legislation contrary to Article 67 could be adopted. ${ }^{225}$ However, this exceptional position the Jews in Upper Silesia found themselves in was abolished in 1937 with the Gesetz über Maßnahmen im ehemaligen oberschlesischen Abstimmungsgebiet. ${ }^{226}$

Apart from the disappearance of equality before the law, the Nuremberg Laws were characterised by unintentional side effects, which caused at least as much havoc. The prohibition on interracial extramarital intercourse was seized by many to fight out personal feuds. Gradually, punishments became more severe as one was of the opinion that earlier punishments were not sufficiently deterent. ${ }^{227}$ However, the Nuremberg Laws were only the beginning.

\subsection{Keeping the Aryan Race Healthy - the Marriage Health Law}

According to the National Socialists not only mixed couples carried the risk of inferior offspring. This was proved by the adoption of the Gesetz zum Schutze der Erbgesundheit des deutschen Volkes ${ }^{228}$ or in short Ehegesundheitsgesetz, which followed shortly after the Nuremberg Laws. The main goal of this law was the prevention of offspring suffering from hereditary diseases. ${ }^{229}$ To this end the law added four impediments to marriage to the existing impediments stated in the Civil Code. According to $\mathbb{S}$ I a marriage could not be concluded in case

222 Gesetz zum Schutze des deutschen Blutes und der deutschen Ehre vom 15. September 1935, Reichsgesetzblatt (1935), I, 1146, § 4 (1): 'Juden ist das Hissen der Reichs- und Nationalflagge und das Zeigen der Reichsfarben verboten.'

223 Ibid., § 4 (2): 'Dagegen ist innen (i.e. Jews) das Zeigen der jüdischen Farben gestattet. Die Ausübung dieser Befugnis steht unter staatlichem Schutz.'

224 Gesetz über das am 15. Mai 1922 in Genf geschlossene deutsch-polnische Abkommen über Oberschlesien vom 11. Juni 1922, Reichsgesetzblatt (1922), II, 237, Article 67 (1): 'Alle deutschen Reichsangehörigen sind vor dem Gesetze gleich und genießen ohne Unterschied des Volkstums, der Sprache oder der Religion die gleichen bürgerlichen und staatsbürgerlichen Rechte.' See L. Gruchmann, "'Blutschutzgesetz" und Justiz', 434.

225 Ibid., Article 65: 'Deutschland verpflichtet sich, die in den Artikeln 66 bis 68 enthaltenen Bestimmungen als Grundgesetze anzuerkennen, mit der Wirkung, daß kein Gesetz, keine Verordnung und keine amtliche Handlung im Gegensatz oder Widerspruch zu ihnen stehen, und daß kein Gesetz, keine Verordnung und keine amtliche Handlung gegen sie Geltung beanspruchen darf.'

226 Gesetz über Maßnahmen im ehemaligen oberschlesischen Abstimmungsgebiet vom 30. Juni 1937, Reichsgesetzblatt (1937), I, 717. See V. Dahm, Das jüdische Buch im Dritten Reich, 51.

227 L. Gruchmann, "Blutschutzgesetz" und Justiz', 434-435.

228 Gesetz zum Schutze der Erbgesundheit des deutschen Volkes vom 18. Oktober 1935, Reichsgesetzblatt (1935), I, 1246.

229 Begründung zu dem Gesetz zum Schutze der Erbgesundheit des Deutschen Volkes, published in W. Stuckart and H. Globke, Kommentare zur deutschen Rassengesetzgebung, band 1, Reichsbürgergesetz, Blutschutzgesetz, Ehegesundheitsgesetz, 187. 
a) one of the partners was suffering from a contagious disease which constituted a threat to the health of the other partner or the potential offspring; ${ }^{230}$

b) one of the partners was under (temporary) legal restraint; ${ }^{231}$

c) one of the partners, without being under legal restraint, was suffering from a mental illness, which was considered undesirable for the Volksgemeinschaft; ${ }^{232}$

d) one of the partners was suffering from a hereditary disease as mentioned in the Gesetz zur Verhütung erbkranken Nachwuchses. ${ }^{233}$

All impediments were aimed at the prevention of undesirable marriages in terms of health. Medical science decided what was to be regarded a contagious disease. Stuckart and Globke stated that one had to consult earlier laws like the Reichsgesetz über die Bekämpfung gemeinfährlicher Krankheiten ${ }^{234}$ from I9oo and the Prussian Gesetz über die Bekämpfung übertragbarer Krankheiten ${ }^{235}$ from i 905 to get examples. E.g. cholera, yellow fever, plague, small pox and typhoid were considered to be contagious diseases. An impediment to marriage because of one of these diseases was only temporary, as it was to be expected that a patient would recover within the foreseeable future. More serious were diseases like tuberculosis ${ }^{236}$ and venereal disease ${ }^{237}$ like gonorrhoea, chancre and syphilis, which took a long time to recover from or could not be cured at all. A vector had to be put on the same footing as someone actually suffering from a contagious disease, as a vector could be equally contagious. Whether or not a person was aware of his condition was obviously insignificant.

Not all contagious diseases caused an impediment to marriage. According to Stuckart and Globke, only in case the health of the other partner or the potential offspring was reasonably at risk a marriage was prohibited. Marriage was also prohibited, however, in case both partners suffered from the same contagious disease. Although they constituted no risk to each other, they could still infect their children. Obviously, no impediment in such case existed when one of the partners was infertile. Infertility had to be proved, except when the woman concerned was over 45 years of age. This last exception was made possible by $\mathbb{S} 25$ of the First Supplementary Decree to the Ehegesundheitsgesetz

230 Gesetz zum Schutze der Erbgesundheit des deutschen Volkes vom 18. Oktober 1935, Reichsgesetzblatt (1935), I, 1246, § 1 (1): 'Eine Ehe darf nicht geschlossen werden, (a) wenn einer der Verlobten an einer mit Ansteckungsgefahr verbundenen Krankheit leidet, die eine erhebliche Schädigung der Gesundheit des anderen Teiles oder der Nachkommen befürchten läßt, [...].'

231 Ibid., § 1 (1) (b): 'wenn einer der Verlobten entmündigt ist oder unter vorläufige Vormundschaft steht, [...].'

232 Ibid., § 1 (1) (c): 'wenn einer der Verlobten, ohne entmündigt zu sein, an einer geistigen Störung leidet, die die Ehe für die Volksgemeinschaft unerwünscht erscheinen läßt, [...].'

233 Ibid., § 1 (1) (d): 'wenn einer der Verlobten an einer Erbkrankheit im Sinne des Gesetzes zur Verhütung erbkranken Nachwuchses leidet.'

234 Reichsgesetz über die Bekämpfung gemeinfährlicher Krankheiten vom 30. Juni 1900, Reichs-Gesetzblatt (1900), 306.

235 Gesetz über die Bekämpfung übertragbarer Krankheiten vom 28. August 1905, Gesetz-Sammlung für die Königlichen Preußischen Staaten (1905), 373.

236 Gesetz zur Bekämpfung der Tuberkulose vom 4. August 1923, Gesetzsamm/ung für Preußen (1923), 474.

237 Gesetz zur Bekämpfung der Geschlechtskrankheiten vom 18. Februar 1927, Reichsgesetzblatt (1927), I, 61. Although this law did not prohibit marriages in case one of the partners was suffering from a venereal disease, $\S 6$ stated that in case this person married another person without informing this person that he or she was suffering from a venereal disease, he or she could be punished with up to three years imprisonment. According to $\S 5$, having sexual intercourse although suffering from a contagious venereal disease which the person was aware of or could reasonably have been aware of was punished with imprisonment up to three years as well, except for provisions in the Penal Code which could demand more severe punishment. 
from 29 November $1935 .{ }^{238}$ This Decree provided another exception. According to $\mathbb{5 0}$ of the Personenstandsgesetz a marriage could be concluded without announcement of marriage (Aufgebot) in case further delay because of a life-threatening disease was no longer desirable. This necessity had to be confirmed by a physician. ${ }^{239}$ According to $\mathbb{2} 24$ of the First Supplementary Decree to the Ehegesundheitsgesetz a couple could in this case be relieved from the impediments of $\mathbb{S}$ I of the Ehegesundheitsgesetz. ${ }^{240}$ The rationale behind this rule was to allow the legitimisation of illegitimate children, who had to be taken into account in case one of the partners was on his deathbed because of a contagious disease. However, $\mathbb{S} 24$ did not contain a relief from the impediments stated in $\mathbb{S}$ of the First Supplementary Decree to the Blutschutzgesetz. ${ }^{241}$

The impediment stated in sub $\mathrm{b}$ seemed to be the odd man out, but was justified by Stuckart and Globke by stating that the conditions leading to a legal restraint were the result of an unhealthy mental constitution, even when someone was not made a ward of court because of a mental illness, but because of squandering or alcoholism. ${ }^{242}$ The explanatory memorandum furthermore stated that there was a risk that the tendency to squandering and alcoholism was hereditary and that therefore people under legal restraint had to be prevented to procreate. Squandering and alcoholism were furthermore the result of a hereditary inferior mental constitution, which would have a negative effect on the upbringing of children. ${ }^{243}$ According to $\$ 6 \mathrm{BGB}$ someone could be made a ward of court when I) as a result of mental illness or feeble-mindedness a person could no longer manage his affairs; 2) as a result of squandering a person had put himself or his family in a precarious situation; 3 ) as a result of alcoholism a person could no longer manage his affairs, had put himself or his family in a precarious situation or was a danger to others. ${ }^{244}$ Naturally, a legal restraint could be removed. ${ }^{245}$ This would also cancel the impediments to marriage, provided that the reasons which had initially caused a legal restraint would not lead to another impediment to marriage under $\mathbb{~ I ~ o f ~ t h e ~ E h e g e s u n d h e i t s g e s e t z . ~ T h i s ~}$ provision surpassed the regulations of the Civil Code which stated that someone who had

238 Erste Verordnung zur Durchführung des Ehegesundheitsgesetzes vom 29. November 1935, Reichsgesetzblatt (1935), I, 1419. See also W. Stuckart and H. Globke, Kommentare zur deutschen Rassengesetzgebung, band 1, Reichsbürgergesetz, Blutschutzgesetz, Ehegesundheitsgesetz, 166-167. Please note that Stuckart and Globke use the objective term 'Verlobte' whilst $\S 25$ of the First Supplementary Decree specifically uses the term 'Frau'. It is likely that the interpretation given by Stuckart and Globke is inaccurate as medically speaking there is no reason to assume infertility with a man at 45 years of age.

239 Reichsgesetz über die Beurkundung des Personenstandes und die Eheschließung vom 6. Februar 1875, Reichsgesetzblatt (1875), 23, § 50: '[...] Wird eine lebensgefährliche Krankheit, welche einen Aufschub der Eheschließung nicht gestattet, ärztlich bescheinigt, so kann der Standesbeamte ( 42 Abs. 1) auch ohne Aufgebot die Eheschließung vornehmen.'

240 Erste Verordnung zur Durchführung des Ehegesundheitsgesetzes vom 29. November 1935, Reichsgesetzblatt (1935), I, 1419, § 24: ‘ 1 des Ehegesundheitsgesetzes steht der Eheschließung nicht entgegen, wenn die Ehe nach §50 des Personenstandsgesetzes vom 6. Februar 1875 (Reichsgesetzbl. S. 23, 33) wegen lebensgefährlicher Erkrankung eines Verlobten ohne Aufgebot geschlossen werden darf.'

241 W. Stuckart and H. Globke, Kommentare zur deutschen Rassengesetzgebung, band 1, Reichsbürgergesetz, Blutschutzgesetz, Ehegesundheitsgesetz, 140, 216-217.

242 W. Stuckart and H. Globke, Kommentare zur deutschen Rassengesetzgebung, band 1, Reichsbürgergesetz, Blutschutzgesetz, Ehegesundheitsgesetz, 164-165.

243 Begründung zu dem Gesetz zum Schutze der Erbgesundheit des Deutschen Volkes, published in W. Stuckart and H. Globke, Kommentare zur deutschen Rassengesetzgebung, band 1, Reichsbürgergesetz, Blutschutzgesetz, Ehegesundheitsgesetz, 188.

$244 \S 6$ BGB: 'Entmündigt kann werden: 1) wer infolge von Geisteskrankheit oder von Geistesschwäche seine Angelegenheiten nicht zu besorgen vermag; 2) wer durch Verschwendung sich oder seine Familie der Gefahr des Notstandes aussetzt; 3) wer infolge von Trunksucht seine Angelegenheiten nicht zu besorgen vermag oder sich oder seine Familie der Gefahr des Notstandes aussetzt oder die Sicherheit anderer gefährdet. [...]'

245 Ibid., '[...] Die Entmündigung ist wieder aufzuheben, wenn der Grund der Entmündigung wegfällt.' 
restricted legal capacity because of feeble-mindedness, squandering or alcoholism, ${ }^{246}$ was allowed to marry with consent of his or her legal guardian or curator bonis. ${ }^{247}$

In order to decide when a condition qualified as a mental disorder in the sense of sub c, a strong appeal was made to the professional knowledge and sense of responsibility of the medical world. Often it was about borderline cases. According to Stuckart and Globke, examples of such borderline cases were psychopaths, who were strictly speaking not mentally ill or feeble-minded nor suffering from a hereditary disease as meant in the Gesetz zur Verhütung erbkranken Nachwuchses. Other cases which qualified were persons who were suffering from a mental disorder which normally would lead to a legal restraint,

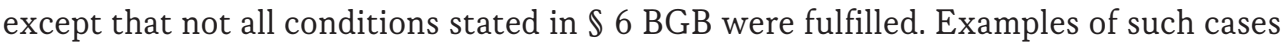
were a squanderer who had so much to spend that his financial situation was never in danger, or a rich alcoholic who had someone employed to manage his affairs. According to Stuckart and Globke these cases nevertheless justified a marriage prohibition. ${ }^{248}$ Marriages were considered to be undesirable for the Volksgemeinschaft when it was likely that the mental disorder was of such severity or nature that it would constitute a risk for the other partner or the children. Whether or not a marriage was beneficial for the mentally disturbed (i.e. the healthy spouse would take good care of the mentally disturbed) was insignificant. Only the interests of the Volksgemeinschaft mattered in this respect. $^{249}$

Sub d was not only aimed at prevention of hereditary defect offspring, but also at prevention of loss of healthy offspring. After all, the healthy partner would be able to get healthy offspring with another than the hereditary defect person. Not all hereditary diseases would lead to an impediment to marriage, only those mentioned in the Gesetz zur Verhütung erbkranken Nachwuchses from I933. Hereditary diseases in the sense of this law were congenital feeble-mindedness, schizophrenia, circular (manic-depressive) insanity, hereditary epilepsy, hereditary St Vitus's dance (Huntington's Chorea), hereditary blindness, hereditary deafness and severe hereditary physical deformation. ${ }^{250}$ Alcoholism caused by the tendency to hereditary psychopathy, which according to $\mathbb{S}$ I (3) Gesetz zur Verhütung erbkranken Nachwuchses ${ }^{251}$ justified sterilisation, did not qualify as hereditary disease in the sense of the Ehegesundheitsgesetz. Nevertheless, alcoholism could qualify as impediment to marriage, in case the requirements of sub b or c were fulfilled. Whether or not a hereditary defect person was sterilised was insignificant. Being hereditary defect

246 See $\S 114$ and 107 BGB.

247 See $\$ 1304$ BGB. Begründung zu dem Gesetz zum Schutze der Erbgesundheit des Deutschen Volkes, published in W. Stuckart and H. Globke, Kommentare zur deutschen Rassengesetzgebung, band 1, Reichsbürgergesetz, Blutschutzgesetz, Ehegesundheitsgesetz, 188. A legal restraint because of a mental illness would lead to a complete loss of legal capacity according to $\$ 104 \mathrm{BGB}$. According to $\$ 105 \mathrm{BGB}$ such a person was not capable to give a valid will which was necessary to conclude a marriage. Therefore, marriage would already have been impossible for such a person before the adoption of the Ehegesundheitsgesetz.

248 W. Stuckart and H. Globke, Kommentare zur deutschen Rassengesetzgebung, band 1, Reichsbürgergesetz, Blutschutzgesetz, Ehegesundheitsgesetz, 169-170.

249 Ibid.

250 Gesetz zur Verhütung erbkranken Nachwuchses vom 14. Juli 1933, Reichsgesetzblatt (1933), I, 529, § 1 (2).

251 Ibid., § 1 (3): 'Ferner kann unfruchtbar gemacht werden, wer an schwerer Alkoholismus leidet.' 
was enough in this respect. A hereditary disease could only cause an impediment to marriage when the other person was fertile. In case of infertility of the other partner, the marriage could be concluded whether the hereditary defect partner was sterilised or not. It did not matter in this respect whether the infertile partner was naturally infertile or because of an artificial intervention. However, sterilisation in order to be able to marry a hereditary defect person was not allowed pursuant $\mathbb{\$}$ I 4 of the Gesetz zur Verhütung erbkranken Nachwuchses. ${ }^{252}$ This article prohibited sterilisation of healthy persons when there was on medical grounds no danger of life or health of the person concerned, even when this person had fully consented to the operation. According to Stuckart and Globke such an act was to a large extent objectionable, as a persons fertility was not only his own concern, but also a very valuable good to the Volksgemeinschaft. This implied that an individual had no unlimited power of disposal of it. ${ }^{253}$ Note that simply being infertile did not cause an impediment to marriage. This is peculiar as we have seen before that the potential loss of healthy offspring - which is evident in case of infertility - did play a part in the considerations to declare a certain condition an impediment to marriage.

Prior to the marriage a couple was obliged to obtain a certificate which proved that the intended marriage was not hindered by any impediment as formulated in $\mathbb{I}{ }^{254}$ Obtaining this certificate was dependent on the results of a medical examination necessary to determine whether the potential husband and wife were not subject to any of the impediments mentioned in $\mathbb{I}$. According to $\mathbb{2}$ of the First Supplementary Decree to the Ehegesundheitsgesetz both partners were obliged to undergo an examination carried out by the Health Office (Gesundheitsamt) of the district in which the couple lived. ${ }^{255}$ Stuckart and Globke added that this rule implied that both partners were obliged to answer all questions of the examining physician considering their health and the health of their next of kin truthfully. Additional information, which was required as part of the examination, had to be produced compulsory. The marriage certificate could also be refused pursuant to $\mathbb{6} 6$ of the First Supplementary Decree to the Blutschutzgesetz, as $\mathbb{7}$ of the First Supplementary Decree to the Blutschutzgesetz ${ }^{256}$ required a marriage certificate to prove the absence of impediments to marriage as stated in $\mathbb{6} 6$ of this Decree. This article in general prohibited all marriages from which offspring was to be expected that constituted a threat to the purity of the German blood. The rationale behind this requirement was

252 Ibid., § 14 (1): 'Eine Unfruchtbarmachung oder Schwangerschaftsunterbrechung, die nicht nach den Vorschriften dieses Gesetzes erfolgt, sowie eine Entfernung der Keimdrüsen sind nur dann zulässig, wenn ein Arzt sie nach den Regeln der ärztlichen Kunst zur Anwendung einer ernsten Gefahr für das Leben oder die Gesundheit desjenigen, an dem er sie vornimmt, und mit dessen Einwilligung vollzieht.'

253 W. Stuckart and H. Globke, Kommentare zur deutschen Rassengesetzgebung, Band 1, Reichsbürgergesetz, Blutschutzgesetz, Ehegesundheitsgesetz, 172-173.

254 Gesetz zum Schutze der Erbgesundheit des deutschen Volkes vom 18. Oktober 1935, Reichsgesetzblatt (1935), I, 1246, § 2: 'Vor der Eheschließung haben die Verlobten durch ein Zeugnis des Gesundheitsamtes (Ehetauglichkeitszeugnis) nachzuweisen, daß ein Ehehindernis nach $\S 1$ nich vorliegt.'

255 Erste Verordnung zur Durchführung des Ehegesundheitsgesetzes vom 29. November 1935, Reichsgesetzblatt (1935), I, 1419, $\S 2$.

256 Erste Verordnung zur Ausführung des Gesetzes zum Schutze des deutschen Blutes und der deutschen Ehre vom 14. November 1935, Reichsgesetzblatt (1935), I, 1334, § 7: 'Vor der Eheschließung hat jeder Verlobte durch das Ehetauglichkeitszeugnis (§ 2 des Ehegesundheitsgesetzes vom 18. Oktober 1935 - Reichsgesetzbl. I S. 1246) nachzuweisen, daß kein Ehehindernis im Sinne des $\S 6$ dieser Verordnung vorliegt. Wird das Ehetauglichkeitszeugnis versagt, so ist nur die Dienstaufsichtbeschwerde zulässig.' 
to prevent marriages between German-blooded persons and persons whose heritage was doubtful, although the birth certificate caused no doubt. This could e.g. be the case with the Rhineland Bastards, illegitimate black half-bloods, who were born in the Rhineland during the French period after the First World War, when the natural father was often unknown. ${ }^{257}$

This obligatory examination offered the opportunity to implement a general marriage consultation. According to Stuckart and Globke only those marriages which medically speaking constituted a threat to the Volksgemeinschaft could be prohibited by law. However, the marriage prohibitions formulated in the Ehegesundheitsgesetz were only a minimum requirement. Obviously, a wide range of marriages could be labelled undesirable to the Volksgemeinschaft. Although these marriages could not be prohibited, they could be discouraged. The Reich Ministry of the Interior and the Prussian Ministry of the Interior together published a list of guidelines for the procedures of the consultancies. ${ }^{258}$ This marriage consultation was without obligations. When the Health Office advised against the marriage and the couple decided to marry nevertheless, the marriage certificate could not be refused. ${ }^{259}$

According to $\mathbb{S} 8$ of the First Supplementary Decree to the Ehegesundheitsgesetz as long as the marriage had not yet been concluded, the marriage certificate could be withdrawn by the Health Office when it subsequently became aware of the existence of impediments to marriage according to $\mathbb{S}$ I of the Ehegesundheitsgesetz. ${ }^{260}$ Subsequently learning about existing impediments according to $\mathbb{S} 6$ of the First Supplementary Decree to the Blutschutzgesetz did not justify the withdrawal of the marriage certificate. The way the Health Office had learned about the existence of the impediments did not matter in this respect. In case the marriage had already been concluded the marriage could be declared void pursuant $\mathbb{3} 3$ of the Ehegesundheitsgesetz, when the marriage certificate had been granted because of false information provided by the couple. ${ }^{261}$

After a marriage certificate had been issued, the marriage had to be concluded within

257 W. Stuckart and H. Globke, Kommentare zur deutschen Rassengesetzgebung, Band 1, Reichsbürgergesetz, Blutschutzgesetz, Ehegesundheitsgesetz, 136-141, 173-175.

258 Grundsätze für die Errichtung und Tätigkeit der Beratungsstellen für Erb- und Rassepflege, Anlage 8: Rundschreiben des Reichsministers des Innern, betr. Richtlinien für die ärztlichen Untersucher der Ehestandsdarlehensbewerber, 16 March 1934 , II 1072/26.2, Reichsgesundheitsblatt (1934), 269, published in W. Stuckart and H. Globke, Kommentare zur deutschen Rassengesetzgebung, band 1, Reichsbürgergesetz, Blutschutzgesetz, Ehegesundheitsgesetz, 234-259. Although these guidelines dealt with the requirements for a marriage loan, the general ideas concerning the racial and physical purity of the German blood were clearly visible. The guidelines were drafted as a result of the Second Supplementary Decree on the allowance of marriage loans (Zweite Durchführungsverordnung über die Gewährung von Ehestandsdarlehen vom 26. Juli 1933, Reichsgesetzblatt (1933), I, 540), which stated in $\$ 5$ whether a spouse suffered from a hereditary defect or a contagious or life-threatening disease, which labeled the marriage as undesirable to the Volksgemeinschaft, was up to a physician to decide. $\S 4$ of the Second Supplementary Decree had stated that a couple of which one of the partners suffered from a contagious or life-threatening disease did not qualify for a marriage loan. Couples of which one of the partners suffered from a hereditary physical or mental defect did not qualify either, which was already determined by $\S 1$ (d) of the First Supplementary Decree (Durchführungsverordnung über die Gewährung van Ehestandsdarlehen (ED-DBO) vom 20. Juni 1933, Reichsgesetzblatt (1933), I, 377).

259 W. Stuckart and H. Globke, Kommentare zur deutschen Rassengesetzgebung, band 1, Reichsbürgergesetz, Blutschutzgesetz, Ehegesundheitsgesetz, 175-176.

260 Erste Verordnung zur Durchführung des Ehegesundheitsgesetzes vom 29. November 1935, Reichsgesetzblatt (1935), I, 1419, § 8 (1): 'Werden dem Gesundheitsamt nach Erteilung des Ehetauglichkeitszeugnisses Ehehindernisse nach § 1 des Gesetzes bekannt, so kann es das Zeugnis zurücknehmen, solange die Ehe nicht geschlossen ist.'

261 W. Stuckart and H. Globke, Kommentare zur deutschen Rassengesetzgebung, band 1, Reichsbürgergesetz, Blutschutzgesetz, Ehegesundheitsgesetz, 201-202. 
six months, rendering the certificate invalid after this period. ${ }^{262}$ This term was chosen as health conditions of both partners could change rapidly.

Despite its alleged importance, $\mathbb{S} 2$ did not come into effect the day after proclamation, unlike the other articles. ${ }^{263}$ This was due to the Health Offices being short-handed as they had only recently been established. According to $\mathbb{S} 8$ (2) it was up to the Minister of the Interior to decide upon the date of commencement of $\mathbb{S} 2 .{ }^{264}$ In the meantime a transitional arrangement would be effective, which declared that only in case of doubt a marriage certificate would be required. ${ }^{265}$ This transitional arrangement was nailed down in $\mathbb{3}$ of the First Supplementary Decree to the Ehegesundheitsgesetz ${ }^{266}$ and was an elaboration of both $\mathbb{8}$ (2) of the Ehegesundheitsgesetz and $\mathbb{S}$ I7 of the First Supplementary Decree to the Blutschutzgesetz. Whether any doubt with regard to any potential impediments to marriage existed was up to the registrar, who would be present at the announcement of marriage, to decide. The registrar had to substantiate his doubts by evidence based on facts. In a serie of circulars the Reich and Prussian Ministry of the Interior published guidelines to clarify the matter. ${ }^{267}$ Otherwise, a registrar had to trust upon the couple's declaration about the absence or presence of an impediment to marriage. Providing false information was punishable and the registrar was obliged to point this out. ${ }^{268}$

Besides being punishable, consciously providing false information and thus unjustly obtaining a marriage certificate or cooperation of a registrar would also lead to nullity (Nichtigkeit) of the marriage. ${ }^{269}$ Marriages which were concluded despite an impediment as stated in $\mathbb{S}$ I of which one or even both partners were not aware of was not void, but disputable (Anfechtbar) following $\mathbb{S}$ I333 and $\mathbb{S}$ I334 BGB. ${ }^{270}$ Disputability would lead

262 Erste Verordnung zur Durchführung des Ehegesundheitsgesetzes vom 29. November 1935, Reichsgesetzblatt (1935), I, 1419, § 7: 'Das Ehetauglichkeitszeugnis wird ungültig, wenn die Ehe nicht binnen sechs Monaten seit der Ausstellung geschlossen wird. [...]'

263 The law was published in the Reichsgesetzblatt on 19 October 1935, coming into force on 20 October 1935. See W. Stuckart and H. Globke, Kommentare zur deutschen Rassengesetzgebung, band 1, Reichsbürgergesetz, Blutschutzgesetz, Ehegesundheitsgesetz, 187.

264 Gesetz zum Schutze der Erbgesundheit des deutschen Volkes vom 18. Oktober 1935, Reichsgesetzblatt (1935), I, 1246, $\S 8$ (2): 'Den Zeitpunkt des Inkrafttretens des $\$ 2$ bestimmt der Reichsminister des Innern. Bis zu diesem Zeitpunkt ist ein Ehetauglichkeitszeugnis nur in Zweifelsfällen vorzulegen.'

265 Begründung zu dem Gesetz zum Schutze der Erbgesundheit des Deutschen Volkes, published in W. Stuckart and H. Globke, Kommentare zur deutschen Rassengesetzgebung, band 1, Reichsbürgergesetz, Blutschutzgesetz, Ehegesundheitsgesetz, 189.

266 Erste Verordnung zur Durchführung des Ehegesundheitsgesetzes vom 29. November 1935, Reichsgesetzblatt (1935), I, 1419, § 3: 'Bis zum Inkrafttreten des $\S 2$ des Gesetzes ist ein Ehetauglichkeitszeugnis nur beizubringen, wenn der Standesbeamte begründete Zweifel hat, ob ein Ehehindernis im Sinne des $\S 1$ des Ehegesundheitsgesetzes oder des $\S 6$ der Ersten Verordnung vom 14. November 1935 zur Ausführung des Gesetzes zum Schutze des deutschen Blutes und der deutschen Ehre (Reichsgesetzbl. I S. 1334) vorliegt.'

267 Runderlaß vom Reichs- und Preußischen Ministerium des Innern, 18 October 1935, IB 3/345, MBliB., 1295, published in W. Stuckart and H. Globke, Kommentare zur deutschen Rassengesetzgebung, band 1, Reichsbürgergesetz, Blutschutzgesetz, Ehegesundheitsgesetz, 228 and Runderlaß vom Reichs- und Preußischen Ministerium des Innern, 26 November 1935, IB $3 / 324$ II, MBliB., 1429, published in W. Stuckart and H. Globke, Kommentare zur deutschen Rassengesetzgebung, band 1, Reichsbürgergesetz, Blutschutzgesetz, Ehegesundheitsgesetz, 151.

268 Runderlaß vom Reichs- und Preußischen Ministerium des Innern, 18 October 1935, IB 3/345, MBliB., 1295, published in W. Stuckart and H. Globke, Kommentare zur deutschen Rassengesetzgebung, band 1, Reichsbürgergesetz, Blutschutzgesetz, Ehegesundheitsgesetz, 228.

269 Gesetz zum Schutze der Erbgesundheit des deutschen Volkes vom 18. Oktober 1935, Reichsgesetzblatt (1935), I, 1246, § 3 (1): 'Eine entgegen den Verboten des $\S 1$ geschlossene Ehe ist nichtig, wenn die Ausstellung des Ehetauglichkeitszeugnisses oder die Mittwirkung des Standesbeamten bei der Eheschließung von den Verlobten durch wissentlich falsche Angaben herbeigeführt worden ist. [...]'

270 W. Stuckart and H. Globke, Kommentare zur deutschen Rassengesetzgebung, band 1, Reichsbürgergesetz, Blutschutzgesetz, Ehegesundheitsgesetz, 178. 
to avoidance, which would lead to annulment. This implied that in case only one of the partners consciously provided false information of which the other partner was not aware of, this would not immediately lead to nullity either. In case the impediment dissolved (e.g. the illness was cured) the nullity was cancelled, declaring the marriage valid from the start. ${ }^{271}$ A marriage was also void when it, in spite of existing impediments, was consciously constituted abroad in order to avoid the rules of the Ehegesundheitsgesetz. ${ }^{272}$

According to $\mathbb{4} 4$ obtaining a marriage which was prohibited deceitfully, was punishable with at least three months imprisonment. ${ }^{273}$ Stuckart and Globke justified the necessity of this article by emphasising the importance of the impediments to marriage as stated in $\mathbb{S}$ I. A marriage was deceitfully obtained when a marriage certificate or cooperation of a registrar was secured due to consciously provided false information. According to Stuckart and Globke the reference to $\mathbb{3}$ did not allow a different interpretation of this article. ${ }^{274}$ However, the marriage had to be declared void in order to start a prosecution. ${ }^{275}$ The reason for nullity did not matter in this respect. In case a prohibited marriage was performed without the couple having provided false information, the physician of the Health Office, who had supplied the marriage certificate, could be prosecuted following $\$ 278$ Penal Code, ${ }^{276}$ whilst the registrar who had performed the marriage could be prosecuted pursuant to $\mathbb{S} 69$ Personenstandsgesetz. ${ }^{277}$ An attempt to deceitfully obtain a marriage prohibited by $\mathbb{S}$ I was punishable as well. ${ }^{278}$

According to $\mathbb{5}(2)$ a foreigner could only be prosecuted pursuant to $\mathbb{S} 4$ after a provision given by the Minister of Justice in consultation with the Minister of the Interior. ${ }^{279}$ However, in practice this situation would rarely happen as $\mathbb{S}_{5}$ (I) stated that the Ehegesundheitsgesetz was not applicable in case the couple or only the man was foreign, ${ }^{280}$ which implied that only a foreign woman could be prosecuted pursuant to $\mathbb{S} 4$.

271 Gesetz zum Schutze der Erbgesundheit des deutschen Volkes vom 18. Oktober 1935, Reichsgesetzblatt (1935), I, 1246, § 3 (2): 'Die Ehe ist von Anfang gültig, wenn das Ehehindernis später wegfällt.'

272 Gesetz zum Schutze der Erbgesundheit des deutschen Volkes vom 18. Oktober 1935, Reichsgesetzblatt (1935), I, 1246, § 3 (1): '[...] Sie ist auch nichtig, wenn sie zum Zwecke der Umgehung des Gesetzes im Ausland geschlossen ist. [...]' This rule was included to prevent couples whose marriage would be prohibited in Germany to get married abroad. However many European countries applied the nationality principle. Therefore, when a foreigner came to a country to marry the law of his fatherland would be applicable, which in many cases would not exclude the Ehegesundheitsgesetz. Belgium and Austria applied the nationality principle based on national regulations, the Netherlands applied the nationality principle based on the Hague Convention on Marriage of 12 June 1902.

273 Gesetz zum Schutze der Erbgesundheit des deutschen Volkes vom 18. Oktober 1935, Reichsgesetzblatt (1935), I, 1246, § 4 (1): 'Wer eine verbotene Eheschließung erschleicht (§ 3), wird mit Gefängnis nicht unter drei Monaten bestraft. [...]'

274 W. Stuckart and H. Globke, Kommentare zur deutschen Rassengesetzgebung, band 1, Reichsbürgergesetz, Blutschutzgesetz, Ehegesundheitsgesetz, 182.

275 Gesetz zum Schutze der Erbgesundheit des deutschen Volkes vom 18. Oktober 1935, Reichsgesetzblatt (1935), I, 1246, § 4 (2): 'Die Verfolgung wegen des vollendeten Vergehens tritt nur ein, wenn die Ehe für nichtig erklärt ist.'

276 'Aerzte und andere approbirte Medizinalpersonen, welche ein unrichtiges Zeugniß über den Gesundheitszustand eines Menschen zum Gebrauche bei einer Behörde oder Versicherungsgesellschaft wider besseres Wissen ausstellen, werden mit Gefängniß von Einem Monat bis zu zwei Jahren bestraft.'

277 Reichsgesetz über die Beurkundung des Personenstandes und die Eheschließung vom 6. Februar 1875, Reichs-Gesetzblatt (1875), 23, § 69: 'Ein Standesbeamter, welcher unter Außerachtlassung der in diesem Gesetze gegebenen Vorschriften eine Eheschließung vollzieht, wird mit Geldstrafe bis zu sechshundert Mark bestraft.'

278 Gesetz zum Schutze der Erbgesundheit des deutschen Volkes vom 18. Oktober 1935, Reichsgesetzblatt (1935), I, 1246, $\S 4$ (1): '[...] Der Versuch ist strafbar.'

279 Gesetz zum Schutze der Erbgesundheit des deutschen Volkes vom 18. Oktober 1935, Reichsgesetzblatt (1935), I, 1246, $\S 5$ (2): 'Die Strafverfolgung eines Ausländers nach § 4 tritt nur auf Aufordnung ein, die der Reichsminister der Justiz im Einvernehmen mit dem Reichsminister des Innern trifft.'

280 Ibid., § 5 (1): 'Die Vorschriften dieses Gesetzes finden keine Anwendung, wenn beide Verlobten oder männliche Verlobte eine fremde Staatsangehörigkeit besitzen.' 
The rationale behind this rule was that the Ehegesundheitsgesetz was meant to maintain the purity of the German blood. Following the Reichs- und Staatsangehörigkeitsgesetz of I9I3 a woman lost her German nationality when she married a foreigner. ${ }^{281}$ Their children would have their father's nationality as well. A foreign woman, however, obtained German nationality when she married a German. ${ }^{282}$ Therefore, a foreign woman had to undergo a medical examination as well, as she had to be fit for marriage according to German law. ${ }^{283}$ According to $\mathbb{} 6$ of the First Supplementary Decree to the Ehegesundheitsgesetz the man was obliged to make sure his fiancée underwent the examination. ${ }^{284}$ The Ehegesundheitsgesetz was furthermore applicable on people who were stateless, but had their residence in Germany ${ }^{285}$ and on stateless people, not having their residence in Germany but marrying in Germany. ${ }^{286}$

\subsection{The New Matrimonial Law for the New Germany}

Despite having an enormous impact, when talking about nazification of matrimonial law, the Blutschutzgesetz and the Ehegesundheitsgesetz only served as makeshift measures. They did not solve the problem of the already existing mixed marriages and when the Third Reich was extended because of the Anschlu $\beta$ of Austria, a general revision of matrimonial law proved to be necessary. This, however, did not go without striking a blow.

\section{- 3.7.1. The build-up to a new marriage law}

As we have seen before in section 3.2.3, the Civil Code from I9oo stated that, generally, divorce was only possible in case one of the partners had committed some wrong, the socalled guilt principle (Verschuldensprinzip). An exception was found in $\mathbb{\$} 1569$ BGB which allowed for divorce in case one of the partners was suffering from a mental disorder for three years already, causing a permanent breakdown of the marriage. Other marriages, however, despite having no reason for continuation whatsoever could not be dissolved. Before the National Socialist take-over one had already attempted to revise divorce law, especially shifting the emphasis to the breakdown principle (Zerrüttungsprinzip). However, all attempts had failed, the last one in I929, largely due to political differences. ${ }^{287}$

The discussion was brought back to life by the Akademie für Deutsches Recht. This Academy for German Law was founded on 26 June 1933 by Hans Frank, who had been appointed Reichskommissar für die Gleichschaltung der Justiz in den Ländern und für

281 Reichs- und Staatsangehörigkeitsgesetz vom 22. Juli 1913, Reichs-Gesetzblatt (1913), 583, § 17 (6): 'Die Staatsangehörigkeit geht verloren für eine Deutsche durch Eheschließung mit dem Angehörigen eines anderen Bundesstaats oder mit einem Ausländer.'

282 Ibid., § 6: 'Durch die Eheschließung mit einem Deutschen erwirbt die Frau die Staatsangehörigkeit des Mannes.'

283 W. Stuckart and H. Globke, Kommentare zur deutschen Rassengesetzgebung, band 1, Reichsbürgergesetz, Blutschutzgesetz, Ehegesundheitsgesetz, 185.

284 Erste Verordnung zur Durchführung des Ehegesundheitsgesetzes vom 29. November 1935, Reichsgesetzblatt (1935), I, 1419, § 6: 'Besitzt nur der Bräutigam die Reichsangehörigkeit, so ist er verpflichtet, die Unterlagen für die Beurteilung der Ehetauglichkeit der Braut beizubringen.'

285 W. Stuckart and H. Globke, Kommentare zur deutschen Rassengesetzgebung, band 1, Reichsbürgergesetz, Blutschutzgesetz, Ehegesundheitsgesetz, 185.

286 Erste Verordnung zur Durchführung des Ehegesundheitsgesetzes vom 29. November 1935, Reichsgesetzblatt (1935), I, 1419, § 29: 'Auf Staatenlose, die ihren gewöhnlichen Aufenthalt im Ausland haben, findet das Ehegesundheitsgesetz keine Anwendung, es sei denn, daß die Ehe in Deutschland geschlossen wird.'

287 D. Blasius, Ehescheidung in Deutschland 1794-1945, 165-187. 
die Erneuerung der Rechtsordnung (Reich Commissioner for the Coordination of State Administrations of Justice and the Renovation of the Legal Order) in April I933, after he had been passed over for the position of Minister of Justice. ${ }^{288}$ The main purpose of the Academy was to prepare a new - National Socialist - legal order. ${ }^{289}$ In order to achieve this the Academy formed over a hundred committees and subcommittees, one of them being the Committee on Family Law including Matrimonial Law, presided by Ferdinand Mößmer. ${ }^{290}$

In 1935 Mößmer published a memorandum on the need for a revision of divorce law including a draft proposal, introducing the breakdown principle as the main ground for divorce. ${ }^{291}$ Mößmer defined marriage as

die von der Volksgemeinschaft anerkannte, auf gegenseitiger Treue, Liebe und Achtung beruhende dauernde Lebensgemeinschaft zweier rassegleicher, erbgesunder Personen verschiedenen Geschlechts zum Zweck der Wahrung und Förderung des Gemeinwohls durch einträchtige Zusammenarbeit und zum Zweck der Erzeugung rassegleicher, erbgesunder Kinder und ihrer Erziehung zu tüchtigen Volksgenossen. ${ }^{292}$

Not the individual was the bearer of rights and duties, but the community of the people, the Volksgemeinschaft. Marriage was defined by its purpose to the Volksgemeinschaft: to produce many healthy and racially valuable children. In case a marriage was no longer of value to the Volksgemeinschaft - i.e. no offspring was to be expected - a divorce should be justified on the ground of permanent breakdown of the marriage. ${ }^{293}$ After a divorce the former partners would have the chance to start new families, in this way still having the opportunity to fulfil their moral obligation to the Volksgemeinschaft.

The permanent breakdown had to be objectively determined by the court. Special judges, selected because of their knowledge, philosophy of life, age, personality or family relations (married, with children) should be appointed to fulfil this difficult task. ${ }^{294}$ According to Mößmer a marriage was disrupted and eligible for divorce in case it was a matter of a permanent situation which was no longer compatible with the essence of marriage as a community based on moral grounds. When the court had established that according to human standards a recovery of this community was no longer to be expected, a divorce was justified. This should become the general ground for divorce, not an additional rule next to the guilt principle, as had been suggested before. ${ }^{295}$ This appears

288 D.L. Anderson, The Academy of German Law, 1933-1944, 41-46.

289 D. Blasius, Ehescheidung in Deutschland 1794-1945, 195; D.L. Anderson, The Academy of German Law, 1933-1944, 45.

290 See for a complete list of all committees and subcommittees of the Academy for German Law D.L. Anderson, The Academy of German Law, 1933-1944, 573-581.

291 F. Mößmer, Neugestaltung des deutschen Ehescheidungsrechtes.

292 F. Mößmer, Neugestaltung des deutschen Ehescheidungsrechtes, 11-12.

293 F. Mößmer, Neugestaltung des deutschen Ehescheidungsrechtes, 11-12; L. Gruchmann, 'Das Ehegesetz vom 6. Juli 1938. Entstehung und Beurteilung', 64; D. Blasius, Ehescheidung in Deutschland 1794-1945, 195-196.

294 F. Mößmer, Neugestaltung des deutschen Ehescheidungsrechtes, 68-69.

295 F. Mößmer, Neugestaltung des deutschen Ehescheidungsrechtes, 12-14; L. Gruchmann, 'Das Ehegesetz vom 6. Juli 1938. Entstehung und Beurteilung', 64. 
most clearly from the proposed $\mathbb{\$} 8$, which stated that divorce was allowed in case that for whatever reason the marital community was disrupted in such a way that recovery of this community was no longer to be expected. ${ }^{296}$ It also appears from the proposed $\mathbb{S} 6$, which stated that divorce based on the grounds stated in draft $\mathbb{S} \mathbb{2}$ to 4 (adultery or crimes against morality, attempted murder of the other spouse or refusal to procreate) was only granted in case a permanent breakdown of the marriage - caused by one of the aforementioned acts - had been determined. ${ }^{297}$

The requirement that the permanent breakdown had to be objectively determined by the court meant that divorce by sheer mutual consent - favoured by the SS - was not allowed. Marriage should not be regarded a mere contract which could be annulled by the partners any time. ${ }^{298}$ Mößmer defended himself against allegations implying that he was just facilitating divorce, thereby degrading the status of marriage. According to Mößmer, the revision of divorce law would only lead to the possibility to dissolve hopeless marriages which would otherwise have been kept together forcedly for no specific purpose. Furthermore, he pointed out that it was not easy to determine whether a marriage was permanently disrupted; in case all criteria were sufficiently taken into account, one could impossibly argue that this revision meant to just facilitate divorce. ${ }^{299}$ In $\mathbb{S}$ I of his draft proposal Mößmer even declared marriage in principle indissoluble. Only marriages which were permanently disrupted and which continuance was undesirable from the point of view of the Volksgemeinschaft could be dissolved. ${ }^{300}$

The importance the National Socialists attached to the concept of marriage as the basis for the Volksgemeinschaft also appeared from the proposal to introduce the possibility of divorce at request of the Public Prosecutor. ${ }^{301}$ According to Mößmer a marriage also had to be considered disrupted when it - despite harmony between the spouses - lacked moral quality, potentially causing a detriment to the Volksgemeinschaft. Public morality and the well-being of the Volksgemeinschaft were more important than the personal interests of the spouses, especially when these interests caused a threat to the Volksgemeinschaft. Practising communist propaganda was included in this respect. ${ }^{302}$

296 F. Mößmer, Neugestaltung des deutschen Ehescheidungsrechtes, 66, § 8: 'Ein Ehegatte kann auf Scheidung der Ehe antragen, wenn aus einem sonstigen Grund das eheliche Verhältnis so tief zerrüttet ist, daß die Wiederherstellung einer dem Wesen der Ehe entsprechenden Lebensgemeinschaft nicht mehr erwartet werden kann. [...].'

297 F. Mößmer, Neugestaltung des deutschen Ehescheidungsrechtes, 66, § 6: 'In den Fällen der §§ 2 mit 4 findet die Scheidung der Ehe nicht statt, wenn sich aus bestimmten Tatsachen, insbesondere aus dem Verhalten des Antragstellers selbst ergibt, daß durch die Verfehlung eine Zerrüttung des ehelichen Verhältnisses im Sinn des $\S 5$ nicht eingetreten ist.'

298 L. Gruchmann, ‘Das Ehegesetz vom 6. Juli 1938. Entstehung und Beurteilung', 64.

299 F. Mößmer, Neugestaltung des deutschen Ehescheidungsrechtes, 14-15.

300 F. Mößmer, Neugestaltung des deutschen Ehescheidungsrechtes, 65, § 1: 'Die Ehe ist grundsätzlich unlösbar. Nur solche Ehen, denen für dauernd die sittliche Grundlage entzogen und deren Aufrechterhaltung vom Standpunkt des Gemeinwohls weder geboten noch erwünscht ist, können nach Maßgabe der folgenden Bestimmungen geschieden werden.'

301 F. Mößmer, Neugestaltung des deutschen Ehescheidungsrechtes, 67, § 10: 'Eine Ehe ist auf Antrag der Staatsanwaltschaft zu scheiden, wenn die Ehegatten in bewußtem und gewolltem Zusammenwirken ein unsittliches oder verbrecherisches Leben führen, durch das die öffentliche Sittlichkeit oder lebenwichtige Interessen der Gemeinschaft dauernd gröblich verletzt werden.'

302 F. Mößmer, Neugestaltung des deutschen Ehescheidungsrechtes, 62-63; L. Gruchmann, 'Das Ehegesetz vom 6. Juli 1938. Entstehung und Beurteilung', 64. 
However, Minister of Justice Franz Gürtner, at that time not a member of the National Socialist Party, ${ }^{303}$ disagreed with Mößmer's ideas, refused to write a preface to the memorandum and even tried to prevent publication. The memorandum was nevertheless published, with a preface of Hans Frank instead. ${ }^{304}$

According to Gürtner, marriage did indeed serve as the basis for the Volksgemeinschaft. However, marriage had to be considered a bond for lifetime, with the obligation to deal with all difficulties and hard times together. Facilitating divorce would inevitably lead to an increase in the number of divorces, which would not only have economic consequences for the Volksgemeinschaft, but would also potentially harm the children involved, the future of the nation. The number of divorces had already dramatically increased over the years ${ }^{305}$ and according to Gürtner it was important that the German people would not get the impression that according to the National Socialists marriage could be taken lightly. The only revision Gürtner would allow was an extension of the existing $\mathbb{} 1569$ BGB to hysteria ${ }^{306}$ According to Blasius Gürtner tried to defend the existing divorce regulations from the BGB. Being a conservative Gürtner was not in favour of extending the grounds for divorce and he cleverly made use of the importance the National Socialists attached to the concept of family and marriage to strenghten his message. ${ }^{307}$

Mößmer sent a reaction on 29 September 1936 stating that the current approach of divorce with the guilt principle departed from an individualistic outlook on the concept of marriage and divorce, whilst the Committee on Family Law of the Academy for German Law had tried to come up with a proposal departing from the community thought by allowing for divorce in case a marriage had objectively lost its value to the Volksgemeinschaft. According to Mößmer, the Minister's fear that the introduction of the breakdown principle would lead to an unlimited facilitation of divorce, causing a moral threat to the community, was completely groundless. ${ }^{308}$ Although Mößmer admitted that the introduction of the breakdown principle would lead to an increase of the number of divorces ${ }^{309}$ he did not consider this a threat to morality as it would only concern a temporary situation. Immediately after the new divorce rules would have come into force, many people who were suffering in a disrupted marriage for years already but had never been eligible for divorce before, would then request a divorce on the ground of the newly introduced breakdown principle. As soon as this flood of old cases had run dry, the number of divorce requests would stabilise again. Additionally, Mößmer pointed out, due to the Blood Protection Law and the Marriage Health Law, many marriages which were

303 Gürtner had been a member of the Deutschnationale Volkspartei (German National People's Party) until 1933, when the party was dissolved. He never formally joined the NSDAP. Gürtner died in 1941. See D. Nicholls, Adolf Hitler. A Biographical Companion, 111.

304 D. Blasius, Ehescheidung in Deutschland 1794-1945, 197-198; L. Gruchmann, 'Das Ehegesetz vom 6. Juli 1938. Entstehung und Beurteilung', 65.

305 From 35 divorces on 100,000 inhabitants in 1919 to 65.1 divorces on 100,000 inhabitants in 1933. See Letter from Minister of Justice F. Gürtner to several ministries as well as to F. Mößmer (19 June 1936), published in W. Schubert, Das Familien- und Erbrecht unter dem Nationalsozialismus, 169-173, 170. See for statistics on divorce numbers also F. Mößmer, Neugestaltung des deutschen Ehescheidungsrechtes, 83.

306 Letter from Minister of Justice F. Gürtner to several ministries as well as to F. Mößmer (19 June 1936), published in W. Schubert, Das Familien- und Erbrecht unter dem Nationalsozialismus, 169-173.

307 D. Blasius, Ehescheidung in Deutschland 1794-1945, 198-199.

308 Reaction from F. Mößmer on the letter of the Minister of Justice from 19 June 1936 (29 September 1936), published in W. Schubert, Das Familien- und Erbrecht unter dem Nationalsozialismus, 173-177, 173-174.

309 F. Mößmer, Neugestaltung des deutschen Ehescheidungsrechtes, 84. 
prone to fail could not be concluded anymore anyhow. Furthermore, Mößmer's draft proposal certainly did not contain a mere facilitation of divorce as the absolute grounds for divorce were abolished. As we have seen before, according to the draft proposal, a fact which under the existing rules lead to an absolute ground for divorce, e.g. adultery, could only lead to divorce in case the court had objectively determined that the marriage was permanently and irretrievably disrupted. With regard to Gürtner's remark that marriage entailed a bond for life, Mößmer stated that no law could ever force a marital community. Gürtner's proposal to extend the existing $\mathbb{S} 1569$ BGB to hysteria was dismissed by Mößmer as too confined and not in line with the current Weltanschauung, contrary to his own proposal. He had not tried to completely revise German divorce law, but only to bring it in line with National Socialism. ${ }^{310}$

As a result of two meetings on the matter, one on 6 August 1936 and the other on I9 September 1936, Mößmer also sent a letter to the Minister of the Interior, once again defending his draft. ${ }^{311}$

On 17 November 1936 the Ministry of Justice organised a conference in order to find out what the different opinions on divorce entailed. ${ }^{312}$ Gürtner started by stating that he had discussed the question whether or not a general revision of divorce law was advisable with Hitler. Hitler had indicated not to be in favour of facilitating divorce as the number of divorces was too high already. He pleaded for restraint. Furthermore, Hitler had criticised the existing possibility to get a divorce on the ground of mental illness of the other spouse. According to Hitler it should be possible to get a divorce when it had become clear that because of the mental illness the mental community between the spouses did no longer exist. ${ }^{313}$ Hitler's anwer was right up Gürtner's street. He felt supported by Hitler because of his order to restraint and defended adultery as absolute ground for divorce. ${ }^{314}$ According to Gürtner adultery encroached on the foundation of justice: trust. Adultery meant a direct breach of confidence and he considered it impossible that a court could consider a marriage in which one of the partners had committed adultery not to be permanently disrupted. ${ }^{315}$ Arthur Gütt, the representative of the Ministry of the Interior however, was not in favour of maintaining the absolute grounds for divorce because of population policies. The existing rules contained too many obstacles to remarry for those who were divorced because of adultery, which was inexpedient in the light of the

310 Reaction from F. Mößmer on the letter of the Minister of Justice from 19 June 1936 (29 September 1936), published in W. Schubert, Das Familien- und Erbrecht unter dem Nationalsozialismus, 173-177, 174-176.

311 Letter from F. Mößmer to the Minister of the Interior (29 September 1936), published in W. Schubert, Das Familien- und Erbrecht unter dem Nationalsozialismus, 177-180.

312 D. Blasius, Ehescheidung in Deutschland 1794-1945, 199; M. Hetzel, Die Anfechtung der Rassenmischehe in den Jahren 1933-1939, 167. A report of this meeting is published in W. Schubert, Das Familien- und Erbrecht unter dem Nationalsozialismus, 185-191. However, Schubert dates the meeting 17 October 1936 instead of 17 November. Both Blasius and Hetzel refer to 17 November 1936.

313 Report of a meeting on the revision of divorce law at the Ministry of Justice (17 November 1936), published in W. Schubert, Das Familien- und Erbrecht unter dem Nationalsozialismus, 185-191, 185-186.

314 D. Blasius, Ehescheidung in Deutschland 1794-1945, 200.

315 Report of a meeting on the revision of divorce law at the Ministry of Justice (17 November 1936), published in W. Schubert, Das Familien- und Erbrecht unter dem Nationalsozialismus, 185-191, 186. 
National Socialist population policy. ${ }^{316}$

Furthermore, a controversy between the Ministry of the Interior and the Ministry of Justice arose with regard to Mößmer's proposal to introduce permanent breakdown of the marriage as the main ground for divorce. According to Gürtner introducing the breakdown principle would lead to a devaluation of the concept of marriage. $\mathrm{He}$ pointed out that there existed countless marital tragedies which could not be solved by the legislator. He furthermore emphasised that community interest entailed a correct appreciation of the concept of marriage by the German population, but that population policy and community interests were not the only things that counted. ${ }^{317}$ Because of the National Socialist population policy however, Gütt requested a connection of divorce law with the Marriage Health Law, stating that the grounds on which a marriage was prohibited under the Marriage Health Law should also be able to serve as grounds for divorce in case a marriage was permanently disrupted. ${ }^{318}$

The matter of mixed marriages was touched upon only briefly. Gürtner reported Hitler's point of view on the matter, who had stated that enabling divorce of mixed marriages was improper and unseemly as was creating an extra term to ask for annulment because of racial differences. Because of this statement Gürtner considered it not possible to dissolve mixed marriages by divorce.$^{319}$ Hetzel points out that Hitler's words on this are not what they seem to be. As in 1936 Hitler could still not risk a conflict with the conservatives and the liberals, dissolution of mixed marriages was not a top priority. Hetzel furthermore takes over the suggestion by Eberhard Jäckel that Hitler's restraint with regard to the dissolution of mixed marriages was prompted by the mixed married couple Scharrer - Aryan man and Jewish woman - who had financially supported the NSDAP during the first years. ${ }^{320}$

Although the support for a revision of divorce law in favour of introducing the breakdown principle as the main ground for divorce appeared to be rather strong, Gürtner decided to come up with his own draft proposal. The first draft dates from I 8 January $1937,{ }^{321}$ was partially discussed and criticised in a meeting presided by Gürtner on 2 February $1937^{322}$ and subsequently revised - at least the first fourteen articles which dealt with the general provisions and the grounds for divorce. ${ }^{323}$

316 Report of a meeting on the revision of divorce law at the Ministry of Justice (17 November 1936), published in W. Schubert, Das Familien- und Erbrecht unter dem Nationalsozialismus, 185-191, 186; D. Blasius, Ehescheidung in Deutschland 17941945, 200.

317 Report of a meeting on the revision of divorce law at the Ministry of Justice (17 November 1936), published in W. Schubert, Das Familien- und Erbrecht unter dem Nationalsozialismus, 185-191, 187-188; D. Blasius, Ehescheidung in Deutschland 1794-1945, 200.

318 Report of a meeting on the revision of divorce law at the Ministry of Justice (17 November 1936), published in W. Schubert, Das Familien- und Erbrecht unter dem Nationalsozialismus, 185-191, 187; D. Blasius, Ehescheidung in Deutschland $1794-$ 1945, 200-201.

319 Report of a meeting on the revision of divorce law at the Ministry of Justice (17 November 1936), published in W. Schubert, Das Familien- und Erbrecht unter dem Nationalsozialismus, 185-191, 190.

320 M. Hetzel, Die Anfechtung der Rassenmischehe in den Jahren 1933-1939, 167-168.

321 Draft of a law on divorce (18 January 1937), published in W. Schubert, Das Familien- und Erbrecht unter dem Nationalsozialismus, 191-198.

322 Report of the meeting on the draft of a law on divorce (2 February 1937), published in W. Schubert, Das Familien- und Erbrecht unter dem Nationalsozialismus, 200-203.

323 Revision of $\S \S 1-14$ of the draft by the Ministry of Justice as a result of the meeting of 2 February 1937, published in W. Schubert, Das Familien- und Erbrecht unter dem Nationalsozialismus, 203-205. 
Paragraph I met Mößmer's wish to place marriage in the service of the Volksgemeinschaft, by stating that divorce was only possible in case the foundations, on which a marriage should be built in order to be of value to the Volksgemeinschaft, were affected. ${ }^{324}$ However, the structure of the grounds for divorce did not substantially differ from the existing regulations in the BGB. The guilt principle remained the starting point, although the number of grounds was somewhat extended, now including refusal to procreate $(\mathbb{5}$ Verweigerung der Fortpflanzung) and refusal of maintenance ( $\mathbb{7}$ Unterhaltsverweigerung). Furthermore, the draft contained four 'other grounds', including mental illness of the other spouse ( $\$ 9$ Geisteskrankheit), which only diffence with the existing $\mathbb{1 5 6 9}$ BGB was the absense of the requirement that the mental illness lasted for three years already during the marriage, disruptive acts of the other spouse caused by a mental disturbance

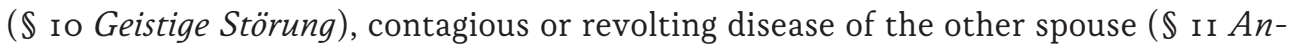
steckende Krankheit) and premature infertility of the other spouse ( $\$$ I2 Unfruchtbarkeit). The only provision which allowed both partners to file for divorce was $\mathbb{\text { I } 4}$ (Funfjährige Trennung), which stated that both partners could file for divorce in case they had lived separated for five years already and reconciliation was not to be expected. With regard to this article Gürtner had given in to the Ministry of the Interior who had requested to shorten the term from ten years, as Gürtner had originally proposed, ${ }^{325}$ to five years. ${ }^{326}$ This article came closest to the general breakdown principle suggested by Mößmer, but was steered away from the dogmatic National Socialist approach based on racial and population policies because of this five year term. ${ }^{327}$ A general breakdown article, like Mößmer's draft $\mathbb{8}$ was not included and the grounds originating from the guilt principle were not judged according to the breakdown principle as Mößmer had suggested in his draft $\mathbb{} 6$.

The remaining articles were discussed on 23 February 1937, were it was decided that $\mathbb{S}$ I5 should contain a provision stating that a divorce based on one of the guilt grounds would not be granted in case it appeared from the behaviour of the innocent spouse that he or she had not experienced the acts of the guilty spouse as disruptive. ${ }^{328}$ Such a provision had already been proposed by Gürtner. ${ }^{329}$ However, this was still not entirely in line with Mößmer's proposal as according to Mößmer the court should determine whether or not a marriage was permanently disrupted.

324 Revision of $\S$ 1-14 of the draft by the Ministry of Justice as a result of the meeting of 2 February 1937, published in W. Schubert, Das Familien- und Erbrecht unter dem Nationalsozialismus, 203-205, § 1: 'Die Ehe kann nur geschieden werden, wenn die Grundlagen zerstört sind, auf denen die Ehe aufgebaut sein muß, um für die Volksgemeinschaft von Wert zu sein. $[\ldots] . '$

325 Draft of a law on divorce (18 January 1937), published in W. Schubert, Das Familien- und Erbrecht unter dem Nationalsozialismus, 191-198, § 14 (1): 'Leben die Eheleute seit zehn Jahren voneinander getrennt und ist eine Wiedervereinigung nicht zu erwarten, so kann jeder von ihnen die Scheidung begehren.'

326 Report of the meeting on the draft of a law on divorce (2 February 1937), published in W. Schubert, Das Familien- und Erbrecht unter dem Nationalsozialismus, 200-203, 203.

327 D. Blasius, Ehescheidung in Deutschland 1794-1945, 201.

328 Report of the meeting on the draft law in divorce (23 February 1937), published in W. Schubert, Das Familien- und Erbrecht unter dem Nationalsozialismus, 207-210, 207.

329 Draft of a law on divorce (18 January 1937), published in W. Schubert, Das Familien- und Erbrecht unter dem Nationalsozialismus, 191-198, § 15: 'Das Recht auf Scheidung wegen Verschuldens besteht nicht, wenn der Verletzte die Verfehlung verziehen oder durch sein Verhalten gezeigt hat, daß er sie nicht als ehezerstörend empfindet.' 
As a result of the meetings, deliberations and remarks from February, the Ministry of Justice presented a new draft on 23 March $1937 \cdot{ }^{330}$ The proposed grounds for divorce had not substantially been altered after the partial revision in the beginning of February. Therefore, the guilt principle remained the starting point from the Ministry's draft. The National Socialist population policy had played a role to a certain extent, but no general breakdown principle had been introduced. The most substantial reform was found in $\mathbb{S}_{\text {I4 }}$, but, due to the installed five year term, this could still not be regarded a Generalklausel in this respect. As was to be expected, this draft proposal was heavily criticised.

Hanns Kerrl, Reichs- und Preußisch Minister für die kirchlichen Angelegenheiten (Reich and Prussian Minister for Church Affairs) sent a letter to Gürtner on 28 April I937 stating that for several reasons he could not accept the proposal. Firstly, Kerrl objected to the partial revision of matrimonial law - only divorce law and not the rules regarding conclusion of marriage or annulment - as all provisions of family law formed an 'organic unity' and should therefore only be revised in total. Furthermore, Kerrl stated that the procedural rules concerning divorce were in more need of a revision than the provisions of substantive law. And finally, he disagreed with the guilt principle, thereby going to the heart of Gürtner's draft. ${ }^{331}$

In reaction to Gürtner's draft the Nationalsozialistischer Rechtswahrerbund (NSRB) presented a counterdraft written in the spirit of the proposal of Mößmer in May I937. ${ }^{332}$ According to the NSRB the Ministry draft had deviated from the trail of renewal blazed by the Academy for German Law. They emphasised the importance of healthy marriages for the Volksgemeinschaft and even suggested to introduce a general breakdown principle, a Zerrüttungs-Generalklausel, which would render all other grounds for divorce redundant. The court - being a National Socialist court - could give a personal, albeit National Socialist interpretation when applying the provision. ${ }^{333}$

Contrary to the previous reactions, the Hauptamt für Volksgesundheit in der NSDAP (Head Office for Public Health of the NSDAP) was rather mild. They approved of the term attached to the breakdown article, although they were in favour of a two or three year term, rather than a five year term. ${ }^{334}$

With a plea of existing uncertainty among the German people with regard to divorce and the negative consequences this would have for the Volksgemeinschaft, Gürtner finally succeeded in receiving Hitler's permission to revise the existing divorce regulations. ${ }^{335}$ In the summer of 1937 the Ministry of Justice declared itself prepared to cooperate with both the Akademie für Deutsches Recht and the NSRB in order to come to an understanding.

330 Draft by the Ministry of Justice of a Law on Divorce (25 March 1937), published in W. Schubert, Das Familien- und Erbrecht unter dem Nationalsozialismus, 210-219.

331 Letter from the Reich and Prussian Minister for Church Affairs to the Reich Minister of Justice (28 April 1937), published in W. Schubert, Das Familien- und Erbrecht unter dem Nationalsozialismus, 220-221.

332 L. Gruchmann, 'Das Ehegesetz vom 6. Juli 1938. Entstehung und Beurteilung', 65.

333 D. Blasius, Ehescheidung in Deutschland 1794-1945, 201.

334 D. Blasius, Ehescheidung in Deutschland 1794-1945, 201-202.

335 On 8 June 1937 he informed Hanns Kerrl about this permission, defending the partial revision of family law, which was objected to by Kerrl in his letter from 28 April 1937. See letter from the Reich Minister of Justice to the Reich and Prussian Minister for Church Affairs (8 June 1937), published in W. Schubert, Das Familien- und Erbrecht unter dem Nationalsozialismus, 221 223, 222. 
As opinions on the matter of divorce still differed greatly, this cooperation resulted in a compromise draft, presented on 3 September $1937 .{ }^{336}$

Again, the starting point was National Socialism and its views on marriage as the basis for the Volksgemeinschaft. Gürtner, however, succeeded in including some provisions that moderated this influence a bit. ${ }^{337}$ The list of grounds for divorce still started with the grounds based on the guilt principle, although the list was shortened. Gürtner's original draft had contained the grounds 'groundless staying away from the domestic community' (Grundloses Fernbleiben von der Hausgemeinschaft), which had been based on the existing \$ 5667 BGB (Bösliche Verlassung) and refusal of maintenance (Unterhaltsverweigerung); both had been dropped. ${ }^{338}$ The earlier proposed 'other grounds' for divorce remained largely unchanged except for the provision on divorce after a five year separation. That provision, which was now $\mathbb{S}$ I2 and aptly named Zerrüttung der Ehe, formed the core of the compromise. The first part of the provision stated that when the domestic community of the spouses had been removed for three years already, whilst, due to a deep and irretrievable breakdown of the marital community, reconciliation was not to be expected, both partners could file for divorce. ${ }^{339}$ This provision was as close as they would get towards a general breakdown principle and it was further limited by $\mathbb{S}$ I2 (2) which stated that in case the partner who filed for divorce was (largely) responsible for the breakdown, the other spouse could contradict the divorce. ${ }^{340}$ This was in order to prevent repudiation of a woman by her husband on the ground of permanent breakdown of the marriage after three years of separation, ${ }^{341}$ leaving her with nothing. In case continuation of the marriage was morally not justified, the contradiction would have no effect. ${ }^{342}$ After all, the core of the National Socialist outlook on marriage was that unhealthy and - above all - unproductive marriages should be eligible for divorce.

The draft was sent to Hitler's Deputy Rudolf $\mathrm{He}^{343}$ and to $\mathrm{Mößmer}^{344}$ on 3 September I937 and to Minister of the Interior Frick ${ }^{345}$ on I4 September I937. Mößmer sent his reply on 4 October 1937, containing primarily linguistic remarks and some remarks on the provisions concerning maintenance. Having been closely involved in drafting this

336 L. Gruchmann, 'Das Ehegesetz vom 6. Juli 1938. Entstehung und Beurteilung', 65-66; D. Blasius, Ehescheidung in Deutschland 1794-1945, 202.

337 D. Blasius, Ehescheidung in Deutschland 1794-1945, 202.

338 New version of a draft of the Ministry of Justice of a law on divorce (September 1937), published in W. Schubert, Das Familienund Erbrecht unter dem Nationalsozialismus, 226-236.

339 New version of a draft of the Ministry of Justice of a law on divorce (September 1937), published in W. Schubert, Das Familienund Erbrecht unter dem Nationalsozialismus, 226-236, § 12 (1): 'Ist die häusliche Gemeinschaft der Ehegatten seit drei Jahren aufgehoben und ihre Wiederherstellung infolge einer tiefgreifenden unheilbaren Zerrüttung des ehelichen Verhältnisses nicht zu erwarten, so kann jeder Ehegatte die Scheidung begehren.'

340 New version of a draft of the Ministry of Justice of a law on divorce (September 1937), published in W. Schubert, Das Familienund Erbrecht unter dem Nationalsozialismus, 226-236, § 12 (2): 'Hat der Ehegatte, der die Scheidung begehrt, die Zerrüttung ganz oder überwiegend verschuldet, so kann der andere der Scheidung widersprechen. [...].'

341 L. Gruchmann, 'Das Ehegesetz vom 6. Juli 1938. Entstehung und Beurteilung', 67.

342 New version of a draft of the Ministry of Justice of a law on divorce (September 1937), published in W. Schubert, Das Familienund Erbrecht unter dem Nationalsozialismus, 226-236, § 12 (2): '[...] Der Widerspruch ist nicht zu beachten, wenn er bei richtiger Würdigung des Wesens der Ehe und des gesamten Verhaltens beider Ehegatten sittlich nicht gerechtfertigt ist.'

343 Letter from the Reich Minister of Justice to the Führer's deputy (3 September 1937), published in W. Schubert, Das Familienund Erbrecht unter dem Nationalsozialismus, 236-237.

344 Letter from the Reich Minister of Justice to Ferdinand Mößmer (3 September 1937), published in W. Schubert, Das Familienund Erbrecht unter dem Nationalsozialismus, 237-238.

345 Letter from the Reich Minister of Justice to the Reich and Prussian Minister of the Interior (14 September 1937), published in W. Schubert, Das Familien- und Erbrecht unter dem Nationalsozialismus, 238. 
proposal, he had no comments on the grounds for divorce, although he did point out that the starting point of marriage as a matter of the community rather than an individual one, was not entirely reflected by phrases like 'Ein Ehegatte kann die Scheidung begehren' instead of 'Ein Ehegatte kann auf Scheidung antragen'. ${ }^{346}$ Frick replied a few days later, approving of the draft. ${ }^{347}$

A reply from Heß only came in January 1938, suffused with National Socialism. First of all, he suggested to drop $\mathbb{S}$ I and 2, which stated that divorce was only possible in case the foundations, on which a marriage should be built in order to be of value to the Volksgemeinschaft, were affected. One should not leave room for discussion about what the requirements for a marriage to be of value of the Volksgemeinschaft were. Furthermore, he stated that in case of premature infertility, divorce should be refused only in case the marriage had produced healthy biological children. Adopted children should not be taken into account in this respect, nor did children from a previous marriage count. The hardship clause of $\mathbb{S}$ I I was criticised by $\mathrm{He} ß$ as well. Obviously a divorce because of premature infertility or a contagious disease was painful for the abandoned spouse. However, pity should not be the prime consideration in such matters. The right to divorce was granted in the interest of the health of the German people, not in the interest of the individuals. Heß not only criticised the grounds for divorce, he disapproved of the term after which no divorce could be requested anymore as well. Paragraph I 4 stated that after ten years after the start or occurrence of the ground for divorce, no divorce was possible anymore. Heß pleaded for an exception clause in case a man whose wife had committed adultery discovered after ten years that the adultery was committed with a Jew. ${ }^{348}$

In a letter of I I March 1938 Gürtner promised Heß to include an exception clause covering this issue. He furthermore indicated to change $\mathbb{S}$ Io (premature infertility) in the sense that divorce would be refused in case the spouses together had a healthy child or together had adopted a child, and not, as in the original draft, in case the partner who filed for divorce had a healthy child or had adopted a healthy child. Apart from some other small changes Gürtner declared himself willing to drop $\mathbb{S}$. He suggested to replace it with a preamble which would explain the National Socialist view on marriage and divorce. With this preamble Gürtner had tried to meet Heß' wishes. ${ }^{349}$

After Heß had approved of the draft, Minister of the Interior Frick agreed to it as well. In his letter from 3I March 1938 he nevertheless emphasised that this draft should only serve to solve the most pressing problems with regard to divorce law and it should not

346 Letter from Ferdinand Mößmer to the Reich Minister of Justice (4 October 1937), published in W. Schubert, Das Familien- und Erbrecht unter dem Nationalsozialismus, 239-241.

347 Letter from the Reich and Prussian Minister of the Interior to the Reich Minister of Justice (7 October 1937), published in W. Schubert, Das Familien- und Erbrecht unter dem Nationalsozialismus, 241.

348 Position of the Führer's Deputy with regard to the draft of 3 September 1937 (12 January 1938), published in W. Schubert, Das Familien- und Erbrecht unter dem Nationalsozialismus, 241-245.

349 Letter from the Reich Minister of Justice to the Führer's Deputy (11 March 1938), published in W. Schubert, Das Familien- und Erbrecht unter dem Nationalsozialismus, 248-251. See for the text of the preamble W. Schubert, Das Familien- und Erbrecht unter dem Nationalsozialismus, 249. See also D. Blasius, Ehescheidung in Deutschland 1794-1945, 202-203. 
stand in the way of a general revision of family law. ${ }^{350}$ However, by that time Germany had incorporated Austria ${ }^{351}$ and as Austria had its own share of problems with regard to marriage and divorce law, this changed the perspective of the legislative activities again.

\section{- 3.7.2. Marriage and divorce law in Austria and the need to adapt the draft revision}

Unlike many Western European countries, e.g. Germany and the Netherlands, Austria did not have an obligatory civil marriage which was generally applicable. Marriage was largely arranged according to religious principles. This appears clearly from the Austrian Civil Code (Allgemeines bürgerliches Gesetzbuch - ABGB), ${ }^{352}$ which stated e.g. in $\$ 64$ that marriages between Christians and non-Christians were not allowed. Marriages were furthermore concluded in the presence of a priest who acted as registrar. ${ }^{353}$ In I868 the possibility of a civil marriage was introduced with the concept of the Notzivilehe. This 'emergency civil marriage' could be concluded in case a priest refused to accept the announcement or conclusion of marriage for reasons which were not acknowledged as an impediment to marriage by the state. ${ }^{354}$ The only part of Austria which acknowledged the obligatory civil marriage for all inhabitants was Burgenland, which had been part of Hungary until I921. The obligatory civil marriage had been introduced in Burgenland in 1894 and in 1922 the parliament of Burgenland decided to maintain Hungarian matrimonial law. ${ }^{355}$ The situation was further complicated when the Konkordat - an agreement between the Holy See and Federal Chancellor Engelberg Dolfuß on the position of the Roman Catholic Church and the applicability of canon law in Austria was ratified in $1934 .{ }^{356}$ Matrimonial law was dealt with in Article VII, which stated in $\mathbb{S}$ I that marriages concluded according to canon law would also have legal consequences under civil law. This was further elaborated by an implementing law from 4 May I934. ${ }^{357}$ The law made a distinction between marriages concluded according to canon law after the concordat had come into force and those which were concluded before this. All in all the concordat did not end the chaos in Austrian matrimonial law, it only made it worse. Especially divorce law was very fragmented, resulting in an unclear and unsatisfactory situation. $^{358}$

350 Letter from the Reich and Prussian Minister of the Interior to the Reich Minister of Justice (31 March 1938), published in W. Schubert, Das Familien- und Erbrecht unter dem Nationalsozialismus, 252. See also D. Blasius, Ehescheidung in Deutschland 1794-1945, 203.

351 Bundesverfassungsgesetz über die Wiedervereinigung Österreichs mit dem Deutschen Reich, Bundesgesetzblatt für den Bundesstaat Österreich (1938), 259, no. 75; Gesetz über die Wiedervereinigung Österreichs mit dem Deutschen Reich vom 13. März 1938, Reichsgesetzblatt (1938), I, 237.

352 Allgemeines bürgerliches Gesetzbuch für die gesammten Deutschen Erbländer der Österreichischen Monarchie vom 1. Juni 1811, Gesetze und Verfassungen im Justiz-Sache (1804-1811), 275, no. 946 (hereafter ABGB).

$353 \S 75$ ABGB. See also O. Lehner, Familie - Recht - Politik, 29.

354 Gesetz vom 25. Mai 1868, Reichs-Gesetz-Blatt für das Kaiserthum Österreich (1868), 93, no. 47. See also O. Lehner, Familie - Recht - Politik, 67, 89.

355 O. Lehner, Familie - Recht - Politik, 110; L. Gruchmann, 'Das Ehegesetz vom 6. Juli 1938. Entstehung und Beurteilung', 68; H. Hofmeister, 'Privatrechtsgesetgebung für Österreich unter der Herrschaft des Nationalsozialismus', 130.

356 Konkordat zwischen dem Heligen Stuhle und der Republik Österreich, Bundesgesetzblatt für den Bundesstaat Österreich (1934), II, 33, no. 2. The Konkordat was signed on 5 June 1933.

357 Bundesgesetz vom 4. Mai 1934, betreffend Vorschriften auf dem Gebiete des Eherechts zur Durchführung des Konkordates zwischen dem Heiligen Stuhle und Österreich vom 5. Juni 1933, B.G.BI. 1934, II. Teil, Nr. 2, Bundesgesetzblatt für den Bundesstaat Österreich (1934), II, 59, no. 8.

358 O. Lehner, Familie - Recht-Politik, 115-117; H. Hofmeister, 'Privatrechtsgesetgebung für Österreich unter der Herrschaft des Nationalsozialismus', 130. 
The ABGB had already stated in $\mathbb{S}$ II5 that divorce (Trennung dem Bande nach) should be arranged according to the rules of the religious community the (non-Roman Catholic) partners adhered to. According to $\mathbb{S}$ i I I Roman Catholics could not divorce at all, even when the other spouse was not a Roman Catholic. Separation from bed and board ( $\$$ I03 ABGB) was allowed for everyone, but this did not enable the possibility to contract a second marriage.

This rigidness of Austrian divorce law had given rise to a questionable legal practice, the Dispensehe. ${ }^{359}$ Although the concept was not new, the Dispensehe came into use in I919, after Albert Sever, a social democrat, had been elected and appointed Landeshauptman (head of government) of Niederösterreich. In order to send a political signal regarding the problems concerning the fragmented and therefore unjust divorce law, Sever had decided to make use of a dispensation clause in the ABGB to allow for second marriages after separation from bed and board. ${ }^{360}$ Paragraph 83 ABGB stated that on important grounds dispensation from an impediment to marriage could be asked from the head of government ${ }^{361}$ of a federal state ${ }^{362}$ However, it was not entirely clear what impediments to marriage exactly dispensation could be granted from and Sever used this indistinctness to allow for second marriages for Roman Catholics by granting them a dispensation from the impediment of marital bond after a separation from bed and board. This allowed for a Notzivilehe before a registrar or - if the partners were willing to convert to another religion - a second marriage, albeit not a canon one. ${ }^{363}$ The Dispensehe lead to a lot of controversies, first of all whether the marital bond of the first marriage was dissolved by the dispensation, the second marriage, or not at all. Was this kind of dispensation even valid and could the second marriage be concluded validly? Despite the risk of bigamy or having no valid marriage, the use of the Dispensehe boomed. By 1930 around 50,000 Dispensehen had already been concluded. ${ }^{364}$

Given these indistinctnesses and uncertainties it is not remarkable that with regard to family law the incorporation lead to high hopes amongst the Austrian population. The problems with regard to matrimonial law and especially divorce law were pressing and Gürtner was aware of this. ${ }^{365}$

Already in April 1938 Gürtner had discussed the problem of a possible reform of Austrian matrimonial law and especially the Dispensehe. Hitler had stated that the matter should be taken care of as soon as possible. The concordat would not stand in the way of a

359 D. Blasius, Ehescheidung in Deutschland 1794-1945, 204; H. Hofmeister, 'Privatrechtsgesetgebung für Österreich unter der Herrschaft des Nationalsozialismus', 130.

360 O. Lehner, Familie - Recht - Politik, 101, 107.

$361 \S 83$ speaks of Landesstelle - state governement. This authority had been transferred to the head of governement in 1918. See L. Gruchmann, 'Das Ehegesetz vom 6. Juli 1938. Entstehung und Beurteilung', 69.

362 § 83 ABGB: 'Aus wichtigen Gründen kann die Nachsicht von Ehehindernissen bei des Landesstelle angesucht werden, welch nach Beschaffenheit der Umstände sich in das weitere Vernehmen zu setzen hat.'

363 O. Lehner, Familie - Recht - Politik, 107; L. Gruchmann, 'Das Ehegesetz vom 6. Juli 1938. Entstehung und Beurteilung', 69.

364 O. Lehner, Familie - Recht - Politik, 107-108.; L. Gruchmann, 'Das Ehegesetz vom 6. Juli 1938. Entstehung und Beurteilung', 69.

365 During a resort meeting on 28 May 1938, Gürtner stated that it was evident that Hitler, when travelling to Austria, would be asked about this matter. See Report on a resort meeting held at the Ministery of Justice, about a draft law on the conclusion of marriage (28 May 1938), published in W. Schubert, Das Familien- und Erbrecht unter dem Nationalsozialismus, $280-281$. 
reform, according to Hitler. ${ }^{366}$ The question was how to reform Austrian matrimonial law in the light of the steps already taken in Germany. Opinions differed on that matter. Gürtner wanted to introduce the newly reformed German divorce law in Austria as well, expanded with a revision of the rules concerning the conclusion of marriage. He asked the representative of the Vienna Ministry of Justice Johann Antoni to come up with transitional provisions for Austria. ${ }^{367}$ On Io May 1938 Gürtner sent a letter to all resorts involved, stating that in the light of the recent incorporation of Austria it had become necessary to harmonise Austrian matrimonial law with German law, which required not only a reform of Austrian divorce law, but also of the Austrian rules concerning the conclusion of marriage. Therefore he proposed, contrary to the original plan, to not only reform German divorce law - something Frick had only agreed to after much deliberation - but also the German rules concerning the conclusion of marriage. A draft proposal was enclosed. He furthermore invited everyone to a meeting on 28 May 1938 the discuss the matter. ${ }^{368}$ Contrary to the draft proposal concerning divorce law, the Academy for German Law had had no hand in this draft. ${ }^{369}$

One day before the meeting would take place Frick replied to Gürtner, stating he agreed upon the need for reform in Austria. However, he disapproved of the draft proposal concerning rules on the conclusion of marriage, as this would be another partial reform in the field of family law, further endangering a general revision of family law. According to Frick it would be better to introduce the existing German rules concerning the conclusion of marriage in Austria, accompanied by some transitional provisions, until a general revision of family law could be brought into force in both Germany and Austria. ${ }^{370}$

The remarks were presented by Frick's representative in the meeting of 28 May. Despite Frick's objections, which were shared by Heß, the full draft was discussed and approved of. No decision was taken on the question whether in case of adultery followed by divorce marriage remained prohibited between the two persons who had committed adultery together ( $\mathbb{S}$ I3I2 BGB). The draft revision of the Criminal Code maintained adultery as an offence prosecuted in case of complaint, which spoke against abolishing this impediment to marriage. Kerrl's representative furthermore suggested to let the character of the content of the law be expressed in its title, suggesting Vereinheitlichung des Eheschließungsrechts im Deutschen Reich or Bis zu endgültigen Regelung des Eherechtes erläßt die Reichsregierung das Nachstehende Gesetz etcetera. ${ }^{371}$

On 3I May Gürtner informed the resorts that he would combine the draft concerning the rules on conclusion of marriages with the already approved draft on divorce law.

366 Note from Gürtner (9 April 1938), published in W. Schubert, Das Familien- und Erbrecht unter dem Nationalsozialismus, 252.

367 H. Hofmeister, 'Privatrechtsgesetgebung für Österreich unter der Herrschaft des Nationalsozialismus', 132.

368 Letter to all resorts involved concerning and including a draft proposal concerning the rules of conclusion of marriage (10 May 1938), published in W. Schubert, Das Familien- und Erbrecht unter dem Nationalsozialismus, 252-273. See also L. Gruchmann, ‘Das Ehegesetz vom 6. Juli 1938. Entstehung und Beurteilung', 69.

369 L. Gruchmann, 'Das Ehegesetz vom 6. Juli 1938. Entstehung und Beurteilung', 69-70.

370 Letter for the Minister of the Interior to the Minister of Justice (27 May 1939), published in W. Schubert, Das Familien- und Erbrecht unter dem Nationalsozialismus, 279. See also L. Gruchmann, 'Das Ehegesetz vom 6. Juli 1938. Entstehung und Beurteilung', 70.

371 Report by Nordmann on resort meeting of 28 May 1938, published in W. Schubert, Das Familien- und Erbrecht unter dem Nationalsozialismus, 280-281. See also L. Gruchmann, ‘Das Ehegesetz vom 6. Juli 1938. Entstehung und Beurteilung’, 70-71 and H. Hofmeister, 'Privatrechtsgesetgebung für Österreich unter der Herrschaft des Nationalsozialismus', 133. 
Although he had full understanding for the objections of Frick and Heß about this being only a partial revision, he pointed out that a general revision of family law for Germany and Austria would take too long. Introducing existing German matrimonial law in Austria would not do, as especially German divorce law was not in line with the current tide and introducing only the new draft on divorce law in Austria would make no sense without revising the rules concerning the conclusion of marriage. By combining the two existing drafts, marital property law would remain untouched and eligible for reform in a general revision of family law at a later stage. An - as a result of the meeting of 28 May - slightly altered draft was attached as were some transitional provisions for Austria. ${ }^{372}$

Frick, however, did not throw in the towel immediately. When he was in Vienna on I June 1938, he asked the former Austrian Minister of Justice Franz Hueber, through his representative Hoche, whether Hueber could not come up with a draft himself introducing the obligatory civil marriage in Austria. Hueber, however, rejected this compromise arguing that it would take too long. In order to tackle all problems Austrian matrimonial law was suffering from, this law had to be quite extensive, which would involve a lot of work, while it was likely that it would be replaced by a German revision of family law within the forseeable future anyhow. ${ }^{373}$ Gürtner pointed out to Frick once more how very time-consuming his proposed way of dealing with the problems concerning matrimonial law was $^{374}$ and Frick finally gave in when he called Gürtner on Io June 1938 and gave his approval. As agreed with Frick, Gürtner sent a telegram to Heß the following day, pointing out that Frick had approved of the combining of the two drafts and requesting Heß to do the same. ${ }^{375} \mathrm{Heß}$ agreed on I4 June $1938 .{ }^{376}$

The following day Hitler requested Gürtner to inform him about the combined drafts. ${ }^{377}$ He approved of the combined drafts the same evening, agreeing with infertility as ground for divorce, although he rejected facilitation of divorce in case of childlessnes. With regard to adultery as impediment to marriage, he wished for dispensation unless there were weighty reasons not to allow a marriage between the two persons who had committed adultery together. ${ }^{378}$

On 29 June 1938 the Gesetz zur Vereinheitlichung des Rechts der Eheschließung und der Ehescheidung im Lande Österreich und im übrigen Reichsgebiet was passed. ${ }^{379}$ It was

372 Letter from the Minister of Justice to the resorts involved (31 May 1938), published in W. Schubert, Das Familien- und Erbrecht unter dem Nationalsozialismus, 281-283. See also L. Gruchmann, 'Das Ehegesetz vom 6. Juli 1938. Entstehung und Beurteilung', 71-72.

373 Letter from the Austrian Minister of Justice Hueber to the Minister of Justice (2 June 1938), published in W. Schubert, Das Familien- und Erbrecht unter dem Nationalsozialismus, 283-285. See also L. Gruchmann, 'Das Ehegesetz vom 6. Juli 1938. Entstehung und Beurteilung', 72-73 and H. Hofmeister, 'Privatrechtsgesetgebung für Österreich unter der Herrschaft des Nationalsozialismus', 133

374 L. Gruchmann, 'Das Ehegesetz vom 6. Juli 1938. Entstehung und Beurteilung', 73.

375 Note from Gürtner (11 June 1938), published in W. Schubert, Das Familien- und Erbrecht unter dem Nationalsozialismus, 285. See also L. Gruchmann, 'Das Ehegesetz vom 6. Juli 1938. Entstehung und Beurteilung', 73.

376 L. Gruchmann, 'Das Ehegesetz vom 6. Juli 1938. Entstehung und Beurteilung', 73.

377 Ibid.

378 Note from Minister of Justice Gürtner concerning a meeting with Hitler (15 June 1938), published in W. Schubert, Das Familien- und Erbrecht unter dem Nationalsozialismus, 286. See also L. Gruchmann, 'Das Ehegesetz vom 6. Juli 1938. Entstehung und Beurteilung', 73-74 and H. Hofmeister, 'Privatrechtsgesetgebung für Österreich unter der Herrschaft des Nationalsozialismus', 133-134.

379 D. Blasius, Ehescheidung in Deutschland 1794-1945, 205. 
enacted on 6 July I938, published in the Reichsgesetzblatt on 8 July I938 and came into force on I August i938. ${ }^{380}$

\section{- 3.7.3. The Marriage Law of 1938}

The Gesetz zur Vereinheitlichung des Rechts der Eheschließung und der Ehescheidung im Lande Österreich und im übrigen Reichsgebiet vom 6. Juli I938 (hereafter Marriage Law) abolished title 2 (Eingehung der Ehe), title 3 (Nichtigkeit und Anfechtbarkeit der Ehe), title 4 (Wiederverheiratung im Falle der Todeserklärung) and title 7 (Scheidung der Ehe) from Book 4, chapter I of the German Bürgerliches Gesetzbuch. ${ }^{381}$ With regard to Austria Gürtner had confined himself to a general provision, which stated that all Austrian regulations which were not in accordance with the Marriage Law would lose their legal effect the moment the Marriage Law would come into force. ${ }^{382}$

The explanatory memorandum of the Marriage Law stated that this law was meant as a first step towards a uniform matrimonial and family law in the newly established German Reich. Apart from this it meant to solve the problems regarding the fragmented and cluttered Austrian matrimonial rules, caused by inflexible dogmatic ecclesiastical convictions. Apart from the personal distresses these convictions had lead to, it was also no longer compatible with the National Socialist ideas of marriage to let the question whether a marriage was valuable to the Volksgemeinschaft be dependent on adherence to a certain denomination. ${ }^{383}$

As we have seen before, earlier legislative attempts to nazify German matrimonial law had lead to the Blutschutzgesetz and the Ehegesundheitsgesetz. These remained fully applicable and references to both laws were included in the Marriage Law. ${ }^{384}$ By furthermore replacing extensive parts of the Civil Code with these new provisions, the big step to a fully nazified family law was taken. Despite the reserve showed by the Ministry of the Interior, Gürtner had never intended the Marriage Law to be a transitional arrangement. This Marriage Law was supposed to be and remain the fundamental Marriage Law of the Third Reich. As Gruchmann points out, it even remained to be so albeit in a denazified form - long after the Third Reich had collapsed. ${ }^{385}$

380 Gesetz zur Vereinheitlichung des Rechts der Eheschließung und der Ehescheidung im Lande Österreich und im übrigen Reichsgebiet vom 6. Juli 1938, Reichsgesetzblatt (1938), I, 807.

381 See $\S 84$ of the Gesetz zur Vereinheitlichung des Rechts der Eheschließung und der Ehescheidung im Lande Österreich und im übrigen Reichsgebiet vom 6. Juli 1938, Reichsgesetzblatt (1938), I, 807. See also D. Blasius, Ehescheidung in Deutschland 1794-1945, 206.

382 Gesetz zur Vereinheitlichung des Rechts der Eheschließung und der Ehescheidung im Lande Österreich und im übrigen Reichsgebiet vom 6. Juli 1938, Reichsgesetzblatt (1938), I, 807, § 128: 'Vorschriften des österreichischen Rechts, die Gegenstände betreffen, die in diesem Gesetz geregelt sind, verlieren mit dem Inkrafttreten dieses Gesetzes ihre Wirksamkeit.'

383 Begründung zu dem Gesetz zur Vereinheitlichung des Rechts der Eheschließung und der Ehescheidung im Lande Österreich und im übrigen Reichsgebiet vom 6. Juli 1938, originally published in Deutsche Reichsanzeiger, no. 157, 9 July 1938 and in Deutsche Justiz (1938), 1102. Furthermore published in F. U. Knost and F. Maßfeller, Das neue Personenstands- und Familienrecht nebst den Staatsangehörigkeitsvorschriften für die neuen deutsche Gebiete, 175 and W. Schubert, Das Familienund Erbrecht unter dem Nationalsozialismus, 143.

384 Begründung zu dem Gesetz zur Vereinheitlichung des Rechts der Eheschließung und der Ehescheidung im Lande Österreich und im übrigen Reichsgebiet vom 6. Juli 1938, published in W. Schubert, Das Familien- und Erbrecht unter dem Nationalsozialismus, 143, 144.

385 L. Gruchmann, 'Das Ehegesetz vom 6. Juli 1938. Entstehung und Beurteilung', 74. In Germany the Marriage Law of 1938 was abolished in May 1998. See Gesetz zur Neuordnung des Eheschließungsrecht vom 4. Mai 1998, Bundesgesetzblatt (1998), I, 833. 
The Marriage Law consisted of five chapters of which chapter I, dealing with rules concerning the conclusion, annulment and termination of marriage, chapter 2, on divorce and chapter 4, containing exceptional and transitional provisions for Austria were the most significant ones. Chapter 3 contained some general transitional provisions whilst chapter 5 concluded the law with three final provisions.

\subsubsection{Conclusion of marriage}

The first chapter of the Marriage Law started with three provisions regarding marital eligibility. Already the first provision announced a significant change compared to $\mathbb{\text { I3O3 }}$ BGB. Sub I of $\mathbb{S}$ I required men to have reached the age of 2I years, women should be at least 16 years old; this was almost literally taken over from $\mathbb{\$}$ I303 BGB. Sub 2, however, stated that in case a man between de age of 18 and 2I wanted to get married, a proof of marriageability was required in addition to a declaration of majority. Paragraph 1303 BGB only requested a declaration of majority. Women younger than I 6 who wanted to get married needed this proof of marriageability as well, in addition to permission of the legal guardian (usually the father) and the person with caring responsibility (usually the mother). The reason for this requirement was that between the age of I8 and $2 \mathrm{I}$ men had some special services to fulfil towards the Volksgemeinschaft, in the form of compulsory military service at the Wehrmacht and labour service (Arbeitsdienst). In case fulfilment of these duties would be hindered by an early marriage, that marriage had to be prevented. Furthermore it had to be certain that this young man was able to support a family and was mentally and morally mature. ${ }^{386}$ The Volksgemeinschaft was always the first matter of importance. However, although previously discussed ${ }^{387}$ fulfilment of military service and labour service by the male partner and proof of a certain domestice knowledge by the female partner was not included as a requirement for marital eligibility due to the indefinable interpretation of such a provision and the disadvantages for the Volksgemeinschaft subsequently caused by this indefinability. ${ }^{388}$ Paragraph 2 of the First Supplementary Decree to the Marriage Law nevertheless stated that a declaration of marriageability would be refused in case a man had not yet fulfilled his military service or labour service. ${ }^{389} \mathrm{~A}$ maximum age to contract a marriage had been considered but had failed as well. The focus point in this consideration was preventing elderly people, by whom infertility was a real possibility, to marry a much younger - and still fertile - partner. However, this age limit was considered indefinable as well, as a definite fertility limit could not be determined. Furthermore, Gürtner would not convey the impression that according to the National Socialist legislator the sole purpose of marriage was begetting

386 Begründung zu dem Gesetz zur Vereinheitlichung des Rechts der Eheschließung und der Ehescheidung im Lande Österreich und im übrigen Reichsgebiet vom 6. Juli 1938, published in W. Schubert, Das Familien- und Erbrecht unter dem Nationalsozialismus, 143, 144; R. Bechert and J. Wiesels, Das neue Eherecht für Großdeutschland, 11-12; L. Gruchmann, 'Das Ehegesetz vom 6. Juli 1938. Entstehung und Beurteilung', 74.

387 Eplanatory remarks to the draft proposal considering the rules of conclusion of marriage, sent to the resorts involved on 10 May 1938, published in W. Schubert, Das Familien- und Erbrecht unter dem Nationalsozialismus, 260-273, 260-261.

388 L. Gruchmann, 'Das Ehegesetz vom 6. Juli 1938. Entstehung und Beurteilung', 74.

389 Erste Verordnung zur Durchführung und Ergänzung des Ehegesetzes vom 27. Juli 1938, Reichsgesetzblatt (1938), I, 923. See also A. Scharnagl, Das neue deutsche Ehegesetz, 22. 
and bearing children and not also the community of spouses, confirmed by marriage. ${ }^{390}$

Another novelty was that in case a minor wanted to get married permission was needed not only from the legal guardian, which was usually the father, but also from the person who had the caring responsibility, ${ }^{391}$ which was usually the mother. ${ }^{392}$ This can be regarded as a first cautious step towards the emancipation of women within the marriage. $^{393}$

Section B of the first chapter dealt with the impediments to marriage, now called marriage prohibitions. According to the explanatory memorandum the basis for these marriage prohibitions was found in the völkish order (völkische Ordnung). This was apparent from both $\mathbb{S} \mathbb{S} 4$ and 5 , which referred to regulations concerning marriage that had already been realised by the new order. It was decided not to include all marriage prohibitions listed in the Blood Protection Law, the Marriage Health Law and its supplementary decrees one by one, as this would lead to a fragmentation of the two basic National Socialist laws. Instead $\mathbb{S} \mathbb{S} 4$ and 5 contained a reference to both laws integrally. ${ }^{394}$

Paragraph 4, titled 'blood differences' (Blutverschiedenheit), invoked the Blood Protection Law and its supplementary decrees to prohibit marriages between persons of German or kindred blood and persons of heterologous blood, including Jews. ${ }^{395}$ In order to define a Jew or a Jewish half-breed, the Reich Citizenship Law and its First Supplementary Decree were used. ${ }^{396}$

Paragraph 5 dealt with 'defect of marital competence' (Mangel der Ehetauglichkeit) as marriage prohibition, invoking the Marriage Health Law and its supplementary decrees, prohibiting a marriage in case one of the partners was suffering from a hereditary (as defined by the Gesetz zur Verhütung erbkranken Nachwuchses from I933) or contagious disease or a mental disturbance. ${ }^{397}$

390 Eplanatory remarks to the draft proposal considering the rules of conclusion of marriage, sent to the resorts involved on 10 May 1938, published in W. Schubert, Das Familien- und Erbrecht unter dem Nationalsozialismus, 260-273, 260, 261-262. See also L. Gruchmann, 'Das Ehegesetz vom 6. Juli 1938. Entstehung und Beurteilung', 74-75.

391 See $\S 3$ of the Gesetz zur Vereinheitlichung des Rechts der Eheschließung und der Ehescheidung im Lande Österreich und im übrigen Reichsgebiet vom 6. Juli 1938, Reichsgesetzblatt (1938), I, 807.

392 See § 1634 BGB. See also Begründung zu dem Gesetz zur Vereinheitlichung des Rechts der Eheschließung und der Ehescheidung im Lande Österreich und im übrigen Reichsgebiet vom 6. Juli 1938, published in W. Schubert, Das Familien- und Erbrecht unter dem Nationalsozialismus, 143, 144-145; R. Bechert and J. Wiesels, Das neue Eherecht für Großdeutschland, 13; A. Scharnagl, Das neue deutsche Ehegesetz, 25.

393 L. Gruchmann, 'Das Ehegesetz vom 6. Juli 1938. Entstehung und Beurteilung', 75.

394 Begründung zu dem Gesetz zur Vereinheitlichung des Rechts der Eheschließung und der Ehescheidung im Lande Österreich und im übrigen Reichsgebiet vom 6. Juli 1938, published in W. Schubert, Das Familien- und Erbrecht unter dem Nationalsozialismus, 143, 146.

395 Gesetz zur Vereinheitlichung des Rechts der Eheschließung und der Ehescheidung im Lande Österreich und im übrigen Reichsgebiet vom 6. Juli 1938, Reichsgesetzblatt (1938), I, 807, § 4: 'Das Verbot von Eheschließungen zwischen Staatangehörigen deutschen oder artverwandten Blutes und Personen artfremden Boutes und die Wirkungen dieses Verbots bestimmen sich ausschließlich nach dem Gesetz zum Schutze des deutschen Blutes und der deutschen Ehre vom 15. September 1935 (Reichsgesetzbl. I S. 1146) und den zu diesem Gesetz ergangenen Durchführungsverordnungen.'

396 R. Bechert and J. Wiesels, Das neue Eherecht für Großdeutschland, 14; A. Scharnagl, Das neue deutsche Ehegesetz, 29-30.

397 Gesetz zur Vereinheitlichung des Rechts der Eheschließung und der Ehescheidung im Lande Österreich und im übrigen Reichsgebiet vom 6. Juli 1938, Reichsgesetzblatt (1938), I, 807, § 5: ‘Das Verbot von Eheschließungen, die aus Gründen der Volksgesundheit unerwünscht sind, und die Wirkungen dieses Verbots bestimmen sich ausschließlich nach dem Gesetz zum Schutze der Erbgesundheit des deutschen Volkes (Ehegesundheitsgesetz) vom 18. Oktober 1935 (Reichsgesetzbl. I S. 1146) und den zu diesem Gesetz ergangenen Durchführungsverordnungen.' 
The following marriage prohibitions were, apart from some textual changes, largely copied from $\mathbb{S}$ I309-I3I5 of the BGB.

Paragraph I3IO BGB was split into two separate articles. Paragraph 6 dealt with the prohibition concerning consanguinity (Verwandtschaft), ${ }^{398}$ whilst $\mathbb{7} 7$ dealt with the prohibition concerning relation by marriage (Schwägerschaft). The provision of $\mathbb{S}$ I3IO (2) BGB, which prohibited marriages between persons of which one had had intercourse with the parents, ancestors or descendants of the other partner, was dropped as such a case rarely happened. ${ }^{399}$ Paragraph 7 (3) furthermore declared that in case of relation by marriage dispensation could be granted, a possibility which did not exist under the old $\$$ I3IO BGB.

Paragraph 1309 BGB, which dealt with the prohibition of bigamy (Doppelehe), was in highly depleted form taken over in $\$ 8$. This new article only stated that no one could enter into a new marriage before his or her previous marriage had been annuled or dissolved. The second provision of $\mathbb{S}$ I309 BGB, which stated that in case two partners wanted to redo the conclusion of marriage an annulment of the first marriage was not required, was not taken over in $\mathbb{8}$, but would be included in one of the supplementary decrees. ${ }^{400}$ Paragraph I3 of the First Supplementary Decree to the Marriage Law did indeed declare that, notwithstanding $\mathbb{S} 8$ of the Marriage Law, repetition of the conclusion of marriage was allowed, in case the partners doubted the validity of their marriage. ${ }^{401}$

Adultery (Ehebruch) as marriage prohibition had lead to objections during the drafting period ${ }^{402}$ but ended up in the Marriage Law as well. In case of adultery, the old $\mathbb{~ I 3 1 2}$ BGB provided a prohibition to marry the person the adultery was committed with, if adultery was indeed given as ground for the divorce. As stated in sub 2, dispensation could be granted. The new $\mathbb{S} 9$ of the Marriage Law stuck to this rule but provided, at Hitler's request, a directive interpretion of the dispensation clause. ${ }^{403}$ Marriage between the adulterer and the person the adultery was committed with should only be prohibited in case there were weigthy reasons not to allow a marriage between the two persons who had committed adultery together, such as the new marriage being a serious disadvantage for the Volksgemeinschaft, e.g. due to the new partner suffering from a hereditary disease or because of too big an age difference between the two partners. The mere fact that adultery had been committed was not enough to prevent the adulterer to get married

398 See footnote 19 of chapter 3.

399 Begründung zu dem Gesetz zur Vereinheitlichung des Rechts der Eheschließung und der Ehescheidung im Lande Österreich und im übrigen Reichsgebiet vom 6. Juli 1938, published in W. Schubert, Das Familien- und Erbrecht unter dem Nationalsozialismus, 143, 146.

400 Begründung zu dem Gesetz zur Vereinheitlichung des Rechts der Eheschließung und der Ehescheidung im Lande Österreich und im übrigen Reichsgebiet vom 6. Juli 1938, published in W. Schubert, Das Familien- und Erbrecht unter dem Nationalsozialismus, 143, 146.

401 Erste Verordnung zur Durchführung und Ergänzung des Ehegesetzes vom 27. Juli 1938, Reichsgesetzblatt (1938), I, 923, $\S 13$ : 'Das Verbot der Doppelehe ( $\$ 8$ des Ehegesetzes) steht einer Wiederholung der Eheschließung nicht entgegen, wenn die Ehegatten Zweifel an der Gültigkeit oder an dem Fortbestand ihrer Ehe hegen.'

402 Report by Nordmann on resort meeting of 28 May 1938, published in W. Schubert, Das Familien- und Erbrecht unter dem Nationalsozialismus, 280-281.

403 Begründung zu dem Gesetz zur Vereinheitlichung des Rechts der Eheschließung und der Ehescheidung im Lande Österreich und im übrigen Reichsgebiet vom 6. Juli 1938, published in W. Schubert, Das Familien- und Erbrecht unter dem Nationalsozialismus, 143, 147; Note from Minister of Justice Gürtner concerning a meeting with Hitler (15 June 1938), published in W. Schubert, Das Familien- und Erbrecht unter dem Nationalsozialismus, 286. See also L. Gruchmann, 'Das Ehegesetz vom 6. Juli 1938. Entstehung und Beurteilung', 75. 
again. In this new marriage new healthy children could be born as well, which would be beneficial to the Volksgemeinschaft. ${ }^{404}$

Paragraph Io, which prohibited marriages between adoptive parents and adopted children (Annahme an Kindes Statt), $\mathbb{\text { I I }}$, which prohibited a woman to remarry within ten months after her previous marriage had been annuled or dissolved (Wartezeit) and $\mathbb{S}$ I2, which prohibited marriages in case no partition of community property between the adult and a minor child or person placed under his guardianship had taken place (Auseinandersetzungszeugnis des Vormundschaftsrichters), were all - apart from some textual changes - copied from $\mathbb{S} \mathbb{S}$ I3II, I3I3 and I3I4 BGB.

Paragraph I3I5 BGB finally, was split and divided over $\mathbb{S}$ I3 and $\mathbb{S}$ I4 of the Marriage Law. Paragraph I3 (Heiratserlaubnis) stated that servicemen, as well as those working for the Reich Labour Service and other civil servants who required a special permission before they were allowed to marry, could not marry without this permission. This article

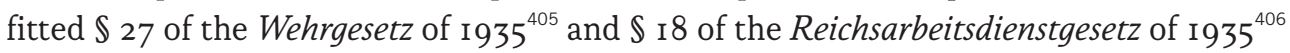
and was an extension of $\mathbb{S}$ I3I5 (I) BGB, which had not included those working for the Reich Labour Service. Paragraph I4 of the First Supplementary Decree to the Marriage Law declared that $\mathbb{S}$ I 3 of the Marriage Law applied to members of the SS as well. ${ }^{407}$

Paragraph I4 (Ehefähigkeitszeugnis für Ausländer), which stated that foreigners needed a declaration proving that according to the laws of their homeland there existed no impediments to the marriage, was a more stringent version of $\mathbb{S}$ I3I5 (2) BGB, which was formulated in a more permissive way.

\subsubsection{Annulment and termination of marriage}

Not all marriage prohibitions lead to annulment of marriage in case of infringement. A distinction has to be made between separating prohibitions (trennende Eheverbote), which lead to annulment in case of infringement and suspensive prohibitions (aufschiebende Eheverbote), which did not affect a marriage which was concluded despite the prohibition.

According to Gruchmann the marriage prohibitions in $\mathbb{S} \mathbb{S} 4$ and 5 were separating impediments, ${ }^{408}$ leading to nullity, but that is jumping to conclusions. Paragraph 20 of the Marriage Law stated that, with regard to $\mathbb{S} \mathbb{S} 4$ and 5 , a marriage was only void (nichtig) in case it was determined to be either by the Blood Protection Law or the Marriage Health Law. This implied that marriages between Jews and persons of German or kindred blood or quarter-Jews, which were concluded in defiance of $\mathbb{S}$ I of the Blood Protection Law, were void, whilst marriages between half-Jews and quarter-Jews or persons of German

404 Begründung zu dem Gesetz zur Vereinheitlichung des Rechts der Eheschließung und der Ehescheidung im Lande Österreich und im übrigen Reichsgebiet vom 6. Juli 1938, published in W. Schubert, Das Familien- und Erbrecht unter dem Nationalsozialismus, 143, 147; R. Bechert and J. Wiesels, Das neue Eherecht für Großdeutschland, 19. See also L. Gruchmann, 'Das Ehegesetz vom 6. Juli 1938. Entstehung und Beurteilung', 75.

405 Wehrgesetz vom 21. Mai 1935, Reichsgesetzblatt (1935), I, 609, § 27: 'Die Angehörigen der Wehrmacht bedürfen zur Heirat der Erlaubnis ihrer Vorgesetzten.'

406 Reichsarbeitsdienstgesetz vom 26. Juni 1935, Reichsgesetzblatt (1935), I, 769, § 18: 'Die Angehörigen des Reichsarbeitsdienstes bedürfen zur Verheiratung der Genehmigung.'

407 Erste Verordnung zur Durchführung und Ergänzung des Ehegesetzes vom 27. Juli 1938, Reichsgesetzblatt (1938), I, 923, § 14: 'Die Vorschriften des $\S 13$ des Ehegesetzes über die Heiratserlaubnis gelten entsprechend für Angehörige der SS, die nach den Anordnungen des Reichsführers SS zur Eingehung einer Ehe einer besonderen Erlaubnis bedürfen.' See also L. Gruchmann, 'Das Ehegesetz vom 6. Juli 1938. Entstehung und Beurteilung', 76.

408 L. Gruchmann, ‘Das Ehegesetz vom 6. Juli 1938. Entstehung und Beurteilung', 75-76. 
or kindred blood or between quarter-Jews amonst each other were valid despite the prohibitions laid down in $\mathbb{S} \mathbb{S} 3$ (I) and 4 of the First Supplementary Decree to the Blood Protection Law. The same was true for the prohibition laid down in $\mathbb{S} 6$ of the First Supplementary Decree to the Blood Protection Law, which stated that all marriages, in which case offspring which would in any way be harmful to the purity of the German blood was to be expected, were prohibited. ${ }^{409}$

The same principle applied to $\mathbb{S}$, implying that marriages concluded in defiance of the Marriage Health Law were only void in case a marriage certificate or cooperation of a registrar had been obtained on the basis of false information consciously provided by the couple or in case the marriage had been consciously constituted abroad in order to avoid the marriage prohibition. ${ }^{410}$ In all other cases a marriage concluded in defiance of the Marriage Health Law was valid, albeit undesirable. As Bechert and Wiesels point out, such marriages could often be terminated pursuant to other provisions, e.g. a defect in the consent of the legal guardian. ${ }^{411}$

Other grounds for annulment were listed in $\mathbb{\$} \mathbb{S}$ I-26 of the Marriage Law, which were largely copied from $\mathbb{S} \mathbb{S}$ I324-I328 BGB.

Paragraph 2I (I) stated that marriages concluded without taking into account the requirements regarding the marriage ceremony as listed in $\mathbb{S}$ I 7 were void. Sub 2 however added that notwithstanding the non-compliance with $\$$ I7, a marriage had to be considered valid when the partners had lived together as spouses for five consecutive years ( $\mathbb{S}$ I324 (2) BGB had required ten consecutive years) or, in case one of the partners had died already, at least for three consecutive years until the death of one of the spouses. This deviated from $\mathbb{S}$ I324 (2) BGB, which had listed as additional requirement that the marriage was registered in the marriage register. ${ }^{412}$ In this respect $\mathbb{S} \mathbb{S} 2 \mathrm{I}(2)$ and I7 should be seen in connection with $\mathbb{I}_{5}$ ( I), which stated that a marriage would only be realised when it was concluded in the presence of a registrar. ${ }^{413}$ This was a novelty as this requirement had not been stated that abundantly clear in the BGB. Furthermore, it follows from $\mathbb{S}$ I5 (I) as well that registration in the marriage register was no longer a constituent requirement. Therefore, in case a marriage was not concluded before a registrar, it did not exist at all, a so-called Nichtehe. ${ }^{414}$ There was no longer a need to declare a Nichtehe void, as had been done in $\mathbb{S}$ I324 BGB. On the other hand, compliance with $\mathbb{S}$ I5 (I) implied that the marriage at least contained the roots of validity. Even when the rules of $\mathbb{S}$ I had not been taken into account, rendering the marriage void according to $\ 2$ I, no one could appeal to

409 R. Bechert and J. Wiesels, Das neue Eherecht für Großdeutschland, 15-16.

410 See $\S 3$ (1) of the Gesetz zum Schutze der Erbgesundheit des deutschen Volkes vom 18. Oktober 1935, Reichsgesetzblatt (1935), I, 1246.

411 R. Bechert and J. Wiesels, Das neue Eherecht für Großdeutschland, 17.

412 See also L. Gruchmann, 'Das Ehegesetz vom 6. Juli 1938. Entstehung und Beurteilung', 76.

413 Begründung zu dem Gesetz zur Vereinheitlichung des Rechts der Eheschließung und der Ehescheidung im Lande Österreich und im übrigen Reichsgebiet vom 6. Juli 1938, published in W. Schubert, Das Familien- und Erbrecht unter dem Nationalsozialismus, 143, 147-149.

414 A. Scharnagl, Das neue deutsche Ehegesetz, 48-50; R. Bechert and J. Wiesels, Das neue Eherecht für Großdeutschland, 21. 
this nullity as long as the marriage had not been annulled by the court $(\mathbb{2} 27)$. $^{415}$

Paragraph 22, which stated that a marriage was void in case one of the partners was not of full legal capacity, unconscious or in a state of mental disturbance at the time the marriage was concluded, was, apart from some minor textual changes, taken over from $\$$ I325 BGB.

Paragraph I325a BGB, adopted in 1933 by Article I ( I) of the Gesetz gegen Mißbräuche bei der Eheschließung und der Annahme an Kindes Statt, ${ }^{416}$ which declared a marriage concluded in order to allow the woman to go by her husbands name void, was expanded by $\mathbb{2} 3$ to cases in which a marriage was concluded only to enable the woman to obtain her husbands nationality. ${ }^{417}$ According to the explanatory memorandum this expansion was added at the request of the Austrian authorities as apparently many 'unwelcome' foreign women contracted such a marriage of convenience as obtaining the Austrian nationality would enable them to find a job in Vienna. As $\mathbb{S}$ I325a BGB did not explicitly list this as a marriage prohibition, an addition was necessary. ${ }^{418}$ However, according to sub 2 the marriage was considered valid when the partners had lived together as spouses for five consecutive years or, in case one of the partners had died already, at least for three consecutive years until the death of one of the spouses. Scharnagl explained in this respect that according to canon law marriages which were, by one or both spouses, concluded as a marriage of convenience were invalid until the intention was renewed, irrespective of the years passed. This had to be done publicly in case the fact that the marriage was a marriage of convenience was known. ${ }^{419}$

Paragraph 24, an almost verbatim copy of $\mathbb{S}$ I 326 BGB, followed from $\mathbb{\$} 8$, listing bigamy as marriage prohibition. Here again, the difference between a separating prohibition and a suspensive prohibition had to be made. In case the first marriage had been valid, the second marriage, concluded despite the prohibition, was void. However, in case the first marriage had been void, for whatever reason, and was annulled, the second marriage was valid. $^{420}$

Paragraph 25 ( I) declared a marriage concluded, in defiance of $\mathbb{S} \$ 6$ and 7 , between blood relatives or in-laws void, as $\mathbb{S} \$ 6$ and 7 contained separating prohibitions. Sub 2, however, declared a marriage between in-laws valid in retrospect in case dispensation had been granted. ${ }^{421}$ Please note in this respect that the marriage prohibition of $\mathbb{S}$ Io was a suspensive prohibition as $\mathbb{S}$ I77I BGB lifted the legal relation of adoption the moment the marriage between the adoptive parent and the adopted child was concluded. ${ }^{422}$

415 Begründung zu dem Gesetz zur Vereinheitlichung des Rechts der Eheschließung und der Ehescheidung im Lande Österreich und im übrigen Reichsgebiet vom 6. Juli 1938, published in W. Schubert, Das Familien- und Erbrecht unter dem Nationalsozialismus, 143, 147-149.

416 Gesetz gegen Mißbräuche bei der Eheschließung und der Annahme an Kindes Statt vom 23. November 1933, Reichsgesetzblatt (1933), I, 979.

417 Begründung zu dem Gesetz zur Vereinheitlichung des Rechts der Eheschließung und der Ehescheidung im Lande Österreich und im übrigen Reichsgebiet vom 6. Juli 1938, published in W. Schubert, Das Familien- und Erbrecht unter dem Nationalsozialismus, 143, 149.

418 Begründung zu dem Gesetz zur Vereinheitlichung des Rechts der Eheschließung und der Ehescheidung im Lande Österreich und im übrigen Reichsgebiet vom 6. Juli 1938, published in W. Schubert, Das Familien- und Erbrecht unter dem Nationalsozialismus, 143, 149. See also L. Gruchmann, 'Das Ehegesetz vom 6. Juli 1938. Entstehung und Beurteilung', 76.

419 A. Scharnagl, Das neue deutsche Ehegesetz, 73-74.

420 R. Bechert and J. Wiesels, Das neue Eherecht für Großdeutschland, 19.

421 R. Bechert and J. Wiesels, Das neue Eherecht für Großdeutschland, 18, 28.

422 Ibid., 18. See also section 3.2.1. 
The marriage prohibition of $\mathbb{9}$ (adultery) finally was a separating prohibition ${ }^{423}$ rendering all marriages concluded in defiance of $\mathbb{9} 9$ void $(\mathbb{S} 26(\mathrm{I}))$, except when dispensation had been granted $(\$ 26(2))$.

The remaining marriage prohibitions ( $\$ \mathbb{S}$ IO-I4) were all suspensive prohibitions, not leading to annulment. ${ }^{424}$

Nullity was not an absolute concept, but a relative one. Only when the grounds for nullity were invoked and the marriage was annulled by the court, one could appeal to this nullity. The nichtige Ehe was not truly void, but avoidable (vernichtbar). ${ }^{425}$ This was determined in $\mathbb{S} 27$, which contained a more stringent rule than the old $\mathbb{S}$ I329 BGB. According to $\mathbb{S}$ I329 BGB in order to enable an appeal to nullity of the marriage, an annulment by the court was required in case the marriage still existed. When the marriage had been dissolved because of divorce or death of one of the spouses, this annulment by the court was no longer necessary. In that case anyone could appeal to the nullity of the marriage on the grounds of $\mathbb{S} \mathbb{1}$ I325-I328 BGB or based on $\mathbb{I}$ I324 BGB in case the marriage had been registered in the marriage register. As a consequence a dissolved marriage, as long as it had not been annulled by the court before it was dissolved, could be considered void in one case and valid in another, depending on the stage the court case was in or the evidence available. This principle had already been abandoned in 1935 by $\$ 8$ (I) of the First Supplementary Decree to the Blood Protection Law and $\mathbb{} 28$ of the First Supplementary Decree to the Marriage Health Law and was now taken over in the Marriage Law as it was no longer tenable according to the National Socialist view on the essence of marriage. Grounds for nullity were first and foremost intended to serve the völkish interests. ${ }^{426}$

Annulment had retroactive effect (ex tunc) and all consequences of the marriage were therefore undone. An exception was made in $\mathbb{3}$ o for children born in a marriage which

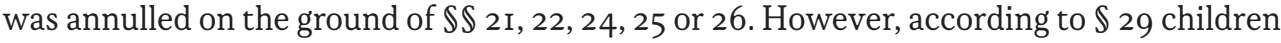
born in a marriage which was annulled on the basis of the Blood Protection Law, the Marriage Health Law or $\ 23$ of the Marriage Law were considered illegitimate. ${ }^{427}$

The provisions of section E, termination of marriage (Aufhebung der Ehe) did not have this ex tunc effect, but were effective from the day the marriage was terminated (ex nunc). ${ }^{428}$ The concept of termination replaced the original concept of disputability of the marriage (Anfechtbarkeit der Ehe), which, albeit indirectly, had had retroactive effect. This change

423 Ibid., 19.

424 Ibid., 18-21.

425 R. Bechert and J. Wiesels, Das neue Eherecht für Großdeutschland, 28-29.

426 Begründung zu dem Gesetz zur Vereinheitlichung des Rechts der Eheschließung und der Ehescheidung im Lande Österreich und im übrigen Reichsgebiet vom 6. Juli 1938, published in W. Schubert, Das Familien- und Erbrecht unter dem Nationalsozialismus, 143, 149. See also L. Gruchmann, 'Das Ehegesetz vom 6. Juli 1938. Entstehung und Beurteilung', 76.

427 Begründung zu dem Gesetz zur Vereinheitlichung des Rechts der Eheschließung und der Ehescheidung im Lande Österreich und im übrigen Reichsgebiet vom 6. Juli 1938, published in W. Schubert, Das Familien- und Erbrecht unter dem Nationalsozialismus, 143, 150-151; A. Scharnagl, Das neue deutsche Ehegesetz, 79-82. See also L. Gruchmann, 'Das Ehegesetz vom 6. Juli 1938. Entstehung und Beurteilung', 77.

428 Gesetz zur Vereinheitlichung des Rechts der Eheschließung und der Ehescheidung im Lande Österreich und im übrigen Reichsgebiet vom 6. Juli 1938, Reichsgesetzblatt (1938), I, 807, § 34: 'Die Ehe wird durch gerichtliches Urteil afgehoben. Sie ist mit der Rechtskraft der Urteils aufgelöst.' 
was inspired by the National Socialist view on and the esteem of the concept of marriage. As Gürtner puts it in his explanatory memorandum, it did not fit in the National Socialist approach to marriage and appreciation thereof to allow partners to dissolve a marriage with retroactive effect on the grounds of reduced legal capacity or absence of consensus ad idem, especially not since that was the effect given to marriages which were concluded despite separating marriage prohibitions, which were inspired by a direct concern of the well-being of the Volksgemeinschaft. Therefore, reduced legal capacity or absence of consensus ad idem could allow the other partner to refuse to continue the marriage but should not enable him to challenge the existence of the marriage bond as such. ${ }^{429}$ According to both Ramm and Gruchmann, this change most clearly expressed the idea of National Socialist matrimonial law as the marital community was 'detached from the individuals and made independent', giving the community priority over the individual. ${ }^{430}$ However, although the effects were the same, as stated in $\mathbb{\$} 42(\mathrm{I}),{ }^{431}$ termination should not be considered the same concept as divorce. In that respect, a distinction had to be made between grounds for dissolution which already existed at the time of conclusion and grounds which arose during the marriage. ${ }^{432}$

Despite the different effect, the grounds for termination were largely based on the grounds for disputability, allowing for termination on the grounds of absence of consent of the legal guardian $(\mathbb{3 5}$ ), error regarding the conclusion of marriage or the person of the other spouse $(\$ 36)$, deception $(\mathbb{3} 8)$ and threat $(\mathbb{3 9}$ ).

The only provision that differed substantially from its BGB counterpart was $\mathbb{} 37$. Paragraph I333 BGB had allowed error concerning 'personal qualities' of the other spouse as a ground for disputability. This had lead to the discussion whether being Jewish qualified as personal quality or not. The new provision no longer used the phrase 'personal qualities', but spoke of 'circumstances concerning the person of the other spouse':

Ein Ehegatte kann Aufhebung der Ehe begehren, wenn er sich bei der Eheschließung über solche die Person des anderen Ehegatten betreffende Umstände geirrt hat, die ihn bei Kenntnis der Sachlage und bei richtiger Würdigung des Wesens der Ehe von der Eingehung der Ehe abgehalten hätten. ${ }^{433}$

429 Begründung zu dem Gesetz zur Vereinheitlichung des Rechts der Eheschließung und der Ehescheidung im Lande Österreich und im übrigen Reichsgebiet vom 6. Juli 1938, published in W. Schubert, Das Familien- und Erbrecht unter dem Nationalsozialismus, 143, 152.

430 T. Ramm, 'Eherecht und Nationalsozialismus', 151-166, 159; L. Gruchmann, 'Das Ehegesetz vom 6. Juli 1938. Entstehung und Beurteilung', 77.

431 Gesetz zur Vereinheitlichung des Rechts der Eheschließung und der Ehescheidung im Lande Österreich und im übrigen Reichsgebiet vom 6. Juli 1938, Reichsgesetzblatt (1938), I, 807, § 42 (1): 'Die Folgen der Aufhebung einer Ehe bestimmen sich nach den Vorschriften über die Folgen der Scheidung.'

432 Begründung zu dem Gesetz zur Vereinheitlichung des Rechts der Eheschließung und der Ehescheidung im Lande Österreich und im übrigen Reichsgebiet vom 6. Juli 1938, published in W. Schubert, Das Familien- und Erbrecht unter dem Nationalsozialismus, 143, 152.

433 Gesetz zur Vereinheitlichung des Rechts der Eheschließung und der Ehescheidung im Lande Österreich und im übrigen Reichsgebiet vom 6. Juli 1938, Reichsgesetzblatt (1938), I, 807, § 37 (1), 'A spouse can request termination of the marriage, in case at the time of its contraction he was unaware of circumstances concerning the person of the other spouse, which would have prevented him from entering into the marriage had he had knowledge of it and a proper understanding of the essence of marriage.' 
This broader description allowed for 'blood difference' to be considered such a circumstance, even when it would not cause a ground for annulment. Bechert and Wiesels give the example of an Aryan marrying a Mischling without knowing to. ${ }^{434}$ Other circumstances allowing for termination were impotence or sexual indifference, infertility of the woman, a severe illness, e.g. a hereditary disease or tuberculosis, a mental disturbance or syphilis, a serious defect in the other spouse's character, e.g. mendacity or dipsomania and prenuptial intercourse by the woman. ${ }^{435}$ Remarkably, Bechert and Wiesels still call this error 'Eigenschaftsirrtum'. ${ }^{436}$ Please also note the change from 'verständiger Würdigung des Wesens der Ehe' (sensible evaluation of the essence of marriage) into 'richtiger Würdigung des Wesens der Ehe' (correct evaluation of the essence of marriage), which limited the room for personal interpretation concerning the essence of marriage. There was only one true understanding of the essence of marriage, the National Socialist one. ${ }^{437}$ Another amendment concerned the exclusion of termination in case termination was morally not justified considering the state the marriage was in. ${ }^{438}$ This provision sought to protect marriages which had proved to be enduring and valuable. ${ }^{439}$

According to $\mathbb{S} 40$ the term wherein the other partner had to file for termination was extended from six months to one year, starting the moment the legal guardian became aware of the marriage, the spouse discovered the error or deception, or when the predicament ended. ${ }^{400}$ Paragraph 54 of the First Supplementary Decree stated that marriages, which were concluded before the Marriage Law had come into force, could be terminated within a year after the Marriage Law had come into force. ${ }^{441}$

This enabled courts to use $\mathbb{S} 37$ to dissolve mixed marriages on the ground of error concerning the meaning of racial distinction until I August 1939, which was more than six years after the National Socialists had come to power and the German people had become aware of the 'true notion of Jewry'. ${ }^{422}$ The assassination of Ernst vom Rath by Herschel Grynszpan in Paris on 7 November 1938 and the subsequent Reichskristallnacht and additional measures taken against the Jews in Germany ${ }^{443}$ provided another landmark

434 R. Bechert and J. Wiesels, Das neue Eherecht für Großdeutschland, 35

435 R. Bechert and J. Wiesels, Das neue Eherecht für Großdeutschland, 34-35; A. Scharnagl, Das neue deutsche Ehegesetz, 8789.

436 R. Bechert and J. Wiesels, Das neue Eherecht für Großdeutschland, 34-35.

437 B. Rüthers, Die unbegrenzte Auslegung, 405.

438 Gesetz zur Vereinheitlichung des Rechts der Eheschließung und der Ehescheidung im Lande Österreich und im übrigen Reichsgebiet vom 6. Juli 1938, Reichsgesetzblatt (1938), I, 807, § 37 (2).

439 Begründung zu dem Gesetz zur Vereinheitlichung des Rechts der Eheschließung und der Ehescheidung im Lande Österreich und im übrigen Reichsgebiet vom 6. Juli 1938, published in W. Schubert, Das Familien- und Erbrecht unter dem Nationalsozialismus, 143, 153; R. Bechert and J. Wiesels, Das neue Eherecht für Großdeutschland, 35; A. Scharnagl, Das neue deutsche Ehegesetz, 89-90; L. Gruchmann, 'Das Ehegesetz vom 6. Juli 1938. Entstehung und Beurteilung', 77.

440 Gesetz zur Vereinheitlichung des Rechts der Eheschließung und der Ehescheidung im Lande Österreich und im übrigen Reichsgebiet vom 6. Juli 1938, Reichsgesetzblatt (1938), I, 807, § 40.

441 Erste Verordnung zur Durchführung und Ergänzung des Ehegesetzes vom 27. Juli 1938, Reichsgesetzblatt (1938), I, 923 , § 54 (1): 'Die Aufhebung einer vor Inkrafttreten des Ehegesetzes geschlossenen Ehe kann auch aus den Gründen des Ehegesetzes begehrt werden, soweit nach den bisherigen Gesetzen ein Ungültigkeitsgrund, der gemäß § 118 Abs. 2 des Ehegesetzes die Aufhebung der Ehe begründen würde, nicht gegeben ist. Die Frist für die Klage auf Aufhebung endet in diesem Falle frühestens ein Jahr nach Inkrafttreten des Ehegesetzes.' See also Reichsgericht, 4 May 1939, Entscheidungen des Reichsgerichts in Zivilsachen, Band 160, no. 49, 270-273.

442 Reichsgericht, 4 May 1939, Entscheidungen des Reichsgerichts in Zivilsachen, Band 160, no. 49, 270-273; Reichsgericht, 29 May 1940, Entscheidungen des Reichsgerichts in Zivilsachen, Band 164, no. 67, 372-380. See also B. Rüthers, Die unbegrenzte Auslegung, 405-407 and H. Hofmeister, 'Privatrechtsgesetgebung für Österreich unter der Herrschaft des Nationalsozialismus', 135.

443 M. Burleigh, The Third Reich, 323-326. 
in the process of becoming aware of this true notion of Jewry. It was considered possible that even after the introduction of the Nuremberg Laws in 1935, which excluded Jews from the Volksgemeinschaft in a racial and political way, many Germans had still failed to grasp the concept and had only become aware of it after these events and subsequent measures, which sought to exclude Jews from public, cultural and economic life as well. ${ }^{444}$ The Court of Appeals of Nuremberg e.g. pointed out that nor the parties involved, nor the state, nor the Volksgemeinschaft had an interest in continuing a mixed marriage. In this case the appellant would be able to remarry an Aryan woman and father Aryan children after termination of his mixed marriage. The Jewish defendant would regain her independence. ${ }^{445}$ Initially the Supreme Court was more reluctant, ${ }^{446}$ but soon revised its opinion and decided that termination of a long existing mixed marriage was always morally justified in the sense of $\mathbb{S} 37(2)$ in case the non-Aryan partner was a first degree half-breed. ${ }^{447}$

\subsubsection{Divorce}

As we have seen before, the final provisions concerning divorce were all largely based on the compromise draft of $\mathrm{I} 937$. As Heß had objected to the inclusion of introductory articles referring to the foundations of marriage in relation to the Volksgemeinschaft, the original first paragraph was dropped. Gürtners preamble was not included either. Only one general introductory provision remained. Paragraph 46 stated that a divorce could only be pronounced by the court, had an ex nunc effect and could only be filed for on the following grounds (i.e. $\$ \$ 47-55$ ). ${ }^{448}$

The explanatory memorandum however, made up for this lack of reference to National Socialism. In its introductory remarks on divorce law it clearly stated that the new divorce regulations were firmly based on the National Socialist notion of the essence of marriage. It continued by explaining the importance of marriage and family for völkish community life, stating that the value and existence of the Volksgemeinschaft depended from its strength and health. Marriage hosted the vital power to ensure the eternity of völkish life. Therefore, procreation was the main goal of marriage. The National Socialist notion of the essence of marriage differed fundamentally from the so-called liberal notion of marriage, which considered marriage to be a bond aimed at individualistic interests. According to National Socialism however, the purpose of marriage lay outside the individual interests of the spouses. The purpose of a revision of divorce law therefore, should not be simply facilitating divorce as this would enable spouses, who just did not find full personal

444 Oberlandesgericht Nuremberg, 14 February 1939, 10 Deutsches Recht 1 (1940), 33-34; Oberlandesgericht Munich, 11 December 1939, 10 Deutsches Recht 8 (1940), 327-328.

445 Oberlandesgericht Nuremberg, 14 February 1939, 10 Deutsches Recht 1 (1940), 33-34, 34.

446 Reichsgericht, 20 May 1940, Entscheidungen des Reichsgerichts in Zivilsachen, Band 164, no. 8, 59-62. The appellant had originally filed for divorce on the ground that her husband was Jewish. The divorce was refused as racial differences were no ground for divorce. Therefore she changed her request to termination on the ground of $\S 37$. The Supreme Court, however, refused termination as well, on procedural grounds, as a revision did not allow for a change of grounds.

447 Reichsgericht, 14 November 1940, cited by G. Frantz, 'Richtung und Grundgedanken der reichsgerichtlichen Rechtsprechung zum Ehegesetz', 11 Deutsches Recht 19/20 (1941), 1028-1035, 1030. See also B. Rüthers, Die unbegrenzte Auslegung, 406-407.

448 Gesetz zur Vereinheitlichung des Rechts der Eheschließung und der Ehescheidung im Lande Österreich und im übrigen Reichsgebiet vom 6. Juli 1938, Reichsgesetzblatt (1938), I, 807, § 46. 
happiness together, to end their marriage, which would cause a devaluation of the importance and value of marriage. Instead the revision aimed to enable the dissolution of marriages which had lost its value to the Volksgemeinschaft. However, Gürtner stuck to the casuistic outline of grounds for divorce, partly still based on the guilt principle, as introducing one general clause allowing for divorce in case the marriage was disrupted in such a way that it had lost its value to the Volksgemeinschaft would infinitely enable divorce by sheer mutual consent. Such a provision would have been possible if the vast majority of the German population would have been imbued with National Socialism, something which could not be expected after just five years. Introducing the breakdown principle as the sole ground for divorce would mean 'a leap in the dark'. Implementing National Socialist principles in divorce law could therefore best be achieved by adapting and expanding the existing grounds for divorce. The final decision whether or not a marriage had lost its value to the Volksgemeinschaft was left to the courts. ${ }^{449}$

The grounds for divorce were listed in $\mathbb{S} \$ 47-55$. As Gürtner had not wanted to abandon the guilt principle, the list started with a classic ground for divorce: adultery $(\mathbb{S} 4)$. Adultery was considered an absolute ground for divorce, ${ }^{450}$ although the notion of 'absolute' had somewhat changed. Originally an absolute ground for divorce entailed that the appellant had the right to divorce when the facts were proven, without the court having to check whether because of the facts the marriage was permanently disrupted. In case of a relative ground for divorce, divorce was only allowed in case the marriage was disrupted in such a way that continuation of the marriage could no longer be expected. The new $\mathbb{S} 56^{451}$ however stated that a divorce on the ground of guilt of the other partner was not allowed in case from the behaviour of the hurt partner followed that he or she had not considered the hurt as disruptive. In case of adultery the court therefore had to check whether the deceived partner had really experienced the adultery as disruptive or whether this ground was just appealed to in order to get a divorce which was desired for whole other reasons. An absolute ground for divorce was not as absolute anymore as it used to be. ${ }^{452}$ According to $\mathbb{S} 47$ (2) divorce was furthermore not allowed in case the hurt partner had approved of the adultery or had enabled it (e.g. by tempting the other spouse to commit adultery in order to get a divorce). ${ }^{453}$

449 Begründung zu dem Gesetz zur Vereinheitlichung des Rechts der Eheschließung und der Ehescheidung im Lande Österreich und im übrigen Reichsgebiet vom 6. Juli 1938, published in W. Schubert, Das Familien- und Erbrecht unter dem Nationalsozialismus, 143, 154-155. See also R. Bechert and J. Wiesels, Das neue Eherecht für Großdeutschland, 4648; T. Ramm, 'Familien- und Jugendrecht im Nationalsozialismus', 76; T. Ramm, Das nationalsozialistische Familien- und Jugendrecht, 7.

450 Begründung zu dem Gesetz zur Vereinheitlichung des Rechts der Eheschließung und der Ehescheidung im Lande Österreich und im übrigen Reichsgebiet vom 6. Juli 1938, published in W. Schubert, Das Familien- und Erbrecht unter dem Nationalsozialismus, 143, 155.

451 Gesetz zur Vereinheitlichung des Rechts der Eheschließung und der Ehescheidung im Lande Österreich und im übrigen Reichsgebiet vom 6. Juli 1938, Reichsgesetzblatt (1938), I, 807, § 56: 'Das Recht auf Scheidung wegen Verschuldens besteht nicht, wenn sich aus dem Verhalten des verletzten Ehegatten ergibt, daß er die Verfehlung des anderen verziehen oder sie als ehezerstörend nicht empfunden hat.'

452 A. Scharnagl, Das neue deutsche Ehegesetz, 99-100. See also Begründung zu dem Gesetz zur Vereinheitlichung des Rechts der Eheschließung und der Ehescheidung im Lande Österreich und im übrigen Reichsgebiet vom 6. Juli 1938, published in W. Schubert, Das Familien- und Erbrecht unter dem Nationalsozialismus, 143, 156.

453 Gesetz zur Vereinheitlichung des Rechts der Eheschließung und der Ehescheidung im Lande Österreich und im übrigen Reichsgebiet vom 6. Juli 1938, Reichsgesetzblatt (1938), I, 807, § 47 (2). 
Adultery as ground for divorce fit the National Socialist world view perfectly, Gürtner explained in his explanatory memorandum. As loyalty was one of the basic principles of National Socialism, this was equally important for the concept of marriage, which found its sense and value in loyalty. ${ }^{454}$

The new $\$ 48$ was the second absolute ground for divorce and reflected the idea of the main goal of marriage being reproduction and preservation of the race; it introduced continuous refusal to procreate as a ground of divorce. ${ }^{455}$ This provision contained two components: I) refusal to beget children and 2) wrongful use of means which would hinder the birth of a child, ${ }^{456}$ e.g. undergoing an operation which could render the woman barren. Procreation could only legally be refused in a very limited number of cases like a severe illness of one of the spouses. Financial reasons could never be used as a sole excuse for refusal to procreate, only in combination with other reasons, e.g. a family with many children (kinderreich) being in financial troubles was allowed to refuse to get more children. However, a divorce was only allowed in case the partner who filed for divorce had a strong desire to have children. A woman who allowed her husband to use contaceptives did not have a right to divorce. ${ }^{457}$ As with adultery the court had to check whether the refusal to procreate as such had indeed permanently disrupted the marriage. ${ }^{458}$

The final ground for divorce based on the guilt principle was a relative one. Paragraph 49 was an adaptation of $\mathbb{1} 1568 \mathrm{BGB}$, a general provision allowing for divorce in case of other marriage faux pas. At the instigation of $\mathrm{He}^{459} \mathrm{Gürtner}$ had chosen not to include the other absolute grounds for divorce from the BGB $(\mathbb{S} 1566$, crimes against life or cruelty and $\mathbb{S} 1567$, desertion with malicious intent) in separate articles as it was most likely that these acts would lead to a divorce on the ground of $\mathbb{4} 49$ anyhow. ${ }^{460}$ Paragraph 49 was formulated in a general way, stating that a divorce was allowed in case the marriage was permanently disrupted, because of a serious marriage lapse or due to dishonourable or

454 Begründung zu dem Gesetz zur Vereinheitlichung des Rechts der Eheschließung und der Ehescheidung im Lande Österreich und im übrigen Reichsgebiet vom 6. Juli 1938, published in W. Schubert, Das Familien- und Erbrecht unter dem Nationalsozialismus, 143, 155-156.

455 Begründung zu dem Gesetz zur Vereinheitlichung des Rechts der Eheschließung und der Ehescheidung im Lande Österreich und im übrigen Reichsgebiet vom 6. Juli 1938, published in W. Schubert, Das Familien- und Erbrecht unter dem Nationalsozialismus, 143, 156. See also L. Pine, Nazi Family Policy, 1933-1945, 18; D. Blasius, Ehescheidung in Deutschland 1794-1945, 206; H. Hofmeister, 'Privatrechtsgesetgebung für Österreich unter der Herrschaft des Nationalsozialismus', 134.

456 Gesetz zur Vereinheitlichung des Rechts der Eheschließung und der Ehescheidung im Lande Österreich und im übrigen Reichsgebiet vom 6. Juli 1938, Reichsgesetzblatt (1938), I, 807, § 48: 'Ein Ehegatte kann Scheidung begehren, wenn der andere sich ohne triftigen Grund beharrlich weigert Nachkommenschaft zu erzeugen oder zu empfangen, oder wenn er rechtswidrig Mittel zur Verhinderung der Geburt anwendet oder anwenden läßt.'

457 R. Bechert and J. Wiesels, Das neue Eherecht für Großdeutschland, 50-51.

458 A. Scharnagl, Das neue deutsche Ehegesetz, 104.

459 Position of the Führer's Deputy with regard to the draft of 3 September 1937 (12 January 1938), published in W. Schubert, Das Familien- und Erbrecht unter dem Nationalsozialismus, 241-245, 242. See also L. Gruchmann, 'Das Ehegesetz vom 6. Juli 1938. Entstehung und Beurteilung', 78. The compromise draft of 1937 had still included crimes against life or cruelty (Lebensnachstellung) as separate ground for divorce.

460 Begründung zu dem Gesetz zur Vereinheitlichung des Rechts der Eheschließung und der Ehescheidung im Lande Österreich und im übrigen Reichsgebiet vom 6. Juli 1938, published in W. Schubert, Das Familien- und Erbrecht unter dem Nationalsozialismus, 143, 156. Gürtner erroneously referred to $\S \S 1565$ and 1566 BGB, instead of $\S 1566$ and 1567. Paragraph 1565, however, had dealt with adultery, which was included in the Marriage Law, albeit in an adapted form. See also R. Bechert and J. Wiesels, Das neue Eherecht für Großdeutschland, 52. 
immoral behaviour of one of the spouses, in such a way that restoration of the marital community according to the essence of marriage was not to be expected. ${ }^{461}$ This had to be considered in the light of objective criteria, the 'human-moral' point of view. ${ }^{462}$ This was a deviation from the previous rule as $\mathbb{S}$ I568 BGB had had an individualistic approach stating that divorce was allowed in case continuation of the marriage could no longer be expected from the innocent spouse. ${ }^{463}$ The Supreme Court had confirmed in I92 I that the question whether the marriage was permanently disrupted had to be answered according to the subjective point of view of the hurt spouse. ${ }^{464}$ The new $\mathbb{} 49^{465}$ furthermore stated that in case the other spouse had committed a marriage faux pas him or herself, a divorce was not allowed, in case this was morally not justified considering a correct evaluation of the essence of marriage. ${ }^{466}$ Again, the individual point of view did not matter in this respect. ${ }^{467}$

As according to the National Socialist notion of marriage, divorce was no longer something which only depended from the personal interests of the individual spouses, but also from the value the marriage had to the Volksgemeinschaft, a second category of grounds for divorce was introduced. Paragraphs 50-53 and 55 allowed for divorce in case marital cohabition was no longer possible, i.e. the purpose of marriage (i.e. procreation) could no longer be fulfilled, without one of the partners being guilty of this breakdown. The National Socialist notion of marriage as germ cell of the nation stands out most clearly in these provisions, with Blasius even calling $\mathbb{S} \$$ 50-53 'eugenic' grounds for divorce. ${ }^{468}$ These eugenic grounds for divorce can be divided into two subcategories: I) mental disorders and 2) physical disorders.

Paragraph 50 allowed for divorce in case of disruptive acts of one of the spouses causing a permanent breakdown of the marriage, whilst these disruptive acts could not be considered a marriage lapse because of a mental disturbance. ${ }^{469}$ As disruptive acts caused by a mental disorder could not be imputed to the person suffering from this mental disorder, no divorce had been allowed by the BGB, whilst restoration of the

461 Gesetz zur Vereinheitlichung des Rechts der Eheschließung und der Ehescheidung im Lande Österreich und im übrigen Reichsgebiet vom 6. Juli 1938, Reichsgesetzblatt (1938), I, 807, § 49: 'Ein Ehegatte kann Scheidung begehren, wenn der andere durch eine sonstige schwere Eheverfehlung oder durch ehrloses oder unsittliches Verhalten die Ehe schuldhaft so tief zerrüttet hat, daß die Wiederherstellung einer ihrem Wesen entsprechenden Lebensgemeinschaft nicht erwartet warden kann. [...].'

462 R. Bechert and J. Wiesels, Das neue Eherecht für Großdeutschland, 53.

463 D. Blasius, Ehescheidung in Deutschland 1794-1945, 206.

464 A. Scharnagl, Das neue deutsche Ehegesetz, 108.

465 Gesetz zur Vereinheitlichung des Rechts der Eheschließung und der Ehescheidung im Lande Österreich und im übrigen Reichsgebiet vom 6. Juli 1938, Reichsgesetzblatt (1938), I, 807, § 49: '[...] Wer selbst eine Verfehlung begangen hat, kann die Scheidung nicht begehren, wenn nach der Art seiner Verfehlung, insbesondere wegen des Zusammenhangs der Verfehlung des anderen Ehegatten mit seinem eigenen Verschulden sein Scheidungsbegehren bei richtiger Würdigung des Wesens der Ehe sittlich nicht gerechtfertigt ist.'

466 Begründung zu dem Gesetz zur Vereinheitlichung des Rechts der Eheschließung und der Ehescheidung im Lande Österreich und im übrigen Reichsgebiet vom 6. Juli 1938, published in W. Schubert, Das Familien- und Erbrecht unter dem Nationalsozialismus, 143, 156.

467 R. Bechert and J. Wiesels, Das neue Eherecht für Großdeutschland, 53.

468 D. Blasius, Ehescheidung in Deutschland 1794-1945, 207-208.

469 Gesetz zur Vereinheitlichung des Rechts der Eheschließung und der Ehescheidung im Lande Österreich und im übrigen Reichsgebiet vom 6. Juli 1938, Reichsgesetzblatt (1938), I, 807, § 50: 'Ein Ehegatte kann Scheidung begehren, wenn die Ehe infolge eines Verhaltens des anderen Ehegatten, das nicht als Eheverfehlung betrachtet werden kann, weil es auf einer geistigen Störung beruht, so tief zerrüttet ist, daß die Wiederherstellung einder dem Wesen der Ehe entsprechenden Lebensgemeinschaft nicht erwartet werden kann.' 
marital community consonant with the essence of marriage was often not possible. The mental disturbance mentioned in $\mathbb{5} 5$ was considered to be a minor mental illness, not removing the mental community between the spouses. Therefore, it was not the mental disturbance itself that constituted the ground for divorce, but the disruptive act caused by the mental disturbance. ${ }^{470}$

In case of a mental illness, which was serious to such an extent that the mental community between the partners was removed and not likely to be restored, a divorce was justified according to $\mathbb{S}_{5} \mathrm{I}^{471}$ This provision was not new, but largely taken over from $\mathbb{S}$ I569 BGB. Contrary to $\mathbb{S} 50$, permanent breakdown of the marriage was not regarded the decisive factor in this respect. Proving that the mental community between the spouses was indeed removed sufficed. The mental community was regarded as everything that fulfilled the 'mental lives of the spouses', including the care of the well-being of the other spouse and the children and participating in the 'political and cultural life of the Volk' ${ }^{472}$ The Supreme Court had originally explained this concept in a less political way by calling it 'a similar awareness of common interests and the common will to encourage those interests' ${ }^{473}$ Paragraph 5I furthermore deviated from the old $\mathbb{S}$ I569 BGB by the absence of the three year term $\mathbb{S}$ I569 BGB had required. According to $\mathbb{S} 5$ it was irrelevant when the mental illness had occurred and how long it already persisted. ${ }^{474}$

Physical disorders were dealt with in $\mathbb{S} \$ 52$ and 53 , respectively providing grounds for divorce in case of contagious or revolting disease of which the danger of contagion would not diminish in the near future ${ }^{475}$ and premature infertility. ${ }^{476}$ Both grounds were new and were introduced because in both cases marital community was considered to have become impossible, as a result of which the purpose of marriage - procreation - could no longer be fulfilled. ${ }^{477}$

Paragraph 52 was in line with the Marriage Health Law of I935, which prohibited in $\$$ I a marriage between two persons of which one was suffering from a contagious disease, which could endanger the other spouse or the future offspring. ${ }^{478}$ As such a disease

470 A. Scharnagl, Das neue deutsche Ehegesetz, 110-111; R. Bechert and J. Wiesels, Das neue Eherecht für Großdeutschland, 58.

471 Gesetz zur Vereinheitlichung des Rechts der Eheschließung und der Ehescheidung im Lande Österreich und im übrigen Reichsgebiet vom 6. Juli 1938, Reichsgesetzblatt (1938), I, 807, § 51: 'Ein Ehegatte kann Scheidung begehren, wenn der andere geisteskrank ist, die Krankheit einen solchen Grad erreicht hat, daß die geistige Gemeinschaft zwischen den Ehegatten aufgehoben ist, und eine Wiederherstellung dieser Gemeinschaft nicht erwartet werden kann.'

472 R. Bechert and J. Wiesels, Das neue Eherecht für Großdeutschland, 59.

473 Reichsgericht, 30 March 1920, Entscheidungen des Reichsgerichts in Zivilsachen, Band 98, 295-298, quote taken from A. Scharnagl, Das neue deutsche Ehegesetz, 112.

474 Begründung zu dem Gesetz zur Vereinheitlichung des Rechts der Eheschließung und der Ehescheidung im Lande Österreich und im übrigen Reichsgebiet vom 6. Juli 1938, published in W. Schubert, Das Familien- und Erbrecht unter dem Nationalsozialismus, 143, 157; A. Scharnagl, Das neue deutsche Ehegesetz, 112-113.

475 Gesetz zur Vereinheitlichung des Rechts der Eheschließung und der Ehescheidung im Lande Österreich und im übrigen Reichsgebiet vom 6. Juli 1938, Reichsgesetzblatt (1938), I, 807, § 52: ‘Ein Ehegatte kann Scheidung begehren, wenn der andere an einer schweren ansteckenden oder ekelerregenden Krankheit leidet und ihre Heilung oder die Beseitigung der Ansteckungsgefahr in absehbarer Zeit nicht erwartet werden kann.'

476 Gesetz zur Vereinheitlichung des Rechts der Eheschließung und der Ehescheidung im Lande Österreich und im übrigen Reichsgebiet vom 6. Juli 1938, Reichsgesetzblatt (1938), I, 807, § 53 (1): 'Ein Ehegatte kann Scheidung begehren, wenn der andere nach der Eheschließung vorzeitig unfruchtbar geworden ist.'

477 Begründung zu dem Gesetz zur Vereinheitlichung des Rechts der Eheschließung und der Ehescheidung im Lande Österreich und im übrigen Reichsgebiet vom 6. Juli 1938, published in W. Schubert, Das Familien- und Erbrecht unter dem Nationalsozialismus, 143, 157. See also L. Pine, Nazi Family Policy, 1933-1945, 18.

478 Gesetz zum Schutze der Erbgesundheit des deutschen Volkes vom 18. Oktober 1935, Reichsgesetzblatt (1935), I, $1246, \S 1$. 
could also occur after the partners had married, a ground for divorce should be included next to the marriage prohibition. The purpose was the same: prevention of unhealthy offspring. ${ }^{479}$ Tuberculosis as well as venereal diseases were considered to be contagious diseases potentially endangering offspring. ${ }^{480}$ However, $\mathbb{S} 52$ was formulated in a broader way, including 'revolting' diseases as well. This made the list of diseases that fell under the scope of $\$ 52$ considerably longer, including things like facial cancer or having had a colostomy because of rectal cancer resulting in a stoma with attached stoma appliance. ${ }^{481}$ However, in case one of the partners had had an accident, which had resulted in severe physical disorders, no divorce was justified. ${ }^{482}$

Premature infertility had been accepted as a ground for disputability under $\mathbb{S}$ I333 BGB and as a ground for termination under $\mathbb{S} 37$ of the Marriage Law. Paragraph 53 followed this line by allowing for divorce in case infertility occurred after the marriage had been concluded. ${ }^{483}$ A divorce on the ground of $\mathbb{S} 53$ was only justified in case the infertility had occurred after the marriage had been concluded, was premature, i.e. the woman being under 40 and the man under 6o, and permanent, which had to be established by a physician. ${ }^{484}$ Scharnagl furthermore pointed out that although the law only mentioned infertility and not impotence, it was likely that impotence fell under the scope of $\mathbb{S} 53$ as well, as impotence would invariably lead to an infertile marriage. ${ }^{485}$ Divorce because of premature infertility was not allowed in case the spouses together had (hereditary) healthy, legitimate children or together had adopted a (hereditary) healthy child. ${ }^{486}$ An adopted child was put on the same footing as biological children as it was considered to be unreasonably harsh on the adopted child to have him lose his home again, just because one of his adoptive parents was infertile, something the spouses apparently had resigned themselves to since they had moved on and had adopted a child instead. ${ }^{487}$ A divorce was furthermore not allowed in case the spouse who filed for divorce was infertile himself or for health reasons was not allowed to enter a new marriage. ${ }^{488}$

479 R. Freisler, Vom alten zum neuen Ehescheidungsrecht, 143-144.

480 R. Bechert and J. Wiesels, Das neue Eherecht für Großdeutschland, 59.

481 A. Scharnagl, Das neue deutsche Ehegesetz, 114; R. Bechert and J. Wiesels, Das neue Eherecht für Großdeutschland, 59.

482 R. Bechert and J. Wiesels, Das neue Eherecht für Großdeutschland, 59.

483 R. Freisler, Vom alten zum neuen Ehescheidungsrecht, 134; A. Scharnagl, Das neue deutsche Ehegesetz, 114-115.

484 R. Bechert and J. Wiesels, Das neue Eherecht für Großdeutschland, 59; A. Scharnagl, Das neue deutsche Ehegesetz, 116. 485 A. Scharnagl, Das neue deutsche Ehegesetz, 116-117.

486 Gesetz zur Vereinheitlichung des Rechts der Eheschließung und der Ehescheidung im Lande Österreich und im übrigen Reichsgebiet vom 6. Juli 1938, Reichsgesetzblatt (1938), I, 807, § 53 (2): 'Die Scheidung ist ausgeschlossen, wenn die Ehegatten miteinander erbgesunde eheliche Nachkommenschaft oder ein gemeinschaftlich an Kindes Statt angenommenes erbgesundes Kind haben.

487 Begründung zu dem Gesetz zur Vereinheitlichung des Rechts der Eheschließung und der Ehescheidung im Lande Österreich und im übrigen Reichsgebiet vom 6. Juli 1938, published in W. Schubert, Das Familien- und Erbrecht unter dem Nationalsozialismus, 143, 157; R. Bechert and J. Wiesels, Das neue Eherecht für Großdeutschland, 60; A. Scharnagl, Das neue deutsche Ehegesetz, 117.

488 Gesetz zur Vereinheitlichung des Rechts der Eheschließung und der Ehescheidung im Lande Österreich und im übrigen Reichsgebiet vom 6. Juli 1938, Reichsgesetzblatt (1938), I, 807, § 53 (3): 'Wer selbst unfruchtbar ist, hat kein Recht auf Scheidung. Das gleiche gilt für den Ehegatten, der eine neue Ehe aus gesundheitlichen Gründen nicht würde eingehen dürfen oder dem das Gesundheitsamt hiervon abraten müßte.' See also Begründung zu dem Gesetz zur Vereinheitlichung des Rechts der Eheschließung und der Ehescheidung im Lande Österreich und im übrigen Reichsgebiet vom 6. Juli 1938, published in W. Schubert, Das Familien- und Erbrecht unter dem Nationalsozialismus, 143, 157; R. Bechert and J. Wiesels, Das neue Eherecht für Großdeutschland, 60; A. Scharnagl, Das neue deutsche Ehegesetz, 117. 
According to $\mathbb{5} 4$ divorce because of mental or physical disorders was in general not allowed when it was 'morally not justified' ${ }^{489}$ The article furthermore explained that this could be the case when a divorce would be unreasonably harsh on the other spouse, for which the duration of the marriage, the age of the spouses and the cause of the illness could be indicative. ${ }^{490}$ The open norm (Generalklausel) 'morally not justified' (sittlich nicht gerechtfertigt) had to be explained from a völkish-moral point of view. ${ }^{491}$ Paragraph 54 left the courts a lot of interpretation freedom, which was nevertheless dictated by 'sound popular feelings' (gesunden Volksempfinden). ${ }^{492}$

Paragraph 55 finally, allowed for divorce in case the spouses had not lived together anymore for three consecutive years already and restoration of the marital community consonant with the essence of marriage was not to be expected because of a permanent breakdown of the marriage:

Ist die häusliche Gemeinschaft der Ehegatten seit drei Jahren aufgehoben und infolge einer tiefgreifenden unheilbaren Zerrüttung des ehelichen Verhältnisses die Wiederherstellung einer dem Wesen der Ehe entsprechenden Lebensgemeinschaft nicht zu erwarten, so kann jeder Ehegatte die Scheidung begehren. ${ }^{493}$

This provision, apart from being the core of the compromise between the Ministry of Justice and the Academy for German Law, can be regarded the key provision of National Socialist divorce law. Firstly, it seemed to introduce the general breakdown principle in German divorce law, although it stuck to the three year term. Furthermore, this permanent breakdown of the marriage had be established objectively by the court. ${ }^{494}$ However, this general breakdown principle was mitigated in sub 2, which, in case the partner who had filed for divorce was (largely) responsible for the disruption of the marriage, granted the right to variance to the other spouse. ${ }^{495}$ The rationale behind this

489 Gesetz zur Vereinheitlichung des Rechts der Eheschließung und der Ehescheidung im Lande Österreich und im übrigen Reichsgebiet vom 6. Juli 1938, Reichsgesetzblatt (1938), I, 807, § 54: 'In den Fällen der §§ 50 bis 53 darf die Ehe nicht geschieden werden, wenn das Scheidungsbegehren sittlich nicht gerechtfertigt ist. [...].'

490 Gesetz zur Vereinheitlichung des Rechts der Eheschließung und der Ehescheidung im Lande Österreich und im übrigen Reichsgebiet vom 6. Juli 1938, Reichsgesetzblatt (1938), I, 807, § 54: '[...] Dies ist in der Regel dann anzunehmen, wenn die Auflösung der Ehe den anderen Ehegatten außergewöhnlich hart treffen würde. Ob dies der Fall ist, richtet sich nach den Umständen, namentlich auch nach der Dauer der Ehe, dem Lebensalter der Ehegatten und dem Anlaß der Erkrankung oder der Unfruchtbarkeit.'

491 G. Frantz, 'Richtung und Grundgedanken der reichsgerichtlichen Rechtsprechung zum Ehegesetz', 11 Deutsches Recht 19/20 (1941), 1028-1035, 1030; R. Bechert and J. Wiesels, Das neue Eherecht für Großdeutschland, 60.

492 Begründung zu dem Gesetz zur Vereinheitlichung des Rechts der Eheschließung und der Ehescheidung im Lande Österreich und im übrigen Reichsgebiet vom 6. Juli 1938, published in W. Schubert, Das Familien- und Erbrecht unter dem Nationalsozialismus, 143, 157-158.

493 Gesetz zur Vereinheitlichung des Rechts der Eheschließung und der Ehescheidung im Lande Österreich und im übrigen Reichsgebiet vom 6. Juli 1938, Reichsgesetzblatt (1938), I, 807, § 55 (1), 'In case the domestic community of the partners has been discontinued for three consecutive years and in case restoration of the marital community consonant with the essence of marriage is not to be expected because of a fundamental, irretrievable disruption of the marital relation, both spouses can file for divorce.'

494 A. Scharnagl, Das neue deutsche Ehegesetz, 121.

495 Gesetz zur Vereinheitlichung des Rechts der Eheschließung und der Ehescheidung im Lande Österreich und im übrigen Reichsgebiet vom 6. Juli 1938, Reichsgesetzblatt (1938), I, 807, § 55 (2): 'Hat der Ehegatte, der die Scheidung begehrt, die Zerrüttung ganz oder überwiegend verschuldet, so kann der andere der Scheidung widersprechen.' 
mitigation was described in evocative language by Gürtner, who stated in the explanatory memorandum that repudiation of a woman by her husband, who had found a younger and more charming woman, had to be prevented. ${ }^{496}$ However, this provision particularly shows both conservatism and a fear for an unlimited increase in the number of divorces and a loss of control. Therefore, the breakdown principle had to go hand in hand with the guilt principle.

This right to variance, however, was not absolute. Sub 2 also stated that the variance would not be taken into account when continuation of the marriage was morally not justified in the light of a correct evaluation of the essence of marriage and the behaviour of both spouses.

\section{[...] Der Widerspruch ist nicht zu beachten, wenn die Aufrechterhaltung der Ehe bei richtiger Würdigung des Wesens der Ehe und des gesamten Verhaltens beider Ehegatten sittlich nicht gerechtfertigt ist. ${ }^{497}$}

Despite the attempt to mitigate the breakdown principle, the true sting of National Socialism was found here. This one sentence provision consisted out of two so-called Generalklausel, open norms; Wesen der Ehe (essence of marriage) and sittlich nicht gerechtfertigt (morally not justified). As we have seen both phrases appeared in other provisions as well, in particular $\mathbb{S} 37$ (I), 49, 50 and 54. Both phrases can be interpreted in several ways; no legal definition was given. As we have seen the open norm 'morally not justified' had to be explained from a völkish-moral point of view. The Supreme Court had defined sittlich (morally) as what was appropriate according to National Socialism. ${ }^{498}$ According to Rüthers this definition of morality lead to a form of population policy utilitarianism; a way of thinking completely focussed on ethnology and biology. The question whether a marriage should be continued or could be dissolved always had to be answered in the light of the völkish interests of the community. The court had to check whether the community would benefit or suffer from a marriage in which case a new marriage could be desirable from a community point of view. ${ }^{499}$ The open norm 'essence of marriage' had to be explained along the same lines. The essence of marriage was to be found in its value to the Volksgemeinschaft. Main purpose of the marriage was giving the Volksgemeinschaft healthy, Aryan children. A marriage in which such procreation was

496 Begründung zu dem Gesetz zur Vereinheitlichung des Rechts der Eheschließung und der Ehescheidung im Lande Österreich und im übrigen Reichsgebiet vom 6. Juli 1938, published in W. Schubert, Das Familien- und Erbrecht unter dem Nationalsozialismus, 143, 158.

497 Gesetz zur Vereinheitlichung des Rechts der Eheschließung und der Ehescheidung im Lande Österreich und im übrigen Reichsgebiet vom 6. Juli 1938, Reichsgesetzblatt (1938), I, 807, § 55 (2): '[...] The variance will not be taken into account, when continuation of the marriage is morally not justified in the light of a correct evaluation of the essence of marriage and the collective behaviour of both spouses.'

498 G. Frantz, 'Richtung und Grundgedanken der reichsgerichtlichen Rechtsprechung zum Ehegesetz', 11 Deutsches Recht 19/20 (1941), 1028-1035, 1030.

499 B. Rüthers, Die unbegrenzte Auslegung, 419. See also Reichsgericht, 13 February 1939, Entscheidungen des Reichsgerichts in Zivilsachen, Band 159, no. 46, 305-311; Reichsgericht, 13 March 1939, Entscheidungen des Reichsgerichts in Zivilsachen, Band 160, no. 4, 15-19; Reichsgericht, 17 April 1939, Entscheidungen des Reichsgerichts in Zivilsachen, Band 160, no. 29, 144-148; Reichsgericht, 6 November 1939, Entscheidungen des Reichsgerichts in Zivilsachen, Band 162, no. 10, 44-47; Reichsgericht, 15 March 1941, Entscheidungen des Reichsgerichts in Zivilsachen, Band 166, no. 25, 188-192; Reichsgericht, 8 March 1941, Entscheidungen des Reichsgerichts in Zivilsachen, Band 166, no. 28, 209-215; Reichsgericht, 5 November 1941, Entscheidungen des Reichsgerichts in Zivilsachen, Band 168, no. 5, 38-39. 
not possible or did not happen, did not meet the essential criteria to be called a marriage in the true sense of the word. ${ }^{500}$ Since the effect of $\mathbb{S} 55$ depended on the interpretation of the open norms given by the court and since both open norms were interpreted in a National Socialist way, albeit formulated neutrally, the provision became a tool for realising National socialist racial beliefs, while personal beliefs of the spouses on the quality of the marriage could entirely be brushed aside. ${ }^{501}$

The importance of the Marriage Law for the National Socialist population policy furthermore appeared from the rules concerning the expiration of the term in which one could file for divorce. Paragraph 57 (2) determined that divorce should be requested within ten years after the ground for divorce had occurred, unless it concerned a form of adultery prohibited by $\mathbb{S} 2$ of the Blood Protection Law. ${ }^{502}$ Race defilement apparently should always and anytime be a reason for divorce.

Although $\mathbb{3}$ of the Marriage Law had taken a cautious step towards the emancipation of women within the marriage, the consequences of divorce still largely departed from the paternalistic outlook on marriage. Basic principle was that a divorced woman retained her husbands family name, ${ }^{503}$ but the use of that name could be refused in case the woman after the divorce made a severe slip against her former husband or conducted in a dishonourable or immoral way against the will of her former husband. ${ }^{504} \mathrm{~A}$ woman was basically still submitted to the control of her former husband, even after a divorce..$^{505}$

However, with regard to the right to maintenance, the emancipation of women was taken to the next level. According to the old $\mathbb{S} 578$ BGB only the partner who was solely responsible for the breakdown of the marriage had a liability to maintenance towards the other spouse. This implied that when the woman shared the guilt, she lost the right to maintenance. This rule was liberalised in the Marriage Law. In case the partners were equally guilty of disruption of the marriage, the partner who could not support him- or

500 B. Rüthers, Die unbegrenzte Auslegung, 408-409. See also Reichsgericht, 12 January 1939, Entscheidungen des Reichsgerichts in Zivilsachen, Band 159, no. 19, 111-114; Reichsgericht, 13 February 1939, Entscheidungen des Reichsgerichts in Zivilsachen, Band 159, no. 46, 305-311; Reichsgericht, 13 March 1939, Entscheidungen des Reichsgerichts in Zivilsachen, Band 160, no. 4, 15-19; Reichsgericht, 17 April 1939, Entscheidungen des Reichsgerichts in Zivilsachen, Band 160, no. 29, 144-148; Reichsgericht, 6 November 1939, 10 Deutsches Recht 6 (1940), no. 3, 242-243; Reichsgericht, 18 November 1939, 10 Deutsches Recht 6 (1940), no. 2, 242.

501 H. Hofmeister, 'Privatrechtsgesetgebung für Österreich unter der Herrschaft des Nationalsozialismus', 135.

502 Gesetz zur Vereinheitlichung des Rechts der Eheschließung und der Ehescheidung im Lande Österreich und im übrigen Reichsgebiet vom 6. Juli 1938, Reichsgesetzblatt (1938), I, 807, § 57 (2): 'Die Scheidung ist nicht mehr zulässig, wenn seit dem Eintritt des Scheidungsgrunden zehn Jahre verstrichen sind. Die Scheidung bleibt jedoch zulässig, wenn ihr Grund ein nach $\S 2$ des Gesetzes zum Schutze des deutschen Blutes und der deutschen Ehre verbotener Ehebruch ist.'

503 Gesetz zur Vereinheitlichung des Rechts der Eheschließung und der Ehescheidung im Lande Österreich und im übrigen Reichsgebiet vom 6. Juli 1938, Reichsgesetzblatt (1938), I, 807, § 62.

504 Gesetz zur Vereinheitlichung des Rechts der Eheschließung und der Ehescheidung im Lande Österreich und im übrigen Reichsgebiet vom 6. Juli 1938, Reichsgesetzblatt (1938), I, 807, § 65 (1): 'Macht die Frau sich nach der Scheidung einer schweren Verfehlung gegen den Mann schuldig oder führt sie gegen seinen Willen einen ehrlosen oder unsittlichen Lebenswandel, so kann ihr das Vormundschaftsgericht auf Antrag des Mannes die Weiterführung seines Namens untersagen. $[\ldots] . '$

505 L. Gruchmann, 'Das Ehegesetz vom 6. Juli 1938. Entstehung und Beurteilung', 78; T. Ramm, 'Eherecht und Nationalsozialismus', 151-166, 158. 
herself had a right to maintenance towards the other spouse. ${ }^{506}$ Paragraph 66 nevertheless did impose the obligation for a woman to support herself as much as possible in case her former husband was (largely) to blame for the disruption, ${ }^{507}$ and even her former husband in case she was (largely) to blame for the divorce and he could not support himself. ${ }^{508}$ Whether or not a woman was used to having a job, considering the lifestyle the spouses had had, was not important. Working was an obligation towards the Volksgemeinschaft. ${ }^{509}$

Custody of the children was granted to the parent who was best equipped to take care of them. ${ }^{510}$ The well-being of the children was decisive in this respect, not the question who of the parents was to blame for the disruption of the marriage. Often custody of the children would be given to the parent who was not to blame for the divorce, as parents should serve as an example to their children. ${ }^{511}$ When it was in the interest of the children, however, custody could be granted to the guilty parent. ${ }^{512}$ This was a radical change from $\mathbb{S}$ I635 BGB which had granted custody of the children to the partner who was not guilty of the disruption, or, in case both partners were equally responsible, the son under six years old and the daughter to the mother and the son over six years old to the father. The starting point of the Marriage Law was that brothers and sisters should be kept together as much as possible. ${ }^{513}$

Considering the provisions in the BGB the changes with regard to maintenance and custody were an improvement. ${ }^{514}$

506 Gesetz zur Vereinheitlichung des Rechts der Eheschließung und der Ehescheidung im Lande Österreich und im übrigen Reichsgebiet vom 6. Juli 1938, Reichsgesetzblatt (1938), I, 807, § 68: 'Sind beide Ehegatten schuld and der Scheidung, trägt aber keener die überwiegende Schuld, so kann dem Ehegatten, der sich nicht selbst unterhalten kann, ein Beitrag zu seinem Unterhalt zugebilligt werden, wenn und soweit dies mit Rüchsicht auf die Bedürfnisse und die Vermögens- und Erwerbsverhältnisse des anderen Ehegatten und der nach $§ 71$ unterhaltspflichtigen Verwandten des Bedürftigen der Billigkeit entspricht. [...].'

507 Gesetz zur Vereinheitlichung des Rechts der Eheschließung und der Ehescheidung im Lande Österreich und im übrigen Reichsgebiet vom 6. Juli 1938, Reichsgesetzblatt (1938), I, 807, §66 (1):'Der allein oder überwiegend schuldige Mann hat der geschiedenen Frua den nach den Lebensverhältnissen der Ehegatten angemessenen Unterhalt zu gewähren, soweit die Einkünfte aus dem Vermögen der Frau und die Erträgnisse einer Erwerbstätigkeit, die von ihr den Umständen nach erwartet werden kann, nicht ausreichen.' Paragraph 69 declared $\$ 66$ similarly applicable to divorces on other grounds than guilt of one of the spouses.

508 Gesetz zur Vereinheitlichung des Rechts der Eheschließung und der Ehescheidung im Lande Österreich und im übrigen Reichsgebiet vom 6. Juli 1938, Reichsgesetzblatt (1938), I, 807, § 66 (2): 'Die allein oder überwiegend schuldige Frau hat dem geschiedenen Mann angemessenen Unterhalt zu gewähren, soweit er außerstande ist, sich selbst zu unterhalten.'

509 Begründung zu dem Gesetz zur Vereinheitlichung des Rechts der Eheschließung und der Ehescheidung im Lande Österreich und im übrigen Reichsgebiet vom 6. Juli 1938, published in W. Schubert, Das Familien- und Erbrecht unter dem Nationalsozialismus, 143, 162.

510 Gesetz zur Vereinheitlichung des Rechts der Eheschließung und der Ehescheidung im Lande Österreich und im übrigen Reichsgebiet vom 6. Juli 1938, Reichsgesetzblatt (1938), I, 807, § 81 (1): 'Ist die Ehe geschieden, so bestimmt das Vormunschaftsgericht, welchem Ehegatten die Sorge für die Person eines gemeinschaftlichen Kindes zustehen soll. Maßgebend ist, was nach Lage der Verhältnisse dem Wohl des Kindes am besten entspricht.

511 Begründung zu dem Gesetz zur Vereinheitlichung des Rechts der Eheschließung und der Ehescheidung im Lande Österreich und im übrigen Reichsgebiet vom 6. Juli 1938, published in W. Schubert, Das Familien- und Erbrecht unter dem Nationalsozialismus, 143, 164.

512 Gesetz zur Vereinheitlichung des Rechts der Eheschließung und der Ehescheidung im Lande Österreich und im übrigen Reichsgebiet vom 6. Juli 1938, Reichsgesetzblatt (1938), I, 807, § 81 (3): ‘Einem Ehegatten, der allein oder überwiegend für schuldig erklärt ist, soll die Sorge nur übertragen werden, wenn dies aus besonderen Gründen dem Wohl des Kindes dient.'

513 Gesetz zur Vereinheitlichung des Rechts der Eheschließung und der Ehescheidung im Lande Österreich und im übrigen Reichsgebiet vom 6. Juli 1938, Reichsgesetzblatt (1938), I, 807, § 81 (2): 'Sind mehrere gemeinschaftliche Kinder vorhanden, so soll die Sorge für die Person aller Kinder dem gleichen Elternteil übertragen werden, sofern nicht eine afweichende Regelung aus besonderen Gründen geboten und mit dem Wohl des Kindes vereinbar ist.' See also Begründung zu dem Gesetz zur Vereinheitlichung des Rechts der Eheschließung und der Ehescheidung im Lande Österreich und im übrigen Reichsgebiet vom 6. Juli 1938, published in W. Schubert, Das Familien- und Erbrecht unter dem Nationalsozialismus, 143, 164.

514 D. Blasius, Ehescheidung in Deutschland 1794-1945, 209. 


\subsubsection{Exceptional and transitional provisions for Austria}

The exceptional provisions of chapter four have been the most significant for Austria, especially in the first months after the incorporation. ${ }^{515}$ According to the explanatory memorandum these exceptional provisions for Austria tried to tackle the most pressing problems of Austrian matrimonial law: I) the lack of a uniform, civil marriage and therefore the lack of state control with regard to marriage conclusions, 2) the prohibition of divorce for Roman Catholics, which had lead to the concept of separation from bed and board, which was not in line with the National Socialist population policy and 3) the Dispensehe as solution for the lack of divorce possibilities which was undesirable from the perspective of legal certainty. ${ }^{516}$

Since in Austria marriages were generally not concluded before a registrar and therefore not entered in the Registry of Births, Deaths and Marriages and since the German Law on the Registry of Births, Deaths and Marriages of $1937^{517}$ would not come into force in Austria until I January 1939, a transitional provision was necessary to regulate the conclusion of civil marriages in the meantime. Paragraph 99 of the Marriage Law declared the district heads to be authorised to act as registrars. ${ }^{518}$ In Burgenland this task was assigned to the register heads ${ }^{519}$ who had already carried out this task from 1894 to $1934 .{ }^{520}$ Paragraph Ioo furthermore stated that the penalty for letting the religious ceremony regarding the conclusion of marriage precede the civil ceremony was Io,000 Reich mark or up to five years imprisonment. ${ }^{521}$

The effect of existing separations from bed and board, a concept unfamiliar in German law, remained unaffected according to $\mathbb{I}$ I $4 .{ }^{522}$ However, as stated in $\mathbb{S}$ II 5 (I), ${ }^{523}$ existing separations from bed and board could be converted into a full divorce at the request of

515 H. Hofmeister, 'Privatrechtsgesetgebung für Österreich unter der Herrschaft des Nationalsozialismus', 134.

516 Begründung zu dem Gesetz zur Vereinheitlichung des Rechts der Eheschließung und der Ehescheidung im Lande Österreich und im übrigen Reichsgebiet vom 6. Juli 1938, published in W. Schubert, Das Familien- und Erbrecht unter dem Nationalsozialismus, 143, 165-166.

517 Personenstandsgesetz vom 3. November 1937, Reichsgesetzblatt (1937), I, 1146.

518 Gesetz zur Vereinheitlichung des Rechts der Eheschließung und der Ehescheidung im Lande Österreich und im übrigen Reichsgebiet vom 6. Juli 1938, Reichsgesetzblatt (1938), I, 807, § 99 (1): 'Standesbeamte im Sinne dieses Gesetzes sind im Lande Österreich außerhalb des Burgenlands der Bezirkshauptmann oder der mit seiner Vertretung in diesen Angelegenheiten Beauftragte, in Wien und in den landesunmittelbaren Städten der Bürgermeister oder der mit seiner Vertretung in diesen Angelegenheiten Beauftragte. [...].'

519 Gesetz zur Vereinheitlichung des Rechts der Eheschließung und der Ehescheidung im Lande Österreich und im übrigen Reichsgebiet vom 6. Juli 1938, Reichsgesetzblatt (1938), I, 807, § 99 (2): 'Im Burgenland sind Standesbeamte im Sinne dieses Gesetzes die staatlichen Matrikelführer. [...].'

520 Begründung zu dem Gesetz zur Vereinheitlichung des Rechts der Eheschließung und der Ehescheidung im Lande Österreich und im übrigen Reichsgebiet vom 6. Juli 1938, published in W. Schubert, Das Familien- und Erbrecht unter dem Nationalsozialismus, 143, 166; A. Scharnagl, Das neue deutsche Ehegesetz, 151.

521 Gesetz zur Vereinheitlichung des Rechts der Eheschließung und der Ehescheidung im Lande Österreich und im übrigen Reichsgebiet vom 6. Juli 1938, Reichsgesetzblatt (1938), I, 807, § 100 (1): 'Wer die religiösen Feierlichkeiten einer Eheschließung vornimmt, bevor die Ehe vor den staatlichen Trauungsorganen geschlossen ist, wird wegen Vergehens an Geld bis zehntausend Reichsmark oder mit strengem Arrest bis zu fünf Jahren bestraft.'

522 Gesetz zur Vereinheitlichung des Rechts der Eheschließung und der Ehescheidung im Lande Österreich und im übrigen Reichsgebiet vom 6. Juli 1938, Reichsgesetzblatt (1938), I, 807, § 114: 'Die Wirkung der Scheidung einer Ehe von Tisch und Bett wird durch das Inkrafttreten dieses Gesetzes nicht berührt. [...].' See also A. Scharnagl, Das neue deutsche Ehegesetz, 159.

523 Gesetz zur Vereinheitlichung des Rechts der Eheschließung und der Ehescheidung im Lande Österreich und im übrigen Reichsgebiet vom 6. Juli 1938, Reichsgesetzblatt (1938), I, 807, § 115 (1): 'Jeder Ehegatte einer von Tisch und Bett geschiedenen Ehe kann den Antrag stellen, daß die Scheidung der Ehe im Sinne dieses Gesetzes ausgesprochen werde. [...].' 
(one of) the spouses. ${ }^{524}$ This was only allowed in case the spouses had not yet reconciled. ${ }^{525}$

The Dispensehe, finally, was legalised in $\$ I $2 \mathrm{I},{ }^{526}$ which stated that marriages concluded after dispensation from the impediment of an already existing marital bond were considered to be valid marriages from the start, unless it was established by the court before I January I939 that the spouses had not lived as spouses anymore since I April I938. In that case the marriage would be annulled. As it would be impossible to check whether all second marriages still existed on I April I938 or whether the spouses had returned to their original spouses, it was decided to automatically legalise all Dispensehen unless someone invoked its nullity before I January i939. This could only be done by the spouses who had a Dispensehe and the former spouses. These terms were deliberately kept short, as to legalise as many Dispensehen as possible. ${ }^{527}$ In case the Dispensehe was not annulled before I January I939, the previous marriage was considered divorced from the date the second marriage was concluded. ${ }^{528}$

\subsubsection{Final provisions}

Apart from some exceptional provisions for Austria the Marriage Law came into force on I August i938. ${ }^{529}$

\subsection{Conclusion}

The main question that had to be answered in this chapter was the question whether and in what way marriage and divorce law in Germany has been influenced by National Socialism. In order to answer that question we have started with an overview of the rules concerning the conclusion of marriage, annulment of marriage and dissolution of marriage before the National Socialist take-over in 1933.

524 Begründung zu dem Gesetz zur Vereinheitlichung des Rechts der Eheschließung und der Ehescheidung im Lande Österreich und im übrigen Reichsgebiet vom 6. Juli 1938, published in W. Schubert, Das Familien- und Erbrecht unter dem Nationalsozialismus, 143, 166; A. Scharnagl, Das neue deutsche Ehegesetz, 159-160; D. Blasius, Ehescheidung in Deutschland 1794-1945, 205; H. Hofmeister, 'Privatrechtsgesetgebung für Österreich unter der Herrschaft des Nationalsozialismus', 134.

525 Gesetz zur Vereinheitlichung des Rechts der Eheschließung und der Ehescheidung im Lande Österreich und im übrigen Reichsgebiet vom 6. Juli 1938, Reichsgesetzblatt (1938), I, 807, § 115 (2): '[...] Dem Antrag ist stattzugeben, wenn feststeht, daß die Ehegatten sich nicht wieder vereinigt haben. [...].'

526 Gesetz zur Vereinheitlichung des Rechts der Eheschließung und der Ehescheidung im Lande Österreich und im übrigen Reichsgebiet vom 6. Juli 1938, Reichsgesetzblatt (1938), I, 807, § 121 (1): 'Eine mit Nachsicht vom Ehehindernis des Ehebandes geschlossene und nicht bereits rechtskräftig für ungültig erklärte Ehe gilt als eine von Anfang an gültige Ehe, es sei denn, daß auf Grund eines vor dem 1. Jänner 1939 gestellten Antrags gerichtlich festgestellt wird, daß die Ehegatten am 1. April 1938 nicht mehr als Ehegatten miteinander gelebt haben. In diesem falle ist die Ehe für nichtig zu erklären. [...].'

527 Begründung zu dem Gesetz zur Vereinheitlichung des Rechts der Eheschließung und der Ehescheidung im Lande Österreich und im übrigen Reichsgebiet vom 6. Juli 1938, published in W. Schubert, Das Familien- und Erbrecht unter dem Nationalsozialismus, 143, 166-167; A. Scharnagl, Das neue deutsche Ehegesetz, 166-167; H. Hofmeister, 'Privatrechtsgesetgebung für Österreich unter der Herrschaft des Nationalsozialismus', 134; D. Blasius, Ehescheidung in Deutschland 1794-1945, 205.

528 Gesetz zur Vereinheitlichung des Rechts der Eheschließung und der Ehescheidung im Lande Österreich und im übrigen Reichsgebiet vom 6. Juli 1938, Reichsgesetzblatt (1938), I, 807, § 122 (1): 'Wir in der Frist des § 121 ein Antrag nicht gestellt oder wird er rechtskräftig abgewiesen, so gilt die frühere Ehe, von deren Bande Nachsicht erteilt wurde, mit der Eingehung der späteren Ehe als im Sinne dieses Gesetzes geschieden.' See also Begründung zu dem Gesetz zur Vereinheitlichung des Rechts der Eheschließung und der Ehescheidung im Lande Österreich und im übrigen Reichsgebiet vom 6. Juli 1938, published in W. Schubert, Das Familien- und Erbrecht unter dem Nationalsozialismus, 143, 167; A. Scharnagl, Das neue deutsche Ehegesetz, 166-167.

529 Gesetz zur Vereinheitlichung des Rechts der Eheschließung und der Ehescheidung im Lande Österreich und im übrigen Reichsgebiet vom 6. Juli 1938, Reichsgesetzblatt (1938), I, 807, § 129. 


\section{- 3.8.1. Germany}

After the introduction of the Personenstandsgesetz in 1876 Germany only recognised civil marriages, which could be concluded between persons of the opposite sex irrespective of their religious background. Since I 900 marriage was regulated by the newly adopted Civil Code. Contrary to the Allgemeines Landrecht für die Preußischen Staaten from I794, the Civil Code did not state that the purpose of marriage was procreation. Instead no definition of marriage was given.

A marriage could be dissolved through either annulment or divorce. One of the grounds for disputability (that, if invoked, subsequently would lead to avoidance, which would lead to annulment) was error concerning the person or personal qualities of the other spouse $(\mathbb{I}$ I333 BGB). We have seen that personal qualities in the sense of this paragraph were defined as essential, i.e. physical, psychological or moral characteristics of a person. Other circumstances and relations, i.e. belonging to a certain religion, social group or family, profession or name could not qualify as personal qualities in the sense of $\mathbb{S}$ I333.

Grounds for divorce were based on the guilt principle, only allowing for divorce in case one of the partners had committed some wrong. An exception was made in $\$$ I569 BGB which allowed for divorce in case of a mental disorder of one of the spouses. Already since the beginning of the I920s it had been discussed whether the guilt principle should be replaced by the breakdown principle, i.e. allowing for divorce in case the marriage was permanently disrupted. However, the proposed introduction of objective permanent breakdown of marriage as additional ground for divorce next to the already existing culpable breakdown of marriage was shelved due to continuous political shifts at the end of the igros.

\section{- 3.8.2. Austria}

Contrary to Germany, Austria did not have a generally applicable obligatory civil marriage. Instead, marriage was largely arranged according to religious principles. The concordat of 1934 consolidated the position of the Roman Catholic Church in Austria, especially with regard to marriage and divorce law. Civil marriage was only possible in exceptional cases, with the exception of Burgenland, that did recognise the obligatory civil marriage. Marriages between Christians and non-Christians were not allowed and divorce was arranged according to the rules of the religious community the partners adhered to. Divorce was prohibited for Roman Catholics, who could only get a separation from bed and board. This rigidness had led to the so-called Dispensehe, an ingenious though questionable legal construction which allowed for a second (civil) marriage after a separation from bed and board.

\section{- 3.8.3. After the National Socialist take-over}

According to the National Socialists marriage was the 'germ-cell of the nation'. From this basic principle we can deduce three goals: I) keeping the Aryan race pure, 2) keeping the Aryan race healthy and 3) expansion of the Aryan race. The National Socialists have certainly tried to achieve these goals by amending marriage and divorce law.

The first goal, keeping the Aryan race pure, had to be achieved through marriage prohibitions with regard to marriages between Aryans and people of 'inferior' races. 
The Blutschutzgesetz of September 1935 and the First Supplementary Decree to the Blutschutzgesetz of November 1935 prohibited marriages between state nationals of German or kindred blood and Jews and marriages in which case offspring that was in any way harmful to the purity of the German blood was to be expected. Additionally, extramarital intercourse between Jews and state nationals of German or kindred blood was prohibited as well, although the term 'intercourse' (Verkehr), later refined to 'sexual intercourse' (Geschlechtsverkehr) led to some interpretation difficulties.

The second goal, keeping the Aryan race healthy, had to be achieved by preventing marriages between healthy Aryans with 'weaker' persons and applying eugenics. The Ehegesundheitsgesetz, adopted in October 1935, prohibited marriages in case one of the future spouses was suffering from undesirable disorders, such as a contagious disease, a mental illness, or a hereditary disease as mentioned in the Gesetz zur Verhütung erbranken Nachwuchses of 1933, which allowed for sterilisation of hereditary ill people and alcoholics.

The third goal, expansion of the Aryan race, had to be realised by propaganda and financial incentives on the one hand, as we have seen in the first chapter, and by facilitating divorce in case no offspring was to be expected. This required an amendment of divorce regulations, which came into force in 1938 as part of the Ehegesetz. Next to adultery and mental illness of one of the spouses, which both already existed as ground for divorce, and the general provision of $\mathbb{S} 49$, which more or less included the old $\mathbb{S} \mathbb{1 5 6 6 -}$ I568 of the Civil Code, several new grounds were introduced, e.g. refusal to procreate, disruptive acts caused by a mental disturbance leading to a permanent breakdown of the marriage, contagious or revolting disease and premature infertility. All these new grounds for divorce were focused on protecting the Volksgemeinschaft, i.e. in case offspring was no longer to be expected, divorce should be granted. Although these changes were presented as being introduced out of compassion for the unfortunate, healthy spouse, the main reason was to assure procreation. For that purpose, the weaker partner could be abandoned. Hitler had already stated in Mein Kampf that the world 'gehört nur dem kraftvollem "Ganzen" und nicht dem schwachen "Halben". ${ }^{30}$

However, it would be going too far to unequivocally conclude that German family law has been completely 'nazified'. First of all, we should note that - although it has been discussed several times - mixed marriages have never been dissolved by a general administrative act, nor did the new divorce regulations contain an article that allowed for divorce on the mere ground of racial differences between the spouses. The article that came closest to such a provision was $\mathbb{3 7}$ of the Marriage Law, which allowed for termination (Aufhebung) in case of error with regard to 'circumstances concerning the person of other spouse' at the time of the marriage conclusion, instead of error concerning 'personal qualities' of the other spouse, as it had been formulated in the former $\mathbb{S}$ I333 of the Civil Code. As we have seen, this broader description enabled courts to dissolve 
marriages on the ground of racial differences, though only until a year after the Marriage Law had come into force.

Secondly, it is important to realise that the amended grounds for divorce still departed from the guilt principle. Paragraph 55 of the Marriage Law seemed to be introducing the breakdown principle, but was mitigated by the guilt principle. Divorce on the mere ground that the marriage was permanently disrupted, whatever the cause might be, as a result of which no offspring was to be expected anymore, was not allowed. The general breakdown principle has never been accepted by the National Socialists due to conservatism, a fear for an unlimited increase in the number of divorces and a loss of control. Apart from that, introducing the breakdown principle, albeit in mitigated form, did not turn the law into a Nazi law. Divorce regulations in Germany were rather obsolete and, as had already been argued before, in need of replacement. Most likely the breakdown principle would have been introduced at a certain point anyway. ${ }^{531}$ On the other hand we have to remark that the breakdown principle as introduced by the National Socialists, started from the National Socialist way of thinking; it was not up to individuals to decide whether their marriage was over, instead the value of the marriage for the Volksgemeinschaft was the decisive factor.

The sting was in the so-called Generalklauseln, the open norms. The existence of these open norms instead of hardcore definitions however, allows for reinterpretation and application in a different way than originally intended, without altering a single word in the provisions itself. This is what the National Socialists had done with the open norms that existed in the Civil Code of I 900 before legislation that incorporated National Socialist principles came into force and this is also what happened after the fall of National Socialism. We have discussed the two open norms found in the Marriage Law of I938: Wesen der Ehe (essence of marriage) and sittlich nicht gerechtfertigt (morally not justified), which were interpreted according to National Socialism until May 1945. In 1946, the allied Kontrollrat (Control Council) largely took over the 1938 Marriage Law. ${ }^{532}$ Only the articles that referred to either the Blood Protection Law or the Marriage Health $\mathrm{Law}^{533}$ and the articles that were focused too much on either the purity ${ }^{534}$ or the expansion ${ }^{535}$ of the Aryan race were deleted, leaving the greater part of the Marriage Law as it was, including the open norms. However, it was exactly because of these open norms that the greater part of the Marriage Law remained. Rüthers explains that on the basis of Kontrollratsgesetz No. I6 of 1946 a new interpretation of the open norms 'essence of marriage' and 'morally not justified' was given by the German Supreme Court (Bundesgerichtshof). According to the Supreme Court marriage should never be regarded to serve an ideological principle or an anonymous collective (like state, race or community), nor an abstract idea of duty with regard to this anonymous collective. ${ }^{536}$

531 See in this respect also L. Gruchmann, 'Das Ehegesetz vom 6. Juli 1938', 79.

532 Kontrollratsgesetz Nr. 16 (Ehegesetz) vom 20. Februar 1946, Amtsblatt des Kontrollrats in Deutschland (1946), 77.

533 In that respect the following paragraphs were deleted: $\S 4, \S 5, \S 20, \S 28(1)$ and $\S 29$.

534 In that respect $\$ 13$ was deleted.

535 In that respect $\S 48$ and $\S 53$ were deleted.

536 B. Rüthers, Die unbegrenzte Auslegung, 413. 
Marriage was again regarded as a bond for life, according to the Christian notion of marriage as an institution. ${ }^{537}$

The continuity of the Marriage Law of 1938 is furthermore clearly visible in Austria. It is safe to say that in Austria this law has had an even greater impact than in Germany as it introduced the obligatory civil marriage for all Austrians, irrespective of their religious background and it allowed for divorce, again for all Austrians, irrespective of their religious background. The Marriage Law of 1938 forms the basis of Austrian matrimonial law until today, although it has been amended several times. The first major changes were made in 1945, right after the fall of the National Socialism, when laws from the Nazi period were continuously being repealed. The Nuremberg Laws were already repealed on I3 May I945. ${ }^{538}$ The Gesetz zur Verhütung erbkranken Nachwuchses followed about two weeks later, on 29 May I945. ${ }^{539}$ A month later it was decided to keep the Marriage Law, although all references to the Nuremberg Laws and the Marriage Health Law were repealed. The Marriage Health Law was repealed at the same time. ${ }^{540}$

537 L. Gruchmann, 'Das Ehegesetz vom 6. Juli 1938', 82-83; B. Rüthers, Die unbegrenzte Auslegung, 412-416, 420-429.

538 Kundmachung der Provisorischen Staatsregierung vom 13. Mai 1945 über die Aufhebung der 'Nürnberger Rassengesetze' (1. Kundmachung über die Aufhebung von Rechtsvorschriften des Deutschen Reiches), Staatsgesetzblatt für die Republik Österreich (1945), 22.

539 Kundmachung der Provisorischen Staatsregierung vom 29. Mai 1945, betreffend die Aufhebung des Gesetzes zur Verhütung erbkranken Nachwuchses (3. Kundmachung über die Aufhebung von Rechtsvorschriften des Deutschen Reiches), Staatsgesetzblatt für die Republik Österreich (1945), 26.

540 Gesetz vom 26. Juni 1945 über Maßnahmen auf dem Gebiete des Eherechtes, des Personenstandsrechtes und des Erbgesundheitsrechtes, Staatsgesetzblatt für die Republik Österreich (1945), 53. 
N.

Racial and

Family Law in

the Netherlands

during the German

Occupation 


\subsection{Introduction}

This chapter intends to answer the question to what extent Dutch marriage and divorce law has been influenced by National Socialism during the German occupation of the Netherlands. In order to answer this main question we first have to answer several subquestions, to wit: what did Dutch marriage and divorce law imply before Io May I940, the day the Netherlands was occupied by Germany? What developments with regard to marriage and divorce law were in progress in the Netherlands at the time of the German invasion? To what extent are occupying forces authorised to amend the existing marriage and divorce law of occupied territories? What measures with regard to marriage and divorce law are implemented by the occupying forces in the Netherlands, and in what way?

This chapter will start with an overview of the existing marriage and divorce regulations at the time the Netherlands was occupied as well as the running discussion with regard to a possible revision of divorce law and the attempts made. In this respect we will also deal with the application of the Nuremberg Laws in the Netherlands between 1935 and 1940. 
The second part of this chapter deals with the period of the occupation. We will start with a short overview of the law of occupation and the administrative situation of occupied Netherlands. Subsequently we will deal with the family and divorce law measures implemented by the occupying forces. In that respect we will also deal with the attempts to revise Dutch divorce law during the occupation.

It has to be remarked that this research does not allow for an extensive treatise on all administrative acts and procedures implemented by the occupying forces. Furthermore, the question what has happened in reality with several groups of people (Jews, half-Jews, mixed married Jews) is beyond the scope of this research as well. In that respect I would like to refer to the works of others, such as C. Stuldreher, who has written an extensive treatise on the position and fate of the mixed married Jews in the Netherlands, and L. de Jong, whose detailed description of the Netherlands during the occupation is still unequalled. 


\subsection{Dutch Family Law before the German Occupation}

The Civil Code of $1838^{1}$ contained the first real Dutch codification of matrimonial law in the Netherlands. However, several views about this topic had already passed in review over the centuries, and with the draft of this law one had not taken the chances. For a long time the Netherlands - although obviously not in its current national configuration - had been Catholic territory, following the canonical notion of marriage as a sacrament, a divine institution administered by the partners to each other and witnessed by a priest. ${ }^{2}$ This changed in 1581, when the Republic of the Seven United Provinces declared itself independent. From that moment on marriage and divorce were considered from a Calvinist point of view, which meant a break with the traditional Catholic conviction of marriage being an indissoluble bond. Divorce because of adultery or desertion was allowed, as was separation from bed and board, even though both were condemned by public opinion. ${ }^{3}$ According to both the Catholic and the Calvinist view, the main goal of marriage was considered to be mutual assistance and procreation. Marriage was patriarchal, the man being head of the family with a wife who owed obedience to her husband. The Calvinist influence diminished substantially after the Batavian revolution of I795, when separation of Church and State was realised..$^{4}$ In I8og the Netherlands, which had become the Kingdom of Holland in 1806 , for the first time introduced a civil marriage when the Napoleonic Code for the Kingdom of Holland (Wetboek Napoleon ingerigt voor het koningrijk Holland) was adopted. This code was more or less in keeping with the Calvinist approach of marriage, although secularised. Marriage was no longer primarily a matter of the church, but a civil contract, regulated by the state. ${ }^{5}$ In I 8 I I the French Civil Code was declared enforceable when the Kingdom of Holland was annexed by Napoleon Bonaparte. ${ }^{6}$ After independence from France in I8I3, William I $\mathrm{I}^{7}$ demanded revision of the existing codes. However, the opinions on marriage and divorce where sharply divided. The mainly roman catholic jurists in the Southern Netherlands wanted the revised Dutch codes to be written in the tradition of the French Civil Code and to secure the canonical views on marriage and divorce, whilst the mainly protestant jurists in the Northern Netherlands preferred a more traditional Dutch kind of legislation. ${ }^{8}$ This problem was only solved in 1838 with the promulgation of the new Dutch Civil Code, which was in many respects a compromise between the two views. By that time the

1 The Dutch Civil Code (Burgerlijk Wetboek) came into force on 1 October 1838, by Royal Decree of 13 April 1838, Staatsblad (1838), No. 12. The Civil Code was originally planned to come into force on 1 February 1831 (Royal Decree of 5 July 1830, Staatsblad (1830), No. 41), but was postponed due to the Belgian Revolt in August 1830 (Royal Decree of 5 January 1831, Staatsblad (1831), No. 1) and subsequently revised (Royal Decree of 24 February 1831, Staatsblad (1831), No. 6).

2 Asser-Wiarda, Handleiding tot de beoefening van het Nederlands Burgerlijk Recht. Personenrecht. Natuurlijke Personen en Familierecht, 86-87; A.H. Huussen, 'The Discussion about the Extension of Divorce in the Netherlands, 1870-1970', 311335,312 . See for an extensive overview of canonical matrimonial law M. Antokolskaia, Harmonisation of Family Law in Europe: A Historical Perspective, 83-114.

3 A.H. Huussen, 'The Discussion about the Extension of Divorce in the Netherlands, 1870-1970', 311-335, 312. See furthermore M. Antokolskaia, Harmonisation of Family Law in Europe: A Historical Perspective, 167-177.

4 Asser-Wiarda, Handleiding tot de beoefening van het Nederlands Burgerlijk Recht. Personenrecht. Natuurlijke Personen en Familierecht, 88; A.H. Huussen, 'The Discussion about the Extension of Divorce in the Netherlands, 1870-1970', 311-335, 312-313.

5 L.J. van Apeldoorn, Geschiedenis van het Nederlandsche Huwelijksrecht, 123-125.

6 M. Antokolskaia, Harmonisation of Family Law in Europe: A Historical Perspective, 198, 206.

7 In 1813 William was still Sovereign Prince of the Netherlands. He became King of the Netherlands in 1815.

8 A.H. Huussen, 'The Discussion about the Extension of Divorce in the Netherlands, 1870-1970', 311-335, 313-314. 
Southern Netherlands had already separated from the Northern Netherlands, although their independence was not recognised until I839. ${ }^{9}$ In some ways the new Civil Code resembled the French Civil Code, e.g. that it considered marriage only in its civil aspects, ${ }^{10}$ although it did not give a clear definition of marriage. ${ }^{11}$ Marriage remained patriarchal, the man being the head of the family. ${ }^{12}$ Married women were not capable of contracting ${ }^{13}$ and had to be represented in court by their husbands. ${ }^{14}$ The man administered his wife's goods, ${ }^{15}$ which task he had to perform with due diligence. ${ }^{16}$ With the arrival of the Industrial Revolution and the 'pillarisation ${ }^{17}$ of Dutch society, new thoughts about the position of women in society arose. Prostitution, illegitimate children, sexuality and contraception became subjects for debate. The patriarchal position of the husband was criticised and the demand for girls' education in order to prevent prostitution became stronger. After the publication of Darwin's The descent of man in I87I, a discussion erupted on whether marriages could legally be prohibited on medical-hygienic grounds. ${ }^{18}$ In 1880 , a state commission was founded in order to draft a revision of the Civil Code. This draft, which, among other things, extended the grounds for divorce, was presented in $\mathrm{I} 886 .{ }^{19}$ However, equality among husbands and wives was rejected as premature. ${ }^{20}$ The draft was not accepted. Nevertheless, the discussion about revision of matrimonial law and the grounds for divorce in particular continued. Following the international debate on eugenics, some propagated a medical examination of future marriage partners, although many rejected a legal prohibition of marriage of eugenically unfit people. ${ }^{21}$ Despite all proposals and suggestions, however, Dutch matrimonial law was not fundamentally changed before I 957 when the legal incapacity of women was abolished, ${ }^{22}$ whilst in I97I only the grounds for divorce were extended. ${ }^{23}$

\section{- 4.2.1. Conclusion of marriage}

According to Article 13I BW a marriage was performed before a registrar of the place of residence of one of the partners, in public, in the town hall, in the presence of at

9 Ibid., 314-315.

10 Article 83 BW: 'De wet beschouwt het huwelijk alleen in deszelfs burgerlijke betrekkingen.'

11 See furthermore about the development of Dutch matrimonial law: A.H. Huussen, 'The Discussion about the Extension of Divorce in the Netherlands, 1870-1970', 311-335; J. Th. De Smidt, Compendium van de geschiedenis van het Nederlands privaatrecht, 17-28; Asser-De Boer, Inleiding tot de beoefening van het Nederlands Burgerlijk Recht. Personen-en Familierecht, 2-7.

12 Article 160 BW: 'De man is het hoofd der echtvereeniging. [...]'

13 Article 163 BW: 'De vrouw, al is zij zelfs buiten gemeenschap van goederen getrouwd, of van goederen gescheiden, kan, zonder bijstand van haren man in de akte, of zonder zijne schriftelijke toestemming, niets geven, vervreemden, verpanden, verkrijgen, het zij voor niet, het zij onder eenen bezwarenden titel. [...]'

14 Article 165 BW: 'De vrouw kan niet in regten verschijnen zonder bijstand van haren man, al is zij buiten gemeenschap van goederen getrouwd, of van goederen gescheiden, of al oefent zij zelfstandig een beroep uit.'

15 Article 160 BW: '[...] Hij bestuurt de goederen aan de vrouw persoonlijk toebehoorende, ten zij het tegendeel zij bedongen. $[\ldots]$ '...

16 Ibid.: '[...] Hij moet die goederen als een goed huisvader beheeren, en is voor alle verzuim in dat beheer verantwoordelijk. [...]'

17 'verzuiling'. This term indicates the fragmentation in which Dutch society was organised. Catholics, Protestants, socialdemocrats and 'neutrals' (mainly liberals) did form their own 'pillar' ('zuil'), with their own political party, schools, sporting clubs, radio station, trade union, et cetera. All Dutch citizens belonged to a certain pillar, almost completely secluding themselves from other citizens, who did not belong to the same pillar.

18 A.H. Huussen, 'The Discussion about the Extension of Divorce in the Netherlands, 1870-1970', 311-335, 318-319.

19 Ibid., 320.

20 Ontwerp tot herziening van het Burgerlijk Wetboek, 1886, Toelichting, 72, 79.

21 A.H. Huussen, 'The Discussion about the Extension of Divorce in the Netherlands, 1870-1970', 317-321.

22 Royal Decree of 13 July 1956, Staatsblad (1956), 1087, no. 413.

23 Wet van 6 mei 1971, houdende herziening van het echtscheidingsrecht, Staatsblad (1971), 693, no. 290. 
least two and not more than four witnesses. ${ }^{24}$ The wording of Article I3I is somewhat ambiguous about the exact role of the registrar. Oppenheim does not comment on the role of the partners and the registrar, but sticks to the wording of Article I3I: the marriage is performed by the registrar, without explaining the true meaning of 'performing'. ${ }^{25}$ Star Busmann is more specific; he clearly states that a marriage is concluded by the partners, albeit with the cooperation of the registrar. The marriage, however, comes into existence by the act of the partners. ${ }^{26}$ Scholten subscribes to this point of view. According to Scholten a marriage was concluded by the partners themselves and performed by the registrar, with 'performing' meaning 'official registration. ${ }^{27}$ It is safe to conclude that the constituent act was therefore executed by the partners, although the official registration of the marriage by the registrar was the binding element. Article 135 BW stated that the partners had to declare before a registrar that they would marry one another. ${ }^{28}$ This had to be done in person. ${ }^{29}$ Despite the fact that a marriage was concluded by a mutual declaration of both partners, a marriage could not be regarded as a contract. Scholten defined marriage as an institution. Although the legal relationship, which was established with the marriage, was based on mutual agreement, the content of the legal relationship was not free to determine. The content of marriage was determined by the law. Therefore, a marriage could not be regarded as a contract. ${ }^{30}$ Star Busmann was a bit more lenient in this respect; in general a marriage could be regarded as a contract, although not in the strict sense of Article 1349 BW. ${ }^{31}$ The requirements for the conclusion of marriage as stated in Article I3I BW originate from medieval canon law, although only mutual agreement was considered a binding element at that time. Omission of one of the other requirements, i.e. public nature of the ceremony, presence of witnesses and official registration or solemnisation by a priest, would only lead to penalties, but not to invalidity of the marriage. Traditionally, mutual agreement had been the only constituent and binding element, although by Germanic influences consummation was sometimes required. In late medieval times, however, discussion arose about what to do with marriages concluded in secrecy, which were, strictly speaking, valid marriages. The Council of Trent (1545-1563) declared that all marriages had to be concluded in the presence of the parish priest and two witnesses. The Council decision was more or less adopted for Holland by the Political Ordinance of 1580 , which declared that a marriage had to be concluded either in church or in presence of a magistrate. In the Protestant Church, the solemnisation by the clergyman became a binding element besides the mutual agreement. After 7 May 1795 a marriage had to be performed before a registrar,

24 Article 131 BW: 'Het huwelijk zal in het openbaar, in het huis der gemeente, ten overstaan van den ambtenaar van den burgerlijken stand der woonplaats van eene der beide partijen, worden voltrokken, en in tegenwoordigheid van ten minste twee en ten hoogsten vier getuigen [...].'

25 Veegens-Oppenheim, Schets van het Nederlandsch Burgerlijk Recht, 96.

26 Land-Star Busmann, Verklaring van het Burgerlijk Wetboek. Boek I, Titel I-XIX en Rechtspersonen, 85.

27 Asser-Scholten, Handleiding tot de beoefening van het Nederlandsch Burgerlijk Recht. Familierecht, 84

28 Article 135 BW: 'De aanstaande echtgenooten zullen, ten overstaan van den ambtenaar van den burgerlijken stand, en in tegenwoordigheid der getuigen, moeten verklaren, dat zij elkander aannemen tot echtgenooten, en dat zij getrouwelijk alle de pligten zullen vervullen, welke door de wet aan den huwelijken staat verbonden zijn.'

29 Article 133 BW: 'De aanstaande echtgenooten zijn verpligt bij de voltrekking van hun huwelijk in persoon voor den ambtenaar van den burgerlijken stand te verschijnen.'

30 Asser-Scholten, Handleiding tot de beoefening van het Nederlandsch Burgerlijk Recht. Familierecht, 43-44.

31 Land-Star Busmann, Verklaring van het Burgerlijk Wetboek. Boek I, Titel I-XIX en Rechtspersonen, 85. 
whilst ecclesiastical solemnisations of marriages were no longer valid. ${ }^{32}$

Generally, a marriage was preceded by an announcement ${ }^{33}$ and notification of marriage. ${ }^{34}$ The marriage could not be concluded within ten days after notification, ${ }^{35}$ but had to be concluded within a year after notification. ${ }^{36}$ Furthermore, the announcement of marriage had to be done by both partners, either orally or in writing. The requirement that the registrar would draw up an act of the announcement of marriage completed the list of external requirements.

Other than the external requirements, which contained formalities regarding the wedding, did the internal requirements focus on the persons who wished to enter into marriage. Failure to comply with one of the internal requirements led to grounds of incompetence to marry, which could be divided into absolute incompetence and relative incompetence.

Most importantly, both partners had to consent to the marriage. ${ }^{37}$ A person who was unable to give informed consent, e.g. a mentally ill person, was therefore unable to marry. Being under legal restraint because of a mental illness caused a ground for interruption (stuiting) by the parents, ${ }^{38}$ in which case the registrar was prohibited to perform the marriage until he had received a final judgement or an authentic document containing the discontinuance of the interruption. ${ }^{39}$ In case the marriage was concluded despite the fact that one of the partners was under legal restraint because of a mental illness, the marriage could be declared void by the court. ${ }^{40}$ Opinions differed on the position of a mentally ill person who was not under legal restraint. Under the Civil Code of 1838 a marriage could not be declared legally null and void, but only in a limited number of cases. The second draft of the Civil Code of J.M. Kemper of I820, however, contained a general article which declared a person who was not of full legal capacity because of lack of intellectual powers, unable of entering into marriage. ${ }^{41}$ This article was not adopted in the final Civil Code of 1838 , although one could argue that Article 85 included this rule.

32 Asser-Scholten, Handleiding tot de beoefening van het Nederlandsch Burgerlijk Recht. Familierecht, 66-69.

33 Article 105 BW: 'Alle personen die met elkander een huwelijk willen aangaan, moeten daarvan aangifte doen bij den ambtenaar van den burgerlijken stand der woonplaats van eene der partijen.'

34 Article 107 BW: 'Vóór het voltrekken van het huwelijk geschiedt daarvan door de zorg van den ambtenaar van den burgerlijken stand afkondiging door middel van aanplakking van een, door dezen ambtenaar opgemaakt, geschrift aan het huis der gemeente [...].'

35 Article 130 BW: 'Het huwelijk zal niet morgen worden voltrokken, vóór den tienden dag na dien der afkondiging, die dag zelf niet daaronder begrepen. [...]'

36 Article 112 BW: 'Wanneer het huwelijk binnen een jaar, te rekenen van de huwelijks-afkondiging, niet is voltrokken, zal hetzelve niet voltrokken mogen worden, dan nadat alvorens wederom eene nieuwe afkondiging zal gedaan zijn.'

37 Article 85 BW: 'Tot het wezen van het huwelijk wordt de vrije toestemming der aanstaande echtgenooten vereischt.'

38 Article 116 BW: 'De vader of de moeder kan het huwelijk stuiten, in de volgende gevallen: [...] 3) Wanneer eene der partijen, uit hoofde van gebrek aan verstandelijke vermogens onder curatele gesteld, of de curatele uit dien hoofde verzocht en op dat verzoek nog niet is beslist; [...].'

39 Article 125 BW: 'Wanneer er stuiting van een huwelijk plaats heeft, zal het aan den ambtenaar van den burgerlijken stand niet geoorloofd zijn hetzelve te voltrekken, dan nadat aan hem zal zijn ter hand gesteld een vonnis in kracht van gewijsde gegaan of een authentieke akte, waarbij de stuiting is opgeheven [...].'

40 Article 143 BW: 'Wanneer een huwelijk is aangegaan door iemand die, uit hoofde van gebrek aan verstandelijke vermogens, is onder curatele gesteld, kan de wettigheid des huwelijks worden betwist door deszelfs vader, moeder en andere bloedverwanten in de opgaande linie, broeders, zusters, ooms en moeijen, mitsgaders door den curator, en eindelijk door het openbaar ministerie. [...]'; Article 140 BW: 'De nietigheid des huwelijks kan alleen door den regter worden uitgesproken.'

41 Ontwerp van het Burgerlijk Wetboek voor het Koningrijk der Nederlanden, 1820, Article 122: 'Die wegens gebrek aan verstandelijk vermogens onbekwaam zijn om zich door onderhandelingen te verbinden, kunnen geen huwelijk aangaan, zelfs niet met de toestemming van hunnen ouders of voogden.' 
However, Star Busmann declared that since Article 122 was not adopted, interruption and annulment because of a mental illness of one of the partners were restricted to what was stated in Article II6 (3) and Article I 43 BW, implying that although a marriage was prohibited in case one of the partners suffered from a mental illness, albeit not being under legal restraint, this did not cause a ground for interruption or annulment in case the marriage was concluded nevertheless. ${ }^{42}$ Scholten disagreed with this point of view, stating that Article II6 (4) ${ }^{43}$ and I42 $\mathrm{BW}^{44}$ were formulated in general terms, allowing application in this case. According to Scholten one should not accept absurd conclusions when not forced by the law to do so. ${ }^{45}$

Free consent furthermore implied that an engagement could be broken off without judicial consequences. Only after the notification of the marriage had taken place damages could be claimed in case one of the partners refused to get married, albeit not because of breaking the marriage promise. ${ }^{46} \mathrm{~A}$ comparison with other legal systems, both in past and present, indicates that this is not something that goes without saying. ${ }^{47}$

Article $86 \mathrm{BW}$ required men to have reached the age of $\mathrm{I} 8$ years, whilst the minimum age for women to get married was 16 years. The king could grant dispensation because of important reasons ${ }^{48}$ which in the majority of cases was pregnancy. Reason for this requirement was that partners had to be capable of having sexual intercourse, which was considered the basis of marriage. In the Netherlands East Indies, but also in France, the required minimum age for women was 15 years. This difference was explained by the fact that in the Dutch climate women were considered to be slower in reaching maturity. ${ }^{49}$

Both partners had to be unmarried $;^{50}$ bigamy and polygamy caused a criminal offence. ${ }^{51}$

Finally, a woman entering into marriage for the second time, had to wait 300 days after the dissolution of the first marriage, ${ }^{52}$ to be sure she was not pregnant from her first husband. However, in case a woman was pregnant from her first husband after the marriage had been dissolved and had given birth before the term had expired, she still had to wait until zoo days after the dissolution, before being allowed to remarry.

42 Land-Star Busmann, Verklaring van het Burgerlijk Wetboek. Boek I, Titel I-XIX en Rechtspersonen, 91-92.

43 Article 116 BW: 'De vader of de moeder kan het huwelijk stuiten, in de volgende gevallen: [...] 4) Wanneer eene der partijen de vereischten niet bezit om overeenkomstig de bepalingen van de eerste afdeeling van dezen titel een huwelijk te kunnen aangaan.'

44 Article 142 BW: 'De wettigheid eens huwelijks, zonder de vrije toestemming der beide echtgenooten, of ook van een van hen aangegaan, kan alleen worden tegengesproken door de echtgenooten of door dengenen van hen, wiens toestemming niet is vrij geweest. [...]'

45 Asser-Scholten, Handleiding tot de beoefening van het Nederlandsch Burgerlijk Recht. Familierecht, 47.

46 Article 113 BW: 'Trouwbeloften geven gene regtsvordering tot het aangaan des huwelijks, noch tot vergoeding van kosten, schaden en interessen, uit hoofde der niet vervulling van de beloften; [...].'

47 Under medieval canon law engagement obliged to marriage. Breaking off the engagement without sufficient grounds was not allowed. The Republic of the Seven United Provinces recognised the claim for celebration of marriage based on the marriage vow, allowing the negligent partner being held in custody or being lead by force to church in order to get wed. Although a forced marriage was not allowed in Germany, $\$ 1298$ BGB stated that interruption of the engagement commits to damages. See AsserScholten, Handleiding tot de beoefening van het Nederlandsch Burgerlijk Recht. Familierecht, 48-50.

48 Article 86 BW: 'Een jongman den vollen ouderdom van achttien, en eene jonge dochter den vollen ouderdom van zestien jaren niet bereikt hebbende, mogen geen huwelijk aangaan. De Koning kan echter, om gewigtige redenen, dit verbod door het verleenen van dispensatie opheffen.'

49 Asser-Scholten, Handleiding tot de beoefening van het Nederlandsch Burgerlijk Recht. Familierecht, 50.

50 Article 84 BW: 'De man kan te gelijkertijd slechts met ééne vrouw, de vrouw slechts met éénen man door het huwelijk verbonden zijn.'

51 Article 237 Penal Code: 'Met een gevangenisstraf van ten hoogste vier jaren wordt gestraft: 1) hij die opzettelijk een dubbel huwelijk aangaat;[...].'

52 Article 91 BW: 'Eene vrouw kan geen nieuw huwelijk aangaan, dan na verloop van drie honderd dagen na de ontbinding van het vorig huwelijk.' 
When the marriage was dissolved pursuant to Article 254 (2) BW ${ }^{53}$ after the man had been absent for at least ten years, the 300 day term was considered unnecessary though. Noncompliance with this rule did not cause a ground for annulment. Interruption was nevertheless allowed. ${ }^{54}$

Failure to comply with one of the aforementioned requirements caused an absolute incompetence to marry. The list of grounds leading to relative incompetence to marry was even longer. Relative incompetence only existed when a marriage between two certain persons was prohibited (and a marriage with another person would be allowed) and when the necessary permission to marry was missing.

Article 87 BW declared a too close bond of consanguinity a relative impediment to marriage. ${ }^{55}$ Whether it concerned illegitimate children or legitimate children was unimportant in this respect. Article 88 (2) BW furthermore prohibited marriages between uncle or great-uncle and niece or great-niece and between aunt or great-aunt and nephew or great-nephew, except for dispensation granted by the king. ${ }^{56}$ In this respect the Dutch Civil Code was stricter than the German Civil Code, which allowed marriages between (great-)uncle and (great-)niece and between (great-)aunt and (great-)nephew. Marriages between first cousins were allowed both in the Netherlands and Germany. ${ }^{57}$

Kinship caused a relative impediment to marriage as well. Article 88 (I) BW prohibited marriages between brothers-in-law and sisters-in-law, except for dispensation granted by the king. ${ }^{58}$ According to Scholten this prohibition was pointless in case a marriage was dissolved due to the decease of the partner through whom the kinship had existed. In that case a dispensation was always granted when asked for, making the prohibition effectively meaningless. The German Civil Code, which was of a later date than the Dutch Civil Code, had omitted this prohibition. ${ }^{59}$

According to Article 89 BW one was not allowed to marry the person one had had an adulterous relation with, in case this adultery had been considered proven by an order of the court. ${ }^{60}$ Any judgement satisfied in this respect, whether it was a criminal judgement, convicting one of the partners for adultery, a civil judgement, dissolving the marriage on the ground of adultery, or any other judgement in which the adulterous relation was proven but considered a side issue. This rule was supposed to have a preventative effect, although in general it was doubtful whether this aim was achieved. The prohibition of Article 89 BW was only effective when the names of the adulterous partners were

53 Article 254 BW: 'Het huwelijk wordt ontbonden: 2) Door afwezigheid van een der echtgenooten gedurende tien jaren, en een daarop volgend nieuw huwelijk van den anderen echtenoot, [...].'

54 Asser-Scholten, Handleiding tot de beoefening van het Nederlandsch Burgerlijk Recht. Familierecht, 51-52.

55 Article 87 BW: 'Het huwelijk is verboden tusschen alle personen, die elkander bestaan in de opgaande en nederdalende linie, hetzij door wettige, hetzij door onwettige geboorte, of door aanhuwelijking; en in de zijdlinie tusschen broeder en zuster, wettige of onwettig.

56 Article 88 BW: 'Ook is het huwelijk verboden: [...] 2) Tusschen oom of oud-oom en nicht of achternicht, mitsgaders tusschen moei of oud-moei en neef of achterneef, wettige of onwettige. De Koning kan, om gewigtige redenen het verbod in dit artikel vervat, door het verleenen van dispensatie opheffen.'

57 Asser-Scholten, Handleiding tot de beoefening van het Nederlandsch Burgerlijk Recht. Familierecht, 52-53.

58 Article 88 BW: 'Ook is het huwelijk verboden: 1) Tusschen schoonbroeder en schoonzuster, wettige of onwettige; [...] De Koning kan, om gewigtige redenen, het verbod, in dit artikel vervat, door het verleenen van dispensatie opheffen.'

59 Asser-Scholten, Handleiding tot de beoefening van het Nederlandsch Burgerlijk Recht. Familierecht, 54.

60 Article 89 BW: 'Een persoon, die bij regterlijk vonnis van overspel is overtuigd, mag nimmer met den medepligtige aan dat overspel in het huwelijk treden.' 
included in the judgement, which was often not the case. Scholten pointed out that the plaintiff was not allowed to demand such an inclusion, effectively making this article a dead letter. ${ }^{61}$

Furthermore, the Civil Code restrained remarrying. Article 9o (I) BW declared that after divorce or separation from bed and board, the ex-partners had to wait a year before they could remarry each other. ${ }^{62}$ After a second divorce or separation from bed and board, however, a third marriage between the ex-partners was not allowed. ${ }^{63}$ Originally, the second marriage was prohibited as well, and was only allowed after amendment of the law in $1922 .^{64}$

Relative incompetence also existed when the necessary permission to marry was missing. Minor ${ }^{65}$ legitimate children, ${ }^{66}$ minor illegitimate children ${ }^{67}$ and children of age but under 30 , whether legitimate or illegitimate, ${ }^{68}$ required permission from both parents, when - in case of illegitimacy - recognised by both parents. In case one or both parents were deceased or deprived of parental rights, the Civil Code provided for alternative solutions. ${ }^{69}$ Those who were made a ward of court because of squandering, alcohol abuse or weak intellectual powers required permission of both the curator bonis and the joint guardian. $^{70}$

In case the intended marriage was in breach of the law, certain people could oppose to conclusion of the intended marriage. This was called interruption (stuiting). ${ }^{71}$ To prevent misuse of law, interruption was only allowed to certain people, e.g. the parents of a minor or a person under legal restraint, the guardian or co-guardian or the grandparents, and only in cases which the law allowed for interruption. ${ }^{72}$ Articles II5 to I20 BW listed the cases in which interruption was allowed for. Interruption happened by means of

61 Asser-Scholten, Handleiding tot de beoefening van het Nederlandsch Burgerlijk Recht. Familierecht, 55. See also Land-Star Busmann, Verklaring van het Burgerlijk Wetboek. Boek I, Titel I-XIX en Rechtspersonen, 88-89; G. Diephuis, Het Nederlandsch Burgerlijk Regt. Familieregt, 36-37; Veegens-Oppenheim, Schets van het Nederlandsch Burgerlijk Recht, 71-72.

62 Article 90 (1) BW: 'Tusschen personen, wier huwelijk is ontbonden overeenkomstig het bepaald in artikel $254,3^{\circ}$. of $4^{\circ}$., kan geen nieuw huwelijk worden gesloten, dan nadat een jaar is verstreken, sedert de ontbinding van hun vorig huwelijk is ingeschreven in de registers van den burgerlijken stand.'

63 Article 90 (2) BW: 'Een verder huwelijk tusschen dezelfde personen is verboden.'

64 Asser-Scholten, Handleiding tot de beoefening van het Nederlandsch Burgerlijk Recht. Familierecht, 56; Veegens-Oppenheim, Schets van het Nederlandsch Burgerlijk Recht, 72. See also Wet tot beperking van het verbod van hertrouwen, gelegen in artikel 90 van het Burgerlijk Wetboek, 18 February 1922, Staatsblad (1922), No. 69. See also the explanatory memorandum Handelingen der Staten-Generaal (Tweede Kamer), bijlagen 1920-1921, no. 476.3, Memorie van Toelichting.

65 Minor were those who had not yet reached the age of 21 years and had not have been married before. See Article 385 BW.

66 Article 92 (1) BW: 'Voor het aangaan van een huwelijk behoeven minderjarige echte kinderen de toestemming hunner ouders.'

67 Article 97 (1) BW: 'Natuurlijk wettiglijk erkende kinderen kunnen zoolang zij minderjarig zijn geen huwelijk aangaan zonder de toestemming van den vader en de moeder door wie zij erkend zijn, [...].'

68 Article 99 (1) BW: 'Echte kinderen, die meerderjarig zijn, doch den vollen ouderdom van dertig jaren nog niet hebben bereikt, zijn insgelijks verpligt om tot het aangaan van een huwelijk de toestemming van hunnen vader en hunne moeder te verzoeken.'; Article 104 BW: 'De bepalingen der laatste vijf artikelen zijn insgelijks toepasselijk op natuurlijke kinderen, ten aanzien van den vader en de moeder door wie zij erkend zijn.'

69 See e.g. Article 92-96 BW; Asser-Scholten, Handleiding tot de beoefening van het Nederlandsch Burgerlijk Recht. Familierecht, 56-63.

70 Article 506 (2) BW: 'De uit hoofde van verkwisting, gewoonte van drankmisbruik of zwakheid van vermogens onder curatele gestelde behoeft om een huwelijk aan te gaan de toestemming van den curator en den toeziend curator; [...].'

71 See on interruption Asser-Scholten, Handleiding tot de beoefening van het Nederlandsch Burgerlijk Recht. Familierecht, 72 81.

72 Article 114 BW: 'Het regt om de voltrekking van een huwelijk te stuiten, komt alleenlijk toe aan de personen en in de gevallen bij de volgende artikelen voorzien.' 
a writ, ${ }^{73}$ which contained all reasons for interruption. ${ }^{74}$ In case the intended marriage was interrupted the registrar was not allowed to conclude the marriage before the interruption was annulled. ${ }^{75}$ Opinions differed on the legal consequences when a marriage was concluded despite an interruption. According to Scholten the text of Article I25 (2) $\mathrm{BW}^{76}$ allowed for both a strict interpretation - the marriage will be declared void - and a broad interpretation - the marriage can be declared void. ${ }^{77}$ Although Opzoomer favoured the broad interpretation, ${ }^{78}$ both Diephuis and Star Busmann were of the opinion that the purpose of interruption was the invalidity of the marriage and that therefore the strict interpretation should prevail. ${ }^{79}$ This would be consistent with the original French text of the draft article I27 (2) of I830, reading: 'Si le mariage a été célébré avant la mainlevée, la procedure sur l'opposition pourra être poursuivie, et le marriage sera declare nul si l'opposition est admise. ${ }^{80}$ According to Star Busmann Article 125 (2) contained an addition to the grounds of nullity, as numbered in section 6 (Article I4O-I54a). ${ }^{81}$

\section{- 4.2.2. Annulment of marriage}

As we have seen before a marriage could not be declared legally null and void because of violation of the law, but only in a limited number of cases. According to Article I40 BW a marriage could only be annulled by judicial decision. ${ }^{82}$ Furthermore, a marriage could only be annulled in a certain number of cases, on request of persons who were entitled by the law to do so. Diephuis pointed out that this strict regulation implied that a marriage which was concluded in defiance of the law could legally exist and continue to exist if those who were entitled to call for annulment failed or chose not to do so. ${ }^{83}$ Article I4 I to I47 BW listed nine grounds for annulment, generally following the list of internal requirements for marriage.

Violation of Article 84, which prohibited bigamy and polygamy, entitled the spouse of the earlier marriage, the spouses of the contested marriage, blood relations in ascending line, interested parties and the Prosecution Counsel to request annulment. ${ }^{84}$

In case the marriage was concluded without the free consent of (one of) the partners,

73 Article 801 (1) Rv: 'Bij stuiting des huwelijks moet het verzet gedaan worden bij eene akte, zoowel aan den ambtenaar van den burgerlijken stand, als aan de partij waartegen het verzet gerigt is, door eenen deurwaarder beteekend.'

74 Article 122 BW: 'In de akte van stuiting moeten alle de middelen worden uitgedrukt, waarop de stuiting gegrond is [....].'; Article 801 (2) Rv: 'Deze akte zal bevatten de gronden van het verzet, en de hoedanigheid welke aan den opposant regt geeft om tegen het huwelijk op te komen.'

75 Article 125 (1) BW: 'Wanneer er stuiting van een huwelijk plaats heeft, zal het aan den ambtenaar van den burgerlijken stand niet geoorloofd zijn hetzelve te voltrekken, dan nadat aan hem zal zijn ter hand gesteld een vonnis in kracht van gewijsde gegaan of een authentieke akte, waarbij de stuiting is opgeheven, op straffe van vergoeding van kosten, schaden en interessen.'

76 Article 125 (2) BW: 'Wanneer het huwelijk mogt zijn voltrokken voor dat de stuiting is opgeheven zal het geding ter zake dier stuiting kunnen worden voortgezet, en het huwelijk worden nietig verklaard, bijaldien de eisch aan den opposant is toegewezen.'

77 Asser-Scholten, Handleiding tot de beoefening van het Nederlandsch Burgerlijk Recht. Familierecht, 78-81.

78 C.W. Opzoomer, Het Burgerlijk Wetboek. Eerste deel, 199-201.

79 G. Diephuis, Het Nederlandsch Burgerlijk Regt. Familieregt, 77-78; Land-Star Busmann, Verklaring van het Burgerlijk Wetboek. Boek I, Titel I-XIX en Rechtspersonen, 110-112.

80 Burgerlijk Wetboek/Code Civil, 1830. This version of the Civil Code was overtaken by events, as the Southern Netherlands had separated from the Nothern Netherlands in 1830, before the Civil Code had come into force. The wording of Article 125 (2) BW has not changed compared to the Dutch version of the wording of Article 127 (2) of the original draft of 1830.

81 Land-Star Busmann, Verklaring van het Burgerlijk Wetboek. Boek I, Titel I-XIX en Rechtspersonen, 111-112.

82 Article 140 BW: 'De nietigheid eens huwelijks kan alleen door den regter worden uitgesproken.'

83 G. Diephuis, Het Nederlandsch Burgerlijk Regt. Familieregt, 107.

84 Article 141 (1) BW: 'De nietigverklaring van een huwelijk, in strijd met artikel 84 aangegaan, kan worden gevorderd door dengene, die met een der echtgenooten door vroeger huwelijk is verbonden, door de echtgenooten zelve, door de bloedverwanten in de opgaande linie, door alle dengenen, die bij de verklaring der nietigheid belang hebben, en door het openbaar ministerie.' 
only that partner was entitled to request annulment. ${ }^{85}$ Free consent was considered absent in case of force - which, according to Scholten, rarely happened ${ }^{86}$ - or error concerning the person of the other spouse. Article I42 (2) BW literally read: 'error in the person', ${ }^{87}$ which by many authors was strictly interpreted as to include only error concerning the identity of the person and not any personal qualities. ${ }^{88}$ The classic example to illustrate this article was the biblical marriage of Jacob with Lea instead of Rachel, an ultimate case of error concerning the identity of the fiancée. Diephuis furthermore added a case in which a blind person $A$ thinks he or she is marrying $B$, but instead is marrying C. ${ }^{89}$ Scholten dismissed this example as unlikely as a blind person would probably identify his or her partner correctly by voice recognition. ${ }^{90}$ Scholten tended to disagree with the strict interpretation of Article I42 (2) BW. By comparing the Dutch Civil Code with the French Code Civil, he added two other interpretations of error: error concerning the civil identity (identité civile), meaning that someone was trying to get married with forged documents, and error concerning a substantial quality (qualité substantielle), although this last interpretation was, with one exception, ${ }^{91}$ not accepted in French case law. ${ }^{92}$ Note the difference between de Dutch strict interpretation of error and the German $\mathbb{\$}$ I333 BGB, which, already before I933, had led to extensive case law concerning e.g. concealed impotence, venereal diseases, mental illnesses etc. ${ }^{93}$ Furthermore, in $\mathbb{1}$ I334 the German Bürgerliches Gesetzbuch allowed for annulment because of deception, a possibility which was not included in the Dutch Civil Code. According to Scholten, this was correct, as deception could either be committed with regard to circumstances, fortune, social status etc. concerning the other spouse, in which case the legislator apparently had not wished for an annulment, or with regard to the person him- or herself, in which case Article I 42 (2) BW would suffice. ${ }^{94}$ In case of three months of continuous cohabitation after regaining full freedom or having discovered the error, the erroneous spouse was no longer admissible. ${ }^{95}$

When a marriage was concluded with a person who, because of a mental illness, was under legal restraint, Article I43 entitled the parents, blood relations in ascending line,

85 Article 142 (1) BW: 'De wettigheid eens huwelijks, zonder de vrije toestemming der beide echtgenooten, of ook van een van hen aangegaan, kan alleen worden tegengesproken door de echtgenooten of door dengenen van hen, wiens toestemming niet is vrij geweest.'

86 Asser-Scholten, Handleiding tot de beoefening van het Nederlandsch Burgerlijk Recht. Familierecht, 96.

87 Article 142 (2) BW: 'Wanneer er dwaling heeft plaats gehad in den persoon met wien men gehuwd is, kan de wettigheid alleen worden betwist door dengenen der echtgenooten, die in dwaling gebragt is.'

88 G. Diephuis, Het Nederlandsch Burgerlijk Regt. Familieregt, 116-117; C.W. Opzoomer, Het Burgerlijk Wetboek. Eerste deel, 218-220; Land-Star Busmann, Verklaring van het Burgerlijk Wetboek. Boek I, Titel I-XIX en Rechtspersonen, 130-131; Veegens-Oppenheim, Schets van het Nederlandsch Burgerlijk Recht, 102.

89 G. Diephuis, Het Nederlandsch Burgerlijk Regt. Familieregt, 117.

90 Asser-Scholten, Handleiding tot de beoefening van het Nederlandsch Burgerlijk Recht. Familierecht, 96.

91 The exception contained a marriage which was concluded during the First World War, between a French woman and a German man, who was thought to be an Alsatian.

92 See Asser-Scholten, Handleiding tot de beoefening van het Nederlandsch Burgerlijk Recht. Familierecht, 96. This view was continued by Wiarda in Asser-Wiarda, Handleiding tot de beoefening van het Nederlands Burgerlijk Recht. Natuurlijke personen en familierecht, 128 in which was referred to a decision of the Amsterdam Court of Appeal of 1939 (Gerechtshof Amsterdam, 2 November 1939, Nederlandsche Jurisprudentie 1940, 175).

93 See also Asser-Scholten, Handleiding tot de beoefening van het Nederlandsch Burgerlijk Recht. Familierecht, $96-97$.

94 Ibid., 97.

95 Article 142 (3) BW: 'In alle de gevallen bij dit artikel voorkomende, is men in den eisch tot nietigverklaring niet ontvankelijk, wanneer er eene aanhoudende zamenwoning gedurende den tijd van drie maanden heeft plaats gehad, sedert dat de echtgenoot zijne volkomen vrijheid bekomen heeft, of de dwaling door hem ontdekt is.' 
siblings, uncles and aunts, the curator bonis and the Prosecution Counsel to request annulment. ${ }^{96}$ After removal of the legal restraint only the spouse concerned was entitled to request annulment, until six months after the removal, after which he or she was inadmissible. ${ }^{97}$ Article 143 did not mention mental illness without being under legal restraint as a ground for annulment, but, according to Scholten, annulment could be based on Article I42 BW, whilst analogous application of Article I43 BW could point out the persons entitled to request annulment, with the exception of the curator bonis. ${ }^{98}$ Oppenheim seemed to hold the same point of view by stating that in case of mental illness free consent was missing. ${ }^{99}$ However, as we have seen before, Star Busmann declared that annulment because of a mental illness of one of the partners was restricted to the literal meaning of Article I43 BW, which did not explicitly list mental illness without legal restraint as a ground for annulment. ${ }^{100}$ He referred to a footnote by Opzoomer, which stated that, although it was absurd, the law provided no consequences when one of the partners suffered from a mental illness, albeit not being under legal restraint. ${ }^{101}$

Being too young was another ground for annulment according to Article $144 \mathrm{j}^{\circ} 86 \mathrm{BW}$. In that case annulment could be requested both by the partner who was too young and the Prosecution Counsel. ${ }^{102}$ Annulment could no longer be requested after the required age had been reached or in case the woman, albeit being too young, was pregnant before the day the legal action was instituted. ${ }^{103}$ As a minimum age was legally required to ensure the ability of procreation, this requirement could obviously be considered superseded in the above-mentioned situation.

Article I 45 BW stated that in case a marriage was concluded in defiance with Article $87,88,89$ or $90 \mathrm{BW}$, the spouses concerned, the parents, blood-relations in ascending line, interested parties and the Prosecution Counsel could request annulment. ${ }^{104}$

Absence of permission of those whose permission was required according to Articles 92 to $98 \mathrm{BW}$ and - according to Scholten - Article 506 (2) BW ${ }^{105}$ entitled those persons to request annulment, ${ }^{106}$ except when the marriage was explicitly or tacitly approved of

96 Article 143 (1) BW: 'Wanneer een huwelijk is aangegaan door iemand die, uit hoofde van gebrek aan verstandelijke vermogens, is onder curatele gesteld, kan de wettigheid des huwelijks worden betwist door deszelfs vader, moeder en andere bloedverwanten in de opgaande linie, broeders, zusters, ooms en moeijen, mitsgaders door den curator, en eindelijk door het openbaar ministerie.'

97 Article 143 (2) BW: 'Na opheffing der curatele, kan de nietigheid alleen worden ingeroepen door den echtgenoot die onder curatele was gesteld, en is ook deze daartoe niet ontvankelijk, na zamenwoning van zes maanden, te rekenen van de intrekking der curatele.'

98 Asser-Scholten, Handleiding tot de beoefening van het Nederlandsch Burgerlijk Recht. Familierecht, 98.

99 Veegens-Oppenheim, Schets van het Nederlandsch Burgerlijk Recht, 102.

100 Land-Star Busmann, Verklaring van het Burgerlijk Wetboek. Boek I, Titel I-XIX en Rechtspersonen, 92.

101 C.W. Opzoomer, Het Burgerlijk Wetboek. Eerste deel, 178.

102 Article 144 (1) BW: 'Indien een huwelijk is aangegaan door een persoon, welke den bij artikel 86 vereischten ouderdom niet bereikt had, zal de nietigverklaring kunnen worden gevraagd, hetzij door dien echtgenoot, hetzij door het openbaar ministerie.'

103 Article 144 (2) BW:'De wettigheid des huwelijks zal nogtans niet kunnen worden betwist: 1) Wanneer op den dag der regtsvordering tot nietigverklaring, de echtgenoot of echtgenooten den vereischten ouderdom hebben bereikt; 2) Wanneer de vrouw, den vereischten ouderdom niet hebbende bereikt, vóór den dag der regtsvordering zwanger is.'

104 Article 154 BW: 'De nietigheid van alle huwelijken, aangegaan, met overtreding der bepalingen in artikel 87, 88,89 en 90 vervat, kan worden ingeroepen, hetzij door de echtgenooten zelven, hetzij door hunne ouders of bloedverwanten in de opgaande linie, hetzij door allen die daarbij belang hebben hetzij eindelijk door het openbaar ministerie.'

105 Asser-Scholten, Handleiding tot de beoefening van het Nederlandsch Burgerlijk Recht. Familierecht, 99.

106 Article 146 (1) BW: 'Wanneer een huwelijk is aangegaan zonder toestemming van den vader, de moeder, de grootouders, den voogd, of den toezienden voogd, zal deszelfs nietigverklaring, in de gevallen, waarin de toestemming, of wel het verhoor van den voogd, volgens artikel 92, 93, 94, 95, 96, 97 en 98 vereischt wordt, alleen kunnen gevorderd worden door degenen wier toestemming fo verhoor, volgens de wet, noodzakelijk is geweest.' 
or when six months after they had learned about the marriage had passed. ${ }^{107}$

In case of incompetence of the registrar or a defiance in either the number or the conditions of the witnesses, Article I47 entitled the spouses, blood-relations in ascending line, curator bonis, joint guardian, interested parties and the Prosecution Council to request annulment. ${ }^{108}$

The final ground for annulment was not included in section six, but was found in Article 25 (2) BW, which - according to Star Busmann and Scholten - could be regarded as an addition to the grounds of annulment. ${ }^{109}$ This article contained the provision that in case a marriage was concluded despite an interruption, the marriage could be annulled. ${ }^{110}$ According to Star Busmann the appellant, i.e. the person who had interrupted the marriage, was entitled to request annulment. ${ }^{111}$

In principle the consequences of having a marriage annulled was that it had never existed, meaning that children would be illegitimate, there had never been a marital community etc. However, this rule was moderated in case of good faith, either of (one of) the spouses, or of others. ${ }^{112}$ In case both partners had been of good faith, the marriage ceased to exist from the day of annulment. ${ }^{113}$ Until that day it had legally existed, with all consequences attached, meaning e.g. that children, born before the day of annulment, were considered legitimate. ${ }^{114}$ The same was true in case of good faith of only one of the spouses, provided that the marriage only had civil consequences in favour of the bona fides spouse and possible children. ${ }^{115}$ Good faith existed in case the spouses were unaware of the fact that their intended marriage was legally prohibited, either because of unawareness concerning the facts or because of unawareness concerning the law. Spouses were presumed to be of good faith. ${ }^{116}$

107 Article 146 (2) BW: 'De regtsvordering tot nietigverklaring kan door de bloedverwanten, wier toestemming vereischt werd, niet worden aangevangen, wanneer het huwelijk door hen uitdrukkelijk of stilzwijgend is goedgekeurd, of wanneer zes maanden zonder tegenspraak van hunne zijde, verloopen zijn, sedert het tijdstip waarop zij van het huwelijk hebben kennis gedragen.'

108 Article 147 (1) BW: 'De nietigheid van een huwelijk, hetwelk niet ten overstaan van den bevoegden ambtenaar van den burgerlijken stand, en in tegenwoordigheid van het vereischte getal getuigen, is voltrokken, kan worden ingeroepen door de echtgenooten, door den vader, de moeder en andere bloedverwanten in opgaande linie, mitsgaders door den voogd, den toezienden voogd, en door allen die daarbij belang hebben, en eindelijk door het openbaar ministerie.'

109 Land-Star Busmann, Verklaring van het Burgerlijk Wetboek. Boek I, Titel I-XIX en Rechtspersonen, 111; Asser-Scholten, Handleiding tot de beoefening van het Nederlandsch Burgerlijk Recht. Familierecht, 100.

110 Article 125 (2) BW: 'Wanneer het huwelijk mogt zijn voltrokken voor dat de stuiting is opgeheven, zal het geding ter zake dier stuiting kunnen worden voortgezet, en het huwelijk worden nietig verklaard, bijaldien de eisch aan den opposant is toegewezen.'

111 Land-Star Busmann, Verklaring van het Burgerlijk Wetboek. Boek I, Titel I-XIX en Rechtspersonen, 111.

112 Asser-Scholten, Handleiding tot de beoefening van het Nederlandsch Burgerlijk Recht. Familierecht, 102.

113 Article 152 BW: 'In de gevallen van de twee voorgaande artikelen, houdt het huwelijk op burgerlijke gevolgen te hebben, te rekenen van den dag waarop hetzelve bij vonnis is nietig verklaard.'

114 Article 150 BW: 'Een huwelijk, hetwelk nietig verklaard is, heeft niettemin alle deszelfs burgerlijke gevolgen, zoowel ten opzigte der echtgenooten, als van de kinderen, wanneer hetzelve te goeder trouw door beide de echtgenooten is aangegaan.'

115 Article 151 (1) BW: 'Wanneer de goede trouw alleenlijk bestaat aan de zijde van een der echtgenooten, heeft het huwelijk gene burgerlijke gevolgen, dan alleen ten voordeele van dien echtgenoot en van de kinderen, uit het huwelijk ontsproten.'

116 Asser-Scholten, Handleiding tot de beoefening van het Nederlandsch Burgerlijk Recht. Familierecht, 102-104; G. Diephuis, Het Nederlandsch Burgerlijk Regt. Familieregt, 135-145. 


\section{- 4.2.3. Dissolution of marriage}

The dissolution of marriage has been subject of an age-long discussion. By pleading with the bible ${ }^{117}$ the Catholic Church has turned against divorce especially for centuries. Marriage was seen as a sacrament, an indissoluble bond. Separation from bed and board was introduced as a make-shift solution, abolishing the obligation of living together. The marriage, however, remained untouched. ${ }^{118}$ This changed after 158I, after which marriage was considered from a Calvinist point of view, allowing for divorce in case of adultery and desertion. ${ }^{119}$ The Canon notion of separation from bed and board remained to exist as well. Nevertheless, divorce, and to a certain extent separation from bed and board, were condemned by public opinion.

In France, the revolution meant a breach with the Canon past, introducing the notion of marriage as a civil contract. In 1792 , revolutionary ideals had also introduced the principle of divorce in French law, arguing that 'what God had permitted to drift apart, man should not forcibly keep together. ${ }^{120}$ This was quite a liberal approach towards divorce, even allowing divorce by mutual consent ${ }^{121}$ and because of incompatibility of personalities. ${ }^{122}$ The Napoleonic Code Civil of I804, however, limited the grounds for divorce to adultery, ${ }^{123}$ outrageous conduct, ill-usage, or grievous injuries, exercised by one of the spouses towards the other ${ }^{124}$ condemnation of one of the spouses to an infamous punishment ${ }^{125}$ and mutual consent. ${ }^{126}$ Separation from bed and board (separation de corps) was provided for as well, although only in cases in which divorce because of a determinate cause was allowed. ${ }^{127}$ Separation by mutual consent was thus not allowed. ${ }^{128}$ Divorce by mutual consent remained rare in practice, as it was aggravated by formalities. ${ }^{129}$ Divorce was entirely abolished in I8I 6 and only reinstituted - after several attempts - in I884. ${ }^{130}$

In 1809 the Netherlands adopted the Wetboek Napoleon, ingerigt voor het Koningrijk Holland, which explicitly prohibited divorce by mutual consent. ${ }^{131}$ Shortly thereafter, in I8I I, the Wetboek Napoleon was replaced by the Code Civil, which was abolished in I838,

117 A complete condemnation of divorce was based on Mark 10:11-12 and Luke 16:17.

118 See for an extensive overview of canonical matrimonial law M. Antokolskaia, Harmonisation of Family Law in Europe: A Historical Perspective, 83-114.

119 The Protestants made use of the bible as well, although they cited Matthew 5:31-32 and 19:7-9 which seemed to allow divorce in case of adultery, and I Corinthians 7:15, which, by a slightly artificial reasoning, seemed to allow divorce in case of desertion.

120 Décret qui détermine les causes, le mode et les effets du divorce du 20 Septembre 1792; see also A.H. Huussen, 'The Discussion about the Extension of Divorce in the Netherlands, 1870-1970', 313.

121 Ibid., Article 2: 'Le divorce a lieu par le consentement mutuel des époux.'

122 Ibid., Article 3: 'L'un des époux peut faire prononcer le divorce sur la simple allégation d'incompatibilité d'humeur ou de caractère.' See also M. Antokolskaia, Harmonisation of Family Law in Europe: A Historical Perspective, 199.

123 Code Civil des Français, Article 229: 'Le mari pourra demander le divorce pour cause d'adultère de sa femme.'; Ibid. Article 230: 'La femme pourra demander le divorce pour cause d'adultère de son mari, lorsqu'il aura tenu son concubine dans la maison commune.'

124 Ibid., Article 231: 'Les époux pourront réciproquement demander le divorce pour excès, sévices ou injures graves, de l'un d'eux envers l'autre.'

125 Ibid., Article 232: 'La condemnation de l'un des époux à une peine infamante, sera pour l'autre époux une cause de divorce.'

126 Ibid., Article 233: 'Le consentement mutuel et perseverant des époux, exprimé de la manière prescrite par la loi, sous les conditions et après les épreuves qu'elle determine, prouvera suffisamment que la vie commune leur est insupportable, et qu'il existe, par rapport à eux, une cause péremptoire de divorce.'

127 Ibid., Article 306: 'Dans les cas où il y a lieu à la demande en divorce pour cause déterminée, il sera libre aux époux de former demande en séparation de corps.'

128 Ibid., Article 307: '[...] elle ne pourra avoir lieu par le consentement mutuel des époux.'

129 See Code Civil des Français, Articles 275-294. See furthermore M. Antokolskaia, Harmonisation of Family Law in Europe: A Historical Perspective, 200.

130 M. Antokolskaia, Harmonisation of Family Law in Europe: A Historical Perspective, 217.

131 Wetboek Napoleon, ingerigt voor het Koningrijk Holland, 1809, Article 218: 'Echtscheiding mag geen plaats hebben dan om wettige redenen; in het bijzonder is de enkele wederzijdsche overeenkomst der echtgenooten daartoe ongenoegzaam.' 
when the new Dutch Civil Code came into force. As we have seen before the subject of divorce had caused quite a stir during the lawmaking process, as the mainly roman catholic jurists in the Southern Netherlands wanted the Dutch Civil Code to be written in the tradition of the French Civil Code and to secure the canonical views on marriage and divorce, whilst the mainly protestant jurists in the Northern Netherlands preferred a more traditional Dutch kind of legislation. In I 820 the revision of the first draft of the new Dutch Civil Code ${ }^{132}$ was presented, introducing five grounds for divorce: adultery, or unnatural indecency, malicious and continuous desertion, attempt of murder against or ill-treatment of the other spouse, his or her parents or children, and a criminal offence sentenced with the scaffold, imprisonment or banishment for more than five years. ${ }^{133}$ Divorce by mutual consent was explicitly prohibited. ${ }^{134}$ As a result of this draft, a fierce discussion erupted, especially in the catholic Southern Netherlands. Public opinion was strongly against divorce, which would only have a negative effect on public morality. Besides, the government should not create legal options for something which was forbidden by the Church. The traditional canon notion of separation from bed and board contained sufficient safeguards for those couples to whom living together had become unbearable. Adherents of divorce claimed that divorce would avoid the greater evil, like adultery, desertion or hostile acts by one of the spouses. Nevertheless, they declared to be opponents of divorce by mutual consent. The Civil Code of 1838 was a compromise between the two views in many respects. ${ }^{135}$

According to Article 254 of the Civil Code of 1838 , a marriage could be dissolved in case of I) decease of one of the spouses, 2) absence of one of the spouses for a certain period of time followed by a new marriage of the other spouse, 3) continued separation from bed and board for five years and 4 ) divorce. ${ }^{136}$

The first cause needs no further explanation. The second cause followed from the fact that the Netherlands was a seafaring nation. Annually, shipping claimed several lives, mostly men, which was often difficult to prove for relatives as accidents often happened

132 Joan Melchior Kemper started working on his first draft in 1814 and presented this draft in 1816, which was, however, overtaken by events, as in 1815, the Southern Netherlands had joined the Northern Netherlands. A revision was necessary, which was presented in 1820 .

133 Ontwerp van het Burgerlijk Wetboek voor het Koningrijk der Nederlanden, 1820, Article 425: 'De echtscheiding mag worden gevorderd: 1) Wegens overspel of onnatuurlijke ontucht door den anderen echtgenoot gepleegd; 2) Wegens moedwillige en bestendige verlating door den anderen echtgenoot; 3) Wegens poging tot moord of doodslag, door den anderen echtgenoot tegen den genen, die de echtscheiding vordert, begaan, of wegens moord of doodslag of poging daartoe tegen de ouders of kinderen van den laatstgemelden begaan; wegens zware verwondingen of verminkingen met geleider lage en verraderlijk aan den laatstgemelden, deszelfs ouders of kinderen toegebragt; 4) Wegens het schuldig of medepligtig zijn van den anderen echtgenoot aan zoodanige misdaden, welke ten minste eene veroordeeling bij uiterlijk gewijsde tot schavotstraf en tevens tot gevangenis of bannisement uit den geheelen Staat, te zamen of afzonderlijk, voor niet minder dan vijf jaren, hebben ten gevolge gehad.'

134 Ibid., Article 422: '[...] De regters moeten toezien dat gene huwelijken ontbonden worden uit versierde oorzaken, of door bedekte overeenkomsten der partijen.'; Article 424: 'Echtscheiding kan geen plaats hebben, dan ten gevolge eener opzettelijke regtsvordering van den eenen echtgenoot tegen den anderen, en op grond van een der redenen, bij het volgend artikel opgeteld, zelfs niet met toestemming der partijen. [...].'

135 A.H. Huussen, 'The Discussion about the Extension of Divorce in the Netherlands, 1870-1970', 313-315.

136 Article 254 BW: 'Het huwelijk wordt ontbonden: 1) Door den dood; 2) Door afwezigheid van een der echtgenooten gedurende tien jaren, en een daarop gevolgd nieuw huwelijk van den anderen echtgenoot, [...]; 3) Door regterlijk vonnis na scheiding van tafel en bed en inschrijving van de daarbij uitgesproken ontbinding des huwelijks in de registers van den burgerlijken stand, [...]; 4) Door echtscheiding, [...].' 
far away. This would leave the other spouse, usually the woman, with no possibilities of remarrying, as nor the Code Civil nor the I 830 draft Civil Code provided for a solution. ${ }^{137}$ Article 254 (2) BW required ten years of absence followed by a new marriage of the other spouse. For people at sea, additional rules were developed after 1838 , starting with a law from $\mathrm{I} 855,{ }^{138}$ which required terms of three years of absence for those who belonged to either the crew or the passengers of a ship ${ }^{139}$ and one year of absence for those who went missing because of an accident happening to a ship or a part of its crew or passengers. ${ }^{140}$ This law was modernised in 1920, ${ }^{141}$ after many fishermen had died during the First World War because of mines and nothing was heard concerning them and their ships. ${ }^{142}$ Article I indicated that for those who belonged to either the crew or the passengers of a ship or for those who went missing because of an accident happening to a ship or a part of its crew or passengers, the ten-year term of Article 254 (2) BW was restricted to one year. ${ }^{143}$

\subsubsection{Separation from bed and board}

In a society in which marriage was considered an indissoluble bond, separation from bed and board provided a reasonable alternative for those couples to whom living together had become impossible, as it left the marriage intact. The Civil Code of I 838 , however, created the opportunity to dissolve the marriage after separation from bed and board, a novelty in the Netherlands. More importantly, indirectly it allowed for dissolution of marriage by mutual consent, even when divorce by mutual consent was strictly prohibited.

Separation from bed and board was allowed on the same grounds as was divorce, i.e. adultery, desertion with malicious intent, sentence to a minimum of four years' imprisonment and ill-treatment or serious injuries inflicted by the other spouse, causing a threat to life. ${ }^{144}$ Separation from bed and board was furthermore allowed in case of excesses, ill-treatments and serious insults by one spouse towards the other spouse, ${ }^{145}$

137 Asser-Scholten, Handleiding tot de beoefening van het Nederlandsch Burgerlijk Recht. Familierecht, $242-243$.

138 Wet, houdende uitzondering op de artikelen 523, 526 en 549 van het Burgerlijk Wetboek, ten opzigte van vermiste personen bij vermoedelijke of bekende scheepsrampen, 9 July 1855, Staatsblad (1855), No. 67.

139 Ibid., Article 1: 'Het tijdsverloop van vijf of tien jaren, in de artikelen 523, 526 en 549 van het Burgerlijk Wetboek gevorderd, wordt beperkt tot drie jaren, wanneer de afwezige tot de bemanning of passagiers blijkt behoord te hebben van een schip, waarvan gedurende dien tijd geene berigten zijn ingekomen. [...].'

140 Ibid., Article 2: 'Hetzelfde tijdsverloop van vijf of tien jaren wordt tot één jaar ingekort, wanneer de afwezige vermist is ter gelegenheid eener noodlottige gebeurtenis, op 's lands kusten, binnenlandsche zeeën of wateren, aan eenig vaartuig, aan een deel zijner bemanning of zijner passagiers overkomen. [...].'

141 Wet, tot wijziging van de termijnen bedoeld in de artikelen 523, 526 en 549 van het Burgerlijk Wetboek en afschaffing der wet van 9 Juli 1855, 26 March 1920, Staatsblad (1920), No. 148 and Wet, houdende verbetering van de wet van den 26 sten Maart 1920, tot wijziging van de termijnen bedoeld in de artikelen 523, 526 en 549 van het Burgerlijk Wetboek en afschaffing der wet van 9 Juli 1855, 4 December 1920, Staatsblad (1920), No. 864.

142 Veegens-Oppenheim, Schets van het Nederlandsch Burgerlijk Recht, 201-202.

143 Wet, tot wijziging van de termijnen bedoeld in de artikelen 523, 526 en 549 van het Burgerlijk Wetboek en afschaffing der wet van 9 Juli 1855, 26 March 1920, Staatsblad (1920), No. 148, Article 1: 'Het tijdsverloop van vijf of tien jaren, in de artikelen 523, 526 en 549 van het Burgerlijk Wetboek gevorderd, wordt beperkt tot één jaar: 1) wanneer de afwezige tot de bemanning of passagiers blijkt behoord te hebben van een vaartuig, waarvan gedurende dien tijd geene berichten zijn ingekomen; 2) wanneer de afwezige vermist is ter gelegenheid eener noodlottige gebeurtenis aan eenig vaartuig, aan een deel zijner bemanning of zijner passagiers is overkomen. [...].'

144 See Article 288 (1) BW: 'In de gevallen, welke grond tot echtscheiding opleveren, zal het aan de echtgenooten vrijstaan om de scheiding van tafel en bed in regten te vragen.' and Article 264 BW: 'De gronden, welke eene echtscheiding kunnen ten gevolge hebben, bestaan alleen in de navolgende: 1) Overspel; 2) Kwaadwillig verlating; 3) Veroordeeling wegens misdrijf tot eene vrijheidsstraf van vier jaren of langer, na het huwelijk uitgesproken; 4) Zware verwondingen of zoodanige mishandelingen, door den eenen echtgenoot jegens den anderen gepleegd, waardoor diens leven wordt in gevaar gebragt of waardoor hem gevaarlijke verwondingen zijn toegebragt.'

145 Article 288 (2) BW: 'Die regtsvordering zal ook kunnen worden aangevangen, ter zake van buitensporigheden, mishandelingen, en grove beleedigingen, door den eenen echtgenoot jegens den anderen begaan.' 
although one of these acts was sufficient to request for separation from bed and board. ${ }^{146}$ Finally, according to Article 29I BW, separation from bed and board could also be pronounced at mutual request, without the partners having to give a ground for such a request. This, however, could only be done after at least two years of marriage. ${ }^{147}$

Article 255 BW stated that after five years of separation from bed and board, and if no reconciliation had taken place, the partners could individually request for dissolution. ${ }^{148}$ Dissolution was done by judicial decision, which had to be entered into the register of births, deaths and marriages. ${ }^{149}$ If this was omitted, the judgement expired after six months, after which dissolution of marriage could no longer be requested on the same ground. ${ }^{150}$ This rule was included in the Civil Code in $1915,{ }^{151}$ although before that date the necessity of registration was often assumed. Nevertheless, the real meaning of registration had been unclear up to then. ${ }^{152}$

Although this procedure indirectly enabled dissolution of marriage by mutual consent, ${ }^{153}$ according to Diephuis it was not at odds with the prohibition of divorce by mutual consent as stated in Article 263 BW. Divorce ended a marriage which still existed in full, whilst dissolution after separation from bed and board ended a marriage which was formally intact, but of which many legal effects had already been removed. Furthermore, dissolution after separation from bed and board occurred gradually, compared to the instant dissolution by divorce. ${ }^{154}$

\subsubsection{Divorce}

Whether or not a marriage could be dissolved by divorce has been an age-long discussion, dominated by mostly religious arguments. According to Oppenheim, however, maintaining a marriage in which both partners had sound reasons to wish for dissolution as the marriage had become unbearable, was not in the public interest. Incidentally, the law only allowed for dissolution by divorce of the civil marriage, not the church marriage. Nevertheless, according to Oppenheim, public interest was not served by a general possibility of divorce without sound reasons either. The general opinion on divorce was that it should certainly not be encouraged. Nevertheless, divorce was a necessary evil, which had to prevent worse. ${ }^{155}$

146 Veegens-Oppenheim, Schets van het Nederlandsch Burgerlijk Recht, 182.

147 Article 291 BW: 'Scheiding van tafel en bed kan ook door den regter worden uitgesproken, op het verzoek, door de beide echtgenooten te zamen gedaan, zonder dat deze gehouden zijn eene bepaalde oorzaak op te geven. Zoodanige scheiding zal niet kunnen worden toegestaan, ten zij de echtgenooten gedurende den tijd van twee jaren zijn getrouwd geweest.'

148 Article 255 BW: 'Wanneer echtgenooten van tafel en bed zijn gescheiden, het zij uit hoofde van eene der redenen bij artikel 288 vermeld, het zij op beider verzoek, en de scheiding gedurende vijf volle jaren, zonder verzoening der partijen, heeft stand gehouden, zal het aan ieder hunner vrijstaan om den anderen in regten op te roepen, en te eischen dat het huwelijk worde ontbonden.'

149 Article 260 (1) BW: 'Het huwelijk wordt ontbonden door het vonnis en de inschrijving van de daarbij uitgesproken ontbinding in de registers van den burgerlijken stand.'

150 Article 276 (5) BW: 'Indien de inschrijving binnen dien termijn niet is geschied, vervalt daardoor de kracht van het vonnis, waarbij de echtscheiding is uitgesproken, en kan die om dezelfde redenen niet opnieuw worden geëischt.'

15127 March 1915, Staatsblad (1915), No. 172.

152 Veegens-Oppenheim, Schets van het Nederlandsch Burgerlijk Recht, 205.

153 Asser-Scholten, Handleiding tot de beoefening van het Nederlandsch Burgerlijk Recht. Familierecht, 239; Veegens-Oppenheim, Schets van het Nederlandsch Burgerlijk Recht, 200-201.

154 G. Diephuis, Het Nederlandsch Burgerlijk Regt. Familieregt, 493-494.

155 Veegens-Oppenheim, Schets van het Nederlandsch Burgerlijk Recht, 199-200; Land-Star Busmann, Verklaring van het Burgerlijk Wetboek. Boek I, Titel I-XIX en Rechtspersonen, 307-308. 
As in Germany, divorce was grounded on the guilt principle, meaning that divorce could only be pronounced in case the summoned partner had committed some wrong. Article 264 of the Civil Code of 1838 contained four grounds for divorce: adultery, desertion with malicious intent, sentence to a degrading punishment and ill-treatment or serious injuries inflicted by the other spouse, causing a threat of life. ${ }^{156}$ Besides the exhaustive account in Article 264, Article 263 explicitly prohibited divorce by mutual consent. $^{157}$

In case of adultery it was irrelevant which of the partners had committed adultery. This was a deviation from the French Code Civil, which declared that in case of adultery committed by the man, divorce was only allowed if the adulterous acts had been committed in the marital home. ${ }^{158}$ In case the woman had committed adultery, her husband could request divorce anytime. ${ }^{159}$ The adulterous acts had to be imputable; no adultery was committed in case a woman was raped. ${ }^{160}$

Article 425 of the i 820 draft of Kemper not only contained adultery as a ground for divorce, but also 'unnatural vice' (onnatuurlijke ontucht). ${ }^{161}$ This ground was omitted from the I 838 Civil Code, according to Scholten because this ground was about sodomy (crimen nefandum) which acts could not be classified as adultery. ${ }^{162}$ However, the German Bürgerliches Gesetzbuch did include this ground in $\mathbb{\$} 1565 .{ }^{163}$

In case both partners had committed adultery, both partners could individually request for divorce. By contrast, the Code Napoleon for the Kingdom of Holland stated in Article 220 that he who, by his own misconduct, had caused a ground for divorce, was no longer entitled to request for divorce because of misconduct by the other spouse. ${ }^{164}$

A declaration that adultery had been committed was sufficient to state adultery as the ground for the requested divorce, a factual description was unnecessary. Presumptive evidence, often deduced from the fact that one of the spouses had spent the night with a third person in the same room were only one bed was present, was enough to get the divorce granted. Furthermore, when a woman gave birth to a child whilst her husband had not been in the possibility to have intercourse with her between the $300^{\text {th }}$ and the

156 Article 264 BW: 'De gronden, welke eene echtscheiding kunnen ten gevolge hebben, bestaan alleen in de navolgende: 1) Overspel; 2) Kwaadwillige verlating; 3) Veroordeeling tot eene onteerende straf, na het huwelijk uitgesproken; 4) Zware verwondingen, of zoodanige mishandelingen, door den eenen echtgenoot jegens den anderen gepleegd, waardoor diens leven wordt in gevaar gebragt, of waardoor hem gevaarlijke verwondingen zijn toegebragt.'

157 Article 263 BW: 'Echtscheiding kan nimmer door onderlinge toestemming plaats hebben.'

158 See Article 230 Code Civil: 'La femme pourra demander le divorce pour cause d'adultère de son mari, lorsqu'il aura tenu son concubine dans la maison commune.'

159 See Article 229 Code Civil: 'Le mari pourra demander le divorce pour cause d'adultère de sa femme.'

160 Asser-Scholten, Handleiding tot de beoefening van het Nederlandsch Burgerlijk Recht. Familierecht, 253; G. Diephuis, Het Nederlandsch Burgerlijk Regt. Familieregt, 507.

161 Ontwerp van het Burgerlijk Wetboek voor het Koningrijk der Nederlanden, 1820, Article 425: 'De echtscheiding mag worden gevorderd: 1) Wegens overspel of onnatuurlijke ontucht door den anderen echtgenoot gepleegd; [...].'

162 Asser-Scholten, Handleiding tot de beoefening van het Nederlandsch Burgerlijk Recht. Familierecht, 253.

$163 \S 1565$ BGB: 'Ein Ehegatte kann auf Scheidung klagen, wenn der andere Ehegatte sich des Ehebruchs oder einer nach den $\S \S 171,175$ des Strafgesetzbuchs strafbaren Handlung schuldig macht. [...].' See also § 175 StGB: 'Die widernatürliche Unzucht, welche zwischen Personen männlichen Geschlechts oder von Menschen mit Thieren begangen wird, ist mit Gefängniß zu bestrafen; auch kann auf Verlust der bürgerlichen Ehrenrechte erkannt werden.'

164 Wetboek Napoleon, ingerigt voor het Koningrijk Holland, 1809, Article 220: 'Die door zijn eigen wangedrag de oorzaak geweest is, dat er eene reden tot echtscheiding aanwezig is, kan van zijnen kant de echtscheiding geenszins vorderen.' See also AsserScholten, Handleiding tot de beoefening van het Nederlandsch Burgerlijk Recht. Familierecht, 253. 
I $8 \mathrm{O}^{\text {th }}$ day before the delivery, this counted as proof of adultery ${ }^{165}$ even when the husband had not repudiated fatherhood in time. ${ }^{166}$

As we have seen before, divorce because of malicious desertion by one of the spouses was recognised in the Protestant era by linking up with I Corinthians 7:15. ${ }^{167}$ Although the Code Civil did not explicitly recognise malicious desertion as a separate ground for divorce, one could often appeal to Article 23I, ${ }^{168}$ citing excès, sévices ou injures graves as ground for divorce. Desertion by malicious intent was understood to mean the refusal to live together, which formulation replaced the old phrasing in the draft revision of the Civil Code of $1886 .{ }^{169}$ According to Diephuis ${ }^{170}$ desertion did not contain repudiation, although Scholten ${ }^{171}$ argued that repudiation was on the same footing as desertion.

The desertion had to be malicious, without legal cause. In case a woman refused to live in a house which was unsuitable, giving their social position, this desertion could not be considered malicious.

Article 266 furthermore required a continuation of the desertion for five years, before divorce could be requested. ${ }^{172}$ The wording of Article 266 (2) BW: 'Divorce [...] can only be requested in case the spouse who has left the communal home without legal cause, insists in his refusal to return to the other spouse ${ }^{\text {,173 }}$ had lead some to believe that a formal request from the deserted spouse to the other spouse to return was necessary. According to both Diephuis and Scholten, however, one could assume that the legislator had meant that unwillingness to return could be deduced from the circumstances, rendering an explicit request to return unnecessary. ${ }^{174}$

With regard to the third ground for divorce, the Civil Code originally used the wording 'sentence to a degrading punishment'. ${ }^{175}$ This was changed in I 884 to 'sentence to a minimum of four years' imprisonment. ${ }^{, 176}$ In both the Code Napoleon for the Kingdom

165 Asser-Scholten, Handleiding tot de beoefening van het Nederlandsch Burgerlijk Recht. Familierecht, 252-253; G. Diephuis, Het Nederlandsch Burgerlijk Regt. Familieregt, 507.

166 In that case the child was regarded as a legitimate child, despite the evident adultery. See Article 307 BW.

167 I Corinthians 7:15: 'But if the unbeliever leaves, let him do so. A believing man or woman is not bound in such circumstances; God has called us to live in peace.'

168 Article 231 Code Civil: 'Les époux pourront réciproquement demander le divorce pour excès, sévices ou injures graves, de l'un d'eux envers l'autre.'

169 Ontwerp tot herziening van het Burgerlijk Wetboek, 1886, Article 230: 'Echtscheiding kan worden gevorderd op grond van: [...] 3) weigering van samenwoning; [...].' See also Article 231 and 232 of the draft.

170 G. Diephuis, Het Nederlandsch Burgerlijk Regt. Familieregt, 508.

171 Asser-Scholten, Handleiding tot de beoefening van het Nederlandsch Burgerlijk Recht. Familierecht, 254-255.

172 Article 266 (3) BW: 'De regtsvordering daartoe kan niet vroeger worden aangevangen, dan na verloop van vijf jaren, te rekenen van het tijdstip waarop de echtgenoot de gemeene woning verlaten heeft.'

173 Article 266 (2) BW: 'De eisch tot echtscheiding, uit hoofde van kwaadwillige verlating kan alleen worden toegestaan, wanneer degene der echtgenooten, die de gemeene woonplaats, zonder wettige oorzaak, heeft verlaten, in zijne weigering volhardt om tot zijnen echtgenoot terug te keeren.'

174 G. Diephuis, Het Nederlandsch Burgerlijk Regt. Familieregt, 510; Asser-Scholten, Handleiding tot de beoefening van het Nederlandsch Burgerlijk Recht. Familierecht, 255.

175 Article 264 (3): 'Veroordeeling tot eene onteerende straf, na het huwelijk uitgesproken.'

176 Wet van 26 April 1884, houdende wijzigingen in het Burgerlijk Wetboek, 26 April 1884, Staatsblad (1884), No. 93. Article 264 (3): 'Veroordeling wegens misdrijf tot eene vrijheidsstraf van vier jaren of langer, na het huwelijk uitgesproken.' 
of Holland ${ }^{177}$ and the 1820 draft of Kemper $^{178}$ the crime which had led to a certain sentence was the decisive factor, whilst in the Civil Code of I 838 , both before and after I 884, the sentence itself was of overriding importance. To serve as ground for divorce, this sentence had to be pronounced within the marriage, not before. With regard to a sentence pronounced abroad, opinions differed. According to Grünebaum ${ }^{179}$ a sentence pronounced abroad could not serve as ground for divorce as this judgement could have been based on facts which would not have been sentenced the same way or sentenced at all in the Netherlands, whilst both Diephuis ${ }^{180}$ and Star Busmann ${ }^{181}$ argued that it could. Article 230 (4) of the draft revision of the Civil Code of I 886 explicitly stated that a foreign sentence because of a crime which in the Netherlands would have been sentenced with at least four years' imprisonment, could serve as a ground for divorce. ${ }^{182}$

Article 264 (4) BW formulated the fourth ground for divorce in a somewhat unusual way: 'serious injuries or ill-treatments inflicted by one of the spouses towards the other spouse, causing a threat to life or serious injuries. ${ }^{183}$ According to Diephuis, this long-winded wording can be explained by looking at the development of the article in the several drafts. The phrasing of the article was changed between I830 and I832, after which an indistinctness in the revision law of 16 June $1832{ }^{184}$ caused this unusual formulation when the Civil Code was edited. According to Diephuis Article 264 (4) BW had to be understood to mean that divorce was allowed I) in case of serious injuries, not causing a threat of life, and 2) in case of ill-treatment, causing a threat of life, without causing serious injuries. ${ }^{185}$ Grünebaum distinguished a third ground for divorce: in case of illtreatment causing serious injuries. However, he added that according to him this ground was redundant, as it was already included in either the first or the second ground. ${ }^{186}$

Attempted murder (without ill-treatment) ${ }^{187}$ was no longer considered a ground for divorce, whilst it was in the Code Civil (Article 23I, excès) and the I 820 draft of Kemper. ${ }^{188}$

177 Wetboek Napoleon, ingerigt voor het Koningrijk Holland, 1809, Article 219: 'Voor wettige redenen voor echtscheiding worden gehouden: [...] 3) Het plegen van zoodanige grove misdaad, welke verwijzing tot lijfstraf, of tot het werken of gevangen zitten in een tuchthuis, voor een zeer langen tijd, van ten minsten tien jaren, of tot bannissement buiten het rijk, mede voor een zeer langen tijd, van ten minsten vijftien jaren, ten gevolge heeft; [...].'

178 Ontwerp van het Burgerlijk Wetboek voor het Koningrijk der Nederlanden, 1820, Article 425: 'De echtscheiding mag worden gevorderd: [...] 4) Wegens het schuldig of medepligtig zijn van den anderen echtgenoot aan zoodanig misdaden, welke ten minste eene veroordeeling bij uiterlijk gewijsde tot schavotstraf en tevens tot gevangenis of bannissement uit den geheelen Staat, te zamen of afzonderlijk, voor niet minder dan vijf jaren, hebben ten gevolge gehad. [...].'

179 Opzoomer-Grünebaum, Het Burgerlijk Wetboek. Tweede Deel, 91-92.

180 G. Diephuis, Het Nederlandsch Burgerlijk Regt. Familieregt, 510-511.

181 Land-Star Busmann, Verklaring van het Burgerlijk Wetboek. Boek I, Titel I-XIX en Rechtspersonen, $312-313$.

182 Ontwerp tot herziening van het Burgerlijk Wetboek, 1886, Article 230: 'Echtscheiding kan worden gevorderd op grond van: [...] 4) onherroepelijke veroordeling tot eene vrijheidstraf van vier jaren of langer, of eene vrijheidstraf van ten minste dien duur ter vervanging van de doodstraf, wanneer de veroordeling na de voltrekking van het huwelijk is uitgesproken hetzij binnenslands, hetzij wegens een misdrijf, waartegen hier te lande eene vrijheidstraf van vier jaren of langer is bedreigd, buitenslands. [...].'

183 Article 264 (4) BW: 'Zware verwondingen of zoodanige mishandelingen, door den eenen echtgenoot jegens den anderen gepleegd, waardoor diens leven wordt in gevaar gebragt of waardoor hem gevaarlijke verwondingen zijn toegebragt.'

184 Wet van den 16 Junij 1832, houdende wijzigingen en veranderingen in het eerste boek van het Burgerlijk Wetboek, Staatsblad (1832), 863, no. 34.

185 G. Diephuis, Het Nederlandsch Burgerlijk Regt. Familieregt, 513.

186 Opzoomer-Grünebaum, Het Burgerlijk Wetboek. Tweede Deel, 93-94.

187 As examples of attempted murder without ill-treatment can be considered poisoning with coal gas, see Arrondissementsrechtbank Amsterdam, 18 March 1904, Weekblad van het Recht 8123 (1904) and contamination, whether of not deliberate, with syphilis, see Arrondissementsrechtbank Amsterdam, 12 October 1906, Weekblad van het Recht 8589 (1907).

188 Ontwerp van het Burgerlijk Wetboek voor het Koningrijk der Nederlanden, 1820, Article 425 (3): 'Wegens poging tot moord of doodslag, door den anderen echtgenoot tegen den genen, die de echtscheiding vordert, begaan [...].' 
Murder of, attempted murder of, or inflicting serious injuries on the parents or children of the other spouse were not considered a ground for divorce either, whilst Article 425 (3) of the I820 draft of Kemper did. ${ }^{189}$

\section{- 4.2.4. Attempts to revise matrimonial law}

During the first half of the $19^{\text {th }}$ century, divorce did not often occur. The majority of the couples chose to stay together, even when the marriage had turned out to be a disappointment. Two explanations can be given for this. Before the industrialisation of society, economical reasons played an important role in the decision to remain married. Both partners often worked on the family farm or in the family store. Divorce meant a serious loss of livelihood for at least one of the partners. The second explanation concerns the position of women. Getting married was an important goal in the life of young women. As soon as they had reached that position, it was best to maintain it. The legal position of married women in general was very weak, e.g. having no legal capacity. In a successful marriage, however, this was often no problem, which was another reason to keep the marriage stable. ${ }^{190}$

From I 870 onwards, however, the number of divorces increased, which led to a change in attitude towards marriage and divorce. Zwaan puts the increase of divorce rates into perspective by pointing out that this increase runs parallel to the decrease in mortality rates in that period. In the past marriages where mostly dissolved because one of the partners passed away, after which the remaining partner often remarried. Because of a decrease in mortality rates marriages lasted longer. According to Zwaan divorce can be seen as a 'functional substitute' for death, although he admits that dissolution of marriage by divorce is a different case than dissolution by death of one of the spouses. ${ }^{191}$ Nevertheless, the call for state intervention within the field of matrimonial law became stronger and the emancipation movement (including the feminists) emerged. Furthermore, the rise of the so-called 'pillarisation' (verzuiling) played an important role in the debate on marriage and divorce in the next decades. In 1867 a discussion was started about the role and position of women in society. According to conservative opinions, the destiny of women was found in motherhood and work at home. The idea of equality of men and women was rejected and girls had to be educated at home to prepare them for their role as mother and housewife. Not everyone agreed with this last point of view, arguing that even to become good mothers and housewives, girls had to receive a proper education. ${ }^{192}$ Although these pleas generally fell on deaf ears, the subservient position of women was slowly brought up for discussion. In I87I the Dutch translation of Darwin's The descent of man was published. As a result of this a discussion erupted on whether marriages could legally be prohibited on

189 Ontwerp van het Burgerlijk Wetboek voor het Koningrijk der Nederlanden, 1820, Article 425 (3): ‘[...] of wegens moord of doodslag, of poging daartoe tegen de ouders of kinderen van den laatstgemelden begaan; wegens zware verwondingen of verminkingen met geleider lage en verraderlijk aan den laatstgemelden, deszelfs ouders of kinderen toegebragt.'

190 T. Zwaan, 'De verbroken viereenheid: een interpretatie van recente transities', in: T. Zwaan (ed.), Familie, huwelijk en gezin in West-Europa, 291.

191 T. Zwaan, 'De verbroken viereenheid: een interpretatie van recente transities', in: T. Zwaan (ed.), Familie, huwelijk en gezin in West-Europa, 291-292.

192 A.H. Huussen, 'The Discussion about the Extension of Divorce in the Netherlands, 1870-1970', 318. 
medical-hygienic grounds, which will be further discussed below. ${ }^{193}$

\subsubsection{The 1886 draft revision of the Civil Code}

At the same time the discussion regarding revision of matrimonial law was further boosted by Sam van Houten ${ }^{194}$ who advocated radical changes such as renouncing the guilt principle, allowing both partners to request divorce. According to Van Houten the persisting will of each of the spouses should suffice as ground. ${ }^{195}$ In I 882 the Nederlandsche Juristen-Vereeniging (Dutch Lawyers Association) voted on a preliminary report by Van Houten. The suggested possibility of a unilateral dissolution of the marriage without reason given was voted down with 47 votes to i 8 . However, Van Houten's proposal to allow divorce by mutual consent was accepted with 54 votes to I I. ${ }^{196}$ In general, however, Van Houten failed to gain approval. The orthodox protestant view on marriage remained conservative, allowing only adultery as a ground for divorce.

In 1886 the draft revision of the Civil Code was presented. Although not very radical, the commission had incorporated some of the discussed ideas. Article 230 of the draft revision cited seven grounds for divorce: I) adultery, 2) unnatural vice, committed during the marriage, 3 ) refusal of living together, 4) sentence to a minimum of four years' imprisonment, either in the Netherlands or abroad, 5) attempted assault on the other spouse or grievous bodily harm of the other spouse, 6) continuous bad treatment of the other spouse and 7) habitual drunkenness or other debauchery. ${ }^{197}$

The explicit prohibition of divorce by mutual consent was omitted. The explanatory memorandum showed that this was a deliberate choice. The Civil Code already provided the opportunity to get the marriage dissolved with mutual consent indirectly as Article 255 allowed the partners to individually request for dissolution after five years of separation from bed and board. The draft revision shortened this period to one year ${ }^{198}$ and deleted the requirement that partners had to attempt reconciliation. ${ }^{199}$ Holding on to the provision of Article 263 seemed 'insincere' and was therefore omitted ${ }^{200}$ Nevertheless, the commission subscribed to the conservative point of view that marriage was not a regular contract which was not to be dissolved frivolously. One had to make sure that the marriage had indeed become unbearable and that it would be impossible for the partners

193 See in this respect J. Noordman, Om de kwaliteit van het nageslacht.

194 Samuel van Houten (1837-1930) was a Dutch Liberal politician, who became known for his Child Protection Act (1874), the first social legislation in the Netherlands.

195 S. van Houten, 'Beschouwingen over de bevolkingsleer in verband met de sexueele moraal', 86-93; S. van Houten, 'Over de maatschappelijke en wettelijke stelling der vrouw', 118-121, 165-184.

196 J.H.A. Lokin and C.J.H. Jansen, Tussen droom en daad, 52-56.

197 Ontwerp tot herziening van het Burgerlijk Wetboek, 1886, Article 230: 'Echtscheiding kan worden gevorderd op grond van: 1) overspel; 2) onnatuurlijke ontucht, gedurende het huwelijk gepleegd; 3) weigering van samenwoning; 4) onherroepelijke veroordeeling tot eene vrijheidstraf van vier jaren of langer, of eene vrijheidstraf van ten minste dien duur ter vervanging van de doodstraf, wanneer de veroordeeling na de voltrekking van het huwelijk is uitgesproken hetzij binnenslands, hetzij wegens een misdrijf, waartegen hier te lande eene vrijheidstraf van vier jaren of langer is bedreigd, buitenslands; 5) aanslag op het leven of zware mishandeling van den eenen echtgenoot, opzettelijk gepleegd, bevorderd of uitgelokt door den anderen; 6) gedurige slechte bejegening van den echtgenoot; 7) gewoonte van dronkenschap of ander liederlijk gedrag.'

198 Ontwerp tot herziening van het Burgerlijk Wetboek, 1886, Article 263 (1): 'Wanneer echtgenooten van tafel en bed zijn gescheiden, hetzij om eene bepaalde oorzaak, hetzij op beider verzoek, en de scheiding een vol jaar heeft geduurd, kunnen zij te zamen bij de rechtbank, die van den eisch of het verzoek kennis genomen heeft, machtiging tot ontbinding des huwelijks vragen, op welk verzoek het openbaar ministerie wordt gehoord.'

199 Ontwerp tot herziening van het Burgerlijk Wetboek, 1886, Toelichting, 120.

200 Ontwerp tot herziening van het Burgerlijk Wetboek, 1886, Toelichting, 123. 
to reconcile. Therefore, the dissolution of marriage had to be preceded by a certain period in which the partners lived separated, a so-called cooling-off period. After this period reconciliation could be a possibility in certain cases and if not, the marriage could still be dissolved. $^{201}$

Furthermore, the commission held on to the guilt principle allowing for divorce only for a limited number of reasons. Therefore divorce because of incurable insanity was not included as a ground for divorce although the demand for this gained strength. With her refusal to incorporate this reason as ground for divorce, the commission followed the French considerations in this respect, arguing that according to psychiatric science it was impossible to determine with certainty that insanity really was incurable, whilst it had become clear that once in a while a mentally ill person was even more or less aware of his condition as his mind was less affected by the illness every so often. ${ }^{202}$

Article 230 did again include unnatural vice as ground for divorce. The explanatory memorandum stated that, although unnatural vice was included in the $1820 \mathrm{draft}$ of Kemper, it was omitted in the 1838 Civil Code as it was not included in the Code Civil and the then Parliament whished to follow the Code Civil as much as possible. The explanatory memorandum argued that as no one had ever doubted that unnatural vice could be compared with adultery and should therefore serve as ground for divorce, it should be included as such in the Civil Code. It furthermore pointed out that unnatural vice was included as ground for divorce in the Allgemeines Landrecht für die Preußischen Staaten, the Privatrechtliches Gesetzbuch für den Kanton Zürich and the Bürgerliches Gesetzbuch für das Königreich Sachsen. Only one act of unnatural vice would suffice as ground for divorce; continuous unnatural vice was not necessary. ${ }^{203}$

Refusal of living together replaced desertion with malicious intent. According to the commission violation of the obligation of living together was of overriding importance, not the desertion itself. ${ }^{204}$ This ground was further elaborated in Article 23I. Divorce could only be requested in case a) one of the partners left the marital home or refused to live in the marital home and lived separated from his partner for consecutive three years or $b$ ) the man refused his wife entrance to the marital home without a legitimate cause and continued this refusal for a year. ${ }^{205}$ The explanatory memorandum added that the word 'refusal' contained 'unwillingness'. In case one of the partners (often the man) was abroad because of his work and therefore did not live together with his wife, Article 230 was not applicable. The period of continued refusal of living together was shortened from five to three years because the commission considered a term of five years too long, whilst three years was more in line with foreign regulations. Furthermore, the term was shortened to one year in case of repudiation, as the position of a repudiated woman was often very difficult. ${ }^{206}$

\footnotetext{
201 Ontwerp tot herziening van het Burgerlijk Wetboek, 1886, Toelichting, 119-120.

202 Ontwerp tot herziening van het Burgerlijk Wetboek, 1886, Toelichting, 118-119.

203 Ontwerp tot herziening van het Burgerlijk Wetboek, 1886, Toelichting, 124.

204 Ontwerp tot herziening van het Burgerlijk Wetboek, 1886, Toelichting, 124.

205 Ontwerp tot herziening van het Burgerlijk Wetboek, 1886, Article 231: 'Wegens weigering van samenwoning kan echtscheiding alleen worden gevorderd: 1) wanneer een der echtgenooten zonder geldige oorzaak de gemeene woning verlaat of weigert te betrekken, en gedurende drie jaren van zijnen echtgenoot verwijderd blijft leven; 2) wanneer de man zonder geldige oorzaak weigert de vrouw in zijne woning te ontvangen, en gedurende een jaar in die weigering volhardt. [...].'

206 Ontwerp tot herziening van het Burgerlijk Wetboek, 1886, Toelichting, 128.
} 
In 1884 the wording of Article 264 (3) and Article 265 (2) BW had already been changed as 'sentence to a degrading punishment' had been replaced by 'sentence to a minimum of four years' imprisonment.' The most important aspect of Article 230 (4) of the I $886 \mathrm{draft}$ revision was that it dealt with the question whether a foreign conviction could serve as a ground for divorce. Article 230 (4) answered this question affirmative, stating that when a person was convicted abroad because of a crime which in the Netherlands would have been punished with at least four years' imprisonment, this sentence could serve as a ground for divorce. ${ }^{207}$ The explanatory memorandum stated that whether a person was convicted in the Netherlands or abroad, did not matter for the amount of disgrace that was brought up on the convicted person. Furthermore, all civilised nations had enough guarantees for a due process of law nowadays. Secondly, Article 230 (4) stated that a death sentence which was commuted to an imprisonment of at least four years could serve as a ground for divorce. ${ }^{208}$ This was because a military tribunal could still impose the death penalty of which the convicted could be reprieved by the king. ${ }^{209}$

We have seen before that the wording of Article 264 (4) BW did not deserve the beauty prize. Article 230 (5) of the 1886 draft revision hoped to end the ambiguities and lack of clarity. However, the most important goal of the revised article was to end the exclusion of attempted poisoning as ground for divorce. Furthermore, divorce had to be possible in case one of the spouses had paid someone to kill the other spouse or had helped him to do so in any way. To avoid new ambiguities the wording of Article 230 (5) followed the definitions given in the Penal Code. ${ }^{210}$

The sixth and seventh grounds stated in Article 230 of the 1886 draft revision were entirely new. In the 1838 Civil Code ill-treatment as such was no ground for divorce, as such a thing could occur in a fit of temper, whilst it was not considered to be common behaviour. In general, the I 886 draft revision stuck to that principle although in Article 230 (6) continuous bad treatment was introduced as a ground for divorce. According to the explanatory memorandum continuous bad treatment did not only include physical violence, but all grievous harm caused by the other spouse. ${ }^{211}$

Article 230 (7) finally introduced alcoholism as ground for divorce, with the explanatory memorandum stating that habitual alcoholism not only destroyed the marriage, but that it often endangered the life of the other spouse as well. ${ }^{212}$

Although not deviating from the guilt principle, the commission did come up with some elaborate changes in its draft revision. However, this proposal did not pass, and the original grounds remained unchanged. ${ }^{213}$

207 Ontwerp tot herziening van het Burgerlijk Wetboek, 1886, Article 230 (4): '[...] hetzij wegens een misdrijf, waartegen hier te lande eene vrijheidstraf van vier jaren of langer is bedreigd, buitenlands;'

208 Ontwerp tot herziening van het Burgerlijk Wetboek, 1886, Article 230 (4): '[...] of eene vrijheidstraf van ten minste dien duur ter vervanging van de doodstraf, [...];'

209 Ontwerp tot herziening van het Burgerlijk Wetboek, 1886, Toelichting, 125.

210 Assault (aanslag) was defined in Article 79 of the Penal Code, title 19 of book 2 of the Penal Code dealt with crimes against life (misdrijven, tegen het leven gericht), whilst grievous bodily harm (zware mishandeling) was defined in Article 302 of the Penal Code and elaborated upon in Article 82. See also Ontwerp tot herziening van het Burgerlijk Wetboek, 1886, Toelichting, 126.

211 Ontwerp tot herziening van het Burgerlijk Wetboek, 1886, Toelichting, 126.

212 Ontwerp tot herziening van het Burgerlijk Wetboek, 1886, Toelichting, 126-127.

213 A.H. Huussen, 'The Discussion about the Extension of Divorce in the Netherlands, 1870-1970', 320. 


\subsubsection{The Big Lie}

Nevertheless, case law widened the grounds for divorce. On 22 June i883, the Dutch Supreme Court ruled that in case of divorce the normal provisions regarding default and confessions as set in Article I962 of the Civil Code, which stated that a judicial confession provided full evidence ${ }^{214}$ and Article 76 of the Code of Civil Procedure, which stated that in case the defendant went by default, the applicant's claim was sustained, ${ }^{215}$ were applicable. This meant that in case the defender confessed to the allegation of adultery or went by default and did not contradict the allegation, this had to be considered as evidence, therefore holding the adultery proven. ${ }^{216}$ Advocate General Van Maanen advised against this judgement as according to him this implicitly cleared the way for divorce by mutual consent. Divorce on the ground of adultery, only proven by a confession or simply by the defendant going by default and not contradicting the allegation was too sensitive to fraud, as spouses who wanted to divorce could simply agree that one of them would confess adultery or would go by default, after which the divorce would be granted. According to Van Maanen, the allegation that the legislator had not provided for an exception in Article I962 of the Civil Code in case of divorce was not true, as Article 263 , which prohibited divorce by mutual consent, could be regarded as this exception. By sticking to the verbatim text of Article I 962 without considering the significance of Article 263, the grounds for divorce would be significantly widened, to which the Supreme Court was not in position. Marriage was a matter of public interest, in which the courts were obliged to request further factual evidence besides a confession in case of an alleged adultery. He pointed out that the only possibility to divorce with mutual consent was given by the legislator, which was in the roundabout way through separation from bed and board on request of both spouses, without the obligation of giving a reason, as stated in Article 291, followed by dissolution of the marriage after five years as described in Article 255, as we have seen before. Therefore, confession of adultery should never be allowed as the only and full evidence of adultery. The fact that Article 822 of the Code of Civil Procedure stated that cases of divorce should be treated in the same way as normal legal claims did not alter that. ${ }^{217}$

Nevertheless, the Supreme Court decided that the general rule of the Articles I903 and I 962 of the Civil Code did not provide exceptions for cases of divorce. According to the Court this was indicated by Article 8 ro of the Code of Civil Procedure, which excluded a single confession as evidence in case of separation of property. Clearly, the legislator had come up with exceptions to the general rules of evidence in civil cases and obviously he had considered it unnecessary to formulate one in case of divorce. Courts were therefore not allowed to extend this prohibition to divorce. Furthermore, Article 263 was not

214 Article 1962 BW: 'De geregtelijke bekentenis levert een volledig bewijs op tegen dengenen die dezelve, het zij in persoon, het zij bij eenen bijzonderen daartoe gevolmagtigde, heeft afgelegd.'

215 Article 76 Rv: 'Indien de gedaagde niet verschijnt, en de voorgeschreven termijnen en formaliteiten in acht genomen zijn, zal er tegen hem verstek verleend worden, en de conclusien van den eischer zullen toegewezen worden, ten ware zij den regter onregtmatig of ongegrond voorkomen.'

216 Hoge Raad, 22 June 1883, Weekblad van het Regt 4924 (1883).

217 Advocate General Van Maanen in Hoge Raad, 22 June 1883, Weekblad van het Regt 4924 (1883). 
eluded by a divorce granted in case the only evidence was a confession of adultery as this confession provided the legal ground for divorce; adultery as set in Article 264 (I) Civil Code. If you looked at it from that angle, the divorce was not based on mutual consent, which therefore did not cause a violation of Article $263 .{ }^{218}$

The Court's judgement was strongly criticised and the procedure was soon referred to as the 'the Big Lie' (de Groote Leugen). Although some authors were in favour of extending the grounds for divorce, one considered this to be a task of the legislator. ${ }^{219}$ According to Scholten this decision had to result in accepting a confession as full evidence in other matters as well, e.g. the annulment of marriages, denial of the legitimacy of a child, application for a wardship order or deprivation of parental rights, which was inexpedient. ${ }^{220}$ Not everyone condemned the Supreme Court's decision. S. van Brakel argued that the general wording of Article I962 BW was applicable to all civil matters. ${ }^{221}$ He supported this statement by pointing to C. Asser, who had stated that the Dutch Civil Code was an improvement of the French Code Civil as it placed the concept of evidence in a separate section of the Civil Code, being applicable in general, instead of being only applicable on contracts. According to Asser, the Code Napoléon had missed that means of proof could be applicable in other matters such as marriages and adultery, supporting a request for divorce. ${ }^{222}$ Scholten disagreed to this historical interpretation by pointing out Article 422 of the 1820 draft of Kemper, which stated that courts had to take care that no marriages were dissolved because of covert contracts between the spouses. ${ }^{223}$ According to Scholten this regulation was only omitted from the 1838 Civil Code because it was apparently considered redundant. ${ }^{224}$

Some lower courts refused to cooperate and requested additional evidence. However, this only resulted in appeal in which the decision of the Supreme Court was followed, after which the lower courts in general gave up their resistance, not counting exceptions. ${ }^{225}$ In an article in the Nederlandsche Juristenblad in I926, C. Briët, who wanted to bring the issue to the notice again, pointed out a decision from the Amsterdam District Court, which declared a contract to divorce with mutual consent void because of unlawful content. ${ }^{226}$ According to Briët this decision showed that in general one acted as if Article 263 BW did no longer exist. Briët therefore praised the Amsterdam District Court for bringing Article 263 BW back to the attention. ${ }^{227}$

218 Hoge Raad, 22 June 1883, Weekblad van het Regt 4924 (1883).

219 C. Briët, 'De groote leugen', 1 Nederlandsch Juristenblad 15 (1926), 214-216; Asser-Scholten, Handleiding tot de beoefening van het Nederlandsch Burgerlijk Recht. Familierecht, 249.

220 Asser-Scholten, Handleiding tot de beoefening van het Nederlandsch Burgerlijk Recht. Familierecht, 249-250.

221 S. van Brakel, 'Rechten, waarover men niet de vrije beschikking heeft en de betekenis in het echtscheidingsgeding', 63 Weekblad voor Privaatrecht, Notaris-ambt en Registratie 3244 (1932), 77-79.

222 C. Asser, Het Nederlandsch Burgerlijk Wetboek, vergeleken met het Wetboek Napoleon, 14, 589. See also S. van Brakel, 'Rechten, waarover men niet de vrije beschikking heeft en de betekenis in het echtscheidingsgeding', 63 Weekblad voor Privaatrecht, Notaris-ambt en Registratie 3244 (1932), 77-79.

223 Ontwerp van het Burgerlijk Wetboek voor het Koningrijk der Nederlanden, 1820, Article 422: '[...] De regters moeten toezien dat geene huwelijken ontbonden worden uit versierde oorzaken, of door bedekte overeenkomsten der partijen.'

224 Asser-Scholten, Handleiding tot de beoefening van het Nederlandsch Burgerlijk Recht. Familierecht, 251.

225 J. Limburg, 'Het Familierecht van het B.W. in zijn karakteristieke eigenschappen tegenover het recht van thans', in P. Scholten and E.M. Meijers, Gedenkboek Burgerlijk Wetboek 1838-1938, 361.

226 Arrondissementsrechtbank Amsterdam, 8 February 1926, Nederlandsche Jurisprudentie 1926, 256

227 C. Briët, 'De groote leugen', 1 Nederlandsch Juristenblad 15 (1926), 214-216. 
Nevertheless, even the strongest opponents accepted this judgement as case law, inciting the legislator to come up with changes ${ }^{228}$ although some feared that the legislator preferred the status quo, being torn between the necessity of cleaning up the procedure and the aversion by many members in parliament to extend the grounds for divorce. For such a proposal it was unlikely a majority in parliament was gained, whilst when the Civil Code was changed so as to exclude confession as full evidence, in practice other solutions would be found. ${ }^{229}$ Despite all critique, this procedure remained the standard procedure until the revision of $197 \mathrm{I}^{230}$

\subsubsection{Discussion about the 'Free Marriage'}

Around the turn of the century, a political shift was established as the Protestant A. Kuyper, leader of the Anti Revolutionary Party, became Prime Minister, effectively ending the liberal hegemony. With the religious parties having a majority in parliament, marriage and divorce again had to undergo a religious interpretation. According to orthodox Protestants, divorce was only acceptable in case of adultery. The status of motherhood was raised, the husband remained the head of the family. However, not all Protestants agreed with this point of view. The more liberal pleaded for desertion as second ground for divorce ${ }^{231}$ and the Vice-President of the Supreme Court W.H. de Savornin Lohman even declared that on Biblical grounds he could not offer resistance against propositions to extend the existing grounds for divorce, although the introduction of insanity as ground for divorce was not self-evident. According to De Savornin Lohman allowing insanity as ground for divorce would mean that divorce on other grounds than the guilt principle would be allowed. Especially in the case of insanity this would cause problems, as it would never be sure, whether the patient would recover from his insanity. Furthermore, he strongly disapproved of divorce by mutual consent. ${ }^{232}$

Divorce by mutual consent remained a favourite subject for discussion. As the religious parties tightened the reins, an alternative for the traditional institution of marriage was presented in the form of the so-called 'Free Marriage' (Vrije Huwelijk). As not all advocates of the Free Marriage came up with well-founded dissertations ${ }^{233}$ about what the Free Marriage exactly contained and why it was preferable to the existing marriage, opponents could easily refute all arguments by comparing the Free Marriage with 'free love' which obviously would pave the way for immorality. Lodewijk van Mierop tried to come up with a definition of Free Marriage by first stating that Free Marriage could not be compared

228 C. Briët, 'De groote leugen', 1 Nederlandsch Juristenblad 15 (1926), 214-216; Asser-Scholten, Handleiding tot de beoefening van het Nederlandsch Burgerlijk Recht. Familierecht, 249-251.

$229 \mathrm{~J}$. Limburg, 'Het Familierecht van het B.W. in zijn karakteristieke eigenschappen tegenover het recht van thans', in P. Scholten and E.M. Meijers, Gedenkboek Burgerlijk Wetboek 1838-1938, 362.

230 A.H. Huussen, 'The Discussion about the Extension of Divorce in the Netherlands, 1870-1970', 320; J. Limburg, 'Het Familierecht van het B.W. in zijn karakteristieke eigenschappen tegenover het recht van thans', in P. Scholten and E.M. Meijers, Gedenkboek Burgerlijk Wetboek 1838-1938, 361.

231 A.H. Huussen, 'The Discussion about the Extension of Divorce in the Netherlands, 1870-1970', 321-324

232 W.H. de Savornin Lohman, Van huwelijk en echtscheiding, 60-61.

233 Van Mierop declared himself against an article published in Pro en Contra in 1905 by W. Hamburger and H. Verkouteren, 'Het Vrije Huwelijk'. Especially Hambuger did not excel in scholarly quality, calling the opponents of the Free Marriage 'conventional bourgeoisie, conservatives, uneducated masses and supporters of polygamy, polyandry and sexual communism', whilst his contribution furthermore mainly consisted of a plea in very strong words against all evils of marriage. 
with free love followed by a new interpretation of the term 'marriage'. According to Van Mierop a true marriage was 'the unification, the merging, the amalgamation, the ripening of twofoldness of two human souls. ${ }^{234} \mathrm{He}$ further explained that marriage was not an institution, but a metaphysical process. Such a marriage would essentially be indissoluble. People who would be married this way, i.e. in case they would have an enduring relationship, would be able to choose to have this marriage legally confirmed, after which it would become a legal marriage, which Van Mierop called a marital union (echtvereniging). Without the confirmation the marriage would remain a Free Marriage. According to Van Mierop the state was not allowed to judge a metaphysical process, but only the legal confirmation of that metaphysical process, which had to be considered a regular contract. Regular contracts had to be dissolvable anytime. According to Van Mierop more and more couples chose to have their marriage not legally confirmed, thus having a Free Marriage. This development emphasised the need for a revision of matrimonial law, as many people chose the Free Marriage because of dissatisfaction with the applicable rules. Especially the legal position of married women, which Van Mierop described as 'slavery', ${ }^{235}$ encountered objections. As the rigid rules concerning marriage impelled the Free Marriage, it had to be recognised as a full marriage. Besides that, Van Mierop noted, Dutch law did not prohibit cohabitation (without being legally married), which illustrated that the legislator's attitude towards the Free Marriage was not only incorrect, but improper as well. ${ }^{236}$

$\mathrm{H}$. Verkouteren, opposed to the Free Marriage, was not convinced of the necessity of the Free Marriage. According to Verkouteren there was no real need for more flexible divorce regulations, people only thought they felt the need. Besides that, a legislator was obviously not obliged to follow every (imaginary) need of the people. ${ }^{237}$ Proponents of the Free Marriage tended to forget all important things regulated in the applicable matrimonial law. Verkouteren indicated that e.g. marital property law would be unsettled in case the Free Marriage was allowed. Besides that, all marital miseries, which apparently seemed to impel the Free Marriage, where grossly exaggerated. A Free Marriage would only encourage indecent behaviour and was unnecessary. After all, 'true love was beyond doubt. ${ }^{238}$ With regard to an extension of the grounds for divorce - without simply allowing divorce by mutual consent - Verkouteren was inconsistent. In an article of I905 he stated that the then existing grounds for divorce were too confined. Besides the existing four grounds, divorce had to be possible in case of ill-treatment or negligence of the children, habitual drunkenness and insanity. ${ }^{239}$ Apparently, this conviction was not written in stone, because in an article he published five years later he categorically repudiated the possibility of extending the grounds for divorce. In this article he discussed the I 886 draft revision of which he stated that he could not reconcile himself with any of the proposed grounds for divorce. He especially repudiated divorce because of habitual

234 L. van Mierop, Waarom het 'vrije huwelik' zin heeft in onze tegenwoordige maatschappij, 16.

235 L. van Mierop, Waarom het 'vrije huwelik' zin heeft in onze tegenwoordige maatschappij, 36.

236 L. van Mierop, Waarom het 'vrije huwelik' zin heeft in onze tegenwoordige maatschappij, 32-33.

237 J.A. Levy and W. Verkouteren. 'Verruiming van echtscheidingsgronden', 22.

238 W. Hamburger and W. Verkouteren, 'Het Vrije Huwelijk', 25-28.

239 W. Hamburger and W. Verkouteren, 'Het Vrije Huwelijk', 28. 
drunkenness or insanity. According to Verkouteren men were often driven to the pub by their wives' behaviour. Insanity could not be a ground for divorce since it did not fulfil the guilt criterion. Furthermore, whether or not the insanity was incurable was often unclear. In many cases, making someone a ward of court, even allowing the woman to be curator bonis of her husband, would provide a solution. In any case, Verkouteren considered separation from bed and board the most extreme measure permissible. ${ }^{240}$

De Savornin Lohman agreed with Verkouteren on rejecting insanity as a ground for divorce because it did not fulfil the guilt criterion. However, he acknowledged the law as a developing entity, admitting that matrimonial law could be up to amendment. ${ }^{241}$ Nevertheless, he strongly disapproved of divorce by mutual consent. According to De Savornin Lohman the Gospel had to be the basis of marriage, not the ideals of the French Revolution. The Free Marriage sprung from these ideals and was therefore to be rejected ${ }^{242}$ In explaining his objections to the Free Marriage, De Savornin Lohman took an article from W. Hamburger, of which Van Mierop had already admitted that it did not excel in scholarly character, as starting point. ${ }^{243}$ Although he admitted that marriage was a contract, he stated that it was a different kind of contract, on which the regular rules of contract law were not applicable. ${ }^{244}$ Marriage was essentially indissoluble. Hamburger's objections to marriage were brushed aside; love and marriage did obviously not exclude one another. And what could possibly be wrong with the vows of mutual faithfulness? ?45 $^{25}$ The argument of subordination of married women De Savornin Lohman considered unjust. Naturally, women were not of full legal capacity, as their responsibilities lay with the family, within the relatively safe walls of the marital home. The legislator had built in enough safeguards to protect the position and property of married women. Comparisons with slavery he considered 'childish'. ${ }^{246}$ Besides, if women were not subordinate to men, apparently men had to be subordinate to women, which obviously was undesirable. ${ }^{247} \mathrm{De}$ Savornin Lohman furthermore agreed with Van Mierop that Dutch law did not prohibit cohabitation. He therefore failed to see the apparent necessity of the Free Marriage, which he considered subordinate to the legal marriage in moral respect. People who considered this unfair were naïve in his opinion. ${ }^{248}$ Allowing divorce by mutual consent would cause a proliferation of divorces, which was inexpedient. The argument that insisting on the prohibition of divorce by mutual consent would only lead to infringements and should therefore be abolished he considered unconvincing. De Savornin Lohman was not impressed by the threat of supporters of the Free Marriage that in due course many would turn their back on the legal notion of marriage. ${ }^{249}$ Obviously legislation should follow new beliefs, but in this case he doubted whether the beliefs concerning marriage had really changed. He disagreed with Sam van Houten, who had stated that through

240 J.A. Levy and W. Verkouteren. 'Verruiming van echtscheidingsgronden', 30-31.

241 W.H. de Savornin Lohman, Van huwelijk en echtscheiding, 59-60.

242 W.H. de Savornin Lohman, Van huwelijk en echtscheiding, 7.

243 W.H. de Savornin Lohman, Van huwelijk en echtscheiding, $8 \mathrm{ff}$.

244 W.H. de Savornin Lohman, Van huwelijk en echtscheiding, 11-12, 44.

245 W.H. de Savornin Lohman, Van huwelijk en echtscheiding, 12-13.

246 W.H. de Savornin Lohman, Van huwelijk en echtscheiding, 43.

247 W.H. de Savornin Lohman, Van huwelijk en echtscheiding, 37

248 W.H. de Savornin Lohman, Van huwelijk en echtscheiding, 31-32.

249 W.H. de Savornin Lohman, Van huwelijk en echtscheiding, 52-55. 
case law the possibility of divorce by mutual consent was reinstated, ${ }^{250}$ as he refused to acknowledge the Supreme Court's decision of $1883 .{ }^{251}$ Marriage was a divine institution and divorce had to be prevented as much as possible.

\subsubsection{Eugenics and matrimonial law}

Although the discussion about amending matrimonial law seemed to consist predominantly of religious and moral arguments, other beliefs gradually started to play a role. Around the turn of the century, the international debate on eugenics started to find response of Dutch authors on medical matters and ethics, of which some propagated medical examination of those who wanted to get married, sketching doom scenarios about the course of marital life in case the partners had not been examined medically prior to the marriage. ${ }^{252}$ In the Netherlands the discussion about eugenics only slowly developed and did not completely get shape before the nineteen thirties, whilst other countries, e.g. the United Kingdom, the United States and Germany, had already put the subject on the agenda long before that. Although eugenics found its roots in Social Darwinism, Social Darwinism never became really popular in the Netherlands, which was too confessional to accept the ideas of Darwin. Instead, in the Netherlands the discussion focussed on hygiene, which is contrary to Social Darwinism, as it influences the natural selection process. Eugenics, however, can be seen as some form of reproduction hygiene. In order to prevent hereditary and contagious diseases, early marriage and having a lot of children was discouraged. ${ }^{253}$ Tuberculosis, alcoholism and venereal diseases were considered common diseases and spreading of these had to be prevented. In doing so, no clear distinction was made between hereditary and contagious diseases. Although at the end of the nineteenth century it was already known that tuberculosis was contagious instead of hereditary, ${ }^{254}$ hereditary characteristics were still taken into account in the fight against the disease. E.g. it was believed that Jews had more resistance to tuberculosis than Native Americans and black people. Furthermore, the so-called 'germ damage ${ }^{255}$ was often taken into account, especially in case of alcoholism. ${ }^{256}$ It was generally believed that alcoholism caused hereditary insanity, ${ }^{257}$ which could degenerate complete families. ${ }^{258}$

The discussion focussed on the question whether a medical examination preceding the marriage, possibly obligatory, had to be introduced. Already around the turn of the

250 S. van Houten, 'Staatkundige Brieven, no. 23', published in De Nieuwe Courant, 1 February 1913.

251 W.H. de Savornin Lohman, Van huwelijk en echtscheiding, 30-31.

252 Especially Hector Treub appeared to be able to give an expressive depiction of the marital misery a marriage between unhealthy people would lead to, H. Treub, Geneeskundige Huwelijkswetgeving, 89-92. His depictions were copied in its entirety by Lodewijk van Mierop who enlarged the subject in great detail and emphasised the importance of a medical examination to prevent all this misery, L. van Mierop, Over het geneeskundig onderzoek vóór het huwelik.

253 In 1900, Treub stated that women younger than 20 years and men younger than 25 years were too young to marry. Procreation was no longer desirable after women had reached the age of 40 and men the age of 50 years, H. Treub, Huwelijk en ziekte, 10. In 1905 he adjusted his age requirement to 18 years for women (whilst Article 86 BW allowed women aged 16 to marry) and 20 years for men (18 years according to Article 86 BW), Treub, Geneeskundige Huwelijkswetgeving, 126. C.J. Wijnaendts Francken worried about early marriages as well, considering 20 the proper age for women to marry, whilst men had to be 25 , C.J. Wijnaendts Francken, Wenschelijk Huwelijksverbod, 32.

254 Treub did not seem to be entirely convinced of the non-heredity of tuberculosis, see H. Treub, Huwelijk en ziekte, 8 and $\mathrm{H}$. Treub, Geneeskundige Huwelijkswetgeving, 114-115.

255 H. Treub, Geneeskundige Huwelijkswetgeving, 115-116; C.J. Wijnaendts Francken, Wenschelijk Huwelijksverbod, 15.

256 H. Treub, Geneeskundige Huwelijkswetgeving, 121.

$257 \mathrm{H}$. Treub, Huwelijk en ziekte, 4, 6.

258 J. Noordman, Om de kwaliteit van het nageslacht, 38-39. 
century, the subject was put on the agenda by Hector Treub, a professor of gynaecology, although he opposed to a legal prohibition of marriages for 'unfit' persons. The medical examination was predominantly meant for the partners themselves, so that they knew beforehand whether they would be marrying someone with a serious illness. Especially for women this would be helpful, as too often a woman was contaminated with e.g. a venereal disease (like syphilis) which her husband had contracted before the marriage. Depending on the outcome of the examination, partners could still decide to cancel the planned marriage. It probably would lead to some broken hearts, which were however preferable to catching a serious disease. ${ }^{259}$ It was quite a businesslike approach to marriage, defended by a comparison with animal breeding, in which all breeding rules were meticulously followed without questions. ${ }^{260}$ Nevertheless, Treub considered a legal prohibition of marriages for people who suffered from a certain disease too much of an intrusion on personal freedom. ${ }^{261}$

Treub found an ally in C.J. Wijnaendts Francken, ${ }^{262}$ a biologist, although Wijnaendts Francken took a more radical tone. He considered Treub's proposal too permissive. As only a mere handful of couples would abandon a planned marriage in case of a serious illness of one of the partners, not only the medical examination preceding the marriage had to be obligatory, a legal prohibition of marriage for 'unfit' persons had to be introduced as well. ${ }^{263}$ Apart from people with a hereditary or contagious disease, Wijnaendts Francken qualified paupers as 'unfit' as well. ${ }^{264}$ Charity and medical science caused a debilitation of the human species, ${ }^{265}$ which was enhanced by the fact that apparently those with the lowest incomes would produce most children. ${ }^{266}$ Wijnaendts Francken acknowledged that a marriage prohibition for those unfit for procreation would mean a serious infringement of personal freedom. He nevertheless considered this infringement justified as it was done for the greater good of human society. Besides that, intrusions on personal freedom occurred already, as marriage was extensively regulated by the law, e.g. prohibiting polygamy. ${ }^{267}$ With these points of view Wijnaendts Francken took a more Social Darwinistic approach. ${ }^{268}$

Both Treub and Wijnaendts Francken were not undisputed. A very fundamental point of critique, although waived aside by Treub, ${ }^{269}$ was that the report, which resulted from the medical check up and which was shared with the partner, would infringe a physician's duty of professional confidentiality. Treub, however, was supported by lawyers ${ }^{270}$ and others like Lodewijk van Mierop, ${ }^{271}$ who considered the medical examination preceding

259 H. Treub, Huwelijk en ziekte, 16-19.

260 H. Treub, Huwelijk en ziekte, 3; H. Treub, Geneeskundige Huwelijkswetgeving, 111-112.

261 H. Treub, Huwelijk en ziekte, 16; H. Treub, Geneeskundige Huwelijkswetgeving, 134; J. Noordman, Om de kwaliteit van het nageslacht, 43-45.

262 C.J. Wijnaendts Francken, Wenschelijk Huwelijksverbod, 11.

263 C.J. Wijnaendts Francken, Wenschelijk Huwelijksverbod, 26-30, 34-35. Treub disagreed with Wijnaendts Francken on the idea of a marriage prohibition and criticised his proposal in Geneeskundige Huwelijkswetgeving, 136.

264 C.J. Wijnaendts Francken, Sociale Ethiek, 252.

265 C.J. Wijnaendts Francken, Wenschelijk Huwelijksverbod, 7-10.

266 C.J. Wijnaendts Francken, Sociale Ethiek, 238-255.

267 C.J. Wijnaendts Francken, Wenschelijk Huwelijksverbod, 35.

268 J. Noordman, Om de kwaliteit van het nageslacht, 46-47.

269 H. Treub, Huwelijk en ziekte, 18; H. Treub, Geneeskundige Huwelijkswetgeving, 127.

270 L. van Mierop, Over het geneeskundig onderzoek vóór het huwelik, 173-174.

271 L. van Mierop, Over het geneeskundig onderzoek vóór het huwelik, 77-79, 173-175. 
the marriage a 'moral requirement'. ${ }^{272}$ However, he rejected a marriage prohibition as propagated by Wijnaendts Francken. ${ }^{273}$ Other arguments were mainly inspired by religious beliefs. It was said that a medical examination preceding marriage would only stimulate promiscuity, an argument which was supported by Treub, ${ }^{274}$ whilst only true monogamy could really solve the problem. Furthermore, it was argued - not entirely erroneous - that an obligatory medical examination would be unfeasible, as that would come down to a mere 40,00o examinations a year. The Netherlands simply did not have enough physicians to carry out that task. ${ }^{275}$

Apart from all critique on the proposed medical examination, support for the proposed marriage prohibition categorically lacked, as it was generally believed that it would not prevent the birth of undesired children. Furthermore, in religious circles marriage and family were regarded superior to the public interest. ${ }^{276}$

\subsubsection{Further attempts to amendments}

Although the revision of matrimonial law did not really get off the ground, it was nevertheless tried. In I9 Io Minister of Justice Nelissen tried to solve the problem of the Big Lie without an extensive discussion about extending the grounds for divorce. ${ }^{277}$ This solution was merely a technical one. An article would be added to the Code of Civil Procedure, stating that no divorce would be granted in case the court was not convinced by legal means of proof about the existence of grounds for divorce, on which the divorce was requested. ${ }^{278}$ However, this proposal was not received with great acclaim, although the attempt to solve this judicial twist was appreciated. Nevertheless, several objections were lodged. Some considered this new article to be contrary to the general rules of civil procedure, which requested legal means of proof and not - as in criminal procedures - convincing means of proof. To request judicial conviction in addition to a confession was in breach with Article I962 of the Civil Code, which recognised a confession as full evidence. ${ }^{279}$ Proponents of the Nelissen draft however, argued that Article I962 of the Civil Code was only applicable on regular civil procedures. Since a request for divorce did not qualify as a regular civil procedure, as it did not deal with a regular contract, Article I962 was not applicable and would thus not stand in the way of the solution chosen by Nelissen. ${ }^{280}$

Furthermore, one doubted the effectiveness of this proposal. Some, especially those who were opposed to divorce in general, argued that this article would leave the courts

272 L. van Mierop, Over het geneeskundig onderzoek vóór het huwelik, 143-151.

273 L. van Mierop, Over het geneeskundig onderzoek vóór het huwelik, 147, 163-176.

$274 \mathrm{H}$. Treub, Geneeskundige Huwelijkswetgeving, 135.

275 J. Noordman, Om de kwaliteit van het nageslacht, 48-56.

276 J. Noordman, Om de kwaliteit van het nageslacht, 48-56, 169-177.

277 Handelingen der Staten-Generaal (Tweede Kamer), bijlagen 1909-1910, no. 208. See also Handelingen der Staten-Generaal (Tweede Kamer), bijlagen 1909-1910, bijlage A, hoofdstuk 4, 2. IV. 13 (p. 5) and 2. IV. 14 (p. 24).

278 Handelingen der Staten-Generaal (Tweede Kamer), bijlagen 1909-1910, no. 208.2: 'Tusschen de artikelen 827 en 828 van het Wetboek van Burgerlijke Rechtsvordering wordt een nieuw artikel 827a ingevoerd, luidende als volgt: "Behoudens het bepaalde bij artikel 265 van het Burgerlijk Wetboek zal de vordering tot echtscheiding niet worden toegewezen, zoo de regtbank niet door wettelijke bewijsmiddelen is overtuigd van het bestaan der gronden, uit hoofde waarvan de echtscheiding wordt gevorderd."

279 Handelingen der Staten-Generaal (Tweede Kamer), bijlagen 1909-1910, no. 208.4, voorlopig verslag, § 2.

280 Handelingen der Staten-Generaal (Tweede Kamer), bijlagen 1909-1910, no. 208.4, voorlopig verslag, § 2. 
free to decide whether a confession was convincing or not, i.e. in real terms, it would not change anything or would at least lead to inequality in jurisdiction. After all, although Article 1962 might be meant to be applicable only on regular civil procedures, the Civil Code nor the Code of Civil Procedure stated that a confession did not count as full evidence in a divorce procedure. Therefore, it would have been better when the draft had contained an article - like Article 8Io of the Code of Civil Procedure - which had excluded a confession as full evidence in divorce cases. ${ }^{281}$

Another reason to doubt the effectiveness of this proposal, was the apparent stubborness of the actual practice. Other manoeuvres would be invented to let the feigned adultery appear as the truth, or - even worse - adultery would actually be committed in order to create a ground for divorce, effectively making this new article counterproductive. ${ }^{282}$

Others were of the opinion that this draft article was unnecessary, either because based on Article 76 of the Code of Civil Procedure courts could already decide to reject the request for divorce in case of default, or because Article 263 of the Civil Code did not forbid divorce by mutual consent if this mutual consent was given indirectly, e.g. by feigning adultery, meaning that the Big Lie was not such a big lie after all. This line of reasoning seemed rather far-fetched, but proponents of this interpretation of Article 263 found proof in the regulation of separation from bed and board, through which, after all, divorce by mutual consent was possible. ${ }^{283}$

Finally, there were members of Parliament who dissaproved, not because they disagreed with the draft as such, but because they were of the opinion that the law concerning divorce had to be amended extensively and not only by this article. The problem was not the Big Lie, but the existing grounds for divorce, which were considered too strict. If the proposed draft would be the only amendment, the possibilities for getting a divorce would be limited even more. Therefore, they indicated they could only agree with this draft if the law concerning divorce would be amended as a whole, e.g. including insanity or habitual drunkeness as grounds for divorce. Of course, others vehemently disagreed with this point of view, arguing that facilitating divorce would only lead to more impetuous marriages. ${ }^{284}$ With these arguments, the whole discussion went back to square one and the I910 Nelissen draft was withdrawn in I912. ${ }^{285}$

In I9I2 Nelissen's successor ${ }^{286}$ Regout tried again, with the same article, although he framed his proposal in a more extensive way in order to prevent intolerable manoeuvres including actually committing adultery to get a divorce ${ }^{287}$ Furthermore, he proposed to shorten the term of separation from bed and board before getting a divorce from five

281 Handelingen der Staten-Generaal (Tweede Kamer), bijlagen 1909-1910, no. 208.4, voorlopig verslag, § 3

282 Handelingen der Staten-Generaal (Tweede Kamer), bijlagen 1909-1910, no. 208.4, voorlopig verslag, $\$ 3$.

283 Handelingen der Staten-Generaal (Tweede Kamer), bijlagen 1909-1910, no. 208.4, voorlopig verslag, § 3.

284 Handelingen der Staten-Generaal (Tweede Kamer), bijlagen 1909-1910, no. 208. 4, voorlopig verslag, § 4.

285 See also Handelingen der Staten-Generaal (Tweede Kamer), zitting 1968-1969, no. 10213.3, Memorie van Toelichting, p. 11.

286 A.P.L. Nelissen resigned in 1910 because of health reasons, after which Th. Heemskerk became Minister of Justice ad interim. E.R.H. Regout became the new Minister of Justice shortly thereafter in 1910.

287 Handelingen der Staten-Generaal (Tweede Kamer), bijlagen 1911-1912, no. 306. 
to three years. ${ }^{288}$ This three year term was more in line with foreign legislation, such as the French and Belgian Civil Codes. Excerpts from several foreign civil codes or other legislation were added to the explanatory memorandum to underline the argument that with this draft the Dutch legislation concerning divorce would be more in line with other jurisdictions. ${ }^{289}$ However, this proposal was repealed in October I9I3. ${ }^{290}$

It should be noted that although all attempts to widen the grounds for divorce failed, divorce law was not made more strict either. Even the Big Lie was - grudgingly perhaps - tolerated. By the nineteen twenties women had obtained a stronger voice, but although proposals to abolish inequalities between men and women were made by women's organisations, extending the grounds for divorce was rejected, especially by catholic women. The idea of a compulsory medical examination prior to the marriage was rejected as well. ${ }^{291}$

The book The Companionate Marriage from Ben Lindsey, ${ }^{292}$ published in 1927 , added some fuel to the flames. Lindsey was a strong advocate of facilitating divorce, not only because he considered maintaining an unsuccessful marriage wrong and unproductive (i.e. divorced people could marry again, successfully, which would eventually lead to two happy marriages instead of one unhappy one), but also because people would always find either loopholes in the law which prohibited divorce or would turn to more cunning devices, not strictly legal, to fulfil the necessary criteria to get a divorce granted. ${ }^{293}$ According to Lindsey, the legislator was somewhat naïve when he did not realise 'how human beings act when living under laws to which they do not assent. ${ }^{294}$ In Dutch religious circles Lindsey's ideas were rejected. ${ }^{295}$

During the nineteen thirties, the lines of the discussion did not substantially change, despite the fact that this were times of economic depression and the emergence of National Socialism. Socialists generally sought extension of the grounds for divorce, whilst all these proposals were categorically rejected by the confessional parties. ${ }^{296}$ The discussion with regard to racial hygiene did not change as well, despite the increased attention the subject generated in Germany. In general, Dutch researchers did not want to obscure the discussion about eugenics with arguments about racial purity and racial superiority. In the Netherlands it was generally denied that it was possible to classify Jews as a separate race. Although German radicalism was criticised, the Dutch attitude towards the German Gesetz zur Verhütung erbkranken Nachwuchses ${ }^{297}$ of I 933 and the Ehegesundheitsgesetz ${ }^{298}$ of 1935 was ambivalent. The laws were published in Dutch

288 Handelingen der Staten-Generaal (Tweede Kamer), bijlagen 1911-1912, no. 306.2, Article 1: 'In artikel 255 van het Burgerlijk Wetboek wordt het woord "vijf" vervangen door "drie"'.

289 Handelingen der Staten-Generaal (Tweede Kamer), bijlagen 1911-1912, no. 306.4, Bijlage der Memorie van Toelichting.

290 A.H. Huussen, 'The Discussion about the Extension of Divorce in the Netherlands, 1870-1970', 324. See also Handelingen der Staten-Generaal (Tweede Kamer), zitting 1968-1969, no. 10213.3, Memorie van Toelichting, p. 11

291 A.H. Huussen, 'The Discussion about the Extension of Divorce in the Netherlands, 1870-1970', 324-325.

292 B.B. Lindsey and W. Evans, The Companionate Marriage, translated as Huwelijk in Kameraadschap.

293 B.B. Lindsey and W. Evans, The Companionate Marriage, 364-370.

294 B.B. Lindsey and W. Evans, The Companionate Marriage, 369.

295 A.H. Huussen, 'The Discussion about the Extension of Divorce in the Netherlands, 1870-1970', 326.

296 A.H. Huussen, 'The Discussion about the Extension of Divorce in the Netherlands, 1870-1970', 327.

297 Gesetz zur Verhütung erbkranken Nachwuchses vom 14. Juli 1933, Reichsgesetzblatt (1933), I, 529.

298 Gesetz zum Schutze der Erbgesundheit des deutschen Volkes vom 18. Oktober 1935, Reichsgesetzblatt (1935), I, 1246. 
eugenic periodicals without comments and were often given the benefit of the doubt by eugenicists who claimed that eugenics had to be separated from the National Socialist racial policies. Noordman states that this ambivalent attitude was perhaps due to the fact that Dutch eugenicists were somewhat jealous of their German colleagues, who were granted all facilities to carry out the research they wanted to do, whilst in the Netherlands eugenicists had to row upstream. ${ }^{299}$

In 1938 Minister of Justice Goseling came with another draft proposal to alter the Civil Code and solve the problem of the Big Lie. ${ }^{300}$ According to the explanatory memorandum a solution had to be found primarily within the realms of procedural law. ${ }^{301}$ An important role was allotted to the president of the court who could either refuse to plan a date for the procedure $\mathrm{s}^{302}$ or could officially indicate his doubts with regard to the sincerity of the petitioner ${ }^{303}$ on the basis of which the court could order additional evidence. ${ }^{304}$ The president of the court, it was reasoned, was the one who spent the most time with the petitioner and the partner during the procedure and was therefore in the best position to decide whether the claimed grounds for divorce were correct. ${ }^{305}$

Apart from the procedural changes, the draft proposal sought to change the Civil Code as well, in almost exactly the same way as Regout had proposed. Article I, ${ }^{306}$ which proposed to shorten the term of separation from bed and board before getting a divorce from five to three years, was literally copied from the Regout draft, whilst Article II, ${ }^{307}$ which stated that a partner was declared inadmissable in case the facts, which could have led to a ground for divorce, had occurred with his explicit or tacit agreement, had copied only the first part of Article III of the Regout draft. This article had to prevent partners, who sought a divorce, from creating a real ground for divorce (e.g. one of the partners actually committing adultery), since the fictitious ground for divorce would no longer

299 J. Noordman, Om de kwaliteit van het nageslacht, 128-134.

300 Handelingen der Staten-Generaal (Tweede Kamer), bijlagen 1938-1939, no. 257.

301 Handelingen der Staten-Generaal (Tweede Kamer), bijlagen 1938-1939, no. 257.3, Memorie van Toelichting, A, § 1.

302 Handelingen der Staten-Generaal (Tweede Kamer), bijlagen 1938-1939, no. 257.2, Article IV: '[...] Indien den president blijkt, dat de eischer de juistheid van zijne opgave der daadzaken niet staande houdt, weigert hij eenen dag te bepalen, waarop beide partijen voor hem zullen verschijnen. [...]'

303 Handelingen der Staten-Generaal (Tweede Kamer), bijlagen 1938-1939, no. 257.2, Article VI: '[...] Indien de verweerder de juistheid van des eischers opgave der daadzaken niet betwist, doch de president niettemin daaraan twijfelt, maakt hij hiervan melding in het proces-verbaal.

Indien de verweerder de conclusiën van den eischer niet tegenspreekt, doch deze den president niettemin onregtmatig voorkomen, zal hij zijn met redenen omkleed gevoelen te dezen eveneens in het proces-verbaal vermelden.'

304 Handelingen der Staten-Generaal (Tweede Kamer), bijlagen 1938-1939, no. 257.2, Article VIII: '[...] Ingeval het procesverbaal van den uitslag der verschijning voor den president eene vermelding bevat, als bedoeld in het vijfde lid van artikel 819 (see Article VI) of ingeval de regtbank ook zonder zoodanig vermelding aan de juistheid van des eischers opgave der daadzaken twijfelt, zal niettegenstaande bekentenis van den verweerder of wanneer deze, na drie malen van maand tot maand in regten te zijn opgeroepen, niet verschijnt, de regtbank, met inachtneming overigens van hetgeen is bepaald in artikel 19a, bevelen, dat partijen in persoon of met derzelver praktizijns voor haar zullen verschijnen. Indien de regtbank zich vereenigt met het door den president in zijn proces-verbaal uitgedrukte gevoelen, onderscheindenlijk de regtbank wordt bevestigd in haar twijfel aan de juistheid van des eischers opgave der daadzaken, zal zij nader bewijs gelasten. [...] Ingeval het proces-verbaal van den uitslag der verschijning voor den president eene vermelding bevat, als bedoeld in het zesde lid van artikel 819 , is het vorige lid van overeenkomstige toepassing. [...]'

305 Handelingen der Staten-Generaal (Tweede Kamer), bijlagen 1938-1939, no. 257.3, Memorie van Toelichting, B, Article VI.

306 Handelingen der Staten-Generaal (Tweede Kamer), bijlagen 1938-1939, no. 257.2, Article I: 'In artikel 255 van het Burgerlijk Wetboek wordt het woord "vijf" vervangen door "drie",

307 Handelingen der Staten-Generaal (Tweede Kamer), bijlagen 1938-1939, no. 257.2, Article II: 'Tusschen de artikelen 270 en 271 van gemeld Wetboek (i.e. the Civil Code) wordt een nieuw artikel 270a ingevoegd, luidende als volgt: "De echtgenoot zal in zijne regtsvordering tot echtscheiding niet ontvankelijk zijn, indien de daadzaken, welke grond tot dezelve hadden kunnen opleveren, met zijne uitdrukkelijke of stilzwijgende toestemming hebben plaats gehad."' 
get a divorce granted when this proposal would be accepted. ${ }^{308}$ However, as Germany occupied the Netherlands in May I940, this proposal was never enacted. ${ }^{309}$

A last attempt to revise Dutch matrimonial law before the Netherlands became occupied territory, came from the Committee for common Action to Reform our Matrimonial Law (Comité voor eene gemeenschappelijke Actie tot Hervorming onzer Huwelijkswetgeving) in I939. ${ }^{310}$ This committee was founded in 1926 and initiated by the Dutch Society of Female Citizens (Nederlandsche Vereeniging van Staatsburgeressen). The committee's proposal was rather daring as it touched upon quite some delicate subjects discussed in the past decades. They inter alia suggested to introduce a compulsory medical examination prior to the marriage, of which results both partners were informed. ${ }^{311}$ However, they rejected the idea to prohibit the intended marriage when the results showed that one of the partners was suffering from a contagious or hereditary disease, which could harm the other partner or any future offspring. ${ }^{312}$ Furthermore, the committee reformulated the existing grounds for divorce and suggested two other, namely the stay of one of the spouses in a psychiatric hospital for a least five consecutive years ${ }^{313}$ and permanent breakdown of the marriage, ${ }^{314}$ although that term was not used in this respect. Instead, the proposal spoke of a marriage which had degenerated in such a way that continuation could no longer be expected from the petitioner. Subcommission B had stated that in this respect one not only had to consider physical and psychological ill-treatment or neglect of family duties, but also behaviour and opinions, which - although not blameworthy made continuation of the marriage unbearable. ${ }^{315}$

In order to solve the Big Lie the committee suggested to include a provision which stated that the court would not accept the stated facts only on the basis of a confession or a lack of contradiction. ${ }^{316}$

As with the 1938 Goseling draft, this proposal was shelved after the German invasion in 1940 .

308 Handelingen der Staten-Generaal (Tweede Kamer), bijlagen 1938-1939, no. 257.3, Memorie van Toelichting, A, § 3.

309 See Handelingen der Staten-Generaal (Tweede Kamer), zitting 1968-1969, no. 10213.3, Memorie van Toelichting, p. 11.

310 A.H. Huussen, 'The Discussion about the Extension of Divorce in the Netherlands, 1870-1970', 327.

311 Comité voor eene gemeenschappelijke Actie tot Hervorming onzer Huwelijkswetgeving, Huwelijk en Echtscheiding, 7: 'Alle personen, die met elkaar een huwelijk willen aangaan, moeten [...] aan dezen ambtenaar (i.e. a registrar) een bewijs overleggen, dat zij met het oog op het huwelijk uiterlijk een maand voordien door een medicus zijn onderzocht, en dat de andere partij met de resultaten van dit medisch onderzoek volledig in kennis is gesteld.'

312 Comité voor eene gemeenschappelijke Actie tot Hervorming onzer Huwelijkswetgeving, Huwelijk en Echtscheiding, 11.

313 Comité voor eene gemeenschappelijke Actie tot Hervorming onzer Huwelijkswetgeving, Huwelijk en Echtscheiding, 7: 'Art. 264a: Verpleging van één der echtgenooten in een krankzinnigengesticht [...] gedurende tenminste vijf achtereenvolgende jaren, is eveneens een grond tot echtscheiding.' The term of five year was chosen based on statistical research which showed that after five years recovery only very rarely occurred. See Comité voor eene gemeenschappelijke Actie tot Hervorming onzer Huwelijkswetgeving, Huwelijk en Echtscheiding, 16.

314 Comité voor eene gemeenschappelijke Actie tot Hervorming onzer Huwelijkswetgeving, Huwelijk en Echtscheiding, 7: 'Art. 264b: Echtscheiding kan ook worden gevorderd als het huwelijk in die mate is verworden, dat de bestendiging ervan niet van de eischende partij kan worden gevergd.'

315 Comité voor eene gemeenschappelijke Actie tot Hervorming onzer Huwelijkswetgeving, Huwelijk en Echtscheiding, 17.

316 Comité voor eene gemeenschappelijke Actie tot Hervorming onzer Huwelijkswetgeving, Huwelijk en Echtscheiding, 7: 'De rechter neemt de bij dagvaarding gestelde feiten niet als bewezen aan enkel op grond van bekentenis of gemis aan tegenspraak.' 


\section{- 4.2.5. The application of the Nuremberg Laws between 1935-1940}

In September 1935 the Netherlands was confronted with another problem regarding matrimonial law: what to do with the Nuremberg Laws ${ }^{317}$ which were adopted in Germany on 15 September 1935 and which prohibited marriages between Jews and German state nationals of German or kindred blood? ${ }^{318}$

In 1902 the Netherlands had been initiator of the Hague Marriage Convention, which stated that the conclusion of marriage was governed by the national law of those who wanted to get married. ${ }^{319}$ Article 4 furthermore stated that persons who wanted to get married abroad had to prove that there existed no impediments to the marriage under the law of their home country. ${ }^{320}$ As both the Netherlands and Germany ${ }^{321}$ had signed and ratified this convention, this meant that German matrimonial law - in this case the Blood Protection Law - was applicable to the conclusion of marriages of Germans in the Netherlands. ${ }^{322}$ By way of an exception Article 3 of the Hague Marriage Convention declared that despite impediments to marriage according to the law of the home country, the host country could nevertheless allow the conclusion of the marriage in case these impediments were solely based on grounds of a religious nature. ${ }^{323}$ However, the impediments listed in the Blood Protection Law were not based on religious grounds but on racial grounds. As we have seen before, Jews were not classified according to their religious beliefs, but according to their race; a person who had converted to Christianity but had four Jewish grandparents was considered a full-Jew, although, ironically enough, whether or not the grandparents were Jewish was determined by whether or not they (had) adhered to the Jewish religious community. ${ }^{324}$ The Gesetz zum Schutze des deutschen Blutes und der deutschen Ehre served to protect - as the name already suggests - the German blood and the German honour, not German Christianity.

This point of view was expressed by both I. Kisch and P.G.M. van Meeuwen, right after promulgation of the Nuremberg Laws. ${ }^{325}$ According to both Kisch and Van Meeuwen,

317 See on this matter also M.E. Verburg, Geschiedenis van het Ministerie van Justitie, 1898-1940, 371-374; F.A.J. van der Ven, “"'Gleichschaltung” en “Umdeutung"', Rechtsgeleerd Magazijn THEMIS 5 (2011), 215-232, 222-225 and - albeit very briefly - C.J.H. Jansen, 'De Duitse Themis op de pijnbank', 85 Nederlands Juristenblad 28 (2010), 1818-1825.

318 See $\S 1$ (1) of the Gesetz zum Schutze des deutschen Blutes und der deutschen Ehre vom 15. September 1935, Reichsgesetzblatt (1935), I, 1146-1147.

319 Convention pour régler les conflits de lois en matière de mariage, Staatsblad (1904), no. 121, Article 1: 'Le droit de contracter mariage est réglé par la loi nationale de chacun des futurs époux, à moins qu'une disposition de cette loi ne se réfère expressément à une autre loi.'

320 Convention pour régler les conflits de lois en matière de mariage, Staatsblad (1904), no. 121, Article 4: 'Les étrangers doivent, pour se marier, établir qu'ils remplissent les conditions nécessaires d'après la loi indiquée par l'article $1 \mathrm{er}$. [...].'

321 Abkommen zur Regelung des Geltungsbereichs der Gesetze auf dem Gebiete der Eheschließung vom 12. Juni 1902, ReichsGesetzblatt (1904), 221.

322 Already right before and during the First World War, France (Nederlandsche Staatscourant, 26 November 1913, no. 277) and Belgium (Nederlandsche Staatscourant, 26 November 1918, no. 277), both belonging to the Allied Powers, had revoked the Convention, although they still applied the provisions of the Convention as far as this did not lead to a violation of public order. See I. Kisch, 'Het Duitsche verbod van gemengde huwelijken', Weekblad van het Recht 12960 (1935); M.E. Verburg, Geschiedenis van het Ministerie van Justitie, 1898-1940, 371.

323 Convention pour régler les conflits de lois en matière de mariage, Staatsblad (1904), no. 121, Article 3: 'La loi du lieu de la célébration peut permettre le mariage des étrangers nonobstant les prohibitions de la loi indiquée par l'article 1er, lorsque ces prohibitions sont exclusivement fondées sur des motifs d'ordre religieux. [...].'

324 Called a 'testimonium pauperatis' by J.W.M. Schröder, who nevertheless concluded that the concept of 'Jew' was a racial concept in Germany, rather than a religious one. See J.W.M. Schröder, 'De Duitsche rassen- en huwelijkswetgeving bezien in het licht van het Nederlandsch Internationaal Privaatrecht', 11 Nederlandsch Juristenblad 44 (1936), 1009-1021, 1014. Part 2 of this article was published in 11 Nederlandsch Juristenblad 45 (1936), 1037-1049.

325 I. Kisch, 'Het Duitsche verbod van gemengde huwelijken', Weekblad van het Recht 12960 (1935); P.G.M. van Meeuwen, 'Het huwelijksverdrag en de nieuwe Duitsche wet tot regeling van de positie der Joden', 10 Nederlandsch Juristenblad 31 (1935), 483-486, 483-484. 
when drafting the Marriage Convention in I902, the contracting states did not suspect that racial qualifications once would become an element in matrimonial law. ${ }^{326}$ If they would have suspected this, they would surely have included this in Article $3,{ }^{327}$ although Van Meeuwen indicated that since some states, albeit no contracting states, prohibited marriages between whites and coloured people, the contracting states could have been aware of this phenomenon. ${ }^{328}$ This point of view was endorsed to by R.D. Kollewijn, ${ }^{329}$ who even quoted Franz Kahn: 'Es könnte aber doch einem oder dem anderen Vertragsstaate in Zukunft einmal belieben, zum Schutze wirklicher oder vermeintlicher nationaler Interessen ein vom Rassengeist diktiertes Eheverbot einzuführen. ${ }^{330}$ However, a broader interpretation of provisions of international treaties was generally not accepted under international law, according to Kisch. ${ }^{331}$ The fact that in the Netherlands the word 'Jew' entailed a religious qualification rather than a racial one did not matter in this respect as well, according to Kisch, as the Convention used the phrase 'grounds of a religious nature' rather than 'impediments regarding professors of a certain religion'. ${ }^{332}$

Because of this Van Meeuwen urged the Dutch government to initiate inclusion of this ground in Article 3. If this would not go through, the Netherlands (and probably other countries too) was left no other choice than to revoke the Convention. However, this could not be done before I June I939, as the Convention was automatically renewed every five years, most recently on I June $1934 \cdot{ }^{333}$ Others, like G.A. Boon and B. BakkerNort, both Members of Parliament, agreed to this point of view. ${ }^{334}$

However, according to H.L. van Zanten, revoking the Convention was not necessary, as compliance with the German Blood Protection Law would be impossible. Dutch registrars would not be able to determine whether someone was of German or kindred blood or Jewish in the sense of the Blood Protection Law, as the German law did not provide any objective criteria regarding this matter. Compliance with the German Blood Protection Law was therefore not possible, so that the Netherlands was not bound by it. 'A l'impossible nul n'est tenu'. 335

J. Versteeg agreed with Van Zanten that it would be very difficult for Dutch registrars to decide whether German nationals complied with all German marital requirements. Therefore, he advised Dutch registrars to refer the couples to the German authorities in order to get an Ehefähigkeitszeugnis, a certificate of fitness to marry. In case this certificate

326 Ibid., ibid., 484.

327 I. Kisch, 'Het Duitsche verbod van gemengde huwelijken', Weekblad van het Recht 12960 (1935).

328 P.G.M. van Meeuwen, 'Het huwelijksverdrag en de nieuwe Duitsche wet tot regeling van de positie der Joden', 10 Nederlandsch Juristenblad 31 (1935), 483-486, 484.

329 R.D. Kollewijn, 'Het Duitsche verbod der "gemengde huwelijken”', 10 Nederlandsch Juristenblad 37 (1935), 577-580, published in full in 'Het Duitse verbod van huwelijken tussen Ariërs en niet-Ariërs', 142 Indisch Tijdschrift van het Recht 4 (1935), 473-482.

330 F. Kahn, 'Die dritte Haager Staatenkonferenz für internationales Privatrecht', in O. Lenel and H. Lewald (eds.), Abhandlungen zum internationalen Privatrecht von Franz Kahn, volume 2, 115, originally published in Zeitschrift für internationales Privatund Öffentliches Recht 3/4 (1903), 201-261, 252-253.

331 I. Kisch, 'Het Duitsche verbod van gemengde huwelijken', Weekblad van het Recht 12960 (1935).

332 Ibid.

333 P.G.M. van Meeuwen, 'Het huwelijksverdrag en de nieuwe Duitsche wet tot regeling van de positie der Joden', 10 Nederlandsch Juristenblad 31 (1935), 483-486, 485.

334 Handelingen der Staten-Generaal (Tweede Kamer), 1935-1936, Report of the 19th Assembly, 21 November 1935, 489-545, 498,501 . Boon had already sent a written question regarding this matter to the Minister of Justice earlier. See also H.L. van Zanten, 'De Duitse "Jodenwet” en Nederland', 10 Nederlandsch Juristenblad 32 (1935), 495-496, 495.

335 H.L. van Zanten, 'De Duitse "Jodenwet" in Nederland', 10 Nederlandsch Juristenblad 32 (1935), 495-496, 496. 
was refused, the Dutch registrar should not hazard to judge upon the matter himself, but should refuse to conclude the marriage. The couple could then refer the matter to the district court, were a judge should decide upon the matter. ${ }^{336}$ Such a case had happened before, in 1933, when a registrar in Rotterdam had refused to conclude a marriage between a German Jew and a German Aryan woman, because they could not provide an Ehefähigkeitszeugnis. The authorities in Leipzig had refused this Ehefähigkeitszeugnis on I7 November 1933, because a marriage between a Jew and an Aryan was not in the interest of preserving the Aryan race. The District Court of Rotterdam, however, decided that the marriage could be concluded without violating Article I of the Hague Marriage Convention, as only the national law of the home country of the partners had to be taken into account. Since there was no German law at that time prohibiting a marriage between a Jew and an Aryan, the argument given by the Leipzig authorities was not a legal argument. ${ }^{337}$ However, this line of reasoning could obviously no longer be upheld after 15 September 1935 .

During a meeting of Parliament on 2I November 1935, when the Justice Budget of I936 was discussed, the matter came up again, through MPs B. Bakker-Nort and G.A. Boon. Bakker-Nort expressed condemnation of the new German matrimonial law and wondered whether the Netherlands was indeed obliged by the Hague Marriage Convention to apply the German Blood Protection Law. According to Bakker-Nort it was impossible to determine who was a 'Jew' and who was of 'German or kindred blood'. Therefore, she came to the same conclusion as Van Zanten: 'à l'impossible nul n'est tenu.' Nevertheless, she asked the Minister of Justice to revoke, on behalf of the Netherlands, the Hague Marriage Convention as the Blood Protection Law contravened the Dutch sense of justice and even the Dutch Constitution which did not distinguish between religions or races. ${ }^{338}$

Boon referred to the dilemma the registrars were faced with, and the - in his view dissapointing solution that had been chosen, namely to request an Ehefähigkeitszeugnis and to refuse conclusion of the marriage in case such a certificate lacked. He pointed out the line of reasoning of the Rotterdam District Court in the case of 18 December 1933 and stated that surely this would mean that, as since 15 September 1935 a legal basis did exist, no marriages between Germans and Jews would be concluded in the Netherlands anymore. According to Boon this was intolerable and he - as well - requested that the Hague Marriage Convention was revoked. However, since this would only come into effect on I June 1939 Boon wondered what had to be done in the meantime. Boon agreed with Bakker-Nort that it was impossible to determine who was a 'Jew' and who an 'Aryan'. According to Boon the concept 'Aryan' was an unscientific concept and taking it into account was unscientific foolishness. He argued in favour of a broad interpretation of Article 3 of the Hague Marriage Convention thereby pointing out that all marriages

$336 \mathrm{~J}$. Versteeg, 'Het standpunt van den Ambtenaar van den Burgerlijken Stand ten opzichte van de nieuwe Duitsche huwelijkswetgeving', 10 Nederlandsch Juristenblad 33 (1935), 511-513, 512-513.

337 Arrondissementsrechtbank Rotterdam, 18 December 1933, Weekblad van het Recht 12744 (1934).

338 Handelingen der Staten-Generaal (Tweede Kamer), 1935-1936, Report of the 19th Assembly, 21 November 1935, 489-545, 498. 
concluded in the Netherlands in defiance of the German Blood Protection Law would be recognised everywhere except in Germany, at least as long as the thousand years of the Thousand Year Reich had not yet passed. ${ }^{339}$

In a reaction Minister of Justice J.R.H. van Schaik stated that an Ehefähigkeitszeugnis was not indispensable as already proven by the judgment of the Rotterdam District Court of I8 December 1933. According to Van Schaik the German Blood Protection Law could furthermore only apply to intended marriages between a German Aryan and a German Jew. The German concept of 'Jude' could never refer to a Dutch Jew, as Dutch law did not distinguish on the basis of race. The word 'Jude' reflected an entirely German concept and could only apply to German nationals. Therefore, German Aryans would be able to marry any Jew except a German one, in the Netherlands. Van Schaik expected that the Netherlands would not be troubled much by this German law. Therefore, he wanted to await court decisions regarding this matter, prior to take measures. As revoking the Hague Marriage Convention could not be done without international consultations, he had decided to play a waiting game regarding this matter. ${ }^{340}$

As Verburg already points out, legal practice regarding this matter was therefore determined by Dutch registrars and especially Dutch district courts. ${ }^{341}$ According to the advice given by Versteeg the registrars refused to conclude marriages in case there was no Ehefähigkeitszeugnis and the district courts seemed to follow the line of reasoning of the Minister of Justice.

On 20 May 1936 the Dordrecht District Court decided that a marriage between two German nationals, of which the man was Jewish, could not be concluded as the German Blood Protection Law prohibited the marriage. Since both partners were German nationals, German law was applicable and since the impediment was not of a religious nature, the marriage could not be concluded in the Netherlands. ${ }^{342}$ Nine days later the Rotterdam District Court decided that the marriage between a German Aryan woman and a Dutch man of Jewish ancestry could be concluded as the German concept of 'Jew' did not apply to the man since he had the Dutch nationality. As he did not adhere to the Jewish religious community, according to Dutch law he was no Jew. Note that the Court did not mention the fact that Dutch law did not distinguish on the basis of race, therefore not dismantling the German concept of 'Jew' for Dutch Jews in general. The Prosecution Counsel for that matter, through W. van Traa, was of the opinion that the marriage could not be concluded as whether or not the man was a Jew should not be determined according to Dutch law but according to German law. Application of the Hague Marriage Convention implied that only the question whether or not the statutum personale of the foreigner applied to that foreigner was relevant. The statutum personale of

339 Handelingen der Staten-Generaal (Tweede Kamer), 1935-1936, Report of the 19th Assembly, 21 November 1935, 489-545, 501-502.

340 Handelingen der Staten-Generaal (Tweede Kamer), 1935-1936, Report of the 19th Assembly, 21 November 1935, 489-545, 525-526. Van Schaik's explanation was also published in the Nederlandsch Juristenblad, see 'De "wetten van Neurenberg"', 10 Nederlandsch Juristenblad 41 (1935), 652-653.

341 M.E. Verburg, Geschiedenis van het Ministerie van Justitie, 1898-1940, 373.

342 Arrondissementsrechtbank Dordrecht, 20 May 1936, Nederlandsche Jurisprudentie 1936, 456. 
the foreigner could never apply to the Dutch partner. Therefore, the prohibition to marry did not extend to the Dutch man of Jewish ancestry, but to the German Aryan woman; she was not eligible to marry him. ${ }^{343}$

The district courts, however, continued to use the statutum personale of the alleged Jew in order to determine whether he was a Jew or not. That would not necessarily be Dutch law; on I6 June 1936 the District Court of 's Hertogenbosch decided that whether or not an Austrian woman was Jewish should be determined according to Austrian law, which did not recognise (yet) the term 'Jew' as a racial concept, other than a religious one. ${ }^{344}$ In case the alleged Jew was stateless, but living in the Netherlands, Dutch law would be the statutum personale. $^{345}$

Apart from the statutum personale, however, the District Court of 's Hertogenbosch decided that classifying persons according to race was a violation of Dutch public order. Therefore, the German Blood Protection Law could not be applicable in the Netherlands. Because of the Hague Marriage Convention the Netherlands was not allowed to make exceptions in case the foreign matrimonial law constituted a violation of Dutch public order. In this case, however, it was not the matrimonial law itself which constituted a violation of public order, but the underlying racial qualifications. ${ }^{346}$

However, this line of reasoning was not adopted by other courts. In 1938 both the District Court of Amsterdam ${ }^{347}$ and Arnhem ${ }^{348}$ prohibited the conclusion of marriage between two German nationals, one of them being Jewish. ${ }^{349}$ The District Court of Arnhem even stated that the principle of human equality was not that essential to Dutch law and Dutch public order that it would oblige the Netherlands to guarantee human equality with regard to the conclusion of marriage to foreigners staying in the Netherlands. ${ }^{350}$ This legal practice - the German Blood Protection Law would only apply to marriages between two German nationals, but would nevertheless apply - had already been confirmed in 1936 by Minister of Justice Van Schaik in a memorandum in reply. ${ }^{351}$

Finally, notwithstanding this ministerial point of view, the District Courts of 's Hertogenbosch and the Hague decided not to comply with $\mathbb{} 6$ of the First Supplementary Decree to the Blood Protection law without striking a blow. This article stated that all marriages, in which case offspring which was in any way harmful to the purity of the German blood was to be expected, were prohibited. ${ }^{352}$ In its decision of 16 June 1936 the District

343 Arrondissementsrechtbank Rotterdam, 29 May 1936, Nederlandsche Jurisprudentie 1936, 454.

344 Arrondissementsrechtbank 's Hertogenbosch, 16 June 1936, Nederlandsche Jurisprudentie 1936, 479.

345 Arrondissementsrechtbank 's Hertogenbosch, 31 July 1936, Nederlandsche Jurisprudentie 1936, 860.

346 Ibid.

347 Arrondissementsrechtbank Amsterdam, 31 January 1938, 100 Weekblad van het Recht 28 (1938), 331.

348 Arrondissementsrechtbank Arnhem, 10 May 1938, Nederlandsche Jurisprudentie 1938, 969.

349 In the Amsterdam case the alleged Jew had only two Jewish grandparents, effectively making her a half-Jew. However, § 3 (1) of the First Supplementary Decree to the Blood Protection Law stated that German half-Jews required approbation by the Minister of the Interior or the Führer's deputy in order to marry someone from German or kindred blood. Since the woman in question did not have this approbation, according to German law the marriage was not allowed either. See Arrondissementsrechtbank Amsterdam, 31 January 1938, 100 Weekblad van het Recht 28 (1938), 331.

350 Arrondissementsrechtbank Arnhem, 10 May 1938, Nederlandsche Jurisprudentie 1938, 969.

351 Handelingen der Staten-Generaal (Tweede Kamer), bijlagen 1936-1937, bijlage A, hoofdstuk 4, 2. IV. 9.

352 Erste Verordnung zur Ausführung des Gesetzes zum Schutze des deutschen Blutes und der deutschen Ehre vom 14. November 1935, Reichsgesetzblatt (1935), I, 1334, § 6: 'Eine Ehe soll ferner nicht geschlossen werden, wenn aus ihr eine die Reinerhaltung des deutschen Blutes gefährende Nachkommenschaft zu erwarten ist.' 
Court of 's Hertogenbosch decided that $\mathbb{} 6$ of the First Supplementary Decree had to be regarded an administrative provision directed to the registrars, rather than a legislative provision regarding the personal eligibility to marry according to Article I of the Hague Marriage Convention. ${ }^{353}$ The District Court of the Hague, however, would not go that far, but decided that $\$ 6$ was not applicable to marriages between a German woman and a foreigner, as in those cases the possible offspring would not have the German nationality. ${ }^{354}$ The Court even referred to Stuckart and Globke, who had specifically stated that in this case the possible offspring would not be harmful to the purity of the German blood. ${ }^{355}$

The Netherlands has not denounced the Hague Marriage Convention as a result of the Nuremberg Laws. According to J.W.M. Schröder, in an article that covered two issues of the Nederlandsch Juristenblad, this was not necessary as the Dutch court decisions had showed that the Nuremberg Laws could be kept at a reasonable distance. He even praised the Dutch district courts for maintaining its sobermindedness and tolerance. ${ }^{356}$ However, nor the Dutch courts (with the exception of the District Court of 's Hertogenbosch) nor the Dutch Minister of Justice have ever turned to a total denunciation of the Blood Protection Law. It remains unclear how many conclusions of marriage have been refused on the basis of the (First Supplementary Decree of the) Blood Protection Law. ${ }^{357}$

\subsection{Years of Occupation}

\section{- 4.3.1. Administrative and legislative competences during occupation}

During the first months of the Second World War, the Netherlands clung to its neutrality, which had prevented involvement in the First World War. Nowadays it is generally believed that the Dutch authorities, not counting exceptions, closed their eyes to the rise of National Socialism and the violatons of the Versailles Treaty of $1919 .{ }^{358}$ Whether the Netherlands was therefore unprepared for a German invasion is disputable however. It has long been assumed that the German invasion of Io May I940 had come as a complete surprise to the badly prepared and marginally equiped Dutch military forces, which nevertheless managed to hold on for five days. Amersfoort and Kamphuis, however, indicate that long before 1940 in military circles it was already assumed that a next war would start without a formal declaration of war. Therefore, by 9 May I 940 the entire Dutch military forces were fully mobilised and on a war footing. ${ }^{359}$ Nevertheless, the Netherlands did not have an elaborate emergency plan regarding the continuation or

353 Arrondissementsrechtbank 's Hertogenbosch, 16 June 1936, Nederlandsche Jurisprudentie 1936, 479.

354 Arrondissementsrechtbank the Hague, 28 August 1936, Nederlandsche Jurisprudentie 1936, 920. In this case a German Aryan woman wished to marry a Dutch man of Indian (nowadays Indonesian) ancestry.

355 W. Stuckart and H. Globke, Kommentare zur deutschen Rassengesetzgebung, band 1, Reichsbürgergesetz, Blutschutzgesetz, Ehegesundheitsgesetz, 133-134.

356 J.W.M. Schröder, 'De Duitsche rassen- en huwelijkswetgeving bezien in het licht van het Nederlandsch Internationaal Privaatrecht', 11 Nederlandsch Juristenblad 45 (1936), 1037-1049, 1048. Part 1 of the article was published in 11 Nederlandsch Juristenblad 44 (1936), 1009-1021.

357 M.E. Verburg, Geschiedenis van het Ministerie van Justitie, 1898-1940, 374.

358 C. van der Heijden, Grijs verleden, 98-108; L. de Jong, Het Koninkrijk der Nederlanden in de Tweede Wereldoorlog, 2:129149, 370-371, 417-422; G. Hirschfeld, Bezetting en collaboratie, 19-21.

359 H. Amersfoort and P.H. Kamphuis (eds.), Mei 1940. De strijd op Nederlands grondgebied, 381. 
devolution of government powers in case of an occupation.

After German forces invaded the Netherlands on io May i940, Queen Wilhelmina fled into exile to London on I3 May I940, followed by the Government. Only two ministers remained in the Netherlands, Minister of Agriculture and Fishery A.A. van Rhijn and Minister of Trade, Industry and Shipping M.P.L. Steenberghe. ${ }^{360}$ Without any governmental consent, they delegated all governmental authority and statutory powers to General H.G. Winkelman, commander-in-chief of the Dutch Armed Forces. ${ }^{361}$ All secretaries-general of the Ministries were instructed to follow orders from the commander-in-chief and further to attend to their departments. ${ }^{362}$ General Winkelman remained the highest legislative and executive body until 25 May I940, when the German military administration was replaced by a civil administration with Arthur Seyss-Inquart as Reichskommissar für die besetzten niederländischen Gebiete.

In 1937 the Council of Ministers, ${ }^{363}$ presided by Prime Minister H. Colijn, had adopted the so-called Aanwijzingen, Instructions based on the Regulations Respecting the Laws and Customs of War on Land (Annex to the IVth Hague Convention Respecting the Laws and Customs of War on Land of 1907, hereafter the Hague Regulations) concerning the attitude government bodies had to adopt towards possible occupying forces. In I938 these Instructions were sent to all provincial governments and mayors, secretly, as one did not want to compromise the Dutch policy of neutrality. However, as none of the members of the Colijn cabinet was a member of the De Geer cabinet, which was the incumbent cabinet in May I940, none of the ministers was aware of the existence of these Instructions at the time of the German invasion. The majority of civil servants was unaware of their existence as well. ${ }^{364}$ For those who did know about the Instructions, the Instructions themselves provided the next problem, since it was both unclear for who

360 A.A. van Rhijn and M.P.L. Steenberghe left for London later on the same day. See L. de Jong, Het Koninkrijk der Nederlanden in de Tweede Wereldoorlog, 3:290-291.

361 The ground for this authority remains debatable. According to Biegel, this basis was not to be found in the War Act of 23 May 1899 (Wet van 23 Mei 1899, houdende bepalingen ter uitvoering van art. 187 der Grondwet, Staatsblad (1899), No. 128), as Article 22 of that act granted a Dutch military authority during wartime limited statutory powers, which could be compared with the statutory powers of the Provincial States and city councils. General Winkelman had not received a letter of authority, signed by the Queen and countersigned by the Council of Ministers and even if he had, he could not derive more powers from it that the Government possessed according to the Constitution. And the Government could not promulgate binding provisions without being authorised to do so by a law, which had to be realised by the States General, the Dutch Parliament. A blank power of attorney for the Government, such as $\S 48$ of the German Weimar Constitution, did not exist in the Dutch Constitution. According to Biegel the question whether or not General Winkelman had received full governmental and statutory powers had to be considered within the perspective of the occupation and international law. According to the Regulations Respecting the Laws and Customs of War on Land (Annex to the 1907 Hague Convention Respecting the Laws and Customs of War on Land), the actual exertion of authority rested with the occupying forces. Winkelman's provisions were allowed and approved of by the Germans. Therefore, according to Biegel, it could be concluded that Winkelman exercised his authority on behalf of the German occupying forces. See F.M. Biegel, Bezettingsrecht, 3-11. Biegel, however, could not have been aware of the oral delegation of powers by Steenberghe and Van Rhijn. See J.N.M.E. Michielsen, The 'Nazification' and 'Denazification' of the Courts in Belgium, Luxembourg and the Netherlands, 19-20.

362 L. de Jong, Het Koninkrijk der Nederlanden in de Tweede Wereldoorlog, 3:288-290; J.N.M.E. Michielsen, The 'Nazification' and 'Denazification' of the Courts in Belgium, Luxembourg and the Netherlands, 19; P.H.J. Körver, De bes/uitwetgeving van de Nederlandse regering in Londen in internationaal-rechtelijk en staatsrechtelijk perspectief, 1-2.

363 It is generally assumed that the Instructions were adopted by the Council of Ministers, although the document itself is ambiguous about it. The ending of the document states that the Instructions are adopted by the Council of Ministers whilst the introduction states that the Instructions are adopted in accordance with the Council of Ministers. See J.H. Sikkes, ...In geval van een vijandelijken aanval. Ambtelijk gedrag in bezettingstijd en de daarvoor geldende aanwijzingen, 14 . De Jong states that the Instructions were drafted by an interdepartmental committee and approved of by the Council of Ministers. See L. de Jong, Het Koninkrijk der Nederlanden in de Tweede Wereldoorlog, 4: 114-115.

364 J.H. Sikkes, ...In geval van een vijandelijken aanval. Ambtelijk gedrag in bezettingstijd en de daarvoor geldende aanwijzingen, 9; L. de Jong, Het Koninkrijk der Nederlanden in de Tweede Wereldoorlog, 2:378-380; J.N.M.E. Michielsen, The 'Nazification' and 'Denazification' of the Courts in Belgium, Luxembourg and the Netherlands, 20. 
the Instructions were intended and what the legal status of the Instructions was. The Instructions were addressed to central, provincial and municipal administrative bodies, as well as administrative bodies of the district water boards, the district peat boards and peat polders, all staff and tram and railway personnel. ${ }^{365}$ For want of clarity it can be assumed that the Instructions were intended for all administrative bodies and all public servants. ${ }^{366}$ Furthermore it is unclear whether the Instructions were binding or not. De Jong states that the Instructions were based on the Hague Regulations and calls the Instructions 'fairly stringent regulations', ${ }^{367}$ but remains ambiguous about the exact legal status. ${ }^{368}$ According to Sikkes the Instructions were intended to clarify the provisions of the Hague Regulations and were as such not binding. Instruction I, however, states that those that were part of a central, provincial, muncipal etc. adminstrative body should remain at their positions in case of an enemy foray, ${ }^{369}$ which implies a binding order. However, the Council of Ministers was not entitled to give binding orders to administrative bodies other than the central administrative bodies. ${ }^{370}$ Whether the Instructions provided for binding provisions remains questionable, ${ }^{371}$ although a Commentary to the Instructions, written by some officials and recognised as an authentic interpretation of the Instructions by the Dutch government in exile, underlined in comment 2 that the Instructions remained in full force. ${ }^{372}$

The general tenor of the Instructions was that public servants had to remain at their posts to serve the interests of the own population. ${ }^{373}$ The disadvantage, that the interests of the occupying forces would be served by this as well, would not counterbalance the negative consequences for the population in case the administrative machinery was completely shut down. ${ }^{374}$ Only in case staying on proved to be more beneficial for the occupying forces than it was to the own population, a public servant was supposed to resign. When still in function, the main task of public servants consisted of making sure that the occupying forces observed the Hague Regulations. ${ }^{375}$ Public servants were told in no unclear terms that death was to be preferred above acting in defiance with the

365 'Aanwijzingen betreffende de houding, aan te nemen door de bestuursorganen van het Rijk, de provinciën, gemeenten, waterschappen, veenschappen en veenpolders, alsmede door het daarbij in dienst zijnde personeel en door het personeel in de dienst bij spoor-en tramwegen in geval van een vijandelijken inval.' For the text of the Instructions see J.H. Sikkes, ...In geval van een vijandelijken aanval. Ambtelijk gedrag in bezettingstijd en de daarvoor geldende aanwijzingen, 97-109 and L.H.N. Bosch Ridder van Rosenthal, 'De "Aanwijzingen"', in J.J. van Bolhuis et al. (eds.), Onderdrukking en Verzet. Nederland in Oorlogstijd (deel 1), 387-394.

366 J.H. Sikkes, ...In geval van een vijandelijken aanval. Ambtelijk gedrag in bezettingstijd en de daarvoor geldende aanwijzingen, 22.

367 'tamelijk stringente voorschriften'

368 L. de Jong, Het Koninkrijk der Nederlanden in de Tweede Wereldoorlog, 4: 114-116.

369 Instructions, Instruction 1: 'Als algemeene regel geldt, dat personen, deel uitmakende van bestuursorganen van het Rijk, de provinciën, gemeenten, waterschappen, veenschappen en veenpolders, en het bij die organen in dienst zijnde personeel, alsmede het personeel in dienst bij spoor-en tramwegen, bij een vijandelijken inval ter plaatse behooren (italics by $\mathrm{me}-\mathrm{ML}$ ) te blijven, [...].'

370 J.H. Sikkes, ...In geval van een vijandelijken aanval. Ambtelijk gedrag in bezettingstijd en de daarvoor geldende aanwijzingen, 14-15.

371 In 1948 the Dutch Central Appeals Court decided that circulars - such as the Instructions - do have binding force (Centrale Raad van Beroep, 11 May 1948, Administratiefrechtelijke Beslissingen 1948, 507), whilst ten years later the same court decided that they had not (Centrale Raad van Beroep, 30 September 1958, Administratiefrechtelijke Beslissingen 1960, 459).

372 See 'Commentaar van mei 1943', published in L.H.N. Bosch Ridder van Rosenthal, 'De "Aanwijzingen"', in J.J. van Bolhuis et al. (eds.), Onderdrukking en Verzet. Nederland in Oorlogstijd (deel 1), 395-397. L.H.N. Bosch Ridder van Rosenthal was one of the officials responsible for the Commentary, see ibid., 386-387.

373 See Instruction 1.

374 Instruction 31.

375 Instructions 24 and 29. 
Hague Regulations or collaboration with the occupying forces. ${ }^{376}$ However, despite the Instructions and the Commentary, Dutch public servants have encountered difficulties in their supposed attitude towards the occupant's administration. ${ }^{377}$

What competences did the occupying forces have?

The so-called laws of war have been developed gradually, starting with isolated milder practices which became usages which through treaties and customs became legal rules. Oppenheim ${ }^{378}$ distinguishes three principles by which the growth of laws and usages of war is determined. The first principle implies that in order to realise the purpose of war - which is overpowering the opponent - any kind and any amount of force, which is necessary to reach that purpose, is justified. Secondly, those kinds and amounts of violence which are not necessary to realise the purpose of war are subsequently not allowed. The third principle is the principle of chivalry, which finds it origins in medieval times and developed during the second half of the nineteenth century, when slowly the realisation grew that war was a matter of the respective armies and that the civilian population had to be spared as much as possible. The purpose of war could also be realised when consideration was shown to the wounded, the prisoners and those who did not fight at all. This realisation ultimately led to the Hague Peace Conferences of I899 and I 907 on which in 1907, amongst other things, the IVth Convention Respecting the Laws and Customs of War on Land (consisting of 9 articles) and the Annex, consisting of the Regulations Respecting the Laws and Customs of War on Land (56 articles) were adopted. ${ }^{379}$ Both the Convention and the Regulations were ratified by Germany ${ }^{380}$ and the Netherlands ${ }^{381}$ on 27 November 1909. ${ }^{382}$ Oppenheim points out that the Convention and the Regulations are only of limited importance, since the majority of the provisions were declaratory of existing customary international law. ${ }^{383}$ Nevertheless, although not without controversy, legislation established during the German occupation and occupier's acts have been judged within the light of the Convention both during the occupation and after. ${ }^{384}$ At the postwar war crime trials, the Convention and the Regulations, just like the Charter of the International Military Tribunal in Nuremberg, were the leading sources of law. ${ }^{385}$

376 Instructions 17 and 18

377 J.H. Sikkes, ...In geval van een vijandelijken aanval. Ambtelijk gedrag in bezettingstijd en de daarvoor geldende aanwijzingen, 42-44; J.N.M.E. Michielsen, The 'Nazification' and 'Denazification' of the Courts in Belgium, Luxembourg and the Netherlands, 21.

378 Oppenheim-Lauterpacht, International Law. A Treatise, volume 2, 226-227.

379 F.M. Biegel, Bezettingsrecht, 6-7. The authentic text of the Convention and the Annex is French. For the official US translation see A. Roberts and R. Guelff, Documents on the Laws of War, 67-84.

380 Upon signature, Germany made a reservation of Article 44 of the annexed Regulations. At ratification, this reservation was maintained. See A. Roberts and R. Guelff, Documents on the Laws of War, 84. IV. Haager Abkommen, betreffend die Gesetze und Gebräuche des Landkriegs vom 18. Oktober 1907/ Ordnung der Gesetze und Gebräuche des Landkriegs, Reichs-Gesetzblatt (1910), 107.

381 Verdrag nopens de wetten en gebruiken van den oorlog te land/Reglement betreffende de wetten en gebruiken van den oorlog te land, Staatsblad (1910), No. 73.

382 A. Roberts and R. Guelff, Documents on the Laws of War, 83-84.

383 Oppenheim-Lauterpacht, International Law. A Treatise, volume 2, 228-229.

384 Hoge Raad, 12 January 1942, Nederlandsche Jurisprudentie 1942, 271 (Toetsingsarrest). See on the controversy with regard to this judgment D. Venema et al. (eds.), Onder de huidige omstandigheden.

385 T.J. Jansma, Het bezettingsrecht in de practijk van de Tweede Wereldoorlog, 72-76. 
During an occupation authority is passed de facto into the hands of the occupant, although the national government remains the legitimate authority. The national government still has sovereignty, although the exercise of sovereignty lies de facto with the occupant. ${ }^{386}$ On I 8 May I940 Hitler issued a decree ${ }^{387}$ by which the German military administration in the Netherlands was replaced by a civil administration. ${ }^{388}$ Arthur Seyss-Inquart was appointed Reichskommissar für die besetzten niederländischen Gebiete. ${ }^{389}$ He accepted this appointment on 25 May 1940. ${ }^{390}$ On 29 May I940 Seyss-Inquart issued Regulation 3/1940 which stated in $\mathbb{S}$ I that the Reichskommissar possessed all powers which in the Dutch Constitution - and all other laws - were attributed to the King and government. ${ }^{391}$ The same paragraph stated that the Reichskommissar was authorised to issue regulations, when this was required in the interest of the German Reich, public order or public safety. These regulations had force of law. ${ }^{392}$ This provision was in accordance with the Decree of I 8 May I940. ${ }^{393}$ In the same paragraph the Decree had stated that Dutch law remained in force, insofar as this was consistent with the occupation. ${ }^{394}$ Paragraph 2 of Regulation 3/I940 confirmed this and added that all regulations issued by the commander-inchief of the Dutch Armed Forces remained in force for the time being. ${ }^{395}$ To help him in the exercise of his duty, Seyss-Inquart appointed four commissioners-general, ${ }^{396}$ who were authorised to request information from and give orders to all Dutch authorities,

386 F.M. Biegel, Bezettingsrecht, 7-8.

387 Erlaß des Führers über Ausübung der Regierungsbefugnisse in den Niederlanden vom 18. Mai 1940, Reichsgesetzblatt (1940), I, 778.

388 Ibid., § 1 : 'Die besetzten niederländischen Gebiete werden dem 'Reichskommissar für die besetzten niederländischen Gebiete' unterstellt. [...] Der Reichskommissar ist Wahrer der Reichsinteressen und übt im zivilen Bereich die oberste Regierungsgewalt aus. [...].'

389 Ibid., § 6 : 'Zum Reichskommissar für die besetzten niederländischen Gebiete bestelle ich den Reichsminister Dr. Arthur SeyßInquart.'

390 F.M. Biegel, Bezettingsrecht, 16; J.H.P. Bellefroid, Beknopt overzicht der Staatsinrichting van Nederland tijdens de bezetting, 5-6; Aufruf des Reichskommissars für die besetzten niederländischen Gebiete an der niederländische Bevölkerung vom 25. Mai 1940, Verordnungsblatt für die besetzten niederländschen Gebiete (1940), 6.

391 Verordnung des Reichskommissars für die besetzten niederländischen Gebiete über die Ausübung der Regierungsbefugnisse in den Niederlanden vom 29. Mai 1940, Verordnungsblatt für die besetzten niederländischen Gebiete (1940), 8, § 1 (1): 'Der Reichskommissar für die besetzten niederländischen Gebiete übt, soweit dies zur Erfüllung seiner Aufgabe nötig ist, alle Befugnisse aus, die nach der Verfassungsurkunde und den Gesetzen bisher den König und der Regierung zustanden.'

392 Ibid., § 1 (2) : 'Erheischen es die Interessen des Grossdeutschen Reiches oder der öffentlichen Ordnung oder des öffentlichen Lebens in den Niederlanden, so trifft der Reichskommissar die notwendigen Massnahmen, und zwar auch solche gesetzgeberischer Art. Diese Verordnungen des Reichskommissars haben Gesetzkraft.'

393 Erlaß des Führers über Ausübung der Regierungsbefugnisse in den Niederlanden vom 18. Mai 1940, Reichsgesetzblatt (1940), I, 778, § 5 (2) : 'Der Reichskommissar kann durch Verordnung Recht setzen. Die Verordnungen werden im "Verordnungsblatt für die besetzten niederländischen Gebiete" verkündet.'

394 Ibid., § 5 (1) : 'Das bisher geltende Recht bleibt in Kraft, soweit es mit der Besetzung vereinbar ist.'

395 Verordnung des Reichskommissars für die besetzten niederländischen Gebiete über die Ausübung der Regierungsbefugnisse in den Niederlanden vom 29. Mai 1940, Verordnungsblatt für die besetzten niederländischen Gebiete (1940), 8, § 2 (1): 'Das bisher geltende niederländische Recht bleibt in Kraft, soweit es mit der Besetzung vereinbar ist und soweit nicht die Bestimmungen des Erlasses des Führers über die Ausübung der Regierungsbefugnisse in den Niederlanden (RGBI. I, S. 778) dem entgegenstehen. Die für die besetzten niederländischen Gebiete geltenden Verordnungen des Oberbefehlhabers des Heeres bleiben bis auf weiteres in Kraft.'

396 Verordnung des Reichskommissars für die besetzten niederländischen Gebiete über die Ausübung der Regierungsbefugnisse in den Niederlanden vom 29. Mai 1940, Verordnungsblatt für die besetzten niederländischen Gebiete (1940), 8, § 4 (1) and Erlass des Reichskommissars für die besetzten niederländischen Gebiete über den organisatorischen Aufbau der Dienststellen des Reichskommissariat vom 3. Juni 1940, Verordnungsblatt für die besetzten niederländischen Gebiete (1940), 11, § 1 (1). Appointed were Friedrich Wimmer as Generalkommissar für Verwaltung und Justiz, Hanns Albin Rauter as Generalkommissar für das Sicherheitswesen, Hans Fischböck as Generalkommissar für Finanz und Wirtschaft and Fritz Schmidt as Generalkommissar zur besonderen Verwendung. See J.J. van Bolhuis, 'Enkele hoofdfiguren van het Duitse bestuur', in J.J. van Bolhuis et al. (eds.), Onderdrukking en Verzet. Nederland in Oorlogstijd (deel 1), 332-353. 
departments and institutes ${ }^{397}$ and whose main job consisted of preparing all decisions of the Reichskommissar. ${ }^{398}$ A more detailed job description was given in $\mathbb{4} 4^{-7}$ of Decree 4/I940.

Furthermore, the secretaries-general, who were accountable to the Reichskommissar, ${ }^{399}$ were given the authority to issue implementation orders with regard to existing Dutch law and regulations issued by the Reichskommissar. ${ }^{400}$ These implementation orders, however, were not allowed to be in violation of existing Dutch laws. ${ }^{401}$ Besides implementation orders, the secretaries-general could also issue independent regulations, pursuant to authorisation by the Reichskommissar. Those regulations had force of law and could be in breach of Dutch law or even the Constitution. When a regulation issued by a secretary-general was not covered by an authorisation order of the Reichskommissar, it was not binding. However, judges were not allowed to test the regulations issued by the secretaries-general against the authorisation order, as these regulations had to be submitted to the Reichskommissar before publication. ${ }^{402}$ Therefore, only the Reichskommissar could check whether a secretary-general had remained within the limits of the autorisation. On 2I June I940 Seyss-Inquart issued a blank authorisation order which allowed the secretaries-general to issue binding regulations necessary to maintain public order and public security. These regulations could even contain penalty clauses. ${ }^{403}$ Authorisation orders allowing a secetary-general to issue a regulation in a specific case were no longer necessary. Regulation 23/I940 provided the basis of the majority for the regulations issued by the secretaries-general. ${ }^{404}$

This delegation of legislative powers to the secretaries-general coincided with Regulation 22/I940 which suspended all activities of both chambers of the States General. ${ }^{405}$ However, the chambers were not dissolved and their mandat was entended ${ }^{406}$

397 Erlass des Reichskommissars für die besetzten niederländischen Gebiete über den organisatorischen Aufbau der Dienststellen des Reichskommissariat vom 3. Juni 1940, Verordnungsblatt für die besetzten niederländischen Gebiete (1940), 11, § 3 (1): 'Die Generalkommissare haben im Rahmen ihrer sachlichen Zuständigkeit das Recht, von allen niederländischen Behörden, Ämtern, Anstalten und Einrichtungen öffentlicher und nichtöffentlicher Art Auskünfte jeder Art einzufordern und ihnen die notwendigen Weisungen zu erteilen.'

398 Ibid., § 3 (2) : 'Sie haben insbesondere die Aufgabe, die Entscheidungen des Reichskommissars gemäss § 2 Abs. 2 der Verordnung über die Ausübung der Regierungsbefugnisse in den Niederlanden vom 29. Mai 1940 [...] vorzubereiten.'

399 Verordnung des Reichskommissars für die besetzten niederländischen Gebiete über die Ausübung der Regierungsbefugnisse in den Niederlanden vom 29. Mai 1940, Verordnungsblatt für die besetzten niederländischen Gebiete (1940), 8, § 3 (2): 'Die Generalsekretäre der niederländischen Ministerien sind dem Reichskommissar im Rahmen ihres sachlichen Bereichs für die ordnungsgemässe Leitung der Amtsgeschäfte verantwortlich. [...].'

400 Verordnung des Reichskommissars für die besetzten niederländischen Gebiete über die Ausübung der Regierungsbefugnisse in den Niederlanden vom 29. Mai 1940, Verordnungsblatt für die besetzten niederländischen Gebiete (1940), 8, § 3 (2): 'Die Generalsekretäre [...] können unter Beobachtung der Bestimmingen des $\S 2$ Abs. 2 und 3 Ausführungsvorschriften zu den geltenden niederländischen Gesetzen und zu den Verordnungen des Reichskommissars erlassen.'

401 J.H.P. Bellefroid, Beknopt overzicht der Staatsinrichting van Nederland tijdens de bezetting, 20.

402 Ibid., 21. See also Arrondissementsrechtbank Rotterdam, 23 June 1941, Nederlandsche Jurisprudentie 1941, 639.

403 Verordnung des Reichskommissars für die besetzten niederländischen Gebiete über die Befugnisse des Generalsekretäre der niederländischen Ministerien, Verordnungsblatt für die besetzten niederländischen Gebiete (1940), 55.

404 J.H.P. Bellefroid, Beknopt overzicht der Staatsinrichting van Nederland tijdens de bezetting, 22-23; F.M. Biegel, Bezettingsrecht, 31-32.

405 Verordnung des Reichskommissars für die besetzten niederländischen Gebiete zur Sicherung der Tätigkeit des Staatsrats sowie einiger öffentlichrechtlicher Vertretungskörperschaften, Verordnungsblatt für die besetzten niederländischen Gebiete (1940), 54, § 1: 'Die Tätigkeit der beiden Kammern der Generalstaaten ruht bis auf weiteres.'

406 Verordnung des Reichskommissars für die besetzten niederländischen Gebiete zur Sicherung der Tätigkeit des Staatsrats sowie einiger öffentlichrechtlicher Vertretungskörperschaften, Verordnungsblatt für die besetzten niederländischen Gebiete (1940), 54, § 4 (1): 'Soweit an sich fällige Wahlen in Übereinstimmung mit den Bestimmungen des § 3 nicht stattfinden, gelten die Mandate der Gewählten als bis auf weiteres verlängert.' 
as elections were suspended for an indefinite period of time. ${ }^{407}$ In July I94I the majority of the political parties ${ }^{408}$ was disbanded ${ }^{409}$ and as of I September I94I all members of the States General were discharged of their obligations which were the result of their membership of the States General and were therefore deprived of their authorities. ${ }^{410}$ Just like the States General the Council of State was out of work, although not dissolved, since June I940. ${ }^{411}$ Therefore, sinces statutes could no longer be made, Article I 2 of the Constitution $^{412}$ was effectively pushed aside. ${ }^{413}$

The notion that the exercise of sovereignty lies de facto with the occupant can be derived from Article 43 of the Hague Regulations of i907, which states:
The authority of the legitimate power having in fact $^{414}$ passed into the hands of the occupant, the latter shall take all the measures in his power to restore, and ensure, as far as possible, public order and civil life, ${ }^{415}$ while respecting, unless absolutely prevented, the laws in force in the country.

This article was the result of an amalgamation of Article 2 and 3 of the Declaration of Brussels of 1874 (which had never become legally binding), ${ }^{416}$ which stated:

\author{
Article 2: The authority of the legitimate Power being suspended and \\ having in fact passed into the hands of the occupant, the latter shall take
}

407 Verordnung des Reichskommissars für die besetzten niederländischen Gebiete zur Sicherung der Tätigkeit des Staatsrats sowie einiger öffentlichrechtlicher Vertretungskörperschaften, Verordnungsblatt für die besetzten niederländischen Gebiete (1940), 54, § 3 (1): 'Wahlen für die Kammern der Generalstaaten finden bis auf weiteres nicht statt.'

408 Parties which were disbanded were: Roomsch-Katholieke Staatspartij (Roman Catholic State Party), Sociaal-Democratische Arbeiderspartij (Social Democratic Labour Party), Antirevolutionaire Partij (Antirevolutionary Party), Christelijk-Historische Unie (Christian Historic Union), Vrijzinnig-Democratische Bond (Liberal Democratic Union), Liberale Staatspartij (Liberal State Party), Christelijk-Democratische Unie (Christian Democratic Union), Staatkundig Gereformeerde Partij (Political Reformed Party).

409 Verordnung des Reichskommissars für die besetzten niederländischen Gebiete über die Auflösung parlamentarischer Parteien, Verordnungsblatt für die besetzten niederländischen Gebiete (1941), 513.

410 Achte Verordnung des Reichskommissars für die besetzten niederländischen Gebiete über besondere verwaltungsrechtliche Massnahmen, Verordnungsblatt für die besetzten niederländischen Gebiete (1941), 637, § 2 (1): 'Die Mitglieder der Generalstaaten [...] sind - unbeschadet der Bestimmungen des $\S 27$, Absätze 1 und 2 - der Pflichten entbunden, die sich für sie aus der Mitgliedschaft in diesen öffentlichrechtlichen Vertretungskörperschaften ergaben. Es stehen ihnen daher die auf dieser Mitgliedschaft beruhenden Befugnisse und Ansprüche nicht mehr zu.'

411 Verordnung des Reichskommissars für die besetzten niederländischen Gebiete zur Sicherung der Tätigkeit des Staatsrats sowie einiger öffentlichrechtlicher Vertretungskörperschaften, Verordnungsblatt für die besetzten niederländischen Gebiete (1940), 54, § 2: 'Die Tätigkeit des Staatsrats [...] ruht bis auf weiteres.'

412 Article 112 of the revised Constitution of 1938.

413 See J.H.P. Bellefroid, Beknopt overzicht der Staatsinrichting van Nederland tijdens de bezetting, 12-15; F.M. Biegel, Bezettingsrecht, 29-31.

414 Italics by $\mathrm{me}-\mathrm{ML}$.

415 The original French text of Article 43 reads: 'L'autorité du pouvoir légal ayant passé de fait entre les mains de l'occupant, celui-ci prendra toutes les mesures qui dépendent de lui en vue de rétablir et d'assurer, autant qu'il est possible, l'ordre et la vie publics en respectant, sauf empêchement absolu, les lois en vigueur dans le pays.' This has been translated into English as: 'The authority of the legitimate power having in fact passed into the hands of the occupant, the latter shall take all the measures in his power to restore, and ensure, as far as possible, public order and safety, while respecting, unless absolutely prevented, the laws in force in the country.' Italics by me - ML. See A. Roberts and R. Guelff, Documents on the Laws of War, 80-81. Schwenk, in an article in 1945, pointed out that the translation of 'la vie publics' into 'safety' is incorrect and suggested 'civil life' instead, as the actual meaning of 'la vie publics' was explained as 'des fonctions sociales, des transactions ordinaires, qui constituent la vie de tous les jours' at the Convention of Brussels of 1874 by Baron Lambermont, the Belgian representative. Therefore, 'civil life' best reflects the meaning of 'la vie publics' although the literal translation would be 'public life'. See E.H. Schwenk, 'Legislative Power of the Military Occupant under Article 43, Hague Regulations', 54 Yale Law Journal 2 (1945), 393-416, 393. See also E. Benvenisti, The International Law of Occupation, 7.

416 E.H. Schwenk, 'Legislative Power of the Military Occupant under Article 43, Hague Regulations', 54 Yale Law Journal 2 (1945), 393-416, 396-397; E. Benvenisti, The International Law of Occupation, 8. 
all the measures in his power to restore and ensure, as far as possible, public order and safety.

Article 3: With this object he shall maintain the laws which were in force in the country in time of peace, and shall not modify, suspend or replace them unless necessary. ${ }^{417}$

At that time these articles had reflected the point of view of the smaller European nations (like the Netherlands), who wanted to prevent that because an occupant had to refrain from legislative activities public life would come to a complete standstill. At the Hague Peace Conference of I 899 however, especially Article 3 was considered to grant too much power to an occupant as it seemed to imply that an occupant in principle has legislative authority. That would imply that might leads to right, an implication heavily contested by both Beernaert, the Belgium representative and Den Beer Portugael, the delegate of the Netherlands. ${ }^{418}$ In 1874 one had been of the opinion that an occupant had nothing to gain by imposing legislative measures in order to regulate daily life matters. Occupations were short and strictly military; only intended as a transitional stage between hostilities and a peace treaty after which often a shifting of borders would take place. Civilians were no party to the conflict. At the end of the $19^{\text {th }}$ century however, this attitude had changed. Armies had grown and would be severely in need of resources during an armed conflict, for which a strong appeal was made to the civilian population of occupied territories. Furthermore, occupations became longer. Therefore it was no longer possible to assume that occupant and civilians could peacefully co-exist without having to bother each other. Slowly the realisation grew that an occupant could have an interest in influencing public order and civil life in an occupied country, a notion which was defended by the Great Powers such as Germany and Russia, but challenged by the smaller European nations. ${ }^{419}$ The text of Article 43 of the Hague Regulations together with the preamble of the Convention, the so-called 'Martens-clause' which stated that in cases not included in the Hague Regulations, both the civilian population and the occupant would remain 'under the protection and the rule of the principles of the law of nations, as they result from the usages established among civilised peoples, from the laws of humanity, and the dictates of the public conscience', provided a compromise. ${ }^{420}$ In retrospect, we can conclude that in this way the Great Powers got what they wanted as experience shows that both Article 43 and the preamble remained vague and, more importantly, multi-interpretable. ${ }^{421}$

417 See D. Schindler and J. Toman, The Laws of Armed Conflicts, 23.

418 E. Benvenisti, The International Law of Occupation, 12-13; D. Venema, Rechters in oorlogstijd, 139.

419 E. Benvenisti, The International Law of Occupation, 10, 26-31; A. Cassese, 'The Martens Clause: Half a Loaf or Simply Pie in the Sky?', 11 European Journal of International Law 1 (2000), 187-216, 193-198.

420 The 'Martens-clause' was inserted at the suggestion of Fyodor Fyodorovich Martens, a member of the Russian delegation. As the Convention of Brussels had already failed to provide for a legally binding document, Martens, who was President of the Sub-Commission in 1899, seeked to avoid another failure. See A. Cassese, 'The Martens Clause: Half a Loaf or Simply Pie in the Sky?', 11 European Journal of International Law 1 (2000), 187-216, who gives an extensive analysis of the Martens-clause and the intentions of Martens. See also D. Venema, Rechters in oorlogstijd, 139-140.

421 Cassese calls the Martens-clause a 'diplomatic ploy', arguing that while it seems that Martens also intended to enhance human rights by suggesting an innovative formulation, he solely chose this vague language to solve a diplomatic problem, thereby serving Russia's interests. See A. Cassese, 'The Martens Clause: Half a Loaf or Simply Pie in the Sky?', 11 European Journal of International Law 1 (2000), 187-216. 
Article 43 consists of several elements. Firstly, the occupant is obliged to take all measures in his power, necessary to restore and ensure public order and civil life. The obligation to restore public order and civil life is a result of the disruptions because of the hostilities attached to an occupation. As an occupation as such is seen as the disruptive factor, the occupant is obliged to restore public order and civil life to the state of affairs before the occupation. This notion does not leave much room for interpretation to the occupant.

Things are a little different with the command to ensure public order and civil life, as the notion that the occupant has to ensure the continuation of public order and civil life as it was before the occupation causes serious economic and social problems in case of an extensive and prolonged occupation. Greenspan indicates the necessity to take political decisions and to formulate and carry out policies in order to ensure the development of a society. ${ }^{422}$ However, this necessity caused occupants more and more to interpret the notion to 'ensure public order and civil life' as full discretionary powers. Benvenisti points out that in fulfilling the obligation to ensure public order and civil life decisions taken and policies implemented were, not surprisingly, always in line with the occupant's interests as well. ${ }^{423}$

Secondly, in restoring and ensuring public order and civil life, the occupant is obliged to respect, unless absolutely prevented, the existing laws of the occupied country. The provision 'unless absolutely prevented' is of course a notion open to interpretation. Implicitly, it does grant the occupant legislative authority, and allows him to deviate from legislation in force. It was exactly this implicit recognition that was contested by Belgium and the Netherlands at the Hague Peace conference of 1899 . Therefore, the wording of the original Article 3 of the Brussels Convention was adapted into the wording of Article 43, which was considered to be more restrictive. However, the wording remains vague and effectively a dead letter, since in practice there will be no power technically preventing an occupant to impose whatever legislation he wishes, as already pointed out by Schwenk and Benvenisti. ${ }^{424}$ However, this notion serves as a framework in which the occupant is allowed to operate, having to find a balance between on the one hand maintaining the status quo ante bellum whilst ensuring continuation of civil life and on the other hand serving its own interests as well. According to Schwenk the notion 'unless absolutely prevented' as such does not mean anything, unless a requirement such as 'by necessity' or 'by the interests of the occupied population' is added. The fact that this has been omitted allows for a discussion about the scope of the article. ${ }^{425}$ Some authors have indicated that adaptations of legislation are allowed in case it is required by military necessity, ${ }^{426}$ or, in a

422 M. Greenspan, The Modern Law of Land Warfare, 225. See also E. Benvenisti, The International Law of Occupation, 11.

423 E. Benvenisti, The International Law of Occupation, 11-12.

424 E.H. Schwenk, 'Legislative Power of the Military Occupant under Article 43, Hague Regulations', 54 Yale Law Journal 2 (1945), 393-416, 399-400; E. Benvenisti, The International Law of Occupation, 12-13.

425 E.H. Schwenk, 'Legislative Power of the Military Occupant under Article 43, Hague Regulations', 54 Yale Law Journal 2 (1945), 393-416, 399-400.

426 J.P.A. François, 'De Bezetting en het Volkenrecht' in J.J. van Bolhuis et al. (eds.), Onderdrukking en Verzet. Nederland in Oorlogstijd (volume 4), 251; C.C. Hyde, International Law (volume 2), 367-368; J.W. Garner, International Law and the World War, 86. See also E.H. Schwenk, 'Legislative Power of the Military Occupant under Article 43, Hague Regulations', 54 Yale Law Journal 2 (1945), 393-416, 400 
more broader sense, if the laws of an occupied country are detrimental to the occupant. ${ }^{427}$ At the time the article was drafted, military necessity was considered to 'absolutely prevent' an occupant from respecting existing legislation, as it was generally believed that an occupant had no interests in changing civil life extensively. However, this proved to be insufficient as the interests of the occupied population had to be served as well, especially in case of a prolonged occupation, as we have seen before. Schwenk argues that confining the notion of 'unless absolutely prevented' to 'military necessity' is too narrow, as this would imply that an occupant does not have to mind about the needs of the occupied civilians at all. Therefore, 'unless absolutely prevented' should be interpreted as 'absolute necessity', which was more or less the original formulation of Article 3 of the Brussels Convention of $1874 .{ }^{428}$ The general feeling in the post World War II-era was that apart from military necessity, an occupant might also lawfully enact laws to serve the interests of the population. Some scholars suggested a 'reasonableness-test' or a 'sincerity-test', i.e. allowing for legislative changes in case it was proven that the occupant was 'equally concerned about his own population'. ${ }^{429}$ However, when talking about racial and family law implemented by the National Socialists, such a test obviously does not hold water.

Was the German behaviour during the five years of occupation in the Netherlands permissible by the Hague Regulations, in particular Article 43?

Already during the war Telders indicated that the German habit of systematical requisitioning for the German state was a violation of public order. As Article 43 obliged the occupant to ensure public order, this conducted a violation of Article $43 .{ }^{430}$ Furthermore, Telders stated that already in October I940, five months after the German invasion, clear signs that putting the Netherlands extensively in the National Socialist sphere of influences was the prime purpose of the occupant were visible. According to Telders, the German occupation of the Netherlands had to be regarded as a disguised annexation. ${ }^{431}$

After the war had ended the Dutch State Commission for Occupation Law (Staatscommissie Bezettingsrecht) ${ }^{432}$ indicated that placing the Netherlands under a civil administration as had been done by the decree of I 8 May I940 was a violation not only of Article 43 but of the entire third section of the Hague Regulations, of which the title

427 G.G. Wilson, Handbook on International Law, 310. In this respect Schwenk also cites Oppenheim, stating that adaptation of legislation is allowed if 'necessitated by [the occupant's] interest', suggesting that Oppenheim considers the general interest of the occupant as sufficient reason to be absolutely prevented to respect the laws in force. E.H. Schwenk, 'Legislative Power of the Military Occupant under Article 43, Hague Regulations', 54 Yale Law Journal 2 (1945), 393-416, 400. When we read Oppenheim closely though, we see that Oppenheim does not refer to a general interest of the occupant but to a military interest, as he says that an occupant has the right to make changes in the laws when 'temporarily necessitated by his interest in maintenance and safety of his army [...].' See Oppenheim-Lauterpacht, International Law. A Treatise, volume 2 (1935), 349-350, italics by me - ML.

428 E.H. Schwenk, 'Legislative Power of the Military Occupant under Article 43, Hague Regulations', 54 Yale Law Journal 2 (1945), 393-416, 400-401.

429 E. Benvenisti, The International Law of Occupation, 14-15.

430 B.M. Telders, 'Nota over het Duitsche Bestuur in Nederlandsch Bezet Gebied', in B.M. Telders, Verzamelde geschriften, 331 362, 333. This memorandum was drafted on 15 October 1940 and directed to the Dutch government in London.

431 Ibid., 333-334.

432 Verslag van de Staatscommissie Bezettingsrecht, 6. 
seemed to suggest that only military administrations were allowed. ${ }^{433}$ This statement was preceded by several decisions of the Special Court of Cassation. On I2 January I949 the Court decided in the case Rauter that the German occupant had lead the way with regard to violations of international law, amongst other things by establishing a civil administration which was independent of the military commander. Referring to the German conviction that in case of war necessity knows no law (Kriegsräson geht vor Kriegsmanier), the Court even issued the statement that the international law of occupation was codified exactly to keep Kriegsräson within the limits of the law. ${ }^{434} \mathrm{On}$ 7 November $1949^{435}$ and 5 December $1949^{436}$ the Court furthermore explained that the occupying forces did have the authority to draft penalty clauses, but only in the capacity of military administrator and not as an unlawful ${ }^{437}$ civil administrator. However, although the International Military Tribunal at Nuremberg did use the Hague Regulations as one of the leading sources of law, it ventured no opinion on the questions whether or not a civil administration was a violation of the Hague Regulations. Some post-war authors have expressed dissapointment on this. ${ }^{438}$ As Article 6 (a) of the Charter of the International Military Tribunal calls a war of aggression or a war in violation of international treaties, agreements or assurances a crime against peace, ${ }^{439}$ an occupation which follows from such a war is therefore unlawful. However, as seen before, this does not mean that all acts of the occupying forces are automatically unlawful as well. These have to be tested against the Hague Regulations. However, with regard to the civil administration established in the Netherlands by the German occupying forces, the International Military Tribunal has refrained from doing so. ${ }^{440}$ The occupations by - amongst others - Germany during World War II are nowadays nonetheless regarded as illegal both because of the aggression that led to the occupation and because of the type of governance chosen by the occupying forces. $^{441}$

Why was this type of governance chosen for the Netherlands? According to Jansma a civil administration was established in countries which faced annexation by the German Reich, as this mode of administration was considered to be more appropriate than a military administration with regard to introducing National Socialism to the population. ${ }^{442}$ The Netherlands was regarded as a Germanic brother nation, ${ }^{443}$ which had

433 The title of section III of the Hague Regulations reads: 'Military Authority over the Territory of the Hostile State' (italics by me - ML). See A. Roberts and R. Guelff, Documents on the Laws of War, 80.

434 Bijzondere Raad van Cassatie, 12 January 1949 (Rauter), Nederlandse Jurisprudentie 1949, 87.

435 Bijzondere Raad van Cassatie, 7 November 1949 (Arlt), Nederlandse Jurisprudentie 1950, 8.

436 Bijzondere Raad van Cassatie, 5 December 1949 (Vogt), Nederlandse Jurisprudentie 1950, 13.

437 See Bijzondere Raad van Cassatie, 7 November 1949 (Arlt), Nederlandse Jurisprudentie 1950, 8: ‘[...] een wederrechtelijk door den bezetter ingesteld burgerlijk bestuur [...].' The Court does not mention why the establishment of a civil administration is unlawful. See also T.J. Jansma, Het bezettingsrecht in de pracktijk van de Tweede Wereldoorlog, 80.

438 T.J. Jansma, Het bezettingsrecht in de pracktijk van de Tweede Wereldoorlog, 78-80.

439 Charter of the International Military Tribunal, 8 August 1945, originally published in United Nations Treaty Series, volume 82, pp. 280-300, Article 6: '[...] The following acts, or any of them, are crimes coming within the jurisdiction of the Tribunal for which there shall be individual responsibility: (a) Crimes against peace: namely, planning, preparation, initiation or waging of a war of aggression, or a war in violation of international treaties, agreements or assurances, or participation in a common plan or conspiracy for the accomplishment of any of the foregoing; [...]'. See for the full text of the Charter D. Schindler and J. Toman, The Laws of Armed Conflicts, 1255-1261.

440 See furthermore T.J. Jansma, Het bezettingsrecht in de pracktijk van de Tweede Wereldoorlog, 79-80.

$441 \mathrm{E}$. Benvenisti, The International Law of Occupation, 68.

442 T.J. Jansma, Het bezettingsrecht in de pracktijk van de Tweede Wereldoorlog, 21.

443 G. Hirschfeld, Bezetting en Collaboratie, 33. 
to become part of the New Order in Europe. Therefore, a civil administration had to be regarded the transitional stage to total annexation. ${ }^{444}$

Violation of the Hague Regulations furthermore appeared from the announcement of the German occupant upon gaining control over a territory that the existing legislation would remain in force as far as this legislation would be compatible either with the goals of the occupation or with the orders issued by the German occupant itself. ${ }^{445}$ As we have seen before for the Netherlands this principle was established by $\mathbb{S} 5$ of the Decree of the Führer of I 8 May I940 ${ }^{446}$ and was confirmed by $\$ 2$ of Regulation 3/1940 ${ }^{447}$ isued on 29 May by the Reichskommissar. Because of the use of the word 'soweit' (as far as) the orders issued by the occupying forces (and in particular the Decree of I 8 May I940) obtained a primary position whilst the legislation in force moved to a secondary position, which, according to Telders, was a reversal of the hierarchy established by the Hague Regulations. ${ }^{448}$ Jansma agreed with Telders that the wording of the decree was more farreaching than the words 'unless absolutely prevented' as stated in Article $43 .{ }^{449}$

In his dissertation Jansma furthermore lists fifteen examples of orders and regulations issued by the occupants, contrary to Article 43, as well as four examples of existing legislation suspended by the German regime. ${ }^{450}$ Also the provision that the Reichskommissar could decide which judicial decisions had to be submitted for approval before upholding ${ }^{451}$ was a breach of Article 43 as it suspended the basic principle of judicial independence. ${ }^{452}$ Jansma concurred with Telders in this respect. ${ }^{453}$

Apart from violations of Article 43, Jansma lists a whole range of violations of the other articles of the Hague Regulations, especially Article 46, which is also acknowledged by the International Military Tribunal in Nuremberg. ${ }^{454}$

Already during the occupation National Socialist lawyers tried to justify the occupant's actions. Striking is an article by the Dutch professor J.J. Schrieke, who was appointed secretary-general of Justice in I94I. In I944 Schrieke wrote an article entitled 'Occupied

444 T.J. Jansma, Het bezettingsrecht in de pracktijk van de Tweede Wereldoorlog, 21. See also E. Benvenisti, The International Law of Occupation, 64 and B.M. Telders, 'Nota over het Duitsche Bestuur in Nederlandsch Bezet Gebied', in B.M. Telders, Verzamelde geschriften, 331-362, 333.

445 E. Benvenisti, The International Law of Occupation, 65.

446 Erlaß des Führers über Ausübung der Regierungsbefugnisse in den Niederlanden vom 18. Mai 1940, Reichsgesetzblatt (1940), I, 778, § 5 (1): 'Das bisher geltende Rechts bleibt in Kraft, soweit es mit der Besetzung vereinbar ist.'

447 Verordnung des Reichskommissars für die besetzten niederländischen Gebiete über die Ausübung der Regierungsbefugnisse in den Niederlanden vom 29. Mai 1940, Verordnungsblatt für die besetzten niederländischen Gebiete (1940), 8, § 2 (1): 'Das bisher geltende niederländische Recht bleibt in Kraft, soweit es mit der Besetzung vereinbar ist und soweit nicht die Bestimmungen des Erlasses des Führers über die Ausübung der Regierungsbefugnisse in den Niederlanden (RGBI. I, S 778) dem entgegenstehen. [...].'

448 B.M. Telders, 'Nota over het Duitsche Bestuur in Nederlandsch Bezet Gebied', in B.M. Telders, Verzamelde geschriften, 331 362, 339-340.

449 T.J. Jansma, Het bezettingsrecht in de pracktijk van de Tweede Wereldoorlog, 25.

450 T.J. Jansma, Het bezettingsrecht in de pracktijk van de Tweede Wereldoorlog, 22-25.

451 Verordnung des Reichskommissars für die besetzten niederländischen Gebiete über die Ausübung der Regierungsbefugnisse in den Niederlanden vom 29. Mai 1940, Verordnungsblatt für die besetzten niederländischen Gebiete (1940), 8, § 6 (3): 'Der Reichskommissar bestimmt, welche Urteile inm vor ihrer Vollstreckung zur Bestätigung vorzulegen sind.'

452 T.J. Jansma, Het bezettingsrecht in de pracktijk van de Tweede Wereldoorlog, 25-26.

453 B.M. Telders, 'Nota over het Duitsche Bestuur in Nederlandsch Bezet Gebied', in B.M. Telders, Verzamelde geschriften, $331-$ 362, 340-341.

454 T.J. Jansma, Het bezettingsrecht in de pracktijk van de Tweede Wereldoorlog, 27 cf. See in particular pp. 29-37. 
Netherlands and the Hague Regulations of $1907^{455}$ in which he tried to refute the statements that the German occupant violated the Hague Regulations. Schrieke trivialised the status of the Hague Regulations by stating they were nothing more than some generally applicable rules of conduct for belligerents in their interrelations and relations with the civil populations. ${ }^{456} \mathrm{~A}$ treaty about which European governments had been meeting and discussing for decades was dismissed in the same casual way some nowadays popular celluloid pirate captains dismiss the 'Code of the Order of the Brethren': 'They're more like guidelines anyway!'457 According to Schrieke the views which had lead to the Hague Regulations were superseded at the time of the German occupation of the Netherlands. World War I had already proven that the civilian population did take part in a war, so a strict separation between military and civil interests did no longer exist. Because of this the Hague Regulations had not to be taken too literally. Furthermore, this was not a war about territorial expansionism. The Germans fought to protect Europe against a dreadful enemy: Bolshevism. According to Schrieke the primary purpose of the German occupation of the Netherlands was to preserve the country from the Bolshevists who surely would violate the Hague Regulations. ${ }^{458}$ Apart from that the National Socialists were striving for a better system, a National Socialist ideal state, and in order to reach that goal the old system had to be overcome, with all means possible. The nature of the occupation was therefore inevitably influenced by its necessity ${ }^{459}$ Kriegsräson geht vor Kriegsmanier.

However, even Schrieke could not ignore Article 43 of the Hague Regulations which stated that the occupant had to restore and ensure public order and civil life, while respecting, unless absolutely prevented, the laws in force in the occupied country. According to Schrieke and contrary to what we have seen before, this article did not provide an upper limit for the authority of the occupant to change existing legislation and issue new laws, but a lower limit, i.e. it outlined what the occupant at least was obliged to do. ${ }^{460}$ Furthermore, the words 'unless absolutely prevented' deserved a reinterpretation. Laws have to be regarded a reflection of social beliefs. As soon as these beliefs change, laws have to change as well and according to Schrieke clearly the moment had come to change the laws. As the occupant was convinced of the wrongfulness of the existing legislation and was heading to a better future, what else could he do but change the laws in force? Therefore, it was clear that the occupant was 'absolutely prevented' to respect the laws in force. Society had changed, the laws had to change with it ${ }^{461}$ Furthermore, the notion that the occupant had only obtained de facto authority whilst the de jure sovereignty remained with the government-in-exile, as had been stated by Regout, Professor at the Catholic University of Nijmegen already in May 1940, ${ }^{462}$ was a thorn in

\footnotetext{
455 J.J. Schrieke, Bezet Nederland en het Haagsche Landoorlogsreglement van 1907.

456 Ibid., 5.

457 Pirates of the Caribbean: The Curse of the Black Pearl, Walt Disney Pictures (2003). For details on the film see www.imdb.com/ title/tt0325980.

458 J.J. Schrieke, Bezet Nederland en het Haagsche Landoorlogsreglement van 1907, 6-7.

459 Ibid., 8.

460 Ibid., 11.

461 Ibid., 13-14.

462 R. Regout, 'De rechtstoestand in bezet gebied', 72 Studiën 133 (1940), 469-475, 472.
} 
Schrieke's side. During the occupation the explanations by Regout were endorsed to by other lawyers, amongst others Biege ${ }^{463}$ and Bellefroid ${ }^{464}$ Schrieke however, stated that by going into exile, the Dutch government had lost its full authority and was therefore replaced in full by the occupant. The German occupant actually had to take up full authority, since the consequences with regard to public order and civil life, i.e. economic life, would otherwise have been desastrous, as without policy measure, the country would have come to an economic standstill. ${ }^{465}$ According to Schrieke, ${ }^{466}$ this was entirely in line with Article 2I of the Dutch Constitution which prohibited the seat of government to be moved abroad. ${ }^{467}$ Telders however, had already fulminated against this notion in 1940, arguing that Article 2I was drafted with regard to the possibility that the King would marry a foreign queen (not uncommon in the $19^{\text {th }}$ century) and following that marriage would move his residence abroad to rule the country from there on a permanent basis. However, in her proclamation of I3 May I940 Wilhelmina had clearly stated the move was only intended as temporary and would be undone as soon as conditions permitted. ${ }^{468}$ Telders admitted the wording of Article 2I was ill-chosen. However, in I922 the article ${ }^{469}$ had been discussed when the Constitution was amended and at that time one was of the opinion that situations in which it was inevitable to move the seat of government abroad temporarily could hardly be described in the Constitution. In case of an enemy offense strict compliance with the Constitution would be difficult anyhow, so one had to resign oneself to departure from this rule as well. ${ }^{470}$ Finally, Telders pointed out that no sanction was prescribed in case the article was violated. ${ }^{471}$ According to Schrieke, however, it was the Dutch government-in-exile who violated the Hague Regulations by constantly calling on the Dutch population to resist. ${ }^{472}$ Schrieke ended his article with a plea for the German cause by stating that the historical process which was taking place was so revolutionary, it could only be justified by the future it was preparing. ${ }^{473}$

With regard to this future - a possible Anschlu $\beta$ of the Netherlands to Germany - and therefore despite the Hague Regulations, an attempt to nazificate Dutch laws was made. To what extent was Dutch family law influenced by National Socialism? In what way

463 F.M. Biegel, Bezettingsrecht, 7-8.

464 J.H.P. Bellefroid, Beknopt overzicht der Staatsinrichting van Nederland tijdens de bezetting, 8.

465 J.J. Schrieke, Bezet Nederland en het Haagsche Landoorlogsreglement van 1907, 12-13. With this argument Schrieke is precursor of Greenspan. See M. Greenspan, The Modern Law of Land Warfare, 225.

466 Ibid., 9-10.

467 Article 21 Constitution (which had been amended in 1938): '[...] In geen geval kan de zetel der Regeering buiten het Rijk worden geplaatst.'

468 Proclamation of 13 May 1940, held in London: 'Nadat volstrekt zeker was geworden, dat wij en onze ministers in Nederland niet langer vrijelijk konden voortgaan met de uitoefening van het staatsgezag, moest het harde, maar noodzakelijke besluit worden genomen den zetel der regeering te verplaatsen naar het buitenland, voor zoolang als onvermijdelijk is en met de bedoeling ons terstond weer in Nederland te vestigen, zoodra zulks maar eenigzins kan.' Published in M.G. Schenk and J.B.Th. Spaan, De Koningin Sprak, 5.

469 At that time still Article 23.

470 Memorandum in Reply to the Senate, Handelingen der Staten-Generaal (Eerste Kamer), bijlagen 1921-1922, 520-527, 522. The Senate had expressed its concern with regard to the strict wording of the article, fearing that it would no allow a temporary movement of the seat of government abroad in case of emergency. See Interim Report of the Commission of Rapporteurs, Handelingen der Staten-Generaal (Eerste Kamer), bijlagen 1921-1922, 492-502, 494. See also F.J.A. Huart, Grondwetsherziening 1917 en 1922, 29.

471 B.M. Telders, 'Nota over het Duitsche Bestuur in Nederlandsch Bezet Gebied', in B.M. Telders, Verzamelde geschriften, 331 $362,338$.

472 J.J. Schrieke, Bezet Nederland en het Haagsche Landoorlogsreglement van 1907, 10-11.

473 Ibid., 20: 'Want het historisch proces, dat zich heden als onder onze oogen afspeelt, is zoo ingrijpend, zoo vernietigend, zoo revolutionair, dat het zijn rechtvaardiging, zijn waarde slechts kan ontleenen aan de toekomst, die het voorbereidt.' 
was German racial and family law implemented or given shape in the Netherlands? What preparations were made and to what extent were they brought into force?

\section{- 4.3.2. Defining the 'Jewish Question' in the Netherlands}

Right after the start of the occupation the Germans, among others through Friedrich Wimmer, Generalkommissar für Verwaltung und Justiz, indicated that the 'Jewish Question' did not exist in the Netherlands. ${ }^{474}$ 'Die Judenfrage existiert in Holland nicht', Wimmer had told Karel Frederiks, secretary-general of the Interior during their first encounter. ${ }^{475}$ In his acceptance speech of 29 May I940, Reichskommissar Seyss-Inquart however, had made clear references to the National Socialist racial ideas, thereby implying that the Dutch people were a brother nation, sharing the same blood. ${ }^{476}$ Also in the Netherlands it was the responsibility of the Germans to protect the superior blood:

Wir Deutsche aber, die wir heute mit einem durch die Erkenntnis für die blutgebundenen und vom Blut bestimmten Werte eines Volkes geschärften Blick durch dieses Land gehen, freuen uns über die niederländischen Menschen. [...] Wir fühlen uns heute immer und unter allen Umstände verantwortlich für das gute Blut; denn Blut verpflichtet auch über äußere Tatsachen und mangelnde Erkenntnis hinaus. ${ }^{477}$

Soon it appeared that according to the German occupants the Jewish Question did exist in the Netherlands. On 22 October 1940 Seyss-Inquart issued a regulation obliging all companies which were owned, run or somehow financed by a Jew to register. ${ }^{478}$ Article 4 of this regulation came up with a definition of a Jew. Everyone with at least three racially full-Jewish grandparents was considered to be a Jew. ${ }^{479}$ Grandparents were considered to be full-Jewish in case they had adhered to the Jewish religious community. ${ }^{480}$ Note the same discrepancy we pointed out earlier when discussing the definition of a Jew the National Socialists came up with in Germany in the First Supplementary Decree to the Reichsbürgergesetz: being racially full-Jewish was determined by a religious factor. Furthermore, persons with two full-Jewish grandparents were put on the same footing as Jews in case I) he or she adhered to the Jewish religious community on 9 May I940 or was admitted as a member after that date, or 2) he or she was married to a Jew on 9 May I940 or married a Jew after that date. ${ }^{481}$ Throughout the occupation this article has been

474 L. de Jong, Het Koninkrijk der Nederlanden in de Tweede Wereldoorlog, 4:693-694.

475 Ibid.; J.J. van Bolhuis, 'Enkele hoofdfiguren van het Duitse bestuur', in J.J. van Bolhuis et al. (eds.), Onderdrukking en Verzet. Nederland in Oorlogstijd (deel 1), 332-353, 350.

476 '[...] dem deutschen Volke blutsnahe niederländische Volk [...]'. See acceptance speech of Seyss-Inquart of 29 May 1940 , 'Aus Anlass der Übernahme der Regierungsgewalt', published in Vier Jahre in den Niederlanden. Gesammelte Reden, 7-12, 11.

477 lbid., 9.

478 Verordnung des Reichskommissars für die besetzten niederländischen Gebiete über die Anmeldung von Unternehmen vom 22. Oktober 1940, Verordnungsblatt für die besetzten niederländischen Gebiete (1940), 546.

479 Ibid., Article 4 (1): 'Jude ist, wer von mindestens drei der Rasse nach volljüdischen Grosselternteilen abstammt.'

480 Ibid., Article 4 (3): 'Als volljüdisch gilt ein Grosselternteil ohne weiteres, wenn er der jüdischen Religionsgemeinschaft angehört hat.'

481 Ibid., Article 4 (2): 'Als Jude gilt auch, wer von zwei volljüdischen Grosselternteilen abstammt und 1) entweder selbst am 9. Mai 1940 der jüdischen Religionsgemeinschaft angehört had oder danach in sie aufgenommen wird, oder 2) am 9. Mai 1940 mit einem Juden verheiratet war oder sich danach mit einem Juden verheiratet.' 
used as a criterion for the concept of 'Jew'. ${ }^{482}$

On Io January I94 I every person, who was completely or partially of Jewish blood, was required to register. ${ }^{483}$ Article 2 of this regulation stated that everyone with at least one racially full-Jewish grandparent was considered to be completely or partially of Jewish blood. ${ }^{484}$ It furthermore confirmed that grandparents were to be considered full-Jewish in case they (had) adhered to the Jewish religious community. ${ }^{485}$ The regulation provided no further clarification with regard to the definition of a Jew, but did state in Article 3 that in case of doubts with regard to whether or not a person had to be considered completely or partially of Jewish blood, the Reichskommissar or a by the Reichskommissar designated authority could decide. ${ }^{486}$

After putting it back and forth for some time, this task finally found its way to the desk of Hans Georg Calmeyer, a German official working under Wimmer and head of the Abteilung Innere Verwaltung. Calmeyer, a controversial and much-discussed person, was a man of principle and above all - if we have to believe the historians - recalcitrant. ${ }^{487} \mathrm{In}$ his chronicle about the Holocaust, Herzberg describes Calmeyer as a peculiar man who wanted to be 'the opposite of everything' ${ }^{488}$ In Germany he had had a Jewish secretary. He had defended communists towards the Nazis and he was looking forward to defend the Nazis towards the communists. Herzberg implies that because the National Socialists persecuted Jews, Calmeyer helped them (sometimes) and that if the situation would have been the reverse, Calmeyer would have done the opposite. ${ }^{489}$ De Jong has a more lenient judgement on Calmeyer. According to De Jong Calmeyer knew he was part of a criminal system and he had a strong feeling of guilt because of all Jews he implicitly sentenced to death in order to save others. ${ }^{490}$ Calmeyer's post-war feelings of guilt are confirmed by Von Frijtag Drabbe Künzel. ${ }^{491}$ Stuldreher however, confirms Calmeyer's recalcitrant personality, but emphasises his deadly accuracy and his dedication with regard to the application of the occupant's provisions. ${ }^{492}$ According to Stuldreher Calmeyer was a 'legalistic German civil servant', who constantly tested the German anti-Jewish

482 A.J. Herzberg, 'Kroniek der Jodenvervolging', in J.J. van Bolhuis et al. (eds.), Onderdrukking en Verzet. Nederland in Oorlogstijd (deel 3), 5-256, 48.

483 Verordnung des Reichskommissars für die besetzten niederländischen Gebiete über die Meldepflicht von Personen, die ganz oder teilweise jüdischen Blutes sind vom 10. Januar 1941, Verordnungsblatt für die besetzten niederländischen Gebiete (1941), 19, Article 1: 'Personen, die ganz oder teilweise jüdischen Blutes sind und sich in den besetzten niederländischen Gebieten aufhalten, sind nach Massgabe der folgenden Bestimmungen zu melden.'

484 Ibid., Article 2 (1): 'Im Sinne dieser Verordnung ist als ganz oder teilweise jüdischen Blutes eine Person anzusehen, wenn sie auch nur von einem der Rasse nach volljüdischen Grosselternteil abstammt.'

485 Ibid., Article 2 (2): 'Als volljüdisch gilt ein Grosselternteil ohne weiteres, wenn er der jüdischen Religionsgemeinschaft angehört hat oder angehört.'

486 Ibid., Article 3 (1): 'Ergeben sich Zweifel darüber, ob eine Person nach § 2 als ganz oder teilweise jüdischen Blutes anzusehen ist, so entscheidet hierüber auf Antrag der Reichskommissar für die besetzten niederländischen Gebiete oder die von ihm bestimmte Stelle.'

487 A.J. Herzberg, 'Kroniek der Jodenvervolging', in J.J. van Bolhuis et al. (eds.), Onderdrukking en Verzet. Nederland in Oorlogstijd (deel 3), 5-256, 137; J. Presser, Ondergang (deel 2), 54-55; L. de Jong, Het Koninkrijk der Nederlanden in de Tweede Wereldoorlog, 6:293; G. von Frijtag Drabbe Künzel, Het geval Calmeyer, 159.

488 A.J. Herzberg, 'Kroniek der Jodenvervolging', in J.J. van Bolhuis et al. (eds.), Onderdrukking en Verzet. Nederland in Oorlogstijd (deel 3), 5-256, 137

489 Ibid.

490 L. de Jong, Het Koninkrijk der Nederlanden in de Tweede Wereldoorlog, 6:294.

491 G. von Frijtag Drabbe Künzel, Het geval Calmeyer, 246, 255, 258.

492 C. Stuldreher, De Legale Rest, 92-93, 131. 
policies against the existing German laws, without expressing objections of principle. ${ }^{493}$ Middelberg criticises this point of view. According to him Calmeyer's legalistic attitude was only to keep up appearances, which allowed him to apply the racial laws moderately. Calmeyer's description of himself being a 'saboteur of anti-Jewish legislation' is therefore justified, according to Middelberg. ${ }^{494}$ Von Frijtag Drabbe Künzel accepts both the views of Stuldreher and Middelberg in this respect, but emphasises Calmeyer's changeability which verged on capriciousness. ${ }^{495}$ According to Von Frijtag Drabbe Künzel Calmeyer's motives can best be described as ambition and boredom. ${ }^{496}$ Ambition, since his career as a barrister in Osnabrück had come to a dead end, ${ }^{497}$ boredom, since he suffered from a lack of intellectual challenges since he had been stationed in the Netherlands.

In any event Calmeyer allowed plenty of persons to deceive him with regard to their descent. It was almost shameful how much adultery apparently had been committed and how many childeren apparently had been born out of wedlock. ${ }^{498}$ It remains unclear how many have been saved by Calmeyer and his staff. The numbers quoted remain controversial to this very day. Calmeyer himself has stated after the war that he has saved around i 8,00o people. ${ }^{499}$ By many historians the number is considered to be much lower. Herzberg puts the number at 2000, ${ }^{500}$ Middelberg at $3500 .{ }^{501}$ Stuldreher, on the other hand, puts the number considerably lower than that, at approximately $50 .{ }^{502}$ However, Stuldreher's calculation methods can be criticised, as explained by Von Frijtag Drabbe Künzel, who estimates that about 3700 people received a more favourable status. ${ }^{503}$ Whatever the case may be, Calmeyer ${ }^{504}$ was helped by the ambiguous definition of a Jew. This lack of clarity was further increased by Gerhard Wander, one of Calmeyers employees and heavily anti-National Socialist, ${ }^{505}$ who, when Calmeyer was on holiday, decided that in case a grandparent had adhered to the Jewish religious community and therefore had to be considered full-Jewish - evidence was allowed which proved differently, e.g. the grandparent itself only had had two Jewish grandparents, which would make him half-Jewish instead of full-Jewish. In Germany a grandparent who had been a member of a Jewish religious community was considered full-Jewish ohne weiteres, an irrefutable presumption of law (praesumtio juris et de jure). In the Netherlands, however, suddenly this presumption of law became refutable, creating an escape clause

\footnotetext{
493 Ibid., 134.

494 M. Middelberg, Judenrecht, Judenpolitik und der Jurist Hans Calmeyer, 373-374.

495 G. von Frijtag Drabbe Künzel, Het geval Calmeyer, 141, 151, 154-155.

496 Ibid., 207, 267-268.

497 Ibid., 49-53, 267; M. Middelberg, Judenrecht, Judenpolitik und der Jurist Hans Calmeyer, 195-197.

498 L. de Jong, Het Koninkrijk der Nederlanden in de Tweede Wereldoorlog, 6:300.

499 G. von Frijtag Drabbe Künzel, Het geval Calmeyer, 143.

500 A.J. Herzberg, 'Kroniek der Jodenvervolging', in J.J. van Bolhuis et al. (eds.), Onderdrukking en Verzet. Nederland in Oorlogstijd (deel 3), 5-256, 140.

501 M. Middelberg, Judenrecht, Judenpolitik und der Jurist Hans Calmeyer, 386.

502 C. Stuldreher, De Legale Rest, 217.

503 G. von Frijtag Drabbe Künzel, Het geval Calmeyer, 144-145. See in this respect also R.E. van Galen-Herrmann, 'De controverse rond het ambtelijk functioneren van Hans Calmeyer tijdens de bezetting 1940-1945'. Van Galen-Herrmann is one of the persons saved by Calmeyer.

504 On 4 March 1992, Calmeyer was posthumously recognised as Righteous Among the Nations by Yad Vashem. See www1. yadvashem.org/yv/en/righteous/stories/calmeyer.asp.

505 Initially Wander had been a supporter of National Socialism. During the war, however, he had a change of heart and encouraged Calmeyer to use his position as Rassereferent to save Jews. He was killed in 1945 by the Sicherheitspolizei as a member of the Dutch resistance. See G. von Frijtag Drabbe Künzel, Het geval Calmeyer, 149-150, 177-178.
} 
for many persons. If someone could prove, whether or not by forgeries, that some of his great- great-grandparents had not been Jewish, either because they were not racially so or because they had not adhered to the Jewish religious community, suddenly his number of full-Jewish grandparents would go down, changing this persons status from full-Jew to Mischling or even to Aryan. And, as Herzberg points out, according to Wander ${ }^{506}$ someone with three Aryan great- great-grandparents, who, accordingly, was 3/I6 Aryan, could not be considered a Jew. ${ }^{507}$ As figure 4.I shows, this would lead to a bizarre genealogy.

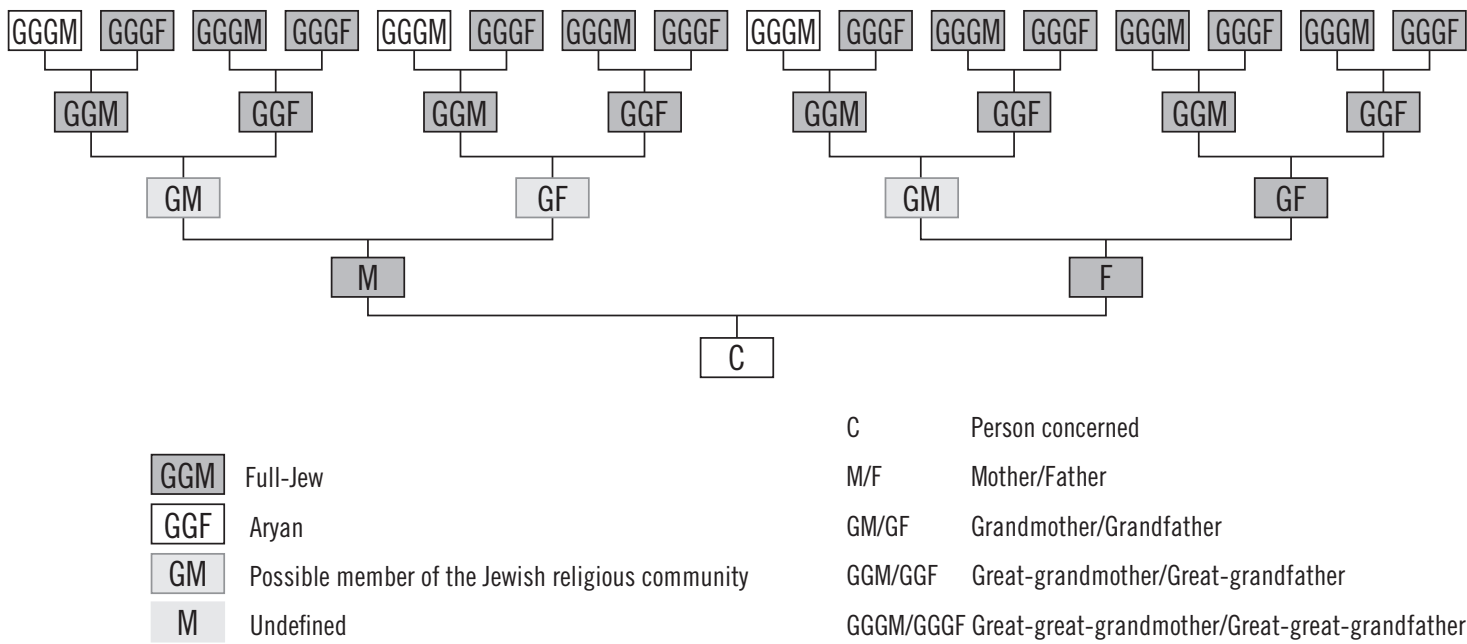

Figure 4.1

It even becomes more complicated if one realises that a person could have several 'status'. A woman who was Aryan by birth, but married to a Jew, was regarded Aryan with regard to her children (because she obviously did not have any Jewish grandparents), Jewish with regard to her grandchilderen (because she was married to a Jew), and Aryan again with regard to her great-grandchilderen. ${ }^{508}$

Everyone who had registered in January I94I got a stamp in his new Personalausweis, an identity card, which became mandatory in October $1940,{ }^{509}$ but was only distributed at

506 De Jong points out that Calmeyer approved of Wanders method as soon as he returned from his holiday. Already in 1941 Calmeyer had called the fact that persons were considered full-Jewish solely based on their membership of the Jewish religious community absurd. See L. de Jong, Het Koninkrijk der Nederlanden in de Tweede Wereldoorlog, 6:301. Middelberg points out that Calmeyer's decision to go along with Wanders method was subsequently approved by Seyss-Inquart. See M. Middelberg, Judenrecht, Judenpolitik und der Jurist Hans Calmeyer, 224.

507 A.J. Herzberg, 'Kroniek der Jodenvervolging', in J.J. van Bolhuis et al. (eds.), Onderdrukking en Verzet. Nederland in Oorlogstijd (deel 3), 5-256, 139; J. Presser, Ondergang (deel 2), 65-66.

508 J. Presser, Ondergang (deel 2), 66.

509 Verordnung des Generalsekretärs im Ministerium des Innern über die Einführung einer als allgemeiner Personalausweis geltenden Kennkarte vom 17. Oktober 1940, Verordnungsblatt für die besetzten niederländischen Gebiete (1940), 566. 
the end of I94I. ${ }^{510}$ Those who were full Jews - the definition from Regulation I 89/I940 $0^{511}$ was used in this respect - got a 'J', half-breeds received either 'B I'512 (later changed into ' $\mathrm{G} \mathrm{I}{ }^{513}$ ) when having two Jewish grandparents and thus being a Halbjude (half-Jew) or 'B II' (later changed into 'G II') when having only one Jewish grandparent, thus being a Vierteljude (quarter-Jew) ${ }^{514}$ When the Star of David became mandatory in $1942,{ }^{515}$ only those with a 'J' on their identity cards - the full Jews according to the definition from I940 - had to wear it. Half-Jews and quarter-Jews were exempted from this precept. ${ }^{516}$ Those who could somehow prove with Calmeyer they were not full-Jewish were later 'de-stard'. ${ }^{17}$

The Netherlands was obviously not the only country in which half-breeds tried to change their ancestry. In June I94I Calmeyer received an extract from an advice from the German Minister of Justice, which had been published in the Deutsche Justiz in May I94I. This explained that persons who had an Aryan mother and a Jewish or a first degree half-breed father increasingly tried to prove that somehow this man was not their natural father. In order to prove this, the child would rely on a testimony by the mother, who unveiled facts which would prove the Jew or the half-breed was not the natural father. However, the Minister of Justice warned, this testimony was often prompted by the desire to protect her child and would contradict all previous statements with regard to the natural father of the child. The statement would not pass a meticulous assessment and check. Therefore, the Minister of Justice continued, such a check was indispensable. ${ }^{518}$ The extract was sent to Calmeyer with the comment that it seemed likely that this explanation was of interest for Calmeyer. ${ }^{519}$

Following the Eleventh Supplementary Decree to the Reichsbürgergesetz of 25 November I94I, which deprived all Jews living abroad of their German Staatsangehörigkeit

510 A.J. Herzberg, 'Kroniek der Jodenvervolging', in J.J. van Bolhuis et al. (eds.), Onderdrukking en Verzet. Nederland in Oorlogstijd (deel 3), 5-256, 49; L. de Jong, Het Koninkrijk der Nederlanden in de Tweede Wereldoorlog, 5:428-429.

511 Verordnung des Reichskommissars für die besetzten niederländischen Gebiete über die Anmeldung von Unternehmen vom 22. Oktober 1940, Verordnungsblatt für die besetzten niederländischen Gebiete (1940), 546.

512 'B' from bastaard (half-breed).

513 'G' from gemengd (mixed ancestry).

514 A.J. Herzberg, 'Kroniek der Jodenvervolging', in J.J. van Bolhuis et al. (eds.), Onderdrukking en Verzet. Nederland in Oorlogstijd (deel 3), 5-256, 49-50; J. Presser, Ondergang (deel 1), 64.

515 This rule was not issued as a formal regulation in the Verordnungsblatt, but only as an order issued by Hans Rauter, Generalkommissar für das Sicherheitswesen on 27 April 1942, published at 29 April 1942. See Bekanntmachung des Generalkommissars für das Sicherheitswesen über die Kennzeichung der Juden in den Niederlanden vom 27. April 1942, Anordnungen des Generalkommissars für das Sicherheitswesen und Höheren SS- und Polizeiführers (1942), 21. The order was furthermore communicated to the presidents of the Jewish Council on 29 April 1942, who informed the Jewish population by circulair. Circulair by the Jewish Council of Amsterdam of 29 April 1942, NIOD archives, access no. 182, inventory no. 1b. See J. Presser, Ondergang (deel 1), 220-222; L. de Jong, Het Koninkrijk der Nederlanden in de Tweede Wereldoorlog, 5:10361038. See for an account of the discussion between Ferdinand Aus der Fünten, employed at the Zentralstelle für jüdische Auswanderung (Central Office for Jewish Emigration) and Abraham Asscher and David Cohen, presidents of the Jewish Council of Amsterdam a report by Willy Lages, head of the Zentralstelle für jüdische Auswanderung, sent to Wimmer, NIOD archives, access no. 077, inventory no. 1851.

516 See circulair by the Jewish Council of Amsterdam of 29 April 1942, NIOD archives, access no. 182, inventory no. 1b.

517 See for an elaborate description of the work and person of Calmeyer G. von Frijtag Drabbe Künzel, Het geval Calmeyer; M. Middelberg, Judenrecht, Judenpolitik und der Jurist Hans Calmeyer; C. Stuldreher, De Legale Rest; A.J. Herzberg, 'Kroniek der Jodenvervolging', in J.J. van Bolhuis et al. (eds.), Onderdrukking en Verzet. Nederland in Oorlogstijd (deel 3), 5-256, 136-140; J. Presser, Ondergang (deel 2), 50-72; L. de Jong, Het Koninkrijk der Nederlanden in de Tweede Wereldoorlog, 6:293-303.

518 Extract from Deutsche Justiz, no. 22 (30 May 1941), NIOD archives, access no. 020, inventory no. 1505.

519 Letter to Calmeyer of 10 June 1941, NIOD archives, access no. 020, inventory no. 1505. 
(nationality), ${ }^{520}$ the German Ministry of Foreign Affairs sent a circular to - amongst others - Wimmer about what to do with German half-breeds living in the Netherlands. ${ }^{521}$ First degree half-breeds would be deprived of their German nationality without delay. Only in special circumstances exceptions could be made, e.g. the first degree half-breed was clearly dedicated to the interests of the German Reich. Second degree half-breeds, however, could not be deprived of their German nationality solely on the ground that they were second degree half-breeds. Only when they fulfilled the conditions of $\mathbb{S} 2$ of the Gesetz über den Widerruf von Einbürgerungen und die Aberkennung der deutschen Staatsangehörigkeit ${ }^{522}$ - e.g. they had acted disloyal to the German Reich, thereby prejudicing the Reichs interests - they could lose their German nationality. However, only a minor offence would suffice in this respect, as the influence of the Jewish blood could be taken into account. ${ }^{523}$

Deprivation of nationality was not limited to Jews living abroad. Non-Jewish partners of Jews would lose their German nationality in case they refused to divorce their Jewish partner or when they would not return to Germany. In this case their children (which would be first degree half-breeds) would lose their German nationality as well. Persons of German blood who undeniably lived separated from their Jewish partner would retain their German nationality, although a divorce was recommended. In case this was not possible because Dutch legislation would not allow that person to travel to Germany, he or she would still retain the German nationality. In case the separation was not undeniable however, a declaration had to be signed which obliged the couple to divorce at the next opportunity. Refusal to sign would lead to deprivation of nationality. Partners of German blood who had converted to the Jewish faith, however, would lose their German nationality straight away. ${ }^{524}$

In January I943 a follow-up was sent which stated that persons born within a marriage between a former German national who was Jewish and a non-German national, e.g. a person with a Jewish mother and a Turkish father, had to be regarded as first degree half-breeds and would therefore be deprived of their German nationality. The Ministry of Foreign Affairs warned that this could lead to indignation with the government of the non-German partner, especially when this half-breed child still lived in this particular country. Whether or not special circumstances had to be taken into account had to be decided on a case-by-case basis. The explicit warning was given that all communication with half-breeds had to take place orally, as it had to be avoided to arm opponents with propaganda. ${ }^{525}$

520 Elfte Verordnung zum Reichsbürgergesetz vom 25. November 1941, Reichsgesetzblatt (1941), I, 722, § 1: 'Ein Jude, der seinen gewöhnlichen Aufenthalt im Ausland hat, kann nicht deutscher Staatsangehöriger sein. [...]'; § 2: 'Ein Jude verliert die deutsche Staatsangehörigheit a) wenn er beim Inkrafttreten dieser Verordnung seinen gewöhnlichen Aufenthalt im Ausland hat, mit dem Inkrafttreten der Verordnung, b) wenn er seinen gewöhnlichen Aufenthalt später im Ausland nimmt, mit der Verlegung des gewöhnlichen Aufenthalts ins Ausland.

521 Circular by the Auswärtiges Amt, D III 7009 (18 December 1942), NIOD archives, access no. 020, inventory no. 1508.

522 Gesetz über den Widerruf von Einbürgerungen und die Aberkennung der deutschen Staatsangehörigkeit vom 14. Juli 1933, Reichsgesetzblatt (1933), I, 480.

523 Circular by the Auswärtiges Amt, D III 7009 (18 December 1942), NIOD archives, access no. 020, inventory no. 1508.

524 Ibid.

525 Circular by the Auswärtiges Amt, D III 146 I (27 January 1943), NIOD archives, access no. 020, inventory no. 1519. 


\section{- 4.3.3. Adoption of the Nuremberg Laws}

Half-breeds, however, were not the only group the German occupant struggled with, metaphorically speaking. After one year of occupation the Nuremberg Laws, which amongst other things prohibited marriages and sexual intercourse between Jews and non-Jews, had not yet been enacted in the Netherlands. This caused resentment amongst the more dedicated Nazi officials in the Netherlands (called 'quibblers' by De Jong), like Generalkommissar für das Sicherheitswesen and Höhere SS- und Polizeiführer Hanns Albin Rauter, SS-Hauptsturmführer (captain) Wilhelm Zöpf, head of the Amsterdam Zentralstelle für jüdische Auswanderung (Central Office for Jewish Emigration) and SSObersturmführer (lieutenant) Erich Rajakowitsch who wished to speed up the nazification of the Netherlands ${ }^{526}$ In June 194I Wimmer's staff formulated a draft regulation which prohibited marriages between a) Jews on the one hand and non-Jews or second degree half-breeds on the other hand and b) second degree half-breeds among themselves. Marriages between first degree half-breeds and non-Jews or second degree half-breeds were only allowed after approbation by the Reichskommissar, or, on his behalf, the Generalkommissar für Verwaltung und Justiz. Furthermore, extramarital intercourse was prohibited between Jews on the one hand and non-Jews and second degree half-breeds on the other hand. ${ }^{527}$ The draft regulation took over the definition of Jew as set out in Regulation I89/1940, but added two categories. Children born from a marriage between a person with a least three Jewish grandparents and another (non-Jewish) person, concluded after that Regulation had entered into force, and children born after 30 April I 942 after extramarital intercourse with a person with at least three Jewish grandparents had to be regarded as Jews as well, ${ }^{528}$ although technically these children should of course be regarded as half-Jews or even quarter-Jews. Note the inconsistency of this part of the definition with the general purpose of the draft regulation; to prohibit marriages between Jews and non-Jews. Marriages concluded despite that prohibition were declared void in $\mathbb{S} 6$, even when concluded abroad, and had therefore never existed. ${ }^{529}$ Then how could a child ever be born in a marriage with a Jew, concluded after this regulation had come into force, because as a consequence of the regulation only extramarital relationships were allowed? Note that the same inconsistency appeared in the regulations applicable in Germany ${ }^{530}$ Incidentally, $\mathbb{} 6$ only declared marriages, concluded in defiance of this regulation, between a) Jews and non-Jews, b) Jews and quarter-Jews, c) half-Jews and non-Jews and d) half-Jews and quarter-Jews void. The draft mentioned no consequences for marriages concluded between quarter-Jews among themselves, which was nevertheless prohibited in $\mathbb{} 4$.

Kammergerichtsrat (justice) Werner Seiffert - who was asked to review the draft -

526 L. de Jong, Het Koninkrijk der Nederlanden in de Tweede Wereldoorlog, 5:980.

527 Verordnung des Reichskommissars für die besetzten niederländischen Gebiete zur Vermeidung der Vermengung von jüdischen und nicht-jüdischen Blut, Vorentwurf A, I 69/41, NIOD archives, access no. 020, inventory no. 2409.

528 Ibid.

529 Verordnung des Reichskommissars für die besetzten niederländischen Gebiete zur Vermeidung der Vermengung von jüdischen und nicht-jüdischen Blut, Vorentwurf A, I 69/41, NIOD archives, access no. 020, inventory no. 2409, § 6 (1): 'Eine den Verboten der $\S \S 2$ oder 3 zuwider geschlossene Ehe ist nichtig, auch wenn sie ausserhalb der besetzten niederländischen Gebiete geschlossen worden ist.'

530 See $\$ 5$ (2) (c) Erste Verordnung zum Reichsbürgergesetz vom 14. November 1935, Reichsgesetzblatt (1935), I, 1333. 
criticised the draft in a letter dated on 4 August I94I, stating that Dutch regulations with regard to racial hygiene had to dovetail as much as possible with the German Blutschutzgesetz, not only because the Blutschutzgesetz had already proven its merit, but also because it would be unseemly not to follow the Reich's example. There was a posibility that in the future the Blutschutzgesetz would be declared directly applicable in the Netherlands as had already happened in the protectorate Bohemia and Moravia. In that sense it would only generate profit if Dutch legislation had already been brought into line with the German rules. Despite this Seiffert had removed the articles which prohibited extramarital intercourse between Jews and non-Jews or second degree halfbreeds, as Seyss-Inquart had decided that this matter as well as the matter of dissolution of mixed marriages did not belong in this regulation. Apart from that Seiffert pointed out that with regard to half-breeds this draft regulation was exactly in line with the Reich's rationale that in case of second degree half-breeds (Vierteljuden) the Jewish part had to be filtered out as soon as possible. Other draft regulations however, had the tendency to equate second degree half-breeds with Jews, which was incompatible with the Reich's basic principles. Finally, Seiffert pointed out that the Blutschutzgesetz spoke of 'Staatsangehörigen deutschen oder artverwandten Blutes'. In the Dutch equivalent of this law one could not, however, use the terms 'Dutch blood' or 'Germanic blood', as those terms did not cover the same overtones. Therefore, Seiffert had used the term 'nichtjüdische niederländische Staatsangehörige', with the result that Indonesian halfbreeds had to be put on the same footing as non-Jews. Seiffert preferred this than to equate them with Jews, although he did point out that this inconvenient situation had to be solved over time. ${ }^{531}$ This letter was also sent to Calmeyer at 5 August I94I I ${ }^{532}$ Seifferts remarks lead to a new draft which largely took over Seifferts recommendations. ${ }^{533}$

This draft was discussed in Berlin in a meeting of I3 August I94I, chaired by then SS-Sturmbannführer ${ }^{54}$ (major) Adolf Eichmann, ${ }^{535}$ head of sub-department IV B 4 Räumungsangelegenheiten und Reichszentrale für jüdische Auswanderung ${ }^{536}$ (Clearance Affairs and Reich Office for Jewish Emigration) at the Reichssicherheitshauptamt (Head Office for Reich Security). ${ }^{537}$ The main subject of discussion, however, was the possible abolition of exceptional provisions with regard to mixed-married and half-breeds. Both in Germany and in the occupied territories the mixed-married and half-breeds to a certain extent enjoyed a priviliged position, as Hitler did not wish to give rise to concern among the families of the non-Jewish partners. Apart from that thousands of quarter-Jews and a few hundred half-Jews fought in the German army. The Dutch draft regulation respected

531 Letter of Kammergerichtsrat Werner Seiffert to Generalkommissariat für Verwaltung und Justiz, Abteilung Rechtsetzung, M Ju 2663/41 (4 August 1941), NIOD archives, access no. 020, inventory no. 1507 (a copy can be found in the NIOD archives, access no. 020, inventory no. 2409). See also Verordnung des Reichskommissars für die besetzten niederländischen Gebiete über das Verbot der Eheschliessung mit Juden, Vorentwurf by Werner Seiffert, NIOD archives, access no. 020, inventory no. 1507.

532 Letter of Kammergerichtsrat Werner Seiffert to Ministerialreferat Innere Verwaltung, Rechtsanwalt Calmeyer, M Ju $2663 / 41$ (5 August 1941), NIOD archives, access no. 020, inventory no. 1507.

533 Verordnung des Reichskommissars für die besetzten niederländischen Gebiete über das Verbot der Eheschliessung mit Juden, Vorentwurf B, I 69/41, NIOD archives, access no. 020, inventory no. 2409 and 1507.

534 He was promoted to the rank of SS-Obersturmbahnführer (lieutenant-colonel) in October 1941.

535 See on Eichmann H. Arendt, Eichmann in Jerusalem, in particular pp. 68-82.

536 Later called Juden- und Räumungsangelegenheiten (Jewish and Clearance Affairs).

537 L. de Jong, Het Koninkrijk der Nederlanden in de Tweede Wereldoorlog, 5:980. 
that priviliged position. Eichmann, however, probably after complaints from quibbler Rajakowitsch, apparently had tried to remove these exceptional provisions from the Dutch draft. The Reich Ministry of the Interior, however, prevented this abolition. ${ }^{538}$

Besides that, Rauter had already tried to block Wimmer's draft and had sent a letter (probably drafted by Rajakowitsch) ${ }^{539}$ to both Seyss-Inquart and Wimmer, arguing that in order to solve the Jewish problem an unambiguous definition of the concept of 'Jew' had to be developed for which a revision of the concept of half-breeds was necessary and asking him whether it would be better to await the outcome of the Berlin deliberations, which were currently going on, before the regulation was brought into force. ${ }^{540} \mathrm{In}$ a memorandum as a result of this letter, these Berlin deliberations were explained. According to Rajakowitsch, these deliberations were organised to deal with plans to promulgate extensive racial laws, in which half-Jews would equate full-Jews, in the whole of Europe. European nations (presumably European nations occupied by Germany) had required a model regulation and in Berlin objections had arisen with regard to the Nuremberg Laws and their supplementary decrees as model regulations. As this Dutch draft was in line with the Nuremberg Laws it was self-evident that in Berlin one was not too happy with it. Therefore, Rajakowitsch considered it advisable to postpone the promulgation of this regulation in the Netherlands. ${ }^{541}$ Wimmer, however, was not aware of any Berlin deliberations with regard to the definition of the concept of 'Jew' and therefore sent one of his staff members, Dr. Carl Stüler to Berlin to make inquiries; the Reich Ministry of the Interior put him at ease. During corridor chats the matter had been discussed, although formal deliberations were out of the question. Hitler himself had turned against this idea as it would affect too many soldiers, in case suddenly (one of) their parents were declared Jewish. It was therefore unlikely that the existing measures would change in the near future as a result of which it was still advisable to closely follow the existing German model regulations when drafting racial laws in the occupied territories. The (original) Dutch regulation therefore did not provide any problems in that respect. ${ }^{542}$

While Rauter and Wimmer were bickering about possible deliberations in Berlin, Vorentwurf $B$ was sent to Seiffert to comment upon, with the request to reply before 25 August 194I. ${ }^{543}$ A reaction was sent to the Abteilung Rechtsetzung on I September 194I, stating that the definition of 'Jew' as set out in $\mathbb{S}$ I of the draft could not muster, as it was incompatible with Regulation I89/1940 and the First Supplementary Decree to the

538 L. de Jong, Het Koninkrijk der Nederlanden in de Tweede Wereldoorlog, 5:980.

539 Ibid.

540 Letter of Hanns Albin Rauter to Generalkommissar für Verwaltung und Justiz Wimmer, BdS. B. Nr. IV B $15842 / 41$ (18 August 1941), NIOD archives, access no. 020, inventory no. 1507 (for a copy sent to Seyss-Inquart see NIOD archives, access no. 020, inventory no. 2409).

541 Vermerk zum Vorgang BdS B Nr. 4B 15842/41, Schreiben des Generalkommissars für das Sicherheitswesen and den Reichskommissar vom 18.8.41, memorandum signed by Calmeyer at 9 September 1941, NIOD archives, access no. 020, inventory no. 1507.

542 Report by Carl Stüler about his meeting with officials of the Ministry of the Interior in Berlin (19 September 1941), NIOD archives, access no. 020, inventory no. 1507; Letter by Carl Stüler to Wimmer about his meeting in Berlin (20 September 1941), NIOD archives, access no. 020, inventory no. 1507 (copies of both documents can be found in the NIOD archives, access no. 020, inventory 2409).

543 Letter from Generalkommissariat für Verwaltung und Justiz, Abteilung Rechtsetzung to Kammergerichtsrat Seiffert, I $69 / 41$ (18 August 1941), NIOD archives, access no. 020, inventory no. 2409 and 1507. 
Reich Citizenship Law of I4 November 1935. The draft regulation stated in $\mathbb{S}$ I (2) that half-breeds with two full-Jewish grandparents were Jewish in case a) he or she adhered to the Jewish religious community on 9 May 1940 or was admitted as a member after that date, or b) he or she was married to a Jew on 9 May 1940 or had married a Jew after that date, or c) he or she was Dutch and was born in a marriage with a Jew (a full-Jew, having three or four Jewish grandparents) which was concluded after this regulation had come into force.$^{544}$ However, those persons were not Jewish, but half-breeds, but were put on the same footing as Jews. Furthermore, it was pointed out that in this draft regulation the definition of 'Jew' was enlarged as option c lacked in Regulation I89/r940. This was inexpedient as it would convey the impression that there existed two definitions of 'Jew' in the Netherlands. ${ }^{545}$ It furthermore lead to the same inconsistency noted earlier as marriages concluded in defiance of the prohibitions set out in $\mathbb{S}$ I were declared void in $\$ 8$, and would therefore never have existed. ${ }^{546}$

Eventually Seyss-Inquart decided not to enact Wimmer's draft, as he considered it would cause too much of a stir. ${ }^{547}$

The matter was discussed again in October I94I when Seyss-Inquarts representative in Amsterdam, Beauftragte Hans Böhmcker observed that blood protection measures had still not been adopted in the Netherlands. Seyss-Inquart, however, decided to postpone any measures. ${ }^{548}$

In November 194I the newly appointed secretary-general of Justice Jaap Schrieke tried again. He proposed to adopt two regulations instead of one, with the first, promulgated by him, prohibiting mixed marriages, whilst the second, promulgated by the Reichskommissar, allowed for exceptions. His proposals were sent to Seiffert to comment upon on 22 November I94I. ${ }^{549}$

The first regulation largely followed the line of Vorentwurf $B$, although Schrieke had taken the liberty to rearrange the order of articles and to reformulate the actual prohibition. Furthermore, he added a defintion of the concept of 'Mischling' (halfbreed), which he had literally taken over from $\mathbb{\$} 2$ (2) of the First Supplementary Decree to the Reich Citizenship Law. ${ }^{550}$ By differentiating between half-Jews who were put on the same footing as full-Jews by $\mathbb{S} 4$ of Regulation I89/1940 and half-Jews as such

544 Verordnung des Reichskommissars für die besetzten niederländischen Gebiete über das Verbot der Eheschliessung mit Juden, Vorentwurf B, I 69/41, NIOD archives, access no. 020, inventory no. 2409 and 1507, § 1 (2): 'Jude im Sinne dieser Verordnung ist, [...] 2) wer von zwei volljüdischen Grosselternteilen abstammt und a) entweder selbst am 9 . Mai 1940 der jüdischen Religionsgemeinschaft angehört hat oder danach in sie aufgenommen worden ist oder b) am 9. Mai 1940 mit einem Juden verheiratet war oder sich danach mit einem Juden verheiratet hat oder c) Niederländer ist und aus einer Ehe mit einem Juden im Sinne der Ziffer 1 abstammt, die nach dem Inkrafttreten dieser Verordnung geschlossen ist.'

545 Letter to the Generalkommissariat für Verwaltung und Justiz, Abteilung Rechtsetzung (1 September 1941), NIOD archives, access no. 020, inventory no. 1507 and 2409 .

546 Verordnung des Reichskommissars für die besetzten niederländischen Gebiete über das Verbot der Eheschliessung mit Juden, Vorentwurf B, I 69/41, NIOD archives, access no. 020, inventory no. 2409 and 1507, § 8 (1): 'Eine dem Verbot des $\$ 1$ zuwider geschlossene Ehe ist nichtig, auch wenn sie ausserhalb der besetzten niederländischen Gebiete geschlossen worden ist.'

547 L. de Jong, Het Koninkrijk der Nederlanden in de Tweede Wereldoorlog, 5:981.

548 Aktenvermerk (note in the records) of 24 October 1941, M Ju 2663/41, NIOD archives, access no. 020, inventory no. 2409.

549 Letter from secretary-general of Justice J.J. Schrieke to Kammergerichtsrat W. Seiffert, R. Nr. 1118 (22 November 1941), NIOD archives, access no. 020, inventory no. 2409.

550 Verordnung des Generalsekretärs im Ministerium für Justiz über das Verbot der Eheschliessung mit Juden, November 1941 , NIOD archives, access no. 020, inventory no. 2409. 
Schrieke enlarged the number of prohibitions. Both Vorentwurf $A$ and $B$ did not prohibit marriages between half-Jews as such among themselves and marriages between halfJews as such and non-Jews or quarter-Jews could be allowed after approbation by the Reichskommissar. Schrieke's $\mathbb{3}$ (3) prohibited marriages between half-Jews as such and non-Jews or quarter-Jews unconditionally. Because of this provision, Schrieke's draft was more stringent than the Nuremberg Laws. Not a word was said about marriages between half-Jews as such among themselves, however. In terms of clear organisation, Schrieke's draft was an improvement. Apart from that, he more or less solved the inconsistency mentioned above. Instead of declaring all marriages concluded in defiance of this law automatically void, Schrieke stated in his draft $\mathbb{} 7$ that those marriages could be declared void, and only at the request of the Public Prosecutor. ${ }^{51}$ The second regulation only consisted out of two articles and stated that the Reichskommissar could make exceptions with regard to the previous regulation. ${ }^{552}$ Seyss-Inquart, however, decided not to enact these drafts. ${ }^{553}$

Rajakowitsch gave it one more try in December 194I, with a somewhat rudimentary draft, based on Vorentwurf $A$ rather than on $B$ and therefore reintroducing the terms of first and second degree half-breeds and the prohibition of extramarital intercourse between Jews on the one hand and non-Jews and second degree half-breeds on the other. Additionally, he proposed to prohibit extramarital intercourse between first degree halfbreeds on the one hand and non-Jews and second degree half-breeds on the other. The draft furthermore prohibited marriages between full-Jews and half-Jews (first degree half-breeds), ${ }^{54}$ a prohibition which had not been included in any of the other drafts and which would explicitly be permitted in later years. Marriages between quarterJews and non-Jews had been allowed in all other drafts, but should only be allowed after approbation according to Rajakowitsch. ${ }^{555}$ This was a fundamental deviation from the German policy that with regard to quarter-Jews the small amount of Jewish blood had to be filtered out as soon as possible through a marriage to a non-Jew. On the other hand did Rajakowitsch allow for marriages between quarter-Jews among themselves after approbation, which was prohibited unconditionally by the previous drafts. ${ }^{556}$ Marriages between half-Jews among themselves were only allowed after approbation. ${ }^{57}$ With this draft the whole project seemed to be back at square one causing one of Wimmer's staff members to scribble in the margins: 'Stellt die Halbjuden den Juden gleich!'558 This draft was not brought into force either, ${ }^{59}$ although Seiffert had expressed his concerns about

551 Ibid., § 7: 'Eine Ehe, die einem Verbot des $\S 3$ zuwider geschlossen worden ist, kann aus diesem Grunde aussliesslich auf Antrag der Staatsanwaltschaft für nichtig erklärt werden, [...].'

552 Verordnung des Reichskommissars für die besetzten niederländischen Gebiete über das Verbot der Eheschliessung mit Juden, November 1941, NIOD archives, access no. 020, inventory no. 2409.

553 L. de Jong, Het Koninkrijk der Nederlanden in de Tweede Wereldoorlog, 5:981.

554 Entwurf einer Verordnung des Reichskommissars über den Blutschutz, 8 December 1941, NIOD archives, access no. 020, inventory no. 2409, § 1: 'Juden dürfen nur mit Juden Eheschliessungen eingehen.'

555 Entwurf einer Verordnung des Reichskommissars über den Blutschutz, 8 December 1941, NIOD archives, access no. 020, inventory no. 2409, § 2: 'Jüdische Mischlinge 1. und 2. Grades bedürfen zu jeder Eheschliessung der Genehmigung des Reichskommissars (Generalkommissar für das Sicherheitswesen).'

556 Ibid.

557 Ibid.

558 Entwurf einer Verordnung des Reichskommissars über den Blutschutz, 8 December 1941, NIOD archives, access no. 020, inventory no. 2409.

559 L. de Jong, Het Koninkrijk der Nederlanden in de Tweede Wereldoorlog, 5:981. 
the delays in a letter to Wimmer on Io December 194I. According to Seiffert the current situation in which Jews were excluded on a large scale but were not prohibited to marry non-Jews was unseemly and caused confusion among the Dutch population. ${ }^{560}$

In March 1942 a new situation arose. On 2I March 1942 the Nationale Dagblad (National Daily, published by the NSB, the Dutch National Socialist Movement ${ }^{561}$ ) published an article in which a strong increase of mixed marriages was pointed out. ${ }^{562}$ In Amsterdam in the second week of March 1942, 74 marriages involving Jews were concluded, I I of them being mixed marriages. The statistics of the third week of March 1942, however, showed that 283 marriages involving Jews were concluded, 22 of them being mixed marriages. ${ }^{563}$ Compared to the figures of the second week, this was an absolute increase of Ioo per cent, but a relative decrease of almost 50 per cent. ${ }^{564}$ The absolute increase, however, was a source of concern for the Germans and on 23 March - two days after the observation was made - Seyss-Inquart decided that the Nuremberg Laws were directly applicable in the Netherlands. This was done without a separate regulation; from now on the occupying forces would act as if the laws were enacted by regulation. ${ }^{565}$ The actual enforcement of the Nuremberg Laws would take place in three steps: first, an announcement stating that mixed marriages were prohibited had to be published in Het Joodsche Weekblad (the Jewish Weekly). Second, all Jews who had announced their intended marriage with an Aryan had to be arrested, and third, all registrars would be instructed by the Generalkommissar für Verwaltung und Justiz to report all announcements of marriage of Jews with Aryans to the Generalkommissar für das Sicherheitswesen. ${ }^{566}$ On 27 March 1942 Het Joodsche Weekblad published an announcement by Abraham Asscher and David Cohen, presidents of the Jewish Council of Amsterdam, stating that by order of the German authorities marriages and extramarital intercourse between Jews and non-Jews was prohibited. ${ }^{567}$ On 3 I March 1942 Wimmer ordered secretary-general of Justice Schrieke to inform the registrars to report all announced mixed marriages at Referat IV B 4 at the Sicherheitspolizei in The Hague. As mixed marriage, he explained, had to be regarded all marriages by which one of the partners was marked as a Jew in his or her passport, by having a 'J' stamped in it. ${ }^{568}$ With this provision the original proposal was cut down to the bone, as nothing was said about marriages between a) half-Jews among themselves, b) quarter-Jews among themselves, c) half-Jews and quarter-Jews and d) half-Jews and non-Jews. On 8 April 1942 Schrieke sent a circular to the registrars, in which he literally quoted Wimmers

560 Letter from Kammergerichtsrat W. Seiffert to Generalkommissar für Verwaltung und Justiz F. Wimmer, Ju 12-2663/41 (10 December 1941), NIOD archives, access no. 020, inventory no. 2409.

561 Strictly speaking the Nationale Dagblad was published by an independent foundation, the Nationale Pers (National Press), to prevent questions, but was nevertheless largely funded by the NSB. See E. Fraenkel-Verkade, Correspondentie van Mr. M.M. Rost van Tonningen, volume 1, 42.

562 Nationale Dagblad, 21 March 1942, 'Vlucht in.... het huwelijk. Een joodsch listigheidje?'

563 Letter from Calmeyer to Seiffert, 25 March 1942, NIOD archives, access no. 020, inventory no. 2409.

564 In the second week of March $194214.86 \%$ of the marriages involving Jews were mixed marriages, in the third week of March only $7.77 \%$ of the marriages involving Jews were mixed marriages. This meant a halving of the share of mixed marriages in terms of percentage.

565 Telegram by Lages to Befehlshaber der Sicherheitspolizei und des SD, 25 March 1942, NIOD archives, access no. 020, inventory no. 2409.

566 Ibid.

567 A. Asscher and D. Cohen, 'Bekendmaking', 1 Het Joodsche Weekblad 51 (1942), 1.

568 Letter of Wimmer to Schrieke, Ve St-448/42 (31 March 1942), NIOD archives, access no. 020, inventory no. 2409. 
memorandum of 3I March, ordering them to do as Wimmer had requested. ${ }^{569}$ Several dozens of arrests took place, supposedly at the end of March I942. Approximately twenty female Jewish partners were arrested and approximately thirty male. The women were deported to concentration camp Ravensbrück; the men were brought to the Dutch concentration camp Amersfoort. They were brought in at the beginning of May with a large yellow ' $\mathrm{R}^{570}$ on their chest. Only one of the women survived in Ravensbrück; all men died, some already in Amersfoort, the others in concentration camp Mauthausen. ${ }^{571}$

Soon after the unofficial promulgation of the new policy a discussion was started about expanding this marriage prohibition. In August 1942 Seiffert asked Calmeyer for his advice with regard to a potential new circular to the registrars in which apart from marriages between full-Jews and non-Jews (a), marriages between $\mathrm{b}$ ) half-Jews and nonJews, c) Jews and quarter-Jews (second degree half-breeds), d) Jews and half-Jews, e) half-Jews among themselves and f) quarter-Jews among themselves would be prohibited as well..$^{572}$ Calmeyer answered by return that he fully approved of the proposal, although he did point out that in some matters this draft deviated from the German legislation, e.g. in Germany marriages between quarter-Jews among themselves could be allowed upon request. Calmeyer furthermore pointed out that it could be in the interest of the German administration in the Netherlands to allow marriages between half-Jews and Jews as because of such a marriage the half-Jew in question had to be regarded as Jew, effectively ending the disputable priviliged position. ${ }^{573}$ In a letter to Seiffert dated 22 August 1942 Calmeyer retracted his statement that marriages between quarter-Jews among themselves were allowed in Germany upon request. He referred to $\mathbb{4} 4$ of the First Supplementary Decree to the Blutschutzgesetz, ${ }^{574}$ explaining that the ground for this prohibition was a fast assimilation of quarter-Jews. In Germany quarter-Jews were therefore only allowed to marry people of German or kindred blood. The circular to the registrars had to be accentuated accordingly. ${ }^{575}$

In a letter to Generalkommissar für Finanz und Wirtschaft Hans Fischböck Wimmer stated that a regulation prohibiting the various kinds of mixed marriages was still within the bounds of possibility in the Netherlands. Until that time, however, the instructions to the registrars had to be accentuated, following the rules in force in Germany. Wimmer pointed out that in Germany mixed marriages between half-Jews and German nationals of German or kindred blood and between half-Jews and quarter-Jews were only allowed

569 Circular by J.J. Schrieke to the registrars, no. 1131 (8 April 1942), NIOD archives, access no. 020, inventory no. 2413. A typewritten copy can be found in the NIOD archives, access no. 020, inventory no. 2409.

570 ' $\mathrm{R}$ ' from Rassenschande (dishonour to the race).

571 L. de Jong, Het Koninkrijk der Nederlanden in de Tweede Wereldoorlog, 5:1024-1025. See also Minutes of the Jewish Council of 29 July 1942, NIOD archives, access no. 182, inventory no. 1c.

572 Letter from Seiffert to Calmeyer, Ju 12 - 2663/41 (6 August 1942), NIOD archives, access no. 020, inventory no. 2409.

573 Letter of Calmeyer to Böttcher, (10 August 1942), NIOD archives, access no. 020, inventory no. 2409.

574 Erste Verordnung zur Ausführung des Gesetzes zum Schutze des deutschen Blutes und der deutschen Ehre vom 14. November 1935, Reichsgesetzblatt (1935), I, 1334, § 4: 'Eine Ehe soll nicht geschlossen werden zwischen staatsangehörigen jüdischen Mischlingen, die nur einen volljüdischen Großelternteil haben.'

575 Letter from Calmeyer to Seiffert, (22 August 1942), NIOD archives, access no. 020, inventory no. 2409. A copy can be found in the NIOD archives, access no. 020, inventory no. 1507. 
after approbation ${ }^{576}$ and that in actual practice this permission was never granted in order to avoid the increase of half-breeds. Nevertheless, notwithstanding this policy, marriages between half-Jews among themselves were allowed in Germany. However, this concerned an exception of which one wanted to get rid of. Therefore, it would be unuseful to adopt this mistake in the Netherlands. Wimmer furthermore emphasised Calmeyers statement that there was no reason to prohibit marriages between Jews and half-Jews as in these cases the half-Jew would profess to Judaism unconditionally, ending his priviliged position himself. Marriages between non-Jews and quarter-Jews could, however, not be prohibited as the Nuremberg Laws did not include the term 'one-eight-Jew' (Achteljuden). Fischböck was kindly requested to send a reaction before io October $1942 .^{577}$

On 9 November I942 Wimmer requested Schrieke to supplement his circular of 8 April i942. Announced marriages between a) Jews and non-Jews, b) half-Jews (G I) and non-Jews, c) Jews and quarter-Jews (G II), d) half-Jews among themselves, e) half-Jews (G I) and quarter-Jews (G II) and f) quarter-Jews among themselves had to be reported at Referat IV $B_{4}$ at the Sicherheitspolizei in the Hague. Marriages between Jews and halfJews (G I) had to be reported at the National Inspectorate of Registers (Rijksinspectie van de Bevolkingsregisters). Furthermore, the marriage partners concerned had to be informed of the fact that the half-Jewish partner would be considered full-Jewish because of the marriage and would therefore get a J on his identity card and had to wear the Star of David. ${ }^{578}$ Schrieke did so on 8 January 1943 . $^{579}$

Uncertainty remained however, not only among the population and the registrars, but also at the Sicherheitspolizei. Sturmscharführer (warrant-officer) Fischer from Referat $I V B_{4}$ at the Sicherheitspolizei called Landgerichtsdirektor (presiding judge of a county court) Böttcher in March 1943 to demand an explanation. Böttcher gave a short verbal explanation but indicated he did not have time to give an extensive lecture. ${ }^{580}$ Later that month Böttcher sent a short explanatory note to Fischer in which he firstly refuted the assertion that the Sicherheitspolizei had not been involved in the development of the marriage prohibitions and secondly stated that only Schrieke's circular of 8 January i943 had come into effect. A draft regulation remained in suspense at the moment, by order of the Reichskommissar. Copies of Schrieke's circulars could be collected; Böttcher did not have any other documents. ${ }^{581}$ However, the uncertainty was apparently caused by the circular itself. In July 1943 the Sicherheitspolizei reported to Wimmer that potential marriage partners erroneously were under the impression that announced mixed marriages had to be reported at the Sicherheitspolizei in order to get an approbation

576 See $\$ 3$ (1) of the Erste Verordnung zur Ausführung des Gesetzes zum Schutze des deutschen Blutes und der deutschen Ehre vom 14. November 1935, Reichsgesetzblatt (1935), I, 1334.

577 Letter from Wimmer to Fischböck, Ve St-1742/42, (29 September 1942), NIOD archives, access no. 020, inventory no. 286.

578 Letter from Wimmer to Schrieke, Ve St-1879/42, (9 November 1942), NIOD archives, access no. 020, inventory no. 286. A copy can be found in the NIOD archives, access no. 020, inventory no. 2413.

579 Circular by J.J. Schrieke to the registrars, no. 1501 (8 January 1943), NIOD archives, access no. 020, inventory no. 2413 and NIOD archives, access no. 020, inventory no. 2413. A typewritten draft in both German and Dutch can be found in the NIOD archives, access no. 020, inventory no. 2413. An earlier typewritten draft in German can be found in the NIOD archives, access no. 020 , inventory no. 1507.

580 Memorandum by Böttcher (Vermerk betr. Verhindering von Mischehen mit Juden bezw. Mischlingen), 5 March 1943, NIOD archives, access no. 020, inventory no. 1507.

581 Letter from Böttcher to Fischer, Ju 12-2663/41, (23 March 1943), NIOD archives, access no. 020, inventory no. 1507. 
to marry. The Sicherheitspolizei, however, would arrest both partners instead. ${ }^{52}$ This message was passed on to Schrieke, who was subsequently asked to tell the registrars to give a short explanation to potential marriage partners about the purpose of the report of their announced marriage to the Sicherheitspolizei ${ }^{583}$ Schrieke complied. ${ }^{584}$ In order to clarify all remaining ambiguities, the new Befehlshaber der Sicherheitspolizei und des SD Major General Erich Naumann sent a letter to Wimmer's Abteilung Innere Verwaltung explaining the rules once and again and stating that in case of violation of these rules the marriage partners had to be arrested and send to concentration camps, half-Jews (and presumably full-Jews as well) to Auschwitz, Aryans and quarter-Jews to 's Hertogenbosch. Registrars who refused to report prohibited mixed marriages had to be arrested and could be send to a concentration camp as well. ${ }^{585}$

All in all, at the beginning of 1944 a regulation prohibiting mixed marriages and otherwise introducing the Blutschutzgesetz had still not been promulgated in the Netherlands. During a meeting on 28 February 1944 this subject came up again. The minutes of this meeting, written by Calmeyer, mention the need for a regulation, which would prohibit both mixed marriages and extramarital intercourse between Jews and non-Jews and which would create the possibility for non-Jews to divorce their Jewish partners. Calmeyer allowed himself the liberty of suggesting that the Hauptabteilung Justiz could perhaps take the lead in drafting such a regulation as they had come up with the earlier drafts as well. According to Calmeyer, Seyss-Inquart was looking forward to a fast submission of a first draft. $^{586}$

This first draft was sent to Wimmer on I8 April I944. According to the accompanying letter this draft corresponded largely with the German Blutschutzgesetz. ${ }^{587}$

Article I prohibited marriages between a) Jews and non-Jews, b) Jews and quarterJews, c) half-Jews and non-Jews, d) half-Jews among themselves, e) half-Jews and quarter-Jews and f) quarter-Jews among themselves ${ }^{588}$ and corresponded therefore to Schrieke's instructions to the registrars from I943. However, the prohibitions set out in this draft were more stringent than the German Blutschutzgesetz and the First Supplementary Decree to that law, as we have seen before that in Germany marriages between half-Jews and non-Jews or quarter-Jews were allowed after approbation (even though this was never granted in actual practice) and that marriages between half-Jews among themselves were not prohibited at all, although according to Wimmer, this was

582 Letter from the Befehlshaber der Sicherheitspolizei und des SD, Referat IV B 4 (probably written by Fischer) to Wimmer, B.Nr. 10 512/43, (5 July 1943), NIOD archives, access no. 020, inventory no. 1507.

583 Letter from Böttcher to Schrieke, Ju 12-2663/41, (16 July 1943), NIOD archives, access no. 020, inventory no. 1507

584 Letter from Referat IV B 4 to the branches of the Befehlshaber der Sicherheitspolizei und des SD, (2 September 1943), NIOD archives, access no. 020, inventory no. 1507.

585 Letter from Naumann to Abteilung Innere Verwaltung, (24 September 1943), NIOD archives, access no. 020, inventory no. 1507.

586 Letter from Calmeyer to Wimmer containing the minutes of the meeting of 28 February 1944, (29 February 1944), NIOD archives, access no. 020 , inventory no. 2413.

587 Letter from Ministerialrat (head of department - by that time most likely Dr Karl Krug) to Wimmer, Ju 12-1309/42, (18 April 1944), NIOD archives, access no. 020, inventory no. 2413.

588 Verordnung des Reichskommissars für die besetzten niederländischen Gebiete über das Verbot der Eheschliessung und des ausserehelichen Verkehrs mit Juden, April 1944, NIOD archives, access no. 020, inventory no. 2413 and 1507, § 1. 
regarded an anomaly in Germany as well, as we have seen before. ${ }^{589}$ Article 9 stated that with regard to the definition of Jew or Jewish half-breed the provisions of Regulation I89/I940 and Regulation 6/I94I were applicable. Sub 2 of this article nevertheless contained the same oversimplified definition as was used in Vorentwurf B back in I94I, stating that Jewish half-breeds were those who were of Jewish blood according to $\mathbb{S} 2$ of Regulation 6/I94I, in as far they were not Jewish. ${ }^{590}$ The draft furthermore reintroduced the prohibition of extramarital intercourse between Jews and non-Jews. ${ }^{591}$ A novelty was $\mathbb{S}_{5}(2)$ which stated that existing mixed marriages (either between Jews and non-Jews or between Jews and quarter-Jews) could be declared void, although it is not entirely clear within what time. ${ }^{592}$ The provision reads 'innerhalb eines Jahres nach diesem Zeitpunkt' but it is unclear what point in time is meant, as it could mean either within a year after the regulation had come into force or within a year after the marriage had been concluded. From a philological point of view the last assumption would be most likely, although from a logical point of view the first assumption would seem the most plausible, a premise Stuldreher endorses to. ${ }^{593}$ The accompanying letter, however, does not offer any further clarification. ${ }^{594}$

A new draft followed on Io May I944, ${ }^{595}$ which almost literally corresponded with the April draft, although the order of articles had been slightly changed. ${ }^{596}$ One important modification though concerned an accentuation of the prohibition of extramarital intercourse, which, according to this draft, should also be applicable between Jews and quarter-Jews. ${ }^{597}$

The final draft formulated by the Abteilung Rechtssetzung concerning a regulation prohibiting mixed marriages and extramarital intercourse dates from 3 August I944 and is somewhat confusingly called 'Erste Fassung' ${ }^{598}$ Contentwise, this draft differed

589 See letter from Wimmer to Fischböck, Ve St-1742/42, (29 September 1942), NIOD archives, access no. 020, inventory no. 286.

590 Verordnung des Reichskommissars für die besetzten niederländischen Gebiete über das Verbot der Eheschliessung und des ausserehelichen Verkehrs mit Juden, April 1944, NIOD archives, access no. 020, inventory no. 2413 and 1507, § 9 (2): 'Jüdischer Mischling ist, wer nach den Bestimmungen des $\S 2$ der Verordnung Nr. 6/1941 jüdischen Blutes ist, soweit er nicht Jude ist.' Italics by me - ML.

591 Verordnung des Reichskommissars für die besetzten niederländischen Gebiete über das Verbot der Eheschliessung und des ausserehelichen Verkehrs mit Juden, April 1944, NIOD archives, access no. 020, inventory no. 2413 and 1507, § 6 : 'Ausserehelicher Verkehr zwischen Juden und nichtjüdischen niederländischen Staatsangehörigen ist verboten.'

592 Verordnung des Reichskommissars für die besetzten niederländischen Gebiete über das Verbot der Eheschliessung und des ausserehelichen Verkehrs mit Juden, April 1944, NIOD archives, access no. 020, inventory no. 2413 and 1507, § 5(2): 'Eine Ehe, die vor dem Inkrafttreten dieser Verordnung zwischen Juden und 1) nichtjüdischen niederländischen Staatsangehörigen; 2) jüdischen Mischlingen niederländischer Staatsangehörigkeit, die nur einen volljüdischen Grosselternteil haben, geschlossen ist, kann innerhalb eines Jahres nach diesem Zeitpunkt auf Klage eines Ehegatten für nichtig erklärt werden. [...]'

593 C. Stuldreher, De Legale Rest, 368.

594 Letter from Ministerialrat to Wimmer, Ju 12-1309/42, (18 April 1944), NIOD archives, access no. 020, inventory no. 2413 'Im Absatz 2 dieses Paragraphen ( $(5-\mathrm{ML}$ ) ist auch eine Anfechtungsmöglichkiet für solche Ehen vorgesehen, die vor dem Inkrafttreten dieser Verordnung zwischen Juden und Nichtjuden oder zwischen Juden und bestimmten jüdischen Mischlingen geschlossen worden sind.'

595 Letter from Ministerialrat to Wimmer, Ju 12-1309/42, (10 May 1944), NIOD archives, access no. 020, inventory no. 2413.

596 Verordnung des Reichskommissars für die besetzten niederländischen Gebiete über das Verbot der Eheschließung und des außerehelichen Verkehrs mit Juden, May 1944, NIOD archives, access no. 020, inventory no. 2413.

597 Verordnung des Reichskommissars für die besetzten niederländischen Gebiete über das Verbot der Eheschließung und des außerehelichen Verkehrs mit Juden, May 1944, NIOD archives, access no. 020, inventory no. 2413, § 4: 'Außerehelicher Verkehr zwischen Juden und nichtjüdischen Niederländer ist verboten. Ebenso ist der außereheliche Verkehr zwischen Juden und vierteljüdischen Niederländer verboten.'

598 Verordnung des Reichskommissar für die besetzten niederländischen Gebiete über das Verbot der Eheschliessung und des ausserehelichen Geschlechtsverkehrs mit Personen jüdischen Blutes, Erste Fassung, 3 August 1944, NIOD archives, access no. 020 , inventory no. 2413 and 1507 
only marginally from the previous draft, although the wording had become slightly cumbersome. However, $\mathbb{S}$ I now also explicitly prohibited marriages between Dutch non-Jews or Dutch quarter-Jews and foreign Jews. ${ }^{599}$ Furthermore, $\mathbb{S} 5(2)$ now clearly stated that mixed marriages concluded before this regulation had come into force could be declared void upon request within a year after this regulation had come into force. ${ }^{600}$

None of the above mentioned drafts have been enacted.

On 8 August 1944 the Abteilung Rechtssetzung sent a message from SS-Sturmbannführer (major) Wilhelm Zöpf about a final draft, formulated by department IV B 4 to the Hauptabteilung Justiz. ${ }^{601}$ This message from Zöpf, which ran to 25 pages, contained this final draft, explanatory remarks and some thoughts considering the content of the draft.

In his memorandum Zöpf again stressed the necessity of legislation especially since Jews were apparently trying to escape the harsh provisions issued by the occupants by entering into a mixed marriage. ${ }^{602}$ Although in August 1944 the majority of the Dutch Jews had already been transported from the Netherlands, the risk of cross-breeding remained, since there was still a significant number of hidden Jews living in the Netherlands (Zöpf estimated the number at a several thousand) as well as several thousands mixed married Jews, about I5,000 half-Jews and some 5000 quarter-Jews. ${ }^{603}$ Further procreation of half-breeds had to be avoided. Zöpf distinguished four ways to achieve this: I) a general prohibition of further contracting mixed marriages; 2 ) diminished divorce conditions in case of existing mixed marriages; 3 ) a general prohibition of mixed extramarital intercourse; and 4) impediments to beget half-breeds. ${ }^{604}$

Zöpf again distinguished between marriages which should be prohibited absolutely (between Jews and Aryans or quarter-Jews and between half-Jews and Aryans) and those which would only be allowed after approbation (between half-Jews among themselves, quarter-Jews among themselves and between half-Jews and quarter-Jews). This approbation should only be granted when proof of infertility could be produced. Zöpf expressed the hope that this provision would invite Jews to have oneself sterilised and because of this, marriages between half-breeds should not be prohibited unconditionally. Furthermore, Zöpf endorsed to the viewpoint that marriages between Jews and half-Jews should by all means be allowed, as this would solve the problem of the priviliged position of the half-Jew. Marriages between quarter-Jews and Aryans could not be prohibited by

599 Verordnung des Reichskommissar für die besetzten niederländischen Gebiete über das Verbot der Eheschliessung und des ausserehelichen Geschlechtsverkehrs mit Personen jüdischen Blutes, Erste Fassung, 3 August 1944, NIOD archives, access no. 020, inventory no. 2413 and 1507, § 1 (2): 'Ein Niederländer, der Nichtjude oder Vierteljude ist, und ein Jude, der nicht Niederländer ist, dürfen die Ehe nicht miteinander eingehen.'

600 Verordnung des Reichskommissar für die besetzten niederländischen Gebiete über das Verbot der Eheschliessung und des ausserehelichen Geschlechtsverkehrs mit Personen jüdischen Blutes, Erste Fassung, 3 August 1944, NIOD archives, access no. 020, inventory no. 2413 and 1507, § 5(2): 'Jeder der Ehegatten kann innerhalb eines Jahres nach dem Inkrafttreten dieser Verordnung verlangen, dass ihr Ehe für nichtig erklärt wird, wenn sie zwischen einem Niederländer, der Nichtjude oder Vierteljude ist, und einem Juden besteht und sie vor dem Inkrafttreten dieser Verordnung eingegangen worden ist.

601 Letter from Abteilung Rechtssetzung to Hauptabteilung Justiz, Ve 1-I 22/44, (8 August 1944), NIOD archives, access no. 020, inventory no. 2413.

602 W. Zöpf, Erlass eines Blutschutzgesetzes in den Niederlanden, 2, NIOD archives, access no. 020, inventory no. 2413.

603 W. Zöpf, Erlass eines Blutschutzgesetzes in den Niederlanden, 2-3, NIOD archives, access no. 020, inventory no. 2413.

604 W. Zöpf, Erlass eines Blutschutzgesetzes in den Niederlanden, 4, NIOD archives, access no. 020, inventory no. 2413. 
Dutch legislation as the Nuremberg Laws did not include the term Achteljuden, ${ }^{605}$ as was already pointed out by Wimmer in a letter to Fischböck in I942. ${ }^{606}$ Zöpf's memorandum furthermore contained a detailed description of what actions a registrar had to undertake in case of announcement of a prohibited mixed marriage. ${ }^{607}$ Marriages which were contracted despite the prohibition were declared void. This article $\left(\mathbb{S}_{3}\right)$ was fully in line with the articles in earlier drafts. ${ }^{608}$ According to Zöpf exceptional provisions, like in the drafts formulated by the Abteilung Rechtssetzung ('Der Reichskommissar für die besetzten niederländischen Gebiete kann Befreiung von den Vorschriften dieser Verordnung erteilen.' ${ }^{609}$ were unneccessary from a legal point of view as $\mathbb{S}$ I (3) already allowed for exceptions (as marriages between half-Jews and quarter-Jews among themselves and with each other were strictly speaking allowed, albeit only after approbation) and inefficient from a political point of view as it was to be expected that in case of possible exceptions all Jews would try to find loop-holes with all one's might. This would put a serious strain on the German administration and was considered a complete waste of time. No exceptions therefore, at least not in the regulation itself, although the possibility to come up with exceptional provisions in the internal circulars was left open. ${ }^{610}$

According to Zöpf the possibility of dissolution of mixed marriages by means of divorce was considered in Germany for years already. However, a regulation enabling compulsory divorces by authority of the state, was not to be expected short-term. Nevertheless, the possibility to somehow dissolve mixed marriages had to be created, especially when the Jewish partner had been carried away for a while already. Therefore Zöpf proposed $\mathbb{S}$, stating that a marriage, contracted before commencement of this regulation, between a Jew and a non-Jew or quarter-Jew could be declared void at the request of one of the spouses. ${ }^{611}$ Contrary to Wimmer's draft from April I944, ${ }^{612}$ this article did not contain the requirement of doing so within one year. Zöpf considered this unneccessary as mixed marriages were effectively already prohibited for two years. ${ }^{613}$

With regard to a prohibition of mixed extramarital intercourse, Zöpf considered the Nuremberg Laws too lenient, as they only prohibited extramarital intercourse between

605 W. Zöpf, Erlass eines Blutschutzgesetzes in den Niederlanden, 5-6, NIOD archives, access no. 020, inventory no. 2413.

606 Letter from Wimmer to Fischböck, Ve St-1742/42, (29 September 1942), NIOD archives, access no. 020, inventory no. 286. 607 W. Zöpf, Erlass eines Blutschutzgesetzes in den Niederlanden, 7-8, NIOD archives, access no. 020, inventory no. 2413.

608 W. Zöpf, Erlass eines Blutschutzgesetzes in den Niederlanden, 9, NIOD archives, access no. 020, inventory no. 2413.

609 Verordnung des Reichskommissars für die besetzten niederländischen Gebiete über das Verbot der Eheschliessung und des ausserehelichen Verkehrs mit Juden, April 1944, NIOD archives, access no. 020, inventory no. 2413 and 1507, § 8; Verordnung des Reichskommissars für die besetzten niederländischen Gebiete über das Verbot der Eheschließung und des außerehelichen Verkehrs mit Juden, May 1944, NIOD archives, access no. 020, inventory no. 2413, § 6 and Verordnung des Reichskommissar für die besetzten niederländischen Gebiete über das Verbot der Eheschliessung und des ausserehelichen Geschlechtsverkehrs mit Personen jüdischen Blutes, Erste Fassung, 3 August 1944, NIOD archives, access no. 020, inventory no. 2413 and 1507, § 9.

610 W. Zöpf, Erlass eines Blutschutzgesetzes in den Niederlanden, 14, NIOD archives, access no. 020, inventory no. 2413.

611 W. Zöpf, Erlass eines Blutschutzgesetzes in den Niederlanden, 10, NIOD archives, access no. 020, inventory no. 2413, § 4 (1): 'Eine Ehe, die vor dem Inkrafttreten dieser Verordnung zwischen einem Juden und einem Nichtjuden oder einem jüdischen Mischling II. Grades geschlossen ist, kann auf Klage eines Ehegatten für nichtig erklärt werden.'

612 Verordnung des Reichskommissars für die besetzten niederländischen Gebiete über das Verbot der Eheschliessung und des ausserehelichen Verkehrs mit Juden, April 1944, NIOD archives, access no. 020, inventory no. 2413 and 1507.

613 W. Zöpf, Erlass eines Blutschutzgesetzes in den Niederlanden, 10, NIOD archives, access no. 020, inventory no. 2413. 
Jews and Aryans ${ }^{614}$ and between Jews and quarter-Jews. ${ }^{615}$ Such a provision would only have the intended result, i.e. prevention of cross-breeding, if the prohibition would extend to the same categories as the marriage prohibition. The fact that the Netherlands would then have more strict legislation in this respect than Germany did not matter according to Zöpf. It would not be the first time the occupying forces in the Netherlands would be ahead of Germany and in Germany the Sicherheitspolizei could interfere earlier. ${ }^{616}$ Therefore $\$ 5$ read: 'The prohibition of extramarital intercourse has the same scope as determined in $\mathbb{S}$ I for contraction of marriages. ${ }^{617}$ However, $\mathbb{S}$ I distinguished between relationships between Jews and non-Jews or quarter-Jews and half-Jews with Aryans, which were absolutely prohibited and between half-Jews and quarter-Jews among themselves and with each other, which could be allowed after approbation. It is unclear whether this distinction had to be made with regard to extramarital intercourse as well.

As actual begetting of half-bloods could not always be prevented, Zöpf considered it necessary to make $\rrbracket_{5}(2)$ of the First Supplementary Decree to the Reich Citizenship Law applicable in the Netherlands as well. This article stated that half-breeds with two full-Jewish grandparents (technically being half-Jewish) would count as full-Jewish in case (among other things) this person a) was born in a marriage between a non-Jew and a Jew, contracted after the Blood Protection Law had come into force or b) was born after 31 July 1936 from an extramarital relationship between a non-Jew and a Jew. ${ }^{618}$ By treating the half-blood offspring as full-Jews the Nazis hoped to dissuade Aryans from procreating with Jews. The son shall bear the iniquity of the father after all. ${ }^{619}$ According to Zöpf both future children begetted in a mixed extramarital relationship and in an already existing mixed marriage and born after a certain date, had to be regarded as Jews, as apparently 'little half-Jews' were brought into the world rashly, probably in hopes of certain privileges for large mixed families. A possible reference date suggested by Zöpf was 28 February $1925 .{ }^{620}$

As had happened to all previous drafts, this draft was not enacted either.

By the end of the occupation in May 1945 no final legislative measures with regard to the prohibition of mixed marriages and mixed extramarital intercourse had been enacted. It is not completely clear why exactly, although it is plausible that the preparation of such

614 Gesetz zum Schutze des deutschen Blutes und der deutschen Ehre vom 15. September 1935, Reichsgesetzblatt (1935), I, 1146, § 2: 'Außerehelicher Verkehr zwischen Juden und Staatsangehöriger deutschen oder artverwandten Blutes ist verboten.' 615 Erste Verordnung zur Ausführung des Gesetzes zum Schutze des deutschen Blutes und der deutschen Ehre vom 14. November 1935, Reichsgesetzblatt (1935), I, 1334, § 11: '[...] Strafbar nach § 5 Abs. 2 des Gesetzes [a man violating the prohibition laid down in $\S 2$ will be punished with imprisonment or detention in a house of correction - ML] ist auch der außereheliche Verkehr zwischen Juden und staatsangehörigen jüdischen Mischlingen, die nur einen volljüdischen Großelternteil haben.'

616 W. Zöpf, Erlass eines Blutschutzgesetzes in den Niederlanden, 11-12, NIOD archives, access no. 020, inventory no. 2413.

617 W. Zöpf, Erlass eines Blutschutzgesetzes in den Niederlanden, 12, NIOD archives, access no. 020, inventory no. 2413, § 5: 'Das Verbot des ausserehelichen Verkehrs besteht im gleichen Umfange, wie es für Eheschliessungen im $\S 1$ festgesetzt ist.'

618 Erste Verordnung zum Reichsbürgergesetz vom 14. November 1935, Reichsgesetzblatt (1935), I, 1333, § 5 (2): 'Als Jude gilt auch der von zwei volljüdischen Großeltern abstammende staatsangehörige jüdische Mischling, [...] c) der aus einer Ehe mit einem Juden im Sinne des Absatzes 1 [a person is Jewish when having three or four full-Jewish grandparents - ML] stammt, die nach dem Inkrafttreten des Gesetzes zum Schutze des deutschen Blutes und der deutschen Ehre vom 15. September 1935 (Reichsgesetzbl. I S. 1146) geschlossen ist, d) der aus dem außerehelichen Verkehr mit einem Juden im Sinne des Absatzes 1 stammt und nach dem 31 . Juli 1936 außerehelich geboren wird.'

619 Ezekiel 18:20.

620 W. Zöpf, Erlass eines Blutschutzgesetzes in den Niederlanden, 13, NIOD archives, access no. 020, inventory no. 2413. 
measures was not yet finished when other developments (like advancing Allied troops) compelled attention, a premise Stuldreher endorses to. ${ }^{621}$

\section{- 4.3.4. The problem of existing mixed marriages}

Prohibiting future mixed marriages did not solve the problem of the already existing mixed marriages, ${ }^{622}$ something about which the occupant did not know what way to turn. They have struggled to come up with a watertight solution, which was hampered by the lack of unanimity within the National Socialist party itself. ${ }^{623}$

\subsubsection{The privileged mixed marriage}

In Germany the mixed married were protected by the so-called privilegierte Mischehe (privileged mixed marriage), although it has been under discussion frequently. ${ }^{624}$ Those who were protected by the 'privileged mixed marriage' did not have to wear the Star of David and did not face immediate deportation, amongst other things. Only mixed marriages with children and childless mixed marriages in which the woman was Jewish were privileged. Jewish men in a childless mixed marriage were treated as regular fullJews, but were nevertheless exempted from deportation. ${ }^{625}$

In the Netherlands Calmeyer has pleaded for the introduction of the privilegierte Mischehe, but although Seyss-Inquart was not fundamentally against this, it has never been formally adopted. When the matter was brought up in May 1942 because of the upcoming deportations, Calmeyer referred to Germany and Belgium where this concept had been adopted with regard to a mandatory membership of a Jewish association of which obligation the mixed married were exempted. According to Calmeyer adoption of the concept of privileged mixed marriages would annul a possible unfavourable psychological effect, caused by the introduction of the Star of David, on Dutch who were favourable to the German cause. ${ }^{626}$ Therefore Calmeyer suggested to issue an implementing order adopting the privileged mixed marriage and to take this position into account when issuing future regulations with regard to any topic. ${ }^{627}$ An incomplete report

621 C. Stuldreher, De Legale Rest, 374.

622 Initially, the number of mixed marriages was estimated at 18,886 , a number which was way too high. This incorrect estimate was caused by confusion with regard to the registration form on which several people had answered question $8 \mathrm{a}$ to $8 \mathrm{~d}$ incorrectly. A more realistic estimate was 9500 mixed marriages of which approximately 1100 considered childless marriages of a Jewess to a non-Jewish husband and around 1500 childless marriages between a Jew and a non-Jewish wife. The number of mixed marriages with children could therefore be put around 6900. See for an explanation of these numbers a letter from the Rijksinspectie van de Bevolkingsregisters (National Inspectorate of Registers) to Calmeyer (27 November 1942), NIOD archives, access no. 020, inventory no. 1507. In a letter to Wimmer Calmeyer gave more exact numbers: 6008 mixed marriages with children and 928 childless marriages between a Jewess and a non-Jew. See letter from Calmeyer to Wimmer (27 November 1942), NIOD archives, access no. 020, inventory no. 1507.

623 L. de Jong, Het Koninkrijk der Nederlanden in de Tweede Wereldoorlog, 7:393; J. Presser, Ondergang (deel 2), 87.

624 See C. Stuldreher, De Legale Rest, 149. At the notorious Wannsee Conference of 20 January 1942 one tried to come up with additional rules with regard to mixed marriages, such as separation of both partners thereby deporting the Jewish partner or accomodating him or her in a so-called Altersghetto (ghetto for elder people), forced sterilisation or forced divorce, although no final decisions were taken with regard to this subject. See also the Besprechungsprotokoll der Wannsee-Konferenz, published in K. Pätzhold and E. Schwarz, Tagesordnung: Judenmord, 102-112, 110. See L. de Jong, Het Koninkrijk der Nederlanden in de Tweede Wereldoorlog, 5:979-980. Despite repeated requests from the quibblers there, Hitler did not want to end this privileged position during the war, as this would cause too much of a stir amongst the families of the non-Jewish marriage partners.

625 C. Stuldreher, De Legale Rest, 122-124, 229; L. de Jong, Het Koninkrijk der Nederlanden in de Tweede Wereldoorlog, 6:278.

626 Vorlage zur Besprechung beim Herrn Reichsminister am 8.5.42 (7 May 1942), 2, NIOD archives, access no. 020, inventory no. 1507.

627 Ibid., 3. 
from a meeting with Seyss-Inquart on 8 May 1942 tells us that the privileged mixed marriage would be recognised in the Netherlands for German nationals. ${ }^{628}$ The question whether or not the privileged mixed marriage would also be adopted for Dutch citizens would be put to Reichsleiter (Reich or National Leader) Martin Bormann, head of the Parteikanzlei (Party Chancellery) and Obergruppenführer (general) Reinhard Heydrich, head of the Reichssicherheitshauptamt (Reich Main Security Office) in Berlin. The report stated that Seyss-Inquart was inclined to adopt the privileged mixed marriage for Dutch citizens in the Netherlands, if both Reich institutions considered a uniform regulation in Germany and the Netherlands desirable. The readiness of Belgium and France to adopt the privileged mixed marriage and to what extent had to be taken into account in this respect. ${ }^{629}$ In case Bormann and Heydrich would give a positive advice, the privileged mixed marriage should not only entail exemption from the Star of David, but also from other measures against Jews. Adoption would occur by means of an implementing order by the Generalkommissar für das Sicherheitswesen and a note on the identity card of the privileged person. ${ }^{630}$ This implementing order, however, has never been issued. ${ }^{631}$ Letters were sent back and forth between several departments. ${ }^{632}$ On 30 June 1942 Calmeyer noted $^{633}$ that in Belgium and northern France the privileged mixed marriage was adopted in an order implementing the regulation on the Star of David of 27 May 1942. ${ }^{634}$ According to Calmeyer, the Netherlands could not be tardy. ${ }^{635}$ He repeated this appeal on 8 July I942, and tried to hurry Seyss-Inquart along by emphasising that the planned deportations to Eastern Europe were about to start in a week. ${ }^{636}$ He furthermore pointed out that an implementing order with regard to the privileged mixed marriage could go hand in hand with a regulation prohibiting future mixed marriages, ${ }^{637}$ which has never been issued, as we have already seen. According to Stuldreher it is likely that Berlin has never responded to the request for permission to adopt the privileged mixed marriage in the Netherlands. ${ }^{638}$

On 26 June 1942 the Jewish Council was informed that men, women and families would be deported to labour camps in Germany, where they would be set to work under the supervision of the German police. On 7 July Cohen was informed by Aus der Fünten that mixed married and half-Jews were exempted from this forced employment, although one had to report oneself to the Zentralstelle für jüdische Auswanderung in case one received

628 Abteilung Innere Verwaltung, Judenstern und Reform der Ausnahmebehandlung von Juden (8 May 1942), 1, NIOD archives, access no. 020, inventory no. 1507. See also C. Stuldreher, De Legale Rest, 174

629 Ibid., 1-2. See also C. Stuldreher, De Legale Rest, 173.

630 Abteilung Innere Verwaltung, Judenstern und Reform der Ausnahmebehandlung von Juden (8 May 1942), 2, NIOD archives, access no. 020, inventory no. 1507. See also C. Stuldreher, De Legale Rest, 173-174.

631 C. Stuldreher, De Legale Rest, 175.

632 See e.g. Letter from Calmeyer to Generalkommissariat zur besondere Verwendung (Thiele) (12 May 1942), NIOD archives, access no. 020, inventory no. 1507.

633 Vermerk zur Frage der priviligierten Mischehe. Stand des Problems am 30.6.42 (30 June 1942), NIOD archives, access no. 020, inventory no. 1507.

634 Verordnung zur Durchführung der Verordnung über die Kennzeichnung von Juden vom 27. Mai 1942, Verordnungsblatt des Militärbefehlshabers in Belgien und Nordfrankreich für die besetzten Gebiete Belgiens und Nordfrankreichs (1942), 945.

635 Vermerk zur Frage der priviligierten Mischehe. Stand des Problems am 30.6.42 (30 June 1942), NIOD archives, access no. 020, inventory no. 1507.

636 Letter to the Reichskommissar about the 'Privilegierung der jüdischen Mischehe' (8 July 1942), NIOD archives, access no. 020, inventory no. 1507.

637 Ibid.

638 C. Stuldreher, De Legale Rest, 179. Heydrich was severely wounded in an assault on his life on 27 May 1942. He died from his injuries on 4 June 1942. See L. de Jong, Het Koninkrijk der Nederlanden in de Tweede Wereldoorlog, 5:1034. 
notice. ${ }^{639}$ On I2 September I942, two months after the Jewish Council was informed about the upcoming forced employment in Eastern Europe a formal announcement was published which stated that in order to qualify for exemption from employment the following groups had to file a request: a) Jews and Jewesses with children from a current or previous marriage to a non-Jew, who were not considered Jews and b) Jewesses still married to a non-Jew. ${ }^{640}$ However, although exemptions would be made based on the marital status of a person, it was not to be called 'privileged mixed marriage'. Officially, the request was limited to a temporary exemption from forced employment. ${ }^{641}$

On I3 October I942 a meeting took place during which the position of the mixed married was discussed. Generalkommissar zur besonderen Verwendung Fritz Schmidt indicated that both groups who were summoned to register on I2 September I942 should be granted permanent protection. Furthermore, a regulation confirming this privileged status had to be issued. ${ }^{642}$ However, on I6 October 1942 Generalkommissar für das Sicherheitswesen Rauter decided that childless Jewesses married to a non-Jew had to be deported as well, with the exception of those who were already pregnant at I2 September ${ }^{643}$ (this concerned I4I women). ${ }^{644}$ Because of this decision the deportation regime in the Netherlands was more stringent than in Germany, where both childless women and men were exempted from deportation.

From a note in pencil from Calmeyer it appears that all attempts to issue a regulation adopting the privileged mixed marriage in the Netherlands were suspended on 25 November 1942. ${ }^{645}$ The Zentralstelle nevertheless continued to distribute the so-called Zurückstellungs-stamp to mixed married Jews. In February I 9435080 mixed married Jews with children had received such a stamp. ${ }^{646}$

In the end the mixed married have not entirely escaped deportation, although those who were deported in many instances concerned 'criminal cases' - criminal in the sense that they had offered help to Jews. The majority of the mixed married Jews who were arrested and brought to Westerbork or Vught have been released for one reason or another. Stuldreher comes to a minimum number of 2059 mixed married Jews who have been arrested and brought to Westerbork or Vught. At least 763 persons have been deported to Auschwitz, Sobibor and Theresienstadt. ${ }^{647}$ During the occupation I093 mixed married Jews were released, 203 were still in Westerbork or Vught at the time of the liberation of the Netherlands. Most likely they were all 'criminal cases', arrested during the last six months of the occupation. ${ }^{648}$

639 C. Stuldreher, De Legale Rest, 184

640 Nieuwe Rotterdamsche Courant, 12 September 1942, ‘Tewerkstelling van Joden'. See also C. Stuldreher, De Legale Rest, 223. 641 C. Stuldreher, De Legale Rest, 226.

642 Sortierung der Juden und Rechtsstellung aussortierter Juden, report from meeting of 13 October 1942, NIOD archives, access no. 020, inventory no. 1507.

643 C. Stuldreher, De Legale Rest, 229.

644 Sortierung der Juden und Rechtsstellung aussortierter Juden, report from meeting of 13 October 1942, NIOD archives, access no. 020 , inventory no. 1507.

645 See note in pencil written on a letter from Abteilung Rechtssetzung to Calmeyer (23 November 1942), NIOD archives, access no. 020, inventory no. 1507. Calmeyer writes: 'Dr. Wimmer am 25.11.42 1) Besprechung mit Stuckart ergibt dass im Reich Änderung möglich. Deshalb: 2) Zunächst jede Förderung einstellen.'

646 C. Stuldreher, De Legale Rest, 233.

647 C. Stuldreher, De Legale Rest, 242, 398.

648 C. Stuldreher, De Legale Rest, 398. 


\subsubsection{Sterilisation of mixed married Jews}

Although relatively few mixed married have been deported, about one third of the mixed married has nevertheless been arrested during the course of the war. As we have seen, a considerable part has been released before the occupation had ended. This release was related to another solution with regard to the problem of the existing mixed marriages the occupant had come up with: 'voluntary' sterilisation. ${ }^{649}$

Forced sterilisation had already been suggested at the Wannsee Conference, although one observed that this would entail a lot of work and bureaucratic problems. ${ }^{650}$ Nine months after the Wannsee Conference Seyss-Inquart decided that all mixed married Jewish men ${ }^{651}$ with children had to be sterilised, as had all mixed married Jewish women ${ }^{652}$ under the age of 45 . Mixed married Jewish women over the age of 45 would be 'de-stard' without sterilisation. Men and women who refused to have themselves sterilised would be deported. ${ }^{653}$ In May 1943 it was decided that women over the age of 45 should not automatically be 'de-stard', but should be put through a medical examination first as the mere age of 45 did not guarantee sterility. Both mixed married Jewish men and women had to be brought to Westerbork, where they would be given the choice: 'voluntary' sterilisation or deportation to Eastern Europe. ${ }^{654}$

On I4 May I943, a few days before this decision was taken, Aus der Fünten had called for a meeting with all mixed married Jews with children in Westerbork. They were given the choice: sterilisation or deportation. Those who would opt for sterilisation would be brought to Amsterdam the same night, the others would be deported with the next transport to Eastern Europe on I8 May I943. The I03 persons present were given 30 minutes to reflect: 52 persons refused sterilisation, ${ }^{655}$ the other $5 \mathrm{I}$ accepted and were brought to Amsterdam the same night. ${ }^{656}$ Whether or not they were indeed sterilised remains uncertain; De Jong claims that they were, ${ }^{657}$ which is questioned by Presser. ${ }^{658}$ In reaction to this incidence in Westerbork, the Dutch denominations sent a letter of

649 Ibid.

650 See the Besprechungsprotokoll der Wannsee-Konferenz, published in K. Pätzhold and E. Schwarz, Tagesordnung: Judenmord, $102-112,111$.

6513984 registrations, see C. Stuldreher, De Legale Rest, 278.

6523969 registrations, see C. Stuldreher, De Legale Rest, 278.

653 Besides the mixed married one also discussed the possible sterilisation of half-Jews, who, in case of refusal, should be treated as full-Jews and subsequently be deported. However, in Germany half-Jews were not equated with full-Jews as we have seen, although according to the RSHA a change of policy was to be expected. This has not happened, as we have seen as well, and the above mentioned policy has subsequently never been implemented in the Netherlands either. See C. Stuldreher, De Legale Rest, 278-279.

654 C. Stuldreher, De Legale Rest, 277-283; L. de Jong, Het Koninkrijk der Nederlanden in de Tweede Wereldoorlog, 7: 274276; J. Presser, Ondergang (deel 1), 357-358; A.J. Herzberg, 'Kroniek der Jodenvervolging', in J.J. van Bolhuis et al. (eds.), Onderdrukking en Verzet. Nederland in Oorlogstijd (deel 3), 129. See also the minutes of a meeting at the Zentralstelle für jüdische Auswanderung in Amsterdam on 18 May 1943, NIOD archives, access no. 077, inventory no. 1317 and a memorandum about medical decisions concerning sterilisations, 18 May 1943, NIOD archives, access no. 077, inventory no. 1317.

655 The non-Jewish wife of one of the men present (and who refused sterilization) informed Zöpf, head of the Zentralstelle für jüdische Auswanderung, at his home address. Zöpf, who apparently had been unaware of what had happened in Westerbork, intervened by telephone and the 52 refusers were not deported the following Tuesday. See J. Presser, Ondergang (deel 1), 362-363. Stuldreher however, states that Albert Konrad Gemmeker, camp commander of Westerbork, has declared after the war that Aus der Fünten had come to Westerbork by order of Zöpf, who had informed Gemmeker about the visit by telephone beforehand. See C. Stuldreher, De Legale Rest, 283.

656 L. de Jong, Het Koninkrijk der Nederlanden in de Tweede Wereldoorlog, 7:277-278; J. Presser, Ondergang (deel 1), 362-363; C. Stuldreher, De Legale Rest, 283-284.

657 L. de Jong, Het Koninkrijk der Nederlanden in de Tweede Wereldoorlog, 7:282, 284.

658 J. Presser, Ondergang (deel 1), 363. 
protest to Seyss-Inquart, ${ }^{659}$ which Herzberg calls 'the most beautiful Dutch ever written in German. ${ }^{660}$ In a reaction on 2I June 1943 Seyss-Inquart informed the denominations that the sterilisations were carried out on a voluntary basis and all protests with regard to this had to be addressed to Rauter. ${ }^{661}$

The Jewish Council was informed about the new policy by Aus der Fünten on I9 May I943. ${ }^{662}$ The minutes of the meeting of the Jewish Council of 20 May 1943 report that Cohen and Asscher have protested strongly against this policy, which however was justified by Aus der Fünten because of its 'voluntary' nature. ${ }^{663}$ Notwithstanding the protests within the Council, the Jewish Council decided to render administrative assistance due to the fact that it concerned 'voluntary' sterilisations and not forced. ${ }^{664}$

On 25 June 1943 it was decided that the posibility of 'de-starring' through sterilisation would also be adopted for childless mixed married Jews, men and women, as the purpose of sterilisation was preventing (further) procreation of the mixed married, making them more 'harmless' (weniger gefährlich) ${ }^{665}$ During the summer of 1943 many mixed married were released from Westerbork, as one considered it best to let people decide about a possible sterilisation when being in a trusted environment, ${ }^{666}$ undoubtly expecting more mixed married Jews to sign up for sterilisation. According to Rauter around 2500 mixed married Jews have been 'de-stard', the majority of the I 46 men because of sterilisation, the majority of the I4I 6 women because of infertility due to age ${ }^{667}$ However, wearing a star has not made any difference with regard to deportation, as only 'criminal cases' have been deported. ${ }^{668}$

It is unclear how many people have actually been sterilised. According to the German Sicherheitsdienst by 22 November 1943442 men and I9 women were sterilised. ${ }^{669}$ The majority of the medical administration has been destroyed and since the beginning of I944 the German police did no longer differentiate between people who were proven infertile by a medical check and those who had actually been sterilised. ${ }^{670}$ Stokvis states that the numbers Rauter quoted in June I 944 are incorrect. According to Stokvis a maximum of 100 men has been surgically attended and only io women. ${ }^{671}$ It is unclear on what data Stokvis has based these assumptions. It is known that some physicians have tried to grant a declaration of infertility without actual sterilisation. Sometimes an

659 The letter was originally written in German. A Dutch translation of this letter is published in F. Kleijn et al. (eds.), 'Het verzet der kerken - bijlagen', in J.J. van Bolhuis et al. (eds.), Onderdrukking en Verzet. Nederland in Oorlogstijd (deel 2), 467.

660 A.J. Herzberg, 'Kroniek der Jodenvervolging', in J.J. van Bolhuis et al. (eds.), Onderdrukking en Verzet. Nederland in Oorlogstijd (deel 3), 129.

661 L. de Jong, Het Koninkrijk der Nederlanden in de Tweede Wereldoorlog, 7:279.

662 C. Stuldreher, De Legale Rest, 287; L. de Jong, Het Koninkrijk der Nederlanden in de Tweede Wereldoorlog, 7:281.

663 Minutes of the meeting of the Jewish Council of 20 May 1943, NIOD archives, access no. 182, inventory no. 1c.

664 C. Stuldreher, De Legale Rest, 288; L. de Jong, Het Koninkrijk der Nederlanden in de Tweede Wereldoorlog, 7:282.

665 C. Stuldreher, De Legale Rest, 291.

666 Ibid., 282.

667 Ibid., 293. These figures (2562 'de-stard', 1146 men, 1416 women) are from 15 June 1944. Stokvis states that Abteilung IV B 4 notified him on 21 June 1944 that the sterilisation programme had been stopped. This was confirmed on 4 July 1944 by Sturmscharführer (warrant-officer) Fischer. See B. Stokvis, Advocaat in bezettingstijd, 27.

668 A.J. Herzberg, 'Kroniek der Jodenvervolging', in J.J. van Bolhuis et al. (eds.), Onderdrukking en Verzet. Nederland in Oorlogstijd (deel 3), 128; C. Stuldreher, De Legale Rest, 294.

669 C. Stuldreher, De Legale Rest, 292; L. de Jong, Het Koninkrijk der Nederlanden in de Tweede Wereldoorlog, 7:285, 392.

670 C. Stuldreher, De Legale Rest, 305.

671 B. Stokvis, Advocaat in bezettingstijd, 17-18. 
unparalleled medical clarification was given in order to achieve this. ${ }^{672} \mathrm{M} . \mathrm{N}$. Roegholt invented a trick whereby sperm was drawn off by pressing the prostate. This sperm was collected in a bowl, which was cold. The sperm in the bowl was left to rest a while before it was examined microscopically, only to conclude that there was no life. Subsequently, the man concerned received a certificate of sterility. Roegholt estimates that at least 800 to Iooo men have been 'de-stard' by this method. ${ }^{673}$ However, Stuldreher deems this number too high. ${ }^{674}$ According to Herzberg around 600 men have been sterilised, but again, it is unclear based on what data this assumption is made. ${ }^{675}$ Stuldreher considers the numbers given by the German Sicherheitsdienst correct, although De Jong notes that even from these numbers it uncertain how many were actually sterilised. ${ }^{676}$ However, the numbers of 22 November 1943 are last numbers known. ${ }^{677}$ In February 1944 it was decided that certificates of infertility were no longer accepted for men under the age of 70 and for women under the age of $60 .{ }^{678}$ Although Zöpf tried to achieve that all 'de-stard' Jews would be re-checked in Westerbork in the summer of I944, to see whether they had indeed been sterilised, this re-check has never taken place. ${ }^{679}$ In the end the sterilisation programme petered out like a damp squib. It has nevertheless caused disturbance amongst the mixed married Jews and the number of people who have actually been sterilised should not be ignored. Furthermore, it pays to realise that the Netherlands was the only occupied country where the Nazis have proceeded with actually sterilising mixed married Jews. ${ }^{680}$ Occupied Netherlands has therefore been the proving ground for quibblers like Rauter and, in Berlin, Himmler, who, as Goebbels, wanted to make Berlin Judenfrei-Judenrein. ${ }^{681}$

\subsubsection{Divorce}

Apart from trying to grant the mixed married Jews a separate status, either by adopting the concept of the privileged mixed marriage or by 'de-starring' mixed married Jews after sterilisation, one has also tried to convince the Aryan partners to file for divorce. After all, after a divorce was granted, the Jewish (ex-)partner was no longer mixed married and could therefore be treated as a regular full-Jew, saving the occupants a lot of headaches. Aryans have therefore continuously been pressured to file for divorce. ${ }^{62}$ De Jong describes a case in which a mixed married Jewish man (who had even been sterilised) was

672 Ibid., 18, 28. Stokvis mentions the following physicians: M.N. Roegholt, M.A. van Bouwdijk Bastiaanse, P.R. Michaël, J. Hazewinkel, H.S. Boogaart, J.R. Prakken, W.P. Plate, L.P.H.J. de Vink, L.I. Swaab, J.F. Schutte, and F.C. van Tongeren. See also C. Stuldreher, De Legale Rest, 300-301; L. de Jong, Het Koninkrijk der Nederlanden in de Tweede Wereldoorlog, 7:284-285.

673 M.N. Roegholt, 'Over het ster-vrij maken van onze gemengd gehuwde Joodsche landgenooten', 318-319. See also C. Stuldreher, De Legale Rest, 301-302; L. de Jong, Het Koninkrijk der Nederlanden in de Tweede Wereldoorlog, 7:285.

674 C. Stuldreher, De Legale Rest, 305-306.

675 A.J. Herzberg, 'Kroniek der Jodenvervolging', in J.J. van Bolhuis et al. (eds.), Onderdrukking en Verzet. Nederland in Oorlogstijd (deel 3), 130.

676 L. de Jong, Het Koninkrijk der Nederlanden in de Tweede Wereldoorlog, 7:285.

677 C. Stuldreher, De Legale Rest, 305.

678 L. de Jong, Het Koninkrijk der Nederlanden in de Tweede Wereldoorlog, 7:392-393.

679 Ibid., 7:394.

680 Ibid., 7:275.

681 C. Stuldreher, De Legale Rest, 279.

682 A.J. Herzberg, 'Kroniek der Jodenvervolging', in J.J. van Bolhuis et al. (eds.), Onderdrukking en Verzet. Nederland in Oorlogstijd (deel 3), 127; F. Kleijn, 'De Samenwerking der Kerken', in J.J. van Bolhuis et al. (eds.), Onderdrukking en Verzet. Nederland in Oorlogstijd (deel 2), 402. 
arrested. When his Aryan wife applied to Sturmscharführer (sergeant major) Fischer, she was told she would be granted 6o Dutch guilders a week if she would file for divorce. She refused and her husband was deported to Auschwitz. ${ }^{683}$

However, as we have seen before, the grounds for divorce were limited in the Netherlands. Divorce on the mere ground that the other partner was Jewish was legally not possible. Implementing forced divorce by legislation has been considered several times. ${ }^{684}$ It has been discussed as a possible solution during the Wannsee Conference and the subsequent meetings of a commission (Arbeitskreis), which was set up during the conference. ${ }^{685}$ However, as Herzberg correctly points out, forced divorce would also have affected a considerable part of the non-Jewish population. Furthermore, it would even not have been in keeping with a pretended upholding of the Dutch Civil Code. ${ }^{686}$ An attempt to prohibit non-Jews to live in the same house as Jews, which automatically would have lead to a ground for divorce in case of mixed married couples, was already rejected by Stüler in 1940 . $^{687}$

According to Stuldreher ${ }^{688}$ the problem was that Dutch divorce law did not have the legal concept of Aufhebung of the marriage, a concept which was adopted in Germany by $\mathbb{3} 37$ of the Ehegesetz of I938. ${ }^{689}$ Aufhebung is difficult to translate. Literally it means 'termination' or 'abolition'. Stuldreher uses the term 'annulment' (nietigverklaring), ${ }^{690}$ but this is not correct, as Aufhebung had the same legal effect as divorce, i.e. no retroactive effect. ${ }^{691}$ In the following the term 'termination' will be used. Paragraph 37 of the Ehegesetz stated that a marriage could be terminated in case of error concerning personal circumstances of the other spouse, which - if known beforehand and with a true understanding of the essence of marriage - would have dissuaded the erring person to enter into the marriage. ${ }^{692}$ According to an undated memorandum concerning dissolution of mixed marriages, ${ }^{693}$ being Jewish was considered a personal circumstance which could lead to termination, although according to Bechert and Wiesels $\mathbb{} 37$ was only applicable in case one of the partners was a halfblood and not a full-Jew. ${ }^{694}$ The request for termination

683 L. de Jong, Het Koninkrijk der Nederlanden in de Tweede Wereldoorlog, 7:394.

684 J. Presser, Ondergang (deel 2), 91.

685 C. Stuldreher, De Legale Rest, 149, 155. See also the Besprechungsprotokoll der Wannsee-Konferenz, published in K. Pätzhold and E. Schwarz, Tagesordnung: Judenmord, 102-112, 111.

686 A.J. Herzberg, 'Kroniek der Jodenvervolging', in J.J. van Bolhuis et al. (eds.), Onderdrukking en Verzet. Nederland in Oorlogstijd (deel 3), 127.

687 C. Stuldreher, De Legale Rest, 49.

688 Ibid., 363.

689 Gesetz zur Vereinheitlichung des Rechts der Eheschließung und der Ehescheidung im Lande Österreich und im übrigen Reichsgebiet vom 6. Juli 1938, Reichsgesetzblatt (1938), I, 807, § 37.

690 C. Stuldreher, De Legale Rest, 363.

691 R. Bechert and J. Wiesels, Das neue Eherecht für Großdeutschland, 39; A Scharnagl, Das neue deutsche Ehegesetz, $93-94$.

692 Gesetz zur Vereinheitlichung des Rechts der Eheschließung und der Ehescheidung im Lande Österreich und im übrigen Reichsgebiet vom 6. Juli 1938, Reichsgesetzblatt (1938), I, 807, § 37 (1): 'Ein Ehegatte kann Aufhebung der Ehe begehren, wenn er sich bei der Eheschließung über solche die Person des anderen Ehegatten betreffende Umstände geirrt hat, die ihn bei Kenntnis der Sachlage und bei richtiger Würdigung des Wesens der Ehe von der Eingehung der Ehe abgehalten hätten.'

693 Vermerk betr.: Auflösung von Mischehen, NIOD archives, access no. 020, inventory no. 286 and 2413 (partially). Part of this memorandum is copied by Wimmer in a letter to Rauter, with regard to dissolution of mixed marriages. See letter from Wimmer to Rauter, betr.: Trennung von Mischehen (25 October 1943), NIOD archives, access no. 020, inventory no. 286.

694 R. Bechert and J. Wiesels, Das neue Eherecht für Großdeutschland, 35. 
had to be filed within a year after discovery of the error. ${ }^{695}$ Although the Ehegesetz makes no mention of it, apparently the date of commencement of the Nuremberg Laws was accepted as the latest moment of discovery ${ }^{696}$ This however, would imply that an appeal to this article was not only not possible anymore with regard to an error concerning race, but had never been possible at all as the Ehegesetz stems from I938, almost three years after the Nuremberg Laws were promulgated. It seems more likely that in Germany

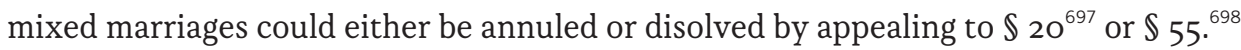

As we have seen before Schrieke had drafted an article allowing for annulment of existing mixed marriages within a year of commencement. This article was included in several draft regulations ${ }^{699}$ with regard to the implementation of the Nuremberg Laws, in particular the Blutschutzgesetz, which, however, have never been enacted.

Finally, a solution could probably be found in an enlargement of the Dutch grounds for divorce. In 1944, Calmeyer still refered to this possibility in a letter to Wimmer. ${ }^{700}$ Since 1942 Schrieke has attempted to revise Dutch divorce law in general, amongst other things extending the grounds for divorce. ${ }^{701}$

\section{- 4.3.5. Attempts to revise Dutch divorce law}

\subsubsection{Schrieke's draft of 1942}

On io October 1942, Schrieke sent a draft revision of Dutch divorce law to Werner Seiffert. In the accompanying letter he explained that the draft contained an adaptation of Dutch divorce law to German law. He proposed to send the draft confidentially to

695 Gesetz zur Vereinheitlichung des Rechts der Eheschließung und der Ehescheidung im Lande Österreich und im übrigen Reichsgebiet vom 6. Juli 1938, Reichsgesetzblatt (1938), I, 807, § 40: '(1) Die Aufhebungsklage kann nur binnen eines Jahres erhoben werden. (2) Die Frist beginnt [...] in den Fällen der $\S \S 36$ bis 38 mit dem Zeitpunkt, in welchem der Ehegatte den Irrtum oder die Täuschung entdeckt [...].'

696 Vermerk betr.: Auflösung von Mischehen, NIOD archives, access no. 020, inventory no. 286.

697 Gesetz zur Vereinheitlichung des Rechts der Eheschließung und der Ehescheidung im Lande Österreich und im übrigen Reichsgebiet vom 6. Juli 1938, Reichsgesetzblatt (1938), I, 807, § 20: 'Eine Ehe ist nur in den Fällen nichtig, in Denen dies im Gesetz zum Schutze des deutschen Blutes und der deutschen Ehre, im Gesetz zum Schutze der Erbgesundheit des deutschen Volkes (Ehegesundheitsgesetz) oder in den $\S \S 21$ bis 26 dieses Gesetzes bestimmt ist.'

698 Ibid., $\$ 55$ (1): 'Ist die häusliche Gemeinschaft der Ehegatten seit drei Jahren aufgehoben und infolge einer tiefgreifende unheilbaren Zerrüttung des ehelichen Verhältnisses die Wiederherstellung einer dem Wesen der Ehe entsprechenden Lebensgemeinschaft nicht zu erwarten, so kann jeder Ehegatte die Scheidung begehren.'

699 See Verordnung des Reichskommissars für die besetzten niederländischen Gebiete über das Verbot der Eheschliessung und des ausserehelichen Verkehrs mit Juden, April 1944, NIOD archives, access no. 020, inventory no. 2413 and 1507 and Verordnung des Reichskommissar für die besetzten niederländischen Gebiete über das Verbot der Eheschliessung und des ausserehelichen Geschlechtsverkehrs mit Personen jüdischen Blutes, Erste Fassung, 3 August 1944, NIOD archives, access no. 020 , inventory no. 2413 and 1507.

700 Letter from Calmeyer to Wimmer (29 February 1944), NIOD archives, access no. 020, inventory no. 2413.

701 Schrieke was, however, not the only one who had busied himself with revising the grounds for divorce. The Supreme Court contributed indirectly to the extension of the grounds for divorce. In the original text of Article 264 of the Civil Code of 1838 , the third ground for divorce read 'criminal sentence implicating a degrading punishment'. In its judgment of 2 October 1851 , the Supreme Court had ruled that this ground could only be applied to Dutch criminal sentences, as it would be impossible to come to a uniform interpretation of the phrase 'degrading punishment' in all European countries. Therefore, a foreign conviction could never form a ground for divorce. See Hoge Raad, 2 October 1851, Nederlandsche Regtspraak XL (1852), § 1. However, in 1943 the Court made U-turn, stating that a foreign conviction could very well serve as a ground for divorce, as the wording of Article 264 (3) BW had been changed in 1884. The phrase 'degrading punishment' had been replaced by 'imprisonment of four years or longer'. As this was objectively measurable, the Court considered that by this revision, the legislator had meant to make the provision of Article 264 (3) BW applicable to foreign convictions as well. Hoge Raad, 5 March 1943, Nederlandsche Jurisprudentie 1943, 203. In this case a German Feldkriegsgericht had sentenced a man to life imprisonment, on charges of espionage. Following this judgment, his wife had filed for divorce on the basis of Article 264 (3) BW. The divorce had been granted, a judgment which was upheld both by the Court of Appeal of The Hague and the Dutch Supreme Court. Apart from that a polemic had been engaged in the Nederlandsch Juristenblad in the first half of 1944 , between J. van Nes and G.J.H. Kuyk. $\rightarrow$ 
the Supreme Court, the five Courts of Appeal, the Rechtsfront ${ }^{702}$ and the nine major denominations to ask for their opinion on the matter. He indicated that he was well aware that this draft contained a precarious matter, which concerned the emotional and religious mentality of the majority of the Dutch population. Did Seiffert agree with the intended procedure? ${ }^{703}$

Seiffert forwarded the draft to Wimmer on 3i October I942, explaining Schrieke's intentions and emphasising the necessity of a revision of Dutch divorce law. According to Seiffert Schrieke had not pursued any religious arguments in the accompanying memorandum, but had merely indicated the current wrongs in Dutch divorce law such as the impossibility of divorce in case of mental illness of one of the spouses, effectively dispelling objections beforehand. ${ }^{704}$ In November I942, Wimmer discussed this letter with Seyss-Inquart, who was convinced that he could fully trust Schrieke and that, therefore, Schrieke could do whatever he thought was best. If Schrieke wished to consult the denominations on their opinions, Seyss-Inquart would let him, on the understanding that Schrieke would not send the draft itself, but would ask the denominations verbally. ${ }^{705}$

What changes did the draft contain? In his explanatory memorandum, Schrieke firstly criticised the notorious judgment of the Supreme Court of I883, which, according to Schrieke, showed contempt for both marriage as such and the law. ${ }^{706}$ Goseling's proposal of 1938 did not go far enough in its attempt to end 'the Big Lie'. The main problem, according to Schrieke, was the limited number of grounds for divorce. These grounds had to be extended in order to comply with recent developments. Although Schrieke was aware of the fact that divorce was a precarious matter and extending the grounds for divorce would encounter many objections, especially religious and judicial ones, he was convinced that anyone would admit that the existing law was unjust, as it did not provide for the possibility of divorce on the ground of permanent breakdown of the marriage. According to Schrieke, divorce should be permitted in case a marriage was broken down in such a way that it was no longer of value to the community, i.e. no children would be

.. Van Nes argued in favour of a differentiation in divorce law with regard to believers and non-believers. The existing grounds for divorce could be maintained - although he was in favour of including insanity as ground for divorce - but the prohibition of divorce by mutual consent could be abrogated for those who did not belief in the sanctity and indissolubility of marriage. In order to determine whether a couple qualified for this exceptional procedure, they to file a petition with a still to be appointed censor who would inquire into the personal beliefs of the couple. Facts, like membership of a religious community could quide the censor when making his decision. The divorce petition should then still be filed with the court. See J. van Nes, 'Het echtscheidingsvraagstuk', 21-22. Kuyk criticised Van Nes' suggestions, in particular with regard to the position of the censor. According to Kuyk an ordinary citizen should not be given the authority to judge about legal consequences of personal beliefs of other citizens. He agreed with Van Nes that the then existing way to get a divorce by 'mutual consent' was not preferable, but in order to solve that problem he suggested to abrogate the prohibition of divorce by mutual consent altogether. See G.J.H. Kuyk, 'Het echtsscheidingsvraagstuk', 37. However, full abrogation of the prohibition of divorce by mutual consent was not possible according to Van Nes, as this would misjudge the beliefs of the majority of the Dutch population. Furthermore, he stated that his intended censor should not just be any ordinary citizen, but an extraordinary wise person, supported by the population. See J. van Nes, 'Naar den Censor', 70-72.

702 The Rechtsfront was founded by NSB leader Anton Mussert on 2 August 1940 and was aimed at the development of National Socialist views with respect to several fields of law. All activities of the Rechtsfront were therefore directed at the construction of a National Socialist nation state. See for more information on the Rechtsfront: D. Venema, Rechters in Oorlogstijd, $50-54$ and J. Meihuizen, Smalle Marges, 293-298.

703 Letter from Schrieke to Seiffert, R. Nr. 1126 (10 October 1942), NIOD archives, access no. 020, inventory no. 2414.

704 Letter from Seiffert to Wimmer, Ju 12-1309/42 (31 October 1942), NIOD archives, access no. 020, inventory no. 2414.

705 Vermerk betr.: Reform der Ehescheidung, signed by Böttcher (14 November 1942), NIOD archives, access no. 020, inventory no. 2414.

706 J.J. Schrieke, Erläuterung des Verordnungsentwurfs, 1942, 1-2, NIOD archives, access no. 020, inventory no. 2414. 
born in case the partners stayed together, e.g. in case of a mental illness of one of the spouses or an incurable contagious disease, infertility or simply in case one of the partners refused to beget children. ${ }^{707}$

To the four existing grounds for divorce, stated in Article 264, Schrieke added five new ones. ${ }^{708}$ The existing first ground - adultery - was extended by the addition 'unless it is endured explicitly or tacitly by the other spouse'. Schrieke added this to discourage actual adultery in order to get a divorce granted, even when it would be difficult to distinguish true cases from fake ones. ${ }^{709}$ This condition had already been formulated by Goseling in $1938,{ }^{710}$ who had copied it from Regout. ${ }^{711}$ The fifth ground would become the refusal, without a reasonable ground, to beget or to receive offspring. ${ }^{712}$ In his explanatory memorandum Schrieke stated that the essence of marriage was procreation and in case one of the partners refused to cooperate to this goal, the other partner should be given the possibility of divorce in order to remarry and yet have children. ${ }^{713}$ The sixth ground became discord, causing a permanent breakdown of the marriage, which could not be repaired anymore and which would render a community according to the essence of marriage impossible, i.e. it would no longer lead to offspring. ${ }^{714}$ Insanity became the seventh ground, formulated as 'mental disorder of one of the spouses, which has abolished every mental community between the spouses, while recovery is not expected to be possible, ${ }^{715}$ In his explanatory memorandum Schrieke stated that the fact that, until now, insanity had not been included in Article 264 as a legal ground for divorce, had caused a lot of tragedy in the past. Including this ground for divorce would only be just. ${ }^{716}$ Ground eight became a contagious or revolting disease of one of the spouses, which was not expected to be cured nor was the danger of contagion expected to diminish within a measurable time. ${ }^{717}$ Finally, premature infertility of one of the spouses became the ninth ground for divorce, provided that no children had already been born within the

707 J.J. Schrieke, Erläuterung des Verordnungsentwurfs, 1942, 2-4, NIOD archives, access no. 020, inventory no. 2414.

708 J.J. Schrieke, Verordnung des Generalsekretärs im Ministerium für Justiz über die Ehescheidung, die Trennung von Tisch und Bett und die Auflösung der Ehe nach Trennung von Tisch und Bett, 1942, NIOD archives, access no. 020, inventory no. 2414.

709 J.J. Schrieke, Erläuterung des Verordnungsentwurfs, 1942, 5, NIOD archives, access no. 020, inventory no. 2414.

710 Handelingen der Staten-Generaal (Tweede Kamer), bijlagen 1938-1939, no. 257.2, Article II.

711 Handelingen der Staten-Generaal (Tweede Kamer), bijlagen 1911-1912, no. 306.2, Article III.

712 J.J. Schrieke, Verordnung des Generalsekretärs im Ministerium für Justiz über die Ehescheidung, die Trennung von Tisch und Bett und die Auflösung der Ehe nach Trennung von Tisch und Bett, 1942, NIOD archives, access no. 020, inventory no. 2414, Article 1, I, 5: 'voortgezette weigering om tot het verwekken of ontvangen van nakomelingenschap mede te werken, zonder dat hiervoor een redelijke grond aanwezig is; [...].'

713 J.J. Schrieke, Erläuterung des Verordnungsentwurfs, 1942, 4, NIOD archives, access no. 020, inventory no. 2414

714 J.J. Schrieke, Verordnung des Generalsekretärs im Ministerium für Justiz über die Ehescheidung, die Trennung von Tisch und Bett und die Auflösung der Ehe nach Trennung von Tisch und Bett, 1942, NIOD archives, access no. 020, inventory no. 2414, Article 1, I, 6: 'zoodanige tweespalt tusschen de echtgenooten, dat het huwelijk tot in zijn grondslagen is aangetast en het herstel eener met het wezen van het huwelijk overeenstemmende levensgemeenschap niet kan worden verwacht; [...].'

715 J.J. Schrieke, Verordnung des Generalsekretärs im Ministerium für Justiz über die Ehescheidung, die Trennung von Tisch und Bett und die Auflösung der Ehe nach Trennung von Tisch und Bett, 1942, NIOD archives, access no. 020, inventory no. 2414, Article 1, I, 7: 'storing der geestvermogens bij een der echtgenoten, waardoor iedere geestelijke gemeenschap opgeheven is, terwijl herstel buitengesloten moet worden geacht; [...].'

716 J.J. Schrieke, Erläuterung des Verordnungsentwurfs, 1942, 4, NIOD archives, access no. 020, inventory no. 2414.

717 J.J. Schrieke, Verordnung des Generalsekretärs im Ministerium für Justiz über die Ehescheidung, die Trennung von Tisch und Bett und die Auflösung der Ehe nach Trennung von Tisch und Bett, 1942, NIOD archives, access no. 020, inventory no. 2414, Article 1, I, 8: 'de aanwezigheid eener ernstige besmettelijke of afschuwwekkende ziekte bij een der echtgenooten, terwijl de genezing der ziekte of het verdwijnen van het besmettingsgevaar binnen afzienbaren tijd niet kan worden verwacht [...].' 
marriage. ${ }^{718}$ Schrieke considered both grounds eight and nine to concern the essence of marriage, as in both cases it would either be certain or very likely that no children would be born (anymore) within the marriage. Their introduction was therefore as necessary as the others were. ${ }^{719}$ Schrieke realised that in certain cases divorce would not be justified as it would be unreasonably hard-hearted to the partner who would be abandoned. Therefore, he included a provision, which allowed the court to deny a claim for divorce, which was submitted on ground six, seven, eight or nine. The same rule applied in case the court considered a divorce not justified from a moral point of view. The duration of the marriage, the age of the spouses and the cause of the discord, disease or infertility had to be taken into account in this respect. ${ }^{720}$

Finally, this article commenced the abrogation of the adversarial role of the judge, as it stated that the judge would ex officio investigate the truth of the facts and conducts adduced by the plaintiff. ${ }^{721}$

In addition to the grounds for divorce, separation from bed and board had been criticised as well. In his explanatory memorandum Schrieke stated that the obligation of cohabitation should not rashly be abolished. Family life and the welfare of the children always remained to be more important than the wish for divorce. Therefore, the possibility of separation from bed and board with mutual consent had to be abolished. ${ }^{722}$

In the existing Civil Code of I 838 Article 288 declared the grounds for divorce directly applicable on separation of bed and board, as we have seen before. In addition, sub 2 stated three extra grounds for separation from bed and board: excesses, ill-treatments and serious insults committed by one of the spouses towards the other one. Article 29I allowed for separation from bed and board by mutual consent. The court could pronounce separation from bed and board, requested by both spouses without giving a ground.

In his draft Schrieke proposed to abrogate Article 288 sub 2, as his proposed extension of Article 264 supposedly made these grounds redundant. Furthermore, the Articles 29I296 had to be abrogated as well, to abolish the possibility of separation from bed and board by mutual consent. ${ }^{723}$

In the existing Article 255, the legislator had provided the possibility to dissolve the

718 J.J. Schrieke, Verordnung des Generalsekretärs im Ministerium für Justiz über die Ehescheidung, die Trennung von Tisch und Bett und die Auflösung der Ehe nach Trennung von Tisch und Bett, 1942, NIOD archives, access no. 020, inventory no. 2414, Article 1, I, 9: 'voortijdige onvruchtbaarheid van een der echtgenooten, ook indien deze na het voltrekken van het huwelijk is ontstaan mits uit het huwelijk geen kinderen zijn geboren.'

719 J.J. Schrieke, Erläuterung des Verordnungsentwurfs, 1942, 4, NIOD archives, access no. 020, inventory no. 2414.

720 J.J. Schrieke, Verordnung des Generalsekretärs im Ministerium für Justiz über die Ehescheidung, die Trennung von Tisch und Bett und die Auflösung der Ehe nach Trennung von Tisch und Bett, 1942, NIOD archives, access no. 020, inventory no. 2414 , Article 1, I: '[...] In de gevallen onder 60.-90. vermeld, zal de rechter de vordering afwijzen, wanneer de andere echtgenoot door echtscheiding onevenredig hard zou worden getroffen of de vordering anderszins uit zedelijk oogpunt niet gerechtvaardigd is. Bij de beoordeling hiervan zal met de begeleidende omstandigheden als den duur van het huwelijk, den leeftijd der echtgenooten en de oorzaak van de tweespalt, de ziekte of de onvruchtbaarheid rekening moeten worden gehouden.' See also J.J. Schrieke, Erläuterung des Verordnungsentwurfs, 1942, 5, NIOD archives, access no. 020, inventory no. 2414.

721 J.J. Schrieke, Verordnung des Generalsekretärs im Ministerium für Justiz über die Ehescheidung, die Trennung von Tisch und Bett und die Auflösung der Ehe nach Trennung von Tisch und Bett, 1942, NIOD archives, access no. 020, inventory no. 2414, Article 1, I: '[...] De rechter onderzoekt ambtshalve de waarheid van de door den eischer ter staving van zijn eisch aangevoerde feiten en gedragingen. [...].'

722 J.J. Schrieke, Erläuterung des Verordnungsentwurfs, 1942, 5-6, NIOD archives, access no. 020, inventory no. 2414.

723 J.J. Schrieke, Verordnung des Generalsekretärs im Ministerium für Justiz über die Ehescheidung, die Trennung von Tisch und Bett und die Auflösung der Ehe nach Trennung von Tisch und Bett, 1942, NIOD archives, access no. 020, inventory no. 2414 , Article 2, I and III. 
marriage five years after separation from bed and board had been pronounced and the partners had not become reconciled. Schrieke proposed to shorten this term from five to three years, as Goseling had already proposed in $1938 .^{724}$ In addition, Article 256 - which stated that the claim for dissolution would be denied in case the defendant did not show up, objected to the claim, or expressed his willingness to reconcile with his partner - had to be abrogated. ${ }^{725}$ According to Schrieke, this article had already caused a lot of distress in the past, as the plaintiff was not allowed to remarry as long as the previous marriage was not yet dissolved, although in fact this marriage did no longer exist. ${ }^{726}$

Apart from a few technical changes, Schrieke finally proposed a revision of the Articles 277 to 28I of the Civil Code, which dealt with the distribution of profits gained from the marriage and a possible right to maintenance. As this is beyond the scope of this research, I will confine myself to mentioning that the main revision was the abrogation of the former distinction between the plaintiff and defendant. The Civil Code only provided for a right to maintenance for the plaintiff and only the plaintiff could keep his profits gained from the marriage. In this respect, Schrieke introduced the guilt principle by stating that both partners could keep their profits except in case the divorce was to blame on the guilt of one of the spouses. In that case, the spouse concerned was deprived from his profits and his right to maintenance. ${ }^{727}$

It is safe to say that Schrieke had to a large extent been inspired by the German Marriage Law (Ehegesetz) of I938. The fifth up to and including the ninth ground for divorce were all, more or less, taken from the German Marriage Law. Ground five - refusal to procreate - could be found in the German $\mathbb{S} 48,{ }^{728}$ whilst ground six - permanent breakdown caused by discord - was inspired by both $\mathbb{4} 49^{729}$ and $\mathbb{5} 5$. $^{730}$ Ground seven - insanity - found its

724 J.J. Schrieke, Verordnung des Generalsekretärs im Ministerium für Justiz über die Ehescheidung, die Trennung von Tisch und Bett und die Auflösung der Ehe nach Trennung von Tisch und Bett, 1942, NIOD archives, access no. 020, inventory no. 2414, Article 3, I; J.J. Schrieke, Erläuterung des Verordnungsentwurfs, 1942, 7, NIOD archives, access no. 020, inventory no. 2414. See Handelingen der Staten-Generaal (Tweede Kamer), bijlagen 1938-1939, no. 257 for Goseling's draft. Goseling had copied this article from an earlier draft by one of his predecessors, Regout, from 1912. See Handelingen der Staten-Generaal (Tweede Kamer), bijlagen 1911-1912, no. 306.

725 J.J. Schrieke, Verordnung des Generalsekretärs im Ministerium für Justiz über die Ehescheidung, die Trennung von Tisch und Bett und die Auflösung der Ehe nach Trennung von Tisch und Bett, 1942, NIOD archives, access no. 020, inventory no. 2414, Article 3, II

726 J.J. Schrieke, Erläuterung des Verordnungsentwurfs, 1942, 7, NIOD archives, access no. 020, inventory no. 2414.

727 J.J. Schrieke, Verordnung des Generalsekretärs im Ministerium für Justiz über die Ehescheidung, die Trennung von Tisch und Bett und die Auflösung der Ehe nach Trennung von Tisch und Bett, 1942, NIOD archives, access no. 020, inventory no. 2414, Article 1, II.

728 Gesetz zur Vereinheitlichung des Rechts der Eheschließung und der Ehescheidung im Lande Österreich und im übrigen Reichsgebiet vom 6. Juli 1938, Reichsgesetzblatt (1938), I, 807, § 48: 'Ein Ehegatte kann Scheidung begehren, wenn der andere sich ohne triftigen Grund beharrlich weigert, Nachkommenschaft zu erzeugen oder zu empfangen, oder wenn er rechtswidrig Mittel zur Verhinderung der Geburt anwendet oder anwenden läßt.'

729 Gesetz zur Vereinheitlichung des Rechts der Eheschließung und der Ehescheidung im Lande Österreich und im übrigen Reichsgebiet vom 6. Juli 1938, Reichsgesetzblatt (1938), I, 807, § 49: 'Ein Ehegatte kann Scheidung begehren, wenn der andere durch eine sonstige schwere Eheverfehlung oder durch ehrloses oder unsittliches Verhalten die Ehe schuldhaft so tief zerrüttet hat, daß die Wiederherstellung einer ihrem Wesen entsprechenden Lebensgemeinschaft nicht erwartet werden kann. [...].'

730 Gesetz zur Vereinheitlichung des Rechts der Eheschließung und der Ehescheidung im Lande Österreich und im übrigen Reichsgebiet vom 6. Juli 1938, Reichsgesetzblatt (1938), I, 807, § 55: '(1) Ist die häusliche Gemeinschaft der Ehegatten seit drei Jahren aufgehoben und infolge einer tiefgreifenden unheilbaren Zerrüttung des ehelichen Verhältnisses die Wiederherstellung einer dem Wesen der Ehe entsprechenden Lebensgemeinschaft nicht zu erwarten, so kann jeder Ehegatte die Scheidung begehren. [...].' 
equal in the German $\mathbb{S}_{5}{ }^{1},{ }^{731}$ ground eight - contagious or revolting disease - was almost literally taken over from $\mathbb{S} 52^{732}$ and ground nine - premature infertility - was a pretty strict abstract of $\mathbb{S} 53$ (I) and (2). ${ }^{733}$ All these new grounds aimed to promote healthy, strong offspring, whilst eliminating the weaker in society. The essence of marriage was to serve the community. Children, therefore, always remained the first goal of marriage. In case a marriage had lost its value to the community, it should be discontinued. The abrogation of Article 256 and the reduction of the term in Article 255 fully agreed with National Socialism as well, as both revisions aimed at discontinuing an unproductive marriage, thereby providing the possibility for one or even both of the spouses to remarry, thereby enlarging the opportunity for both to still fulfil ones duty to the community.

Other changes, however, were fully in line with earlier proposals, but appeared to be unrelated to the occupation and National Socialism. Both Regout in I9I2 and Goseling in 1938 had already proposed to shorten the minimum term for separation from bed and board before getting a divorce from five to three years as this three year term was more in line with foreign legislation, such as the French and Belgian Civil Codes. ${ }^{734}$ The proposed addition to the first ground for divorce could indeed be found in $\$ 47$ (2) of the German Marriage Law of $1938,{ }^{735}$ but that article had largely been copied from the old $\mathbb{S}$ I565 (2) BGB. ${ }^{736}$ Furthermore, this change had already been proposed both by Regout and Goseling as well, and was merely intended to solve the problem of 'the Big Lie'.

Furthermore, Schrieke's first draft concerning the revision of divorce law made no mention of mixed marriages, nor did it seem to give a possibility to dissolve mixed marriages through indirect ways. As we have seen before, Schrieke had drafted an article allowing for annulment of existing mixed marriages within a year of commencement. However, according to the undated memorandum concerning dissolution of mixed marriages which has been discussed before, this provision did not fit well in Schrieke's draft revision of divorce law. Therefore, the provision was included in several draft

731 Gesetz zur Vereinheitlichung des Rechts der Eheschließung und der Ehescheidung im Lande Österreich und im übrigen Reichsgebiet vom 6. Juli 1938, Reichsgesetzblatt (1938), I, 807, § 51: 'Ein Ehegatte kann Scheidung begehren, wenn der andere geisteskrank ist, die Krankheit einen solchen Grad erreicht hat, daß die geistige Gemeinschaft zwischen den Ehegatten aufgehoben ist, und eine Wiederherstellung dieser Gemeinschaft nicht erwartet werden kann.'

732 Gesetz zur Vereinheitlichung des Rechts der Eheschließung und der Ehescheidung im Lande Österreich und im übrigen Reichsgebiet vom 6. Juli 1938, Reichsgesetzblatt (1938), I, 807, § 52: 'Ein Ehegatte kann Scheidung begehren, wenn der andere an einer schweren ansteckenden oder ekelerregenden Krankheit leidet und ihre Heilung oder die Beseitigung der Ansteckungsgefahr in absehbarer Zeit nicht erwartet werden kann.'

733 Gesetz zur Vereinheitlichung des Rechts der Eheschließung und der Ehescheidung im Lande Österreich und im übrigen Reichsgebiet vom 6. Juli 1938, Reichsgesetzblatt (1938), I, 807, § 53: '(1) Ein Ehegatte kann Scheidung begehren, wenn der andere nach der Eheschließung vorzeitig unfruchtbar geworden ist. (2) Die Scheidung is ausgeschlossen, wenn die Ehegatten miteinander erbgesunde eheliche Nachkommenschaft ode rein gemeinschaftlich an Kindes Statt angenommenes erbgesundes Kind haben. [...].'

734 Handelingen der Staten-Generaal (Tweede Kamer), bijlagen 1911-1912, no. 306.3, Memorie van Toelichting.

735 Gesetz zur Vereinheitlichung des Rechts der Eheschließung und der Ehescheidung im Lande Österreich und im übrigen Reichsgebiet vom 6. Juli 1938, Reichsgesetzblatt (1938), I, 807, § 47 (2): ‘Er hat kein Recht auf Scheidung, wenn er dem Ehebruch zugestimmt oder inn durch sein Verhalten absichtlich ermöglicht oder erleichert hat.'

$736 § 1565$ (2) BGB: 'Das Recht des Ehegatten auf Scheidung ist ausgeschlossen, wenn er dem Ehebruch oder der strafbaren Handlung zustimmt oder sich der Teilnahme schuldig macht.' 
regulations ${ }^{737}$ with regard to the prohibition of mixed marriages, ${ }^{738}$ which, however, have never been enacted.

\subsubsection{Reactions to the first draft}

In December 1942, Schrieke sent his draft to the Dutch Supreme Court and the five Courts of Appeal, to the Rechtsfront, the Instituut voor Rechtsvernieuwing (Institute for Judicial Reform ${ }^{739}$ and to the major denominations. In February, March and April 1943 he received responses from the Rechtsfront, the Instituut voor Rechtsvernieuwing, the Court of Appeal of The Hague and the denominations. The Supreme Court only responded on 2 December 1943, a year after Schrieke had sent his draft.

Both the Rechtsfront and the Institute for Judicial Reform, whose remarks were sent to Schrieke by H.M. Fruin, chairman of both the Rechtsfront and the Institute for Judicial Reform, ${ }^{740}$ were very enthusiastic about the draft revision. Both considered the widening of the grounds for divorce an improvement, whilst Fruin added to be very pleased that with this revision, Schrieke would finally put an end to the practice of 'the Big Lie'. ${ }^{741}$ S.A. van Lunteren, head of the department of Civil Law of the Institute for Judicial Reform, indicated that the department was particularly pleased with the adoption of incurable insanity as ground for divorce and the abolition of the adversarial role of the judge (lijdelijkheid van de rechter), ${ }^{742}$ something which was emphasised by Fruin as well. ${ }^{743}$

On behalf of the department of Civil Law, Van Lunteren had some small remarks as well. With regard to the new ninth ground - premature infertility - the department suggested to include the provision that the infertile spouse did not have the right to file for divorce him- or herself. ${ }^{744}$ This provision was included in $\mathbb{5 3}$ (3) of the German

737 See Verordnung des Reichskommissars für die besetzten niederländischen Gebiete über das Verbot der Eheschliessung und des ausserehelichen Verkehrs mit Juden, April 1944, NIOD archives, access no. 020, inventory no. 2413 and 1507 and Verordnung des Reichskommissar für die besetzten niederländischen Gebiete über das Verbot der Eheschliessung und des ausserehelichen Geschlechtsverkehrs mit Personen jüdischen Blutes, Erste Fassung, 3 August 1944, NIOD archives, access no. 020 , inventory no. 2413 and 1507.

738 Vermerk betr.: Auflösung von Mischehen, NIOD archives, access no. 020, inventory no. 286 and 2413 (partially). Part of this memorandum is copied by Wimmer in a letter to Rauter, with regard to dissolution of mixed marriages. See letter from Wimmer to Rauter, betr.: Trennung von Mischehen (25 October 1943), NIOD archives, access no. 020, inventory no. 286.

739 The Instituut voor Rechtsvernieuwing (Institute for Judicial Reform) was founded by Henry Mary Fruin in 1942. It can be regarded as the Dutch equivalent of the Akademie für Deutsches Recht and its purpose was to reform Dutch law according to National Socialism. The Institute consisted of several departments, of which only the department of Civil Law, presided by S.A. van Lunteren, has functioned to a certain extent. This section has drafted, amongst other things, a revision of Dutch civil procedural law, entitled Hoofdlijnen van een nieuw Burgerlijk Procesrecht. See for more information on the Instituut voor Rechtsvernieuwing D. Venema, Rechters in Oorlogstijd, 54-55, 108-109; C.J.H. Jansen and D. Venema, De Hoge Raad en de Tweede Wereldoorlog, 180, 305; C.J.H. Jansen, Doorgaan of stoppen?, 14-15.

740 Letter from H.M. Fruin to Schrieke (6 March 1943), NIOD archives, access no. 020, inventory no. 2414, subfolder 'Mede te zenden ambtsberichten, Departement van Justitie'.

741 Letter from H.M. Fruin to Schrieke (6 March 1943), NIOD archives, access no. 020, inventory no. 2414, subfolder 'Mede te zenden ambtsberichten, Departement van Justitie'.

742 S.A. van Lunteren, Opmerkingen omtrent het ontwerp op de echtscheiding gemaakt door de sectie voor Burgerlijk Recht van het Instituut voor Rechtsvernieuwing, NIOD archives, access no. 020, inventory no. 2414, subfolder 'Mede te zenden ambtsberichten, Departement van Justitie'.

743 Letter from H.M. Fruin to Schrieke (6 March 1943), NIOD archives, access no. 020, inventory no. 2414, subfolder 'Mede te zenden ambtsberichten, Departement van Justitie'.

744 S.A. van Lunteren, Opmerkingen omtrent het ontwerp op de echtscheiding gemaakt door de sectie voor Burgerlijk Recht van het Instituut voor Rechtsvernieuwing, NIOD archives, access no. 020, inventory no. 2414, subfolder 'Mede te zenden ambtsberichten, Departement van Justitie'. 
Marriage Law of I $938 .^{745}$ Other grounds for divorce could perhaps be widened a little more. With regard to the existing second ground - desertion with malicious intent Van Lunteren suggested to shorten the term after which a divorce could be requested from five to three years. The fourth ground - ill-treatment or serious injuries inflicted by the other spouse, causing a threat to life - was considered too strict, in particular since the possibilities to request a separation from bed and board were diminished. Van Lunteren suggested to replace the requirement that the ill-treatment had caused a threat to life with the requirement that the ill-treatment was so severe that continuation of the marriage could no longer be expected. With regard to the fifth ground - refusal to procreate - Van Lunteren suggested to add abortion, since according to the new draft, this could no longer lead to separation from bed and board. Furthermore, Van Lunteren wondered why, with regard to dissolution after separation from bed and board, the second appearance in court (comparitie) was upheld, since a reconciliation was unlikely, had it not come to that at the first appearance in court. Van Lunteren saw no reason to delay the dissolution, when the marriage had actually already ceased to exist. ${ }^{746}$ Fruin endorsed to this point of view, although according to him the entire appearance procedure with regard to reconciliation could be abolished. Although he furthermore agreed with the abolition of separation from bed and board by mutual consent, Fruin suggested to widen the number of grounds for separation from bed and board, as separation from bed and board had always been allowed in more cases than divorce. With regard to the grounds for divorce he suggested to add homosexuality as ground for divorce. ${ }^{747}$

Most of the denominations were far less enthusiastic. Both the Archbishop of Utrecht, ${ }^{748}$ the Episcopate of the Old-Catholic Church, ${ }^{749}$ and the combined Protestant Churches ${ }^{750}$ considered the draft revision a violation of Article 43 of the Hague Regulations. The Protestant Churches even added that besides a violation of this article, the draft revision was a violation of the Regulations 3/1940 and 23/I940 of the Reichskommissar himself, which stated that Dutch law would remain in force, insofar as it was consistent with the

745 Gesetz zur Vereinheitlichung des Rechts der Eheschließung und der Ehescheidung im Lande Österreich und im übrigen Reichsgebiet vom 6. Juli 1938, Reichsgesetzblatt (1938), I, 807, § 53 (3): 'Wer selbst unfruchtbar ist, hat kein Recht auf Scheiding. [...].'

746 S.A. van Lunteren, Opmerkingen omtrent het ontwerp op de echtscheiding gemaakt door de sectie voor Burgerlijk Recht van het Instituut voor Rechtsvernieuwing, NIOD archives, access no. 020, inventory no. 2414, subfolder 'Mede te zenden ambtsberichten, Departement van Justitie'.

747 Letter from H.M. Fruin to Schrieke (6 March 1943), NIOD archives, access no. 020, inventory no. 2414, subfolder 'Mede te zenden ambtsberichten, Departement van Justitie'.

748 Letter from the Archbishopric of Utrecht to Schrieke, (13 February 1943), NIOD archives, access no. 020, inventory no. 2414, subfolder 'Mede te zenden ambtsberichten, Departement van Justitie'.

749 Letter from the Episcopate of the Old-Catholic Church to Schrieke, (19 March 1943), NIOD archives, access no. 020, inventory no. 2414, subfolder 'Mede te zenden ambtsberichten, Departement van Justitie'.

750 Letter of the combined Protestant Churches to Schrieke, (13 February 1943), NIOD archives, access no. 020, inventory no. 2414, subfolder 'Mede te zenden ambtsberichten, Departement van Justitie'. To this belonged the Nederlandsche Hervormde Kerk, the Gereformeerde Kerken in Nederland, the Gereformeerde Kerken in Nederland in Hersteld Verband, the Christelijk Gereformeerde Kerk, the Evangelisch-Luthersche Kerk, the Hersteld Evangelisch-Luthersche Kerk, the Remonstrantsche Broederschap and the Algemeene Doopsgezinde Societeit. 
occupation, ${ }^{751}$ and that the secretaries-general were allowed to issue binding regulations necessary to maintain public order and public security ${ }^{752}$ - not more. ${ }^{753}$ In addition to this legal argument, the most important reason for rejection was the fact that this revision disowned the sacredness of marriage, which - according to church principles - could never be dissolved. The Episcopate of the Old-Catholic Church indicated that existing Dutch divorce laws forced the churches to recognise divorce and even a second marriage after divorce, although the Old-Catholic Church would continue to prohibit its members to divorce and would administer disciplinary measures against those who would enter into a second marriage after divorce. The Episcopate even suggested to introduce some legal requirements with regard to entering into a marriage in order to prevent marriages from getting on the rocks. ${ }^{754}$ The Archbishop of Utrecht, finally, concluded his letter with the remark that this draft revision would mean a serious insult of the most sacred feelings of the majority of the Dutch population. ${ }^{755}$

However, the Free Catholic Church, through Monsignor Vreede, took a different view. As the Free Catholic Church was not fundamentally opposed to divorce as such, but did consider divorce as something which should not be taken lightly, Vreede welcomed an extension of the grounds for divorce. Ground seven - incurable insanity - was applauded upon in particular. Vreede did have some remarks though. As the marriage vows of the Free Catholic Church included the vow 'for better for worse, in sickness and in health', he repudiated ground eight, incurable contagious or revolting disease. Although he accepted ground five - refusal to procreate - he considered ground nine - premature infertility too far-reaching. Finally, ground six - discord, causing a permanent breakdown of the marriage - was considered to be unsufficiently objective. Vreede feared that this ground would be used to sidestep the prohibition of divorce by mutual consent as formulated by Article 263 of the Civil Code. And although the Free Catholic Church was not opposed to divorce by mutual consent, Vreede indicated that abolishing this prohibition now would probably lead to wanton behaviour, which was undesirable as well. Vreede concluded his letter by stating that he agreed with the proposed changes with regard to separation from bed and board. Not a word was said about Article 43 of the Hague Regulations. ${ }^{756}$

751 Verordnung des Reichskommissars für die besetzten niederländischen Gebiete über die Ausübung der Regierungsbefugnisse in den Niederlanden vom 29. Mai 1940, Verordnungsblatt für die besetzten niederländischen Gebiete (1940), 8, $\$ 2$ (1): 'Das bisher geltende niederländische Recht bleibt in Kraft, soweit es mit der Besetzung vereinbaar ist und soweit nicht die Bestimmungen des Erlasses des Führers über die Ausübung der Regierungsbefugnisse in den Niederlanden (RGBI. I, S. 778) dem entgegenstehen. [...].'

752 Verordnung des Reichskommissars für die besetzten niederländischen Gebiete über die Befugnisse des Generalsekretäre der niederländischen Ministerien, Verordnungsblatt für die besetzten niederländischen Gebiete (1940), 55, § 1 (1): 'Die Generalsekretäre der niederländischen Ministerien sind ermächtigt, im Rahmen ihres sachlichen Zuständigkeitsbereichs die zur Wahrung der öffentlichen Ordnung und zur Sicherung des öffentlichen Lebens notwendigen Massnahmen zu treffen, insbesondere Rechtsvorschriften zu erlassen [...].'

753 Letter of the combined Protestant Churches to Schrieke, (13 February 1943), NIOD archives, access no. 020, inventory no. 2414, subfolder 'Mede te zenden ambtsberichten, Departement van Justitie'.

754 Letter from the Episcopate of the Old-Catholic Church to Schrieke, (19 March 1943), NIOD archives, access no. 020, inventory no. 2414, subfolder 'Mede te zenden ambtsberichten, Departement van Justitie'.

755 Letter from the Archbishopric of Utrecht to Schrieke, (13 February 1943), NIOD archives, access no. 020, inventory no. 2414, subfolder 'Mede te zenden ambtsberichten, Departement van Justitie'.

756 Letter from Monsignor A.G. Vreede, bishop of the Free Catholice Church, to Schrieke, (28 April 1943), NIOD archives, access no. 020 , inventory no. 2414 , subfolder 'Mede te zenden ambtsberichten, Departement van Justitie'. 
On 5 March 1943, the President of the Court of Appeal in The Hague replied to Schrieke, compiling the considerations of his colleagues. Although none of the judges referred to Article 43 of the Hague Regulations, in general, the members of the Court of Appeal considered the occupation not to be the opportune moment for a revision of divorce law. Nevertheless, the majority was not entirely unfavourably disposed towards the notion of extending the grounds for divorce. Again, ground seven - incurable insanity - was applauded upon by most of the judges, as was the reduction of the term in Article 255 . Ground six, however, was heavily criticised, for the same reason as it was criticised by Vreede. Discord would be very hard to determine objectively by the court, and allowing divorce on this ground would not solve the problem of 'the Big Lie'. As one of the judges remarked: 'This will become a rewarding subject for legal proceedings'. Besides, discord should not in all cases be a ground for divorce; in general it was believed that married partners had to solve their problems instead of running away for them by means of a divorce. Ground five - refusal to procreate - led to raised eyebrows as well, as did ground nine, premature infertility. Both were considered to cause difficulties with regard to proof. Ground eight - contagious or revolting disease - was only accepted in case it concerned a disease caused by guilt of the sufferer, such as a venereal disease. In addition, it was suggested to introduce chronic alcohol abuse as a ground for divorce as well, as had been suggested several times already since $1886 .^{757}$

The Supreme Court took its time, but finally came with the most elaborate report, including statistics. The committee, which was set up to draft a report in preparation for a plenary discussion, had presented a report running to eighty pages in July I 943 in which it not only advised upon the draft proposal at hand, but presented its own ideas on a revision of Dutch divorce law as well. However, as the Supreme Court in the end decided to advise against a revision of part of the Civil Code during the occupation as Article 43 of the Hague Regulations did not allow for this, they considered it a protestatio actui contrariae to come up with its own draft revision. ${ }^{758}$ The final report was therefore shortened to fifteen pages, of which seven consisted of statistical data, in which Dutch divorce figures were compared to foreign figures, in particular Germany and Switzerland. ${ }^{759}$

As said, the Supreme Court advised against enactment of the proposed revision. A revision of the Civil Code and in particular of family law during the occupation was considered a violation of Article 43 of the Hague Regulations and Regulation 23/r940. According to the Supreme Court it was evident that the authors of Article 43 of the Hague Regulations particularly had meant family law when stating that the occupant had

757 Letter from the President of the Court of Appeal in The Hague to Schrieke, (5 March 1943), NIOD archives, access no. 020, inventory no. 2414, subfolder 'Mede te zenden ambtsberichten, Departement van Justitie'.

758 Letter from the Dutch Supreme Court to Schrieke, (2 December 1943), NIOD archives, access no. 020, inventory no. 2414 subfolder 'Mede te zenden ambtsberichten, Departement van Justitie'.

759 Statistical memorandum from the Dutch Supreme Court, (2 December 1943), NIOD archives, access no. 020, inventory no. 2414, subfolder 'Mede te zenden ambtsberichten, Departement van Justitie'. 
to respect, 'unless absolutely prevented, the laws in force in the country' ${ }^{760}$ Nevertheless, the Supreme Court admitted that in case of a sustained occupation altered circumstances would probably call for a revision of the Civil Code. At the moment that was, however, out of order. Furthermore, the Supreme Court considered Schrieke's statement that the grounds for divorce had already caused objections for years correct, but these objections had not changed because of the German occupation and did not, therefore, give cause for revision. In addition to this the Supreme Court was of the opinion that the matter at issue could not be decided upon without allowing public opinion to express itself, which would be impossible during the occupation.

Despite all these fundamental objections the Supreme Court did advise on the content of the draft as well. Supported by statistical data, the Court raised objections to the majority of the newly proposed grounds for divorce. According to the Court, ground six - discord causing a permanent breakdown - would lead to an increase of the number of divorce instead of a decrease. This was founded by a presentation of divorce figures, which showed that the majority of divorces in Germany $\left(74.33 \%\right.$ in $1937,{ }^{761} 67.84 \%$ in $194 \mathrm{I}^{762}$ ) and Switzerland (between I92 I and I938 figures fluctuated between 74.65 and $79.96 \%)^{763}$ were pronounced on this ground. Besides that, as from I93I, the relative number of divorces in Germany was constantly at least one and a half times as high as the Dutch number. ${ }^{764}$ Instead of solving 'the Big Lie', this ground would probably become 'the New Big Lie'. This assumption was strengthened by the fact that, because Article 256 BW would be abolished, this draft revision would allow for a divorce after three years of separation from bed and board, even if one of the partners disagreed. Because of this, the Supreme Court expected a yearly increase in divorces of io percent, and a few thousand extra cases in the first years after enactment of this revision. ${ }^{765}$ Besides the probable increase in divorce, the Court raised another objection with regard to the proposed abolition of Article 256 BW. By abolishing this article, divorce would become more likely after three years of separation from bed and board, effectively turning separation from

760 The advice sent to Schrieke was not a unanimous decision. The then president of the Supreme Court J. van Loon, appointed by the occupying forces, considered rejection of the draft on the ground of a possible violation of Article 43 of the Hague Regulations legally weak and on top of that a political argument. According to Van Loon only the occupying forces could decide whether they were 'absolutely prevented' to respect the laws in force in the Netherlands. It was not up to the Supreme Court to decide whether the occupying forces violated Article 43 of the Hague Regulations. J. Donner, however, disagreed. 'The only thing we have against the occupying forces are the Hague Regulations. They give us something to hold on to.' According to Donner the draft constituted a violation of Article 43 and the Supreme Court was surely entitled to point this out. See on this matter C.J.H. Jansen and D. Venema, De Hoge Raad in de Tweede Wereldoorlog, 148-149 and D. Venema, Rechters in Oorlogstijd, 280-281.

761 Statistical memorandum from the Dutch Supreme Court, (2 December 1943), 6, NIOD archives, access no. 020, inventory no. 2414 , subfolder 'Mede te zenden ambtsberichten, Departement van Justitie'.

762 The figures of 1941 are not given in the statistical memorandum, but only in the report from the Dutch Supreme Court to Schrieke, (2 December 1943), 4, NIOD archives, access no. 020, inventory no. 2414, subfolder 'Mede te zenden ambtsberichten, Departement van Justitie'.

763 Statistical memorandum from the Dutch Supreme Court, (2 December 1943), 5, NIOD archives, access no. 020, inventory no. 2414, subfolder 'Mede te zenden ambtsberichten, Departement van Justitie'.

764 Report from the Dutch Supreme Court to Schrieke, (2 December 1943), 4, NIOD archives, access no. 020, inventory no. 2414, subfolder 'Mede te zenden ambtsberichten, Departement van Justitie'. In the statistical memorandum a comparison between divorce figures in Europe is included, in which the Dutch divorce figure is listed as 19 (per 10,000 marriages) and the German as 32.1 (per 10,000 marriages), which would put the German divorce figure as almost 1.7 times as high as the Dutch. However, the Dutch divorce figures are from 1929-1932 and the German ones from 1932-1934, which makes the comparison somewhat biased. See Statistical memorandum from the Dutch Supreme Court, (2 December 1943), 4, NIOD archives, access no. 020, inventory no. 2414, subfolder 'Mede te zenden ambtsberichten, Departement van Justitie'.

765 Report from the Dutch Supreme Court to Schrieke, (2 December 1943), 4-5, NIOD archives, access no. 020, inventory no. 2414, subfolder 'Mede te zenden ambtsberichten, Departement van Justitie'. 
bed and board in to some sort of delayed divorce, but divorce nevertheless. This, however, would be unacceptable for the Catholic part of the nation (about one third of the Dutch population) to who divorce was off limits. Separation from bed and board, therefore, served as a compromise. ${ }^{766}$ In addition, the Supreme Court declared itself strongly against the introduction of the eighth ground - contagious or revolting disease. Such a disease could never form a ground for divorce, as precisely in such hard times, spouses would need to support each other. According to the Supreme Court such a provision would run counter to the religious and moral beliefs of the vast majority of the Dutch people. The fact that Schrieke had included the possibility for the judge to dismiss a request for divorce in case he considered it unreasonable hard-hearted to the partner who would be abandoned, only proved the injustice of the provision. ${ }^{767}$ Finally, the Court disagreed with the conviction that procreation was the main goal of marriage. It therefore declared ground nine - premature infertility - objectionable. Statistics furthermore showed that in the Netherlands about one out of every eight marriages remained childless. In spite of this, the Court did not expect a dramatic increase in the number of divorces, as German divorce figures showed that after this ground was introduced in I938, about 0.23 percent of the divorces was pronounced on that ground. ${ }^{768}$ The Supreme Court concluded its report by making a suggestion as how to solve 'the Big Lie', which solution would not be an extension of the grounds for divorce, but a revision of procedural rules. ${ }^{769}$ The slow procedure and criticism of the Supreme Court have probably contributed to the fact that in the end the draft has never been enacted. ${ }^{770}$

\subsubsection{Schrieke's second draft of 1944}

As a result of the responses received, Schrieke drafted a second revision, which he sent to Ministerialrat Karl N. Krug, who had succeeded Seiffert as head of the Hauptabteilung Justiz, on 8 June I944. He enclosed the responses ${ }^{771}$ and a new explanatory memorandum, designed for the press, after promulation of the revision. The underlying idea of this new draft was exactly the same as with the previous one: the existing reprehensible divorce practices caused by the Supreme Court's judgment of i 883, which made Article 263 BW - prohibiting divorce by mutual consent - a dead letter, whilst additionally, the

766 Report from the Dutch Supreme Court to Schrieke, (2 December 1943), 7, NIOD archives, access no. 020, inventory no. 2414 subfolder 'Mede te zenden ambtsberichten, Departement van Justitie'

767 Report from the Dutch Supreme Court to Schrieke, (2 December 1943), 5-6, NIOD archives, access no. 020, inventory no. 2414, subfolder 'Mede te zenden ambtsberichten, Departement van Justitie'.

768 Report from the Dutch Supreme Court to Schrieke, (2 December 1943), 6, NIOD archives, access no. 020, inventory no. 2414, subfolder 'Mede te zenden ambtsberichten, Departement van Justitie'. See also the Statistical memorandum from the Dutch Supreme Court, (2 December 1943), 7, NIOD archives, access no. 020, inventory no. 2414, subfolder 'Mede te zenden ambtsberichten, Departement van Justitie'.

769 Report from the Dutch Supreme Court to Schrieke, (2 December 1943), 8, NIOD archives, access no. 020, inventory no. 2414, subfolder 'Mede te zenden ambtsberichten, Departement van Justitie'.

770 P.E. Mazel, In naam van het Recht..., 53-54; C.J.H. Jansen and D. Venema, De Hoge Raad in de Tweede Wereldoorlog, 149; D. Venema, Rechters in Oorlogstijd, 281. According to J. van Loon, part of this ministering delay was due to him, as he - being President of the Supreme Court at that time - had managed only with a supreme effort to prevent enforcement of the draft in 1944. See J. van Loon, 'Een antwoord op de brochure van Mr. N.C.M. van den Dries: "De Hooge Raad der Nederlanden tijdens de bezetting"', in W.M.A. Weitjens, Ter informatie, 15-16.

771 Schrieke neatly listed all bodies the first draft was sent to, subsequently stating that he enclosed all received approbations, which he had taken into account when revising his draft proposal. However, in the light of what precedes it is evident that something can be said against these approbations. See letter from Schrieke to Krug, (8 June 1944), NIOD archives, access no. 020, inventory no. 2414. 
Dutch grounds for divorce were too confined, especially compared to other European countries. ${ }^{772}$ This second draft was more detailed than the previous one, although the majority of the proposed revisions concerned administrative changes. Nevertheless, Schrieke had taken the Code of Civil Procedure and the Criminal Code in hand as well.

In his letter to Krug Schrieke discussed the critical remarks he had received as a result of the previous draft. He firmly contradicted the allegation that a revision of divorce law would violate Article 43 of the Hague Regulations or Regulations 3/1940 and 23/1940. According to Schrieke $\mathbb{S} 2$ of Regulation 3/1940 was interpreted more broadly than allowed for by $\mathbb{\$} 5(2)$ of Decree I/I940 ${ }^{773}$ and $\mathbb{S}$ I of Regulation 3/1940, ${ }^{774}$ whilst $\mathbb{I}$ of Regulation 23/1940 and Article 43 of the Hague Regulations were interpreted too strict. However, in what way $\mathbb{\$} 5$ (2) of Decree I/1940 and $\mathbb{~ I ~ o f ~ R e g u l a t i o n ~ 3 / 1 9 4 0 ~ r e s t r i c t e d ~} \mathbb{} 2$ of Regulation 3/1940, Schrieke did not explain and even an objective and careful reading of these paragraphs does not reveal any restrictions in this respect. The interpretation of Article 43 of the Hague Regulations and of the phrase 'necessary to maintain public order and public security' and Schrieke's point of view on the matter have already been discussed extensively. Schrieke nevertheless had some sympathy for the remark that now was not the right moment to deal with such a fundamental matter as divorce, although he did point out that the considerations put forward in his draft revision had all been discussed before, and this undesirable legal pratice dragged on for more than fifty years already. The time was ripe for a revision. ${ }^{775}$

He furthermore criticised the Supreme Court's juggling with statistics. According to Schrieke the figures quoted by the Supreme Court only reflected an administrative reality. Figures with regard to juvenile delinquency, caused by disrupted marriages (which still existed on paper) were revealing in that respect. In addition, Schrieke denounced the numerous references to religious customs. The loss of common decency was well under way, enhanced by the current divorce practices. ${ }^{76}$ The religious argument with regard to the indissolubility of marriage was dismissed by Schrieke in any case. For decades the Netherlands already had a civil marriage, which was dissoluble, so that battle was fought. ${ }^{777}$

772 J.J. Schrieke, Toelichting (explanatory memorandum belonging to the second draft), 1944, 1, NIOD archives, access no. 020, inventory no. 2414. See also letter from Schrieke to Krug, (8 June 1944), NIOD archives, access no. 020, inventory no. 2414.

773 Erlaß des Führers über Ausübung der Regierungsbefugnisse in den Niederlanden vom 18. Mai 1940, Reichsgesetzblatt (1940), I, 778, § 5 (2): 'Der Reichskommissar kann durch Verordnung Recht setzen. Die Verordnungen werden im "Verordnungsblatt für die besetzten niederländischen Gebiete" verkündet.'

774 Verordnung des Reichskommissars für die besetzten niederländischen Gebiete über die Ausübung der Regierungsbefugnisse in den Niederlanden vom 29. Mai 1940, Verordnungsblatt für die besetzten niederländischen Gebiete (1940), 8, § 1: ‘(1) Der Reichskommissar für die besetzten niederländischen Gebiete übt, soweit dies zur Erfüllung seiner Aufgabe nötig ist, alle Befugnisse aus, die nach der Verfassungsurkunde und den Gesetzen bisher dem König und der Regierung zustanden. (2) Erheischen es die Interessen des Grossdeutschen Reiches oder der öffentlichen Ordnung oder des öffentlichen Lebens in den Niederlanden, so trifft der Reichskommissar die notwendigen Massnahmen, und zwar auch solche gesetzgeberischer Art. Diese Verordnungen des Reichskommissars haben Gesetzeskraft.'

775 Letter from Schrieke to Krug, (8 June 1944), point VI, NIOD archives, access no. 020, inventory no. 2414.

776 Letter from Schrieke to Krug, (8 June 1944), point IX, NIOD archives, access no. 020, inventory no. 2414.

777 Letter from Schrieke to Krug, (8 June 1944), point VII, NIOD archives, access no. 020, inventory no. 2414 
Schrieke ended his letter by stating that he was well aware of the fact that more objections could be raised. However, when time would come for the redevelopment of the Netherlands under the 'New Order', one would be grateful for all the work already finished then. ${ }^{778}$

Obviously, Article 264 BW was again subject to some changes, although compared to the previous draft, the article was not revised to a large extent. The addition to the first - already existing - ground, 'unless it is endured explicitly or tacitly by the other spouse', was removed again. The original text from the existing third ground, 'sentence to four years or more of imprisonment because of a crime', was replaced by 'sentence because of a degrading crime. ${ }^{779}$ The discussion about how to interpret the existing ground four was ended by simplifying the text, which read in the proposal: 'crime against life or grievous bodily harm, committed by one of the spouses against the other spouse. ${ }^{780}$ With regard to the proposed fifth ground - refusal to procreate - nothing substantial was changed compared to the previous draft. The proposed ground six from the previous draft was now transposed to place nine, all other grounds moved up one place. The term 'discord' was replaced by 'other serious facts, which have caused a permanent breakdown of the marriage'. ${ }^{781}$ Ground six (previously ground seven) - incurable insanity - was not substantially altered. Notwithstanding the negative responses of the denominations and the Supreme Court with regard to the grounds of contagious or revolting disease and premature infertility, Schrieke decided to keep these provisions, as in all these cases he considered the marriage as broken down. Continuation would not only be iniquitous, but would also cause a lot of suffering. ${ }^{782}$ Besides, the court could always decide otherwise, ${ }^{783}$ which was completely in accordance with the German law. ${ }^{784}$

778 Letter from Schrieke to Krug, (8 June 1944), point X, NIOD archives, access no. 020, inventory no. 2414.

779 J.J. Schrieke, Verordnung des Generalsekretärs im Ministerium für Justiz über die Ehescheidung, die Scheidung von Tisch und Bett und einige einschlägige Sachgegenstände, 1944, NIOD archives, access no. 020, inventory no. 2414, Article 1, I: '[...] 3) veroordeeling $[\ldots]$ wegens een onteerend misdrijf; [...].'

780 J.J. Schrieke, Verordnung des Generalsekretärs im Ministerium für Justiz über die Ehescheidung, die Scheidung von Tisch und Bett und einige einschlägige Sachgegenstände, 1944, NIOD archives, access no. 020, inventory no. 2414, Article 1, I: '[...] 4) misdrijf tegen het leven of zware mishandeling, door den eenen echtgenoot begaan jegens den anderen; [...].'

781 J.J. Schrieke, Verordnung des Generalsekretärs im Ministerium für Justiz über die Ehescheidung, die Scheidung von Tisch und Bett und einige einschlägige Sachgegenstände, 1944, NIOD archives, access no. 020, inventory no. 2414, Article 1, I: '[...] 9) andere ernstige feiten, welke tot een zoodanige ontwrichting van het huwelijk hebben geleid, [...].'

782 J.J. Schrieke, Toelichting (explanatory memorandum belonging to the second draft), 1944, 2, NIOD archives, access no. 020 , inventory no. 2414.

783 The new draft still included the provision, which allowed the court to deny a claim for divorce, which was submitted on ground six, seven, eight or nine, in case the other spouse would be disproportinately affected by a divorce or in case the court considered a divorce not justified from a moral point of view. The duration of the marriage, the age of the spouses and the cause of the disease, infertility or breakdown had to be taken into account in this respect. See J.J. Schrieke, Verordnung des Generalsekretärs im Ministerium für Justiz über die Ehescheidung, die Scheidung von Tisch und Bett und einige einschlägige Sachgegenstände, 1944, NIOD archives, access no. 020, inventory no. 2414, Article 1, I: ‘[...] In de gevallen, onder 60.-90. vermeld, zal de rechter de vordering tot echtscheiding afwijzen, wanneer de andere echtgenoot door echtscheiding onevenredig hard zou worden getroffen of de vordering anderszins uit zedelijk oogpunt niet gerechtvaardigd is. Bij de beoordeling hiervan zal met de begeleidende omstandigheden als den duur van het huwelijk, den leeftijd der echtgenooten en de oorzaak van de ziekte, de onvruchtbaarheid of de ontwrichting rekening moeten worden gehouden.'

784 Gesetz zur Vereinheitlichung des Rechts der Eheschließung und der Ehescheidung im Lande Österreich und im übrigen Reichsgebiet vom 6. Juli 1938, Reichsgesetzblatt (1938), I, 807, §54: ‘In den Fällen der §§ 50 bis 53 darf die Ehe nicht geschieden werden, wenn das Scheidungsbegehren sittlich nicht gerechtfertigt ist. Dies ist in der Regel dann ansunehmen, wenn die Auflösung der Ehe den anderen Ehegatten außergewöhnlich hart treffen würde. Ob dies der Fall ist, richtet sich nach den Umständen, namentlich auch nach der Dauer der Ehe, dem Lebensalter der Ehegatten und dem Anlaß der Erkrankung oder der Unfruchtbarkeit.' 
Although in his letter to Krug Schrieke had explained that he had sought alliance with the German Marriage Law, he had nevertheless held on to the legal concept of separation from bed and board, although this did not exist in the German Marriage Law. In the Netherlands, Schrieke explained, this concept was deeply rooted in national custom. However, the nature of the concept was changed in this draft revision. Originally, separation from bed and board was intended as an independent legal concept, a full alternative for divorce. In the new set-up separation from bed and board would merely serve as some sort of pre-phase, as a build-up to a full divorce. Therefore, separation from bed and board had to meet the same requirements as divorce, but could easier be converted into a full divorce. ${ }^{785}$

As in the previous draft, this draft revision proposed to abolish Article 288 (2) BW, which allowed for separation from bed and board in case of excesses, ill-treatments and serious insults by one spouse towards the other spouse. ${ }^{786}$ Furthermore, the procedure, which had to be followed in order to get a separation from bed and board, was simplified by abolishing Article $29 \mathrm{I}$ to $296 \mathrm{BW}^{787}$

Dissolution after separation from bed and board was simplified as well, by shortening the minimum term of separation before divorce could be requested from five to three years ${ }^{788}$ Furthermore, the draft revision again proposed to abolish Article 256, dismissing the possibility of having a dissolution after separation from bed and board being obstructed by one unwilling spouse. ${ }^{789}$ All these revisions had already been suggested by the first draft. Additionally, this draft proposed to simplify the reconciliation procedure, ${ }^{790}$ although the term 'reconciliation' was replaced by 'reunification'. ${ }^{791}$

The proposed revisions of marital property law largely remained the same in this draft, although Schrieke added a provision which stated that inheritances and donations to one of the spouses after the divorce suit was filed, were considered never to have been part of the community of property. ${ }^{792}$

The majority of the remaining revisions of the Civil Code concerned small, individual changes. The five-year term in Article 266 was reduced to three years as well. ${ }^{793}$ The distinction between man and woman was largely abrogated e.g. in the Articles 267 and

785 Letter from Schrieke to Krug, (8 June 1944), point III, NIOD archives, access no. 020, inventory no. 2414.

786 J.J. Schrieke, Verordnung des Generalsekretärs im Ministerium für Justiz über die Ehescheidung, die Scheidung von Tisch und Bett und einige einschlägige Sachgegenstände, 1944, NIOD archives, access no. 020, inventory no. 2414, Article 2, I.

787 J.J. Schrieke, Verordnung des Generalsekretärs im Ministerium für Justiz über die Ehescheidung, die Scheidung von Tisch und Bett und einige einschlägige Sachgegenstände, 1944, NIOD archives, access no. 020, inventory no. 2414, Article 2, III.

788 J.J. Schrieke, Verordnung des Generalsekretärs im Ministerium für Justiz über die Ehescheidung, die Scheidung von Tisch und Bett und einige einschlägige Sachgegenstände, 1944, NIOD archives, access no. 020, inventory no. 2414, Article 3, I.

789 J.J. Schrieke, Verordnung des Generalsekretärs im Ministerium für Justiz über die Ehescheidung, die Scheidung von Tisch und Bett und einige einschlägige Sachgegenstände, 1944, NIOD archives, access no. 020, inventory no. 2414, Article 3, II.

790 J.J. Schrieke, Verordnung des Generalsekretärs im Ministerium für Justiz über die Ehescheidung, die Scheidung von Tisch und Bett und einige einschlägige Sachgegenstände, 1944, NIOD archives, access no. 020, inventory no. 2414, Article 3, III-V.

791 See e.g. J.J. Schrieke, Verordnung des Generalsekretärs im Ministerium für Justiz über die Ehescheidung, die Scheidung von Tisch und Bett und einige einschlägige Sachgegenstände, 1944, NIOD archives, access no. 020, inventory no. 2414, Article 2, V.

792 J.J. Schrieke, Verordnung des Generalsekretärs im Ministerium für Justiz über die Ehescheidung, die Scheidung von Tisch und Bett und einige einschlägige Sachgegenstände, 1944, NIOD archives, access no. 020, inventory no. 2414, Article 1, IX.

793 J.J. Schrieke, Verordnung des Generalsekretärs im Ministerium für Justiz über die Ehescheidung, die Scheidung von Tisch und Bett und einige einschlägige Sachgegenstände, 1944, NIOD archives, access no. 020, inventory no. 2414, Article 1, III. 
268, which dealt with leaving the marital home and a possible right to maintenance during the legal proceedings. ${ }^{794}$ A newly proposed Article $62 \mathrm{~b}$ stated that a woman would go under the name of her husband, which she would keep after she was widowed. She would regain her own family name after divorce or dissolution after separation from bed and board. ${ }^{795}$

The final proposed revisions directly saw upon abolishing 'the Big Lie'. Both Article $265^{796}$ and $274^{797} \mathrm{BW}$ were abrogated, ${ }^{798}$ dismissing the possibility to side-step the formal divorce procedure in case of adultery or four years imprisonment. Furthermore, Schrieke proposed to include a new Title six A in the fourth Book of the Civil Code. ${ }^{799}$ This Title - containing the Articles I982a to I982e - declared the previous six Titles of the fourth Book not applicable to cases of divorce, separation from bed and board and dissolution after separation from bed and board, as long as the cases did not deal with marital property law. The main consequence of this new Title would be the abrogation of the adversarial role of the judge. As seen before, in the previous draft this abrogation was only expressed in a small addition to Article 264. The newly proposed Article I982b stated that, during the legal proceedings, the court was no longer passive but could actively collect and estimate evidence. ${ }^{800}$ Furthermore, according to the newly proposed Article i982c, the judge could even ex officio summon witnesses and order submission of evidence. ${ }^{801}$

This abrogation of the adversarial role of the judge was also the main proposed revision in the Code of Civil Procedure, as well as some small technical changes, like replacing the word 'reconciliation' with 'reconstruction' in Article 8 I9 (I) Rv. ${ }^{802}$ With regard to solving the problem of 'the Big Lie' and in an attempt to prevent divorces on fictitious

794 J.J. Schrieke, Verordnung des Generalsekretärs im Ministerium für Justiz über die Ehescheidung, die Scheidung von Tisch und Bett und einige einschlägige Sachgegenstände, 1944, NIOD archives, access no. 020, inventory no. 2414, Article 1, IV.

795 J.J. Schrieke, Verordnung des Generalsekretärs im Ministerium für Justiz über die Ehescheidung, die Scheidung von Tisch und Bett und einige einschlägige Sachgegenstände, 1944, NIOD archives, access no. 020, inventory no. 2414, Article 4, I.

796 Article 265 stated that in case one of the partners was convicted for adultery or, because of an other crime, to four years imprisonment, only a copy of that judgment was required to get a divorce. See Article 265 BW: 'Wanneer een der echtgenooten tot eenige straf is verwezen, bij een vonnis, waaruit van een begaan overspel blijkt, zal men tot het bekomen van echtscheiding geene andere formaliteiten behoeven in acht te nemen, dan dat aan de arrondissements-regtbank een afschrift van dat vonnis worde aangeboden, met bij voeging van het bewijsschrift dat hetzelve vonnis door geen wettige regtsmiddelen aan eenig beroep onderworpen is. Deze bepaling is insgelijks toepasselijk, wanneer de echtscheiding gevraagd wordt uit hoofde van de veroordeeling van één der echtgenooten wegens misdrijf tot eene vrijheidsstraf van vier jaren of langer.'

797 Article 274 stated that this copy had to be lodged with the court within six months after the judgment had been passed. See Article 274 BW: 'Indien in de beide gevallen, bij artikel 265 voorzien, de echtgenoot zes maanden heeft laten verloopen, te rekenen van den dag waarop het vonnis kracht van gewijsde bekomen heeft, is hij niet meer ontvankelijk om eene regtsvordering tot echtscheiding aan te vangen. [...].'

798 J.J. Schrieke, Verordnung des Generalsekretärs im Ministerium für Justiz über die Ehescheidung, die Scheidung von Tisch und Bett und einige einschlägige Sachgegenstände, 1944, NIOD archives, access no. 020, inventory no. 2414, Article 1, II and VIII.

799 J.J. Schrieke, Verordnung des Generalsekretärs im Ministerium für Justiz über die Ehescheidung, die Scheidung von Tisch und Bett und einige einschlägige Sachgegenstände, 1944, NIOD archives, access no. 020, inventory no. 2414, Article 4, IX.

800 J.J. Schrieke, Verordnung des Generalsekretärs im Ministerium für Justiz über die Ehescheidung, die Scheidung von Tisch und Bett und einige einschlägige Sachgegenstände, 1944, NIOD archives, access no. 020, inventory no. 2414, Article 4, IX, Article 1982b: 'In zaken, rakende scheiding des huwelijks, [...] is de rechter geheel vrij in het verzamelen en het waardeeren van het bewijs.'

801 J.J. Schrieke, Verordnung des Generalsekretärs im Ministerium für Justiz über die Ehescheidung, die Scheidung von Tisch und Bett und einige einschlägige Sachgegenstände, 1944, NIOD archives, access no. 020, inventory no. 2414, Article 4, IX, Article 1982c: 'De rechter kan ambtshalve getuigen dagvaarden en de overlegging van bewijsmateriaal gelasten.'

802 J.J. Schrieke, Verordnung des Generalsekretärs im Ministerium für Justiz über die Ehescheidung, die Scheidung von Tisch und Bett und einige einschlägige Sachgegenstände, 1944, NIOD archives, access no. 020, inventory no. 2414, Article 5, V. 
grounds, ${ }^{803}$ Schrieke proposed an entirely new text for Article $822 \mathrm{Rv}$, which now stated that even in case of default, the court would only sustain the claim in case the legitimacy and validity of the claim had been proven conclusively. ${ }^{804}$ Furthermore, after Article $827 \mathrm{a}$ Rv five new articles were included, of which the newly drafted Article $827 \mathrm{~b}$ stated that in divorce cases the court was no longer bound by the facts presented by the parties. ${ }^{805}$ The proposed Article $827 \mathrm{~d}$ stated that the judge could obtain the advice of official bodies and private individuals. $^{806}$

Finally, Schrieke proposed one alteration in the Criminal Code, which revision was in keeping with the abrogation of the adversarial role of the court. The newly drafted Article I93a Sr stated that someone who did not obey the judicial order to submit evidence in divorce cases, was liable to a maximum of four months imprisonment. ${ }^{807}$

To what extent had Schrieke, by drafting his revision of Dutch divorce law, been influenced by National Socialism? In the foregoing it has already been explained that Schrieke's first draft was definitely affected by National Socialism, in particular with regard to the grounds for divorce. In his explanatory memorandum Schrieke presented his second draft - again - as a solution to 'the Big Lie'. ${ }^{808}$ Widening the grounds for divorce had been pleaded before several times as we have seen and the abrogation of the adversarial role of the court resulted from the wish to put an end to this judicial monstrosity as well. However, both in his letter to Krug and his explanatory memorandum Schrieke admitted that he had sought alliance with the new German Marriage Law ${ }^{809}$ and this clearly appears from the draft. Before the war Dutch lawyers had already pleaded for the inclusion of insanity as ground for divorce. Schrieke adopted this point of view, but added several extra grounds which had not been discussed in the Netherlands before in such an extensive way. The Christian notion of marriage as an eternal bond between two persons through fair and foul was brushed aside by Schrieke. He kept his ground that one of the prime foundations of marriage - its natural purpose - was procreation. ${ }^{810}$

803 J.J. Schrieke, Toelichting (explanatory memorandum belonging to the second draft), 1944, 2, NIOD archives, access no. 020, inventory no. 2414

804 J.J. Schrieke, Verordnung des Generalsekretärs im Ministerium für Justiz über die Ehescheidung, die Scheidung von Tisch und Bett und einige einschlägige Sachgegenstände, 1944, NIOD archives, access no. 020, inventory no. 2414, Article 5, VIII: ‘[...] Artikel 822. De rechter wijst, ook in geval van verstek, de vordering slechts toe, indien zijn bevoegdheid, en de rechtmatigheid en gegrondheid van de vordering hem overtuigend zijn gebleken. [...]'.

805 J.J. Schrieke, Verordnung des Generalsekretärs im Ministerium für Justiz über die Ehescheidung, die Scheidung von Tisch und Bett und einige einschlägige Sachgegenstände, 1944, NIOD archives, access no. 020, inventory no. 2414, Article 5, XV: '[...] Artikel $827 \mathrm{~b}$. In gedingen, rakende de scheiding des huwelijks, is de rechter bij zijn onderzoek niet beperkt tot de feiten, welke door partijen zijn aangevoerd. [...]'.

806 J.J. Schrieke, Verordnung des Generalsekretärs im Ministerium für Justiz über die Ehescheidung, die Scheidung von Tisch und Bett und einige einschlägige Sachgegenstände, 1944, NIOD archives, access no. 020, inventory no. 2414, Article 5, XV: '[ ...] Artikel 827d. De rechter kan in deze gedingen het advise inwinnen van ambtelijke instanties en particuliere personen. [...]'.

807 J.J. Schrieke, Verordnung des Generalsekretärs im Ministerium für Justiz über die Ehescheidung, die Scheidung von Tisch und Bett und einige einschlägige Sachgegenstände, 1944, NIOD archives, access no. 020, inventory no. 2414, Article 6: '[...] Artikel 193a. Hij die opzettelijk in gedingen, rakende scheiding des huwelijks, niet voldoet aan een rechterlijke last tot overlegging van bewijsmateriaal, wordt gestraft met gevangenisstraf van ten hoogste vier maanden.'

808 J.J. Schrieke, Toelichting (explanatory memorandum belonging to the second draft), 1944, 1-2, NIOD archives, access no. 020 , inventory no. 2414.

809 Letter from Schrieke to Krug, (8 June 1944), point II, NIOD archives, access no. 020, inventory no. 2414; J.J. Schrieke, Toelichting (explanatory memorandum belonging to the second draft), 1944, 3, NIOD archives, access no. 020, inventory no. 2414.

810 J.J. Schrieke, Toelichting (explanatory memorandum belonging to the second draft), 1944, 2, NIOD archives, access no. 020, inventory no. 2414; J.J. Schrieke, Erläuterung des Verordnungsentwurfs, 1942, 4, NIOD archives, access no. 020, inventory no. 2414. 
In his explanatory memorandum belonging to the first draft Schrieke had already stated that in a healthy Volksgemeinschaft it should be possible to get a divorce in case one of the partners refused to procreate. When a marriage had lost its value to the community, divorce would be the only option. ${ }^{811}$ From his letter to Krug it appeared that Schrieke considered adapting Dutch matrimonial law along the lines of National Socialism inevitable. He even indicated to take courage from the idea that, despite objections raised now, one would be grateful for all the work already finished when time would come for the redevelopment of the Netherlands under the 'New Order'. ${ }^{812}$

However, whether nazificating divorce law was the starting point of his draft revisions remains to be seen. The need for a revision of Dutch divorce law was evident, both to proponents and opponents of divorce. Although the timing was definitely off, Schrieke's considerations are to a certain extent not that unreasonable, in particular not in the light of the last failed attempt of 1938 . To some extent Schrieke just resumed the thread where it had been dropped by Goseling. This impression is strengthened by the fact that none of Schrieke's drafts made any mention of mixed marriages, nor did they seem to give the possibility to dissolve mixed marriages through indirect ways. Contrary to the German Marriage Law ${ }^{813}$ Schrieke's drafts did not contain an article which allowed for divorce because of permanent breakdown of the marriage because of unspecified reasons. On the contrary, no divorce remained the basic principle, judging by the fact that Schrieke did not touch the prohibition of divorce by mutual consent.

However, although perhaps not the starting point, with his draft revision Schrieke nevertheless would have provided the occupying forces with a strong tool to restructure Dutch family life according to National Socialist principles. With a view to a possible annexation of the Dutch sister nation to the Aryan Third Reich, the need for this restructure was evident.

\subsubsection{The aftermath of Schrieke's drafts}

Krug forwarded Schrieke's second draft to Seyss-Inquart via Wimmer on 6 July $1944,{ }^{814}$ listing all existing problems in the field of matrimonial law (albeit exaggerated to a certain extent) and emphasising the fact that Schrieke's draft aimed at solving all these problems. Krug indicated that opposition to these revisions was to be expected. However, he was convinced that the majority of these objections would run dry. Others he dismissed as not important. Although he did not call a spade a spade, Krug dismissed the argument that a revision of divorce law during the occupation would be a violation of Article 43 of the Hague Regulations by quoting Schrieke: "bekannte Worte, die durch fortgesetzte

811 J.J. Schrieke, Erläuterung des Verordnungsentwurfs, 1942, 3-4, NIOD archives, access no. 020, inventory no. 2414.

812 Letter from Schrieke to Krug, (8 June 1944), point X, NIOD archives, access no. 020, inventory no. 2414.

813 See Gesetz zur Vereinheitlichung des Rechts der Eheschließung under der Ehescheidung im Lande Österreich und im übrigen Reichsgebiet vom 6. Juli 1938, Reichsgesetzblatt (1938), I, 807, § 55 (1): 'Ist die häusliche Gemeinschaft der Ehegatten seit drei Jahren aufgehoben und infolge einer tiefgreifenden unheilbaren Zerrüttung des ehelichen Verhältnisses die Wiederherstellung einer dem Wesen der Ehe entsprechenden Lebensgemeinschaft nicht zu erwarten, so kann jeder Ehegatte die Scheidung begehren.'

814 Letter from Krug to Seyss-Inquart via Wimmer, (6 July 1944), NIOD archives, access no. 020, inventory no. 2414. 
Wiederholung nicht überzeugender werden. ${ }^{815}$ Krug did not expect serious troubles with the denominations and the courts. Although the denominations did not fully agree with the intended revision, both Schrieke and Krug were convinced that in due course they would give in. With regard to the courts, Schrieke had ruled out the possibility that the regulation would be undermined. Both the denominations and the courts could hardly deny the problems the current situation posed. ${ }^{816}$ The position of the NSB, however, was still unclear. Both the Institute for Judicial Reform and the Rechtsfront had approved of the draft revision, but Fruin had at the same time indicated that, by order of Mussert, the recommendations given by the Institute for Judicial Reform and the Rechtsfront should not automatically be regarded as a reflection of the opinion of the NSB, in particular not when it concerned the political and religious part of the matter. ${ }^{817}$ Krug suspected that Mussert preferred to wait with promulgation of substantive amendments of the law until he had assumed power. In his letter Krug indicated that Schrieke would contact Mussert personally on the matter and that Schrieke was furthermore convinced that Mussert would consent to the draft revision. Furthermore, Krug emphasised that the revision of divorce law was an internal Dutch affair, which did not affect the interests of the occupying forces. The initiative had been fully taken by Schrieke, who had considered this task his life-task-project. Nevertheless, the time was right to enact such a regulation, although Krug admitted that with regard to the state of affairs of the war other things might be more important. As no Dutch parliament nor political parties would hinder the enactment however, this was perhaps the moment to finish the long-anticipated reform Furthermore, Kurg expected that the fact that, despite all hostile invasion threats, the occupying forces would succeed in 'an act of peaceful construction', would surely impress. Krug finished by requesting permission to pass the draft revision. ${ }^{818}$

Krugs final argument was supported by Wimmer, who was afraid that Seyss-Inquart considered the revision of Dutch divorce law unimportant in the light of the state of affairs of the war. ${ }^{819}$ This also appears from a letter from Krug to the German Reich Ministry of Justice from I2 January I945. Krug forwarded Schrieke's proposal to Ministerialdirektor (deputy secretary at the Reich Ministry of Justice) Josef Altstötter, stating that, since Seyss-Inquart had decided against enactment of the proposal as he considered the moment not opportune, he hoped that Altstötter would find the time to study the draft. Krug again emphasised the importance of the draft and the fact that the necessity of a revision of Dutch divorce law was generally acknowledged in the Netherlands. ${ }^{820}$ However, the war position of Germany rapidly deteriorated in I945, which left the proposal lying on the desks. At the Luneburg Heath on Friday 4 May 1945 admiral Von Friedeburg signed for the capitulation of the German troops in North-West

815 'known words, which will not become more convincing by repetition'. Letter from Krug to Seyss-Inquart via Wimmer, (6 July 1944), 3, NIOD archives, access no. 020, inventory no. 2414. Quote taken from letter from Schrieke to Krug, (8 June 1944), point VI, NIOD archives, access no. 020, inventory no. 2414.

816 Letter from Krug to Seyss-Inquart via Wimmer, (6 July 1944), NIOD archives, access no. 020, inventory no. 2414.

817 Letter from H.M. Fruin to Schrieke, (6 March 1943), NIOD archives, access no. 020, inventory no. 2414, subfolder 'Mede te zenden ambtsberichten, Departement van Justitie'.

818 Letter from Krug to Seyss-Inquart via Wimmer, (6 July 1944), NIOD archives, access no. 020, inventory no. 2414.

819 Letter from Wimmer to Seyss-Inquart via Harster, (2 August 1944), NIOD archives, access no. 020, inventory no. 2414.

820 Letter from Krug to Altstötter, (12 January 1945), NIOD archives, acces no. 020, inventory no. 2414. 
Europe, including the Netherlands. ${ }^{821}$ General Blaskowitz signed the elaborate conditions for capitulation on Sunday 6 May I $945{ }^{822}$ Schrieke's proposal for the revision of Dutch divorce law has therefore never been enacted.

\subsection{Conclusion}

In order to answer the question to what extent Dutch marriage and divorce law has been influenced by National Socialism we had to determine the existing regulations concerning marriage and divorce at the time of the German invasion, the applicable rules concerning occupation, the administrative situation of the Netherlands and the measures concerning marriage and divorce law implemented by the occupying forces.

\section{- 4.4.1. Dutch marriage and divorce law before the German occupation}

The Dutch Civil Code of I 838 only recognised secular civil marriages. Church marriages were allowed, but only after a civil marriage had been concluded. Furthermore, church marriages did not have legal consequences. That especially the Roman Catholic Church was still very influential in legislative circles, can be seen in the stringency of Dutch divorce law. Divorce with mutual consent was explicitly prohibited. The guilt principle was the basic principle, only allowing for divorce in case of adultery, desertion with malicious intent, sentence to a degrading punishment and ill-treatment or serious injuries inflicted by the other spouse, causing a threat of life. Those who did not want to divorce because of religious reasons, but could not live with their partner anymore either, could separate from bed and board.

The strictness of Dutch divorce law had already been under discussion, the moment the German occupying forces invaded the Netherlands. Especially the prohibition of divorce by mutual consent was frowned upon, as some, in particular the proponents of the so-called 'Free Marriage', were of the opinion that since marriages could deteriorate without one of the partners being specifically guilty of something, divorce with mutual consent on the ground of permanent breakdown of the marriage should be possible. We have seen that in practice this prohibition was side-stepped, either through a separation from bed and board by mutual consent after a minimum of two years of marriage, followed by dissolution of the marriage after another five years, or through the so-called 'Big Lie', made possible by a judgement of the Dutch Supreme Court in I883. However, although this judgement proved to be a solution for many couples requesting a divorce, everyone even the ones in favour of divorce by mutual consent - agreed that this construction did not deserve the beauty prize. It made evidently clear though, that the Netherlands was in need of a revision of divorce law.

821 L. de Jong, Het Koninkrijk der Nederlanden in de Tweede Wereldoorlog, 10b:1331.

822 L. de Jong, Het Koninkrijk der Nederlanden in de Tweede Wereldoorlog, 10b:1359. The full text of the conditions for capitulation is published in the report of the Enquêtecommissie Regeringsbeleid 1940-1945, Verslag houdende de uitkomsten van het onderzoek, part 5b, Ministers- en kabinetscrises, voorbereiding terugkeer (Staten-Generaal, militair gezag, vertrouwensmannen), 581-583. 


\section{- 4.4.2. The law of occupation and the German civil administration in the Netherlands}

Article 43 of the Regulations Respecting the Laws and Customs of War on Land of 1907 obliged occupying forces to restore and ensure, as far as possible, public order and civil life, whilst respecting, unless absolutely prevented, the laws in force in the occupied territories. The exact scope of this article has been brought up for discussion, especially after the end of the Second World War. The goal of this article was to guarantee the continuation of everyday life, without civilians having to be afraid to be used for war purposes. However, occupying forces have to protect their own war interests as well, causing reality to be at odds with theory. Furthermore, in case of a prolonged occupation occupying forces will have to turn into policy makers and legislators, in particular in order to prevent the national economy from collapsing.

Bearing this in mind, the German civil administration can be regarded a violation of Article 43 of the Hague Regulations, just like the German decree stating that the existing Dutch legislation would remain in force as far as this legislation would be compatible with the goals of the occupation. Furthermore, we have seen that the German occupying forces have implemented many regulations of which it is questionable whether they were necessary to restore and ensure public order and civil life. The majority of the regulations concerning Jews certainly did not qualify as thus. However, in this respect it has to be noted that a considerable part of the anti-Jewish policy was not introduced through legislation, but through police regulations.

\section{- 4.4.3. Marriage and divorce law and the position of Jews in that respect during the German occupation}

The definition of Jew as it was established in October 1940 has been used throughout the occupation. Although the concepts of half-Jews (persons having two Jewish grandparents) and quarter-Jews (persons having only one Jewish grandparent) were used in practice, these terms were never officially defined. As in Germany, the occupying forces have struggled with the definition of Jew, especially with regard to half-breeds. Several quibblers have tried to equate half-Jews with full-Jews. However, this was strongly disapproved of by the authorities in Berlin and every proposal or draft with regard to this idea was immediately shot down.

Another problem the German authorities in the Netherlands struggled with was the way to establish whether the grandparents of a person had been Jewish or not. Grandparents were considered to be full-Jewish in case they (had) adhered to the Jewish religious community. In Germany no proof to the contrary by means of proof of lineage of the grandparents was allowed, as the Reich Citizenship Law did not recognise the concept of Achteljuden (one-eight-Jews). However, in the Netherlands this proof to the contrary was allowed on the initiative of Dr. Wander, which only made the situation even more confusing. The problem was that the National Socialists tried to come up with a racial definition of Jew in which the blanks had to be filled in by religious facts; in this way it is impossible to come up with a watertight definition. In case of doubts one had to apply to Dr. Calmeyer, a controversial figure, who is internationally praised (including a posthumously distinction by Yad Vashem) for supposedly saving approximately 3700 
Jews, by giving them a different 'status'. Some historians, however, doubt this. Stuldreher leaves it at approximately 50 saved Jews, whilst an at least equally large group got a more unfavourable status through Calmeyers agency.

Apart from struggling with the definition of Jew, the German authorities have struggled with a prohibition of mixed marriages as well. The occupying forces have tried several times to introduce the Nuremberg Laws, in particular the Blood Protection Law and the First Supplementary Decree to the Blood Protection Law, in the Netherlands. However, they have never succeeded in adopting laws prohibiting marriages and sexual intercourse between non-Jews and (several degrees of) Jews. Instead, the occupying forces issued a police regulation in March 1942, published in Het Joodsche Weekblad, that prohibited marriages between Jews ( $\mathrm{J}_{2}, \mathrm{~J}_{3}$ and $\left.\mathrm{J}_{4}\right)$ and non-Jews. With regard to marriages between half-Jews and quarter-Jews on the one hand and half-Jews, quarter-Jews and non-Jews on the other hand no official rules have ever been issued. However, in January I943 a circular was issued by secretary-general of Justice Jaap Schrieke to the Dutch registrars, stating that they should report all announced marriages between a) Jews and non-Jews, b) half-Jews (G I) and non-Jews, c) Jews and quarter-Jews, d) half-Jews (G I) amongst themselves, e) half-Jews (G I) and quarter-Jews and f) quarter-Jews amongst themselves at Referat IV B 4 at the Sicherheitspolizei in the Hague. The Sicherheitspolizei subsequently arrested both partners in case such a report was made. Furthermore, the occupying forces have never wanted to prevent marriages between half-Jews and full-Jews, as by concluding a marriage with a full-Jew, the status of the half-Jew changed from half-Jew (G I) to full-Jew (J2), thereby ending his privileged position. This prohibition of mixed marriages was a violation of the secular civil marriage, as Dutch marriage law did not distinguish between marriage partners on the ground of religion. However, the National Socialists did not consider mixed marriages to be a religious affair, but a racial one.

Interestingly enough, the occupying forces have tried to introduce the status of privileged mixed marriage for all already existing mixed marriages that had produced children, or mixed marriages without children in which the woman was Jewish. Although the status of privileged mixed marriage has never been formally introduced, those who would have fallen under the scope of this regulation were offered the opportunity to have themselves registered as potentially privileged mixed married, in order to escape deportation. However, this has only partially worked out. In this respect the occupying forces have tried to introduce sterilisation (of the Jewish partner) as alternative for deportation. Additionally, it has been tried to facilitate divorce for the benefit of the nonJewish partner.

Professor Jaap Schrieke, who, as secretary-general of Justice, has substantially contributed to the legislative attempts to prohibit mixed marriages, has attempted to revise Dutch divorce law. The German, National Socialist model served as an example in this respect, although Schrieke indicated that revision of Dutch divorce law was necessary anyhow and had become even more necessary since the 'Big Lie' judgement of the Dutch Supreme Court in I883. Although Schrieke kept the existing grounds for divorce, based on the guilt principle, he added several new grounds, of which the basis 
was the breakdown principle. The German Marriage Law of 1938 served as an example in this respect. However, as with the Marriage Law, Schrieke did not include a general breakdown article. Furthermore, although Schrieke admitted that with his draft he had sought alliance with the new German Marriage Law, it remains to be seen whether nazification of Dutch divorce law was the starting point. We have seen before that Dutch divorce law was in need of a revision, and several of the grounds introduced by Schrieke had been discussed before. Although some articles seemed to include a direct link to the National Socialist idea of Volksgemeinschaft, Schrieke did not include a possibility to dissolve mixed marriages on the mere ground of racial differences. Furthermore, since Schrieke kept the explicit prohibition of divorce by mutual consent, 'no divorce' seemed to remain the basic principle. In the end, though the motive for extending the grounds for divorce can partially be regarded as influenced by National Socialism, the proposed grounds themselves could hardly be considered like that.

It furthermore remains to be seen whether the proposed revision of divorce law would really have made it to the law books, considering the difficulties with the implementation of e.g. the Nuremberg Laws. Although the occupying forces could hardly be called 'sensitive', they were hesitant with regard to implementing drastic racial laws, as this could lead to social upheaval. On the other hand, Schrieke's revision of divorce law could hardly be called anti-Jewish. However, although the discussion was going on for several decades already, the Netherlands was perhaps not yet ready for accepting an extension of the grounds for divorce. In the end it took until I97I before the guilt principle was replaced by the breakdown principle, also allowing for divorce by mutual consent. ${ }^{823}$

In the end we can say that the attitude of the occupying forces towards Dutch marriage and divorce law has been ambivalent. In general, although Article 43 of the Hague Regulations has certainly not been respected, the occupying forces have taken the reception of the Dutch population into account when promulgating regulations. Not because of the restrictions of Article 43, but in order to avoid social upheaval. After all, when your goal is to slowly win the population over, causing a stir is not the wisest move. This had led to complications when coming up with a watertight definition of Jew and has prevented the enactment of the Nuremberg Laws.

On the other hand, amongst the occupying forces in the Netherlands quibblers have certainly tried to enact German racial laws in the Netherlands, sometimes even suggesting more stringent rules than existed in Germany. Basically, some Germans in the Netherlands have tried to be 'more Catholic than the Pope', or, to keep it within the theme, 'more brown than Hitler'. Dutch civil servants have facilitated this hair-splitting.

In reality, we can conclude that family life certainly was influenced by the occupying forces, and therefore by National Socialism.

823 Wet van 6 mei 1971, houdende herziening van het echtscheidingsrecht, Staatsblad (1971), No. 290. 
V.

Conclusion 
Has family law, in particular marriage and divorce law, been influenced by National Socialism?

Before we can answer this main question, some subquestions had to be answered first. To start with, we had to answer - as far as possible - the question what National Socialism entails. What role did the family play in National Socialism? Secondly, we had to establish what family policy and matrimonial law entailed before the National Socialist take-over in 1933 (respectively I940 for the Netherlands). Thirdly, we had to establish what kind of family policy was pursued by the National Socialists and what kind of family law measures they have issued, both in Germany and in the Netherlands. With regard to the Netherlands, we also had to answer the question whether the occupying forces were allowed to change then existing Dutch family law.

In the previous chapters and subconclusions I have tried to answer these questions. Now the main question has to be answered. This will happen through three steps: first a small summary of the findings on the question what National Socialism entailed will be given. Secondly, the main 'achievements' of the National Socialists will briefly be summarised. Finally, the main question of this research will be answered. 


\subsection{National Socialism - the family as germ-cell of the nation}

In the second chapter it has been determined that four elements of thought have influenced or at least inspired National Socialism: völkish nationalism, Social Darwinism, racial hygiene (eugenics) and anti-Semitism. All those four elements somehow return in National Socialism.

The element of völkish nationalism can be seen in the key role the Volk played in National Socialism. The Volk had to be preserved and strengthened. For this purpose a Volksgemeinschaft had to be created in which the public interest would prevail over the rights and interests of the individual. Inferior elements - Jews, but also 'Gypsies' (Roma and Sinti), homosexuals, communists or simply 'weak' people - had to be eliminated from society. Marriage and the family were regarded as the 'germ-cell of the nation'. Three goals were deduced from this basic principle: I) keeping the Aryan race pure, 2) keeping the Aryan race healthy and 3) expansion of the Aryan race. In the first goal the elements of racial hygiene and anti-Semitism can be recognised. Keeping the Aryan race pure had to be achieved by preventing the 'mingling' of pure, Aryan blood, with inferior blood. Especially Jewish blood was regarded detrimental for the quality of the Volk. Marriages and sexual relationships between Aryans and Jews were regarded as fundamentally wrong. Secondly, all 'weak' elements, especially those suffering from hereditary disorders, had to be filtered out by means of eugenics. The influence of Social Darwinism is strongly visible here. The third goal, finally, could only be achieved by the Volk itself, which had to start breeding fast. The immortality of the German Volk, the Aryan race, could not be guaranteed without a future generation.

\subsection{National Socialism in practice}

In what ways have the National Socialists tried to achieve their goals?

We have seen that National Socialist population and family policy was strongly pronatal. Motherhood was idolised and financial benefits were introduced to encourage Aryan couples to procreate. However, the National Socialists can hardly be called pioneers in this respect. German society was not unfamiliar with pro-natal government policies. Emphasising traditional family life, idolising motherhood and stimulating the nation's birth-rate through financial incentives had all happened during the Weimar years already. The fanaticism and meticulousness with which these measures were applied by the National Socialists, however, was new.

Furthermore, although it had been discussed during the politically turbulent Weimar years several times already, the National Socialists managed to indeed widen the grounds for divorce in the Ehegesetz of 1938 . The motive behind this amendment was a community argument; marriages that no longer were of any value to the Volksgemeinschaft (i.e. no (more) offspring was likely to be born) had to be dissolved, thereby enabling the expartners to still fulfil their moral obligation to the Volksgemeinschaft by allowing them to marry someone else. Although the guilt principle remained the leading basis for the grounds for divorce, the breakdown principle was now conditionally introduced. A general provision allowing for divorce in case the partners considered the marriage to be permanently disrupted was still considered one step too far. Furthermore, a divorce should not be granted to solve the individual problems of the partners, but to solve the 
problems the marriage would pose for the Volksgemeinschaft in case the partners were forced to stay together. Refusal to procreate became a ground for divorce, based on the presumption that such a refusal would cause a permanent breakdown of the marriage. The same line of reasoning was applied to the ground of 'premature infertility'. Although the infertile partner could hardly be blamed for the fact that he or she was infertile, this condition was considered to have such devastating consequences for the wedded bliss, that divorce was allowed. Other new grounds for divorce became disruptive acts caused by a mental disturbance leading to a permanent disruption of the marriage and a contagious or revolting disease. Although these changes were presented as being introduced out of compassion for the unfortunate, healthy spouse, the main reason was to assure offspring.

The Aryan race was not meant to be increased at all costs. National Socialist family policy proved to be very selective, even within its own ranks. The application of eugenics in order to solve social problems had already been discussed during the Weimar years, but lost its voluntary character after the National Socialist take-over. The Gesetz zur Verhütung erbkranken Nachwuchses from 1933, which ordered compulsory sterilisation of hereditary ill people and alcoholics, and the 1935 Gesetz zum Schutze der Erbgesundheit des deutschen Volkes, which prohibited marriages between healthy Aryans and sick or unstable people, Aryan or not, both served the 'health' of the Aryan race, by trying to prevent the generation of hereditary 'unfit' children. Abortion was carried out, even up until the end of the sixth month of the pregnancy, in case a child which was expected to be hereditary unfit was conceived anyhow. Although formally consent of the woman concerned was necessary, that requisite was often ignored in practice.

Finally, although it has never been legalised, disabled children en mentally ill adults were 'euthanized' through gassing between 1938 and I94I, to create bed space for anticipated military casualties. In I94I this so-called 'Aktion T-4' was officially cancelled. However, mental patients in asylums were still killed after 194I, although starvation or lethal injections were used, rather than gassing.

Keeping the Aryan race pure proved to be a struggle for the National Socialists. First of all we have to conclude that the National Socialists never managed to come up with a watertight definition of the concept of 'Jew'. Judaism was considered to be a race, rather than a religion. Nevertheless, in order to decide whether a person was Jewish or not, the status of the grandparents had to be determined, who were considered Jewish in case they (had) adhered to the Jewish religious community. A racial concept was therefore defined by religious criteria. Apart from the definition of 'Jew', it is highly questionable whether people can be racially classified at all the way the National Socialists did. The answer to that question has to be 'no', since the methods they used to classify people, not only physically (e.g. cranial measurements), but also mentally are all based on superseded views. Apart from that we have to bear in mind that lineage determination was hindered by practical obstacles, e.g. the absence of sound documentation, such as personal records or a register of births, deaths and marriages. 
During the Nazi years several people have tried to tighten the definition of 'Jew', especially that of 'half-Jew' and 'quarter-Jew'. Additionally, this group has tried to end the privileged position of the mixed married. However, all these attempts have been thwarted by Hitler himself, who did not want to affront the families of the non-Jewish partners. Apart from that, a considerable number of quarter-Jews and half-Jews fought in the German army. He might also have been relatively generous to this group of people because of uncertainties with regard to his own lineage, but this is impossible to prove.

In the Netherlands the situation was made even more confusing. In Germany whether a person was considered full-Jewish was dependent on the number of Jewish grandparents. A grandparent was considered Jewish in case he or she (had) adhered to the Jewish religious community. No proof of lineage was allowed as proof to the contrary. However, in the Netherlands this proof of lineage of the grandparents was allowed. In case a person could prove that (one of) his grandparents had not been of Jewish descent although they had adhered to the Jewish religious community, this could change his status.

In order to keep the Aryan race pure, the National Socialists had to prevent marriages and sexual relationships between Aryans and Jews. However, when they took over in I933, no law existed that prohibited mixed marriages. It took until September I 935 to come up with legislative provisions that did. In the mean time registrars tried to refuse the conclusion of mixed marriages by referring to 'general national principles'. By explaining what these 'general national principles' were, they drew inspiration from the Gesetz zur Wiederherstellung des Berufsbeamtentums and its first supplementary decree, which came up with a rudimentary definition of Jew. Minister of the Interior Frick, however, although agreeing that the law was not 'fully conform to National Socialist views', stated that until the law had changed, mixed marriages were not prohibited and should be concluded by the registrars. The Supreme Court confirmed this. In reality however, registrars continued to refuse the conclusion of mixed marriages. They were supported in this by several Petty Courts and County Courts.

Mixed marriages that already existed before the National Socialist take-over were suddenly stigmatised as detrimental to the purity of the Aryan race. However, divorce on the mere ground that one of the partners was Jewish was not possible, as the Civil Code only allowed divorce in case one of the partners had committed some pre-defined wrong. Instead, several people tried to annul their marriage by referring to $\mathbb{I}$ I333 of the Civil Code, which allowed for annulment in case of error concerning a personal quality of the other spouse. The Supreme Court confirmed in I934 that being Jewish could be considered a 'personal quality' in the sense of this paragraph, and conditionally allowed annulment of marriage on the ground that the other spouse was Jewish.

The Gesetz zum Schutze des deutschen Blutes und der deutschen Ehre of September 1935 and its first supplementary decree from November 1934 finally prohibited marriages between Jews and state nationals of German or kindred blood, Jews and quarter-Jews and between quarter-Jews themselves. For marriages of half-Jews with either quarterJews or non-Jews approbation by the Minister of the Interior and the Führer's deputy was required. All other marriages, in which case offspring that was in any way harmful to the purity of the German blood was to be expected, were prohibited as well, as was 
extramarital intercourse between Jews and Aryans. The First Supplementary Decree to the Blood Protection Law refined the term 'extramarital intercourse' to 'sexual intercourse', a term that was interpreted broadly in practice.

Implementing a marriage prohibition for mixed couples in the Netherlands did not go without striking a blow. The occupying forces have tried several times to introduce the Blood Protection Law and its first supplementary decree, but have failed to do so. The main reason the marriage prohibitions from the Blood Protection Law and its supplementary decree were not introduced by a legislative act, was that the German officials could not come to an understanding regarding the position of half-Jews. Being further removed from Berlin, several officials, amongst others Rauter and Rajakowitsch, tried to tighten the definition of 'half-Jew' by suggesting putting half-Jews on a par with full-Jews. This met with opposition from others, such as Wimmer and Seyss-Inquart, causing repeated delays. Seyss-Inquart's hesitant attitude, caused by fear for potential social unrest, did not help the matter. In the end, only a police regulation was issued in March 1942, which was published in Het Joodsche Weekblad. This police regulation prohibited marriages and extramarital intercourse between Jews ( $\mathrm{J}_{2}$, J3 and $\mathrm{J}_{4}$ ) and nonJews. This rule was supplemented in January 1943 by a circular from secretary-general of Justice Jaap Schrieke to the Dutch registrars, stating that they should report all announced marriages between a) Jews and non-Jews, b) half-Jews (G I) and non-Jews, c) Jews and quarter-Jews, d) half-Jews (G I) amongst themselves, e) half-Jews (G I) and quarter-Jews and f) quarter-Jews amongst themselves at Referat IV B 4 at the Sicherheitspolizei in the Hague. The Sicherheitspolizei subsequently arrested both partners in case such a report was made. Marriages between half-Jews and full-Jews were allowed, as this would change the status from the half-Jew ( $\mathrm{G} \mathrm{I}$ ) to full-Jew ( $\mathrm{J} 2$ ), thereby ending his privileged position.

The German occupying forces in the Netherlands have never introduced legislation allowing for divorce or annulment of mixed marriages that already existed. The nonJewish partner in a mixed marriage was often pressured to file for divorce (after which the Jewish partner would be deported), but that could only be done via a 'detour', such as the 'Big Lie', which required cooperation between the two partners. Schrieke has attempted to revise Dutch divorce law, inspired by the German Marriage Law of 1938, but these drafts have never contained articles that allowed for divorce or annulment on the mere ground that one of the partners was Jewish either. Schrieke's draft revision was primarily focused on rendering the practice of the 'Big Lie' (i.e. alleged adultery) unnecessary by expanding the grounds for divorce. Although Schrieke sought alliance with the German Marriage Law by declaring that procreation was the natural purpose of marriage, the majority of his changes can hardly be called National Socialist.

\subsection{National Socialist family law?}

That brings us to the main question of this research: has family law, in particular marriage and divorce law been influenced by National Socialism in Germany and the Netherlands?

If we consider this question without looking at the historical context and development of family law, the answer has to be 'yes'. 
Marriage and divorce law have clearly been put at the service of National Socialism. This becomes clear amongst other things from provisions like marriage prohibitions between Jews and non-Jews, the prohibition of extramarital intercourse between Jews and non-Jews, the reinterpretation of $\mathbb{S} 1333$ of the Civil Code in order to dispose of mixed marriages and the introduction of refusal to procreate and premature infertility as grounds for divorce. This has happened both in Germany and in the Netherlands, although we have seen that the majority of changes with regard to family law in the Netherlands have occurred through police regulations, rather then legislative provisions.

Officially the German occupying forces in the Netherlands have been hindered by Article 43 of the Regulations Respecting the Laws and Customs of War on Land of 1907 that prohibits occupying forces to enact laws and amendments, other than necessary for restoring and ensuring public order and civil life, although the scope of the article has been under discussion several times. In any case, the German occupying forces have not taken the slightest notice of Article 43. They have, however, taken possible social upheaval into account; Seyss-Inquart has initially refused to introduce the Nuremberg Laws in the Netherlands, to prevent unrest. In the end Dutch family law has not been nazified as much as originally planned. Although a definition of 'Jew' has officially been promulgated, the Blood Protection Law has never formally been enacted. A revision of divorce law has been drafted, but has never been enacted either. This is due to the differing opinions between the German officials in the Netherlands with regard to terminology and scope of the drafts and time limitations. The German occupation of the Netherlands ended in May I945, whilst as of autumn 1944 the Germans had other priorities than the revision of Dutch matrimonial law. Schrieke's draft revision of Dutch divorce law had been sent to Berlin, but obviously landed under a big pile of paper there. We can nevertheless conclude that although family law has not de jure been influenced by National Socialism, de facto it has been, due to the several police regulations that have been enacted. In reality everyday family life of those who were Jewish to a certain extent and those who were married or wanted to get married to someone who was (partly) Jewish has certainly been influenced by National Socialism.

However, if we do take the historical context and development of family law into account, the answer inclines to a 'no'.

On a conceptual level the National Socialists have not changed that much. All of their measures have been only been sub-legislation and sometimes even ad hoc provisions, without clear definitions. We can even observe a certain continuity in German marriage and divorce law from the Weimar years to the National Socialist period and after. The discussion with regard to the revision of divorce law, especially expanding the grounds for divorce from the guilt principle to the breakdown principle, had been going on for several years already and the National Socialists followed that line. The same arguments that had been used during the Weimar years came up again when the Marriage Law of I938 was drafted and although this law did expand the grounds for divorce it was not a radical break with the past. The guilt principle remained the basic principle and the breakdown principle was only conditionally introduced. We have seen before that the sting was in the so-called Generalklauseln, the open norms. Open norms like Wesen der 
Ehe (essence of marriage) and sittlich nicht gerechtfertigt (morally not justified) allowed for apparent innocent provisions to be interpreted in a National Socialist way, a practice that has been reversed after the fall of National Socialism. Because of these open norms the Marriage Law was largely taken over by the allied Control Council in 1946, ensuring this continuity. With regard to references to legislation regarding racial and social hygiene in German marriage and divorce law, we can conclude that National Socialism has not had a lasting influence on marriage and divorce law as all those laws and references to those laws have been repealed after the fall of National Socialism.

In the Netherlands it had been decided that revision of divorce law was needed long before the German invasion. The 1883 'Big Lie' judgement of the Supreme Court had created an inexpedient leeway with regard to use of 'adultery' as ground for divorce, in practice allowing for divorce by mutual consent. As in Germany expanding the grounds for divorce from the guilt principle to the breakdown principle, in particular including incurable insanity as ground for divorce, had been discussed extensively before. We have seen before that Schrieke's attempts to revise Dutch divorce law were largely motivated by his desire to end the 'Big Lie'. That does not alter the fact that the German Marriage Law has served as an example when Schrieke drafted his revision, but it would be going too far to call his draft National Socialist. It is more likely that Schrieke wanted to kill two birds with one stone, with ending the 'Big Lie' remaining his primary concern.

Revisions of marriage and divorce law and especially divorce law seem to be primarily inspired by slowly changing social standards, an expression of 'O Tempora, O Mores', rather than an explosive rise of an extreme 'ideology'. Religion has long been the main factor of influence on divorce law. When the influence of religion declined - especially since the $1960-i e s$ - the rules regarding divorce became less stringent. This is clearly visible in the Netherlands were the grounds for divorce have not been widened until I97I, almost thirty years after the end of the Second World War. Apparently it had not been considered fully socially acceptable before. Although we can not read tea-leaves, it is likely that the grounds for divorce would have been expanded anyhow, both in Germany and in the Netherlands. The National Socialists have used drafts and arguments that already existed, and have used their position of absolute power to push those drafts, slightly adapted to their own ideas, through. 'Polderen', solving problems through dialogue, is not necessary for a dictator.

A special word has to be said about Austria. We have seen that the German Marriage Law of I938, which was promulgated in Austria as well, as it was then already part of the German Reich, introduced the obligatory civil marriage for all Austrians, irrespective of their religious background and allowed for divorce, again for all Austrians, irrespective of their religious background. As the Marriage Law of 1938 - albeit amended - still forms the basis of Austrian matrimonial law, we can conclude that the National Socialists have influenced Austrian matrimonial law to a large extent. However, it is not so much National Socialism as well as the National Socialists that have influenced Austrian matrimonial law, as the German authorities simply started the Marriage Law from the basis of German matrimonial law, which already recognised the obligatory civil marriage and divorce for all citizens. The landslide with regard to Austrian marriage and divorce 
law therefore should not be considered in the light of National Socialism as such, but as a highly necessary modernisation, which has been made possible through the absolute power the National Socialists had.

Marriage and divorce law in Germany, Austria and the Netherlands have been influenced by National Socialism, but have not become 'National Socialist Family Law.' 
Samenvatting 
Recht kan gewoonlijk gezien worden als een reflectie van de in een bepaalde maatschappij heersende normen en waarden en is derhalve, evenals een maatschappij zelf, aan verandering onderhevig. Een verandering in de heersende opvattingen in een maatschappij kan een verandering in de heersende politieke stromingen teweegbrengen, hetgeen zijn weerslag kan hebben op de inhoud van het recht. In dit onderzoek stond de vraag centraal of het nationaal-socialisme gedurende de periode 1933-1945 het familierecht, in het bijzonder het huwelijks- en echtscheidingsrecht, heeft beïnvloed. Het onderzoek is daarbij in beginsel gelimiteerd tot Duitsland, het eerste land waar de nationaal-socialisten daadwerkelijk aan de macht kwamen, en Nederland, dat door de Duitse nationaal-socialisten beschouwd werd als een broedernatie. Omdat Oostenrijk vanaf 1938 onderdeel was van het Derde Rijk, is bij de behandeling van de Duitse huwelijkswet uit 1938 ook aandacht besteed aan het Oostenrijkse huwelijks- en echtscheidingsrecht. 
Teneinde deze hoofdvraag te kunnen beantwoorden was de behandeling van een aantal deelvragen noodzakelijk. Allereerst diende de vraag beantwoord te worden wat nationaal-socialisme inhoudt en welke rol de familie innam in het nationaal-socialisme. Ook was het daarbij van belang een beschrijving te geven van de Duitse en Nederlandse bevolkings- en familiepolitiek in de jaren voorafgaand aan de nationaal-socialistische machtsovername. Om te kunnen vaststellen welke veranderingen zijn doorgevoerd door de nazi's, diende er vervolgens een overzicht gemaakt te worden van de regels ten aanzien van huwelijkssluiting, nietigverklaring van het huwelijk en echtscheiding welke bestonden in Duitsland en Nederland vóór de nationaal-socialistische machtsovername in 1933 respectievelijk 1940. Het grootste deel van dit proefschrift is gewijd aan een beschrijving van de beleidsmaatregelen die voortkwamen uit de nationaal-socialistische bevolkings- en familiepolitiek en de veranderingen welke de nazi's hebben doorgevoerd of hebben trachten door te voeren in het huwelijks- en echtscheidingsrecht in Duitsland en Nederland. Voor Nederland was het daarbij tevens noodzakelijk de vraag te beantwoorden of een bezettingsmacht wijzigingen aan mocht brengen in het toenmalige Nederlandse familierecht. 


\section{Nationaal-socialisme - de familie als kiemcel van de natie}

In hoofdstuk 2 is vastgesteld dat het nationaal-socialisme is beïnvloed of in elk geval is geïnspireerd door vier gedachtestromingen: völkisch nationalisme, sociaaldarwinisme, de raciale gezondheidsleer (eugenetica) en antisemitisme. Al deze vier stromingen zijn als elementen op de een of andere manier terug te vinden in het nationaal-socialisme.

Het element völkisch nationalisme blijkt duidelijk uit de sleutelrol die het Volk speelde in het nationaal-socialisme. Hoofddoel was de bescherming en versterking van het Volk. Teneinde dit doel te bereiken diende er een Volksgemeinschaft ontwikkeld te worden, waarin de belangen van de gemeenschap prioriteit hadden boven de individuele belangen van de leden van die gemeenschap. 'Inferieure' elementen, zoals Joden, 'zigeuners' (Roma en Sinti), homoseksuelen, communisten, of eenvoudigweg 'zwakke' mensen, dienden uit de maatschappij geëlimineerd te worden. Het huwelijk en het gezin werden beschouwd als de 'kiemcel van de natie'. Uit deze opvatting werden drie doelen afgeleid: I) het Arische ras diende zo zuiver mogelijk gehouden te worden, 2) het Arische ras diende zo gezond mogelijk gehouden te worden en 3) het Arische ras diende zich zo veel mogelijk te vermenigvuldigen. In het eerste doel laten de elementen rassenleer en antisemitisme zich duidelijk herkennen. Door vermenging van puur, Arisch bloed met 'inferieur' bloed te voorkomen kon het Arische ras zo zuiver mogelijk gehouden te worden. Met name Joods bloed werd beschouwd als bijzonder schadelijk voor de kwaliteit van het Volk. Huwelijken en seksuele relaties tussen Ariërs en Joden werden dan ook ten strengste afgekeurd. Alle 'zwakke' elementen in de maatschappij, met name zij die leden aan erfelijke aandoeningen, konden weggefilterd worden door middel van eugenetica. De invloed van de sociaaldarwinistische leer is duidelijk zichtbaar hier. Het derde doel tenslotte, de vermenigvuldiging van het Arische ras, kon alleen bewerkstelligd worden door het Volk zelf, hetgeen zich in rap tempo diende te gaan voortplanten. De onsterfelijkheid van de Duitse natie, het Arische ras, kon niet gegarandeerd worden zonder toekomstige generaties.

\section{Nationaal-socialisme in de praktijk}

\section{- 2.1 Duitsland}

De nationaal-socialistische bevolkings- en familiepolitiek was sterk natalistisch. Naast een verheerlijking van het moederschap introduceerde men financiële voordelen welke Arische stellen moesten stimuleren zich snel voort te planten. Het voert echter te ver om de nationaal-socialisten als pioniers op dit gebied te beschouwen, aangezien de Duitse maatschappij van I933 allerminst onbekend was met natalistische overheidsmaatregelen. Reeds in de Weimar-tijd had de overheid veel nadruk gelegd op het belang van een sterke bevolkingsgroei zowel door verheerlijking van het moederschap en het traditionele gezinsleven als door financiële stimuleringsmaatregelen. Het fanatisme en de precisie waarmee de nationaal-socialisten te werk gingen kan echter wel degelijk opvallend genoemd worden.

Vermenigvuldiging van het Arische ras diende niet te geschieden tegen iedere prijs. De nationaal-socialistische bevolkingspolitiek was zeer selectief, ook binnen de Arische bevolkingsgroep zelf. Eugenetica als oplossing voor maatschappelijke problematiek 
was reeds besproken in de Weimar-tijd. Met de machtsovername van de nazi's verloor eugenetica echter haar vrijwillige karakter. Ter bevordering van de gezondheid van het Arische ras werd in 1933 het Gesetz zur Verhütung erbkranken Nachwuchses ingevoerd, welke verplichte sterilisatie voor erfelijk zieken en alcoholisten beval. Deze werd in I935 gevolgd door het Gesetz zum Schutze der Erbgesundheit des deutschen Volkes, welke huwelijken tussen gezonde Ariërs en zieke of zwakke mensen, Arisch of niet, verbood. Beide wetten trachtten een generatie van erfelijk belaste kinderen te voorkomen. Ingeval een ongeboren kind vermoed werd erfelijk belast te zijn, werd abortus toegepast, zelfs nog tot aan het einde van de zesde maand van de zwangerschap. Daarbij was formeel gezien de instemming van de aanstaande moeder vereist, maar dat vereiste werd in de praktijk over het algemeen genegeerd.

Tussen I938 en I94I zijn gehandicapte kinderen en geestelijk zieke volwassenen tenslotte massaal 'ge-euthanaseerd' door middel van vergassing, om ziekenhuisbedden vrij te maken voor de te verwachten gewonde militairen. Daarbij dient opgemerkt te worden dat dit beleid nooit formeel gelegaliseerd is. In I94I heeft men dit zogenaamde 'Aktion T-4' programma officieel gestopt. Dat neemt echter niet weg dat ook na I94I psychiatrische patiënten in inrichtingen nog steeds gedood werden, hoewel dit niet langer geschiedde door vergassing maar door uithongering of door middel van een dodelijke injectie.

De nationaal-socialisten hebben geworsteld met het zuiver houden van het Arische ras. Zo is het de nazi's nooit gelukt om met een waterdichte definitie van het begrip 'Jood' te komen. Het Jodendom werd beschouwd als een ras en niet als een religie. Om echter te kunnen bepalen of iemand tot het Joodse ras behoorde, diende de afkomst van de grootouders in ogenschouw genomen te worden. Bepalend voor de vraag of deze grootouders tot het Joodse ras behoorden of hadden behoord was echter de vraag of zij lid waren (geweest) van de Joodse religieuze gemeenschap. Bij de definiëring van het begrip 'Jood' op raciale gronden heeft men dus toch terug gegrepen op religieuze criteria. Daarnaast is het natuurlijk maar de vraag of mensen überhaupt wel raciaal ingedeeld kunnen worden op de manier die de nationaal-socialisten voor ogen hadden. Het antwoord op die vraag kan alleen maar ontkennend zijn, aangezien de methoden die de nazi's toepasten, zoals schedelmetingen, gebaseerd waren op inmiddels achterhaalde opvattingen. Daarnaast werd en wordt afstammingsonderzoek veelal gehinderd door praktische obstakels, bijvoorbeeld door het ontbreken van goede documentatie, zoals een geboorteregister.

Gedurende de nazi-tijd is door verschillende personen getracht de definitie van het begrip 'Jood' aan te scherpen, met name waar het ging om 'half-Joden' en 'kwart-Joden'. Tevens heeft men getracht een einde te maken aan de geprivilegieerde positie van gemengd gehuwde Joden. Al deze pogingen zijn echter door Hitler zelf tegengehouden. Volgens Hitler diende men rekening te houden met het feit dat in geval van halfbloed Joden en gemengd gehuwden een deel van de familie in elk geval Arisch was. Daarnaast is aanscherping door hem ook tegengehouden om pragmatische redenen - veel van deze mensen vochten mee in het Duitse leger en konden wel eens aan het muiten slaan als een deel van hun familie opgepakt werd - maar wellicht ook vanwege twijfel over zijn eigen afkomst. Dat laatste is echter niet te bewijzen. 
In Nederland is de situatie nog verwarrender geworden doordat hier, in tegenstelling tot in Duitsland, tegenbewijs ten aanzien van de afstamming van de grootouders werd toegestaan. Indien een persoon kon bewijzen dat zijn grootouders niet Joods waren geweest, hoewel zij wel tot de Joodse religieuze gemeenschap hadden behoord, kon dat diens status aanzienlijk verbeteren.

Teneinde het Arische ras zuiver te houden, dienden huwelijken en geslachtelijke relaties tussen Ariërs en Joden verboden te worden. Ten tijde van de nationaal-socialistische machtsovername in 1933 bestonden er geen wetten meer welke gemengde huwelijken verboden. Het heeft tot september 1935 geduurd voordat een dergelijke maatregel in Duitsland weer werd ingevoerd. In de tussentijd trachtten ambtenaren van de burgerlijke stand de sluiting van gemengde huwelijken tegen te gaan, door zich te beroepen op 'algemene nationale principes'. Deze 'algemene nationale principes' waren terug te vinden in het Gesetz zur Wiederherstellung des Berufsbeamtentums en de bijbehorende eerste verordening, welke een eerste rudimentaire definitie van het begrip 'Jood' bevatten. Minister van Binnenlandse Zaken Frick beval de ambtenaren van de burgerlijke stand echter om de voorgenomen gemengde huwelijken gewoon te sluiten omdat dergelijke huwelijken formeel (nog) niet verboden waren bij wet. Hij gaf daarbij wel toe dat de bestaande wet niet geheel 'conform de nationaal-socialistische opvattingen' was. Dit standpunt werd bevestigd door het Reichsgericht. In de praktijk bleven ambtenaren van de burgerlijke stand echter weigeren gemengde huwelijken te sluiten. Zij werden in deze praktijk gesteund door verschillende lagere gerechten (Amtsgerichten en Landgerichten).

Gemengde huwelijken die dateerden van voor de nationaal-socialistische machtsovername werden van de een op de andere dag gestigmatiseerd als schadelijk voor de zuiverheid van het Arische ras. Echtscheiding enkel op grond dat één van de partners Joods was, was echter niet toegestaan, aangezien het Duitse Burgerlijk Wetboek (Bürgerliches Gesetzbuch, BGB) echtscheiding alleen toestond in geval van schuld van één van de partners aan één van de door het BGB voorgeschreven feiten. Verschillende mensen trachtten in plaats daarvan hun huwelijk nietig te laten verklaren op grond van $\mathbb{S}$ I333 BGB, hetgeen nietigverklaring toestond in geval één van de partners zich ten tijde van de huwelijkssluiting had vergist omtrent persoonlijke kwaliteiten van de andere partner. Het Reichsgericht bevestigde in I934 dat de Joodse afkomst van één van de partners gekwalificeerd kon worden als 'persoonlijke eigenschap' in de zin van \ I333 BGB en dat derhalve nietigverklaring van een gemengd huwelijk onder bepaalde voorwaarden mogelijk was.

Het Gesetz zum Schutze des deutschen Blutes und der deutschen Ehre van september I 935 en de bijbehorende eerste verordening van november 1935 verboden uiteindelijk huwelijken tussen Joden en Duitse staatsburgers van Duits of aanverwant bloed, tussen Joden en kwart-Joden en tussen kwart-Joden onderling. Voor huwelijken tussen halfJoden met kwart-Joden of niet-Joden was voorafgaande toestemming van de Minister van Binnenlandse zaken en Hitler's plaatsvervanger noodzakelijk. Alle overige huwelijken waarin nageslacht dat potentieel schadelijk voor de zuiverheid van het Duitse bloed te verwachten was, werden eveneens verboden, evenals buitenechtelijke gemeenschap tussen Joden en Ariërs. De eerste aanvullende verordening behorende bij 
het Blutschutzgesetz definieerde de term 'buitenechtelijke gemeenschap' als 'geslachtsverkeer', een term die vervolgens in de praktijk ruim geïnterpreteerd werd.

Het is de nationaal-socialisten in 1938 voorts gelukt om het echtscheidingsrecht te herzien, hetgeen men in de Weimar-tijd tevergeefs geprobeerd heeft. De reden voor deze herziening was gelegen in de gemeenschap; huwelijken die geen waarde meer hadden voor de volksgemeenschap, omdat het onwaarschijnlijk was dat er nog nageslacht geboren zou worden, dienden ontbonden te worden, zodat de ex-partners opnieuw konden trouwen om dan vervolgens met hun nieuwe echtgeno(o)t(e) alsnog hun morele plicht ten aanzien van de volkgemeenschap te kunnen vervullen. Hoewel het schuldprincipe het uitgangspunt bleef in het echtscheidingsrecht, werd nu onder bepaalde voorwaarden het ontwrichtingsprincipe geïntroduceerd. Een algemene bepaling welke echtscheiding toestond in geval beide partners het huwelijk duurzaam ontwricht achtten, werd nog steeds als te vergaand bestempeld. Daarbij kwam nog dat een huwelijk niet ontbonden diende te worden als oplossing voor de problemen tussen de partners, maar als oplossing voor de problemen die zouden ontstaan voor de volksgemeenschap op moment dat twee van elkaar vervreemde mensen gedwongen werden getrouwd te blijven. Weigering tot voortplanting werd een echtscheidingsgrond, waarbij aangenomen werd dat een dergelijke weigering onvermijdelijk een permanente ontwrichting van het huwelijk tot gevolg zou hebben. Bij de introductie van voortijdige onvruchtbaarheid als echtscheidingsgrond werd een vergelijkbare gedachtegang gevolgd. Hoewel voortijdige onvruchtbaarheid maar zelden de schuld van de onvruchtbare partner was, werd een dergelijke situatie geacht een dusdanig zware wissel op het huwelijksgeluk te trekken, dat echtscheiding werd toegestaan. Nageslacht was bij voortijdige onvruchtbaarheid uiteraard niet meer te verwachten, waardoor het huwelijk zijn waarde voor de volksgemeenschap hoe dan ook verloren had. Als nieuwe gronden voor echtscheiding werden tevens ingevoerd de permanente ontwrichting van het huwelijk veroorzaakt door destructief gedrag van één van de partners, dat weer geacht werd veroorzaakt te worden door een geestelijke stoornis en een besmettelijke of 'weerzinwekkende' ziekte van één van de partners. Hoewel deze veranderingen ingevoerd werden onder het mom van compassie voor de ongelukkige, gezonde partner, was de werkelijke reden gelegen in het zekerstellen van nageslacht.

\section{-2.2 Nederland}

In Nederland had het instellen van een huwelijksverbod voor gemengde stellen nogal wat voeten in de aarde. De Duitse bezetter heeft verschillende malen tevergeefs getracht het Duitse Blutschutzgesetz met de bijbehorende verordeningen in te voeren. De belangrijkste reden waarom de bepalingen uit deze wet met bijbehorende verordeningen niet wettelijk zijn afgekondigd is gelegen in het feit dat de Duitse ambtenaren het onderling niet eens konden worden over de positie van half-Joden. Verschillende ambtenaren, waaronder Rauter en Rajakowitsch, hebben geprobeerd de definitie van 'half-Jood' aan te scherpen, daarbij gebruik makend van het feit dat men in Nederland buiten de directe invloedssfeer van Berlijn viel. Hun bedoeling was om half-Joden (die geen lid waren van de Joods religieuze gemeenschap en derhalve niet als J2, maar als G I bestempeld werden) 
gelijk te stellen aan vol-Joden (J2, J3 en J4, waarbij het getal voor het aantal Joodse grootouders stond). Dit voorstel stuitte echter op weerstand van anderen, waaronder Wimmer en Seyss-Inquart, hetgeen aan de lopende band vertragingen veroorzaakte. Seyss-Inquarts aarzelende houding, die voornamelijk veroorzaakt werd door angst voor mogelijke maatschappelijke onrust, droeg hier aan bij. Uiteindelijk is in maart 1942 een politieverordening uitgevaardigd in Het Joodsche Weekblad welke huwelijken en buitenechtelijke geslachtelijke omgang tussen Joden en niet-Joden verbood. Deze regel is in januari 1943 aangevuld door een circulaire van de secretaris-generaal van Justitie, Jaap Schrieke, aan de Nederlandse ambtenaren van de burgerlijke stand, waarin hun bevolen werd alle voorgenomen huwelijken tussen a) Joden en niet-Joden, b) half-Joden (G I) en niet-Joden, c) Joden en kwart-Joden, d) half-Joden (G I) onderling, e) half-Joden (G I) en kwart-Joden en f) kwart-Joden onderling te melden bij het Referat IV B 4 bij de Sicherheitspolizei in Den Haag. In geval van een dergelijke melding werden beide partners vervolgens gearresteerd door de Sicherheitspolizei. Huwelijken tussen half-Joden en volJoden bleven toegestaan, aangezien hiermee de status van de half-Jood (G I) automatisch veranderde in vol-Jood $(\mathrm{J} 2)$. Hiermee eindigde dan ook automatisch diens geprivilegieerde positie, een positie waarmee de bezetter toch al in zijn maag zat.

De Duitse bezettingsmacht heeft in Nederland uiteindelijk geen wetgeving geïntroduceerd die echtscheiding of nietigverklaring van reeds bestaande gemengde huwelijken mogelijk maakte. De niet-Joodse partners zijn wel vaak onder druk gezet om zich op de een of andere manier te laten scheiden van hun Joodse partner (waarna de Joodse partner gedeporteerd werd), maar dit was alleen mogelijk via een juridische omweg, zoals de bekende ‘Groote Leugen' (verondersteld, niet tegengesproken overspel), hetgeen samenwerking tussen beide partners vereiste. Secretaris-generaal van Justitie Schrieke heeft getracht het Nederlandse echtscheidingsrecht te herzien, waarbij hij zich heeft laten inspireren door de Duitse huwelijkswet van 1938. Geen van zijn ontwerpen bevatte echter een bepaling die echtscheiding of nietigverklaring mogelijk maakte op de enkele grond dat één van de partners Joods was. Schrieke’s herzieningspogingen moeten vooral gezien worden als een poging de sterk bekritiseerde praktijk van de 'Groote Leugen' te doen stoppen, door het aantal echtscheidingsgronden uit te breiden. Hoewel Schrieke daarbij wel degelijk aansluiting zocht bij de Duitse huwelijkswet, getuige ook zijn opmerkingen dat voortplanting het natuurlijke doel van het huwelijk is, kan het merendeel van zijn voorgestelde aanpassingen niet nationaal-socialistisch genoemd worden.

\section{Nationaal-socialistisch familierecht?}

De hoofdvraag van dit onderzoek, te weten de vraag of het Duitse en Nederlandse familierecht, in het bijzonder het huwelijks- en echtscheidingsrecht, beïnvloed is door het nationaal-socialisme kan uiteindelijk op twee niveaus beantwoord worden.

Als de historische context en de ontwikkeling van het familierecht als zodanig buiten beschouwing gelaten wordt, dient de vraag bevestigend beantwoord te worden.

Het huwelijks- en echtscheidingsrecht zijn aantoonbaar ten dienste van het nationaalsocialisme gesteld. Dit blijkt vooral uit bepalingen zoals huwelijksverboden tussen 
Joden en niet-Joden, het verbod op geslachtelijke omgang tussen Joden en niet-Joden, de herinterpretatie van $\mathbb{1}$ I333 BGB teneinde zich te kunnen ontdoen van de gemengde huwelijken en het introduceren van echtscheidinggronden zoals weigering tot voortplanting en voortijdige onvruchtbaarheid. Dit is zowel in Duitsland als in Nederland gebeurd, hoewel in Nederland de meerderheid van de wijzigingen in het familierecht via politieverordeningen hebben plaatsgevonden, in plaats van via officiële wetswijzigingen.

Formeel gezien is de Duitse bezetter in Nederland hierbij gehinderd door Artikel 43 van het Haags Landoorlogsreglement van 1907, hetwelk een bezettingsmacht verbood wetten en wetswijzigingen uit te vaardigen welke niet strikt noodzakelijk zijn voor het herstel en de verzekering van de openbare orde en het openbare leven. Daarbij moet wel aangetekend worden dat de reikwijdte van dit artikel lange tijd ter discussie heeft gestaan. Hoe het ook zij, de Duitse bezetters hebben niet de minste notie genomen van dit artikel. Wel hebben zij rekening gehouden met mogelijke maatschappelijke onrust; Seyss-Inquart heeft in eerste instantie geweigerd de Neurenberger wetten in te voeren in Nederland omdat hij bang was voor protesten vanuit de Nederlandse bevolking. Uiteindelijk is het Nederlandse familierecht niet zo ver genazificeerd als oorspronkelijk gepland. Hoewel er wel reeds in 1940 een formele definitie van het begrip 'Jood' is afgekondigd in het Duitse Verordeningenblad voor het bezette Nederlandsche gebied, is het Blutschutzgesetz nooit formeel ingevoerd. Een herziening van het Nederlandse echtscheidingsrecht is voorbereid, maar is eveneens nooit ingevoerd. Zoals eerder aangegeven is dit terug te voeren op de verschillende opvattingen ten aanzien van de terminologie en het bereik van de ontwerpen. Ook gebrek aan tijd heeft hierbij een rol gespeeld. De Duitse bezetting van Nederland eindigde uiteindelijk in mei 1945. Reeds vanaf de herfst 1944 hadden de Duitsers andere dingen aan hun hoofd dan een herziening van het Nederlandse huwelijks- en echtscheidingsrecht. Schrieke's voorstel tot herziening van het Nederlandse echtscheidingsrecht is weliswaar naar Berlijn gezonden, maar is daar vervolgens onder op de stapel terecht gekomen. We kunnen echter concluderen dat, hoewel het Nederlandse familierecht niet de jure beïnvloed is door het nationaal-socialisme, dit vanwege de verschillende politieverordeningen de facto wel degelijk gebeurd is. In de praktijk is het dagelijkse familieleven van hen die geheel of gedeeltelijk Joods waren en hen die getrouwd waren of wilden trouwen met iemand die geheel of gedeeltelijk Joods was wel degelijk beïnvloed door het nationaal-socialisme.

Als de historische context en de ontwikkeling van het familierecht wel in ogenschouw genomen wordt, nijgt het antwoord op de hoofdvraag naar een ontkenning.

Conceptueel gezien hebben de nationaal-socialisten geen grote veranderingen doorgevoerd. Nationaal-socialistische maatregelen zijn enkel doorgevoerd door middel van losse wetjes en soms zelfs door ad hoc bepalingen, zonder duidelijke definities. Er valt zelfs een zekere continuiteit te bespeuren in het Duitse huwelijks- en echtscheidingsrecht. De discussie over de herziening van het echtscheidingsrecht, met name de uitbreiding van de echtscheidingsgronden van het schuldprincipe naar het ontwrichtingsprincipe speelde al jaren; de nationaal-socialisten hebben deze lijn dus niet zelf bedacht, maar enkel voortgezet. Alle argumenten welke in de Weimar-tijd al gebruikt waren, werden bij het ontwerp van de huwelijkswet van 1938 opnieuw aangehaald. Hoewel deze 
wet het aantal echtscheidingsgronden uitbreidde, kan dat niet gezien worden als een radicale breuk met het verleden. Het schuldprincipe bleef het uitgangspunt en het ontwrichtingsprincipe werd enkel onder voorwaarden geïntroduceerd. Het venijn zat in de open normen. Open normen zoals Wesen der Ehe (essentie van het huwelijk) en sittlich nicht gerechtfertigt (zedelijk niet gerechtvaardigd) maakten het mogelijk ogenschijnlijk onschuldige bepalingen op een nationaal-socialistische manier te interpreteren. $\mathrm{Na}$ de val van het nationaal-socialisme is deze praktijk teruggedraaid. Het bestaan van deze open normen heeft er echter wel toe geleid dat de Geallieerde Controleraad in I946 de huwelijkswet uit 1938 grotendeels heeft overgenomen, hetgeen de continuïteit verder versterkt. Ten aanzien van de raciale en eugenetische bepalingen welke doorgevoerd zijn in het huwelijks- en echtscheidingsrecht kan geconcludeerd worden dat deze bepalingen geen blijvende invloed hebben gehad, aangezien al deze bepalingen herroepen zijn na de val van het nationaal-socialisme.

In Nederland werd herziening van het echtscheidingsrecht al langere tijd als noodzakelijk beschouwd. Het 'Groote Leugen'-arrest van de Hoge Raad uit I883 had een ongewenste speelruimte gecreëerd in het gebruik van 'overspel' als grond voor echtscheiding. In de praktijk werd hierdoor echtscheiding met wederzijds goedvinden toegestaan, hoewel de wet dit uitdrukkelijk verbood. Ook in Nederland was in een eerder stadium al gesproken over een mogelijke uitbreiding van het aantal echtscheidingsgronden en de introductie van het ontwrichtingsprincipe. Met name krankzinnigheid als mogelijke echtscheidingsgrond was reeds uitgebreid bediscussieerd. Schrieke's pogingen het Nederlandse echtscheidingsrecht te herzien zijn dan ook voornamelijk ingegeven door de wens een einde te maken aan de 'Groote Leugen'. Dat verandert niets aan het feit dat Schrieke wel degelijk een voorbeeld heeft genomen aan de Duitse huwelijkswet van I938, maar dat maakt zijn voorstellen nog niet nationaal-socialistisch van aard. Het is waarschijnlijker dat Schrieke twee vliegen in één klap heeft willen slaan, waarbij het beëindigen van de 'Groote Leugen' zijn primaire doelstelling is geweest.

Herzieningen van het echtscheidingsrecht lijken eerder ingegeven te worden door een langzaam veranderende maatschappij als zodanig, waarbij echtscheidingsrecht veel meer een uitdrukking van 'O tempora, o mores' is, in plaats van een explosief opgekomen, extreme ideologie. Religie heeft lange tijd de inhoud van het echtscheidingsrecht beïnvloed. Naarmate de invloed van de kerken afnam - met name vanaf de jaren zestig - zijn de regels ten aanzien van echtscheiding steeds minder strikt geworden. Dit is voornamelijk in Nederland heel goed zichtbaar, waar de gronden voor echtscheiding uiteindelijk pas herzien zijn in I97I, bijna dertig jaar na het einde van de Tweede Wereldoorlog. Eerder werd dit blijkbaar niet maatschappelijk aanvaardbaar geacht. Hoewel het natuurlijk koffiedik kijken blijft, is het waarschijnlijk dat de gronden voor echtscheiding uiteindelijk toch wel uitgebreid zouden zijn, zowel in Duitsland als in Nederland. De nationaalsocialisten hebben bestaande ontwerpen en argumenten gebruikt en hebben uiteindelijk hun machtspositie ingezet om deze ontwerpen, enigszins aangepast aan het nationaalsocialistisch gedachtegoed, in te voeren. Een dictator hoeft immers niet te polderen.

Oostenrijk dient hierbij nog apart vermeld te worden. In hoofdstuk 3 is aangetoond dat de Duitse huwelijkswet van I938, die ook uitgevaardigd werd in Oostenrijk omdat 
Oostenrijk tegen die tijd deel uitmaakte van het Derde Rijk, het verplichte burgerlijk huwelijk invoerde voor alle Oostenrijkers ongeacht hun religieuze achtergrond. Omdat deze huwelijkswet, hoewel aangepast, in Oostenrijk nog steeds de basis vormt voor het huwelijks- en echtscheidingsrecht, kan gesteld worden dat de nationaal-socialisten wel degelijk een vergaande invloed op het Oostenrijkse huwelijks- en echtscheidingsrecht hebben gehad. Daarbij moet wel aangetekend worden dat het Oostenrijkse huwelijks- en echtscheidingsrecht niet zozeer beïnvloed is door het nationaal-socialisme als zodanig, maar door de nationaal-socialisten, aangezien de huwelijkswet van 1938 uitging van het Duitse huwelijksrecht dat al een verplicht burgerlijk huwelijk kende en tevens alle burgers toestond echtscheiding aan te vragen, zonder daarbij onderscheid te maken op grond van religie. De aardverschuiving welke in het Oostenrijkse huwelijks- en echtscheidingsrecht heeft plaatsgevonden moet daarom niet zo zeer worden toegeschreven aan het nationaalsocialistisch gedachtegoed, maar dient beschouwd te worden als een broodnodige modernisering, welke mogelijk werd gemaakt door de absolute macht van de nationaalsocialisten.

De eindconclusie luidt dan ook dat het huwelijks- en echtscheidingsrecht in Duitsland, Oostenrijk en Nederland, hoewel beïnvloed door het nationaal-socialisme, geen nationaal-socialistisch familierecht is geworden. 


\section{Zusammenfassung}


Das Recht kann gewöhnlich als eine Abspiegelung der Werte und Normen betrachtet werden, die innerhalb einer bestimmten Gesellschaft gelten und unterliegt deshalb, ebenso wie eine Gesellschaft, ständigen Veränderungen. Einer Veränderung der herrschenden Auffassungen innerhalb einer Gesellschaft kann ebenfalls eine Veränderung herrschender politischideologischer Richtungen folgen, die ihre Auswirkung auf den Inhalt des Rechtes haben können.

Die Zentralfrage dieser Doktorarbeit ist, ob der Nationalsozialismus während im Zeitraum von 1933 bis 1945 das Familienrecht, und im Besonderen das Ehe- und Ehescheidungsrecht, beeinflusst hat. Die Forschungsarbeit beschränkte sich dabei grundsätzlich auf Deutschland, als Land das tatsächlich zuerst eine nationalsozialistische Regierung bekam, und die Niederlande, die aus der Sicht der deutschen Nationalsozialisten wie eine Brüdernation betrachtet wurde. Da Österreich ab 1938 ein Teil des deutschen Reiches wurde, wurde in der Forschung und Behandlung des deutschen Ehegesetzes auch einige Bemerkungen zum österreichischen Ehe- und Ehescheidungsrecht gemacht. 
Zur Beantwortung der Zentralfrage war die Behandlung einiger Teilfragen erforderlich. Zuerst musste die Frage nach dem Inhalt und der Rolle der Familie innerhalb des Nationalsozialismus beantwortet werden. Dabei herrschte ebenfalls Bedarf nach einer Beschreibung der deutschen und niederländischen Bevölkerungs- und Familienpolitik der Jahre, die der nationalsozialistischen Machtübernahme vorabgingen. Um die Rechtsveränderungen, die von den Nazis durchgeführt wurden, feststellen zu können, war es weiter erforderlich, eine Übersicht hinsichtlich der Regeln der Eheschließung, Nichtigkeit und Ehescheidung aufzustellen, die jeweils in Deutschland und den Niederlanden existierten vor der nationalsozialistischen Machtübernahme in 1933 und 1940. Der Hauptanteil dieser Doktorarbeit wurde der Beschreibung der politischen Maßnahmen gewidmet, die aus der nationalsozialistischen Bevölkerungsund Familienpolitik hervorkamen, und den Veränderungen, die von den Nazis innerhalb des Ehe- und Ehescheidungsrechtes in Deutschland und den Niederlanden durchgeführt oder angesetzt wurden. Im Zusammenhang mit den Niederlanden war es dabei erforderlich die Frage zu beantworten, ob eine Besatzungsmacht Änderungen des damaligen Familienrechts durchführen durfte. 


\section{Nationalsozialismus - die Familie als Keimzelle einer Nation}

Im zweiten Kapitel wurde festgestellt, dass der Nationalsozialismus beeinflusst beziehungsweise inspiriert wurde von vier Denkrichtungen: völkischer Nationalismus, Sozialdarwinismus, Rassenhygiene (Eugenetik) und Antisemitismus. Irgendwie kann man im Nationalsozialismus stets diese vier Denkrichtungen als Elemente zurückfinden.

Das Element völkischer Nationalismus ist in der Schlüsselrolle wiederzuerkennen, die das Volk innerhalb des Nationalsozialismus darstellt. Das Hauptziel war die Beschützung und Verstärkung des Volkes. Um dieses Ziel zu erreichen, war die Entwicklung einer Volksgemeinschaft notwendig, worin die Interessen der Gemeinschaft Priorität über die individuellen Interessen der Mitglieder der Gemeinschaft genossen. 'Minderwertige' Elemente, wie Juden, 'Zigeuner' (Roma und Sinti), Homosexuelle, Kommunisten, oder kurzweg 'schwache' Menschen, mussten aus der Gesellschaft eliminiert werden. Die Ehe und die Familie galten als die 'Keimzelle der Nation'. Aus dieser Überzeugung wurden drei Ziele abgeleitet: I) die arische Rasse musste so rein wie möglich bleiben, 2) die arische Rasse musste so gesund wie möglich bleiben und 3) die arische Rasse sollte sich in der Personenanzahl so weit möglich ausbreiten. Im ersten Ziel lassen sich die Elemente der Rassenhygiene und des Antisemitismus deutlich erkennen. Durch die Verhinderung der Vermischung von 'reinem, arischen Blut' mit 'minderwertigem' Blut würde die arische Rasse so rein wie möglich bleiben. Vor allem jüdisches Blut wurde als besonders schädlich für die Qualität des Volkes eingestuft. Aus diesem Grund wurden Ehen und sexuelle Beziehungen zwischen Ariern und Juden strengstens abgelehnt. Alle 'schwachen' Elemente innerhalb der Gesellschaft, vor allem solche, die genetisch vorbelastet waren, konnten mittels Eugenetik 'herausgefiltert' werden. Darin ist der Einfluss des Sozialdarwinismus deutlich wiederzuerkennen. Zum Schluss konnte das dritte Ziel, die Ausbreitung der arischen Rasse, nur durch das Volk realisiert werden, welches sich in einem raschen Tempo fortpflanzen sollte. Laut der Ideologie konnte die Unsterblichkeit und das Fortbestehen der deutschen Nation - die arische Rasse - ohne den Zuwachs zukünftiger Generationen nicht garantiert werden.

\section{Nationalsozialismus in der Praxis}

\section{- 2.1 Deutschland}

Die nationalsozialistische Bevölkerungs- und Familienpolitik war stark pronatalistisch. Zusätzlich zur Verherrlichung der Mutterschaft wurden gesetzlich finanzielle Vorteile für arische Paare eingeführt, um eine schnelle Fortpflanzung zu fördern. Allerdings waren die Nationalsozialisten keine Pioniere auf dem Gebiet des Natalismus, weil in der deutschen Gesellschaft vor 1933 bereits pronatalistische Regierungsmaßnahmen existierten. Schon zu Zeiten der Weimarer Republik legten Regierungen großen Wert auf einen starken Bevölkerungswachstum, der sowohl durch Verherrlichung der Mutterschaft und des traditionellen Familienlebens als auch mittels finanzieller Förderungsmaßnahmen stimuliert wurde. Dennoch kann man den angewandten Fanatismus und die Präzision der Nationalsozialisten als auffällig bezeichnen.

Die Vervielfältigung der arischen Rasse durfte jedoch nicht gegen jeden Preis geschehen. Die nationalsozialistische Bevölkerungspolitik war sehr selektiv, auch innerhalb der 
eigenen arischen Bevölkerungsgruppe. Eugenetik als Lösung für gesellschaftliche Probleme wurde bereits zu Zeiten der Weimarer Republik thematisiert. Mit der Machtübernahme der Nazis verlor die Eugenetik jedoch ihren freiwilligen Charakter. Zur Gesundheitsförderung der arischen Rasse trat 1933 das Gesetz zur Verhütung erbkranken Nachwuchses in Kraft, welches die verpflichtete Sterilisation bei Bürgern mit Erbkrankheiten und Alkoholikern anordnete. Weiterhin wurde 1935 das Gesetz zum Schutze der Erbgesundheit des deutschen Volkes erlassen, welches Ehen zwischen Ariern und kranken oder schwachen Bürgern, arisch oder nicht, verbot. Beide Gesetze bezweckten das Entstehen einer Generation erblich belasteter Kinder zu verhindern. Im Falle der Vermutung erblicher Vorbelastung eines ungeborenen Kindes wurde eine Abtreibung ausgeführt, sogar bis zum Ende des sechsten Schwangerschaftsmonats. Formell war die Einwilligung der angehenden Mutter erforderlich, aber diese Voraussetzung wurde in der Praxis im Allgemeinen ignoriert.

Letztendlich wurden zwischen 1938 und I94I behinderte Kinder und geistig kranke Erwachsene massenhaft durch Vergasung 'euthanasiert', um Krankenhausbetten für erwartet verwundete Soldaten frei zu machen. Dazu muss angemerkt werden, dass diese Politik nie formell legalisiert wurde. In I94I wurde diese sogenannte 'Aktion T4' offiziell eingestellt. Nichtsdestotrotz wurden auch nach 194I psychiatrische Patienten in Pflegeanstalten weiterhin umgebracht, üblich durch Aushungerungen oder durch tödliche Injektionen.

Die Nationalsozialisten haben sich intensiv um die Erhaltung der Reinheit der arischen Rasse bemüht. In diesem Rahmen ist es den Nazis nie gelungen zu einer wasserdichten Definition des Begriffs 'Jude' zu kommen. Das Judentum wurde als eine Rasse und nicht als Religion betrachtet. Zur Feststellung, ob jemand der jüdischen Rasse angehörte, musste die Abstammung der Großeltern beurteilt werden. Bei der Frage, ob diese Großeltern der jüdischen Rasse angehörten oder angehört hatten, war allerdings die Frage bestimmend, ob sie Mitglied der jüdischen Religionsgemeinschaft (gewesen) waren. Damit wurde bei der Rassendefinition 'Jude' in Realität auf religiöse Kriterien zurückgegriffen. Darüber hinaus bleibt es fragwürdig, ob Menschen aufgrund einer Rasse eingeordnet werden können nach Ansicht der Nationalsozialisten. Diese Frage kann nur verneint werden, da die Methoden der Nazis, wie zum Beispiel Schädelmessungen, ihre Basis in wissenschaftlichen oder medizinischen Auffassungen hatten, die inzwischen längst überholt worden sind. Zusätzlich wurde und wird Abstammungsforschung meistens durch praktische Hindernisse behindert, wie zum Beispiel das Fehlen angemessener Dokumentation, wie ein Geburtenregister.

Während der Nazi-Zeit haben verschiedene Personen versucht die Definition des Rassenbegriffs 'Jude' zu verschärfen, vor allem bei den Bezeichnungen 'Halbjuden' und 'Vierteljuden'. Auch wurde versucht die teilweise privilegierte Position der gemischt verheirateten Juden aufzuheben. Jedoch wurden diese Versuche von Hitler selbst aufgehalten, weil er im Falle der Halbjuden und gemischten Ehen die arischen Familienmitglieder nicht brüskieren wollte. Ein zusätzlicher pragmatischer Grund, um die Verschärfung des Rassenbegriffes aufzuhalten, wird Hitler auch zugeschrieben, weil viele Viertel- und Halbjuden in der deutschen Armee mitkämpften. Zudem wurde Hitlers 
'mildere' Position gegenüber dieser Gruppe aus Zweifel über seine eigene Abstammung erklärt - diese Hypothese wurde allerdings nie bewiesen.

In den Niederlanden war die Lage noch unübersichtlicher. Im Gegenzug zur deutschen Abstammungsprüfung wurde in den Niederlanden ein Gegenbeweis der Abstammung der Großeltern erlaubt. Falls jemand beweisen konnte, dass seine Großeltern nichtjüdischer Abstammung waren, obwohl sie zur jüdischen Glaubensgemeinschaft gehört hatten, so konnte dies den Status des betreffenden Bürgers erheblich verbessern.

Um die Reinheit der arischen Rasse zu erhalten, mussten Ehen und sexuelle Beziehungen zwischen Ariern und Juden verboten werden. Während der nationalsozialistischen Machtübernahme in 1933 existierten keine Gesetze mehr, die Mischehen verboten. Es dauerte bis I935, bevor ein solches gesetzliches Verbot wieder in Deutschland in Kraft trat. In der Zwischenzeit versuchten Standesbeamte der Schließung von Mischehen entgegenzuwirken, indem man sich auf 'allgemeine nationale Prinzipien' berief. Diese 'allgemeine nationale Prinzipien' konnte man dem Gesetz zur Wiederherstellung des Berufsbeamtentums und der zugehörigen ersten Verordnung entnehmen, die eine erste rudimentäre Definition des Begriffs 'Jude' umfassen. Der damalige Reichsinnenminister Frick ordnete an, dass Standesbeamten weiterhin vorgenommene Mischehen schließen müssten, da solche Ehen gesetzlich (noch) nicht verboten waren. Allerdings fügte Frick seiner Anordnung bei, dass die existierenden Gesetze 'vielleicht nationalsozialistischen Auffassungen nicht voll zu entsprechen scheinen'. Diese Auffassung wurde später vom Reichsgericht bestätigt, aber in der Praxis verweigerten Standesbeamte weiter Mischehen zu schließen. In dieser Praxis wurden sie von verschiedenen Amtsgerichten und Landgerichten unterstützt.

Mischehen, die bereits vor der nationalsozialistischen Machtübernahme existierten, wurden von einem auf den nächsten Tag stigmatisiert und als schädlich für die Reinheit der arischen Rasse bezeichnet (Rassenschande). Eine Scheidung aufgrund des Judentums einer der Ehepartner war nicht erlaubt, da das Bürgerliche Gesetzbuch (BGB) nur eine Scheidung ermöglichte, indem einer der Ehepartner Schuld an einem der im BGB beschriebenen Scheidungsgründe hatte. Verschiedene Menschen versuchten an Stelle der üblichen Scheidungsgründe aufgrund $\mathbb{\$}$ I333 BGB ihre Ehe anzufechten. Eine Anfechtung der Ehe war möglich, wenn einer der Ehepartner sich während der Eheschließung über die persönlichen Eigenschaften des anderen Ehegatten geirrt hatte. Das Reichsgericht bestätigte I934, dass die jüdische Abstammung einer der Ehepartner als eine 'persönliche Eigenschaft' im Sinne des $\mathbb{S}$ I333 BGB qualifiziert werden konnte und dass eine Nichtigkeitserklärung einer Mischehe unter bestimmten Konditionen möglich war.

Das Gesetz zum Schutze des deutschen Blutes und der deutschen Ehre vom I5. September I 935 und die erste Verordnung vom I4. November 1935 verboten schließlich Ehen zwischen Juden und Staatsangehörigen des deutschen oder artverwandten Blutes, zwischen Juden und Vierteljuden sowie zwischen Vierteljuden untereinander. Für eine Ehe zwischen Halbjuden mit Vierteljuden oder Nicht-Juden war vorab eine Genehmigung des Reichsinnenministers und des Stellvertreters des Führers erforderlich. Alle übrigen Ehen, wobei eine mögliche 'Schädlichkeit für die Reinheit des deutschen Blutes' zu erwarten war, wurden verboten, ebenso wie außerehelicher Verkehr zwischen Juden und 
Ariern. Die erste zusätzliche Verordnung zum Blutschutzgesetz definierte das Konzept 'außerehelicher Verkehr' als 'Geschlechtsverkehr', ein Konzept das anschließend in der Praxis sehr breit interpretiert wurde.

Es ist den Nationalsozialisten im Jahr 1938 weiter gelungen das Ehescheidungsrecht zu revidieren, was in der Zeit der Weimarer Republik vergeblich versucht wurde. Der Grund der Revision lag innerhalb der Gemeinschaft; Ehen, die keinen Wert mehr für die Volksgemeinschaft hatten, weil es unwahrscheinlich war, dass Nachkommen geboren werden würden, mussten aufgehoben werden, damit Ex-Ehepartner erneut eine Ehe eingehen konnten, um mit einem neuen Ehepartner ihre moralische Pflicht an die Volksgemeinschaft zu erfüllen. Obwohl das Verschuldensprinzip Ausgangspunkt des Ehescheidungsrechtes blieb, wurde nun unter bestimmten Voraussetzungen das Zerrüttungsprinzip eingeführt. Allerdings wurde eine allgemeine Bestimmung die eine Scheidung ermöglichte im Falle, dass beide Ehepartner behaupteten die Ehe sei dauerhaft zerrüttet, noch als zu weitgehend beurteilt. Die Auflösung einer Ehe wurde grundsätzlich nicht als Lösung für Eheprobleme betrachtet, sondern als Lösung für Probleme der Volksgemeinschaft, wenn zwei verfremdete Eheleute gezwungen wurden verheiratet zu bleiben. Dennoch wurde eine 'Verweigerung der Fortpflanzung' zu einem rechtsgültigen Scheidungsgrund, wobei angenommen wurde, dass eine solche Verweigerung eine unvermeidlich dauerhafte Zerrüttung der Ehe verursachen würde. Bei der Einführung des Scheidungsgrunds 'vorzeitige Unfruchtbarkeit' wurde eine vergleichbare Argumentation verfolgt. Obwohl eine vorzeitige Unfruchtbarkeit in Realität nur selten zu Schulden des unfruchtbaren Ehepartners kam, wurde eine solche Situation als eine dermaßen schwere Belastung des Eheglücks beurteilt, dass eine Scheidung erlaubt war. Da Nachkommen bei einer vorzeitigen Unfruchtbarkeit nicht mehr zu erwarten waren, verlor eine Ehe ihren Wert für die Volksgemeinschaft. Als neue Scheidungsgründe im Zusammenhang mit der dauerhaften Zerrüttung einer Ehe wurden ebenfalls 'destruktives Benehmen einer der Ehepartner wegen einer geistigen Störung' und eine 'ansteckende oder ekelerregende Krankheit eines Ehepartners' eingeführt. Obwohl diese Veränderungen den Anschein hatten Mitgefühl und Verständnis für den unglücklichen, gesunden Ehepartner zu zeigen, ist der wahre Grund der Gesetzänderungen auf die Sicherstellung der Nachkommenschaft zurückzuführen.

\section{- 2.2 Die Niederlande}

Die Einführung eines Eheverbots für gemischte Paare verlief in den Niederlanden nicht reibungslos. Die deutsche Besatzungsmacht hat - ohne Erfolg - verschiedene Versuche veranlasst, um das deutsche Blutschutzgesetz mit den davon abgeleiteten Verordnungen in den Niederlanden Geltung zu verschaffen. Der wichtigste Grund dafür, dass die Bestimmungen dieses Gesetzes und davon abgeleitete Verordnungen keine Rechtskraft erlangten, lag in der Uneinigkeit unter deutschen Beamten über die Position der Halbjuden. Mehrere deutsche Beamten in den Niederlanden, wie Rauter und Rajakowitsch, haben außerhalb der direkten Einflußsphäre Berlins versucht die Definition des 'Halbjuden' zu verschärfen. Es war ihre Absicht um Halbjuden - die kein Mitglied der jüdischen Religionsgemeinschaft waren und deshalb nicht als J2 aber als 
G I eingestuft wurden - mit Volljuden gleichzustellen (mit Einstufung J2, J3 und J4, wobei die Zahl die Anzahl der jüdischen Großeltern ausdruckte). Dieses Konzept stieß jedoch auf beträchtlichen Widerstand von anderen hohen Beamten, wie Wimmer und SeyssInquart, welcher fortwährende Verzögerungen zur Folge hatte. Die vorsichtige Haltung Seyss-Inquarts aus Furcht vor möglicher gesellschaftlicher Unruhe hatte ebenso einen Verzögerungseffekt. Schließlich wurde im März 1942 in der von Juden gelesenen Zeitung Het Joodsche Weekblad eine Polizeiverordnung erlassen, die Ehen und außerehelichen Verkehr zwischen Juden und Nicht-Juden verbot. Diese Verordnung wurde im Januar I943 mit einem Rundschreiben des Generalsekretärs der Justiz, Jaap Schrieke, mit einem Dienstbefehl an die niederländischen Standesbeamten ergänzt, um alle geplanten Ehen zwischen a) Juden und Nicht-Juden, b) Halbjuden (G I) und Nicht-Juden, c) Juden und Vierteljuden, d) Halbjuden (G I) mit Halbjuden und f) Vierteljuden mit Vierteljuden beim Referat IV B4 der Sicherheitspolizei in Den Haag zu melden. Im Falle einer derartigen Meldung wurden anschließend beide Partner von der Sicherheitspolizei verhaftet. Ehen zwischen Halbjuden und Volljuden wurden zugelassen, weil sich dadurch der Status eines Halbjuden (G I) automatisch änderte in Volljude (J2). Dadurch endete ebenfalls automatisch die privilegierte Position des Halbjuden, die der deutschen Besatzungsmacht bereits bürokratische Kopfschmerzen bereitete.

Die deutsche Besatzungsmacht hat in den Niederlanden letztendlich keine Gesetzgebung eingeführt, die eine Scheidung oder Nichtigkeitserklärung bereits existierender Mischehen ermöglichte. Dennoch wurden nicht-jüdische Ehepartner häufig unter Druck gesetzt, sich von ihrem jüdischen Ehepartner scheiden zu lassen (nachdem der jüdische Ehepartner deportiert wurde), aber eine Scheidung war nur über einen juristischen Umweg möglich, wie der bekannte 'Groote Leugen' (eine ‘Große Lüge', indem der vermutete Ehebruch vom beschuldigten Ehepartner nicht abgestritten wurde), welcher eine Zusammenarbeit beider Eheleute erforderte. Generalsekretär der Justiz Schrieke hat - inspiriert vom deutschen Ehegesetz aus I938 - versucht das niederländische Ehescheidungsrecht zu revidieren, jedoch umfasste keine seiner Thesen eine Bestimmung, die eine Ehescheidung oder Nichtigkeitserklärung aufgrund der Tatsache ermöglichte, dass einer der Ehepartner Jude war. Schriekes Revisionsversuche können vor allem als ein Versuch betrachtet werden, um die stark kritisierte Praxis der 'Großen Lüge' zu beenden, mit dem Ziel die Anzahl der Scheidungsgründe auszubreiten. Obwohl Schrieke einen Anschluss zum deutschen Ehegesetz suchte, was durch seine Bemerkungen über Fortpflanzung als natürliches Ziel der Ehe bestätigt wird, können die meisten seiner Konzeptänderungen nicht als nationalsozialistisch gedeutet werden.

\section{Nationalsozialistisches Familienrecht?}

Die Zentralfrage dieser Doktorarbeit, ob das deutsche und niederländische Familienrecht - und im Besonderen das Ehe- und Ehescheidungsrecht - vom Nationalsozialismus beeinflusst wurde, kann schließlich auf zwei Ebenen beantwortet werden.

Wenn der historische Kontext und die Entwicklung des Familienrechts an sich (selbständig) außer Betracht gelassen wird, muss die Zentralfrage mit einer Bestätigung beantwortet werden. 
Das Ehe- und Ehescheidungsrecht wurde nachweisbar im Dienst des Nationalsozialismus gestellt. Dies geht vor allem hervor aus Bestimmungen wie dem Eheverbot zwischen Juden und Nicht-Juden, dem Verbot des außerehelichen Verkehrs zwischen Juden und Nicht-Juden, der Neuinterpretation des $\mathbb{}$ I333 BGB, um existierende Mischehen aufzuheben und der Einführung neuer Scheidungsgründe wie Verweigerung der Fortpflanzung und vorzeitige Unfruchtbarkeit. Die Ausführung dieser Bestimmungen war sowohl in Deutschland als in den Niederlanden Realität, wobei in den Niederlanden die meisten Änderungen des Familienrechts durch Polizeiverordnungen an Stelle von offiziellen Gesetzesänderungen angeordnet wurden.

Offiziell wurde die deutsche Besatzungsmacht in den Niederlanden dabei durch Artikel 43 der Haager Landkriegsordnung aus dem Jahr 1907 behindert; die Ordnung verbot jeder Besatzungsmacht die Anordnung oder Änderung von Gesetzen, die nicht unbedingt für die Wiederherstellung und Sicherung der öffentlichen Ordnung und des öffentlichen Lebens erforderlich waren. Dazu muss angemerkt werden, dass der Rahmen des Artikels 43 lange Zeit zur Diskussion stand. Trotz allem hat die deutsche Besatzungsmacht dem Artikel keine Bedeutung gewidmet, jedoch ständig einen möglichen Ausbruch ziviler Unruhe in Betracht gezogen. Aus Angst vor Protesten seitens der Bevölkerung hat Seyss-Inquart in erster Linie die Einführung der Nürnberger Gesetze in den Niederlanden abgelehnt. Letztendlich wurde das niederländische Familienrecht nicht so weit 'nazifiziert' wie es ursprünglich vorgesehen war. Obwohl bereits I940 eine offizielle Definition des Begriffs 'Jude' im deutschen Verordnungsblatt für die besetzten niederländischen Gebiete bekanntgegeben wurde, bekam das Blutschutzgesetz in den Niederlanden nie offizielle Gesetzeskraft. Eine Revision des niederländischen Ehescheidungsrechts wurde zwar vorbereitet, aber wurde ebenfalls nie realisiert, was auf die verschiedenen amtlichen Auffassungen hinsichtlich der Definition 'Jude' zurückzuführen ist. Ebenfalls hat dabei Zeitmangel eine Rolle gespielt; die deutsche Besatzung der Niederlande endete im Mai I945, und seit Herbst I944 entstanden für die Besatzungsmacht weit wichtigere Prioritäten als eine Revision des niederländische Ehe- und Ehescheidungsrechts. Schriekes Konzeptrevision des niederländischen Ehescheidungsrechts wurde zwar nach Berlin geschickt, aber ist dort eher unten im Stapel neuer Gesetzgebungsvorschläge gelandet. So kann man zum Schluss kommen, dass obwohl das niederländische Familienrecht nicht de jure vom Nationalsozialismus beeinflusst wurde, dieser Einfluss de facto und nachweisbar durch Polizeiverordnungen existierte. Die Wirklichkeit des täglichen Familienlebens von Menschen, die teilweise oder vollständig jüdisch waren und diejenigen,. die verheiratet waren oder heirateten wollten mit einem jüdischen Ehepartner, wurde zweifellos vom Nationalsozialismus beeinflusst.

Falls bei der Beantwortung der Zentralfrage doch der historische Kontext und die Entwicklung des Familienrechts in Anbetracht genommen werden, so neigt sich die Antwort einer Verneinung zu.

Auf konzeptioneller Ebene haben die Nationalsozialisten keine großen Änderungen durchgeführt. Der Hauptteil der nationalsozialistischen Maßnahmen wurde generell nicht durch eine Änderung bestehender Gesetzbücher eingeführt, aber viel mehr 
mittels des Entwurfes gesonderter Gesetze und sogar durch den Erlass von ad hoc Bestimmungen oder Bekanntmachungen, ohne deutliche Definitionen. Es ist sogar eine gewisse Kontinuität im deutschen Ehe- und Ehescheidungsrecht zu beobachten. Die Diskussion über die Revision des Ehescheidungsrechts - im Besonderen über eine Ausbreitung der Scheidungsgründe vom Verschuldensprinzip in das Zerrüttungsprinzip - wurde schon seit Jahren geführt; die Nationalsozialisten haben diesen theoretischen Ansatz bloß weiter durchgesetzt und nicht selbst konzipiert. Alle Argumente aus der Weimarzeit wurden bei dem Entwurf des Ehegesetzes I 938 wiederholt. Obwohl mit dem Erlass des Ehegesetzes in 1938 die Anzahl der Scheidungsgründe erweitert wurde, kann diese Entwicklung nicht gedeutet werden, als ein radikaler Bruch mit der Vergangenheit. Das Verschuldensprinzip blieb Grundlage des Gesetzes und das Zerrüttungsprinzip wurde nur unter bestimmten Voraussetzungen eingeführt. Der Teufel steckte in den Generalklauseln; Generalklauseln wie das 'Wesen der Ehe' und 'sittlich nicht gerechtfertigt' ermöglichten eine nationalsozialistische Interpretation von scheinbar unschuldigen Bestimmungen. Nach dem Fall des Nationalsozialismus kehrte sich diese Praxis der Interpretation. Dennoch hat die Existenz der Generalklauseln dazu geführt, dass der Alliierter Kontrollrat in 1946 das Ehegesetz aus 1938 größtenteils übernommen hat, was die Beobachtung einer gewissen Kontinuität weiter begründet. Hinsichtlich der eugenetischen und Rassenbestimmungen, die im Ehe- und Ehescheidungsrecht durchgeführt wurden, kann geschlussfolgert werden, dass diese Bestimmungen keinen bleibenden Einfluss gehabt haben, da diese Bestimmungen nach dem Fall des Nationalsozialismus wiederrufen wurden.

In den Niederlanden wurde eine Revision des Scheidungsrechts schon seit Längerem als notwendig betrachtet. Das 'Groote Leugen'-Urteil ('Große Lüge') des Hohen Rates aus I 883 hatte eine unerwünschten Spielraum geschaffen für die Anwendbarkeit von Ehebruch als Scheidungsgrund. In der Praxis wurde dadurch eine Ehescheidung mit gegenseitiger Zustimmung erlaubt, obwohl im Gesetz ein ausdrückliches Verbot bestand. Auch in den Niederlanden wurde bereits über eine eventuelle Erweiterung der Anzahl der Scheidungsgründe und über die Einführung des Zerrüttungsprinzips diskutiert. Dabei wurde vor allem über Geistesstörung als möglichen Scheidungsgrund viel argumentiert. Schriekes Versuche das niederländische Ehescheidungsrecht zu reformieren, wurden vor allem aus der Überzeugung motiviert, dass der 'Großen Lüge' ein Ende bereitet werden musste. In der Tat hat Schrieke bei seiner Konzeptrevision das deutsche Ehegesetz von 1938 als Vorbild genommen, dennoch würde es zu weit führen, seine Änderungsvorschläge als nationalsozialistisch zu bezeichnen. Es ist wahrscheinlicher anzunehmen, dass Schrieke einen doppelten Zweck auf einmal erreichen wollte, wobei die Beendung der 'Großen Lüge' sein Hauptzweck war.

Änderungen des Ehescheidungsrechts scheinen eher durch eine Gesellschaft angekurbelt zu werden, die sich selbst langsam verändert, wobei das Scheidungsrecht viel mehr einen Ausdruck 'O Tempora, O Mores' darstellt, an Stelle ein Ausdruck einer explosiv wachsenden extremen Ideologie zu sein. Religion hat lange Zeit den Inhalt des Ehescheidungsrechts beeinflusst. Als der Einfluss der Kirche zurücklief - vor allem ab den 6o-er Jahren des vorigen Jahrhunderts - wurden die Regeln bezüglich einer Ehescheidung weniger streng. Diese Entwicklung ist vor allem in den Niederlanden deutlich erkennbar, 
wo die Scheidungsgründe erst I97I revidiert wurden, fast 30 Jahre nach Ende des zweiten Weltkriegs. Zuvor bestand wohl noch keine vollständige gesellschaftliche Akzeptanz für eine Gesetzesänderung. Es ist sehr wahrscheinlich, dass die Scheidungsgründe in Deutschland und den Niederlanden auch ohne den Nationalsozialismus auf Dauer ausgebreitet worden wären. Die Nationalsozialisten haben bestehende Konzepte und Argumente benutzt und schließlich ihre Machtposition eingesetzt, um diese Konzepte. einigermaßen angepasst an nationalsozialistisches Denken, einzuführen. Ein Diktator lässt sich im Grunde genommen nicht durch demokratische Prozesse oder Dialogpolitik aufhalten.

Österreich bedarf hier noch einer gesonderten Erwähnung. In Kapitel 3 wird beschrieben wie das deutsche Ehegesetz aus I938 auch in Österreich (als Teil des Dritten Reiches) erlassen wurde und dort die Zivilehe für alle Österreicher unabhängig derer religiösen Hintergründe verpflichtete. Weil das Ehegesetz, inzwischen in angepasster Form, in Österreich noch immer die Grundlage des Ehe- und Ehescheidungsrechts darstellt, kann festgestellt werden, dass die Nationalsozialisten einen weitgreifenden Einfluss auf das österreichische Ehe- und Ehescheidungsrecht hatten. Dieser Behauptung muss man hinzufügen, dass das österreichische Ehe- und Ehescheidungsrecht nicht so sehr vom Nationalsozialismus, aber von den Nationalsozialisten beeinflusst wurde. Das Ehegesetz aus dem Jahr 1938 ging davon aus, dass bereits eine verpflichtete Zivilehe existierte und dass allen Bürgern das Recht eines Scheidungsantrags gegeben sei, ohne einen Unterschied zu machen aufgrund der Religion. Der dadurch verursachte Erdrutsch innerhalb des österreichischen Ehe- und Ehescheidungsrechts kann deswegen nicht so sehr dem Nationalsozialismus zugeschrieben werden, aber sollte wie eine notwendige Modernisierung betrachtet werden, die ermöglicht wurde durch die absolute Macht der Nationalsozialisten.

Die Schlussfolgerung dieser Doktorarbeitet lautet, dass das Ehe- und Ehescheidungsrecht in Deutschland, Österreich und den Niederlanden zwar zeitweise vom Nationalsozialismus beeinflusst wurden, aber kein nationalsozialistisches Familienrecht geworden sind. 
Amersfoort \& Kamphuis

Amersfoort, H. and P.H. Kamphuis, Mei 1940. De strijd op Nederlands grondgebied, (Boom, 2012)

\section{Anderson}

Anderson, D.L., The Academy of German Law, 1933-1944, (Garland Publishing, Inc., 1987)

\section{Antokolskaia}

Antokolskaia, M., Harmonisation of Family Law in Europe: A Historical Perspective, (Intersentia, 2006)

\section{Apeldoorn, 1925}

Apeldoorn, L.J. van, Geschiedenis van het Nederlandsche Huwelijksrecht vóór de invoering van de Fransche wetgeving, (Uitgeversmaatschappij Holland, 1925)

\section{Apeldoorn, 1943}

Apeldoorn, L.J. van, Inleiding tot de studie van het Nederlandsche Recht, (S. Gouda Quint, 1943)

\section{Arendt}

Arendt, H., Eichmann in Jerusalem. A Report on the Banality of Evil, (Penguin Books, 1994)

\section{Asscher \& Cohen}

Asscher, A and D. Cohen, 'Bekendmaking', 1 Het Joodsche Weekblad 51 (1942), 1, (reprint: Omniboek, 1979)

\section{Asser}

Asser, C., Het Nederlandsch Burgerlijk Wetboek, vergeleken met het Wetboek Napoleon, (De Gebroeders van Cleef, 1838)

\section{Baynes}

Baynes, N.H., The Speeches of Adolf Hitler. April 1922-August 1939, (Oxford University Press, 1942)

\section{Bechert \& Wiesels}

Bechert, R. and J. Wiesels, Das neue Eherecht für Großdeutschland, (Verlag W. Kohlhammer, 1943)

\section{Bellefroid}

Bellefroid, J.H.P., Beknopt overzicht der Staatsinrichting van Nederland tijdens de bezetting, (Dekker \& Van de Vegt N.V., 1942)

\section{Benvenisti}

Benvenisti, E, The International Law of Occupation, (Princeton University Press, 2004)

\section{Biegel}

Biegel, F.M., Bezettingsrecht. Een korte schets van het staatsrecht en de staatsinrichting gedurende de Duitsche bezetting in Nederland, (N. Samsom N.V., 1940)

\section{Blasius}

Blasius, D., Ehescheidung in Deutschland 1794-1945, (Vandenhoeck \& Ruprecht, 1987)

\section{Bock, 1984}

Bock, G., 'Racism and Sexism in Nazi Germany: Motherhood, Compulsory Sterilization, and the State', in: R. Bridenthal, A. Grossmann and M. Kaplan (eds.), When Biology Became Destiny. Women in Weimar and Nazi Germany, (Monthly Review Press, 1984), 271-296

\section{Bock, 1985}

Bock, G., '"Zum Wohle des Volkskörpers..." Abtreibung und Sterilisation im Nationalsozialismus', in: M. Schmidt and G. Dietz (eds.), Frauen unterm Hakenkreuz. Eine Dokumentation, (Deutscher Taschenbuch Verlag, 1985), 78-84

\section{Bock, 1994}

Bock, G., 'Antinatalism, Maternity and Paternity in National Socialist Racism', in: D.F. Crew, Nazism and German Society, 1933-1945, (Routledge, 1994)

\section{Boer, de}

Boer, J. de (ed.), Mr. C. Asser's Handleiding tot de Beoefening van het Nederlands Burgerlijk Recht. Personen- en Familierecht, (Kluwer, 2006). Original edition by C. Asser

\section{Bolhuis}

Bolhuis, J.J. van, 'Enkele hoofdfiguren van het Duitse bestuur', in: J.J. van Bolhuis, C.D.J. Brandt, H.M. van Randwijk and B.C. Slotemaker (eds.), Onderdrukking en Verzet. Nederland in Oorlogstijd, (Van Loghum Slaterus/J.M. Meulenhoff, 1947), 1:332-353

\section{Bookbinder}

Bookbinder, P., Weimar Germany. The Republic of the reasonable, (Manchester University Press, 1996)

\section{Bosch}

Bosch Ridder van Rosenthal, L.H.N. 'De Aanwijzingen', in: J.J. van Bolhuis, C.D.J. Brandt, H.M. van Randwijk and B.C. Slotemaker (eds.), Onderdrukking en Verzet. Nederland in Oorlogstijd, (Van Loghum Slaterus/J.M. Meulenhoff, 1947), 1:385-397

\section{Brakel}

Brakel, S. van, 'Rechten, waarover men niet de vrije beschikking heeft en de betekenis in het echtscheidingsgeding', 63 Weekblad voor Privaatrecht, Notarisambt en Registratie 3244 (1932), 77-79 
Brecht

Brecht, B., Gesammelte Werke.

Gedichte 1, (Suhrkamp Verlag, 1967)

Bridenthal, Grossmann \& Kaplan

Bridenthal, R., A. Grossmann and M. Kaplan (eds.), When Biology Became Destiny. Women in Weimar and Nazi Germany, (Monthly Review Press, 1984)

\section{Bridenthal \& Koonz}

Bridenthal, R. and C. Koonz, 'Beyond Kinder, Küche, Kirche: Weimar Women in Politics and Work', in: R. Bridenthal, A. Grossmann and M. Kaplan (eds.), When Biology Became Destiny. Women in Weimar and Nazi Germany, (Monthly Review Press, 1984), 33-65

Briët

Briët, C., 'De groote leugen', 1

Nederlandsch Juristenblad 15

(1926), 214-216

Bukey

Bukey, E.B., Hitler's Austria. Popular Sentiment in the Nazi Era, 19381945, (The University of North Carolina Press, 2000)

\section{Burleigh}

Burleigh, M., The Third Reich. A New History, (Pan Macmillan, 2000)

\section{Burleigh \& Wippermann}

Burleigh, M. and W. Wippermann, The Racial State: Germany 1933-1945,

(Cambridge University Press, 1991)

\section{Cameron et al.}

Cameron, N., R.H. Stevens and P. Andriesse (eds.), Hitlers tafelgesprekken 1941-1944, (De Prom, 2005). Translated by P. Andriesse from the English edition Bormann-Vermerke: Hitler's Table Talk, (Weidenfeld and Nicholson, 1953). Original edition by H. Picker (ed.), Tischgespräche im Führerhauptquartier 1941/1942, (AthenäumVerlag, 1951) and revised edition by H. Picker (ed.), Tischgespräche im Führerhauptquartier, (Seewald Verlag, 1963/1976, Studienausgabe 1977)

\section{Carp}

Carp, J.H., Beginselen van NationaalSocialisme, (Nenasu, 1942)

\section{Cassese}

Cassese, A., 'The Martens Clause: Half a Loaf or Simply Pie in the Sky?', 11 European Journal of International Law 1 (2000), 187-216

\section{Cohen}

Cohen, L.A., Handboek der Openbare Gezondheidsregeling en der Geneeskundige Politie, met het oog op de behoeften en de wetgeving van Nederland, (J.B. Wolters, 1872)
Dahm

Dahm, V., Das jüdische Buch im Dritten Reich, (Verlag C.H. Beck, 1993)

\section{Damsma}

Damsma, D., 'De dubbele revolutie en het gezin', in: T. Zwaan (ed.), Familie, huwelijk en gezin in West-Europa. Van Middeleeuwen tot moderne tijd, (Boom/ Open universiteit, 2004), 165-192

\section{Darwin}

Darwin, C., On the origin of species by means of natural selection, or the preservation of favoured races in the struggle for life, reprint of first edition, (Watts \& Co., 1950)

\section{Deuel}

Deuel, W., People under Hitler, (Lindsay Drummond, 1942)

\section{Dievoet}

Dievoet, E. van, Het Burgerlijk Recht van België en Nederland van 1800 tot 1940, (De Sikkel/Martinus Nijhoff, 1943).

\section{Elon}

Elon, A., Duitsland en zijn Joden. Geschiedenis van het Duitse Jodendom van 1743 tot 1933, (Meulenhoff 2002). Translated by M. de Boer

\section{Enquêtecommissie Regeringsbeleid} 1940-1945

Enquêtecommissie Regeringsbeleid 1940-1945, Verslag houdende de uitkomsten van het onderzoek, Deel $5 b$, Ministers- en kabinetscrises, voorbereiding terugkeer (Staten-Generaal, militair gezag, vertrouwensmannen, (Staatsdrukkerij- en uitgeverijbedrijf, 1950)

\section{Falckenberg}

Falckenberg, O. (ed.), Das Buch von der Lex Heinze. Ein Kulturdokument aus dem Anfange des Zwanzigsten Jahrhunderts, (Commissionsverlag von L. Staackmann, 1900)

\section{Feuchtwanger}

Feuchtwanger, E., 'The transition from Weimar to the Third Reich: the politica dimension', in: P. Panayi (ed.), Weimar and Nazi Germany. Continuities and Discontinuities, (Pearson Education Limited, 2001), 105-133

\section{Field}

Field, G.G., Evangelist of Race. The Germanic Vision of Houston Stewart Chamberlain, (Columbia University Press, 1981)

\section{Fischer}

Fischer, L., 'Rasseschande als strafbare Handlung', Zeitschrift der Akademie für Deutsches Recht (1934), 536-537
Fraenkel

Fraenkel, E., The Dual State. A Contribution to the Theory of Dictatorship, (Oxford University Press, 1941)

\section{Fraenkel-Verkade}

Fraenkel-Verkade, E., Correspondentie van Mr. M.M. Rost van Tonningen, dee 1, (Martinus Nijhoff, 1967)

\section{François}

François, J.P.A., 'De Bezetting en het Volkenrecht', in: J.J. van Bolhuis, C.D.J. Brandt, H.M. van Randwijk and B.C. Slotemaker (eds.), Onderdrukking en Verzet. Nederland in Oorlogstijd, (Van Loghum Slaterus/J.M. Meulenhoff 1947), 4:245-266

\section{Frantz}

Frantz, G., 'Richtung und Grundgedanken der reichsgerichtlichen Rechtsprechung zum Ehegesetz', 11 Deutsches Recht 19/20 (1941), 1028-1035

\section{Freisler 1933}

Freisler, R., 'Recht, Richter und Gesetz', 95 Deutsche Justiz 49 (1933), 694-696

\section{Freisler 1937}

Freisler, R., Vom alten zum neuen Ehescheidungsrecht. Kritik, Vorschlag, Begründung, (R. v. Decker's Verlag, G. Schenck, 1937)

Frijtag Drabbe Künzel, von Frijtag Drabbe Künzel, G. von, Het geval Calmeyer, (Mets \& Schilt, 2008)

\section{Galen-Herrmann, van}

Galen-Herrmann, R.E. van, 'De controverse rond het ambtelijk functioneren van Hans Calmeyer tijdens de bezetting 1940-1945', 81 Nederlands Juristenblad 17 (2006), 940-944

\section{Galton 1869}

Galton, F., Hereditary Genius. An inquiry into its laws and consequences, reprint, (Julian Friedman Publishers/St Martin's Press, 1978)

\section{Galton 1883}

Galton, F., Inquiries into Human Faculty and its Development, electronic edition available at www.galton. org/books/human-faculty/text/galton1883-human-faculty-v4.pdf, last accessed on 27 September 2012

\section{Galton 1910}

Galton, F., The Eugenic College of Kantsaywhere, manuscript electronically available at www.ucl.ac.uk/library/ special-coll/ksw.shtml, last accessed on 27 September 2012 


\section{Garner}

Garner, J.W., International Law and the World War, (Longmans, Green and Co., 1920)

\section{Gisevius}

Gisevius, H.B., Adolf Hitler, (De Fontein, 1973). Translated by J.F. Kliphuis

\section{Gobineau}

Gobineau, J.A. de, Essai sur l'inégalité des races humaines, (Librairie de Paris, 1933)

\section{Greenspan}

Greenspan, M., The Modern Law of Land Warfare, (University of California Press, 1959)

\section{Groß}

Groß, W., 'Unsere Arbeit gilt der deutschen Familie', 10 Nationalsozialistische Monatshefte 107 (1939), 99-106

\section{Grossmann}

Grossmann, A., 'Abortion and Economic Crisis: The 1931 Campaign Against Paragraph 218', in: R. Bridenthal, A. Grossmann and M. Kaplan (eds.), When Biology Became Destiny. Women in Weimar and Nazi Germany, (Monthly Review Press, 1984), 66-86

\section{Gruchmann 1983}

Gruchmann, L., "“Blutschutzgesetz” und Justiz. Zu Entstehung und Auswirkung des Nürnberger Gesetzes vom 15. September 1935', 31 Vierteljahrshefte für Zeitgeschichte 3 (1983), 418-442

\section{Gruchmann 1989}

Gruchmann, L., 'Das Ehegesetz vom 6. Juli 1938. Entstehung und Beurteilung', 11 Zeitschrift für neuere Rechtsgeschichte 1/2 (1989), 63-83

\section{Grunberger}

Grunberger, R., A Social History of the Third Reich, (Penguin Books, 1991)

\section{Günther 1930}

Günther, H.F.K., Rassenkunde des deutschen Volkes, (J.F. Lehmanns Verlag, 1930)

\section{Günther 1943}

Günther, H.F.K., Kort Overzicht der Rassenkunde, (Uitgeverij Westland, 1943). Translated from Kurzer Abriß der Rassenkunde

\section{Haeckel 1902}

Haeckel, E., Natürliche SchöpfungsGeschichte. Gemeinverständliche wissenschaftliche Vorträge über die Entwicklungs-Lehre, $10^{\text {th }}$ edition, (Georg Reimer, 1902)

\section{Haeckel 1904}

Haeckel, E., Die Lebenswunder. Gemeinverständliche Studiën über biologische Philosophie, (Alfred Kröner, 1904)
Hagen

Hagen, J., Nietzsches weerklank in Nazi-Duitsland, (Uitgeverij Aspekt, 2003)

\section{Hamburger \& Verkouteren}

Hamburger, W. and H. Verkouteren, 'Het Vrije Huwelijk', 1 Pro en Contra 1 (1905), 1-33

\section{Hausen}

Hausen, K., 'Mother's Day in the Weimar Republic', in: R. Bridenthal, A. Grossmann and M. Kaplan (eds.), When Biology Became Destiny. Women in Weimar and Nazi Germany, (Monthly Review Press, 1984), 131-152

\section{Heiden}

Heiden, K., Adolf Hitler. Das Zeitalter der Verantwortungslosigkeit, (Europa Verlag, 1936)

\section{Heijden, van der}

Heijden, C. van der, Grijs verleden. Nederland en de Tweede Wereldoorlog, (Olympus, 2003)

\section{Herder}

Herder, J.G., Ideen zur Philosophie der Geschichte der Menschheit, (Deutscher Klassiker Verlag, 1989)

\section{Herzberg}

Herzberg, A.J., 'Kroniek der Jodenvervolging', in: J.J. van Bolhuis, C.D.J. Brandt, H.M. van Randwijk and B.C. Slotemaker (eds.), Onderdrukking en Verzet. Nederland in Oorlogstijd, (Van Loghum Slaterus/J.M. Meulenhoff, 1947), 3:5-256

Hetzel

Hetzel, M., Die Anfechtung der Rassenmischehe in den Jahren 1933-1939, (Mohr Siebeck, 1997)

\section{Hirschfeld}

Hirschfeld, G., Bezetting en collaboratie, (H.J.W. Becht, 1991). Translated by $P$. Jaarsma

\section{Hitler 1937}

Hitler, A., Mein Kampf, $275^{\text {th }}-276^{\text {th }}$ edition, (Zentralverlag der NSDAP, 1937)

\section{Hitler 1999}

Hitler, A., Mein Kampf, (Houghton Mifflin Company, 1999). Translated by R. Manheim

\section{Hofmeister}

Hofmeister, H., 'Privatrechtsgesetzgebung für Österreich unter der Herrschaft des Nationalsozialismus', in: U. Davy et al. (eds.), Nationalsozialismus und Recht. Rechtssetzung und Rechtswissenschaft in Österreich unter der Herrschaft des Nationalsozi alismus, (Wirtschaftsverlag Dr. Anton Orac, 1990)
Höhn

Höhn, R., 'Staatsangehöriger und Reichsbürger', Deutsches Recht (1936), 20-23

\section{Houten, van 1876}

Houten, S. van, 'Beschouwingen over de bevolkingleer in verband met de sexueele moraal', (1876), in S. van Houten, Maatschappelijke en Wettelijke Stelling der Vrouw. Verspreide opstellen, (Martinus Nijhoff, 1918)

\section{Houten, van 1877}

Houten, S. van, 'Over de maatschappelijke en wettelijke stelling der vrouw', (1877), in S. van Houten, Maatschappelijke en Wettelijke Stelling der Vrouw. Verspreide opstellen, (Martinus Nijhoff, 1918)

\section{Houten, van 1913}

Houten, S. Van, 'Staatkundige Brieven, no. 23', De Nieuwe Courant, 1 February 1913

\section{Houwing et al.}

Houwing, J.F., A. Grünebaum and N. De Beneditty (eds.), Het Burgerlijk Wetboek verklaard door Mr. C.W. Opzoomer, Tweede Deel, (Boekh. Vh. Gebr. Belinfante, 1918). Original edition by C.W. Opzoomer

Huart

Huart, F.J.A., Grondwetsherziening 1917 en 1922, (S. Gouda Quint, 1925)

\section{Hubbard}

Hubbard, W.H., Familiengeschichte. Materialien zur deutschen Familie seit dem Ende des 18. Jahrhunderts, (Verlag C.H. Beck, 1983)

\section{Huussen Jr.}

Huussen Jr., A.H., 'The Discussion about the Extension of Divorce in the Netherlands, 1870-1970', 63 Tijd schrift voor Rechtsgeschiedenis 3/4 (1995), 311-335

\section{Hyde}

Hyde, C.C., International Law chiefly as interpreted and applied by the United States, volume 2, (Little, Brown, and Company, 1922)

\section{Jansen 2006a}

Jansen, C.J.H., 'De Lex-van Oven: 50 jaar opheffing handelingsonbekwaamheid van de gehuwde vrouw', 81 Nederlands Juristenblad 23 (2006), 1256-1260

\section{Jansen $2006 b$}

Jansen, C.J.H., Doorgaan of stoppen? Enkele beschouwingen over recht en rechtsbeoefening in Nederland tijdens de Tweede Wereldoorlog, (Boom Juridische uitgevers, 2006) 


\section{Jansen 2010}

Jansen, C.J.H., 'De Duitse Themis op de pijnbank. Het Duitse nationaalsocialisme in het Weekblad van het Recht en het Nederlands Juristenblad (19331940)', 85 Nederlands Juristenblad 28 (2010), 1818-1825

\section{Jansen \& Venema}

Jansen, C.J.H. and D. Venema, De Hoge Raad en de Tweede Wereldoorlog. Recht en rechtsbeoefening in de jaren 1930-1950, (Boom, 2011)

\section{Jansma}

Jansma, T.J., Het bezettingsrecht in de pracktijk van de Tweede Wereldoorlog, (H. Veenman \& Zonen, 1953)

\section{Jong, de}

Jong, L. de, Het Koninkrijk der Nederlanden in de Tweede Wereldoorlog, (SDU Uitgeverij Koninginnegracht/Boom, 1995)

\section{Kahn}

Kahn, F., 'Die dritte Haager Staatenkonferenz für internationales Privatrecht', Zeitschrift für Internationales Privat- und Öffentliches Recht 1/2, 3/4, 5 (1902/1903), 1-21, 201-261, $385-437$

\section{Kant}

Kant, I., Von den verschiedenen Rassen der Menschen, in: W. Weischedel (ed.), Werke in sechs Banden, Band VI, Schriften zur Anthropologie, Geschichtsphilosophie, Politik und Pädagogik, (WBG, 2011)

\section{Kerrl \& Freisler}

Kerrl, H. and R. Freisler, Nationalsozialistisches Strafrecht. Denkschrift des Preußischen Justizministers, (R. v. Decker's Verlag, G. Schenck, 1933)

\section{Kipp \& Wolff 1920}

Kipp, T. and M. Wolff, Das Familienrecht, (N.G. Elwert'sche Verlagsbuchhandlung (G. Braun), 1920)

\section{Kipp \& Wolff 1931}

Kipp, T. and M. Wolff, Das Familienrecht, (N.G. Elwert'sche Verlagsbuchhandlung (G. Braun), 1931)

Kisch

Kisch, I., 'Het Duitsche verbod van gemengde huwelijken', 97 Weekblad van het Recht 12960 (1935)

\section{Kleijn et al.}

Kleijn, F., J.G. Stokman, H.C. Touw and Th. Delleman, 'Het verzet der kerken', in: J.J. van Bolhuis, C.D.J. Brandt, H.M. van Randwijk and B.C. Slotemaker (eds.), Onderdrukking en Verzet. Nederland in Oorlogstijd, (Van Loghum Slaterus/J.M. Meulenhoff, 1947), 2:385-469

\section{Klinksiek}

Klinksiek, D., Die Frau im NS-Staat, Schriftenreihe der Vierteljahreshefte für Zeitgeschichte, volume 44, (Deutsche Verlags-Anstalt, 1982)

\section{Kloek}

Kloek, E., 'Huwelijk en gezinsleven tijdens het Ancien Régime, 16501800', in: T. Zwaan (ed.), Familie, huwelijk en gezin in West-Europa. Van Middeleeuwen tot moderne tijd, (Boom/ Open universiteit, 2004)

\section{Knegtmans et al.}

Knegtmans, P.J., P. Schulten and J. Vogel, Collaborateurs van niveau. Opkomst en val van de hoogleraren Schrieke, Snijder en Van Dam, (Vossiuspers AUP, 1996)

\section{Knost \& Maßfelle}

Knost, F.U. and F. Maßfeller, Das neue Personenstands- und Familienrecht nebst den Staatsangehörigkeitsvorschriften für die neuen deutschen Gebiete, (Verlag für Standesamtswesen $\mathrm{GmbH}, 1940$ )

\section{Kohlhepp}

Kohlhepp, R., 'Franz Wieacker und die NS-Zeit', 122 Zeitschrift der SavignyStiftung für Rechtsgeschichte. Romanistische Abteilung (2005), 203-223

\section{Kollewijn 1935a}

Kollewijn, R.D., 'Het Duitsche Verbod der "gemengde huwelijken"', 10 Nederlandsch Juristenblad 37 (1935), 577-580

\section{Kollewijn 1935b}

Kollewijn, R.D., 'Het Duitse verbod van huwelijken tussen Ariërs en niet-Ariërs', 142 Indisch Tijdschrift van het Recht 4 (1935), 473-482

\section{Körver}

Körver, P.H.J., De Bes/uitwetgeving van de Nederlandse regering in Londen in internationaal-rechtelijk en staatsrechtelijk perspectief, (Kluwer, 2004)

\section{Krausnick \& Broszat}

Krausnick, H. and M. Broszat, Anatomy of the SS State, (Paladin, 1970).

Translated by D. Long and M. Jackson

Kuyk

Kuyk, G.J.H., 'Het echtscheidingsvraagstuk', 19 Nederlandsch Juristenblad 5 (1944), 37

\section{Lauterpacht, 1935}

Lauterpacht, H. (ed.), International Law. A Treatise. Volume II, Disputes, War and Neutrality, (Longmans, Green and Co., 1935). Original edition by L. Oppenheim

\section{Lauterpacht, 1948}

Lauterpacht, H. (ed.), International Law. A Treatise. Volume I, Peace, (Longmans, Green and Co., 1948). Original edition by L. Oppenheim

\section{Lauterpacht, 1952}

Lauterpacht, H. (ed.), International Law. A Treatise. Volume II, Disputes, War and Neutrality, (Longmans, Green and Co., 1952). Original edition by L. Oppenheim

\section{Lavater}

Lavater, J.C., Physiognomische Fragmente zur Beförderung der Menschen kenntnis und Menschenliebe, reprint, (Philipp Reclam, 1984)

\section{Lehner}

Lehner, O., Familie - Recht - Politik. Die Entwicklung des österreichischen Familienrechts im 19. und 20. Jahrhundert, (Springer Verlag, 1987)

\section{Lenel \& Lewald}

Lenel, O. and H. Lewald, Abhandlungen zum internationalen Privatrecht von Franz Kahn, (Verlag von Duncker \& Humblot, 1928)

\section{Leppin}

Leppin, R., 'Der Schutz des deutschen Blutes und der deutschen Ehre. Ein Überblick über Rechtsprechung und Schriftum', 66 Juristische Wochenschrift 49 (1937), 3076-3082

\section{Lepsius 2003}

Lepsius, O., 'The Problem of Perceptions of National Socialist Law or: Was there a Constitutional Theory of National Socialism?' in: C. Joerges and N. Singh Ghaleigh (eds.), Darker Legacies of Law in Europe. The Shadow of National Socialism and Facism over Europe and its Legal Traditions, (Hart Publishing, 2003), 19-41

\section{Lepsius 2004}

Lepsius, O., 'Gab es ein Staatsrecht des Nationalsozialismus?', 26 Zeitschrift für Neuere Rechtsgeschichte $1 / 2$ (2004), 102-116

\section{Levy \& Verkouteren}

Levy, J.A. and H. Verkouteren, 'Verruiming van echtscheidingsgronden', Pro en Contra (1910), 1-36

\section{Lichter \& Knost}

Lichter, M. and F.U. Knost, Deutsches und ausländisches Staatsangehörigkeitsrecht, (Verlag für Standesamtswesen $\mathrm{GmbH}, 1935$ )

\section{Limburg}

Limburg, J., 'Het Familierecht van het BW in zijn karakteristieke eigenschappen tegenover het recht van thans', in P. Scholten and E.M. Meijers (eds.), Gedenkboek Burgerlijk Wetboek 18381938, (W.E.J. Tjeenk Willink, 1938), 347-363 


\section{Lindsey \& Evans 1927}

Lindsey, B.B. and W. Evans, The Companionate Marriage, (Boni \& Liveright, 1927)

\section{Lindsey \& Evans 1928}

Lindsey, B.B. and W. Evans, Huwelijk in Kameraadschap, (H. Meulenhoff, 1928). Translated by E.A. Voogd-Pull

\section{Lokin \& Jansen}

Lokin, J.H.A. and C.J.H. Jansen, Tussen droom en daad. De Nederlandse Juristen-Vereniging 1870-1995, (W.E.J. Tjeenk Willink, 1995)

\section{Loon, van}

Loon, J. van, 'Een antwoord op de brochure van Mr. N.C.M. van den Dries: "De Hooge Raad der Nederlanden tijdens de bezetting"', in: W.M.A. Weitjens (ed.), Ter informatie, (s.l., 1946), 5-20

\section{Lösener}

Lösener, B., 'Als Rassereferent im Reichsministerium des Innern', 9 Vierteljahrshefte für Zeitgeschichte 3 (1961), 264-313

\section{Lösener \& Knost}

Lösener, B. and F.U. Knost, Die Nürnberger Gesetze über das Reichsbürgerrecht und den Schutz des deutschen Blutes und der deutschen Ehre, (Verlag Franz Vahlen, 1937)

\section{Malthus}

Malthus, T.R., An Essay on the Principle of Population; or A View of its past and present Effects on Human Happiness; With an Inquiry into our Prospects respecting the future Removal or Mitigation of the Evils which it occasions, reprint of the 1803 edition, (Cambridge University Press, 1992)

\section{Maltin}

Maltin, L. (ed.), Speelfilmencyclopedie, (Uitgeverij Rostrum, 1988). Translated by G. van Evert (ed.)

\section{Mazel}

Mazel, P.E., In naam van het Recht... De Hoge Raad en de Tweede Wereldoor log, (Gouda Quint, 1984)

\section{Meeuwen, van}

Meeuwen, P.G.M. van, 'Het huwelijksverdrag en de nieuwe Duitsche wet tot regeling van de positie der Joden', 10 Nederlandsch Juristenblad 31 (1935), 483-486

\section{Meihuizen}

Meihuizen, J., Smalle Marges. De Nederlandse advocatuur in de Tweede Wereldoorlog, (Boom, 2010)

\section{Meijers}

Meijers, E.M., 'Echtscheiding met onderling goedvinden in Frankrijk', Weekblad voor Privaatrecht, Notarisambt en Registratie 2252 (1913), 83-85

\section{Michielsen}

Michielsen, J.N.M.E., The 'Nazification' and 'Denazification' of the Courts in Belgium, Luxembourg and the Netherlands. The Belgian, Luxembourg and Netherlands courts and their reactions to occupation measures and measures from their governments returning from exile, (Universitaire Pers Maastricht, 2004)

\section{Middelberg}

Middelberg, M., Judenrecht, Judenpolitik und der Jurist Hans Calmeyer in den besetzten Niederlanden 1940-1945, (V \& $R$ unipress, 2005)

\section{Mierop, van 1906}

Mierop, L. van, Over het geneeskundig onderzoek vóór het huwelik, (Uitgeversvereeniging 'Vrede', 1906)

\section{Mierop, van 1910}

Mierop, L. van, Waarom het 'vrije huwelik' zin heeft in onze tegenwoordige maatschappij, (W. Versluys, 1910)

\section{Miller}

Miller, R.L., Nazi Justiz. Law of the Holocaust, (Praeger, 1995)

\section{Minar}

Minar, D.M., 'Ideology and Political Behavior', 5 Midwest Journal of Political Science 4 (1961), 317-331

\section{Minkenhof}

Minkenhof, A.A.L., 'Het ontwerp echtscheidingsrecht', 101 Weekblad voor Privaatrecht, Notaris-ambt en Registratie 5103 (1970), 499-505

\section{Mitteis 1923}

Mitteis, H., Bürgerliches Recht. Familienrecht, (Verlag von Julius Springer, 1923)

\section{Mitteis 1931}

Mitteis, H., Bürgerliches Recht. Familienrecht, (Verlag von Julius Springer, 1931)

Mosse

Mosse, G.L., The Crisis of German Ideology. Intellectual Origins of the Third Reich, (Howard Fertig, 1981)

\section{Mößmer 1934}

Mößmer, F., 'Rassenmischehe und geltendes Recht', Zeitschrift der Akademie für Deutsches Recht (1934), 86-92

\section{Mößmer 1935}

Mößmer, F., Neugestaltung des deutschen Ehescheidungsrechtes, (Deutsche Rechts- und WirtschaftsWissenschafts Verlags Gesellschaft $\mathrm{mbH}, 1935$ )

Müller, I.

Müller, I., Hitler's Justice. The Courts of the Third Reich, (Harvard University Press, 1991). Translated by D.L. Schneider
Müller, L.A. v.

Müller, L.A. v., Die Beurkundung des Personenstandes und die Eheschließung nach dem Reichsgesetze vom 6. Januar 1875. Ein Handbuch zur Erleichterung des Gesetzesvollzuges hauptsächlich für Standesbeamte, (Verlag der C.H. Beck'schen Buchhandlung, 1882)

\section{Mullins}

Mullins, W.A., 'On the Concept of Ideology in Political Science', 66 The American Political Science Review 2 (1972), 498-510

Münch, von

Münch, I. von (ed.), Gesetze des NS Staates. Dokumente eines Unrechtssystems, (Ferdinand Schöningh, 1994)

\section{Nes, van $1944 a$}

Nes, J. van, 'Het echtscheidingsvraagstuk', 19 Nederlandsch Juristenblad 3 (1944), 21-22

\section{Nes, van $1944 b$}

Nes, J. van, 'Naar den Censor', 19 Nederlandsch Juristenblad 9 (1944), 70-72

\section{Nicholls}

Nicholls, D., Adolf Hitler. A Biographical Companion, (ABC-Clio, 2000)

\section{Noam \& Kropat}

Noam, E. and W.A. Kropat, Juden vor Gericht 1933-1945, (Kommission für die Geschichte der Juden in Hessen, 1975)

\section{Noordman}

Noorman, J., Om de kwaliteit van het nageslacht. Eugenetica in Nederland, 1900-1950, (SUN, 1989)

\section{Oppenheim, A.S.}

Oppenheim, A.S. (ed.), Schets van het Nederlandsch Burgerlijk Recht. Eerste deel, Personenrecht, (H.D. Tjeenk Willink \& Zoon, 1923). Original edition by J.D. Veegens

Panayi

Panayi, P., 'Continuities and discontinuities in German history, 1919-1945', in: P. Panayi (ed.), Weimar and Nazi Germany. Continuities and Discontinuities, (Pearson Education Limited, 2001), 3-29

\section{Pätzhold \& Schwarz}

Pätzhold, K. and E. Schwarz, Tagesordnung: Judenmord. Die WannseeKonferenz am 20. Januar 1942. Eine Dokumentation zur Organisation der 'Endlösung', (Metropol, 1992)

\section{Pelinka}

Pelinka, A., Austria. Out of the Shadow of the Past, (Westview Press, 1998)

\section{Pine 1997}

Pine, L., Nazi Family Policy, 1933

1945, (Berg, 1997) 


\section{Pine 2001}

Pine, L., 'Women and the family', in: P. Panayi (ed.), Weimar and Nazi Germany. Continuities and Discontinuities, (Pearson Education Limited, 2001), 199-217

\section{Ploetz}

Ploetz, A., Die Tüchtigkeit unserer Rasse und der Schutz der Schwachen. Ein Versuch über Rassenhygiene und ihr Verhältnis zu den humanen Idealen, besonders zum Socialismus, (S. Fischer, 1895)

\section{Presser}

Presser, J., Ondergang. De Vervolging en Verdelging van het Nederlandse Jodendom 1940-1945, (Staatsuitgeverij/ Martinus Nijhoff, 1965)

\section{Przyrembel}

Przyrembel, A., Rassenschande. Reinheitsmythos und Vernichtungslegitimation im Nationalsozialismus, (Vandenhoeck \& Ruprecht, 2003)

\section{Ramm 1973}

Ramm, T., 'Eherecht und Nationalsozialismus', in: G. Doeker and W. Steffani (eds.), Klassenjustiz und Pluralismus. Festschrift für Ernst Fraenkel zum 75. Geburtstag am 26 Dezember 1973, (Hoffmann und Campe, 1973), 151166

\section{Ramm 1983}

Ramm, T., 'Familien- und Jugendrecht im Nationalsozialismus', in: H. Rottleuthner (ed.), Recht, Rechtsphilosophie und Nationalsozialismus, (Franz Steiner Verlag GmbH, 1983), 75-81

\section{Ramm 1984}

Ramm, T., Das nationalsozialistische Familien- und Jugendrecht, (R. v. Decker \& C.F. Müller, 1984)

\section{Ranieri}

Ranieri, F., '200 Jahre Code civil. Die Rolle des französischen Rechts in der Geschichte des europäischen Zivilrechts oder zum Aufstieg und Niedergang eines europäisches Kodifikationsmodells', in: W. Schubert and M. Schmoeckel (eds.), 200 Jahre Code civil. Die napoleonische Kodifikation in Deutschland und Europa, (Böhlau Verlag, 2005), 85-125

\section{Regout}

Regout, R., 'De rechtstoestand in bezet gebied', 72 Studiën. Katholiek Cultureel Tijdschrift 133 (1940), 469-475

\section{Rissom}

Rissom, R., Fritz Lenz und die Rassenhygiene, (Matthiesen Verlag, 1983)

\section{Roberts \& Guelff}

Roberts, A. and R. Guelff (eds.), Documents on the Laws of War, (Oxford University Press, 2005)

\section{Robinsohn}

Robinsohn, H., Justiz als politische Verfolgung. Die Rechtsprechung in 'Rassenschandefällen' beim Landgericht Hamburg 1936-1943, Schriftenreihe der Vierteljahrshefte für Zeitgeschichte, volume 35, (Deutsche Verlags-Anstalt, 1977)

\section{Roegholt}

Roegholt, M.N., 'Over het ster-vrij maken van onze gemengd gehuwde Joodsche landgenooten', 89 Nederlandsch Tijdschrift voor Geneeskunde 27 (1945), 318-319

\section{Rohlfes}

Rohlfes, J., 'Judenemanzipation in Preußen. Das "Edikt betreffend die bürgerlichen Verhältnisse der Juden in dem Preußischen Staate" vom 11 März 1812', 51 Geschichte in Wissenschaft und Unterricht. Zeitschrift des Verbandes der Geschichtslehrer Deutschlands 5/6 (2000), 333-348

\section{Rosenberg, Alfred 1934}

Rosenberg, A., Der Mythus des 20. Jahrhunderts. Eine Wertung der seelich-geistigen Gestaltenkämpfe unserer Zeit, (Hoheneichen-Verlag, 1934)

\section{Rosenberg, Alfred 1982}

Rosenberg, A., The Myth of the Twentieth Century. An Evaluation of the Spiritual-Intellectual Confrontations of Our Age, (The Noontide Press, 1982). Translated by V. Bird

\section{Rosenberg, Arthur}

Rosenberg, A., Entstehung und $\mathrm{Ge}$ schichte der Weimarer Republik, (Europäische Verlagsanstalt, 1983)

Rüthers

Rüthers, B., Die unbegrenzte Auslegung. Zum Wandel der Privatrechtsordnung im Nationalsozialismus, (Athenäum Fischer Taschenbuch Verlag, 1973)

\section{Rutten}

Rutten, L.E.H., 'Ongewenste consequenties bij echtscheiding en scheiding van tafel en bed', 16 Nederlandsch Juristenblad 38 (1941), 701-712

\section{Savornin Lohman, de}

Savornin Lohman, W.H. de, Van Huwelijk en Echtscheiding, (D.A. Daamen, 1913)

\section{Schaik, van}

Schaik, J.R.H. van, 'De "wetten van Neurenberg"', 10 Nederlandsch Juristenblad 41 (1935), 652-653

\section{Schallmayer 1903}

Schallmayer, W., Vererbung und Auslese. Grundriss der Gesellschaftsbiologie und der Lehre vom Rassedienst, (Fischer, 1903)

\section{Schallmayer 1905}

Schallmayer, W., Beitrage zu einer Nationalbiologie, nebst einer Kritik der methodologischen Einwände und einem Anhang über wissenschaftliches Kritikerwesen, (Costenoble, 1905)

\section{Scharnagl}

Scharnagl, A., Das neue deutsche Ehegesetz mit den für das Land Österreich und das Sudetenland geltenden Sondervorschriften, (Verlag KöselPustet, 1939)

\section{Schenk \& Spaan}

Schenk, M.G. and J.B.Th. Spaan (eds.), De Koningin Sprak. Proclamaties en radio-toespraken van H.M. Koningin Wilhelmina gedurende de oorlogsjaren 1940-1945, (Ons Vrije Nederland, 1945)

\section{Schindler \& Toman}

Schindler, D. and J. Toman (eds.), The Laws of Armed Conflicts. A Collection of Conventions, Resolutions and Other Documents, (Martinus Nijhoff Publishers, 2004)

\section{Schmidt \& Dietz}

Schmidt, M. and G. Dietz (eds.), Frauen unterm Hakenkreuz, (Deutscher Taschenbuch Verlag, 1985)

\section{Schollen}

Schollen, M., Das Reichsgesetz über die Beurkundung des Personenstandes und die Eheschließung vom 6. Februar 1875 (RGBI. S. 23). Auf der Grundlage des vom 1. Januar 1900 an geltenden Rechts, (Ferd. Dümmlers Verlagsbuchhandlung, 1900)

\section{Scholten}

Scholten, P. (ed.), Mr. C. Asser's Handleiding tot de Beoefening van het Nederlandsch Burgerlijk Recht. Eerste deel, Personenrecht. Eerste stuk, Familierecht, (W.E.J. Tjeenk Willink, 1936). Original edition by $\mathrm{C}$. Asser

\section{Schrieke}

Schrieke, J.J., Bezet Nederland en het Haagsche Landoorlogsreglement van 1907, (N.V. Drukkerij Elsevier, 1944)

\section{Schröder}

Schröder, J.W.M., 'De Duitsche rassen- en huwelijkswetgeving bezien in het licht van het Nederlandsch Internationaal Privaatrecht', 11 Nederlandsch Juristenblad 44/45 (1936), 1009 1021/1037-1049

\section{Schubert 1977}

Schubert, W., 'Das französische Recht in Deutschland zu Beginn der Restaurationszeit (1814-1820)', 94 Zeitschrift der Savigny-Stiftung für Rechtsgeschichte. Germanistische Abteilung (1977), 129-184 


\section{Schubert 1986}

Schubert, W. (ed.), Die Projekte der Weimarer Republik zur Reform des Nichtehelichen-, des Adoptions- und des Ehescheidungsrecht, (Ferdinand Schöningh, 1986)

\section{Schubert 1993}

Schubert, W. (ed.), Das Familienund Erbrecht unter dem Nationalsozialismus. Ausgewählte Quellen zu den wichtigsten Gesetzen und Projekten aus den Ministerialakten, (Ferdinand Schöningh, 1993)

\section{Schwenk}

Schwenk, E.H., 'Legislative Power of the Military Occupant under Article 43 Hague Regulations', 54 Yale Law Journal 2 (1945), 393-416

\section{Seyss-Inquart}

Seyss-Inquart, A., Vier Jahre in den Niederlanden. Gesammelte Reden, (Volk und Reich Verlag, 1944)

\section{Siebert}

Siebert, W., Das Recht der Familie und die Rechtsstellung des Volksgenossen, (Deutscher Rechtsverlag GmbH, 1944)

\section{Sikkes}

Sikkes, J.H., ...In geval van een vijandelijken inval. Ambtelijk gedrag in bezettingstijd en de daarvoor geldende aanwijzingen, (Kluwer, 1985)

\section{Smidt, de}

Smidt, J. Th. de, Compendium van de geschiedenis van het Nederlands privaatrecht, (Kluwer, 1977)

\section{Smith}

Smith, H.W., The Butcher's Tale. Murder and Anti-Semitism in a German Town, (W.W. Norton \& Company, 2002)

\section{Staatscommissie Bezettingsrecht} Verslag van de Staatscommissie Bezettingsrecht, (Staatsdrukkerijen Uitgeverijbedrijf, 1955)

\section{Star Busmann}

Star Busmann, C.W. (ed.), Verklaring van het Burgerlijk Wetboek, eerste deel, (De Erven F. Bohn, 1914). Original edition by N.K.F. Land

\section{Stark}

Stark, G.D., 'Pornography, Society, and the Law In Imperial Germany', 14 Central European History 3 (1981), 200-229

\section{Stokvis}

Stokvis, B., Advocaat in bezettingstijd, (Polak \& Van Gennep, 1968)

\section{Stolleis}

Stolleis, M., The Law under the Swastika. Studies on Legal History in Nazi Germany, (The University of Chicago Press, 1998). Translated by T. Dunlap

\section{Stuckart \& Globke}

Stuckart, W. and H. Globke, Reichsbürgergesetz, Blutschutzgesetz, Ehegesundheitsgesetz, (C.H. Beck'sche Verlagsbuchhandlung, 1936)

\section{Stuldreher}

Stuldreher, C.J.F., De Legale Rest. Gemengd gehuwde Joden onder de Duitse bezetting, (Boom, 2007)

\section{Tacitus}

Tacitus, C., Germania, (Aris \& Phillips Ltd, 1999). Translated by H.W. Benario

\section{Telders 1938}

Telders, B.M., 'Het BW en de rechtspraak van 1838 tot heden, in het bizonder de standaard-arresten van den Hoogen Raad (Arrêts de Règlement)', in: P. Scholten en E.M. Meijers (eds.), Gedenkboek Burgerlijk Wetboek 18381938, (W.E.J. Tjeenk Willink, 1938)

\section{Telders 1947}

Telders, B.M., Verzamelde geschriften, deel IV, (Martinus Nijhoff, 1947)

\section{Todorov}

Todorov, T., Memory as a Remedy for Evil, (Seagull Books, 2010). Translated by $\mathrm{G}$. Walker

\section{Treub 1900}

Treub, H., Huwelijk en ziekte, (De Erven F. Bohn, 1900)

\section{Treub 1905}

Treub, H., Geneeskundige Huwelijkswetgeving, (De Erven F. Bohn, 1905)

\section{Usborne}

Usborne, C., The Politics of the Body in Weimar Germany. Women's Reproductive Rights and Duties, (MacMillan Press, 1992)

\section{Van den hole}

Van den hole, L., Honderd jaar Duits Burgerlijk Wetboek (BGB). 1 januari 1900 - 31 december 1999, (Leo Van den hole, 2004)

\section{Ven, van der}

Ven, F.A.J. van der, "'Gleichschaltung" en "Umdeutung". Oftewel, hoe het Nationaalsocialistische gedachtegoed na 1933 kon doordringen in het Duitse burgerlijke recht', Rechtsgeleerd Magazijn THEMIS 5 (2011), 215-232

\section{Venema}

Venema, D., Rechters in oorlogstijd. De confrontatie van de Nederlandse rechterlijke macht met nationaal-socialisme en bezetting, (Boom Juridische uitgevers, 2007)

\section{Venema, De Groot-van Leeuwen \\ \& Mertens}

Venema, D., L. de Groot-van Leeuwen and T. Mertens (eds.), Onder de huidige omstandigheden. De Hoge Raad en het Toetsingsarrest 1942, (Boom Juridische uitgevers, 2008)

\section{Verburg}

Verburg, M.E., Geschiedenis van het Ministerie van Justitie. Deel II, 18981940, (Sdu Uitgevers, 2001)

\section{Versteeg}

Versteeg, J., 'Het standpunt van den Ambtenaar van den Burgerlijken Stand ten opzichte van de nieuwe Duitsche huwelijkswetgeving', 10 Nederlandsch Juristenblad 33 (1935), 511-513

Voegeli

Voegeli, W., 'Nazi Family Policy: Securing Mass Loyalty', 28 Journal of Family History 1 (2003), 123-148

Wiarda

Wiarda, J. (ed.), Mr. C. Asser's Handleiding tot de Beoefening van het Nederlands Burgerlijk Recht. Eerste deel, Personenrecht. Eerste stuk, Natuurlijke Personen en Familierecht, (W.E.J. Tjeenk Willink, 1957)

Original edition by $\mathrm{C}$. Asser

Wijnaendts Francken 1897

Wijnaendts Francken, C.J., Sociale Ethiek. Wijsgeerig-sociologisch onderzoek, (H.D. Tjeenk Willink, 1897)

\section{Wijnaendts Francken 1901}

Wijnaendts Francken, C.J., Wenschelijk Huwelijksverbod, (H.D. Tjeenk Willink \& Zoon, 1901)

Wilson

Wilson, G.G., Handbook on Inter national Law, (West Publishing Co. 1939)

\section{Winkler}

Winkler, H.A., Weimar 1918-1933. Die Geschichte der ersten deutschen Demokratie, (Verlag C.H. Beck, 1998)

\section{Wöhrmann}

Wöhrmann, 'Die Auflösung der Ehe zwischen Juden und Ariern', 62 Juristische Wochenschrift 37 (1933), 2041

\section{Zanten, van}

Zanten, H.L. van, 'De Duitse “Jodenwet" en Nederland', 10 Nederlandsch Juristenblad 32 (1935), 495-496

\section{Zwaan 2004a}

Zwaan, T., 'Recente transities in huwelijk, gezin en levenscyclus', in: T. Zwaan (ed.), Familie, huwelijk en gezin in West-Europa. Van Middeleeuwen tot moderne tijd, (Boom/Open universiteit, 2004)

\section{Zwaan 2004b}

Zwaan, T., 'De verbroken viereenheid: een interpretatie van recente transities', in: T. Zwaan (ed.), Familie, huwelijk en gezin in West-Europa. Van Middeleeuwen tot moderne tijd, (Boom/ Open universiteit, 2004) 


\section{Periodicals}

Nationale Dagblad, 21 March 1942,

'Vlucht in... het huwelijk. Een joodsch

listigheidje?'

Nieuwe Rotterdamsche Courant, 12

September 1942, 'Tewerkstelling van

Joden'

\section{Internet sources}

All websites have been last accessed on 17 July 2012.

www.dhm.de/lemo/html/dokumente/wilhelm142/index.html www.dhm.de/lemo/html/dokumente/wilhelm144/index.html www.bundesarchiv.de/oeffentlichkeitsarbeit/bilder_dokumente/

00755/index-0.html.de

www.ilo.org/dyn/normlex/en/f?p=NORMLEXPUB:11300:0::NO:11300:P11300_

INSTRUMENT ID:312148:NO

www.imdb.com/title/tt0033750/

www.imdb.com/title/tt0325980/

www1.yadvashem.org/yv/en/righteous/stories/calmeyer.asp 


\section{Archival source list}

NIOD Institute for War, Holocaust, and Genocide Studies.

020 Generalkommissariat für Verwaltung und Justiz

286 (Stab) Stukken betreffende het nemen van maatregelen tegen gemengde huwelijken

1505 (Hauptabteilung Inneres) Stukken betreffende het vaststellen van de afstamming van joodse Mischlinge

1507 (Hauptabteilung Inneres) Stukken betreffende aangelegenheden met betrekking tot gemengde huwelijken tussen joden en niet-joden

1508 (Hauptabteilung Inneres) Brief van het Aussenministeriums te Berlijn aan Generalkommissar F. Wimmer, betreffende behandeling van joodsche Mischlinge en niet-joodse aan joden verwante personen, met geleidebrief

1519 (Hauptabteilung Inneres) Stukken betreffende de behandeling van joodse Mischlinge

2409 (Hauptabteilung Justiz) Stukken betreffende het tegengaan van gemengde huwelijken

2413 (Hauptabteilung Justiz) Stukken betreffende het voorbereiden van een verordening over het verbod op huwelijken en buitenechtelijk verkeer met Joden

2414 (Hauptabteilung Justiz) Stukken betreffende het herzien van het echtscheidingsrecht

077 Generalkommissariat für das Sicherheitswesen (Höhere SS- und Polizeiführer Nord-West)

1317 Stukken betreffende maatregelen met betrekking tot de Abbau der Rückstellungsgruppen alsmede rapporten over de behandeling van het joodse vraagstuk in Nederland, 1942-1945

1851 (Befehlshaber der Sicherheitspolizei und des Sicherheitsdienstes/ständiger Vertreter) Brief aan de Generalkommissar für Verwaltung und Justiz over de invoering van de jodenster

182 Joodsche Raad voor Amsterdam

1b Circulaires van de voorzitters van de Joodsche Raad voor Amsterdam inzake o.m. de invoering van de jodenster

1c Notulen van de vergaderingen van de Joodsche Raad. Punten van bespreking o.m. de invoering van de jodenster 


\section{Table of Legislation}

\section{The majority of the German (language) legislation has been accessed through ALEX, an online database of historical Austrian and German legislation, published by the Österreichische Nationalbibliothek, available at: http://alex.onb.ac.at/index.htm. When legislation has been accessed through ALEX, this has been indicated with an $\underline{\text { a. }}$}

\begin{abstract}
International Law
Convention pour régler les conflits de lois en matière de mariage, The Hague, 12 June 1902

IVth Hague Convention Respecting the Laws and Customs of War on Land and Annex to the Convention concerning Regulations Respecting the Laws and Customs of War on Land, The Hague, 1907
\end{abstract}

Convention concerning the Employment of Women before and after Childbirth of 28 November 1919 (convention C003, adopted by the International Labour Organisation)

Charter of the International Military Tribunal, 8 August 1945 United Nations Treaty Series, volume 82, 280-300

\section{Austria}

Allgemeines bürgerliches Gesetzbuch fúr die gesammten Deutschen Erbländer der Österreichischen Monarchie vom 1. Juni 1811, Gesetze und Verfassungen im Justiz-Sache (1804-1811), 275, no. 946 a

Gesetz vom 25. Mai 1868, wodurch die Vorschriften des zweiten Hauptstückes des allg. bürgerl. Gesetzbuches über das Eherecht für Katholiken wieder hergestellt, die Gerichtsbarkeit in Ehesachen der Katholiken den weltlichen Gerichtsbehörden überwiesen und Bestimmungen über die bedingte Zulässigkeit der Eheschließung vor weltlichen Behörden erlassen werden, Reichs-Gesetz-Blatt für das Kaiserthum Österreich (1868), 93, no. $47 \underline{\mathrm{a}}$

Konkordat zwischen dem Heiligen Stuhle und der Republik Österreich, Bundesgesetzblatt für den Bundesstaat Österreich (1934), II, 33, no. 2 a

Bundesgesetz vom 4. Mai 1934, betreffend Vorschriften auf dem Gebiete des Eherechts zur Durchführung des Konkordates zwischen dem Heiligen Stuhle und Österreich vom 5. Juni 1933, B.G.BI. 1934, II. Teil, Nr. 2, Bundesgesetzblatt für den Bundesstaat Österreich (1934), II, 59, no. $8 \underline{\mathrm{a}}$

Bundesverfassungsgesetz über die Wiedervereinigung Österreichs mit dem Deutschen Reich, Bundesgesetzblatt für den Bundesstaat Österreich (1938), 259 a

Kundmachung der Provisorischen Staatsregierung vom 13. Mai 1945 über die Aufhebung der 'Nürnberger Rassengesetze' (1. Kundmachung über die Aufhebung von Rechtsvorschriften des Deutschen Reiches), Staatsgesetzblatt für die Republik Österreich (1945), 22

Kundmachung der Provisorischen Staatsregierung vom 29. Mai 1945, betreffend die Aufhebung des Gesetzes zur Verhütung erbkranken Nachwuchses (3. Kundmachung über die Aufhebung von Rechtsvorschriften des Deutschen Reiches), Staatsgesetzblatt für die Republik Österreich (1945), 26

Gesetz vom 26. Juni 1945 über Maßnahmen auf dem Gebiete des Eherechtes, des Personenstandsrechtes und des Erbgesundheitsrechtes, Staatsgesetzblatt für die Republik Österreich (1945), 53

\section{France}

Décret qui détermine les causes, le mode et les effets du divorce du 20 Septembre 1792, published in: Lepec, M. (ed.), Recueil Général des Lois, Décrets, ordonnances, etc. Depuis le mois de Juin 1789 jusqu'au mois d'Août 1830, Tome Troisième, (L'Administration du Journal des Notaires et des Avocats, 1839)

\section{Germany}

Allgemeines Landrecht für die Preußischen Staaten vom 5. Februar 1794, Neue Ausgabe, 11. April 1803, (Nauck, 1806)

Staatsgrundgesetz für die Herzogthümer Coburg und Gotha vom 3. Mai 1852, Gemeinschaftliche Gesetzsammlung für die Herzogthümer Coburg und Gotha (1852), no. 2, 3

Gesetz betreffend die Gleichberechtigung der Konfessionen in bürgerlicher und staatsbürgerlicher Beziehung vom 3. Juli 1869, Bundes-Gesetzblatt des Norddeutschen Bundes (1869), 292

Gesetz über den Erwerb und den Verlust der Bundes- und Staatsangehörigkeit vom 1. Juni 1870, Bundes-Gesetzblatt des Norddeutschen Bundes (1870), 355

Verfassung des Deutschen Bundes, Bundes-Gesetzblatt des Norddeutschen Bundes (1870), 627

Gesetz betreffend die Verfassung des Deutschen Reiches vom 16. April 1871, Reichs-Gesetzblatt (1871), 63

Strafgesetzbuch für das Deutsche Reich vom 15. Mai 1871, Reichs-Gesetzblatt (1871), 127

Reichsgesetz über die Beurkundung des Personenstandes und die Eheschließung vom 6. Februar 1875, Reichs-Gesetzblatt (1875), 23

Bürgerliches Gesetzbuch vom 18. August 1896, ReichsGesetzblatt (1896), 195

Einführungsgesetz zum Bürgerlichen Gesetzbuche vom 18. August 1896, Reichs-Gesetzblatt, (1896), 604

Reichsgesetz über die Bekämpfung gemeinfährlicher Krankheiten vom 30. Juni 1900, Reichs-Gesetzblatt (1900), 306

Abkommen zur Regelung des Geltungsbereichs der Gesetze auf dem Gebiete der Eheschließung vom 12. Juni 1902, Reichs-Gesetzblatt (1904), 221

Gesetz über die Bekämpfung übertragbarer Krankheiten vom 28. August 1905, Gesetz-Sammlung für die Königlichen Preußischen Staaten (1905), 373

IV. Haager Abkommen, betreffend die Gesetze und Gebräuche des Landkriegs vom 18. Oktober 1907/Ordnung der Gesetze und Gebräuche des Landkriegs, Reichs-Gesetzblatt (1910), 107 
Reichs- und Staatsangehörigkeitsgesetz vom 22. Juli 1913 Reichs-Gesetzblatt (1913), 583

Gesetz zur Änderung des Gesetzes, betreffend die Unterstützung von Familien in den Dienst eingetretener Mannschaften, vom 28. Febuar 1888 (Reichs-Gesetzbl.

S. 59) vom 4. August 1914, Reichs-Gesetzblatt (1914), 332

Bekanntmachung, betreffend Ausdehnung der Wochenhilfe während des Krieges vom 23. April 1915,

Reichs-Gesetzblatt (1915), 257

Verordnung über die Wahlen zur verfassungsgebenden deutschen Nationalversammlung vom 30. November 1918 , Reichs-Gesetzblatt (1918), 1345

Die Verfassung des Deutschen Reiches vom 11. August 1919, Reichs-Gesetzblatt (1919), $1383 \underline{\text { a }}$

Gesetz über Wochenhilfe und Wochenfürsorge vom 26. September 1919, Reichs-Gesetzblatt (1919), 1757 a

Gesetz über den Personenstand vom 11. Juni 1920, Reichs-Gesetzblatt (1920), 1209 a

Gesetz über das am 15. Mai 1922 in Genf geschlossene deutsch-polnische Abkommen über Oberschlesien vom 11. Juni 1922, Reichsgesetzblatt (1922), II, 237 a

Gesetz zur Bekämpfung der Tuberkulose vom 4. August 1923, Gesetzsammlung für Preußen (1923), 374 a

Gesetz zur Abänderung des Strafgesetzbuchs vom 18. Ma 1926, Reichsgesetzblatt (1926), I, 239 a

Gesetz zur Bekämpfung der Geschlechtskrankheiten vom 18. Februar 1927, Reichsgesetzblatt (1927), I, 61 a

Gesetz über das Washingtoner Übereinkommen, betreffend die Beschäftigung der Frauen vor und nach der Niederkunft vom 16. Juli 1927, Reichsgesetzblatt (1927), II, $497 \underline{\text { a }}$

Gesetz zur Behebung der Not von Volk und Reich vom 24. März 1933, Reichsgesetzblatt (1933), I, 141 a

Gesetz zur Wiederherstellung des Berufsbeamtums vom 7 April 1933, Reichsgesetzblatt (1933), I, 175 a

Erste Verordnung zur Durchführung des Gesetzes zur Wiederherstellung des Berufsbeamtums vom 11. April 1933, Reichsgesetzblatt (1933), I, $195 \underline{\text { a }}$

Gesetz zur Abänderung strafrechtlicher Vorschriften vom 26. Mai 1933, Reichsgesetzblatt (1933), I. $295 \underline{\text { a }}$

Gesetz zur Verminderung der Arbeitslosigkeit vom 1. Juni 1933, Reichsgesetzblatt (1933), I, 323 a

Durchführungsverordnung über die Gewährung von

Ehestandsdarlehen vom 20. Juni 1933,

Reichsgesetzblatt (1933), I, 377 a

Gesetz über den Widerruf von Einbürgerungen und die Aberkennung der deutschen Staatsangehörigkeit vom 14. Juli 1933, Reichsgesetzblatt (1933), I, 480 a

Gesetz zur Verhütung erbkranken Nachwuchses vom 14. Juli 1933, Reichsgesetzblatt (1933), I, 529 a

Zweite Durchführungsverordnung über die Gewährung von Ehestandsdarlehen vom 26. Juli 1933 ,

Reichsgesetzblatt (1933), I, 540 a
Gesetz gegen Mißbrauche bei der Eheschließung und der Annahme an Kindes Statt vom 23. November 1933, Reichsgesetzblatt (1933), I, 979 a

Gesetz gegen gefährliche Gewohnheitsverbrecher und über Maßregeln der Sicherung und Besserung vom 24. November 1933, Reichsgesetzblatt (1933), I, 995 a

Verordnung zur Ausführung des Gesetzes zur Verhütung erbkranken Nachwuchses vom 5. Dezember 1933 , Reichsgesetzblatt (1933), I, 1021 a

Verordnung über die deutsche Staatsangehörigkeit vom 5. Februar 1934, Reichsgesetzblatt (1934), I, 85 a

Gesetz über das Staatsoberhaupt des Deutschen Reichs vom 1. August 1934, Reichsgesetzblatt (1934), I, $747 \underline{\text { a }}$

Wehrgesetz vom 21. Mai 1935, Reichsgesetzblatt (1935), I, 609 a

Reichsarbeitsdienstgesetz vom 26. Juni 1935 , Reichsgesetzblatt (1935), I, $769 \underline{\text { a }}$

Gesetz zur Änderung des Gesetzes zur Verhütung erbkranken Nachwuchses vom 26. Juni 1935, Reichsgesetzblatt (1935), I, $773 \underline{a}$

Gesetz zur Änderung des Strafgesetzbuchs vom 28. Juni 1935, Reichsgesetzblatt (1935), I, 839 a

Vierte Verordnung zur Ausführung des Gesetzes zur Verhütung erbkranken Nachwuchses vom 18. Juli 1935, Reichsgesetzblatt (1935), I, 1035 a

Reichsflaggengesetz vom 15. September 1935 , Reichsgesetzblatt (1935), I, 1145

Reichsbürgergesetz vom 15. September 1935 , Reichsgesetzblatt (1935), I, 1146 a

Gesetz zum Schutze des deutschen Blutes und der deutschen Ehre vom 15. September 1935, Reichsgesetzblatt (1935), I, 1146 a

Gesetz zum Schutze der Erbgesundheit des deutschen Volkes vom 18. Oktober 1935, Reichsgesetzblatt (1935), I, 1246 a

Erste Verordnung zum Reichsbürgergesetz vom 14. November 1935, Reichsgesetzblatt (1935), I, 1333 a

Erste Verordnung zur Ausführung des Gesetzes zum Schutze des deutschen Blutes und der deutschen Ehre vom 14. November 1935, Reichsgesetzblatt (1935), I, 1334 a

Erste Verordnung zur Durchführung des Ehegesundheitsgesetzes vom 29. November 1935, Reichsgesetzblatt (1935), I, 1419 a

Zweites Gesetz zur Änderung des Gesetzes zur Verhütung erbkranken Nachwuchses vom 4. Februar 1936, Reichsgesetzblatt (1936), I, $119 \underline{\text { a }}$

Fünfte Verordnung zur Ausführung des Gesetzes zur Verhütung erbkranken Nachwuchses vom 25. Februar 1936, Reichsgesetzblatt (1936), I, 122 a

Gesetz über Maßnahmen im ehemaligen oberschlesischen Abstimmungsgebiet vom 30. Juni 1937, Reichsgesetzblatt (1937), I, 717 a

Personenstandsgesetz vom 3. November 1937, Reichsgesetzblatt (1937), I, $1146 \underline{\text { a }}$ 
Gesetz über die Wiedervereinigung Österreichs mit dem Deutschen Reich vom 13. März 1938, Reichsgesetzblatt (1938), I, 237 a

Gesetz zur Vereinheitlichung des Rechts der Eheschließung und der Ehescheidung im Lande Österreich und im übrigen Reichsgebiet vom 6. Juli 1938, Reichsgesetzblatt (1938), I, $807 \underline{\text { a }}$

Erste Verordnung zur Durchführung und Ergänzung des Ehegesetzes vom 27. Juli 1938, Reichsgesetzblatt (1938), I, $923 \underline{\text { a }}$

Verordnung des Führers und Reichskanzlers über die Stiftung des Ehrenkreuzes der Deutschen Mutter vom 16. Dezember 1938, Reichsgesetzblatt (1938), I, 1923 a

Satzung des Ehrenkreuzes der Deutschen Mutter vom 16. Dezember 1938, Reichsgesetzblatt (1938), I, 1924 a

Verordnung zur Ergänzung der Ersten Ausführungsverordnung zum Blutschutzgesetz vom 16. Februar 1940, Reichsgesetzblatt (1940), I, 394 a

Erlaß des Führers über Ausübung der Regierungsbefugnisse in den Niederlanden vom 18. Mai 1940, Reichsgesetzblatt (1940), I, $778 \underline{\text { a }}$

Gesetz zur Änderung des Reichsstrafgesetzbuchs vom 4. September 1941, Reichsgesetzblatt (1941), I, 549 a

Elfte Verordnung zum Reichsbürgergesetz vom 25. November 1941, Reichsgesetzblatt (1941), I, 722 a

Verordnung zum Schutz von Ehe, Familie und Mutterschaft vom 9. März 1943, Reichsgesetzblatt (1943), I, 140 a

Kontrollratsgesetz Nr. 16 (Ehegesetz) vom 20. Februar 1946, Amtsblatt des Kontrollrats in Deutschland (1946), 77 a

Gesetz zur Neuordnung des Eheschließungsrecht vom 4. Ma 1998, Bundesgesetzblatt (1998), I, 833 a

\section{The Netherlands}

Acts of Parliament, executive decrees and acts

Wetboek Napoleon, ingerigt voor het Koningrijk Holland, (Koninklijke Staatsdrukkerij, 1809)

Besluit van den 5 Julij 1830, houdende bepaling van het tijdstip der invoering van de nieuwe Wetboeken en van de Regterlijke Organisatie, Staatsblad van het Koningrijk der Nederlanden (1830), 792, no. 41

Besluit van den 5 Januarij 1831, houdende opschorting der invoering van de nationale wetgeving en regterlijke instellingen, Staatsblad van het Koningrijk der Nederlanden (1831), 52, no. 1

Besluit van den 24 Februarij 1831, tot herziening der reeds aangenomen Wetboeken, en der Wet op de organisatie der regterlijke magt en het beleid der justitie, Staatsblad van het Koningrijk der Nederlanden (1831), 811, no. 6

Wet van den 16 Junij 1832, houdende wijzigingen en veranderingen in het eerste boek van het Burgerlijk Wetboek, Staatsblad van het Koningrijk der Nederlanden (1832), 863, no. 34

Besluit van den 13 April 1838, houdende bepaling van het tijdstip waarop de invoering der nieuwe Nederlandsche Wetgeving en de instelling van den Hoogen Raad zal plaats hebben, Staatsblad van het Koningrijk der Nederlanden (1838), 1119, no. 12
Wet van den 9 Julij 1855, houdende uitzondering op de artikelen 523, 526 en 549 van het Burgerlijk Wetboek, ten opzigte van vermiste personen bij vermoedelijke of bekende scheepsrampen, Staatsblad van het Koningrijk der Nederlanden (1855), 30, no. 67

Wet van 26 April 1884, houdende wijzigingen in het Burgerlijk Wetboek, Staatsblad van het Koninkrijk der Nederlanden (1884), 54, no. 93

Wet van 23 Mei 1899, houdende bepalingen ter uitvoering van art. 187 der Grondwet, Staatsblad van het Koninkrijk de Nederlanden (1899), no. 128

Besluit van 15 Juni 1904, bevelende de plaatsing in het Staatsblad van de op 12 Juni 1902 mede door Nederland onderteekende drie Conventiën van Internationaal Privaatrecht, Staatsblad van het Koninkrijk der Nederlanden (1904), 93, no. 121

Besluit van 22 Februari 1910, bepalende de bekendmaking in het Staatsblad van 12 verdragen en van eene verklaring, onder dagteekening van 18 October 1907 ter tweede Vredesconferentie gesloten, Staatsblad van het Koninkrijk der Nederlanden (1910), no. 73

Wet, tot wijziging van artikel 276 van het Burgerlijk Wetboek en van daarmede verband houdende artikelen van dat Wetboek en van het Wetboek van Burgerlijke Rechtsvordering, 27 Maart 1915, Staatsblad van het Koninkrijk der Nederlanden (1915), 48, no. 172

Wet, tot wijziging van de termijnen bedoeld in de artikelen 523, 526 en 549 van het Burgerlijk Wetboek en afschaffing der wet van 9 Juli 1855 (Staatsblad no. 67), 26 Maart 1920, Staatsblad van het Koninkrijk der Nederlanden (1920), no. 148

Wet, houdende verbetering van de wet van den 26sten Maart 1920 (Staatsblad no. 148), tot wijziging van de termijnen bedoeld in de artikelen 523, 526 en 549 van het Burgerlijk Wetboek en afschaffing der wet van 9 Juli 1855 (Staatsblad no. 67), 4 December 1920, Staatsblad van het Koninkrijk der Nederlanden (1920), no. 864

Wet tot beperking van het verbod van hertrouwen, gelegen in artikel 90 van het Burgerlijk Wetboek, 18 Februari 1922, Staatsblad van het Koninkrijk der Nederlanden (1922), no. 69

Besluit van 13 juli 1956, houdende inwerkingtreding van de wet van 14 juni 1956 (Stb. 343) tot opheffing van de handelingsonbekwaamheid van de gehuwde vrouw, Staatsblad van het Koninkrijk der Nederlanden (1956), 1087, no. 413

Wet van 6 mei 1971, houdende herziening van het echtscheidingsrecht, Staatsblad van het Koninkrijk der Nederlanden (1971), 693, no. 290

\section{Occupant's measures}

Verordnung des Reichskommissars für die besetzten niederländischen Gebiete über die Ausübung der Regierungsbefugnisse in den Niederlanden vom 29. Mai 1940, Verordnungsblatt für die besetzten niederländischen Gebiete (1940), 8

Erlass des Reichskommissars für die besetzten niederländischen Gebiete über den organisatorischen Aufbau der Dienststellen des Reichskommissariat vom 3. Juni 1940, Verordnungsblatt für die besetzten niederländischen Gebiete (1940), 11 
Verordnung des Reichskommissars für die besetzten niederländischen Gebiete zur Sicherung der Tätigkeit des Staatsrats sowie einiger öffentlichrechtlicher Vertretungskörperschaften, Verordnungsblatt für die besetzten niederländischen Gebiete (1940), 54

Verordnung des Reichskommissars für die besetzten niederländischen Gebiete über die Befugnisse des Generalsekretäre der niederländischen Ministerien, Verordnungsblatt für die besetzten niederländischen Gebiete (1940), 55

Verordnung des Generalsekretärs im Ministerium des Innern über die Einführung einer als allgemeiner Personalausweis geltenden Kennkarte vom 17. Oktober 1940, Verordnungsblatt für die besetzten niederländischen Gebiete (1940), 566

Verordnung des Reichskommissars für die besetzten niederländischen Gebiete über die Anmeldung von Unternehmen vom 22. Oktober 1940, Verordnungsblatt für die besetzten niederländischen Gebiete, (1940), 546

Verordnung des Reichskommissars für die besetzten niederländischen Gebiete über die Meldepflicht von Personen, die ganz oder teilweise jüdischen Blutes sind vom 10. Januar 1941, Verordnungsblatt für die besetzten niederländischen Gebiete (1941), 19

Verordnung des Reichskommissars für die besetzten niederländischen Gebiete über Auflösung parlamentarischer Parteien, Verordnungsblatt für die besetzten niederländischen Gebiete (1941), 513

Achte Verordnung des Reichskommissars für die besetzten niederländischen Gebiete über besondere verwaltungsrechtliche Massnahmen, Verordnungsblatt für die besetzten niederländischen Gebiete (1941), 637

Bekanntmachung des Generalkommissars für das Sicherheitswesen über die Kennzeichung der Juden in den Niederlanden vom 27. April 1942, Anordnungen des Generalkommissars für das Sicherheitswesen und Höheren SS- und Polizeiführers (1942), 21

\section{Other}

Programm der Nationalsozialistischen Deutschen Arbeiterpartei, 24 February 1920, published in: Feder, G. (ed.), Das Programm der N.S.D.A.P. und seine weltanschaulichen Grundgedanken, (Verlag Frz. Eher Nachf., GmbH, 1932), $19-23$

Casti Connubii, encyclical of Pope Pius XI on Christian marriage to Venerable Brethren, Patriarchs, Primates, Archbishops, Bishops, and other local ordinaries enjoying peace and communion with the apostolic see (31 December 1930), available at: www.vatican.va/holy_father/pius_xi/encyclicals/ documents/hf_p-xi_enc_31121930_casti-connubii_en.html, last accessed on 17 July 2012

Verordnung zur Durchführung der Verordnung über die Kennzeichnung von Juden vom 27. Mai 1942, Verordnungsblatt des Militärbefehlshabers in Belgien und Nordfrankreich für die besetzten Gebiete Belgiens und Nordfrankreichs (1942), 945

\section{Published draft legislation}

Ontwerp van het Burgerlijk Wetboek voor het Koningrijk der Nederlanden, aan de Staten-Generaal aangeboden den 22sten November 1820, (J.W. Leeuwen, 1864)

Burgerlijk Wetboek/Code Civil, officiële uitgave/édition officielle, (Algemeene Lands Drukkerij/ l'Impremie de l'État, 1830)
Ontwerp tot herziening van het Burgerlijk Wetboek, den Koning aangeboden door de Staatscommissie, ingesteld bij Zijner Majesteits Besluits van 28 Februari 1880, no. 8, eerste boek, (Gebr. Belinfante, 1886)

Ontwerp tot herziening van het Burgerlijk Wetboek, den Koning aangeboden door de Staatscommissie, ingesteld bij Zijner Majesteits Besluits van 28 Februari 1880, no. 8, eerste boek, Toelichting, (Gebr. Belinfante, 1886)

Comité voor eene gemeenschappelijke Actie tot Hervorming onzer Huwelijkswetgeving, Huwelijk en Echtscheiding, ( $N$. Samsom N.V., 1939)

\section{Parliamentary Reports (Kamerstukken)}

Handelingen der Staten-Generaal (Tweede Kamer), bijlagen 1909-1910, no. 208

No. 208.2, Ontwerp van wet

No. 208.4, Voorloopig verslag

Handelingen der Staten-Generaal (Tweede Kamer), bijlagen 1909-1910, bijlage A, hoofdstuk 4

2. IV. 13, Voorloopig verslag

2. IV. 14, Memorie van Antwoord

Handelingen der Staten-Generaal (Tweede Kamer), bijlagen 1911-1912, no. 306

No. 306.2, Ontwerp van wet

No. 306.3, Memorie van Toelichting

No. 306.4, Bijlage der Memorie van Toelichting

Handelingen der Staten-Generaal (Tweede Kamer), bijlagen 1920-1921, no. 476

No. 476.3, Memorie van Toelichting

Handelingen der Staten-Generaal, (Eerste Kamer), bijlagen 1921-1922

Voorlopig Verslag over wetsontwerp no. 90

Eindverslag over wetsontwerp no. 90, Memorie van Antwoord

Handelingen der Staten-Generaal (Tweede Kamer), 19351936, II, 19e Vergadering, 21 november 1935, 489-545

Handelingen der Staten-Generaal (Tweede Kamer), bijlagen 1936-1937, bijlage A, hoofdstuk 4

2. IV. 9, Memorie van Antwoord

Handelingen der Staten-Generaal (Tweede Kamer), bijlagen 1938-1939, no. 257

No. 257.2, Ontwerp van wet

No. 257.3, Memorie van Toelichting

Handelingen der Staten-Generaal (Tweede Kamer), zitting 1968-1969, no. 10213

No. 10213.3, Memorie van Toelichting

\section{Historical editions of law books}

France

Code Civil des Français. Édition originale et seule officielle, (L'Imprimerie de la Republique, 1804)

\section{Germany}

Zimmerle, L. (ed.), Bürgerliches Gesetzbuch mit Einführungsgesetz, Erbhofgesetz, Gesetz gegen Mißbräuche bei der Eheschließung und der Annahme an Kindes Statt sowie anderen wichtigen Nebengesetzen, (Verlag Franz Vahlen, 1934) 
Oppenhoff, F.C. (ed.), Das Strafgesetzbuch für das Deutsche Reich nebst dem Einführungs-Gesetze vom 31. Mai 1870, - dem Einführungs-Gesetze und den Einführungs-

Verordnungen zum Preußischen Strafgesetzbuche und dem Einführungs-Gesetze für Elsaß-Lothringen vom 30. August 1871, (Georg Reimer, 1873)

\section{The Netherlands}

Fruin, Th.A., (ed.), De Nederlandsche Wetboeken zooals zij tot op 1 Januari 1936 zijn gewijzigd en aangevuld, benevens de belangrijkste der tot hunne verklaring dienstige wetten en wettelijke verordeningen, met verwijzing naar de tot elk artikel betrekkelijke Fransche en Nederlandsche wetsbepalingen, (Martinus Nijhoff, 1936). Original edition by J.A. Fruin 


\section{Table of Cases}

\section{Germany}

Supreme Court (Reichsgericht)

Reichsgericht 30 March 1920, Entscheidungen des Reichsgerichts in Zivilsachen, Band 98, 295-298

Reichsgericht 12 July 1934, 63 Juristische Wochenschrift 42 (1934), 2613-2615

Reichsgericht, Großer Senat für Strafsachen 9 December 1936, 70 Entscheidungen des Reichsgerichts in Strafsachen, no. 117, 375-377

Reichsgericht 15 January 1937, cited by R. Leppin, in 66 Juristische Wochenschrift 49 (1937), 3076-3082, 3079 Reichsgericht, 1. Strafsenat des Reichsgerichts 9 February 1937, 71 Entscheidungen des Reichsgerichts in Strafsachen, no. 52, 129-133

Reichsgericht, Großer Senat für Strafsachen 23 February 1938, 100 Deutsche Justiz, 11 (1938), 422-424

Reichsgericht, 4. Strafsenat des Reichsgerichts 14 October 1938, 101 Deutsche Justiz 2 (1939), 102-103

Reichsgericht 12 January 1939, Entscheidungen des

Reichsgerichts in Zivilsachen, Band 159, no. 19, 111-114

Reichsgericht 13 February 1939, Entscheidungen des

Reichsgerichts in Zivilsachen, Band 159, no. 46, 305-311

Reichsgericht 13 March 1939, Entscheidungen des

Reichsgerichts in Zivilsachen, Band 160, no. 4, 15-19

Reichsgericht 17 April 1939, Entscheidungen des

Reichsgerichts in Zivilsachen, Band 160, no. 29, 144-148

Reichsgericht 4 May 1939, Entscheidungen des

Reichsgerichts in Zivilsachen, Band 160, no. 49, 270-273

Reichsgericht 6 November 1939, Entscheidungen des

Reichsgerichts in Zivilsachen, Band 162, no. 10, 44-47

Reichsgericht 6 November 1939, 10 Deutsches Recht 6

(1940), no. 3, 242-243

Reichsgerecht 18 November 1939, 10 Deutsches Recht 6

(1940), no. 2, 242

Reichsgericht 20 May 1940, Entscheidungen des

Reichsgerichts in Zivilsachen, Band 164, no. 8, 59-62

Reichsgericht 29 May 1940, Entscheidungen des

Reichsgerichts in Zivilsachen, Band 164, no. 67, 372-380

Reichsgericht 14 November 1940, cited by G. Frantz, in 1

Deutsches Recht 19/20 (1941), 1028-1035, 1030.

Reichsgericht 8 March 1941, Entscheidungen des

Reichsgerichts in Zivilsachen, Band 166, no. 28, 209-215

Reichsgericht 15 March 1941, Entscheidungen des

Reichsgerichts in Zivilsachen, Band 166, no. 25, 188-192

Reichsgericht 5 November 1941, Entscheidungen des

Reichsgerichts in Zivilsachen, Band 168, no. 5, 38-39

Courts of Appeals (Oberlandesgerichten)

Oberlandesgericht Karlsruhe 2 March 1934, Der Deutsche

Rechtspfleger (1934), 292 and Höchstrichterliche Rechtsprechung 7 (1934), no. 489

Oberlandesgericht Nürnberg 14 February 1939, 10

Deutsches Recht 1 (1940), 33-34

Oberlandesgericht München 11 December 1939, 10

Deutsches Recht 8 (1940), 327-328

Oberlandesgericht Kassel 20 April 1943, cited in full by

E. Noam and W.A. Kropat, Juden vor Gericht 1933-1945, 168-173

County Courts (Landgerichten)

Landgericht Köln (no date) 1933, 95 Deutsche Justiz 52

(1933), 819

Landgericht Königsberg 26 August 1935, 97 Deutsche

Justiz 38 (1935), 1387

Landgericht Augsburg 19 December 1935, 65 Juristische Wochenschrift 11 (1936), 750-751

Landgericht Nürnberg-Fürth 14 March 1936, 65 Juristische Wochenschrift 20 (1936), 1397

Landgericht Hamburg 12 November 1937, 971/37, cited by

H. Robinsohn, Justiz als politische Verfolgung, 67-68
Landgericht Hamburg 9 February 1938, 1762/37, cited by H. Robinsohn, Justiz als politische Verfolgung, 67-68 Landgericht Hamburg 29 June 1938, 2049/37, cited by $\mathrm{H}$. Robinsohn, Justiz als politische Verfolgung, 35

Petty Courts (Amtsgerichten)

Amtsgericht Wetzlar 17 June 1935, 64 Juristische Wochenschrift 29 (1935), 2083

Amtsgericht Bad Sülze 8 July 1935, 64 Juristische

Wochenschrift 32 (1935), 2309

Special Courts (Sondergerichten)

Sondergericht Nürnberg 13 March 1942, cited in full by A. Przyrembel, Rassenschande, 522-538

\section{The Netherlands}

Supreme Court (Hoge Raad)

Hoge Raad 2 October 1851, Nederlandsche Regtspraak XL (1852), § 1

Hoge Raad 22 June 1883, Weekblad van het Regt 4924 (1883)

Hoge Raad 12 January 1942, Nederlandsche Jurisprudentie 1942, 271

Hoge Raad 5 March 1943, Nederlandsche Jurisprudentie 1943,203

Courts of Appeal (Gerechtshoven)

Gerechtshof Amsterdam 2 November 1939, Nederlandsche Jurisprudentie 1940, 175

District Courts (Arrondissementsrechtbanken)

Arrondissementsrechtbank Amsterdam 18 March 1904, Weekblad van het Recht 8123 (1904)

Arrondissementsrechtbank Amsterdam 12 October 1906,

Weekblad van het Recht 8589 (1907)

Arrondissementsrechtbank Amsterdam 8 February 1926

Nederlandsche Jurisprudentie 1926, 256

Arrondissementsrechtbank Rotterdam 18 December 1933

Weekblad van het Recht 12744 (1934)

Arrondissementsrechtbank Dordrecht 20 May 1936,

Nederlandsche Jurisprudentie 1936, 456

Arrondissementsrechtbank Rotterdam 29 May 1936

Nederlandsche Jurisprudentie 1936, 454

Arrondissementsrechtbank 's Hertogenbosch 16 June 1936 ,

Nederlandsche Jurisprudentie 1936, 479

Arrondissementsrechtbank 's Hertogenbosch 31 July 1936,

Nederlandsche Jurisprudentie 1936, 860

Arrondissementsrechtbank 's Gravenhage 28 August 1936,

Nederlandsche Jurisprudentie 1936, 920

Arrondissementsrechtbank Amsterdam 31 January 1938,

100 Weekblad van het Recht 28 (1938), 331

Arrondissementsrechtbank Anhem 10 May 1938

Nederlandsche Jurisprudentie 1938, 969

Arrondissementsrechtbank Rotterdam 23 June 1941,

Nederlandsche Jurisprudentie 1941, 639

Central Appeals Court for the public service and social security matter (Centrale Raad van Beroep)

Centrale Raad van Beroep 11 May 1948, Administratiefrechtelijke Beslissingen 1948, 507

Centrale Raad van Beroep 30 September 1958

Administratiefrechtelijke Beslissingen 1960, 459

Special Court of Cassation (Bijzondere Raad van Cassatie)

Bijzondere Raad van Cassatie 12 January 1949,

Nederlandse Jurisprudentie 1949, 87

Bijzondere Raad van Cassatie 7 November 1949,

Nederlandse Jurisprudentie 1950, 8

Bijzondere Raad van Cassatie 5 December 1949,

Nederlandse Jurisprudentie 1950, 13 




\section{Curriculum Vitae}

Mariken Lenaerts (Weert, I8 January I98I) received her secondary education (Gymnasium) in Weert, studied Dutch Law (VTR Metajuridica) at Maastricht University and graduated in August 2004. Her master thesis entitled 'National Socialist Family Law in the Netherlands. Academics' attitude towards National Socialism: active resistance, condemnable passiveness or collaboration?' was awarded the scriptieprijs, the award for the best master thesis at the Faculty of Law of Maastricht University in 2004. During her studies she worked as editorial assistant for the Maastricht Journal of European and Comparative Law. In addition she was a board member for several student organisations, a member of the Faculty Council in 2002-2003 and a member of the University Council in 2003-2004. Mariken is currently employed as a teacher at the Department of Foundations and Methods of Law. She teaches a wide variety of courses, but mainly in the field of legal philosophy and legal history. 


\section{Colophon}

Copyright 2012, M.F. Lenaerts

Cover, book design and editing

Henry Smaal grafisch ontwerp, www.henrysmaal.nl Cover image

Beeldbank WO2 - NIOD

\section{Printing}

Gildeprint, Enschede

A commercial edition of this dissertation is forthcoming.

All rights reserved. No part of this publication may be reproduced, translated, stored or introduced into a retrieval system, or transmitted, in any form or by any means (electronic, mechanical, photocopying, recording or otherwise), without the prior written permission of the author/copyright owner.

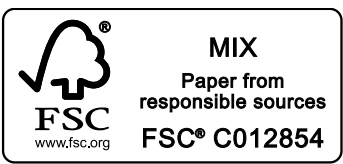



This book answers the question whether family law, in particular marriage and divorce law, in Germany and the Netherlands has been influenced by National Socialism in the period I933-I945. In order to answer this question the author provides an in-depth analysis of National Socialism and the ideological role of marriage, family and children according to National Socialism. The book furthermore gives an elaborate overview of the rules concerning marriage and divorce that existed in Germany and the Netherlands before the National Socialist take-over. Finally the book provides an indepth analysis of the measures adopted by the National Socialists concerning marriage and divorce law. Special attention is given to the attempts to revise Dutch divorce law. For this the author has made extensive use of the archives of the NIOD Institute for War, Holocaust and Genocide Studies, that are only partially public. 